\title{
De rechtspositie van mensen met een verstandelijke handicap : van beperking naar ontplooiing
}

Citation for published version (APA):

Frederiks, B. J. M. (2004). De rechtspositie van mensen met een verstandelijke handicap : van beperking naar ontplooiing. [Doctoral Thesis, Maastricht University]. Sdu Uitgevers.

https://doi.org/10.26481/dis.20040916bf

Document status and date:

Published: 01/01/2004

DOI:

10.26481/dis.20040916bf

Document Version:

Publisher's PDF, also known as Version of record

\section{Please check the document version of this publication:}

- A submitted manuscript is the version of the article upon submission and before peer-review. There can be important differences between the submitted version and the official published version of record.

People interested in the research are advised to contact the author for the final version of the publication, or visit the DOI to the publisher's website.

- The final author version and the galley proof are versions of the publication after peer review.

- The final published version features the final layout of the paper including the volume, issue and page numbers.

Link to publication

\footnotetext{
General rights rights.

- You may freely distribute the URL identifying the publication in the public portal. please follow below link for the End User Agreement:

www.umlib.nl/taverne-license

Take down policy

If you believe that this document breaches copyright please contact us at:

repository@maastrichtuniversity.nl

providing details and we will investigate your claim.
}

Copyright and moral rights for the publications made accessible in the public portal are retained by the authors and/or other copyright owners and it is a condition of accessing publications that users recognise and abide by the legal requirements associated with these

- Users may download and print one copy of any publication from the public portal for the purpose of private study or research.

- You may not further distribute the material or use it for any profit-making activity or commercial gain

If the publication is distributed under the terms of Article $25 \mathrm{fa}$ of the Dutch Copyright Act, indicated by the "Taverne" license above, 


\section{De rechtspositie van mensen met een verstandelijke handicap}

Van beperking naar ontplooiing 


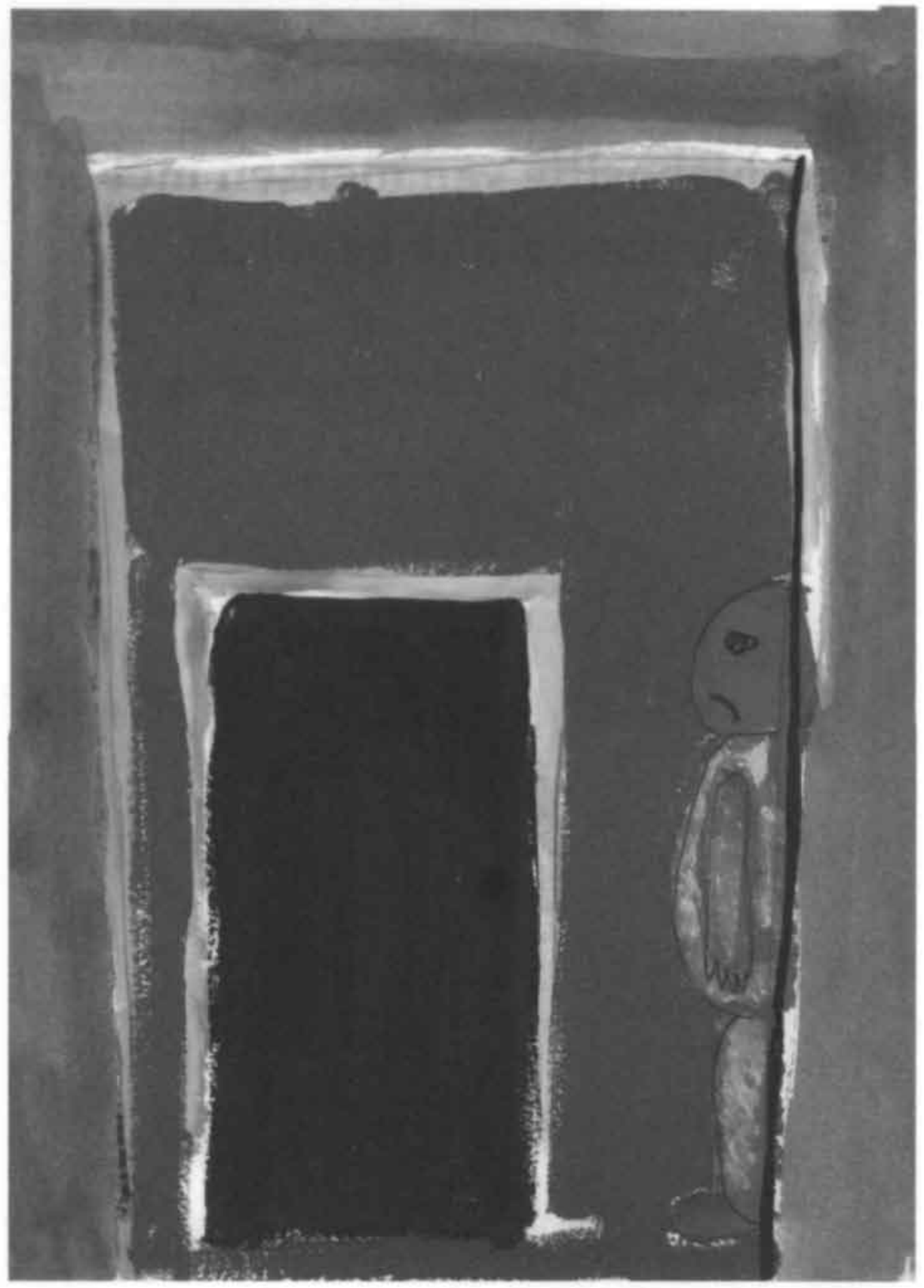

\section{'Vrijheidsbeperking vamuit het perspectief van een cliënt met een verstandelijke handicap'}

Deze tekening is gemaakt door Paul Goedhard, een cliënt met een verstandelijke handicap (groep Ambacht, Stichting Pepijn en Paulus te Echt). "Vrijheidsbeperking is een moeilijk onderwerp om over te schilderen. Cliênten die beperkt zijn in hun vrijheid' willen hier vaak niet over schilderen. Het is doorgaans een thema met een negatieve lading", aldus Conny Benders, Stichting Pepijn en Paulus. 


\title{
De rechtspositie van mensen met een verstandelijke handicap
}

\section{Van beperking naar ontplooiing}

\author{
PROEFSCHRIFT
}

ter verkrijging van de graad van doctor aan de

Universiteit Maastricht, op gezag van de

Rector Magnificus Prof. mr. G.P.M.F. Mols

volgens het besluit van het College van Decanen

in het openbaar te verdedigen op

donderdag 16 september 2004 om 14.00 uur

door

Brenda-Jolanda Maria Frederiks 
Promotor:

Co-promotor:

Beoordelingscommissie: Prof. dr. G.A.M. Widdershoven (voorzitter)

Dr.mr. K. Blankman (Vrije Universiteit Amsterdam) Prof. dr. L.M.G. Curfs

Prof. J.H. Hubben (Vrije Universiteit Amsterdam)

Prof. J.C.M. Willems (Vrije Universiteit Amsterdam/ Universiteit Maastricht)

Deze uitgave is mede mogelijk gemaakt dankzij financiële bijdragen van de Maurits van Kattendijke Stichting en de Stichting Jan Jongmans Fonds. 




\section{Voorwoord}

Toen ik in de zomer van 1998, net afgestudeerd, besloot om te gaan promoveren kreeg ik vanuit mijn omgeving niet altijd even inspirerende opmerkingen te horen: 'Ga je nu nog een studie doen?' 'Weet je zeker dat je vier jaar lang, eenzaam op een kamer, wilt gaan lezen en schrijven?' Het is niet eenvoudig om aan een buitenstaander uit te leggen wat promoveren inhoudt. Ik hoop dat dit boek (een deel van) deze vragen beantwoordt.

De gegevens die ik de afgelopen jaren heb verzameld, hoefde ik gelukkig niet eenzaam op een kamer te analyseren en uit te werken, in tegendeel. Ik heb het als zeer plezierig en motiverend ervaren dat een groot aantal mensen bij mijn onderzoek betrokken zijn geweest. Allereerst wil ik mijn promotor, Frans van Wijmen, bedanken. Hij is degene geweest die met het idee kwam om onderzoek te doen naar de rechtspositie van mensen met een verstandelijke handicap. Zijn creativiteit en gevoel voor taal kwamen regelmatig zeer goed van pas. Daarnaast wil ik Jos Dute, mijn co-promotor en dagelijks begeleider, bedanken. De onvermoeibare wijze waarop je echt elke tekst van $\mathrm{A}$ tot $\mathrm{Z}$ hebt gelezen, waardeer ik zeer. Door jouw kritische opmerkingen werd ik elke keer weer aan het denken gezet, wat niet altijid even gemákkèiijk was.

Daarnaast hebben ook de leden van de begeleidingscommissie, ieder op zich, een belangrijke bijdrage geleverd aan dit onderzoek, waarvoor mijn dank. Deze commissie bestond uit: dr. mr. K. Blankman, prof. dr. A.Th.G. van Gennep, mw. H. Luchtman- van Stekelenburg, dr. M.E.W. Melchior, drs. C. van Miert, mr. J.C.M.J. Monden en drs. W. van der Sluijs.

Kees Blankman wil ik, naast zijn bijdrage aan de begeleidingscommissie, ook bedanken voor de prettige samenwerking tijdens de evaluatie van de Wet Bopz. Hetzelfde geldt voor Luuk Arends. Tijdens onze dagen op de 'hei' hebben we ellenlange discussies gevoerd over de Wet Bopz. Nog altijd denk ik dat we niet uitgediscussieerd zijn. Uiteindelijk heeft onze samenwerking ertoe geleid dat we een alternatief wetsvoorstel hebben geschreven voor de sectoren psychogeriatrie en verstandelijk gehandicaptenzorg. Luuk en Kees, ik hoop dat we in de nabije toekomst nog meer van deze gezamenlijke projecten gaan doen en natuurlijk wordt ons eerste gezamenlijke project het dagje zeilen dat jullie nog tegoed hebben. Luuk, veel succes met de laatste loodjes.

Guy Widdershoven wil ik bedanken voor zijn 'introductie in de zorgethiek'. Regelmatig werd mij door medewerkers van de sectie gezondheidsethiek en wijs- 
begeerte verweten dat ik me, met mijn uitstapjes naar de zorgethiek, op eenhellend vlak begaf. Dit heeft naar mijn mening juist positief bijgedragen aal de ontwikkeling van mijn visie op vrijheidsbeperking.

Ook vanuit het veld heb ik zeer veel medewerking gekregen voor mijn orderzoek. In september 1998 was de verstandelijk gehandicaptenzorg nog een grote onbekende voor mij. Een korte, zeer intensieve kennismaking met het reld, waarvoor ik Monique Vollebregt wil bedanken, bracht daar snel veranderin in. Een paar maanden later kon ik deze kennismaking voortzetten. Drie voorziningen waren bereid om mee te werken aan dit onderzoek, waarvoor mijn dank. De contacten met de cliënten, de vertegenwoordigers en de hulpverleners heb is als zeer inspirerend ervaren. In welke woning ik ook kwam observeren, het afsceid viel elke keer weer zwaar.

De regionale Bopz-commissie Limburg heeft ook een belangrijke bijdrage aal dit onderzoek geleverd. Tijdens de bijeenkomsten van deze commissie zijn vershillende bepalingen uit de Bopz uitvoerig besproken en toegelicht met voorbeeden uit de praktijk. Ik ben blij dat ik als buitenstaander-zijnde een jurist- ook mocht aanschuiven. In het bijzonder wil ik bedanken Ad Willemse. In Seattle raaten wij al aan de praat over mijn onderzoek. In een later stadium was je ook bereid om de eerste versies van mijn hootdstukken van commentaar te voorzien. Daarvoor mijn dank. Dit geldt overigens ook voor Rita Zijlstra en Marian Maaskant, ook jullie hebben een aantal hoofdstukken van commentaar voorzien. Theo Verhappen, en ook Ad Willemse, wil ik nog bedanken voor het beantwoorden van de vele vragen die ik had over de praktijk. Altijd kreeg ik weer een onuitputtende lijst met voorbeelden teruggemaild.

De leden van de sectie gezondheidsrecht wil ik bedanken voor hun morele support de afgelopen jaren. Dit geldt in het bijzonder voor Nicole de Bijl, Helma Duynstee en Maartje Houtsma, die de laatste twee jaar mijn kamergenote is geweest. Ook wil ik Ineke Leeuwen bedanken voor het checken van de vele voetnoten.

Margreet Sluiter verdient ook alle lof. $\mathrm{Zij}$ ging de uitdaging aan om de samenvatting van dit boek in keurig en correct Engels te vertalen. Ook wil ik je nog bedanken voor al het andere vertaalwerk dat je de afgelopen jaren verzet hebt. Ineke Verburg wil ik bedanken voor het CRC-ready maken van het proefschrift.

Tot slot een dankwoord voor mijn twee paranimfen, Katinka van Dongen en Els Kuijper. Katinka, wij zijn praktisch gelijktijdig begonnen met promoveren en we zijn ook gelijktijdig klaar met ons 'levenswerk'. Ik vond het zeer fijn dat ik tijdens mijn promotie af en toe even mijn verhaal kwijt kon bij een 'lotgenoot'. Els, 
jouw voortdurende enthousiasme (tijdens het hardlopen, fotograferen, winkelen etc.) gaven regelmatig net die extra energie die ik nodig had om door te gaan met het proefschrift. Ik moet zeggen dat ik de afgelopen maanden onze hardloopactiviteiten enorm heb gemist! Ik hoop dat we binnenkort weer kunnen gaan hardlopen! Nog even geduld.

En, pap en mam, ik ben (voorlopig) klaar met studeren! Dank voor de onvermoeibare, lieve support van de afgelopen jaren. Ik ben blij dat ik 'vrijwillig' voor deze (lange) studieweg heb mogen en kunnen kiezen. Het wordt nu echter tijd dat ik jullie ga inhalen met Harry Potter, deel 5 ligt al veel te lang te wachten. 



\section{Inhoudsopgave}

$\begin{array}{ll}\text { Lijst van afkortingen } & 15\end{array}$

1. Inleiding 19

1.1 Aanleiding 20

1.2 Het juridische kader 22

1.3 Functie van het recht in de zorg voor mensen met een $\begin{array}{ll}\text { verstandelijke handicap } & 25\end{array}$

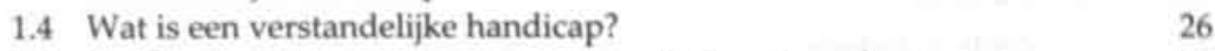

1.5 Een beschrijving van de sector verstandelijk gehandicaptenzorg 29

1.6 Recente ontwikkelingen in de zorg $\quad 31$

1.7 Terminologie $\quad 35$

$\begin{array}{lll}1.8 \text { Opzet } & 37\end{array}$

2. Methoden van onderzoek 39

2.1 Inleiding 39

2.2 Probleemstelling en vraagstellingen 40

2.3 Juridisch onderzoek 41

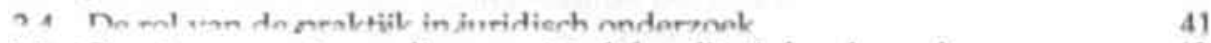

2.5 Opzet en verantwoording empirisch kwalitatief onderzoek 43

2.5.1 Twee onderzoeken $\quad 43$

2.5.2 Kwalitatief onderzoek $\quad 44$

2.5.3 Rol van de onderzoeker $\quad 45$

2.5.4 Afbakening van het onderzoek 46

$\begin{array}{lll}2.5 .5 & \text { Drie voorzieningen } & 47\end{array}$

2.5.5.1 Afspraken met voorzieningen $\quad 48$

2.5.5.2 Beschrijving van de voorzieningen $\quad 49$

2.5.5.3 Beschrijving van de woningen $\quad 50$

2.5.5.4 Beschrijving van de cliënten $\quad 53$

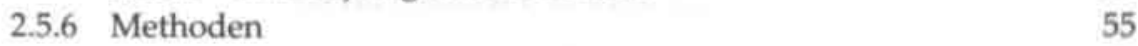

2.5.6.1 Observaties $\quad 56$

$\begin{array}{ll}2.5 .6 .2 & \text { Interviews } \\ & 58\end{array}$

2.5.6.3 Dossieronderzoek 63

2.5.7 Integratie gegevens van de tweede evaluatie Wet Bopz 64

$\begin{array}{ll}2.5 .8 & \text { Analyse van de resultaten }\end{array}$

2.6 Generaliseerbaarheid van de bevindingen 68 
3. Een normatief kader voor de interne rechtspositie van mensen met een verstandelijke handicap

3.1 Inleiding

3.2 Betekenis van het recht binnen de verstandelijk gehandicaptenzorg

3.2.1 Functie van het recht binnen de verstandelijk gehandicaptenzorg

3.2.2 Juridisering

3.3 Rechtsbeginselen in de verstandelijk gehandicaptenzorg 85

3.3.1 Inleiding

3.3.2 Zelfbeschikking

3.3.3 Bescherming

3.3.4 Goede zorg

3.3.5 Goede zorg en de zorgethiek

3.3.6 Ontplooiing

4. Goed hulpverlenerschap $\quad 115$

4.1 Inleiding 115

4.2 De juridische betekenis van goed hulpverlenerschap 116

4.3 Goed hulpverlenerschap in de zorg voor mensen met een verstandelijke handicap

4.4 Verantwoordelijkheden van een persoonlijk begeleider

4.5 Kwaliteitsnormen en kwaliteitsbeleid in de sector verstandelijk gehandicaptenzorg

4.6 Richtlijnen in de zorg voor mensen met een verstandelijke handicap

4.6.1 Richtlijnen van beroepsgroepen en voorzieningen voor mensen met een verstandelijke handicap

4.6.2 Overige richtlijnen

4.6.3 Problemen rond het formuleren van richtlijnen

4.7 Beschouwing

5. Vrijheidsbeperking: een juridische analyse

5.1 Inleiding

5.2 Het begrip vrijheidsbeperking

5.3 Criteria en motieven voor de toepassing van vrijheidsbeperking

5.3.1 Institutionele karakter

5.3.2 Onvrijwillige opneming

5.3.3 Proportionaliteit, subsidiariteit en effectiviteit

5.3.4 Motieven voor de toepassing van vrijheidsbeperking 
5.4 Vormen van vrijheidsbeperking

5.4.1 Dwangbehandeling 163

$\begin{array}{ll}\text { 5.4.2 Middelen of maatregelen } & 171\end{array}$

$\begin{array}{lll}5.4 .3 & \text { Huisregels } & 177\end{array}$

5.4.4 Beperkingen in het recht op bewegingsvrijheid 180

5.5 Waarborgen rondom vrijheidsbeperking 182

5.6 Vrijheidsbeperking bij een artikel 60 Bopz-indicatie $\quad 186$

5.7 Vrijheidsbeperking bij vrijwillig opgenomen cliënten 189

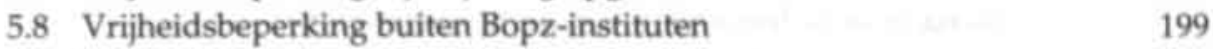

5.9 Beschouwing 201

6. Vrijheidsbeperking in de praktijk 207

$\begin{array}{ll}6.1 & \text { Inleiding } \\ 6.2 & \text { Casuintiek }\end{array}$

$\begin{array}{ll}\text { 6.2 Casuïstiek uit de praktijk } & 207\end{array}$

6.3 De rol van vrijheidsbeperking in de praktijk 211

6.3.1 Wettelijke vormen van vrijheidsbeperking in de praktijk 213

6.3.1.1 Dwangbehandeling 213

6.3.1.2 Middelen of maatregelen $\quad 215$

$\begin{array}{ll}\text { 6.3.1.3 Huisregels } & 219\end{array}$

6.3.1.4 Beperkingen in de het recht op bewegingsvrijheid 221

6.3.2 Niet-wettelijke vormen van vrijheidsbeperking in de praktijk 225

6.3.2.1 Pedagogische maatregelen 226

6.3.2.2 Begeleidingsafspraken: straffen en belonen 227

6.3.2.3 Vrijheidsbeperking buiten Bopz-instituten 228

6.3.2.4 Vrijheidsbeperking bij vrijwillig opgenomen cliënten 229

$\begin{array}{ll}6.4 & \text { Alternatieven voor vrijheidsbeperking } 230\end{array}$

$\begin{array}{ll}6.5 & \text { Registreren en melden } \\ 6.631\end{array}$

6.6 De Wet Bopz een geschikt kader? 233

$\begin{array}{ll}6.7 \text { Beschouwing } & 240\end{array}$

7. Een alternatieve regeling voor de toepassing van vrijheidsbeperking in de verstandelijk gehandicaptenzorg

7.1 Inleiding

7.2 De noodzaak van een alternatieve regeling 249

$\begin{array}{ll}7.3 & \text { Uitgangspunten alternatieve regeling } 254\end{array}$

$\begin{array}{ll}7.4 & \text { Inhoud alternatieve regeling } \\ 7.4157\end{array}$

7.4.1 De kern van de alternatieve regeling 259

7.4.2 De toepassing van vrijheidsbeperking onder de alternatieve regeling 270

$\begin{array}{ll}\text { 7.4.3 Plaats van de regeling } & 291\end{array}$

7.4.3.1 De alternatieve regeling ondergebracht in de Wet Bopz 
7.4.3.2 De alternatieve regeling ondergebracht in de Wgbo of Wgbo-plus

7.4.3.3 De alternatieve regeling vormgegeven door zelfregulering

7.4.3.4 De alternatieve regeling in een afzonderlijke wet

7.5. Kanttekeningen alternatieve regeling

7.5.1 Een aparte regeling voor de sector verstandelijk gehandicaptenzorg

7.5.2 Criteria voor de toepassing van vrijheidsbeperking: gevaar wordt vervangen door noodzaak

7.5.3 De reikwijdte van de regeling: toename van het aantal toepassingen van vrijheidsbeperking

7.5.4 De locaties van vrijheidsbeperking: onvoldoende toezicht op bepaalde locaties

7.5.5 Het begrip vrijheidsbeperking: gradaties aanbrengen

7.5.6 Toestemming van de cliënt

8. Conclusies en aanbevelingen

\section{Samenvatting}

Summary

Literatuur 


\section{Lijst van afkortingen}

$\begin{array}{ll}\text { AAMR } & \text { American Association on Mental Retardation } \\ \text { ADL } & \text { Activiteiten van het dagelijkse leven } \\ \text { ADHD } & \text { Attention Deficit Hyperactivity Disorder } \\ \text { AMvB } & \text { Algemene maatregel van bestuur } \\ \text { Atlas-ti } & \text { Archiv fuer Technik, Lebenswelt und Alltagssprache-text } \\ & \text { Interpretation } \\ \text { Art. } & \text { Artikel } \\ \text { AVVV } & \text { Algemene vergadering verpleegkundigen en verzorgenden } \\ \text { AVG } & \text { Arts voor verstandelijk gehandicapten } \\ \text { Awb } & \text { Algemene wet bestuursrecht } \\ \text { AWBZ } & \text { Algemene Wet Bijzondere Ziektekosten } \\ \text { BBI } & \text { Bisschop Bekkers Instituut } \\ \text { BUPO } & \text { Internationaal verdrag inzake burgerlijke en politieke rechten } \\ \text { BW } & \text { Burgerlijk Wetboek } \\ \text { BJ } & \text { Bopz Jurisprudentie } \\ \text { Bopz } & \text { Wet bijzondere opnemingen in psychiatrische ziekenhuizen } \\ \text { CBO } & \text { Het Kwaliteitsinstituut voor de Gezondheidszorg } \\ \text { CBZ } & \text { College Bouw Ziekenhuisvoorzieningen } \\ \text { Cvp } & \text { Cliëntenvertrouwenspersoon } \\ \text { EAT } & \text { Elektro Aversietherapie } \\ \text { ESH } & \text { Europees Sociaal Handvest } \\ \text { EHRM } & \text { Europees hof voor de rechten van de mens } \\ \text { Evrm } & \text { Europees verdrag tof bescherming van de rechten van de mens } \\ \text { FvO } & \text { en de fundamentele vrijheden } \\ \text { Gbgb } & \text { Federatie van ouderverenigingen } \\ \text { GGZ } & \text { Geen bereidheid en geen bezwaar } \\ \text { Gvt } & \text { Geestelijke gezondheidszorg } \\ \text { Gw } & \text { Gezinsvervangend tehuis } \\ \text { HR } & \text { Grondwet } \\ \text { IBS } & \text { Hoge Raad } \\ \text { ICD } & \text { Inbewaringstelling } \\ \text { ICF } & \text { International Classification of Diseases } \\ \text { IGZ } & \text { International Classification of Functioning, Disability and } \\ \text { IKG } & \text { Health } \\ \text { IQ } & \text { Inspectie voor de Gezondheidszorg } \\ \text { kBJ } & \text { Informatie- en klachtenbureau gezondheidszorg } \\ & \text { Intelligentiequotiënt } \\ & \text { Kwartaalblad Bopz Jurisprudentie (tijdschrift 1998-2000) } \\ & \end{array}$


KNMG De Koninklijke Nederlandsche Maatschappij tot bevordering der Geneeskunst

Kwz Kwaliteitswet zorginstellingen

Lvh Lichte verstandelijke handicap

MGv Maandblad Geestelijke volksgezondheid

MvT Memorie van Toelichting

MvA Memorie van Antwoord

MBO Middelbaar Beroepsonderwijs

NCvG Noordelijk Centrum voor Gezondheidsvraagstukken

NGBZ Vereniging voor deskundigheidsbevordering in de zorg voor mensen met een verstandelijke handicap

NJ

NJB

NIP

NU'91

NVAVG

NVO

NVSPH

Nwv

Nzi

$\mathrm{Pbg}$

Pvp

RIO

RIVM

RM

RMO

RVZ

SPD

Stb

Stcr

TK

TvGr

UVRM

$\mathrm{Vh}$

VGN

VN

VRK

VWS
Nederlandse Jurisprudentie

Nederlands Juristenblad

Nederlands Instituut van Psychologen

Nieuwe Unie'91, de beroepsorganisatie van de verpleging en verzorging

Nederlandse Vereniging voor Artsen in zorg voor mensen met een verstandelijke handicap (voorheen NVAVZ)

Nederlandse Vereniging van Pedagogen en onderwijskundigen

Nederiandise Vereniging voor Sociaal Pedagogisch Huipverieners

Niet-wettelijk vertegenwoordiger

Nederlands zorginstituut

Persoonsgebonden budget

Patiëntenvertrouwenspersoon

Regionaal Indicatieorgaan

Rijksinstituut voor Volksgezondheid en Milieu

Rechterlijke machtiging

Raad voor Maatschappelijke Ontwikkeling

Raad voor de Volksgezondheid en Zorg

Sociaal pedagogische dienst (sinds 1 januari 2004 MEE)

Staatsblad

Staatscourant

Tweede Kamer

Tijdschrift voor Gezondheidsrecht

Universele Verklaring van de rechten van de mens

Verstandelijke handicap

Vereniging Gehandicaptenzorg Nederland

Verenigde Naties

Verdrag inzake de rechten van het kind

Ministerie van Volksgezondheid, Welzijn en Sport 
Wet big Wet op de beroepen in de individuele gezondheidszorg

Wbp

Wgbo

Wgbh/cz

Wkcz

Wmo

Wmcz

Wvg

WvSr

Wzv

ZonMw Wet bescherming persoonsgegevens

Wet op de geneeskundige behandelingsovereenkomst

Wet gelijke behandeling gehandicapten en chronisch zieken

Wet klachtrecht cliënten zorgsector

Wet medisch-wetenschappelijk onderzoek met mensen

Wet medezeggenschap cliënten zorginstellingen

Wet voorzieningen gehandicaptenzorg

Wetboek van Strafrecht

Wet ziekenhuisvoorzieningen

ZorgOnderzoek Nederland en NWO-Medische Wetenschappen 



\section{Inleiding}

\section{Een casus uit de praktijk ${ }^{1}$}

Leonie heeft een lichte verstandelijke handicap en is 27 jaar. Zij woont sinds kort in een begeleid zelfstandige woonoorm. Ze deelt het huis met drie clïnten en heeft een eigen kamer. Leonie krijgt per week een dantal uren ondersteuning van haar persoonlijk begeleider. Leonie woonde een paar jaar geleden nog in een woning die onderdeel uitmaakte van een groot instituut. Op haar 20\% was ze met een Bopz-indicatic' opgenomen. Ze woonde samen met 8 cliënten. Zelf praat ze niet meer veel over deze periode. Het ging op dat moment ook niet goed met Leonie. Ze moest veel tijd doorbrengen op haar kamer en als het echt uit de hand liep werd $z e$ in een afzonderingsruimte' geplaatst. Een ruimte waar ze niet grang wilde zijn, aldus Leonic. Ze kon, ondanks dat ze aangaf dat $z e$ het niet eens was met deze beslissing, niet voorkomen dat ze in deze ruimte werd geplaatst. Eigenlijk wilde ze weg en ergens anders wonen. Ze mocht van de begeleiding en haar ouders niet alleen reizen, ze mocht niet met haar toenmalige vriend op stap gaan of op bezoek gaan bij haar ouders en ze mocht ook miet teveel roken of alcohol drinken. Al deze beperkingen werden haar opgelegd, zonder dat de reden ervan werd uitgelegd. Leonie verbleef op een gegeven moment alleen nog maar op haar kamer of in de afzonderingsruimte en wilde ook niet meer werken. Ze vond haar toenmalige werk niet meer leuk en wilde graag schilderen in het atelier, dat onderdeel uitmaakte van de stichting waar ze woonde. Ze belandde in een vicieuze cirkel, die moeilijk te doorbreken was. Het verzet dat ze in eerste instantie nog tegen haar verbliff toonde verdween spoedig.

De afgelopen jaren is er veel veranderd in het leven van Leonie. Door een fusie van het instituut met een andere stichting moest keonie verhuizen. Ze werd, ondanks haar Bopz-

1 Deze casus is fictief. De namen en gebeurtenissen zijn verzonnen om een realistisch beeld te geven van het leven van een cliënt met een verstandelijke handicap.

2 Een cliënt met een verstandelijke handicap wordt met een Bopz-indicatie opgenomen als hij (vanwege zijn verstandelijke handicap) niet in staat is verzet of bereidheid ten opzichte van de noodzakelijk geachte opname en voortgezet verblijf kenbaar te maken.

3 Een afzonderingsruimte is een ruimte die wordt gebruikt om een cliënt met een verstandelijke handicap op een verantwoorde wijze af te zonderen in het kader van de Wet Bopz. Dit in verband met dreigend gevaar voor de cliënt of diens omgeving. De ruimte dient sober (prikkelarm) en veilig te zijn ingericht. College voor Ziekenhuisvoorzieningen, Bouwkundige-functionele maatstaven ten behoeve van nieuwbouwplannen voor afzonderingsvoorzieningen in de verstandelijk gehandicaptenzorg, Rapportnummer 075, Utrecht: 1999. 
indicatie, geplaatst in een gezinsvervangend tehuis (got)'. In het begin verbleef Lecnie veel op haar eigen kamer. Het was niet eenvoudig om te wennen aan de nieuwe woo $15 i$ tuatie. Theo, haar nieuwe persoonlijk begeleider, vond echter dat er iets moest gebetiren met Leonie. Haar ontwikkeling stond al jaren stil en de nabije toekomst zag er op ceze manier niet echt rooskleurig uit. Het kostte heel wat moeite om een band op te bouthen met Leonie. Maar, na een paar maanden lukte het Theo om Leonie uit haar isolement te halen. De wensen van Leonie werden vastgelegd in haar zorgplan. Theo zou op zock gian naar een andere baan voor haar. Ook werden duidelijke afspraken gemaakt over het roten en het drinken van alcohol. Haar moeder was het in eerste instantic niet eens met al drze beslissingen. Het kostte behoorlijk wat overredingskracht van Theo om aan de ouders uit te leggen dat het op deze manier veel beter met Leonie zou gaan. Ze maakte bijna gien ruzie meer met andere clï̈nten, waardoor ze nog maar zelden naar haar kamer werd stuurd. Toen op een gegeven moment de gelegenheid zich voordeed dat Leonie naar rn kleinere woning kon verhuizen met minder cliënten, wat haar gedrag gunstig kon b $\boldsymbol{c}_{\mathrm{in}}$ vloeden, werd in overleg met de ouders besloten om deze stap te nemen. Het feit dai $z e$ nog steeds in het bezit was van een Bopz-indicatie deed geen afbreuk aan deze beslissir ${ }_{\mathrm{g}}$.

\section{$1.1 \quad$ Aanleiding}

Deze casus illustreert (een deel van) de problematiek die zich kan voordoen in

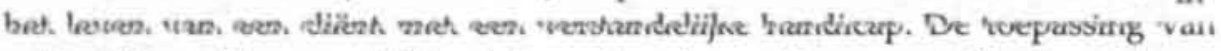
vrijheidsbeperking vormt hier de kern. Leonie wordt op verschillende manieren geconfronteerd met vrijheidsbeperking: verplicht op haar kamer blijven, in een afzonderingsruimte worden geplaatst, afspraken over alcohol en roken en afspraken over de omgang met haar vriend. Ze is zeven jaar geleden het instituut binnen gekomen met een Bopz-indicatie, omdat ze bij opneming noch bezwaar maakte, noch kon aangeven dat ze bereid tot opneming was. Deze Bopz-indicatie zegt echter nog niets over de toepassing van vrijheidsbeperking. Pas als sprake is van gevaar voor Leonie zelf of voor anderen mag zij, tegen haar wil, in haar vrijheid worden beperkt. Leonie toonde verzet tegen de toepassing van vrijheidsbeperking. Ook wilde ze eigenlijk niet meer in het instituut blijven. Haar verzet heeft niet geleid tot een andere juridische status.

Ook nu ze niet meer in een instituut met een Bopz-aanmerking woont, heeft ze nog steeds dezelfde juridische status. Het aanvragen van een rechterlijke machtiging had ertoe kunnen bijdragen dat een rechter de schrijnende situatie van Leonie was komen beoordelen. Uiteindelijk wist het personeel, zonder acht te

4 Een gvt is een voorziening die wordt gerekend tot de semi-murale zorg. Een Bopz-indicatie biedt geen bescherming aan cliënten die woonachtig zijn in een gvt: de Wet bijzondere opnemingen psychiatrische ziekenhuizen (de Wet Bopz) is vooralsnog niet van toepassing in de semi-murale zorg. 
slaan op de juridische status van Leonie, dankzij de juiste ondersteuning en begeleiding, de vicieuze cirkel, waarin Leonie zich bevond, te doorbreken. De bovenstaande casus laat ook de spanning zien tussen praktijk en wetgeving in de zorg voor mensen met een verstandelijke handicap. De Wet Bopz biedt in deze casus niet de bescherming die de wetgever met deze wet beoogt te bereiken.

Hoe schrijnend de situatie van Leonie in het begin ook was, in haar geval kan uiteindelijk toch nog worden gesproken van een succesverhaal dat niet voor alle cliẻnten in de verstandelijk gehandicaptenzorg opgaat. Recente gegevens laten zien dat een dwangbehandeling gemiddeld langer dan een jaar duurt. Deze cliënten wordt de mogelijkheid om een ontwikkeling door te maken vooralsnog onthouden. Daarvoor zijn verschillende redenen aan te wijzen. In de eerdergenoemde casus konden de wensen van Leonie inzichtelijk worden gemaakt. De helft van de cliënten heeft echter een dusdanige ernstige verstandelijke handicap dat zij minder goed in staat zijn om hun wensen kenbaar te maken. Een bijkomend probleem bij deze cliènten is, dat de oorzaak van eventuele gedragsproblemen niet eenvoudig te achterhalen is. Dit alles betekent dat de mate waarin cliënten een ontwikkeling kunnen doormaken deels afhankelijk is van de kwaliteiten van hulpverleners. Het is uiteindelijk de hulpverlener die beslist, weliswaar in overieg met de cliënt en/of zijn vertegenwoordiger, of een cliënt in zijn vriiheid wordt benerkt. Deze beslissing zal een hulbverlener moeten verantwoorden door aan te tonen dat minder ingrijpende oplossingen onvoldoende bescherming bieden aan een cliënt. Daarnaast zal hij aannemelijk moeten maken dat vrijheidsbeperking een bijdrage levert aan de verdere ontwikkeling van een cliënt. Dit laatste is geen eenvoudige opgave. Op bepaalde momenten heeft een hulpverlener geen andere keuze en moet hij ingrijpen in het leven van een cliënt. In deze studie wordt het uitgangspunt gehanteerd dat elke toepassing van vrijheidsbeperking, voor zover mogelijk is, een bijdrage moet leveren aan de ontplooiing van cliënten. Aldus zijn begrippen als goed hulpverlenerschap en goede zorg onlosmakelijk verbonden met vrijheidsbeperking.

In het verleden is een aantal studies verricht naar de rechtspositie van cliënten in relatie tot de toepassing van vrijheidsbeperking. Een tweetal ervan betrof de rechtspositie van de gedwongen opgenomen psychiatrische patiënt ${ }^{5}$ en één had als onderwerp de vrijwillig opgenomen psychiatrische patiënt. ${ }^{6}$ Een vergelijkbaar juridisch onderzoek op het gebied van de rechtspositie van mensen met een verstandelijke handicap ontbreekt tot nu toe. Deze studie beoogt deze achter-

5 P.J.H. Laurs, Recht voor psychiatrische patiënten (diss. Utrecht), Arnhem: Gouda Quint 1988 en C.J. van de Klippe, Dwangtoepassing na onvrijwillige psychiatrische opname (diss. Amsterdam UvA), Nijmegen: Ars Aequi Libri 1997.

6 J. Legemaate, De rechtspositie van vrijwillig opgenomen psychiatrische patiënten (diss. Amsterdam UvA), Arnhem: Gouda Quint 1991. 
stand weg te werken. Door middel van juridisch en empirisch onderzoek wodt de problematiek rondom de toepassing van vrijheidsbeperking in de zorg vor mensen met een verstandelijke handicap in kaart gebracht. De nadruk ligt ople interne rechtspositie van cliënten, waaronder hier wordt verstaan de waarbrgen waar cliënten aanspraak op kunnen maken als zij tijdens hun verblijf in en voorziening worden geconfronteerd met vrijheidsbeperking. De inhoud van it boek biedt zowel voor (gezondheids)juristen als mensen uit de zorgprakfik nieuwe inzichten in de rechtspositie van mensen met een verstandelijke hanicap. Behalve de rechtsbeginselen bescherming en zelfbeschikking is de aandant gericht op het recht op goede zorg en, een voor de verstandelijk gehandicaptnzorg nieuw rechtsbeginsel, het recht op ontplooiing. De centrale vraag in dee studie luidt: 'Wat is de (interne) rechtspositie van cliënten in de zorg voor mensen ret een verstandelijke handicap in relatie tot de toepassing van vrijheidsbeperking, hoe krgt deze in de praktijk gestalte en welke aanbevelingen kunnen terzake worden gedaan? 'n hoofdstuk 2, methoden van onderzoek, wordt de probleemstelling nader toeelicht en uitgewerkt in een aantal vraagstellingen. In de volgende paragratn vindt een verkenning plaats van de sector verstandelijk gehandicaptenzorg. Fet begrip verstandelijke handicap wordt nader toegelicht. Ook wordt een beschijving gegeven van de sector: hoeveel cliënten met een verstandelijke handiep kent Nederland, waar wonen deze cliënten en welke ontwikkelingen zijner gaande in de sector verstandelijk gehandicaptenzorg.

\subsection{Het juridische kader}

De casus, die aan het begin van dit hoofdstuk is neergezet, illustreert dat met name de vrijheid van de cliënt in het geding is. Een hulpverlener mag deze alleen beperken als wordt voldaan aan bepaalde voorwaarden die zijn vastgelegd in de Wet bijzondere opnemingen in psychiatrische ziekenhuizen (Wet Bopz). Deze wet maakt onderdeel uit van een serie patiëntenwetten die in de jaren negentig van de vorige eeuw door de wetgever is geïntroduceerd. Deze wetgeving is niet alleen gericht op een verbetering van de kwaliteit van de gezondheidszorg maar heeft vooral betrekking op de verbetering van de individuele gezondheidszorg. Dit blijkt onder meer uit de patiëntenwetten die op dit terrein tot stand zijn gekomen: de Wet op de geneeskundige behandelingsovereenkomst (Wgbo), de Wet bijzondere opnemingen in psychiatrische ziekenhuizen (Wet Bopz), de Wet bescherming persoonsgegevens (Wbp), de regeling curatele, de regeling mentorschap en de regeling bewindvoering, de Wet op de orgaandonatie, de Wet medisch-wetenschappelijk onderzoek met mensen (Wmo), de Wet klachtrecht cliënten zorgsector (Wkcz) en de Wet medezeggenschap cliënten zorginstellingen (Wmcz). Deze wetten leveren ieder op hun eigen manier een bijdrage aan de verbetering van de rechtspositie van cliënten in de verstandelijk gehandicaptenzorg. Naast het creëren van duidelijkheid over de rechten van 
cliënten, worden ook de taken en bevoegdheden van hulpverleners en vertegenwoordigers in relatie tot de cliënt inzichtelijk gemaakt.

In deze studie ligt de nadruk op de Wet Bopz; niet onbelangrijk is daarnaast de Wgbo. Beide wetten zijn van toepassing in de verstandelijk gehandicaptenzorg. De reikwijdte van deze wetten vormt overigens nog regelmatig een punt van discussie. In de beginfase van het ontwerp van de Wet Bopz viel de sector verstandelijk gehandicaptenzorg niet onder het bereik van deze wet. Deze sector is pas in een later stadium onder de reikwijdte van het wetsvoorstel gebracht. Om te voorkomen dat de rechterlijke macht overspoeld zou worden met aanvragen voor rechterlijke machtigingen voor cliënten in deze sector, is de procedure voor een Bopz-indicatie toegevoegd. Dit betekent dat een cliënt met een verstandelijke handicap die niet kan aangeven of hij bereid is tot een opneming dan wel bezwaar heeft tegen opneming niet van tevoren wordt gezien door een rechter, in tegenstelling tot in de psychiatrie.

Centraal in de Wgbo staat de overeenkomst die in alle vrijheid tussen een hulpverlener en een cliënt wordt gesloten. De wetgever beperkt de reikwijdte van deze wet door de nadruk te leggen op geneeskundige handelingen (artikel 7:446 lid 1 BW), waardoor alleen handelingen die op het gebied van de geneeskunst worden verricht onder de reikwijdte van deze regeling vallen. ${ }^{7}$ Deze bepaling heeft ook consequenties voor de verstandelijk gehandicaptenzorg. Alleen in die gevallen waar geneeskundige handelingen worden verricht, is sprake van een geneeskundige behandelingsovereenkomst in de zin van de Wgbo. In de zorg voor mensen met een verstandelijke handicap ligt het accent doorgaans niet op het verrichten van geneeskundige handelingen, maar op het ondersteunen van cliënten. Een groot deel van de dagelijkse zorg komt voor rekening van een persoonlijk begeleider. Ook vervult de gedragsdeskundige een belangrijke rol bij het bieden van zorg aan cliënten. De schakelbepaling artikel 7:464 BW biedt nog een mogelijkheid om de inhoud van de Wgbo van overeenkomstige toepassing te verklaren op de sector verstandelijk gehandicaptenzorg. Deze bepaling heeft vrijwel geen toegevoegde waarde in deze sector. Het gaat (wederom) om geneeskundige handelingen die bovendien niet in het kader van een overeenkomst worden verricht. Als voorbeeld noemt de wetgever een gedwongen verpleging

7 De wetgever hanteert een strikte interpretatie van het begrip geneeskundige handelingen. In de MvT wordt opgemerkt dat er geen reden is om activiteiten die in uiteenlopende omstandigheden door allerlei personen en instellingen kunnen worden gepleegd (...) onder de wet te brengen zijn. Indien de relatie met het begrip geneeskunst wordt losgelaten zal in te veel situaties omtrent de toepasselijkheid van de regeling onduidelijkheid ontstaan (Kamerstukken II 1989. 90,21561 , nr. 3, p. 9-10). 
in een tbs-kliniek. ${ }^{5}$ Tussen het merendeel van de cliẻnten en de voorziening waar een cliënt komt te wonen wordt echter een overeenkomst gesloten. Een uitzondering dient te worden gemaakt voor de cliënten die gedwongen worden opgenomen.' Om onduidelijkheid in de sector verstandelijk gehandicaptenzorg te voorkomen, dient de inhoud van de Wgbo analoog te worden toegepast op de zorg die wordt verleend aan vrijwillig en onvrijwillig opgenomen cliënten. Deze wet kent een aantal basale uitgangspunten die ook in deze sector in acht moet worden genomen..$^{10}$ Het zou niet terecht zijn als cliënten in de somatiek en de psychiatrie wel een beroep kunnen doen op de rechten die in de Wgbo zijn neergelegd en cliënten in de zorg voor mensen met een verstandelijke handicap niet." Dit zou leiden tot ongelijke rechtsposities. Een soortgelijke discussie kan worden gevoerd over de reikwijdte van de Wet Bopz. In deze wet is het doel van het behandelingsplan het verbeteren of het wegnemen van de stoornis zodanig dat het gevaar wordt weggenomen (artikel 38 lid $3 \mathrm{Bopz}$ ). In de sector verstandelijk gehandicaptenzorg is het niet eenvoudig om aan deze doelstelling tegemoet te komen. Toch is de Wet Bopz van toepassing in deze sector.

Ondanks een omvangrijk juridisch kader bestaan zowel in theorie als in praktijk nog onduidelijkheden over de rechtspositie van mensen met een verstandelijke handicap. Een cliënt die in een gvt woont mag niet worden beperkt in zijn vrijheid. Vanuit deze gedachte geniet hij meer rechtsbescherming dan een cliënt die in een instituut met een Bopz-aanmerking woont en die op grond van de Wet Bopz wel in zijn vrijheid mag worden beperkt. De praktijk laat evenwel een ander beeld zien. De populatie in een gvt verschilt steeds minder van cliënten die

8 Kamerstukken II 1989-1990, 21 561, nr. 3, p. 46-47.

9 Onvrijwillig opgenomen cliënten vormen echter een minderheid in de zorg voor mensen met een verstandelijke handicap: meer dan $70 \%$ van de cliënten is vrijwillig opgenomen, zie hoofdstuk 5.

10 In de kamerstukken zijn ook enkele aanknopingspunten te vinden voor deze opvatting. In de nadere memorie van antwoord wordt opgemerkt dat 'voor zover de wet in verpleeghuizen niet van toepassing zou zijn, in de praktijk zoveel mogelijk gehandeld zal worden overeenkomstig de regels van het wetsvoorstel' (Kamerstukken II 1991-92, 21 561, nr. 11, p. 18-19).

Gevers is ook van mening dat de Wgbo buiten zijn formele toepassingsgebied een uitstralende werking heeft (J.K.M., Gevers "De toepassing van de WGBO in a-typische situaties", Tijdschrift voor Gezondheidsrecht (20) 1996-1, p. 8-15).

11 In de Memorie van Toelichting bij het wetsontwerp van de Wgbo wordt opgemerkt dat de normen van deze regeling zoveel als mogelijk is moeten gelden voor onvrijwillig opgenomen psychiatrische patiënten (Kamerstukken II 1991-92, $21561, \mathrm{nr} .3$, p. 51). 
in een instituut wonen, ${ }^{12}$ waardoor in een gvt ook vrijheidsbeperkende maatregelen nodig kunnen zijn. De Wet Bopz is echter niet van toepassing in deze setting, waardoor een cliënt feitelijk minder rechtsbescherming geniet dan een cliênt die in een instituut woont. Het huidige juridische kader geeft ook geen duidelijk antwoord op de vraag op welke wijze hulpverleners de juiste balans kunnen vinden tussen de waarden: bescherming en zelfbeschikking. Van het recht mag echter worden verwacht dat daarin grenzen worden aangegeven voor hulpverleners. Uiteraard kan niet alles in wetgeving worden vastgelegd. In samenwerking met de praktijk dienen deze grenzen nader ingevuld te worden. De spanning tussen deze twee waarden is terug te vinden in rechtsvragen omtrent de toepassing van vrijheidsbeperking, privacy, vertegenwoordigingsvraagstukken en goed hulpverlenerschap. In deze studie wordt afstand genomen van de tegenstelling tussen bescherming en zelfbeschikking. De aandacht verschuift naar goede zorg en ontplooiing van cliënten. Bekeken zal worden op welke wijze deze begrippen ook terug te vinden zijn in het huidige juridische kader. Op plaatsen waar deze begrippen onvoldoende worden benadrukt, zal huidige wetgeving mogelijk plaats moeten maken voor alternatieve regelingen. Hoofdstuk 7 introduceert een alternatieve Wet Bopz voor de sector verstandelijk gehandicaptenzorg.

\subsection{Functie van het recht in de zorg voor mensen met een verstandelijke handicap}

Hoewel de rechtspositie van cliënten met een verstandelijke handicap de afgelopen jaren verbeterd is door de komst van een arsenaal aan patiëntenwetgeving, is het van belang dat voor deze cliënten extra maatregelen worden getroffen. Legemaate acht de enkele gelijkstelling van de rechtspositie van vrijwillig opgenomen psychiatrische patiënten met ğje van patiënten in de algemene gezondheidszorg uit het oogpunt van rechtsbescherming niet toereikend. ${ }^{13}$ Hij stelt voor om voor deze cliënten speciale voorzieningen te treffen, in de sfeer van rechtshandhaving. ${ }^{14}$ Deze redenering gaat ook op voor de verstandelijk gehan-

12 Dit geldt overigens niet voor de groep cliënten met een (zeer) ernstige handicap. Deze groep bevindt zich voornamelijk nog in instituten.

13 Hij wijst op een aantal factoren waaronder de duur van het verblijf, de elementen van dwang en de aard en ingrijpendheid van een psychiatrische behandeling die tot een ongelijke relatie tussen een patiënt en de hulpverlener leiden. Deze relatie is ongelijker dan in de algemene gezondheidszorg doorgaans het geval is (Legemaate 1991, p. 24-25).

14 Legemaate 1991, p. 24-25. Legemaate baseert zich daarbij ook op eerdere publicaties van Roscam Abbing en Kelk, waarin wordt gewezen op de negatieve in- 
dicaptenzorg. Eén van de functies van het recht is om te voorkomen dat de vriiheid van cliënten zonder duidelijke argumentatie wordt beperkt. De wetgever heeft de mogelijkheid om voorwaarden te stellen aan het toepassen van vrijheidsbeperkende maatregelen. Van de Klippe stelt dat deze voorwaarden dienen om hulpverleners in staat te stellen de opdracht, die zij in het kader van de wet hebben, naar behoren uit te oefenen. $\mathrm{Zij}$ gaat echter uit van een enge opdracht voor de hulpverlener, namelijk het afwenden van uit de geestesstoornis voortvloeiend gevaar. ${ }^{15}$ Deze zinsnede is afkomstig uit de Wet Bopz ${ }^{16}$ en veronderstelt dat het zelfbeschikkingsrecht van cliënten zoveel mogelijk gerespecteerd moet worden. Dit uitgangspunt is te beperkt voor de verstandelijk gehandicaptenzorg. De functie van het recht dient in deze sector niet alleen gericht te zijn op het voorkomen van gevaarlijke situaties, maar kent een ruimere doelstelling: het bieden van goede zorg. De opdracht aan een hulpverlener dient zodanig te zijn dat hij een cliënt ondersteuning biedt om zich verder te kunnen ontwikkelen. Dit betekent dat naast het bevorderen van de zelfbeschikking van cliënten, het ook tot de taken van een hulpverlener kan behoren om een cliënt in bescherming te nemen. Deze verruiming van de bevoegdheden van hulpverleners verplicht de wetgever om extra toezicht te houden op het handelen van hulpverleners. In dat kader wordt van hulpverleners verlangd dat zij zich toetsbaar opstellen.

\subsection{Wat is een verstandelijke handicap?}

Het begrip verstandelijke handicap is niet eenvoudig te omschrijven. De afgelopen jaren zijn verschillende (nieuwe) definities van dit begrip gegeven. De American Association on Mental Retardation (AAMR) is in 2002 met een nieuwe definitie gekomen: 'Een verstandelijke handicap verwijst naar functioneringsproblemen die worden gekenmerkt door significante beperkingen in zowel het intellectuele functioneren als in het adaptieve gedrag zoals dat tot uitdrukking komt in conceptuele, sociale en praktische vaardigheden. De functioneringsproblemen ontstaan vóór de leeftijd

vloed van een instituut. Beide publicaties dateren echter uit de jaren tachtig van de vorige eeuw. Inmiddels is een arsenaal aan patiëntenwetgeving ontstaan (H.D.C. Roscam Abbing, In de beperking toont zich de meester (inagurale reden Maastricht), Alphen aan den Rijn: Samsom Uitgeverij 1983, p. 15 en C. Kelk, Recht voor geïnstitutionaliseerden: de functies van het recht in penitentiaire inrichtingen, psychiatrische ziekenhuizen en andere totale instituties (inaugurale reden Utrecht), Arnhem: Gouda Quint 1983).

15 Van de Klippe 1997, p. 8-9.

16 Artikel 38 lid 5 Bopz en artikel 39 lid 1 Bopz. 
van 18 jaar' ${ }^{\prime}$ w " Deze definitie illustreert dat meerdere factoren bepalend zijn voor het vaststellen van een verstandelijke handicap. Een persoon moet allereerst significante beperkingen in het intellectueel functioneren ondervinden, ook moet sprake zijn van aanwezige significante beperkingen in adaptieve vaardigheden die met de intellectuele beperkingen samenhangen en niet te wijten zijn aan andere stoornissen of belemmeringen vanuit de omgeving. Tot slot moeten de beperkingen zijn ontstaan voor het achttiende levensjaar. Als een persoon voldoet aan alle drie de kenmerken, kan worden gesproken van een verstandelijke handicap.

De AAMR heeft, naast een definitie voor het vaststellen van een verstandelijke handicap, ook een model ontwikkeld, op grond waarvan de vorm en de intensiteit van ondersteuning kunnen worden bepaald. In dit model wordt benadrukt dat de vraag of sprake is van een verstandelijke handicap, oftewel een beperking in het menselijk functioneren, voor een groot deel wordt bepaald door de omgeving. ${ }^{19}$ Dit model onderscheidt vijf dimensies van het menselijk functioneren, die onderling met elkaar samenhangen. Het model is gebaseerd op de gedachte dat een beperking in de ene dimensie in samenhang met de andere dimensies moet worden gezien. Het hebben van een goede gezondheid zegt nog niets over de wijze waarop een persoon in zijn functioneren wordt beperkt. Het betreft de volgende vijf dimensies:

17 R. Luckasson, S. Brothwick-Duffy, W. Buntinx, D. Coulter, P. Craig, R. Schalock, M. Snell, D. Spitalnik, S. Spreat en M. Tassé, Mental Retardation: Definition, Classification and Systems of Supports, Washington: American Association on Mental Retardation 2002.

18 W.H.E. Buntinx, "Wat is een verstandelijke handicap? Definitie, assessment en ondersteuning volgens het AAMR-model", Nederlands Tijdschrift voor de Zorg aan verstandelijk gehandicapten (29) 2003-1, p. 8-9.

19 De ICF heeft ook een model ontwikkeld om functioneringsproblemen in kaart te brengen (World Health Organization, ICF, International Classification of Functioning, Disability and Health, Geneva: WHO 2001). Dit model kan, in vergelijking met het AAMR model, worden gezien als een algemeen model om functioneringsproblemen te begrijpen. Het AAMR model is speciaal toegespitst op mensen met een verstandelijke handicap. De omgeving vervult in het ICF model ook een belangrijke rol (W.H.E. Buntinx, "De 'International Classification of Functionining Disability and Health' (ICF) en de nieuwe definitie van verstandelijke handicap van de American Assocaiation on Mental Retardation", in: G.H.M.M. ten Horn, W.H.E. Buntinx, R. Habekothé, E.Th. Klapwijk, W.A.I. van Leeuwen \& B. van Zijderveld (red.), Handboek mogelijkheden, Vraaggerichte zorg voor mensen met een verstandelijke handicap (L.10.2.2: 1-26), Maarssen: Elsevier 2002). 
1. Verstandelijke mogelijkheden: onder deze dimensie wordt verstaan de intelligentie zoals deze wordt gemeten met intelligentietests.

2. Adaptief gedrag: deze dimensie is een verzamelbegrip voor conceptuele, sociale en praktische vaardigheden die een persoon nodig heeft om in het dagelijkse leven te kunnen functioneren. Naast activiteiten van het dagelijks leven (ADL) wordt in dit kader ook gewezen op het onderhouden van contacten en de vaardigheden om te schrijven en te lezen.

3. Participatie, interactie, sociale rollen: deze dimensie beoordeelt in hoeverre personen in staat zijn om te functioneren in verschillende settings. Een aantal van deze settings zijn het werk, de woning, familie- en vriendenkring en vrije tijd. Van een persoon zal een andere rol worden verwacht als hij zelfstandig woont in plaats van in een woonvoorziening met voldoende begeleiding.

4. Gezondheid: de lichamelijk en geestelijke gezondheid van een persoon is bepalend voor het functioneren van een persoon.

5. Context: deze laatste dimensie heeft betrekking op de totale omgeving waarin een persoon functioneert.

Een cliènt met een verstandelijke handicap heeft er belang bij dat zijn functioneringsproblemen in kaart worden gebracht. Aan de hand van een dergelijke beschrijving is het mogelijk om een profiel van ondersteuningsbehoeften te ontwikkelen. ${ }^{20}$ Het doel is om met voldoende en individueel toegesneden ondersteuning het functioneren van een cliënt met een verstandelijke handicap te verbeteren op elk van de vijf dimensies. ${ }^{21}$ In het kader van vraaggestuurde zorg verdient het aanbeveling om de keuze voor de vorm en intensiteit van ondersteuning zoveel mogelijk te laten bepalen door de cliënt zelf en/of zijn vertegenwoordiger. $\mathrm{Er}$ bestaat ook een verband tussen het AAMR model en goede zorg. Op grond van dit model kan onder goede zorg worden verstaan, zorg die rekening houdt met de vijf dimensies die in het model van de AARM worden genoemd.

In de definitie van de AAMR wordt ook het IQ richtinggevend geacht voor de bepaling van een verstandelijke handicap. In de sector verstandelijk gehandicaptenzorg wordt over het algemeen een vaste indeling gehanteerd die gebaseerd is op ICD-10, een classificatiestandaard van de World Health Organiza-

20 Buntinx 2003, p. 4-24.

21 Het AAMR model verdeelt ondersteuning in negen gebieden: ontwikkeling, onderwijs en opvoeding, huiselijke activiteiten, leven in de lokale samenleving, werken, gezondheid en veiligheid, gedrag, sociale activiteiten en behartigen van eigen belangen (Buntinx, 2003). 
tion. ${ }^{2}$ Met de kennis van de AAMR en de International Classification of Functioning (ICF) mag duidelijk zijn dat het IQ niet allesbepalend is, maar slechts een indicatie geeft voor de aanwezigheid van een verstandelijk handicap.

\section{Tabel 1. Bepaling verstandelijke handicap aan de hand van IQ}

\begin{tabular}{|l|l|l|}
\hline Mate van verstandelijke handicap & IQ & Verstandelijke leeftijd ${ }^{23}$ \\
\hline Licht & $50-69$ & Tussen 9 en 12 jaar \\
\hline Matig & $35-49$ & Tussen 6 en 9 jaar \\
\hline Ernstig & $20-34$ & Tussen 3 en 6 jaar \\
\hline Zeer ernstig & 20 & Onder 3 jaar \\
\hline
\end{tabular}

\subsection{Een beschrijving van de sector verstandelijk gehandicaptenzorg}

\section{De omvang van de sector}

In totaal kent Nederland circa 103.000 mensen met een verstandelijke handicap, waarvan 53.000 cliënten een ernstige verstandelijke handicap hebben. Deze gegevens zijn gebaseerd op het onderzoek van Maas et al. ${ }^{24}$ In een meer recent onderzoek, dat uitgevoerd is in Limburg, ${ }^{25}$ wordt het aantal mensen met een verstandelijke handicap geschat op 111.000. De variatie die bestaat tussen de uitkomsten van de verschillende prevalentie-onderzoeken wordt mogelijk veroorzaakt door de methode van onderzoek en de verschillende definities die worden gehanteerd. Het aantal mensen met een verstandelijke handicap is tussen 1986 en 1999 gestegen met 7\%. De oorzaak voor deze toename is voor een deel terug te voeren op een hogere kwaliteit van zorg in de verstandelijk gehandicaptenzorg. Mensen met een verstandelijke handicap hebben een verbeterde levensverwachting gekregen. De verwachting is dat deze verbetering zich in de nabije toekomst voortzet, waardoor het aantal 50 -plussers met een verstandelijke handicap zal toenemen. Onduidelijk is nog wat de effecten zullen zijn van prenatale diagnostiek en de toename van de gemiddelde leeftijd waarop vrouwen kinderen krijgen. ${ }^{26}$

22 World Health Organization, International statistical classification of diseases and related health problems (10th ed.), Geneva: Author 1993.

23 In ICD-10 wordt ook de verstandelijke (volwassen) leeftijd genoemd waarmee cliënten met een bepaald $1 Q$ kunnen worden vergeleken.

24 J.M.A.G. Maas, S. Serail en A.J.M. Janssen., Frequentieonderzoek geestelijke gehandicapten 1986, Tilburg: IVA, 1988.

25 H.M.J. Schrojenstein Lantman-de Valk, E.W.A. van Heurn-Nijsten, M. Wullink, Prevalentie-onderzoek mensen met een verstandelijke beperking in Nederland, Maastricht: Universiteit Maastricht, Capaciteitsgroep huisartsgeneeskunde, 2002.

$26 \mathrm{http}: / / w w w \cdot r i v m \cdot n l$ 


\section{Hoofdstuk 1}

\section{Soorten voorzieningen}

De sector verstandelijk gehandicaptenzorg bestrijkt een breed terrein. Cliënen met een verstandelijke handicap wonen en werken verspreid over verschillerde voorzieningen of wonen thuis. Het merendeel van de cliënten, in totaal mer dan 37.000 , is nog steeds woonachtig in instituten..$^{2}$ Deze voorzieningen beholen tot de intramurale zorg. Op 1 januari 2002 kent de sector verstandelijk gehandicaptenzorg 154 instellingen met een totale capaciteit van 37.333 bedden.28 29 ten kenmerk van intramurale voorzieningen is dat zij 24-uur per dag ondersteuning bieden aan cliënten. Daarnaast beschikken zij doorgaans over speciale afdeingen voor cliënten met onder meer autisme, een meervoudige ernstige verst ${ }_{\text {in }}$ delijke handicap en gedragsproblemen. Sociowoningen worden ook gerekend tot de intramurale zorg. $\mathrm{Zij}$ maken onderdeel uit van een instituut, maar bev $\mathrm{i}_{\mathbf{n}}$ den zich doorgaans in de buurt van het instituut. Een ander deel van de cliënen is te vinden in de semi-murale sector. Dit gedeelte van de sector biedt plaats an 17.600 cliënten. ${ }^{*}$

In het rapport van Schrojenstein Lantman et al wordt gesproken over cliënen die gebruik maken van ondersteund wonen (53.000) en cliënten die zelfstantig of thuis wonen (58.000)." ${ }^{31}$ Onder ondersteund wonen wordt verstaan cliënten tie in een instelling voor 24-uurs zorg wonen, gvt'en, voorzieningen voor begelid zelfstandig wonen en individueel zelfstandig wonen. Er wordt geen onderschid meer gemaak't tussen intramurale en sem-murale voorzieningen. Tusseñ bède vormen van voorzieningen bestonden in het verleden duidelijke verschillen. Een belangrijk verschil is dat cliënten van semi-murale voorzieningen overdag doorgaans naar dagbesteding zijn, dat zich op een ander locatie bevindt. Alleen in de uren dat cliënten niet naar hun werk gaan wordt door hulpverleners ondersteuning geboden. Het onderscheid tussen een instituut en een gvt is de laatste jaren

27 http://www.rivm.nl

28 L.P. Bartels, Instellingen van intramurale gezondheidszorg, Basisgegevens per 1-12002, Utrecht: Prismant 2002.

29 Van Gennep wijst erop dat de sector verstandelijk gehandicaptenzorg op het gebied van instituten achter loopt met andere landen. In Nederlands is min of meer sprake van een tweedeling in de zorg voor mensen met een verstandelijke handicap. Enerzijds wonen nog altijd veel cliënten in een instituut en anderzijds maakt ook een deel van de cliënten gebruik van ondersteuning in de samenleving (A.Th.G. van Gennep, De Tweedeling (Afscheidsrede Maastricht) Maastricht 2002). Daarbij moet wel de opmerking worden gemaakt dat instituten aan het veranderen zijn. Een instituut voor verstandelijk gehandicaptenzorg bestaat tegenwoordig uit kleinschalige woningen.

30 http://www.rivm.nl

31 Schrojenstein Lantman-De Valk et al., 2002. 
steeds meer vervaagd. Het niveau van cliënten die in een semi-murale woonvorm wonen gaat steeds meer lijken op cliënten die in een instituut woonachtig zijn. Hoewel in Nederland nog veel grote instituten in stand worden gehouden, ondergaat de intramurale zorg een aantal veranderingen. De grote gebouwen worden steeds meer vervangen door kleinere gebouwen en woningen in de wijk. Aangezien het onderscheid tussen intramurale en semi-murale zorg langzamerhand komt te vervallen, kan beter worden gesproken over verschillende vormen van ondersteuning. Instituten beginnen kenmerken te vertonen van transmurale voorzieningen: ze bieden verschillende vormen van ondersteuning aan. Naast het bieden van ondersteuning bij het wonen in een voorziening, wordt ondersteuning geboden aan mensen die nog thuis wonen of zelfstandig wonen. Cliënten die niet in een voorziening wonen, kunnen eventueel met een Persoonsgebonden Budget ( $\mathrm{Pgb}$ ) hulp inkopen. Deze hulp kan ook worden ingekocht bij een Stichting die intramurale en semi-murale zorg aanbiedt.

Van de groep cliënten die volgens het rapport van Schrojenstein Lantman et al thuis wonen, maakt meer dan de helft geen gebruik van bestaande voorzieningen voor mensen met een verstandelijke handicap. Deze groep cliënten is bijvoorbeeld niet terug te vinden in voorzieningen voor dagbesteding. De andere helft van de thuis wonende cliënten woont zelfstandig of thuis bij ouders of andere verzorgers. Tot deze groep worden ook gerekend cliënten met een Pgb. Een cliënt kan ervoor kiezen zelf een woonruimte te huren via een woningbouwvereniging. De benodigde zorg en ondersteuning kan hij inkopen bij een Stichting die zorg aan mensen met een verstandelijke handicap biedt. Dit betekent dat het bieden van zorg en ondersteuning wordt gescheiden van het wonen. Het is ook mogelijk dat met een aantal andere cliënten een kleinschalige woonvorm wordt opgezet. De gewenste begeleiding wordt ingekocht met Pgb's. De zorg oftewel ondersteuning kan worden geboden door de Sociaal Pedagogische Dienst $(\mathrm{SPD})^{32}$, een gvt of een intramurale voorziening.

\subsection{Recente ontwikkelingen in de zorg}

Naast een toename van patiëntenwetgeving, heeft zich de afgelopen jaren een aantal ontwikkelingen voorgedaan in de sector verstandelijk gehandicaptenzorg die ook van betekenis zijn voor de invulling van de rechtspositie van mensen met een verstandelijke handicap. De ontwikkelingen hebben als gemeenschappelijk kenmerk dat vanuit een andere visie naar de zorg voor mensen met een verstandelijke handicap wordt gekeken. Deze visie is gebaseerd op het burgerschapsmodel, dat in de jaren negentig van de vorige eeuw zijn intrede doet in de

De SPD heet sinds 1 januari 2004 'MEE'. 
sector. ${ }^{33}$ In dit model wordt een cliënt beschouwd als een volwaardig persoon met rechten en plichten als ieder andere burger. Een centraal begrip in de nieuwe visie is community care, waaronder wordt verstaan dat mensen met een verstandelijke handicap ook de kans moeten krijgen om gewoon te leven en deel te nemen aan de samenleving. ${ }^{34}{ }^{35}$ De Wet gelijke behandeling gehandicapten en chronisch zieken $(\mathrm{Wgbh} / \mathrm{cz})$ is op 1 december 2003 in werking getreden en kan worden beschouwd als de wettelijke grondslag voor community care. ${ }^{66}$ In deze wet wordt benadrukt dat discriminatie van mensen met een verstandelijke handicap verboden is. ${ }^{37}$ In enkele gevallen is het wel toegestaan om een onderscheid te maken. De situatie kan dusdanig zijn dat de risico's voor de veiligheid en gezondheid van een cliënt met een verstandelijke handicap te groot zijn. Ook mogen speciale voorzieningen voor mensen met een handicap worden getroffen. Deze voorzieningen zijn toegestaan omdat zij de participatie in de samenleving bevorderen. De $\mathrm{Wgbh} / \mathrm{cz}$ is voorlopig alleen van toepassing op arbeid, het beroep, het beroepsonderwijs en het openbaar vervoer. In het kader van community care is het wenselijk dat deze wet wordt uitgebreid naar andere levensterreinen, waaronder huisvesting en zorg. ${ }^{30}$ Mensen met een handicap komen doorgaans terecht in woningen die onvoldoende aansluiten op hun behoeften. ${ }^{39}$ Daar

33 A. van Gennep en C. Steman, "Beperkte burgers, Over volwaardig burgerschap voor mensen met verstandelijke beperking", Utrecht: NIZW 1997b; A. van Gennep, Emancipatie van de zwaksten in de samenleving, Over paradigma's van verstandelijke handicap, Amsterdam: Boom 2000.

34 Raad voor de Volksgezondheid en Zorg, Samen leven in de samenleving: community care en community living, Zoetermeer 2002.

35 Inmiddels is de term community care al weer achterhaald en wordt gesproken over community living waaronder wordt verstaan 'leven in en deelnemen aan de samenleving' (Raad voor de Volksgezondheid en Zorg 2002, p. 11).

36 Wet van 3 april 2003 tot vaststelling van de Wet gelijke behandeling op grond van handicap of chronische ziekte, Stb. 206, iwtr. 1 december 2003 (Besluit van 11 augustus 2003, Stb. 329).

37 Artikel 1 van de Grondwet verbiedt ook discriminatie op grond van handicap of chronische ziekte. In dit artikel wordt echter niet nadrukkelijk verwezen naar handicap of chronische ziekte.

38 In de motie van het lid Bussemaker c.s. is voorgesteld dat de reikwijdte van de $\mathrm{Wgbh} / \mathrm{cz}$ wordt uitgebreid naar andere levensterreinen, waaronder in ieder geval sport en recreatie, goederen en diensten, wonen, stedelijke ruimte en voortgezet onderwijs (Kamerstukken II, vergaderjaar 2001-02, 28 169, nr. 15).

39 Uit het rapport 'Samen leven in de samenleving: community care en community living' van de RVZ komt naar voren dat het aantal aangepaste woningen voor lichamelijk gehandicapten tekort is om aan de vraag te voldoen (RVZ 2002, p. 23). 
komt bij dat deze woningen in achterstandswijken staan. Een ander punt van kritiek is het gebrek aan variatie in het woning - en ook zorgaanbod. De Pgb-regeling en de modernisering van de AWBZ kunnen hierin verandering aanbrengen. ${ }^{\infty}$ at

Het gevolg van de community care gedachte is dat een cliënt de mogelijkheid krijgt om zelf te bepalen waar hij wil gaan wonen. Ondersteuning vormt in dit kader een belangrijk begrip. Om het mogelijk te maken dat cliënten in de samenleving gaan wonen, moeten zij aanspraak kunnen maken op ondersteuning, die aangepast is aan hun individuele situatie. Van belang is dat de vraag van de cliënt het uitgangspunt vormt voor het vaststellen van de vorm en intensiteit van ondersteuning die wordt geboden. In de sector wordt ook wel gesproken over vraagsturing. Dit principe staat sinds het eind van de jaren negentig van de vorige eeuw centraal in de zorg voor mensen met een verstandelijke handicap. ${ }^{e}$ De belangstelling voor community care heeft ertoe geleid dat instituten op grote schaal zijn gaan deconcentreren. De ondersteuning die in het verleden in instituten werd geboden, wordt steeds meer verplaatst naar de samenleving. Cliënten verhuizen van het terrein van het instituut naar kleinschalige woonvormen in de wijk. Recente onderzoeken tonen echter aan dat community care nog niet het beoogde effect heeft gehad. ${ }^{33}{ }^{4}$ Ondanks het gegeven dat een aanzienlijk aantal cliënten in de samenleving is gaan wonen, valt de participatie en de zeg-

40 RVZ 2002, p. 22.

41 Sinds 1 april 2003 zijn de institutionele aanspraken vervangen door functiegerichte aanspraken. De functies zijn: huishoudelijke verzorging, persoonlijke verzorging, verpleging, ondersteunende begeleiding, activerende begeleiding, behandeling en verblijf.

42 Ook de modernisering van de AWBZ, die op 1 april 2003 in werking is getreden, is gebaseerd op de gedachte van vraagsturing. De modernisering van de AWBZ heeft als uitgangspunt dat cliënten kunnen kiezen uit zorg in natura of een persoonsgebonden budget. Beide vormen bieden aan een cliënt voldoende keuzemogelijkheden. Een cliënt die kiest voor zorg in natura heeft recht op een zorgarrangement dat in overeenstemming is met zijn, in het indicatieorgaan op onafhankelijke wijze en objectieve wijze vastgestelde zorgbehoefte (antwoorden op kamervragen over de keuzevrijheid in het proces van vermaatschappelijking van verstandelijk gehandicapten).

43 Raad voor de Volksgezondheid en Zorg, 2002 en Raad voor Maatschappelijke Ontwikkeling, De handicap van de samenleving: over mogelijkheden en beperkingen van community care, Den Haag 2002.

44 E. H. Overkamp, Instellingen nemen de wijk: een analyse van het beleid inzake de deconcentratie van instellingen voor mensen met een verstandelijke handicap en zijn empirische effecten (diss. Twente), Assen: Van Gorcum 2000. 
genschap die zij over hun eigen leven hebben tegen. Blijkbaar is het on oldoende om cliënten alleen maar uit het instituut te plaatsen. De boodschap an de adviezen van de Raad voor de Volksgezondheid en Zorg (RVZ) en de had voor Maatschappelijke Ontwikkeling (RMO) luidt dat er een beroep moten worden gedaan op de omgeving, om community care een kans van slage te geven. Daarnaast dient elke partij, die betrokken is bij community care, zijn erantwoordelijkheid te nemen.

Hoewel het accent de afgelopen jaren is verschoven naar deconcentratie var de zorg, komt de overheid ook tegemoet aan de wensen van cliënten om ophet terrein van het instituut te mogen blijven wonen. Deze wijze van handelen 'uit aan bij de kern van vraagsturing. In beginsel had het Ministerie van VW: de intentie om alle instituten te sluiten. Inmiddels is de minister op dit stand teruggekomen." Het huidige beleid biedt ruimte aan cliënten om zelf te kiøen waar zij willen wonen: in een woonwijk of in een instituut.t6 Een wijziging ${ }^{i}$ de Wet ziekenhuisvoorzieningen (Wzv) heeft tot gevolg dat instituten op grond,an de beleidsregels ex artikel $3 \mathrm{Wzv}$ verplicht zijn om aan iedere cliënt een leefvensenonderzoek voor te leggen. ${ }^{z}$ Cliënten die hun leven lang in een instituut ebben gewoond, zullen niet snel kiezen voor een plek in de samenleving. De IVZ wijst op het risico dat cliënten met bepaalde kenmerken over zullen blijver als instituten in stand worden gehouden. Een dergelijk risico mag echter geen bletsel vormen om instituten te sluiten. De kans bestaat dat de institutionele zorg zich onder invloed van community care positief zal gaan ontwikkelen. Volgens de RVZ zal ook binnen instituten de ondersteuning steeds meer worden afgestemd op de vraag van de cliënt. Instituten zullen gaan samenwerken met andere instanties en organisaties, zodat de kloof die nu nog bestaat tussen instituten en de samenleving kleiner gaat worden. ${ }^{48}$

45 Op de voorkant van het februari nummer 2003 van Markant is te lezen 'bouwen op het instellingsterrein, het mag weer!' Ondanks dat het Ministerie van VWS een restrictief beleid voert voor het bouwen van grootschalige voorzieningen, gaf het Bouwcollege in 2002 meer vergunningen voor bouw en verbouw van grootschalige voorzieningen dan voor kleinschalige. In de Staatscourant werden vergunningen voor 888 plaatsen op hoofdlocaties en 749 voor gedeconcentreerde plaatsen gemeld. Het is echter nog wel mogelijk dat buiten het toezicht van het bouwcollege kleinschalige woonvormen worden gebouwd. Deze voorzieningen zijn uit de WZV gehaald (Staatscourant 15 april 2003, nr. 74, p. 15). Overigens bestaat een instituut ook steeds meer uit kleinschalige woonvormen die worden gebouwd op het terrein van het instituut of in de woonwijk. Staatscourant 15 april 2003, nr. 74, p. 15. RVZ 2002, p. 40-41. 


\subsection{Terminologie}

In dit boek keren een aantal termen regelmatig terug. De meest terugkerende term is cliënten met een verstandelijke handicap." Over het algemeen wordt in de hoofdstukken geen onderscheid gemaakt tussen een lichte, matige, ernstige en zeer ernstige verstandelijke handicap. Elke cliënt heeft, ongeacht zijn niveau van verstandelijke handicap, dezelfde rechtspositie. Alleen in passages, waarbij het relevant is dat een cliënt een lichte verstandelijke handicap heeft of een matige, (zeer) ernstige verstandelijke handicap, wordt dit vermeld. ${ }^{5}$ Een andere veelgebruikte term is vertegenwoordiger. Onder een vertegenwoordiger wordt verstaan een familielid of ander natuurlijk persoon ${ }^{51}$ die de belangen behartigt van een cliènt. Een wilsonbekwame cliënt met een verstandelijke handicap kan op drie verschillenende manieren worden vertegenwoordigd: een wettelijk vertegenwoordiger, ${ }^{12}$ een niet-wettelijke vertegenwoordiger ${ }^{50}$ en een persoonlijk gemachtigde. ${ }^{4}$ Een vertegenwoordiger wordt geacht te handelen als een goed vertegen-

49 Naast verstandelijke handicap wordt ook wel gesproken over 'verstandelijke beperking'. In deze studie is gekozen voor 'verstandelijke handicap',

50 Een cliënt met een lichte verstandelijke handicap zal doorgaans andere en wellicht ook minder ondersteuning nodig hebben dan een cliënt met een matige, (zeer) ernstige verstandelijke handicap. Daarnaast kan een cliënt met een lichte verstandelijke handicap eerder (partieel) wilsbekwaam worden beschouwd.

51 Een bewindvoerder hoeft niet altijd een natuurlijk persoon te zijn. In artikel 1:435 lid $6 \mathrm{BW}$ is bepaald dat ook een rechtspersoon tot bewindvoerder kan worden benoemd.

52 In plaats van wettelijk vertegenwoordiger wordt ook gesproken over een 'benoemde vertegenwoordiger'. De wetgever onderscheidt drie vormen: mentor, curator en bewindvoerder. Onder een wettelijk vertegenwoordiger wordt ook verstaan de ouders van een minderjarig kind. Deze laatste categorie wordt hier buiten beschouwing gelaten, maar is essentieel om het probleem goed te begrijpen.

53 Een andere naam voor een niet-wettelijk vertegenwoordiger is een onbenoemde vertegenwoordiger. Deze vorm van vertegenwoordiging is geregeld in artikel 7:465 lid $3 \mathrm{BW}$. Indien er geen persoonlijk gemachtigde of wettelijk vertegenwoordiger is, kunnen familieleden (waaronder de ouders, broer of zus) namens de cliënt een beslissing nemen.

54 Een wilsbekwame cliënt kan schriftelijk laten vastleggen wie hij als vertegenwoordiger wil aanwijzen, vooruitlopend op de situatie dat hij wilsonbekwaam wordt. Over het algemeen wordt deze vorm van vertegenwoordiging met name gebruikt door mensen die aan het begin van een proces van dementie staan. Deze personen kunnen, nu ze nog bekwaam zijn, een persoon aanwijzen die 
woordiger (artikel 7:466 lid 6 BW). De strekking van deze bepaling is dat en vertegenwoordiger de taak heeft om de capaciteiten van cliënten te ontwikkele. In de regeling mentorschap is bepaald dat de mentor bevordert dat de betrakene rechtshandelingen en andere handelingen zelf verricht, indien deze tot en redelijke waardering van zijn belangen ter zake in staat kan worden geacht (arikel 1:454 lid 1 BW). De wetgever verbiedt dat een hulpverlener van de voorzining, waar de cliënt verblijft of zorg van ontvangt, als vertegenwoordiger otreedt. $\$$ \% Naast de cliënt en de vertegenwoordiger, keert in dit boek de ten persoonlijk begeleider regelmatig terug. ${ }^{37}$ Een persoonlijk begeleider is het direce aanspreekpunt voor een cliënt en/of zijn vertegenwoordiger. Hij is degene di, op basis van het zorgplan, een cliënt ondersteuning biedt die zoveel mogelik gericht is op het bevorderen van de mogelijkheden van een cliënt. Daarnaat gaat hij na of de afspraken die in het zorgplan zijn vastgelegd worden nagekmen. Vanuit deze rol wijst hij de andere teamleden op de uitvoering van de aspraken. Ook bespreekt hij met de cliënt en/of zijn vertegenwoordiger de vootgang van het zorgplan. Indien nodig kan een zorgplan in overleg met teamlden, andere hulpverleners, de cliënt en/of zijn vertegenwoordiger worden bijgsteld. De persoonlijk begeleider is verantwoordelijk voor het verwerken van dze wijzigingen in het zorgplan. De achtergrond van een persoonlijk begeleidr kan zeer uiteenlopen. Het kan gaan om een verpleegkundige, verzorgende f een persoonlijk begeleider met een agogische opleiding (sociaal pedagogische hulpverleners)..$^{58}$

hun belangen gaat vertegenwoordigen zodra dementie een ernstiger vorm aan gaat nemen.

55 Artikel 1:452 lid 6d BW (regeling mentorschap).

56 In de memorie van toelichting van de regeling mentorschap noemt de wetgever als belangrijkste reden 'belangenverstrengeling'. De positie van de mentor dient onafhankelijk te zijn ten opzichte van de hulpverlener c.q. het instituut. Dit belet niet de mogelijkheid om een vroegere huisarts of een persoonlijk begeleider van het vorige instituut tot mentor te benoemen. Tevens kan een professionele mentor, die werkzaam is bij een stichting, worden ingeschakeld. De wetgever tracht te voorkomen dat een mentor, die tevens hulpverlener is, vanuit zijn rol als belangenbehartiger een conflict moet aangaan met zijn collega's of directie (Kamerstukken II 1991/92, 22 474, nr. 3, p. 23).

57 In plaats van persoonlijk begeleider wordt ook wel gesproken over zorgcoördinator.

58 Een stichting voor verstandelijk gehandicaptenzorg hanteert de volgende functie-eisen voor een persoonlijk begeleider: kennis op MBO-niveau 3 of 4 richting verpleging/verzorging of sociaal-pedagogisch/woonbegeleiding dan wel diploma Z-verpleegkundige. Indien een verpleegkundige opleiding is gevolgd, is 
De cliẻnt met een verstandelijke handicap verblijft of thuis of in een voorziening. De term voorziening is inmiddels een breed begrip geworden, aangezien de laatste jaren een grote diversiteit aan voorzieningen is ontstaan. In het rapport van Schrojenstein Lantman et al wordt in dit kader dan ook terecht gesproken over vormen van ondersteuning. In Nederland is de meest bekende vorm van een voorziening nog altijd het instituut. Deze term is enigszins achterhaald. Het duidt erop dat instituten nog steeds bestaan uit grote (verouderde) gebouwen, ver van de bewoonde wereld. De meeste instituten voldoen echter niet meer aan deze beschrijving: zij bestaan uit kleinschalige woningen die zich ook buiten het terrein van een instituut (in een woonwijk) bevinden. Een modernere benaming voor instituut is instelling. Dit begrip wordt, aangezien het meer betekenissen heeft en daardoor tot verwarring zou leiden, niet gebruikt in dit boek. De termen instituut en voorziening worden naast elkaar gebruikt. Andere vormen van een voorziening zijn onder meer een gvt, begeleid zelfstandig wonen en een dagverblijf.

\subsection{Opzet}

Dit boek bestaat, inclusief de inleiding (hoofdstuk 1), uit 8 hoofdstukken. In hoofdstuk 2 worden de methoden van onderzoek beschreven. In dit hoofdstuk komt, naast een toelichting op de probleemstelling en de vraagstellingen, aan de orde op welke wijze de empirische gegevens voor het onderzoek zijn verzameld en geanalyseerd. De juridische uitgangspunten, die de basis vormen voor de andere hoofdstukken in dit boek, worden in hoofdstuk 3 uiteengezet in het normatief kader. Dit hoofdstuk is opgebouwd uit twee onderdelen. Behalve de betekenis van het recht binnen de verstandelijk gehandicaptenzorg, worden het belang en de inhoud van vier rechtsbeginselen geschetst. Naast het recht op zelfbeschikking en bescherming komen ook het recht op goede zorg en het recht op ontplooiing aan de orde. Alvorens in hoofdstuk 5 tot en met 7 wordt ingegaan op de problematiek van vrijheidsbeperking, wordt in hoofdstuk 4 de rol van de hulpverlener in de zorg voor mensen met een verstandelijke handicap toegelicht. Als gevolg van de visie die in deze studie wordt ingenomen en veranderingen die zich de afgelopen jaren hebben voorgedaan in de sector verstandelijk gehandicaptenzorg wordt van een hulpverlener verwacht dat hij een andere houding inneemt. De betekenis van goed hulpverlenerschap en goede zorg worden in dit hoofdstuk toegelicht. In hoofdstuk 5 wordt de aandacht gericht op het huidige juridische kader ten aanzien van de toepassing van vrijheidsbeper-

ook een BIG-registratie vereist. Aanvullende eisen zijn: bijhouden van vakkennis en ontwikkelingen in de verstandelijk gehandicaptenzorg en enige kennis van automatisering. 
king in de zorg voor mensen met een verstandelijke handicap. De juridische atlyse illustreert dat het huidige kader, de Wet Bopz, onvoldoende handvatn biedt om de interne rechtspositie van cliënten te waarborgen. De bevindingen $n$ hoofdstuk 6 illustreren op welke wijze cliënten met een verstandelijke handiç in de dagelijkse (zorg)praktijk worden beperkt in hun vrijheid. Deze bevindgen bevestigen de uitkomsten van hoofdstuk 5 , inhoudende dat de Wet $B C z$ een ongeschikt kader is voor de sector verstandelijk gehandicaptenzorg. En alternatieve regeling, die het accent legt op rechtsbescherming en goede zor, kan een oplossing bieden voor de problematiek die zich rondom de toepassig van vrijheidsbeperking voordoet. Hoe deze regeling eruit moet komen te $z^{n}$ wordt in hoofdstuk 7 besproken. In dit hoofdstuk worden ook de knelpunn van een dergelijke regeling geschetst. Het boek wordt afgesloten met een aanl conclusies en aanbevelingen (hoofdstuk 8 ) ter verbetering van de rechtsposie van mensen met een verstandelijke handicap.

In deze studie is literatuur verwerkt tot en met 30 april 2004. 


\section{Methoden van onderzoek}

\section{$2.1 \quad$ Inleiding}

Binnen het rechtswetenschappelijk onderzoek is de aandacht voor de empirie groeiende. Verschillende juristen wijzen er op dat ook de rechtswetenschap zich het belang van empirisch onderzoek moet realiseren. Stolker is van mening dat elke vorm van wetenschap, waaronder de rechtswetenschap, principieel open en daarmee controleerbaar en falsifieerbaar hoort te zijn. ${ }^{1}$ Muller voegt daaraan toe dat de relevantie van de rechtswetenschap voor de maatschappij zal toenemen door een combinatie van theoretisch onderzoek en empirische verificatie van veronderstellingen. ${ }^{2}$ Ook binnen het gezondheidsrecht wordt het belang van de praktijk onderschreven. Gevers wijst erop dat de aandacht voor de vraag hoe het recht in de praktijk functioneert ook in de toekomst actueel moet blijven. ${ }^{3}$

Ook in dit onderzoek neemt de empirie een belangrijke plaats in waardoor recht wordt gedaan aan de praktijk van de zorg voor mensen met een verstandelijke handicap. Naast een analyse van het juridische kader voor de toepassing van vrijheidsbeperking wordt aan de orde gesteld op welke wijze in de praktijk invulling wordt gegeven aan dit kader. De manier waarop de empirische gegevens zijn verzameld wordt in dit hoofdstuk verantwoord.

Hoofdstuk 2 vangt aan met een omschrijving van het doel van het onderzoek, de probleemstelling en de (afgeleide) vraagstellingen (paragraaf 2.2). In paragraaf 2.3 wordt het juridische onderzoek kort toegelicht. Vervolgens wordt stilgestaan bij de rol die de praktijk in dit onderzoek vervult (paragraaf 2.4). De opzet en verantwoording van het empirische kwalitatieve onderzoek komt aan bod in paragraaf 2.5. In deze paragraaf wordt ingegaan op de aard van het onderzoek (kwalitatief onderzoek), de rol van de onderzoeker, de afbakening van het onderzoek, de voorzieningen waar het onderzoek heeft plaatsgevonden, de verschillende methoden van onderzoek die zijn gebruikt voor de gegevens-

1 C.J.J.M. Stolker, "Ja, geleerd zijn jullie wel! Over de status van de rechtswetenschap", Nederlands Juristenblad (78) 2003-15, p. 776. In het artikel van De Geest wordt de discussie over de status van de rechtswetenschap voortgezet. G. De Geest, "Hoe maken we van de rechtswetenschap een volwaardige wetenschap?', Nederlands Juristenblad (79) 2004-2, p. 58-66.

2 E.R. Muller, "Conflictbeslechting: Kruisbestuiving van rechtswetenschap en bestuurskunde", Meijers-reeks nr. 39, Deventer: Kluwer 2001, p. 9.

3 J.K.M. Gevers, "Gezondheidsrecht - een plaatsbepaling opnieuw beschouwd", in: J.C.J. Dute, J.K.M. Gevers en G.R.J. de Groot (red.), Omzien naar de toekomst, Houten/Diegem: Bohn Stafleu Van Loghum 2002, p. 19-20. 
verzameling, de integratie van de gegevens van de tweede evaluatie Wet Boz en de wijze waarop de resultaten zijn geanalyseerd. De beperkingen van iet empirische onderzoek worden toegelicht in paragraaf 2.6 .

\subsection{Probleemstelling en vraagstellingen}

Het doel van dit onderzoek is om inzichtelijk te maken hoe de (interne) rectspositie ${ }^{4}$ van cliënten met een verstandelijke handicap zowel in wet- en regeleving is vastgelegd als in de praktijk wordt vormgegeven, in het bijzonder ret betrekking tot de toepassing van vrijheidsbeperking. De Wet bijzondere opemingen in psychiatrische ziekenhuizen, die in 1994 in werking is getreden, heft ook gevolgen voor de rechtspositie van cliënten met een verstandelijke haricap. Door middel van dit onderzoek zal duidelijk worden welke rechten cliënen hebben als zij in hun vrijheid worden beperkt. Daarnaast beoogt het onderzek in kaart te brengen welke problemen zich in de praktijk voordoen als het de ralisatie van deze rechten betreft. Bekeken zal worden of de uitgangspunten un het juridische kader voor de toepassing van vrijheidsbeperking aansluiten bijle kenmerken van de verstandelijk gehandicaptenzorg. Op deze manier is het rogelijk om de gedachtevorming over de rechtspositie van cliënten met een vrstandelijke handicap te stimuleren en bij te dragen aan een verbetering daarva. Het doel van het onderzoek leidt tot de voleend prorobleemstelling-

'Wat is de (interne) rechtspositie van cliënten in de zorg voor mensen met een verstandelijke handicap in relatie tot de toepassing van vrijheidsbeperking, hoe krijgt deze in de praktijk gestalte en welke aanbevelingen kunnen terzake worden gedaan?'

De probleemstelling is nader uitgewerkt aan de hand van de volgende vraagstellingen:

1. Wat is het gezondheidsrechtelijke kader voor de (interne) rechtspositie van cliënten in de zorg voor mensen met een verstandelijke handicap?

2. Hoe verhoudt dit algemene kader zich tot de regelgeving die betrekking heeft op de toepassing van vrijheidsbeperking in de zorg voor mensen met een verstandelijke handicap?

Aan het begin van het onderzoek stond de interne rechtspositie van cliënten met een verstandelijke handicap centraal. In het doel van het onderzoek en in de vraagstellingen staat het woord 'interne' echter tussen haakjes. De reden hiervan is dat in een latere fase het onderscheid tussen interne en externe rechtspositie is komen te vervallen: in de alternatieve regeling (hoofdstuk 7) wordt niet meer gesproken over een interne of externe rechtspositie. 
3. Welke problemen doen zich voor in de praktijk van de zorg voor mensen met een verstandelijke handicap ten aanzien van hun (interne) rechtspositie als het gaat om de toepassing van vrijheidsbeperking?

4. Welke juridische mogelijkheden zijn er om de gevonden knelpunten op te lossen?

5. Wat betekent één en ander voor zowel wetgeving en zelfregulering als de praktijk?

\subsection{Juridisch onderzoek}

Het onderzoek kende een aantal fases. Om de eerste en tweede vraagstelling te kunnen beantwoorden is een juridische analyse uitgevoerd. Deze bestond uit het verkennen, ordenen en analyseren van in huidige en toekomstige (patiënten)wetgeving, jurisprudentie, (rechtsgeleerde) literatuur, standaarden, richtlijnen en protocollen neergelegde opvattingen inzake de rechtspositie van mensen met een verstandelijke handicap. Tevens zijn publicaties van de Inspectie voor de Gezondheidszorg en de brancheorganisatie VGN meegenomen. Naast juridische literatuur is ten behoeve van de beeldvorming rondom mensen met een verstandelijke handicap ook algemene literatuur over de sector verstandelijk gehandicaptenzorg bestudeerd. Het doel van deze juridische analyse was om een gezondheidsrechtelijk kader te formuleren inzake de rechtspositie van mensen met een verstandelijke handicap. Dit normatief kader wordt nader omschreven in hoofdstuk 3. Tevens is voor een aantal onderwerpen, waaronder vrijheidsbeperking en goed hulpverlenerschap, een werkdocument opgesteld. Deze werkdocumenten zijn in een latere fase van het onderzoek nader uitgewerkt. ${ }^{5}$

\subsection{De rol van de praktijk in juridisch onderzoek}

Dit onderzoek kan worden geplaatst onder de noemer juridisch-empirisch onderzoek. Deze vorm van onderzoek bestrijkt zowel wet- en regelgeving als de praktijk. Het uitgangspunt is dat tussen beide aspecten sprake is van interactie: rechtsregels kunnen niet los worden gezien van de praktijk. Juridisch-empirisch onderzoek vertoont overeenkomsten met empirisch-ethisch onderzoek. Het belang van empirische gegevens voor de zorgethiek wordt door diverse ethici onderschreven. Een reden voor empirisch-ethisch onderzoek is dat hulpverleners regelmatig aangeven dat zij het moeilijk vinden om ethische richtlijnen en principes toe te passen in de dagelijkse praktijk. Empirisch-ethisch onderzoek kan bijdragen aan een betere afstemming tussen ethische theorievorming en de da-

5 Het werkdocument goed hulpverlenerschap is uitgewerkt in hoofdstuk 4 en het werkdocument vrijheidsbeperking is uitgewerkt in hoofdstuk 5. 
gelijkse praktijk. Een ethicus kan verkregen inzichten uit de praktijk gebruiken om een ethische theorie verder te verfijnen. ${ }^{6}$

De betekenis die binnen de ethiek wordt toegekend aan empirisch-ethisch onderzoek zou binnen het recht ook moeten gelden voor juridisch-empirisch onderzoek. Inzichten uit de praktijk maken het mogelijk om wet- en regelgeving te verfijnen en aan te passen aan de sector, waar de desbetreffende wet- en regelgeving van toepassing is. Een kenmerk van juridisch-empirisch onderzoek is dat wet- en regelgeving niet als onveranderlijk wordt beschouwd. Ook in de praktijk kunnen juiste opvattingen bestaan over wet- en regelgeving, waardoor aanvullingen of aanpassingen noodzakelijk kunnen zijn. Het doel van het onderhavige onderzoek is om recht te doen aan de praktijk. Door naar de praktijk te luisteren, wordt inzichtelijk gemaakt welke (juridische) problemen zich op de werkvloer voordoen rondom de rechtspositie van cliënten met een verstandelijke handicap. Deze problemen worden positief benaderd, aangezien het niet functioneren van een wet verschillende oorzaken kan hebben. Het huidige juridische kader in de zorg voor mensen met een verstandelijke handicap kan onmogelijk alle problemen die zich voordoen in de praktijk oplossen. ${ }^{7}$ Uit het empirische onderzoek kan echter ook naar voren komen dat het juridische kader niet aansluit bij de specifieke eigenschappen van de verstandelijk gehandicaptenzorg. In feite hebben wetgeving en praktijk in de zorg voor mensen met een verstandelijke handicap dezelfde doelstelling: het verbeteren van de rechtspositie van mensen met een verstandelijke handicap. ${ }^{8}$ De rechtsbescherming die de Wet Bopz beoogt te bieden aan cliënten pakt in de praktijk evenwel anders uit. Eerdere onderzoeken laten zien dat als gaat het om de toepassing van vrijheidsbeperking in de praktijk nog veel verbeterd kan worden ten aanzien van de interne rechtspositie van cliënten met een verstandelijke handicap. De oorzaak moet worden gevonden in zowel het huidige juridische kader als de praktijk. Dit onderzoek beoogt deze interactie inzichtelijk te maken teneinde de rechtspositie van cliënten met een verstandelijke handicap te verbeteren.

6 A. Lelie, "Reflectie op wetenschappelijk handelen. Empirisch onderzoek in de medische ethiek", Tijdschrift voor geneeskunde en ethiek (8) 1998-1, p. 2.

7 Hierbij kan worden gedacht aan een tekort aan personeel, ongekwalificeerd personeel of de bouw van een voorziening. Deze factoren kunnen ook aanleiding geven tot problemen rondom de rechtspositie van cliënten met een verstandelijke handicap. Daarnaast is ook bepalend of hulpverleners voldoende op de hoogte zijn van wetgeving en of zij de uitgangspunten van het juridische kader onderschrijven.

8 Naast deze doelstelling geldt in de praktijk nog een aantal andere doelstellingen waaronder doelmatig werken. 
Om meer zicht te krijgen op de interactie die zich voordoet tussen de praktijk en wetgeving zijn de empirische gegevens aan de hand van een aantal vragen geanalyseerd. Deze vragen kunnen worden beschouwd als een nadere uitwerking van de vraagstellingen 2 en 3 (paragraaf 2.2). In hoofdstuk 5 en 6, waarin respectievelijk het juridische kader van vrijheidsbeperking en de toepassing van vrijheidsbeperking in de praktijk aan de orde komen, worden de volgende vragen beantwoord:

- In hoeverre is vrijheidsbeperking vastgelegd in een juridisch kader (hoofdstuk 5).

- In hoeverre wordt in het juridische kader, ten aanzien van de toepassing van vrijheidsbeperking, rekening gehouden met de specifieke eigenschappen van de verstandelijk gehandicaptenzorg? (hoofdstuk 5)

- In hoeverre wordt in de praktijk van de zorg voor mensen met een verstandelijke handicap ten aanzien van de toepassing van vrijheidsbeperking rekening gehouden met het juridische kader? Deze vraag valt uiteen in twee subvragen: Is de toepassing van vrijheidsbeperking in de praktijk voorzien van voldoende waarborgen? Zijn hulpverleners zich in de praktijk voldoende bewust van het juridische kader of wordt deze genegeerd? (hoofdstuk 6)

- In hoeverre hangen knelpunten rondom de toepassing van vrijheidsbeperking bij mensen met een verstandelijke handicap samen met de specifieke eigenschappen van de praktijk van de verstandelijk gehandicaptenzorg (hoofdstuk 6).

\subsection{Opzet en verantwoording empirisch kwalitatief onderzoek}

\subsubsection{Twee onderzoeken}

De empirische gegevens die voor deze studie zijn verzameld zijn afkomstig van twee onderzoeken. Beiden hadden als doel om de derde vraagstelling te beantwoorden: 'Welke problemen doen zich in de praktijk van de zorg voor mensen met een verstandelijke handicap voor ten aanzien van hun (interne) rechtspositie als het gaat om de toepassing van vrijheidsbeperking?' Allereerst zijn drie voorzieningen uit het zuiden van het land geselecteerd. Daarnaast zijn ook de gegevens van de tweede evaluatie Wet Bopz voor de verstandelijk gehandicaptenzorg in het empirische onderzoek verwerkt. ${ }^{9}$ Deze evaluatie is in 2001 uitgevoerd door de Vrije Universiteit Amsterdam in samenwerking met de Universisector, Den Haag: ZonMw 2002. 
teit Maastricht en de Erasmus Universiteit Rotterdam. De nadruk ligt in paragraaf 2.5 op de verantwoording van het empirische onderzoek dat in drie voorzieningen in het zuiden van het land heeft plaatsgevonden. In subparagraaf 2.5.7 wordt kort stilgestaan bij de wijze waarop de gegevens in het kader van het evaluatieonderzoek zijn verzameld.

\subsubsection{Kwalitatief onderzoek}

Het empirische onderzoek was kwalitatief van aard. Kwalitatief onderzoek wordt gebruikt om de aard en de betekenis van sociale verschijnselen te onderzoeken. Dit uitgangspunt past binnen de doelstelling van het empirische gedeelte van dit onderzoek 'het inzichtelijk maken van problemen ${ }^{10}$ die zich in de praktijk van de zorg voor mensen met een verstandelijke handicap voordoen ten aanzien van hun (interne) rechtspositie als het gaat om de toepassing van vrijheidsbeperking'. Door middel van kwalitatief onderzoek kan nader inzicht worden verkregen in de aard en de betekenis van de gevonden problemen, die binnen de context van de sector verstandelijk gehandicaptenzorg kunnen worden verklaard. Kwalitatief onderzoek gaat van de veronderstelling uit dat menselijk gedrag kan worden verklaard op basis van de betekenisverleningen in het leven van alledag." In de zorg voor mensen met een verstandelijke handicap construeren hulpverleners, vertegenwoordigers en cliënten hun eigen wereld door de betekenis die zij geven aan hun handelingen en ervaringen.

Kwalitatief onderzoek kenmerkt zich door een open en flexibele procedure van gegevensverzameling. ${ }^{12}$ Een vaste werkwijze voor het verzamelen van gegevens binnen kwalitatief onderzoek ontbreekt. Door gebruik te maken van verschillende methoden kan een zo reëel en gedetailleerd mogelijk beeld van de werkelijkheid worden verkregen. Van belang is dat de onderzoeker ook daadwerkelijk deelneemt aan de te onderzoeken werkelijkheid. ${ }^{13}$ De onderzoeksmethode participerend observeren biedt hiertoe voldoende mogelijkheden. Een ander ken-

10 Problemen worden in dit kader ruim opgevat: het kan zowel gaan om belemmerende factoren als om bevorderende factoren. Als hulpverleners niet handelen conform de wet, hoeft hun handelen niet per definitie verkeerd te zijn. Het (afwijkend) handelen van hulpverleners kan ook leiden tot creatieve en positieve oplossingen die de (interne) rechtspositie van cliënten met een verstandelijk handicap bevorderen.

11 I. Maso en A. Smaling, Kwalitatief onderzoek: praktijk en theorie, Amsterdam: Boom 1998, p. 10

12 Maso en Smaling 1998, p. 9.

13 F. Wester, Strategieën voor kwalitatief onderzoek, Brussum: Coutinho 1995, derde druk, p. 16-18. 
merk van kwalitatief onderzoek is dat het verzamelen en analyseren van gegevens zich cyclisch afwisselen. Indien het onderzoek uit meer fases bestaat en verschillende onderzoeksmethoden worden ingezet kunnen gegevens, die in de eerste fase van het onderzoek zijn gevonden, worden gebruikt voor de volgende fase. Ook in dit onderzoek hebben de uitkomsten van de verschillende methoden elkaar aangevuld. De uitkomsten van het juridische onderzoek hebben richting gegeven aan de fases die daarna volgden. Hetzelfde kan worden gezegd over de methode participerende observatie. De observaties voorzagen de interviews van nadere interpretaties; bijzonderheden die tijdens het observeren de aandacht trokken, konden in de interviews nader worden bevraagd.

De kenmerken van kwalitatief onderzoek - geen vaste werkwijze, het deelnemen aan de te onderzoeken werkelijkheid en het voortdurend aanpassen van de onderzoeksmethoden - leiden regelmatig tot kritiek op deze vorm van onderzoek. Critici plaatsen vraagtekens bij de objectiviteit van kwalitatief onderzoek. Onder objectiviteit wordt verstaan 'recht doen aan het object van studie', ${ }^{4}$ Het is echter onjuist om te veronderstellen dat objectiviteit alleen kan worden bereikt door het hanteren van een strikte werkwijze of door maximale afstandelijkheid van de onderzoeker. Kwalitatief onderzoek kan niet voldoen aan deze beperkte en eenzijdige opvatting van objectiviteit. Binnen deze vorm van onderzoek is een ruimere opvatting vereist: ook de rol van de onderzoeker is bepalend. Het streven naar objectiviteit betekent niet de uitsluiting van de subjectiviteit van de onderzoeker. De persoonlijke betrokkenheid van de onderzoeker is onmisbaar en essentieel om de te onderzoeken werkelijkheid op een juiste wijze weer te geven..$^{15}$

\subsubsection{Rol van de onderzoeker}

Een kwalitatieve onderzoeker onderscheidt zich van andere onderzoekers doordat hij zich in de positie van de ander verplaatst. ${ }^{16} \mathrm{Hij}$ kan als onderzoeker verschillende rollen aannemen, die nader worden toegelicht in het observeerderparticipeerder continuüm van Gold. ${ }^{17}$ Hierin worden vier verschillende rollen genoemd: de volledig observeerder, de participerende observeerder, de observerende participeerder en de volledige participeerder. In het onderhavige onderzoek werd de rol ingenomen van participerende observeerder waaronder wordt verstaan een onderzoeker die observeert en ook interviewt in de alledaagse leefwereld van de onderzochte, bij enkele activiteiten aanwezig is of er min of

14 Maso en Smaling 1998, p. 66-67.

15 Maso en Smaling 1998, p. 66-67.

16 In dit onderzoek de hulpverlener, de vertegenwoordiger en de cliënt.

17 R. Gold, "Roles in sociological field observations", Social Forces, 1958-36, p. 217223. 
meer aan meedoet, maar niet participeert zoals de onderzochte actoren en as aan sommige activiteiten zoals werken, eten en slapen (...) niet meedoet. ${ }^{18}$ Dre rol betekende voor dit onderzoek dat zoveel mogelijk werd geparticipeerd inde alledaagse wereld van cliënten. De onderzoeker was aanwezig bij activiteiten ie gedurende de dag plaatsvonden (eten, vrije tijd, werken). Afhankelijk vante situatie, werd op bepaalde momenten deelgenomen aan deze activiteiten $n$ werd op andere momenten alleen geobserveerd.

De rol van de onderzoeker in dit onderzoek kan echter over het algemeen wrden beschreven als terughoudend en passief; de onderzoeker bevond zich vornamelijk op de achtergrond. Er werd niet geparticipeerd in zorgsituaties. Vor deze rol is bewust gekozen. Tijdens het participerend observeren konden zh diverse situaties voordoen waarbij een terughoudende rol de voorkeur vrdiende boven een actieve, interveniërende rol. Te denken valt aan conflicten tssen cliënten en persoonlijk begeleiders of een situatie waarbij vrijheidsbeperkig toegepast moet worden. Ook bestond het gevaar dat medewerkers van de vning de onderzoeker in zouden gaan zetten voor allerlei werkzaamheden, wardoor het observeren bemoeilijkt zou worden. Om deze situaties voor te zijris gekozen voor een passieve rol teneinde alle aandacht en tijd te kunnen besteen aan het participerend observeren. Daarnaast is ervoor gekozen om tijdens et onderzoek, ondanks de voorkennis over bepaalde thema's, niet op te tredenis

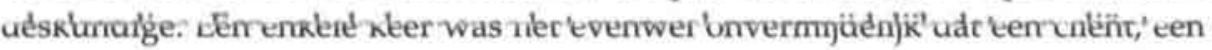
vertegenwoordiger of een persoonlijk begeleider een vraag aan de onderzoeker voorlegde die op dat moment ook werd beantwoord. Ook bepaalde het niveau van de cliënt de mate van participatie in de leefwereld van cliënten. Naarmate de mobiliteit en spreekvaardigheid van een cliënt groter was, was het moeilijker om daadwerkelijk op de achtergrond te blijven en niet deel te nemen aan diverse activiteiten dan wel een conversatie met cliënten te mijden.

\subsubsection{Afbakening van het onderzoek}

De verstandelijk gehandicaptenzorg is zeer divers: dé cliënt met een verstandelijke handicap bestaat niet. In dit onderzoek zijn zowel cliënten met een (zeer) ernstige verstandelijke handicap als cliënten met een matige tot lichte verstandelijke handicap betrokken. Deze keuze is bewust gemaakt teneinde qua niveau van cliënten een zo representatief mogelijk antwoord te kunnen geven op de vraagstellingen die in dit onderzoek centraal staan. Een cliënt met een (zeer) ernstige verstandelijke handicap heeft doorgaans een andere ondersteuningsbehoefte dan een cliënt met een lichte verstandelijke handicap. Het scala aan patiëntenwetgeving is echter op beide cliënten van toepassing.

18 Maso en Smaling 1998, p. 104. 
Om de haalbaarheid van het onderzoek veilig te stellen was het noodzakelijk om enige beperkingen in het onderzoek aan te brengen. In dit onderzoek zijn alleen volwassen cliënten met een verstandelijke handicap betrokken. Deze keuze had als gevolg dat minderjarigen buiten het onderzoek zijn gelaten. Een andere beperking is de nadruk die (nog) wordt gelegd op institutionele zorg. Ondanks de ontwikkelingen die gaande zijn in de zorg voor mensen met een verstandelijke handicap - waaronder deconcentratie en de modernisering van de AWBZ - wonen nog altijd meer dan 37.000 cliënten in instituten. ${ }^{19}$ Het zou geen recht doen aan de rechtspositie van mensen met een verstandelijke handicap als deze vorm van voorziening buiten beschouwing zou zijn gelaten. Het accent is evenwel niet alleen gelegd op de intramurale zorg; ook de semi-murale zorg is betrokken in het onderzoek. Andere vormen van zorg, zoals de thuiszorg of voorzieningen die via een persoonsgebonden budget zijn gefinancierd, zijn niet meegenomen. Het lag niet binnen de mogelijkheden om, naast twee instituten en een semi-murale voorziening, ook nog andere voorzieningen in het onderzoek te betrekken. Veel knelpunten die zich in instituten en gvt'en voordoen, zullen zich ook voordoen in de extramurale zorg. Andere knelpunten zullen afnemen als cliënten met een verstandelijke handicap een instituut verlaten om elders te gaan wonen. Aan de keuze voor institutionele zorg is echter ook een aantal 'voordelen' verbonden. In instituten komt doorgaans (nog) veel vrijheidsbeperking voor, wordt de (ruimtelijke) privacy van cliënten onvoldoende gewaarborgd en worden veel cliënten nog niet vanuit het juiste kader - het bieden van ondersteuning - benaderd. Deze bevindingen maken duidelijk dat het ook anders kan; zij geven genoeg aanwijzingen om de rechtspositie van cliënten met een verstandelijke handicap, in en buiten een instituut, in de toekomst te verbeteren.

\subsubsection{Drie voorzieningen}

Drie verschillende voorzieningen voor verstandelijk gehandicaptenzorg in de regio Midden- en Zuid-Limburg zijn bereid gevonden om deel te nemen aan het empirische onderzoek. De voorkeur ging, binnen de diversiteit aan voorzieningen voor verstandelijk gehandicaptenzorg, uit naar twee grote instituten en een semi-murale voorziening. ${ }^{20}$

19 http://www.rivm.nl

20 In een semi-murale voorziening is de Wet Bopz niet van toepassing. Dit hoeft overigens niet te betekenen dat in deze setting geen vrijheidsbeperkende maatregelen voorkomen. 


\subsubsection{Afspraken met voorzieningen}

Voordat het onderzoek van start kon gaan, diende eerst de directie en (in één van de drie voorzieningen) de cliëntenraad van de betrokken voorzieningen toestemming te geven voor deelname aan het onderzoek. Aangezien de cliëntenraad van een vooraf geselecteerde voorziening geen toestemming verleende, werd alsnog een nieuwe voorziening benaderd. Vervolgens werden met elke voorziening voorafgaand aan het empirische onderzoek een aantal afspraken gemaakt. In elke voorziening werd allereerst een contactpersoon aangewezen. Deze persoon regelde in samenspraak met de hoofden van de woningen de selectie van de woningen en de cliënten. Daarnaast fungeerde hij als aanspreekpunt gedurende de periode dat het onderzoek in de voorziening gaande was.

Onder de medewerkers, die werkzaam waren in de geselecteerde woningen van de voorzieningen, werd een notitie verspreid met een korte beschrijving van het onderzoek. Hierin werd onder meer aangegeven dat zorgvuldig zou worden omgegaan met privacygevoelige gegevens van cliënten, vertegenwoordigers en hulpverleners. ${ }^{21}$ Individuele hulpverleners hadden, ondanks de door de directie verleende toestemming, te allen tijde het recht om de onderzoeker in het kader van de participerende observatie de toegang tot een bepaalde situatie te ontzeggen. Tijdens het onderzoek is niet van deze mogelijkheid gebruik gemaakt. Daarnaast is ook toestemming gevraagd aan de cliënten en/of vertegenwoordigers van de cliënten die deelnamen aan het onderzoek. Ook voor deze groep was een notitie opgesteld die werd verspreid onder de deelnemende cliënten en/of vertegenwoordigers. Elke cliënt en/of zijn vertegenwoordiger moest schriftelijk toestemming geven voor inzage in zijn dossier, voor het observeren gedurende een week en het afnemen van een interview met hem en zijn vertegenwoordiger.

De aanwezigheid van de onderzoeker had ook gevolgen voor de andere cliënten die verbleven in een geselecteerde woning. Het was niet de bedoeling om aan alle cliënten van een woning toestemming te vragen voor deelname aan het onderzoek. Per woning werden immers maar twee cliënten daadwerkelijk betrokken bij het onderzoek. De keuze werd echter opengelaten aan de voorziening zelf. Afhankelijk van het beleid van een voorziening werd aan de overige cliënten en/of vertegenwoordigers toestemming gevraagd of werd uitgegaan van een geen bezwaarsysteem. Het onderzoek kon binnen de drie voorzieningen pas van start gaan als alle cliënten en/of vertegenwoordigers akkoord gingen met het gegeven dat gedurende een week een onderzoeker de activiteiten van cliënten in een woning kwam observeren.

21 De gegevens zijn anoniem verwerkt. Bovendien heeft de onderzoeker een geheimhoudingsplicht als het gaat om persoonlijke informatie over cliënten, vertegenwoordigers of hulpverleners. 


\subsubsection{Beschrijving van de voorzieningen}

Het onderzoek heeft plaatsgevonden in twee intramurale voorzieningen en een semi-murale voorziening. Alle drie de geselecteerde voorzieningen zijn aanbieders van zorg-en ondersteuning voor mensen met een verstandelijke handicap in de regio Limburg. De voorzieningen hebben sinds het empirische onderzoek heeft plaatsgevonden (2000) een aantal veranderingen ondergaan, waarvan de belangrijkste zijn fusies, het vervangen van verouderde paviljoenen en cliënten die zijn verhuisd naar locaties buiten het terrein van de intramurale voorziening. De beschrijvingen die in deze paragraaf worden gegeven hebben betrekking op de situatie waarin de voorzieningen zich bevonden in het jaar 2000 .

De eerste intramurale voorziening biedt in het jaar 2000 plaats aan 353 plaatsen 24-uurszorg, waarvan een aantal plaatsen wordt ingezet voor zorg op maat. ${ }^{2}$ De intramurale voorziening bestaat uit een hoofdlocatie met groepswoningen. Deze locatie biedt onder meer ook ruimte aan een bewegingscentrum, een arbeids- en bezigheidscentrum, een boerderij, recreatieve voorzieningen en behandelruimtes. Buiten de locatie bevinden zich vier sociowoningen. Het niveau van de verstandelijke handicap van de cliënten varieert van een lichte verstandelijke handicap tot een zeer ernstige verstandelijke handicap: ${ }^{23}$

\section{Tabel 2. Mate van handicap van cliênten (voorziening 1)}

\begin{tabular}{|l|l|}
\hline Mate van handicap & Aantal \\
\hline Licht & 23 \\
\hline Matig & 124 \\
\hline Ernstig & 121 \\
\hline Zeer ernstig & 85 \\
\hline Totaal & 353 cliënten \\
\hline
\end{tabular}

De tweede intramurale voorziening biedt in het jaar 2000 plaats aan 422 plaatsen 24-uurszorg, waarvan een aantal plaatsen wordt ingezet voor zorg op maat. ${ }^{24} \mathrm{De}$

22 Onder zorg op maat wordt in dit kader verstaan: thuiszorg, short stay, beschermd wonen, logeren en dagopvang voor diverse externe doelgroepen.

23 De cliënten onderscheiden zich ook door een aantal (bijkomende) stoornissen: motorische stoornissen, stoornissen in de sensibiliteit, coördinatiestoornissen en houdingsafwijkingen, stoornissen van het optische systeem, stoornissen van het auditieve systeem, taalontwikkelingsstoornissen, inhibitieproblematiek (ADHD), stoornissen in het bewustzijn (epilepsie), gedragsproblematiek, psychiatrische problematiek, autisme en hartafwijkingen.

24 Onder zorg op maat wordt in dit kader verstaan: thuiszorg, short stay, individueel begeleid zelfstandig wonen, logeren en dagopvang voor diverse externe doelgroepen. 
intramurale voorziening bestaat uit een hoofdlocatie met groepswoningen. Deze locatie biedt onder meer ook ruimte aan een bewegingscentrum, arbeids- en bezigheidscentrum, boerderij, recreatieve voorzieningen en behandelruimtes. Buiten de locatie bevinden zich 11 sociowoningen. Het niveau van de verstandelijke handicap van de cliënten varieert van een lichte verstandelijke handicap tot een zeer emstige verstandelijke handicap. ${ }^{2 s}$

Tabel 3. Mate van handicap van cliënten (voorziening 2)

\begin{tabular}{|l|l|}
\hline Mafe van handicap & Aantal \\
\hline Licht & 41 \\
\hline Matig & 228 \\
\hline Ernstig & 115 \\
\hline Zeer ernstig & 38 \\
\hline Totaal & 422 cliënten \\
\hline
\end{tabular}

De derde voorziening, een semi-murale voorziening, biedt in het jaar 2000 plaats aan 194 cliënten die verspreid wonen over een aantal gvt'en in Limburg. In totaal gaat het om zeven hoofdlocaties die onderverdeeld kunnen worden in een aantal nevenvestigingen. Andere activiteiten van deze voorziening zijn in 2000: dagcentra voor volwassen cliënten en oudere cliënten, kinderdagcentra, begeleid wonen en arbeidsintegratie. Het niveau van de verstandelijke handicap van de cliënten varieert van een lichte verstandelijke handicap tot een matige verstandelijke handicap.

\subsubsection{Beschrijving van de woningen}

In elke voorziening zijn, in overleg met de contactpersoon van de voorziening en de afdelingshoofden, drie woningen uitgekozen. Bij de keuze van de woningen is rekening gehouden met de diversiteit aan woningen die in een instituut en een semi-murale voorziening aanwezig is.

In de eerste intramurale voorziening werden drie karakteristieke woningen uitgekozen. In de eerste woning wonen 8 cliënten ( 3 vrouwen en 5 mannen) die bijna allemaal ouder zijn dan 50 jaar. Cliënten komen op deze groep wonen als hun algemene gezondheidstoestand dusdanig achteruit is gegaan is dat specifieke zorg geboden is. Een aantal cliënten is afkomstig van een gvt. Het merendeel

25 De cliënten onderscheiden zich ook door een aantal andere (bijkomende) stoornissen: motorische stoornissen, stoornissen in de sensibiliteit, coördinatiestoornissen en houdingsafwijkingen, stoornissen van het optische systeem, stoornissen van het auditieve systeem, taalontwikkelingsstoornissen, inhibitieproblematiek (ADHD), stoornissen in het bewustzijn (epilepsie), gedragsproblematiek, psychiatrische problematiek, autisme en hartafwijkingen. 
van de cliënten heeft, mede door hun hoge leeftijd, ook geen vertegenwoordiger meer. Dit betekent dat de begeleiding, die doorgaans een verpleegkundige achtergrond heeft, regelmatig in overleg met een arts een beslissing moet nemen. De cliënten hebben, op één na, niet de beschikking over een eigen kamer.

De tweede woning biedt verblijf aan tien mannen in de leeftijd van 34 tot 51 jaar. $\mathrm{Zij}$ hebben een ernstige verstandelijke handicap waartoe ook gedragsstoornissen behoren hetgeen zich uit in enigerlei vorm van probleemgedrag. In de ondersteuning wordt de nadruk gelegd op de individuele omgang waarbij duidelijkheid, structuur en veiligheid kernbegrippen zijn. De afdeling is gesloten; niemand kan zonder toestemming de woning verlaten of binnentreden. Een aantal cliënten heeft een eigen kamer; de andere cliènten moeten hun kamer delen. Overdag gaan de cliënten naar verschillende vormen van dagbesteding.

In de derde woning wonen 11 cliënten, waarvan 10 mannen en een vrouw. Deze indeling is door verschuivingen en overplaatsingen tot stand gekomen. De groep heeft het karakter van een seniorengroep. De doelstelling van deze woning is enerzijds het instandhouden van huidige vaardigheden en anderzijds het zo goed mogelijk tegemoet komen aan hun wensen. De cliënten kunnen naar behoefte gebruik maken van dagactiviteiten waaronder de soos. Ook in deze woning beschikken niet alle cliënten over een eigen kamer. Slechts een aantal cliënten heeft een eigen kamer; de deur van de kamer van de vrouwelijke cliënt gaat gedurende de nacht op slot om te voorkomen dat zij wordt lastiggevallen door een van de tien mannen.

In de tweede intramurale voorziening is, naast twee woningen, een sociowoning uitgekozen. In deze woning wonen drie zeer zelfstandige cliënten. De woning is geschakeld aan een andere woning, waar vier cliënten woonachtig zijn. Elke cliënt heeft een eigen kamer. Daarnaast is er een badkamer, woonkamer en een keuken, waar elke avond zelfstandig wordt gekookt en gezamenlijk wordt gegeten. De sfeer doet zeer huiselijk aan. De woning doet een groot beroep op het eigen initiatief en de zelfwerkzaamheid van de cliënten. De begeleiding stimuleert de cliënten om zoveel mogelijk zelf beslissingen te nemen. Daar waar nodig ondersteunt de begeleiding de cliënten. De drie cliënten gaan overdag naar hun werk. Een cliënt gaat zelfstandig op de fiets en de andere twee worden met speciaal busvervoer naar hun werk gebracht.

De tweede woning biedt huisvesting aan acht cliënten die allen een (zeer) ernstige meervoudige handicap hebben. De begeleiding van deze bewoners is gericht op instandhouding van en daar waar mogelijk ontwikkelingsgericht inspelen op en begeleiding bij zowel fysieke als psychische achteruitgang. De cliënten zijn kwetsbaar en totaal afhankelijk van de geboden zorg. De begeleiding van deze groep heeft als belangrijkste doel de cliënten een ontspannen en prettig leven te bieden, ondanks het gegeven dat de cliënten een kort levensperspectief hebben. De medische zorg is voornamelijk gericht op pijnbestrijding. De verwezenlijking van deze doelen vereist een nauwe samenwerking met o.a. de 
(wettelijk) vertegenwoordigers, artsen, fysiotherapie, ergotherapie en logopede. De cliënten beschikken, op één cliënt na, niet over een eenpersoonskamer. Em deel van de cliënten slaapt in de centrale woonkamer. De overige vier cliënten liggen verdeeld over twee aparte slaapkamers: drie in één kamer en een cliënt slaapt alleen in een kamer. De dagactiviteiten, waaronder snoezelen, vinden voor een groot deel plaats in een centrale ruimte in het midden van woning 2 met een andere woning. Cliënten hebben per week gemiddeld vier uur aan aciviteiten, mits hun fysieke gesteldheid dit toelaat. De meeste activiteiten vragen een 'een op een' begeleiding. De activiteiten worden aangeboden door twee $\mathrm{x}$ tiviteitenbegeleiders.

In de derde woning, woning $3 \mathrm{~A}$ en $3 \mathrm{~B}$, wonen cliënten met ernstige gedragspoblemen, in totaal 14 cliënten. Beide woningen bevinden zich in één gebouw an vormen een gesloten afdeling. Woning $3 \mathrm{~B}$ heeft echter een meer gesloten karaster dan woning $3 \mathrm{~A}$, aangezien de cliënten in woning $3 \mathrm{~B}$ niet vrij kunnen rondlpen in de woning. De meeste cliënten van deze woning hebben kamertraining: zij verblijven op hun kamer met de deur op slot. Deze cliënten mogen alleen onder begeleiding hun kamer verlaten. Beide woningen beschikken over een sepreerruimte en enkele ruimtes voor crisisopvang, die doorgaans ook worden gbruikt voor langdurige opvang.

Drie gvt'en van de semi-murale voorziening hebben deelgenomen aan het ondezoek. In het eerste gvt dat werd bezocht wonen zeven cliënten in een geschakeld huis die overdag naar hun werk of een dagactiviteitencentrum gaan. Elke cliënt heeft een eigen kamer, waar hij zich kan terugtrekken. De cliënten zijn niet in staat om al dan niet onder begeleiding zelfstandig te gaan wonen. De begeleiding bereidt dagelijks het eten voor de cliënten. Ook moeten de cliënten op tal van andere aspecten worden aangestuurd waaronder persoonlijke hygiëne. Met een aantal cliënten zijn ook afspraken gemaakt over alcoholgebruik, geld en omgang met vrienden en vriendinnen.

In het tweede gvt wonen twee groepen van ieder 9 cliënten waarvan de meeste cliënten ouder dan 50 jaar zijn. Een deel van deze cliënten bezoekt nog regelmatig een dagactiviteitencentrum waaronder de soos. Andere cliënten blijven, mede vanwege hun leeftijd, de gehele dag thuis. De cliënten beschikken allemaal over een eigen, ruime kamer. Daarnaast kunnen zij zich op diverse plaatsen in de woning terugtrekken. De woning heeft een grote tuin en een serre. Het avondeten vindt plaats in twee aparte woonkamers en wordt bereid in de bijbehorende keuken. Gedurende de gehele dag is begeleiding aanwezig.

Het derde gvt kent een korte geschiedenis. Zeer recentelijk zijn zes cliënten, tussen de 20 en 30 jaar, verhuisd naar deze locatie. In overleg met de cliënten en hun vertegenwoordigers is besloten dat zij hun toenmalige woonplaats (gvt) mochten omruilen voor een plaats in dit kleinschalige gvt. Het betreft zes cliënten die zeer zelfstandig werden bevonden. Elke cliënt heeft de beschikking over een eigen kamer. Cliënten geven aan dat zij in deze woonvorm veel meer pri- 
vacy genieten dan in hun vorige woning. Per dag maken zij aanspraak op gemiddeld zeven uur begeleiding. In de ochtend is doorgaans geen begeleider aanwezig. De cliënten helpen ook bij het koken en zijn gezamenlijk verantwoordelijk voor een aantal huishoudelijke werkzaamheden. De zes cliënten hebben voltijds of parttime dagbesteding. Aangezien het gvt niet in de buurt ligt van een ander gvt geldt de afspraak dat in de avond de voordeur en achterdeur op het nachtslot gaan. Ook mogen cliënten na het vertrek van de begeleiding niemand binnenlaten in de woning.

\subsubsection{Beschrijoing van de cliënten}

De onderzoekspopulatie is zo gevarieerd mogelijk samengesteld aangezien het onderzoek betrekking heeft op de gehele sector verstandelijk gehandicaptenzorg waaronder in deze studie wordt verstaan alle niveaus van verstandelijke handicap. Per woning zijn, in overleg met de contactpersoon van de voorziening en de afdelingshoofden, twee cliënten uitgekozen (in totaal 19 cliënten). ${ }^{20}$ Deze beperking is aangebracht omdat het niet reëel was om alle cliënten, die in een woning verblijven, in dit onderzoek te betrekken. De afdelingshoofden hadden verschillende redenen om te komen tot hun keuze van cliënten. ${ }^{z}$ Het resultaat leverde een zeer gevarieerd en representatief beeld op van de verschillende niveaus van verstandelijke handicap die de sector verstandelijk gehandicaptenzorg onderscheidt. Slechts één cliënt was met een Bopz-indicatie opgenomen. De overige cliënten verbleven vrijwillig in de verschillende voorzieningen.

26 In één woning werden door een afdelingshoofd omwille van hun interessante geschiedenis niet twee maar drie cliënten uitgekozen.

$27 \mathrm{Er}$ werden cliënten uitgekozen waar voornamelijk de Bopz-problematiek speelt, cliënten waarvoor alles wordt bepaald (ondanks dat ze zelf veel kunnen beslissen), cliënten waarbij de vertegenwoordiger een grote invloed heeft, cliënten die ondanks een hoog niveau emotioneel niet goed ontwikkeld zijn waardoor de begeleiding deze cliënten voortdurend in bescherming moet nemen, cliënten die in een sociowoning wonen en zelfstandig willen gaan wonen, cliënten met borderliner problematiek en cliënten met een zeer laag niveau die geen vertegenwoordiger hebben. 
Tabel 4. Beschrijving van de geselecteerde cliënten

\begin{tabular}{|c|c|c|c|c|c|}
\hline Cliênten & Leeftijds & Geslacht & Woonvorm & Niveau & Vertegenwoordigers \\
\hline \multicolumn{6}{|l|}{ Voorziening 1} \\
\hline 1 & 69 & $M$ & Instituut & $\begin{array}{c}\text { Syndroom van } \\
\text { Down }\end{array}$ & $\begin{array}{c}\text { Geen vertegenwoor- } \\
\text { diger }\end{array}$ \\
\hline 2 & 56 & v & $\begin{array}{l}\text { Instituut } \\
\text { (vroeger } \\
\text { gvt) }\end{array}$ & $\begin{array}{l}\text { Syndroom van } \\
\text { Down/dementie }\end{array}$ & $\begin{array}{l}\text { Niet wettelijk verte- } \\
\text { genwoordiger (zus) } \\
\text { (nwv) }\end{array}$ \\
\hline 3 & 40 & $M$ & Instituut & $\begin{array}{c}\text { Emstige ver- } \\
\text { standelijke han- } \\
\text { dicap (vh) en } \\
\text { gedragsproble- } \\
\text { men }\end{array}$ & $\begin{array}{l}\text { Bewindvoerder en } \\
\text { mentor }\end{array}$ \\
\hline $4^{11}$ & 52 & $M$ & Instituut & $\begin{array}{c}\text { Ernstige vh/ } \\
\text { gedragsproble- } \\
\text { men }\end{array}$ & Curator \\
\hline 5 & 55 & $\mathrm{M}$ & Instituut & Matige vh & Curator \\
\hline 6 & 58 & M & Instituut & $\begin{array}{c}\text { Matige } \\
\text { vh/psychiatrisch }\end{array}$ & $\begin{array}{c}\text { Geen vertegenwoor- } \\
\text { diger }\end{array}$ \\
\hline 7 & 62 & V & Instituut & $\begin{array}{l}\text { Lichte tot matige } \\
\text { vh }\end{array}$ & $\begin{array}{c}\text { Geen vertegenwoor- } \\
\text { diger }\end{array}$ \\
\hline \multicolumn{6}{|l|}{ Voorziening 2} \\
\hline 8 & 40 & $\mathrm{M}$ & $\begin{array}{l}\text { Socio- } \\
\text { woning }\end{array}$ & Lichte vh & Nwv (zus) \\
\hline 9 & 43 & $\mathrm{~V}$ & $\begin{array}{l}\text { Socio- } \\
\text { woning }\end{array}$ & Lichte vh & $\begin{array}{c}\text { Geen vertegenwoor- } \\
\text { diger }\end{array}$ \\
\hline 10 & 26 & $M$ & Instituut & $\begin{array}{l}\text { Ernstige meer- } \\
\text { voudig vh }\end{array}$ & Curator \\
\hline 11 & 20 & $M$ & Instituut & $\begin{array}{c}\text { Ernstige meer- } \\
\text { voudige vh }\end{array}$ & $\begin{array}{c}\text { Bewindvoerder en } \\
\text { mentor }\end{array}$ \\
\hline 12 & 51 & $M$ & Instituut & $\begin{array}{c}\text { Matige vh/ge- } \\
\text { dragsproblemen }\end{array}$ & Nwv (broer) \\
\hline 13 & 50 & $M$ & Instituut & $\begin{array}{l}\text { Matige vh/ ge- } \\
\text { dragsproblemen }\end{array}$ & Nwv (zus) \\
\hline
\end{tabular}

28 Als peildatum is genomen januari 2000.

29 Opties zijn: geen vertegenwoordiger, niet-wettelijk vertegenwoordiger, mentor, bewindvoerder of curator.

30 Het betrof in dit geval een gesloten afdeling. Dat gold ook voor cliënten 4, 12 en 13.

31 Dit was de enige cliënt met een Bopz-indicatie. Dit betekende overigens niet dat alleen bij deze cliënt vrijheidsbeperking aan de orde was. Dat was ook in enige mate het geval bij enkele andere cliënten, die allemaal vrijwillig waren opgenomen. 


\begin{tabular}{|c|c|c|c|c|c|}
\hline Cliênten & Leeftijds & Geslacht & Woonvorm & Niveau & Vertegenwoordiger"s \\
\hline \multicolumn{6}{|l|}{ Voorziening 3} \\
\hline 14 & 51 & M & gvt & $\begin{array}{c}\text { Lichte verstan- } \\
\text { delijke handicap } \\
\text { (lvh) }\end{array}$ & Nwv (broer) \\
\hline 15 & 20 & V & gvt & Borderliner & Nwv (moeder) \\
\hline 16 & 57 & V & $\mathrm{gvt}$ & Lvh & Nwv (zus) \\
\hline 17 & 52 & V & gvt & Lvh & Curator \\
\hline 18 & 27 & $\mathbf{M}$ & gvt & Lvh & Nvw (ouders) \\
\hline 19 & 32 & M & gvt & $\begin{array}{c}\text { Lichamelijke } \\
\text { handicap + (zeer) } \\
\text { lvh }\end{array}$ & Bewindvoerder \\
\hline
\end{tabular}

\subsubsection{Methoden}

Het empirische onderzoek werd uitgevoerd aan de hand van drie verschillende kwalitatieve methoden: participerende observaties, semi-gestructureerde interviews en dossieronderzoek. ${ }^{\text {I }}$ In alle drie de methoden vervulde de cliënt een centrale rol. In elke voorziening werden de geselecteerde cliënten gedurende een week geobserveerd, hun dossier werd ingezien en tot slot vond een interview (indien mogelijk) met de cliënt, zijn vertegenwoordiger en zijn persoonlijk begeleider plaats.

Voorafgaand aan het empirische onderzoek heeft in januari 2000 een pilot plaatsgevonden in een intramurale voorziening voor verstandelijk gehandicaptenzorg in Limburg. Deze voorziening behoorde niet tot de drie voorzieningen die geselecteerd waren voor het empirische onderzoek. De pilot had als doel om de instrumenten (interviewschema, itemlijst en checklist voor dossiers) die gebruikt zouden gaan worden in de drie verschillende voorzieningen te testen en waar mogelijk bij te stellen. Naast het afnemen van enkele interviews met cliënten, persoonlijk begeleiders en vertegenwoordigers is gedurende twee weken in een aantal woningen geobserveerd en heeft dossieronderzoek plaatsgevonden. Daarnaast is ter voorbereiding op het empirische onderzoek bij elke geselecteerde voorziening een aantal documenten opgevraagd. ${ }^{30}$ Van deze informatie is gebruik gemaakt bij de toepassing van de drie kwalitatieve methoden. ${ }^{34}$

32 In de literatuur over kwalitatief onderzoek wordt in dit kader gesproken over triangulatie. Teneinde de interne betrouwbaarheid van het onderzoek te vergroten kan worden gebruik gemaakt van meerdere, elkaar bevestigende methoden (Maso en Smaling 1998, p. 69-70). Triangulatie was ook aan de orde doordat de interviews bij drie verschillende groepen respondenten zijn afgenomen: bij cliënten, vertegenwoordigers en persoonlijk begeleiders.

33 Het betrof de volgende lijst: beleidsplan, kwaliteitsjaarverslag, nota of jaarverslag van de M\&M-commissie, informatie over de woningen, organisatiestruc- 
In dit onderzoek is bewust gekozen voor meer dan één methode. Door gebruik te maken van drie verschillende methoden - observeren, dossieronderzoek en interviews - kon een zo volledig mogelijk beeld worden verkregen van de onderwerpen die centraal stonden in dit onderzoek. De interviews leverden niet op alle gebieden de verwachte informatie op. ${ }^{35}$ Deze lacunes in gegevens zijn aangevuld met het materiaal dat verzameld is door middel van participerende observaties en/of dossieronderzoek. Omgekeerd gold ook dat interviews de mogelijkheid boden om onduidelijkheden die naar voren kwamen in de gegevens, die zijn verzameld door observaties en dossieronderzoek, te verhelderen.

\subsubsection{Observaties}

De onderzoeksmethode participerende observatie is een methode die binnen kwalitatief onderzoek veelvuldig wordt toegepast. Onder deze methode wordt ook wel verstaan 'het zorgvuldig, aandachtig en systematisch gadeslaan van de uiterlijke gedragingen waarin de onderzoekers zijn geïnteresseerd'. ${ }^{36}$ Het gaat met name om de betekenissen die de onderzochten, in dit geval cliënten en persoonlijk begeleiders, in hun dagelijks leven aan de processen en gedragingen toekennen. In dit onderzoek is ook gebruik gemaakt van observaties. Deze methode bood allereerst de mogelijkheid om gegevens te verzamelen van cliënten die niet of minder in staat waren om hun mening te verwoorden. De onderzoeker kon, door deel te nemen aan het dagelijks leven van een cliënt met een (zeer) ernstige verstandelijke handicap, ervaren hoe het is om in een instituut te wonen. Daarnaast was het mogelijk om de interacties die zich binnen een woning voordeden te bestuderen. Te denken valt aan interacties tussen cliënten onderling, tussen cliënten en hulpverleners en tussen hulpverleners onderling. ${ }^{37}$ Ook konden, naast de verbale uitingen, de non-verbale uitingen van hulpverleners en cliënten worden geobserveerd. Een ander voordeel van participerend observe-

tuur, voorbeeld van een zorgplan, voorbeeld van een dossier, nota's en/of protocollen over thema's zoals sterilisatie, vrijheidsbeperking, vertegenwoordiging, wilsonbekwaamheid, orgaandonatie, aanmelding en opneming nieuwe cliënten, autonomie en privacy en de Wet Bopz.

34 De interviews boden onder meer voldoende ruimte om nader in te gaan op de inhoud van een aantal documenten.

35 Dit gold met name bij de interviews van cliënten (zie paragraaf 2.5.6.2).

36 Maso en Smaling 1998, p. 49.

37 Vragen die hierbij een rol speelden waren: wordt de cliënt betrokken bij het nemen van beslissingen, wordt over cliënten gesproken of met cliënten? 
ren is dat het verzamelen van gegevens niet beperkt blijft tot een momentopname.ss

De participerende observaties hebben voorafgaand aan de interviews plaatsgevonden. De observaties hadden als doel om de problemen die zich in de praktijk van de zorg voor mensen met een verstandelijke handicap voordoen ten aanzien van hun (interne) rechtspositie in kaart te brengen. In elke voorziening werden slechts twee cliënten gedurende een week geobserveerd." In de praktijk betekende dit doorgaans niet dat de onderzoeker ook daadwerkelijk een gehele week in een woning aanwezig was. In overleg met de cliënten en/of de persoonlijk begeleiders werd een schema opgesteld. In elke woning is geprobeerd om zowel een ochtend, een middag als een avond aanwezig te zijn. Van dit schema is echter een aantal keren afgeweken. Dit gold met name in de gut'en en de sociowoning. In de sociowoning gaven cliënten aan dat zij het niet prettig zouden vinden als de onderzoeker gedurende een gehele dag aanwezig zou zijn in hun woning. In overleg met de drie aanwezige cliënten is besloten om alleen in de namiddag en de avond te komen observeren. Dezelfde afspraken werden gemakkt met de cliënten die woonachtig waren in twee van de drie gut'en. Ook in deze twee gvt'en werd afgesproken om alleen in de namiddag en de avond te observeren. $*$

In het merendeel van de woningen is geobserveerd in de woonkamer. In de woningen waar cliënten met gedragsproblemen woonden, werd doorgaans letterlijk vanuit een stoel geobserveerd. In andere woningen werd ook in de woning rondgelopen en deelgenomen aan de dagelijkse activiteiten waaronder het avondeten. Daarnaast werden cliënten een ochtend of een middag geobserveerd tijdens hun werkzaamheden in bijvoorbeeld een dagcentrum, de soos of de sociale werkplaats. Ook werd een aantal bijeenkomsten van cliënten- en deelnemersraden bijgewoond.

38 Een interview kent deze beperking wel. In dit onderzoek zijn echter beide methoden naast elkaar gebruikt, waardoor zij elkaars tekortkomingen kunnen aanvullen.

39 Het observeren van slechts twee cliënten had als voordeel dat binnen het onderzoek de aandacht verdeeld kon worden over cliënten met verschillende achtergronden: cliënten met een verstandelijke handicap en autisme, gedragsproblemen, psychische problemen en cliënten met een (zeer) ernstige verstandelijke handicap.

40 In tegenstelling tot cliënten met een (zeer) ernstige verstandelijke handicap was in twee van de drie gvt'en de sociowoning overdag doorgaans niemand aanwezig in de woning; cliënten waren op dat moment naar hun werk en kwamen rond vier uur of later weer thuis. 
Het observeren van cliënten werd door een aantal factoren belemmerd. Een aantal cliënten moest volgens de afspraken die in het zorgplan waren vastgelegd van tijd tot tijd naar hun kamer worden gebracht om tot rust te komen." Andere cliënten trokken zich vrijwillig terug op hun kamer, aangezien zij zeer gehecht waren aan hun privacy. Bij deze laatste groep cliënten was het echter wel mogelijk om, met toestemming van de cliënt, hun kamer binnen te treden.

Om het onderzoek enigszins af te bakenen vormde een itemlijst het kader voo: de participerende observaties. Deze lijst had als doel om zo dicht mogelijk bij de onderzoeksvragen te blijven en het overzicht tijdens het observeren niet uit het oog te verliezen. Deze lijst is gebaseerd op de literatuur die in het juridische onderzoek is bestudeerd en de eerste kennismaking die met het veld is gemaakt. De begrippen zijn in willekeurige volgorde op een lijst geplaatst en varieerde van rechten, zorgplan, vertegenwoordiger, autonomie, huisregels, privacy, dwang, drang, afspraken, verzet, gevaar tot wilsonbekwaamheid. Na afloop van elke observatie werd deze lijst nagelopen. Als zich iets voor had gedaan op het gebied van één van de begrippen, werd dit genoteerd. Daarnaast is een lijst met enkele standaardvragen opgesteld. ${ }^{42}$ Deze vragen werden ook elke dag na afloop van het observeren beantwoord. Op deze manier werd getracht enige structuur aan te brengen in de vele ervaringen die de onderzoeker gedurende een dag opdeed. De overige (bijzondere) ervaringen, die niet konden wonden ondergebracht bij een van de begrippen uit de itemlijst of geen antwoord gaven op een standaardvraag, werden in een dagboek genoteerd. Deze aantekeningen werden doorgaans niet tijdens het observeren gemaakt. Het maken van notities in de woning bleef beperkt tot het noteren van een aantal steekwoorden om zoveel mogelijk aandacht te kunnen besteden aan de rol van participerend observeerder.

\subsubsection{Interviews}

De interviews waren semi-gestructureerd. Een kenmerk van een semi-gestructureerd interview is dat de vragen en antwoorden niet van tevoren vastliggen maar de onderwerpen wel. Elk onderwerp wordt doorgaans met een of meer beginvragen geïntroduceerd. Vervolgens komt een aantal van tevoren vastge-

41 Door hulpverleners werd ook wel gesproken over 'kamertraining'.

42 Een voorbeeld van enkele vragen: Hoe zag de dagindeling eruit? Deden zich opvallende gebeurtenissen voor? Heeft de cliënt vandaag zelf een beslissing genomen? Deden zich situaties voor waaruit blijkt dat een persoonlijk begeleider de cliënt niet betrekt bij het maken van een afweging? (achterhouden van informatie, bepaalde zaken niet vertellen). 
stelde onderwerpen aan de orde die door middel van een open beginvraag en doorvragen worden uitgediept. 3

In dit onderzoek zijn in totaal 56 interviews afgenomen (tabel 4), waarvan 47 verdeeld over drie groepen respondenten: de cliënt (13), de persoonlijk begeleider (19) en de vertegenwoordiger (15). ${ }^{4}$ Op deze manier kon vanuit drie verschillende perspectieven informatie worden verzameld over de (interne) rechtspositie van cliênten en de problemen die zich daarbij voordeden. Het interviewschema bestond naast het thema vrijheidsbeperking ook uit een aantal andere thema's waaronder rechtspositie, autonomie, zorgplan, privacy, vertegenwoordiging en opnieuw rechtspositie. Door deze thema's mee te nemen in het interview kon een zo breed mogelijk beeld worden gevormd van de rechtspositie van cliënten aangaande de toepassing van vrijheidsbeperking. De thema's stonden centraal in het interviewschema van zowel de cliënt, de persoonlijk begeleider als de vertegenwoordiger. $\mathrm{Na}$ een korte introductie werd elk thema ingeleid met een algemene stelling waarover de respondenten hun mening mochten geven. ${ }^{\text {s }}$ Vervolgens bestond de mogelijkheid om een aantal vragen, die van tevoren waren opgesteld, voor te leggen aan de respondent. Er was echter ook voldoende ruimte om, mede naar aanleiding van de stelling die beantwoord moest worden, af te wijken van deze vragen of langer stil te staan bij een antwoord op een vraag dan wel door te vragen. Teneinde voldoende te waarborgen dat de antwoorden van de respondenten met elkaar konden worden vergeleken dienden in ieder geval in elk interview de eerder genoemde thema's aan bod te komen.

43 D.B. Baarda, M.P.M. de Goede en A.G.E. van der Meer-Middelburg, Basisboek. Open interviewen, Houten: Educatieve Partners Nederland BV 1996, p. 26.

44 De overige negen interviews zijn afgenomen bij twee artsen voor verstandelijk gehandicapten, een hoofd pedagogische dienst, twee stafmedewerkers, een beheerder bewonersgelden, een vertrouwenspersoon, een pastoraal medewerker en een directeur. Het doel van deze interviews, ook semi-gestructureerd, was om aanvullende informatie te krijgen over de (interne) rechtspositie van cliënten met een verstandelijke handicap. In het interview met de arts lag de nadruk op de wijze waarop in een instelling wordt omgegaan met de Bopz.

45 Deze stellingen zijn overigens weggelaten bij de interviewschema's van de cliënten. 
Tabel 5. Geinterviewde personen in drie voorzieningen

\begin{tabular}{|l|l|}
\hline Respondent & Aantal \\
\hline Cliënt & $13^{\text {s }}$ \\
\hline Vertegenwoordiger & 15 \\
\hline Persoonlijk begeleider & 19 \\
\hline Arts voor verstandelijk gehandicapten & 2 \\
\hline Hoofd pedagogische dienst & 1 \\
\hline Stafmedewerker & 2 \\
\hline Beheerder bewonersgelden & 1 \\
\hline Vertrouwenspersoon & 1 \\
\hline Pastoraal medewerkster & 1 \\
\hline Directeur & 1 \\
\hline Totaal & 56 \\
\hline
\end{tabular}

Aangezien de vragen zoveel mogelijk dienden aan te sluiten bij het perspectief van de respondent was het onvermijdelijk dat de interviewschema's van de verschillende respondenten op een aantal punten van elkaar verschilden. Ten aanzien van het thema vrijheidsbeperking werd in het interviewschema van de vertegenwoordiger de nadruk gelegd op de betrokkenheid van de vertegenwoordiger bij het maken van afspraken en het nemen van beslissingen aangaande vrijheidsbeperking en werd gevraagd in hoeverre de vertegenwoordiger werd geïnformeerd als een cliënt in zijn vrijheid werd beperkt. In het interviewschema van de persoonlijk begeleider lag ten aanzien van dit thema de nadruk op de overwegingen om een cliënt in zijn vrijheid te beperken, de kennis van de Wet Bopz en de wijze waarop deze wet in de instelling is geïntroduceerd. Het interviewschema van de cliënten bestond ook uit de eerder genoemde thema's. De inhoud was echter op een aantal punten aangepast.

In de literatuur worden verschillende complicerende factoren genoemd waar bij het interviewen van cliënten met een verstandelijke handicap rekening mee moet worden gehouden. ${ }^{47}$ In dit onderzoek is op verschillende manieren met deze factoren omgegaan. Voorafgaand aan het empirische onderzoek heeft onderzoeker een training 'interviewen mensen met een verstandelijke handicap' gevolgd." Hierin werd benadrukt dat cliënten met een verstandelijk handicap zich eerst veilig moeten voelen voordat zij bereid zijn om hun eigen mening over

46 Er waren 19 cliënten, verdeeld over drie voorzieningen en negen woningen, geselecteerd voor dit onderzoek. Het was echter niet mogelijk om, mede vanwege het niveau van de cliënten, bij alle cliënten een interview af te nemen.

47 A.R. Huizing, M.A. Maaskant, J.P.H. Hamers en W. Groot, Een eigen invulling. Zorgbehoeften van mensen met een verstandelijke handicap, Maastricht: Universitaire Pers Maastricht 2002, Bijlage 1.

Deze training is verzorgd door mw. L. den Dulk van Raad op Maat. 
bepaalde onderwerpen te geven. In dit onderzoek is deze veiligheid gecreëerd door, voorafgaande aan het interview, de cliënt een week te observeren in zijn woning waardoor hij al in een eerder stadium kennis heeft kunnen maken met de onderzoeker. Tevens zijn de cliënten voldoende geïnformeerd over de opzet van het interview. Aan het begin van het interview is het doel van het interview toegelicht, is verteld over welke onderwerpen vragen werden gesteld, is uitgelegd waar de informatie voor gebruikt ging worden, is verteld hoe lang het interview zou duren en is tot slot aan de cliënt uitgelegd dat de uitkomsten van het interview vertrouwelijk werden behandeld. Hieronder werd ook verstaan dat de persoonlijk begeleider of de vertegenwoordiger niet zonder toestemming van de cliënt zijn antwoorden mocht inzien. Daarnaast is aan de cliënt duidelijk gemaakt dat er geen goede of foute antwoorden zijn en dat de cliënt altijd de keuze heeft om een bepaalde vraag niet te beantwoorden." Vervolgens is het interview van start gegaan met een aantal zeer algemene vragen over zijn werk, zijn woning en vrienden en/of familie teneinde de cliënt eerst op zijn gemak te stellen.

Het interviewschema voor cliënten omvatte minder vragen, waardoor het interview doorgaans niet langer duurde dan een half uur. Ook bestond de mogelijkheid om het interview tussentijds te onderbreken voor een korte pauze." ${ }^{.0}$ Doordat rekening is gehouden met bovengenoemde factoren vormde het interview een goede methode om gegevens te verzamelen bij cliënten met een matige tot lichte verstandelijke handicap. Een belangrijk aspect in dit onderzoek is dat cliënten serieus zijn genomen en dat geluisterd is naar wat zij te vertellen hadden over hun (interne) rechtspositie. De kans blijft bestaan dat cliënten sociaal wenselijke antwoorden geven. Deze kans is evenwel ook aanwezig bij mensen die geen verstandelijke handicap hebben. De sociaal wenselijkheid van cliënten, persoonlijk begeleiders en vertegenwoordigers kon voor een deel worden voor-

49 H. Prosser en J. Bromley, Interviewing people with intellectual disabilities, in: E. Emerson, C. Hatton, J. Bromley and A. Caine (eds), Clinical Psychology and People with Intellectual Disabilities, Chichester: John Wiley and Sons Ltd. 1998, p. 102.

50 Cliënten vertonen soms bewegingsdrang en beschikken, ten gevolge van innerlijke onrust, over een slecht en kortdurend concentratievermogen (M.C.O. Kersten, "Het betrekken van mensen met een verstandelijke handicap bij dataverzameling voor wetenschappelijk onderzoek: methodologische consequenties", in: D.A. Flikweert \& M.C.O. Kersten (Eds), Wetenschappelijk onderzoek ten behoeve van de zorg voor mensen met verstandelijke handicap, Plenaire lezingen van het congres gehouden op 29 en 30 oktober 1998 (pp. 68-84), Utrecht: NGBZ en BBI 1999 en M.C.O Kersten en M.I.M. Schuurman, Ervaren mogelijkheden en beperkingen. Een instrument voor bevraging van mensen met een verstandelijke handicap, Utrecht: BBI 2000 . 
komen door duidelijke vragen te stellen in een taal die aansloot bij het niveu van de respondent. Daarnaast zijn in de analyse de antwoorden van cliëntn naast de antwoorden van persoonlijk begeleiders en die van vertegenwoordigrs gelegd, waardoor het mogelijk was om vanuit drie perspectieven naar de atwoorden te kijken. Ook kon in deze fase een vergelijking worden gemaakt ret de bevindingen uit het dossieronderzoek en de observaties.

De interviews zijn op verschillende locaties afgenomen. De interviews met le vertegenwoordigers vonden doorgaans bij de vertegenwoordigers thuis plats. Het vinden van een juiste locatie voor de interviews met de persoonlijk begetiders was niet altijd even eenvoudig. In de meeste gevallen werd uitgewelen naar een kamer of een kantoorruimte buiten de aanwezigheid van de cliëntn. Het kwam echter ook een aantal keren voor dat, bij afwezigheid van een kntoorruimte of vanwege een tekort aan personeel, het interview in aanwezighid van de geselecteerde cliënt plaatsvond en/of in aanwezigheid van andere clinten. De interviews met de cliënten vonden doorgaans plaats in de kamer vande cliënt. Niet alle cliënten hadden echter de beschikking over een eigen kaner, waardoor uitgeweken moest worden naar een andere ruimte. Een enkele ker vond een interview plaats in een kantoorruimte. Van deze mogelijkheid is ecker zo weinig mogelijk gebruik gemaakt aangezien cliënten zich niet altijd op un

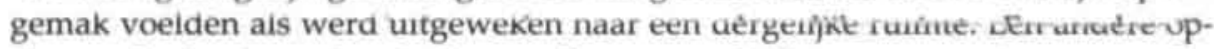
tie was dat het interview in de woonkamer werd afgenomen met het gevaar dat cliënten in aanwezigheid van andere cliënten snel afgeleid zouden zijn, dat andere cliënten zich zouden gaan bemoeien met het gesprek en/of dat cliënten zich geremd zouden voelen in het geven van antwoorden. Ook van deze mogelijkheid is zo min mogelijk gebruik gemaakt. Twee keer heeft een persoonlijk begeleider het interview met een cliënt bijgewoond. De kans was aanwezig dat de onderzoeker allerlei vragen en gedachten zou oproepen bij de geïnterviewde cliënten. Teneinde goede nazorg te kunnen bieden aan de geïnterviewde cliënten, was het volgens de persoonlijk begeleiders van twee cliënten (cliënt 12 en 13 , tabel 4) beter als zij bij het interview aanwezig konden zijn. De twee cliënten voelden zich door de aanwezigheid van hun persoonlijk begeleider niet geremd in het geven van antwoorden. De persoonlijk begeleiders bleven, volgens afspraak, op de achtergrond aanwezig. Toch moet er rekening mee worden gehouden dat de aanwezigheid van derden, in dit geval een persoonlijk begeleider, invloed heeft op de uitkomsten van een interview. ${ }^{51}$

51 B. Emans, Interviewen, Theorie, techniek en training, Groningen: Wolters-Noordhoff 1990, p. 22-23. 
De interviews zijn allemaal opgenomen met een taperecorder. Aan het begin van het interview is hiervoor toestemming gevraagd aan de respondent. De interviews zijn vervolgens anoniem uitgewerkt, waarna de tapes zijn vernietigd.

\subsubsection{Dossieronderzoek}

In elke woning die bij het onderzoek betrokken was is een aantal dossiers van cliënten bestudeerd. Het betrof uitsluitend de dossiers van cliënten die waren geselecteerd. Elke cliënt en/of zijn vertegenwoordiger heeft (schriftelijk) toestemming gegeven voor inzage in zijn dossier. ${ }^{52}$ In totaal zijn 19 dossiers ingezien.

Het dossier bestond doorgaans uit een aantal onderdelen, waaronder het zorgplan, die niet allemaal in één centraal dossier terug te vinden waren. Op een aantal plaatsen werd gesproken van een moederdossier en een afgeleid dossier. Het moederdossier bevond zich op de hoofdlocatie of het kantoor van de woning/afdeling en het afgeleide dossier was aanwezig in de woning. In de gvt'en ontbrak doorgaans het (uitgebreide) medisch gedeelte van het dossier. Dit gedeelte was in het bezit van de huisarts van de desbetreffende cliënten en kon daardoor niet in zijn geheel worden ingezien. De inzage bleef beperkt tot een (beknopte) samenvatting van de medische gegevens die aanwezig was in het dossier van de cliënt. Hoewel de dossiers van alle 19 geselecteerde cliënten konden worden ingezien, wisselde de kwaliteit van de informatie die werd gevonden in de dossiers. Lang niet alle informatie was actueel; op bepaalde locaties was het zorgplan al jaren niet meer geëvalueerd. Op andere locaties was door de verhuizing en overplaatsing van cliënten al geruime tijd geen aandacht meer besteed aan het bijhouden van het dossier. In één gvt waren ontwikkelingen gaande om cliënten zo veel mogelijk zelf hun zorgplan te laten schrijven.

De dossiers zijn in de regel aan het begin van of voorafgaand aan de participerende observatie bestudeerd waardoor tijdig inzicht werd verkregen in de individuele situatie van een cliënt die gedurende een week werd geobserveerd. ${ }^{53}$ Het dossieronderzoek is uitgevoerd aan de hand van een checklist die voor een belangrijk deel is gebaseerd op wettelijke bepalingen. Zowel in de Wgbo als in de Wet Bopz zijn ten aanzien van de toepassing van vrijheidsbeperking enkele be-

52 Indien een vertegenwoordiger ontbrak en de cliënt niet in staat was om zelf toestemming te geven, gaf in de twee geselecteerde instituten de (algemeen) directeur of de manager zorg toestemming.

53 Het betreft onder meer gegevens over de juridische status, de toepassing van vrijheidsbeperking en de aanwezigheid van een (wettelijk) vertegenwoordiger. 
palingen over dossiervoering te vinden. ${ }^{4}$ In de Wet Bopz is bepaald dat in het zorgplan genoteerd dient te worden welke redenen geleid hebben tot de toepassing van dwangbehandeling of middelen of maatregelen (artikel 56 lid le en 1f). $\$ 5$

\subsubsection{Integratie gegevens van de tweede evaluatie Wet Bopz}

Naast een kwalitatief onderzoek in drie verschillende voorzieningen voor verstandelijk gehandicaptenzorg, zijn ten behoeve van het thema vrijheidsbeperking de resultaten van de tweede evaluatie van de Wet Bopz 'interne rechtspositie verstandelijk gehandicaptensector' in dit onderzoek geintegreerd. $.7 \%$

De tweede evaluatie Wet Bopz is in 2001 uitgevoerd en kende twee onderzoeksvragen:

- In hoeverre zijn de bepalingen van de Wet Bopz bekend en worden deze in de praktijk toegepast?

- In hoeverre vormt de Wet Bopz een geschikt kader om de rechtspositie te waarborgen van de cliënten van instituten voor verstandelijk gehandicaptenzorg?

De evaluatie bestond zowel uit een kwantitatief als een kwalitatief onderdeel. Het kwantitatieve gedeelte van het onderzoek bestond uit een schriftelijke enquête die verstuurd is naar alle instituten die in de verstandelijk gehandicaptenzorg een Bopz-aanmerking hebben. De inhoud van de vragenlijst had betrekking op de interne rechtspositie van zowel vrijwillig als onvrijwillig opgenomen cliënten. Eerder onderzoek had immers aangetoond dat vrijheidsbeperking ook bij vrijwillig opgenomen cliënten voorkomt. De vragen in de vragenlijst zijn gegroepeerd aan de hand van een aantal onderwerpen die in de Wet Bopz worden

54 Artikel 7:454-7:457 BW en artikel 56 en 57 Bopz. Dit laatste artikel is nader uitgewerkt in het Besluit patiëntendossier Bopz van 3 november 1993, Stb. 562 (gewijzigd bij het Besluit van 12 april 1996, Stb. 261).

55 Deze bepaling is overigens niet van toepassing op cliënten die met een Bopzindicatie zijn opgenomen.

56 In dit boek wordt alleen de term 'middelen of maatregelen' gebruikt. Hiermee wordt de discussie vermeden wanneer sprake is van 'middelen of maatregelen' conform artikel 39 lid 1 Bopz en wanneer van 'middelen en maatregelen' conform artikel 39 lid 2 Bopz.

57 Arends, Blankman en Frederiks 2002.

58 De bevindingen van de Evaluatie Wet Bopz zijn voornamelijk verwerkt in hoofdstuk 5, 6 en 7 van dit proefschrift. 
genoemd: $:$ de totstandkoming van het zorgplan, de uitvoering van het zorgplan, het voorkomen van noodsituaties, de toepassing van huisregels en de interpretatie van enige begrippen die de wet noemt (verzet, gevaar). De enquête werd afgesloten met een open vraag 'of in de instituten, in vergelijking met vrijwillig opgenomen cliënten, anders met Bopz-cliënten werd omgegaan'. In totaal zijn 163 instituten aangeschreven. De respons bedroeg, nadat alle instituten tweemaal een herinnering hadden ontvangen, 100 instituten $(61 \%)$. Onder de instituten die de vragenlijst niet retourneerden bevond zich een aantal orthopedagogische instituten. Hoewel zij formeel onder de Wet Bopz vallen gaven zij te kennen dat zij niet tot de beoogde doelgroep van het onderzoek behoren.

Het kwalitatieve gedeelte van het evaluatieonderzoek had als voornaamste doel om de resultaten die werden gevonden in het eerste gedeelte van de evaluatie te verduidelijken. Daarnaast werd gekeken in hoeverre de Wet Bopz een geschikt kader vormt voor de rechtspositie van cliënten in de zorg voor mensen met een verstandelijke handicap. ${ }^{\infty}$ Naast een aantal semi-gestructureerde interviews en dossieronderzoek heeft ook een invitational conference plaatsgevonden.

In totaal zijn vier instituten voor verstandelijk gehandicaptenzorg bezocht. Deze zijn geselecteerd uit de instituten die de schriftelijke enquête hebben geretourneerd. Hoewel de enquête anoniem was, heeft een aantal instituten het geretourneerde formulier voorzien van een stempel of van een begeleidende brief. Twee instituten behoorde tot degene die snel reageerde, een instituut maakte deel uit van de groep die op het eerste rappel reageerde en een instituut behoorde tot de groep die reageerde op het laatste rappel. Daarnaast is rekening gehouden met de grootte, de ligging en het aantal Bopz-cliënten. De resultaten van de schriftelijke enquête toonden aan dat in maar liefst een derde van de Bopz-instituten geen Bopz-cliënten verbleven. Aanvullend is nog een (vijfde) instituut bij het onderzoek betrokken die helemaal geen Bopz-cliënten kende. In dit instituut is alleen de beleidsverantwoordelijke voor de Bopz gënterviewd.

De interviews bestonden uit aantal vaste onderwerpen, die aangepast zijn aan de kennis, expertise en ervaringen van de respondenten. Doel van de vragen was te achterhalen hoe de Wet Bopz naar de praktijk wordt vertaald en wat de ervaringen hiermee zijn. Enkele onderwerpen waren: activiteiten die een insti-

59 Deze onderwerpen komen later terug in de interviews, die in het kader van de evaluatie Wet Bopz zijn gehouden, en vormden ook het uitgangspunt voor de opzet van het evaluatierapport.

60 Het antwoord op deze vraag heeft ook bijgedragen aan het beantwoorden van vraagstelling vier en vijf die in het onderhavige onderzoek centraal staan: 'Welke juridische mogelijkheden zijn er om de gevonden knelpunten op te lossen?' En 'Wat betekent een en ander voor zowel wetgeving en zelfregulering als de praktijk?' 
tuut ondernam om de Wet Bopz te operationaliseren, toepassing van middelen of maatregelen en het registreren en het melden van middelen of maatregelen. In totaal zijn 26 semi-gestructureerde interviews afgenomen. In elk instituut is gesproken met: degene die beleidsbepalend was voor de uitvoering van de Wet Bopz (directeur of beleidsverantwoordelijke Bopz), een arts voor de verstandelijk gehandicapten, een vertegenwoordiger, een persoonlijk begeleider en een cliènt. Daarnaast is ook gesproken met een aantal andere personen waaronder twee inspecteurs voor de gezondheidszorg (aandachtsgebied verstandelijk gehandicaptenzorg) en een orthopedagoog.

\section{Tabel 6. Geïnterviewde personen Evaluatie Wet Bopz}

\begin{tabular}{|l|l|}
\hline Respondent & Aantal \\
\hline Client & 4 \\
\hline Vertegenwoordiger & 4 \\
\hline Persoonlijk begeleider & 4 \\
\hline Arts voor verstandelijk gehandicapten & 4 \\
\hline Orthopedagoog & 1 \\
\hline Beleidsverantwoordelijke Bopz & 3 \\
\hline Andere beleidsmedewerker & 2 \\
\hline Directeur & 2 \\
\hline Inspecteur Gezondheidszorg & 2 \\
\hline Totaal & 26 \\
\hline
\end{tabular}

In elk instituut is, behalve de interviews die zijn afgenomen, een viertal dossiers onderzocht. Aan de hand van een checklist (die is gebaseerd op de Wet Bopz) is bekeken in hoeverre de verplichtingen die de Wet Bopz stelt aan een dossier in de praktijk zijn vertaald en ook worden toegepast. De zorgdossiers zijn door de instituten at random gekozen. Een uitzondering werd gemaakt voor het dossier van de cliënt die werd geïnterviewd; zijn dossier werd in ieder geval bekeken.

De Bopz-evaluatie is afgesloten met een invitational conference. Het doel hiervan was om de voorlopige uitkomsten en aanbevelingen ter validering voor te leggen aan deskundigen afkomstig uit de zorg voor mensen met een verstandelijke handicap. De genodigden werden verdeeld in kleinere werkgroepen, waar onder leiding van een voorzitter werd gediscussieerd over een aantal stellingen. Vervolgens vond een plenaire terugkoppeling plaats van de uitkomsten van de werkgroepen. Van de bijeenkomst is een verslag gemaakt.

\subsubsection{Analyse van de resultaten}

Alvorens de bevindingen uit de praktijk naast het juridische kader konden worden geplaatst, dienden eerst de veelheid en diversiteit van bevindingen te worden geanalyseerd. Binnen kwalitatief onderzoek bestaat geen vaste werkwijze voor het analyseren van gegevens. Het is daarom belangrijk om de wijze waarop 
de analyse plaatsvindt zorgvuldig vast te leggen zodat niet alleen de onderzoeker, maar ook derden, dit proces in een later stadium kunnen reconstrueren. ${ }^{61}$ Het empirische materiaal - de uitgetypte interviews, de observaties, het dossieronderzoek en de werkdocumenten- ${ }^{-2}$ zijn ingevoerd in de computer en vervolgens geanalyseerd met behulp van het computerprogramma Atlas-ti. Dit is een analyseprogramma, dat speciaal is ontwikkeld voor kwalitatief onderzoek. ${ }^{63}$ Het empirische materiaal werd onderverdeeld in een aantal documenten. Van elke voorziening werd een eigen document aangemaakt, waarin de interviews, observaties en dossieronderzoek die in deze voorziening hadden plaatsgevonden zijn ondergebracht. Deze documenten maakten het mogelijk om voor elke voorziening in kaart te brengen welke problemen zich ten aanzien van de (interne) rechtspositie van cliënten voordeden. Daarnaast zijn alle interviews, observaties en dossieronderzoeken ieder in een eigen document ondergebracht. Vervolgens zijn alle interviews nader onderverdeeld. Voor elke groep respondenten - de vertegenwoordigers, de persoonlijk begeleiders en de cliënten - is ook een eigen document vervaardigd, waardoor het mogelijk werd om de (interne) rechtspositie van cliënten vanuit verschillende perspectieven te benaderen. Naast deze documenten, is zowel voor de werkdocumenten als voor de gegevens van de Bopz-evaluatie een apart document aangemaakt.

In het programma Atlas-ti is de itemlijst, die als uitgangspunt diende bij het participerend observeren, ingevoerd. De thema's die centraal stonden in de interviews maakten ook onderdeel uit van deze lijst. Tijdens het analyseren is de itemlijst uitgebreid met enkele begrippen die veelvuldig in het empirische onderzoek terugkeerden, maar nog niet waren opgenomen in de itemlijst. Nadat alle documenten waren aangemaakt, is een start gemaakt met het doorlezen van alle documenten. Atlas-ti biedt de mogelijkheid om in de kantlijn van documenten begrippen te plaatsen, waardoor alle documenten konden worden gecodeerd. ${ }^{44}$ De veelheid aan begrippen die hierdoor ontstond, is zoveel mogelijk geclusterd in thema's waaronder vrijheidsbeperking, vertegenwoordiging en goed hulpverlenerschap. Nadat alle documenten waren gecodeerd konden aan de hand van de begrippen of de thema's verschillende uitdraaien worden ge-

61 Wester 1995, p. 134.

62 In een latere fase zijn ook de gegevens van de evaluatie Wet Bopz toegevoegd.

63 Het gebruik van een computerprogramma is slechts een hulpmiddel om de analyse systematisch(er) uit te voeren. Het computerprogramma voert niet de analyse uit; het is nog altijd de onderzoeker die de analyse uitvoert, de gegevens codeert en ordent en de resultaten interpreteert.

64 Codering levert een bestand op van geordende gegevens waarop de uiteindelijke bevindingen van onderzoekers zijn gebaseerd. In dit bestand zijn alle relevante gegevens opgenomen (Wester 1995, p. 136). 
maakt. Zo konden alle citaten van vertegenwoordigers over het thema vrijheidsbeperking worden uitgedraaid. Hetzelfde was mogelijk met de citaten van cliënten en persoonlijk begeleiders. Het materiaal dat is verzameld rondom het thema vrijheidsbeperking is geanalyseerd aan de hand van een tweetal vragen (zie ook paragraaf 2.4):

1. In hoeverre wordt in de praktijk van de zorg voor mensen met een verstandelijke handicap ten aanzien van de toepassing van vrijheidsbeperking rekening gehouden met het juridische kader? Deze vraag is onderverdeeld in twee subvragen: Is de toepassing van vrijheidsbeperking in de praktijk voldoende gewaarborgd? Zijn hulpverleners zich in de praktijk voldoende bewust van het juridische kader of wordt deze genegeerd?

2. In hoeverre hangen knelpunten rondom de toepassing van vrijheidsbeperking bij mensen met een verstandelijke handicap samen met de specifieke eigenschappen van de praktijk van de verstandelijk gehandicaptenzorg?

Het materiaal is uiteindelijk teruggebracht tot het thema vrijheidsbeperking, waarin overigens ook aspecten van vertegenwoordiging, privacy en het zorgplan zijn meegenomen. De belangrijkste reden voor deze reductie van het materiaal was dat in de bevindingen over het thema vrijheidsbeperking voldoende

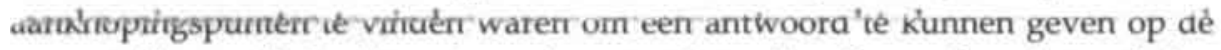
vraagstellingen die in dit onderzoek centraal stonden. Bovendien sloten de bevindingen aan bij de lijn die reeds ingezet was in het normatief kader, waarin de nadruk wordt gelegd op het recht op goede zorg en het recht op ontplooiing. Het behandelen van nog meer thema's, waaronder vertegenwoordiging en privacy, zou in het kader van de doelstelling van dit proefschrift nauwelijks meer nieuwe informatie opleveren. Dit betekent overigens niet dat de informatie die verzameld is over de andere thema's niet van betekenis is geweest voor dit proefschrift. De informatie heeft (indirect) bijgedragen aan de gedachtevorming over de rechtspositie van cliënten met een verstandelijke handicap die tijdens dit onderzoek heeft plaatsgevonden.

\subsection{Generaliseerbaarheid van de bevindingen}

Vanwege de beperkte omvang van het empirische onderzoek kunnen geen algemene uitspraken worden gedaan over de (interne) rechtspositie van cliënten met een verstandelijke handicap aangaande de toepassing van vrijheidsbeperking. Kwalitatief onderzoek is niet gericht op het generaliseren van uitspraken; deze vorm van onderzoek kenmerkt zich door het nauwkeurig beschrijven en eventueel verklaren van hetgeen onderzoekers in de empirie hebben aangetrof- 
fen. ${ }^{65}$ Hierdoor is het mogelijk geweest om in dit onderzoek meer inzicht te verkrijgen in de problemen die zich voordoen ten aanzien van de toepassing van vrijheidsbeperking in de praktijk van de zorg voor mensen met een verstandelijke handicap. De onderzoeker was niet geinteresseerd in hoe vaak een bepaald probleem zich voordeed; van belang was om de relevantie van een bepaald probleem in kaart te brengen.

Kwalitatief onderzoek sluit het generaliseren van bevindingen niet geheel uit. Dat geldt ook voor dit onderzoek. De mate van generaliseerbaarheid ${ }^{\omega}$ wordt mede bepaald door de nauwkeurigheid waarmee alle stappen in het onderzoek zijn beschreven, ook wel de methodologische verantwoording genoemd. 67 in deze paragraaf wordt nog een aantal aanvullingen gegeven op de procedure die in dit onderzoek is gevolgd. Tijdens het onderzoek zijn de bevindingen voorgelegd aan deskundigen uit de praktijk met de vraag of zij zich konden herkennen in de bevindingen van dit onderzoek. ${ }^{\omega}$ Deze methode wordt ook wel genoemd 'member check'. Daarnaast is gebruik gemaakt van triangulatie. Enerzijds zijn drie verschillende methoden gebruikt - dossieronderzoek, participerende observaties en interviews - en anderzijds vonden de interviews vanuit drie verschillende perspectieven plaats.

Naast een goede methodologische onderbouwing van het onderzoek is een aantal andere (methodologische) kwaliteiten ook van invloed op de generaliseerbaarheid van het onderzoek. Het betreft in dit geval de benuttingswaarde, de implementaire waarde en de participatieve waarde van het onderzoek.70 De benuttingswaarde heeft betrekking op de bruikbaarheid van de uitkomsten van dit onderzoek voor de verstandelijk gehandicaptenzorg. Kunnen hulpverleners zich vinden in de resultaten? Draagt het onderzoek bij aan een verbetering van de rechtspositie van mensen met een verstandelijke handicap als het gaat om de

65 I. Maso, Kwalitatief onderzoek, Meppel: Boom 1987, p. 15-16.

66 In plaats van generaliseerbaarheid wordt ook wel gesproken over 'externe validiteit' waaronder wordt verstaan de generaliseerbaarheid van onderzoeksconclusies naar andere personen, situaties en tijdstippen dan die van het onderzoek (Maso en Smaling 1998, p. 73).

67 Wester 1995, p. 205.

68 Overigens is een nauwkeurige beschrijving allereerst bepalend voor het vergroten van de interne validiteit, die betrekking heeft op de 'juistheid van de bevindingen'.

69 Daarbij moet worden gedacht aan terugkombijeenkomsten in de deelnemende voorzieningen, twee invitational conferences en praktijkbeschrijvingen die zijn gelezen door medewerkers van de geselecteerde voorzieningen. Ook zijn de bevindingen regelmatig voorgelegd aan de begeleidingscommissie.

70 Maso en Smaling 1998, p. 83-86. 
toepassing van vrijheidsbeperking? In dit onderzoek is getracht om zoveel mogelijk aan te sluiten bij het taalgebruik van de potentiële gebruikers: de hulpverleners, de vertegenwoordigers van cliënten, beleidsmakers en juristen. ${ }^{n}$ Daarnaast zijn diverse voorbeelden uit de praktijk aangehaald om de herkenbaarheid te vergroten. Deze voorbeelden en beschrijvingen van de praktijk zijn overigens ook tijdens het onderzoek voorgelegd aan deskundigen uit de drie voorzieningen teneinde te controleren of in de verslaglegging een reëel beeld werd geschetst van de praktijk.

De implementaire waarde heeft betrekking op de vraag of de uitkomsten van het onderzoek ook daadwerkelijk geïmplementeerd kunnen gaan worden. In hoofdstuk 7 wordt een alternatieve regeling voor de toepassing van vrijheidsbeperking in de verstandelijk gehandicaptenzorg geschetst. Los van het feit dat deze regeling op een aantal punten nog niet gedetailleerd is uitgewerkt, zal het niet eenvoudig zijn om deze regeling op zeer korte termijn in te gaan voeren. Naast het aanpassen dan wel vervangen van de Wet Bopz zal ook rekening moeten worden gehouden met het wijzigen van andere wetgeving.

De participatieve waarde van het onderzoek kan worden verhoogd door alle partijen die een rol spelen bij het verbeteren van de rechtspositie van cliënten met een verstandelijke handicap te betrekken. In dit onderzoek is zowel het perspectief van de cliënt, van de vertegenwoordiger als die van de persoonlijk begeleider meegenomen. Ook zijn andere hulpverleners (artsen en gedragsdeskundigen) en de Inspectie bij het onderzoek betrokken geweest. Door de uitkomsten van het onderzoek tijdens twee invitational conferences ${ }^{72}$ voor te leggen aan een groep genodigden, die allen werkzaam zijn in de verstandelijk gehandicaptenzorg, werd de kring van betrokkenen uitgebreid met beleidsmakers, juristen, inspecteurs, de VGN, de FvO en ambtenaren van het Ministerie van VWS. De resultaten van beide invitational conferences zijn uitgewerkt in een verslag en verwerkt in dit proefschrift.

Op grond van de resultaten van dit onderzoek, is het mogelijk om een aantal uitspraken te doen over de rechtspositie van cliënten met een verstandelijke handicap aangaande de toepassing van vrijheidsbeperking. In hoeverre deze uitkomsten daadwerkelijk overdraagbaar zijn naar andere settings in de zorg

71 Het ligt in de bedoeling dat de kern van het verhaal in de nabije toekomst in een beknopte en eenvoudige versie zal verschijnen voor persoonlijk begeleiders en zelfs voor cliënten.

72 De eerste invitational conference vond plaats aan het einde van de Evaluatie Wet Bopz, op 14 september 2001. De tweede invitational conference vond plaats op 20 November 2002, waarin de alternatieve regeling voor de toepassing van vrijheidsbeperking in de verstandelijk gehandicaptenzorg en de psychogeriatrie centraal stond. 
voor mensen met een verstandelijke handicap wordt voor een deel ook bepaald door de lezers van dit boek. Hulpverleners kunnen op grond van hun eigen ervaringen bepalen in hoeverre de inzichten, die in hoofdstuk 6 aan de hand van praktijkervaringen worden gegeven, overdraagbaar zijn naar hun eigen setting. 



\section{Een normatief kader voor de interne rechtspositie van mensen met een verstandelijke handicap}

\subsection{Inleiding}

Aan het einde van de vorige eeuw doet het burgerschapsparadigma zijn intrede in de verstandelijk gehandicaptenzorg. ${ }^{1}$ De achterliggende gedachte daarvan is dat mensen met een verstandelijke handicap gelijkwaardig zijn aan mensen zonder een verstandelijke handicap en dezelfde rechten en plichten hebben als iedere andere burger in de samenleving. In dit nieuwe paradigma staat niet langer zorg centraal maar ondersteuning. Onder ondersteuning wordt verstaan:

'Het geheel aan hulpmiddelen en strategieën om de ontwikkeling, de opvoeding, de belangen en het persoonlijk welzijn van mensen met een verstandelijke handicap te bevorderen. ${ }^{2}$

Het burgerschapsparadigma geldt voor elke cliënt, onafhankelijk van de vraag of hij een lichte verstandelijk handicap heeft dan wel een (zeer) ernstige meervoudig handicap. De essentie van het paradigma is dat ondersteuning flexibel wordt gegeven. De cliënt wordt geholpen bij het vaststellen van de mate van ondersteuning die hij nodig heeft om zich te kunnen ontplooien. Dit zal in de praktijk betekenen dat bepaalde cliënten, met name mensen met een (zeer) ernstige meervoudige handicap, meer ondersteuning nodig hebben dan andere cliënten. Deze aanpak wordt ook gepropageerd door de overheid. In diverse beleidsstukken benadrukt zij dat mensen met een verstandelijke handicap de kans moeten krijgen om zo zelfstandig mogelijk te functioneren.

In de nota 'De perken te buiten' ${ }^{3}$ wordt voor de eerste keer de koerswijziging binnen de sector verstandelijk gehandicaptenzorg onder woorden gebracht. De belangrijke uitgangspunten zijn respectievelijk 'gelijke rechten, gelijke plichten en gelijke behandeling', 'integratie en participatie' en waar nodig 'bescherming en compensatie'. In de Zorgnota 2000 wordt het begrip volwaardig burgerschap ${ }^{4}$ ge-

1 A.Th.G. van Gennep, Emancipatie van de zwaksten in de samenleving: over paradigma's van verstandelijke handicap, Amsterdam: Boom 2000.

2 Luckasson et al 2002.

3 Kamerstukken II 1994/1995, 24 170, nr. 1-2, p. 19-21.

4 Onder volwaardig burgerschap wordt verstaan: het streven naar een situatie voor mensen met functiebeperkingen waarin sprake is van formeel en materieel gelijke rechten. Principes van non-discriminatie en gelijke kansen moeten daarbij wettelijk zijn vastgelegd. 
noemd als leidraad voor de sector gehandicaptenzorg. Een aantal aspecten valt onder dit begrip, te weten een goede kwaliteit van bestaan, het maken van eigen keuzes en de mogelijkheid van ondersteuning.

Volwaardig burgerschap, zoals door de overheid bedoeld, krijgt in de praktijk gestalte door middel van community care. Onder dit begrip wordt verstaan dat mensen met een beperking binnen de samenleving de kans moeten krijgen om hun leven naar eigen inzicht in te richten. Waar nodig kunnen zij aanspraak maken op ondersteuning. ${ }^{5}$ Professionals, mantelzorg, vrijwilligers en de samenleving als geheel ondersteunen mensen met een verstandelijke handicap op een dusdanige manier, dat het mogelijk wordt dat elke burger, met of zonder beperking, een plaats krijgt binnen de maatschappij.

Uit het beleid van de overheid kan worden afgeleid dat mensen met een verstandelijke handicap in beginsel op gelijke wijze als mensen zonder een verstandelijke handicap moeten worden benaderd. Een persoon met een verstandelijke handicap zal echter nooit volledig gelijkgesteld kunnen worden met andere burgers. Mensen met een verstandelijke handicap hebben nu eenmaal op bepaalde momenten meer behoefte aan ondersteuning dan de gemiddelde burger. Van Gennep spreekt over een onrechtvaardige behandeling als mensen met een verstandelijke handicap evenveel ondersteuning krijgen als mensen zonder een verstandelijke handicap. ${ }^{\circ}$

De overheid erkent dat mensen met een verstandelijke handicap niet zonder een bepaalde mate van ondersteuning kunnen. In de nota 'De perken te buiten' wijst zij op het belang van bescherming en compensatie. Daarmee volgt de overheid het idee dat de zelfbeschikkingsdoctrine niet toereikend is in de verstandelijk gehandicaptenzorg. Deze doctrine neemt in de hedendaagse samenleving een centrale plaats in. Het uitgangspunt van het zelfbeschikkingsrecht is dat ieder individu vrij en autonoom is en de ruimte moet krijgen om zijn leven naar eigen inzicht in te vullen. ${ }^{7}$ Uiteraard mag het niet zo zijn dat het zelfbeschikkingsrecht van mensen met een verstandelijke handicap terzijde wordt geschoven enkel en alleen omdat zij dit recht niet kunnen uitoefenen, aldus Leenen:

'Omdat de mens het zelfbeschikkingsrecht als mens heeft, is niet relevant in welke mate hij het zelfbeschikkingsrecht kan uitoefenen. (...) Ook minderjarigen en mensen met een verstandelijke handicap hebben het zelfbeschikkingsrecht, ook al kunnen zij in de feitelijke uitoefening eroan zijn beperkt. Ook hun zelfbeschikkingsrecht moet worden gerespec-

5 RVZ 2002, p. 10.

6 Van Gennep 2000, p. 110.

7 Leenen, H.J.J., Handboek gezondheidsrecht, Deel 1 Rechten van mensen in de gezondheidszorg, vierde herziene druk bewerkt door H.J.J. Leenen en Gevers, Houten/Diegem: Bohn Stafleu Van Loghum 2000, p. 32. 
teerd en alles dient in het werk te worden gesteld het zich naar de mate van het mogelijke te laten verwezenlijken."

Het recht dient mogelijkheden te creëren om mensen met een verstandelijke handicap de gelegenheid te bieden hun capaciteiten, zoveel als mogelijk is, te kunnen benutten. Daarbij dient afstand te worden genomen van de veel besproken tegenstelling: het bieden van bescherming of het bevorderen van zelfbeschikking. Teveel aandacht voor bescherming doet de rechten van cliënten tekort en teveel aandacht voor het zelfbeschikkingsrecht ontkent de problemen in het functioneren van cliënten. Beide beginselen zijn echter van essentieel belang in de zorg voor mensen met een verstandelijke handicap. Het is een taak van het recht om een bijdrage te leveren aan het vinden van een optimale balans tussen zelfbeschikking en bescherming. In deze studie zijn elementen van beide beginselen terug te vinden in het rechtsbeginsel recht op goede zorg. Een persoonlijk begeleider biedt een cliënt goede zorg in de zin van betrokkenheid, ondersteuning en waar nodig bescherming.

De intentie van het recht op goede zorg is ook om de mogelijkheden van mensen met een verstandelijke handicap zoveel mogelijk tot ontplooiing te brengen. Naast het rechtsbeginsel goede zorg is ook het rechtsbeginsel recht op ontplooiing van belang in de verstandelijk gehandicaptenzorg. Centraal in deze studie staat het idee dat het recht op zelfbeschikking en het recht op bescherming niet voldoende zijn om tegemoet te komen aan de uitgangspunten van het recht op ontplooiing. Het recht op goede zorg biedt deze mogelijkheid wel, aangezien zij elementen bevat van zowel zelfbeschikking als bescherming. Beide elementen, weliswaar in een juiste balans, zijn noodzakelijk om uiteindelijk een bijdrage te leveren aan het recht op ontplooiing. In dif kader is het ook toelaatbaar en noodzakelijk om mensen met een verstandelijke handicap te beschermen. Het uiteindelijk doel van bescherming is dat deze functioneel bijdraagt aan de ontwikkeling van mensen met een verstandelijke handicap. Met andere woorden: bescherming wordt ingezet om de zelfstandigheid van cliënten te bevorderen.

Het begrip ontplooiing is niet geheel nieuw in de verstandelijk gehandicaptenzorg. De jaren zestig van de vorige eeuw stonden in het teken van het zelfontplooiingsideaal. In de verstandelijk gehandicaptenzorg ontstond het idee dat alle mensen, met of zonder handicap(s), hun eigen mogelijkheden en talenten zouden moeten ontdekken en ontplooien en dat de maatschappij dusdanig ingericht moest worden dat zij deze zelfontplooiing niet blokkeerde maar ondersteunde. ${ }^{9}$

8 Leenen 2000 , p. 32.

9 E. Tonkens, Het zelfontplooiingsregime: de actualiteit van Dennendal en de jaren zestig. Amsterdam: Bert Bakker 1999, p. 22. 
In deze studie wordt het zelfonplooiingsideaal van de vorige eeuw verder verfijnd. Naast zelfbeschikking mag het aspect bescherming niet ontbreken. Mensen met een verstandelijke handicap hebben recht op zelfbeschikking, maar kunnen ook niet zonder een bepaalde mate van bescherming. Beide componenten dragen uiteindelijk bij aan de ontplooiing van mensen met een verstandelijke handicap.

In dit hoofdstuk wordt de basis gelegd voor de overige hoofdstukken van dit boek. Allereerst wordt ingegaan op de betekenis van het recht in relatie tot de rechtspositie van mensen met een verstandelijke handicap (3.2.1). Daarbij wordt ook aandacht besteed aan het aspect juridisering. Vanuit de gehandicaptenzorg en de ethiek zijn geluiden hoorbaar dat teveel aandacht voor rechten zal leiden tot een verschraling van de zorg in de gehandicaptenzorg. In paragraaf 3.2.2 zal worden beargumenteerd dat het rechtendiscours, oftewel het denken in rechten en plichten, ook van wezenlijk belang is in de verstandelijk gehandicaptenzorg. Vervolgens worden in paragraaf 3.3 de eerder genoemde rechtsbeginselen - zelfbeschikking, bescherming, goede zorg en ontplooiing - besproken. Hoofdstuk 3 wordt afgesloten met een beschouwing, waarin de inhoud van dit hoofdstuk nogmaals de revue zal passeren.

\subsection{Betekenis van het recht binnen de verstandelijk gehandicaptenzorg}

\subsubsection{Functie van het recht binnen de verstandelijk gehandicaptenzorg}

In de vorige paragraaf werd al geconstateerd dat in de huidige visie op de gehandicaptenzorg wordt benadrukt dat mensen met een verstandelijke handicap dezelfde rechten hebben als mensen zonder een verstandelijke handicap. De enkele gelijkstelling van deze beide groepen is evenwel niet toereikend voor een gepaste rechtspositie van mensen met een verstandelijke handicap. In de proefschriften van Legemaate ${ }^{10}$ en Van de Klippe ${ }^{11}$ zijn aanknopingspunten te vinden voor deze redenering. Weliswaar gaan beide proefschriften over een andere doelgroep, te weten de psychiatrische patiënt, de problematiek vertoont veel overeenkomsten met de rechtspositie van mensen met een verstandelijke handicap. Legemaate acht het niet voldoende als de rechtspositie van vrijwillig opgenomen psychiatrische patiënten wordt gelijkgesteld met die van patiënten in de algemene gezondheidszorg. Daarmee zou ook de beschermende functie van het recht in het gedrang komen. ${ }^{12}$ Met name in de geestelijke gezondheidszorg is

10 Legemaate 1991, p. 24-25.

11 Van de Klippe 1997, p. 8-9.

12 Legemaate, Recht en realiteit: juridische normering en het therapeutisch proces (inaugurale rede Rotterdam) Houten/Zaventum: Bohn Stafleu Van Loghum 1994a, p. 9. 
sprake van een ongelijke verhouding tussen de patiënt en de hulpverlener. Dit is mede een gevolg van het toepassen van vrijheidsbeperkende maatregelen, de aard en de ingrijpendheid van de behandeling en (de duur van) het verblijf in een instituut. Deze factoren zijn ook van toepassing op mensen met een verstandelijke handicap die zijn opgenomen in een instituut of een andere voorziening. Gezien de kwetsbare positie waarin mensen met een verstandelijke handicap zich bevinden, heeft het recht in de verstandelijk gehandicaptenzorg allereerst een beschermingsfunctie. ${ }^{13}$ Niet alleen in de verstandelijk gehandicaptenzorg, maar vrijwel in de gehele care sector staat deze functie van het recht op de voorgrond. ${ }^{14}$ Dit betekent niet dat in de care sector geen ruimte is voor een andere functie van het recht, te weten het waarborgen van de individuele ontplooiing en vrijheid. ${ }^{15}$ In het gezondheidsrecht wordt deze functie veelal aangeduid met het respecteren van het zelfbeschikkingsrecht van een individu. ${ }^{16}$ Het recht heeft als taak om te garanderen dat elk individu, binnen het kader van zijn mogelijkheden, de gelegenheid krijgt om zijn leven naar eigen inzicht in te vullen.

Beide functies van het recht, het bieden van bescherming respectievelijk het waarborgen van het zelfbeschikkingsrecht, zijn noodzakelijk voor een adequate vormgeving van de rechtspositie van mensen met een verstandelijke handicap.

13 De beschermende functie van het recht wordt in deze studie verwoord in het beschermingsbeginsel. Dit beginsel kent een nauwe betekenis: 'de vrijheid van een cliënt met een verstandelijke handicap wordt beperkt teneinde de cliënt te beschermen tegen zichzelf' (zie voor een nadere beschrijving paragraaf 3.3.3). In het recht wordt naast het beschermingsbeginsel ook gesproken over het rechtsbeschermingsbeginsel. Beide beginselen zijn gericht op het bieden van bescherming aan cliënten die in hun rechten en vrijheden worden beperkt. Het is echter gebruikelijk dat het rechtsbeschermingsbeginsel wordt gelijkgesteld met alle rechtsmiddelen die een cliënt kan aanwenden teneinde te waarborgen dat hij wordt beschermd tegen (on)rechtmatig optreden van hulpverleners, instituten of voorzieningen waar de cliënt verblijft en de overheid.

14 F.C.B. van Wijmen, "Klagen noch kwijnen - enige beschouwingen over ontwikkelingen in de rechtsbescherming van verpleeghuispatiënten", in: J.C.J. Dute, J.K.M. Gevers en G.R.J. de Groot, Omzien naar de toekomst, Houten/Diegem: Bohn Stafleu van Loghum 2002, p. 230.

15 J.C.J. Dute, "Hoofdlijnen van de regulering van de gezondheidszorg", in: J.C.J. Dute en H.E.G.M. Hermans (red.), Regulering van de gezondheidszorg, Maarssen: Elsevier Gezondheidszorg 2000a, p. 19.

16 De betekenis die in de care sector aan ontplooiing wordt gegeven is doorgaans beperkt. Het begrip wordt gelijkgesteld met zelfbeschikking oftewel negatieve vrijheid. In deze studie wordt evenwel een ruimere betekenis toegekend aan ontplooiing: ook bescherming en positieve vrijheid worden tot dit begrip gerekend. 
In de praktijk blijkt het niet eenvoudig te zijn om deze twee functies van het recht naast elkaar toe te passen, ook omdat ze worden geïnterpreteerd als tegenpolen van elkaar. In de dagelijkse zorgverlening aan mensen met een verstandelijke handicap lopen hulpverleners regelmatig tegen situaties aan, waarin zij een keuze moeten maken tussen enerzijds het bieden van bescherming en anderzijds het loslaten van cliënten. Hulpverleners voelen zich al snel verantwoordelijk voor de gevaren waaraan cliënten worden blootgesteld. Dit vormt vaak een reden om een cliënt in bescherming te nemen, teneinde te voorkomen dat hem iets zal overkomen waarvoor zij verantwoordelijk worden gesteld. Hulpverleners moeten echter cliënten niet beschermen om de kansen op aansprakelijkheid voor zichzelf te verkleinen. Van belang is dat cliënten tegen zichzelf worden beschermd omdat zij op dat moment geen juiste inschatting kunnen maken van de risico's die verbonden zijn aan een bepaalde handeling. Het is niet realistisch om te veronderstellen dat de tegenstelling tussen bescherming en zelfbeschikking kan worden opgelost. Wel is het mogelijk om tot een soort middenweg te komen. De onderlinge verhouding tussen de verschillende functies van het recht dient zodanig te zijn, dat zij elkaar kunnen aanvullen in plaats van tegenwerken. Binnen de verstandelijk gehandicaptenzorg heeft het recht, althans voor zover mogelijk is, als doel om de ontplooiing van cliënten te bevorderen. Deze bijzondere functie van het recht komt tot uitdrukking in het recht op ontplooiing en bevat zowel aspecten van bescherming als het waarborgen van het zelfbeschikkingsrecht van individuen. Kelk omschrijft het recht op ontplooiing als het voortdurend aandacht besteden aan de mogelijkheden voor de patiënten om zich te blijven ontwikkelen.' ${ }^{17}$ Vanuit het oogpunt van bescherming zullen hulpverleners geneigd zijn om een cliënt te beschermen tegen gevaren. Dit is terecht, als bescherming in een bredere context wordt gezien. In het kader van het recht op ontplooiing dient het bieden van bescherming niet alleen gericht te zijn op het afwenden van gevaar maar ook daadwerkelijk bij te dragen aan de mogelijkheden van een cliënt. In de inleiding van dit hoofdstuk werd gesproken over functionele bescherming. Bescherming dient niet alleen functioneel te zijn, maar ook op maat. De plaats van het recht in de verstandelijk gehandicaptenzorg dient zodanig te zijn dat zij uiteindelijk, in welke vorm dan ook, instaat voor een gepaste rechtspositie van mensen met een verstandelijke handicap. Dit betekent onder meer bescherming op maat en gebruik maken van de mogelijkheden van mensen met een verstandelijke handicap.

17 C. Kelk, "Klagen of kwijnen: de rechten van verpleeghuispatiënten en de behandeling van hun klachten", Preadvies Vereniging voor Gezondheidsrecht, Utrecht: 1985, p. 38. 


\subsubsection{Juridisering}

Juridisering wordt door Schuyt's omschreven als: 'De omvorming van spontane relaties in juridische relaties, zodanig dat deze sociale relaties voornamelijk of soms zelfs uitsluitend worden gedefinieerd in juridische termen'. In de verstandelijk gehandicaptenzorg is deze ontwikkeling ook waarneembaar. Naast de medische bril en de pedagogische bril, wordt steeds vaker door een juridische bril naar de zorgverlening gekeken. De rechtspositie van mensen met een verstandelijke handicap is aan het einde van de vorige eeuw versterkt door een aantal patiëntenwetten, ${ }^{19}$ waarvan de inhoud ook van betekenis is voor hulpverleners die werkzaam zijn in de verstandelijk gehandicaptenzorg.

De groei aan regelgeving wordt door hulpverleners beschouwd als juridisering, een term die over het algemeen een negatieve lading heeft. ${ }^{20}$ Dit is echter een te snel oordeel. Een belangrijk doel van juridisering is de versterking en verbetering van de rechtspositie van cliënten, een doelstelling die door hulpverleners nog onvoldoende wordt onderschreven. De verklaring hiervoor moet worden gezocht in de visie die men heeft op de functie van het recht. De wijze waarop juridisering wordt beoordeeld, hangt in sterke mate af van deze visie. ${ }^{21}$ Door te benadrukken dat het recht vrijheidswaarborgende, humaniserende en emancipatoire effecten heeft, kan juridisering ook als een positief concept worden beschouwd.22 Legemaate stelt dan ook voor om juridisering neutraal te omschrijven, zodat meer ruimte wordt gecreëerd voor een open discussie. Op deze manier wordt het mogelijk om goede (positieve) juridisering te onderscheiden van

18 C.J.M. Schuyt, "Tussen witte jassen en zwarte toga's. De plaats van het gezondheidsrecht in de moderne samenleving", in: J.H. Hubben, J.H. en H.D.C. Roscam Abbing (red.), Gezondheidsrecht in perspectief, Utrecht: De Tijdstroom 1993, p. 156-168.

19 Wet Bopz, Wgbo, Wet medezeggenschap cliënten zorginstellingen, Wet klachtrecht cliënten zorgsector en regeling mentorschap.

20 G. Widdershoven, R.L.P. Berghmans, en S. P.K. Welie, "Zelfbeschikking of goede zorg? Ethische kanttekeningen bij juridisering in de hulpverlening", in: A.H. Schene e.a. (red.), Jaarboek voor psychiatrie en psychotherapie, Houten/ Diegem: Bohn Stafleu Van Loghum 2003, p. 325-338.

21 J.H.M. Klanderman, "Juridisering en dejuridisering", in: A.R.J. Groot en H. J.L.M van de Luytgaarden (red.), Zonder meer recht, Zwolle: W.E.J. Tjeenk Willink 1993, p. 296.

22 W.G. van der Velden, "Onderzoek van juridisering als probleem". In: A.R.J. de Groot en H.J.L.M. van de Luytgaarden, Zonder meer recht, Zwolle: W.E.J. Tjeenk Willink 1993, p. 384. 
negatieve juridisering. ${ }^{23}$ In de afgelopen jaren zijn onder meer de patiëntenrechten geaccentueerd, is de verantwoordingsplicht en de noodzaak tot toetsbaarheid van hulpverleners en instellingen wettelijk vastgelegd en heeft het veld een eigen verantwoordelijkheid gekregen ten aanzien van de ontwikkeling van kwaliteitsnormen. Dit zijn voorbeelden van juridisering van het goede soort, aldus Legemaate. ${ }^{2 t}$

\section{Juridisering in de verstandelijk gehandicaptenzorg}

Ook in de verstandelijk gehandicaptenzorg is juridisering onontbeerlijk. Het recht heeft als doel om de rechtspositie van mensen met een verstandelijke handicap te verbeteren en te versterken. Mensen met een verstandelijke handicap zijn afhankelijk van hulp en ondersteuning van een persoonlijk begeleider en/of een vertegenwoordiger. Daarnaast verblijft een aanzienlijk aantal cliënten nog steeds in een instituut, waar vrijheidsbeperkende maatregelen worden toegepast en de privacy nog al eens te wensen overlaat. In de laatste jaren is de samenleving zich gaan realiseren dat ook mensen met een verstandelijke handicap rechten hebben. Hulpverleners behoren in hun dagelijkse werkzaamheden stil te staan bij de vraag of zij zorgvuldig omgaan met deze rechten. Schendingen van rechten zijn wellicht te wijten aan de cultuur binnen instituten, de werkdruk en de kwaliteit van het personeel of doordat hulpverleners zich onvoldoende realiseren welke gevolgen hun handelen heeft voor de rechtspositie van cliënten. In dit kader kan juridisering een belangrijke bijdrage leveren aan het bereiken van de eerdergenoemde doelstelling: het verbeteren en versterken van de rechtspositie van cliënten. Het is niet alleen een taak van hulpverleners om meer stil te staan bij de rechten van mensen met een verstandelijke handicap, maar ook om deze rechten te verduidelijken naar cliënten toe. Als cliënten niet in staat zijn om hun rechten te claimen, is het een taak van hulpverleners om deze rechten veilig te stellen. Daartoe behoort ook dat hulpverleners hun handelen inzichtelijk maken en inbreuken op rechten van cliënten verantwoorden naar buiten toe. De 'bewijslast' wordt op deze manier omgekeerd: niet cliënten moeten zich beroepen op hun rechten, maar hulpverleners moeten motiveren waarom zij bepaalde rechten van cliënten beperken. In de Wgbo en de Wet Bopz zijn hiervoor voldoende aanknopingspunten te vinden.

Vanuit de ethiek komen andere geluiden. In de verstandelijk gehandicaptenzorg zijn normen en waarden als vrijheid, autonomie en rechten ondergeschikt aan

23 J. Legemaate, "Goed recht: de betekenis en de gevolgen van het recht voor de praktijk van de hulpverlening", Preadvies. Vereniging voor Gezondheidsrecht, Utrecht: 1994 b, p. 12-13.

24 J. Legemaate, Professie, management en gezondheidsrecht, Den Haag: Koninklijke Vermande 2003a, p. 20. 
afhankelijkheid, relaties en het bieden van goede zorg. Hulpverleners zijn bang dat juridisering in de verstandelijk gehandicaptenzorg de primaire doelstelling van de hulpverlening, namelijk het bieden van goede zorg aan de cliënt, tekort doet. ${ }^{25}$ Hulpverleners worden gedwongen om op een andere manier te kijken naar hun handelen. Naast het bieden van goede zorg moeten zij ook rekening houden met de rechten van cliënten. Een hulpverlener moet zijn handelen verantwoorden: in het zorgplan, naar de cliënt, naar de vertegenwoordiger en naar collega's toe. Ethici spreken in dat kader ook wel over de verschraling van de zorg. Reinders is van mening dat 'het morele karakter van zorgrelaties door het rechtendiscours wordt vertekend'. Widdershoven vraagt zich af of de praktijk beter wordt als hulpverleners meer oog hebben voor de rechten en plichten van cliënten.

Wanneer de zorg geheel volgens regelethische beginselen zou worden ingericht, is het niet denkbeeldig dat datgene waar het werkelijk om gaat verdwijnt: de dagelijkse contacten, de persoonlijke betrokkenheid, het gevoel van verantwoordelijkheid dat de verzorgenden tegenover de bewoners hebben. 2 t

Het rechtendiscours gaat in de ogen van ethici uit van strategisch handelen en heeft te weinig oog voor communicatief handelen en de dialoog tussen de hulpverlener en de cliënt. Individualiteit en uiteindelijk afstandelijkheid zijn het resultaat van het rechtendiscours. ${ }^{28}$ Deze kritiek is echter niet terecht. Er wordt uitgegaan van een te beperkte visie op het recht. Ethici zijn van mening dat het recht 'doorslaat' naar de verkeerde kant. Het zelfbeschikkingsrecht zou teveel worden benadrukt en op gespannen voet staan met goede zorg. ${ }^{29}$ In deze studie wordt benadrukt dat er ook mogelijkheden zijn om uit te gaan van een ruimere visie. De rechtsbeginselen goede zorg en recht op ontplooiing maken het mogelijk om verder te kijken dan alleen het zelfbeschikkingsrecht. Het is een verkeerde veronderstelling van ethici dat individualiteit en afstandelijkheid de enige en ultieme doelen van het recht zijn in de verstandelijk gehandicaptenzorg. In de zorgethiek wordt een grote nadruk gelegd op afhankelijkheid en het bieden van zorg. Dit is in de context van deze studie een te beperkt uitgangspunt.

25 J. Legemaate, "De Bopz en de vrijwillige opneming. Een voorbeeld van ongewenste juridisering", Maandblad Geestelijke volksgezondheid (49) 1994-6/7, p. 668678.

26 J.S. Reinders, "Grenzen van het rechtendiscours", in: H.A.M. Manschot en M.A. Verkerk, Ethiek van de zorg, Amsterdam/Meppel: Boom 1994, p. 75.

27 G. Widdershoven, Ethiek in de kliniek, Amsterdam/Meppel: Boom 2000, p. 137.

28 Widdershoven 2000 , p. 138.

29 Widdershoven, Berghmans en Welie 2003, p. 328-330. 
In de verstandelijk gehandicaptenzorg heeft een cliënt niet alleen zorg nodig, maar ook ondersteuning. Het geven van ondersteuning omvat meer dan het in standhouden van de afhankelijke positie van cliënten. Een cliënt dient ook de ruimte te krijgen om zijn eigen capaciteiten te ontplooien. Daarbij heeft hij ondersteuning nodig van zijn persoonlijk begeleider en vertegenwoordiger. Deze gedachtegang is terug te vinden in diverse patiëntenwetten (o.a. Wet medezeggenschap cliënten zorginstellingen, regeling mentorschap en curatele). Cliënten die niet hun eigen belangen kunnen behartigen, kunnen worden bijgestaan door een vertegenwoordiger. Een taak van een vertegenwoordiger is echter wel dat hij de (rest)capaciteiten van een cliènt respecteert en zoveel mogelijk tot ontwikkeling brengt.

Hulpverleners lijken zich te scharen achter de ethici. Zij maken duidelijk dat zij zich beperkt voelen door wetgeving: zij beweren minder bevoegdheden te hebben door de introductie van de omvangrijke patiëntenwetgeving waardoor ook het bieden van goede zorg in het gedrang komt. Het recht heeft als functie om de grenzen van het handelen van hulpverleners aan te geven en ervoor te zorgen dat hulpverleners verantwoording afleggen over hun wijze van handelen. Hierdoor is het onvermijdelijk dat wetgeving zich bemoeit met bepaalde aspecten van de zorginhoud. De Wgbo, de Wet Bopz en de Wet big bieden evenwel ook ruimte aan hulpverleners om te handelen volgens hun eigen inzichten. Een hulpverlener behoudt het recht om op grond van goed hulpverlenerschap bepaalde handelingen niet te verrichten en daarbij af te wijken van de wens van een cliënt of een vertegenwoordiger. Bovendien zijn in de Wet Bopz diverse begrippen niet nader ingevuld, wat de mogelijkheid biedt voor hulpverleners om deze naar eigen inzicht in te vullen. ${ }^{30}$

De kritiek van ethici is ook gebaseerd op de veronderstelling dat het recht alleen de negatieve vrijheid centraal zou stellen: een cliënt is vrij wanneer hij gevrijwaard blijft van beïnvloeding door anderen. ${ }^{31}$ Dit betekent dat elke cliënt op grond van zijn zelfbeschikkingsrecht zelf mag bepalen wat er met hem gebeurt. In de verstandelijk gehandicaptenzorg zou dit een te beperkt uitgangspunt zijn. In de hele discussie over het rechtendiscours wordt vergeten dat het recht ook aspecten omvat van het concept positieve vrijheid. Dit concept is volgens ethici de kern van de hulpverlening in de verstandelijk gehandicaptenzorg. Het draait in dit concept niet zo zeer om zelfbeschikking, maar eerder om zelfontplooiing. Hulpverleners ondersteunen een cliënt bij het maken van een keuze. Het is niet be-

30 In paragraaf 3.3.5 wordt ook uitgelegd dat de Wet Bopz de nadruk legt op het zelfbeschikkingsrecht. Dit uitgangspunt biedt te weinig ruimte voor hulpverleners om goede zorg te kunnen bieden aan cliënten met een verstandelijke handicap.

31 I. Berlin, Twee opvattingen van vrijheid, Amsterdam/Meppel:Boom 1996. 
langrijk welke keuze hij maakt, maar hoe hij tot deze keuze komt. Begrippen als betrokkenheid, steun en waar nodig kritiek staan centraal. Ethici benadrukken dat dit concept verschilt van de gedachtegang over zelfbeschikking. Cliënten komen in een context van communicatie en zorg tot beslissingen. Binnen deze zorgrelatie wordt een cliènt niet beschouwd als een individu met zijn eigen rechten, maar als iemand die vanwege zijn afhankelijkheid is aangewezen op zorg. Vanuit dit kader wijst Reinders erop dat het perspectief van zelfbeschikking niet past in de sector verstandelijk gehandicaptenzorg:

'Binnen een zorgrelatie wordt de ander niet primair gezien als individu met eigen voorkeuren en belangen maar als iemand die gezien zijn afhankelijkheid op onze sympathie is aangewezen. Daarom is het perspectief van zorgzaamheid geschikter voor de morele articulatie van de relaties waarvan mensen met een verstandelijke handicap deel uitmaken dan het perspectief van autonomie en zelfbeschikking. ${ }^{32}$

Reinders gaat echter voorbij aan het feit dat het recht ook ruimte biedt voor positieve vrijheid. Het recht kent naast individuele grondrechten ook sociale grondrechten. Bij sociale grondrechten, zoals het recht op gezondheid, gaat het om het bieden van ontplooiingskansen aan de mens en om het deelhebben aan de maatschappelijke verworvenheden. Sociale grondrechten zijn ook wel te beschouwen als participatierechten..$^{33}$ Hieruit kan worden afgeleid dat het recht niet alleen gericht is op het veilig stellen van de onafhankelijkheid van individuen.

Ook Tronto spreekt de gedachtegang van Reinders over de rol van het zelfbeschikkingsrecht in de verstandelijk gehandicaptenzorg tegen. Eén van de doelen van zorg is om een einde te maken aan afharikelijkheid en deze niet te maken tot een permanente toestand. Van belang is dat elk individu, waaronder ook mensen met een verstandelijke handicap, de ruimte krijgt om zijn leven naar eigen inzicht in te vullen. ${ }^{34}{ }^{35}$ Dit betekent geenszins dat mensen met een verstandelijke handicap, geheel onafhankelijk van anderen, beslissingen moeten nemen. Het recht biedt ook mogelijkheden om wilsonbekwame cliënten te ondersteunen. Daarnaast stelt het recht grenzen aan de uitoefening van het zelfbeschikkingsrecht. Niet elke wens van een cliënt kan worden uitgevoerd. Voorkomen moet worden dat een besluit van een cliënt zijn eigen ontwikkeling in de weg staat en

32 Reinders 1994, p. 85.

33 Leenen 2000, p. 25.

34 J.C. Tronto, Moral boundaries: a political argument for an ethic of care, New York/ London: Routledge 1993, p. 163.

35 Van Gennep spreekt ook de gedachtegang van Reinders tegen. Het perspectief van zorgzaamheid past niet in het moderne zorgconcept (Van Gennep 2002). 
een gevaar oplevert voor andere cliënten. Deze beperkingen van het zelfbeschikkingsrecht hebben niet de intentie om cliënten minder afhankelijk te maken van andere mensen, maar om cliënten de kans te geven optimaal gebruik te maken van hun restcapaciteiten. Op dit punt lopen de visies van het recht en ethiek nog teveel uiteen. In deze studie wordt geprobeerd om de tegenstelling tussen beide disciplines te verkleinen.

\section{Grenzen aan juridisering}

In het proefschrift van Tonkens wordt opgemerkt dat het zelfontplooiingsregime in de verstandelijk gehandicaptenzorg goed is aangeslagen. Het heeft in de jaren zeventig en tachtig van de vorige eeuw tot veel veranderingen geleid. Aan het einde van de vorige eeuw is naast zelfontplooiing, ook aandacht gekomen voor zelfbeschikking, een concept dat nauw verwant is aan zelfontplooiing. Zelfbeschikking heeft echter een engere betekenis dan zelfontplooiing. Tonkens kent verschillende dimensies toe aan zelfbeschikking. Formalisering, waartoe ook juridisering hoort, is een van deze dimensies. Cliënten kunnen gebruik maken van diverse wetten, regels en procedures om hun autonomie te vergroten en zich te wapenen tegen paternalisme. ${ }^{66}$ Als voorbeeld worden genoemd zorgplannen, cliëntenraden, kwaliteitsverslagen, de Wet Bopz, de Wgbo en de regeling mentorschap. Het is de vraag of formalisering van de sector verstandelijk gehandi-

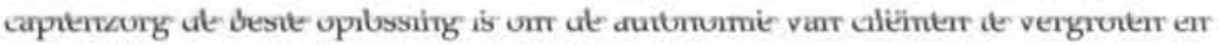
paternalisme te voorkomen, aldus Tonkens.

'Formalisering berust op een geïnstitutionaliseerd wantrouwen ten aanzien van de geïnstitutionaliseerde zorg en kent dus nadelen. (...) Er is misschien meer voor te zeggen om het probleem van de kant van de begeleiders te benaderen, door hen te helpen om te gaan met de risico's en problemen die samenhangen met hun macht over de cliënten. (...) Uitgangspunt is dat betutteling geen zonde is maar een dilemma. ${ }^{37}$

Juridisering heeft echter ook zijn grenzen, in dat opzicht heeft Tonkens gelijk met haar kritiek op wetgeving. Een overmaat aan regelgeving zal niet worden aanvaard door hulpverleners en te gecompliceerde regelingen zullen vereenvoudigd geïnterpreteerd of genegeerd worden. Op zo'n moment zal de wal het schip keren. ${ }^{38}$ In dat kader is het gewenst dat wetgeving, wil zij een kans van slagen hebben in de verstandelijk gehandicaptenzorg, voldoet aan bepaalde vereisten. Van belang is dat de wetgever rekening houdt met de specifieke eigenschappen van de sector. In de verstandelijk gehandicaptenzorg neemt, naast de

\section{Tonkens 1999, p. 27-28.}

37 Tonkens 1999, p. 239-240.

38 Klanderman, p. 337. 
arts, ook de gedragdeskundige en de persoonlijk begeleider een belangrijke plaats in, een groot deel van de cliënten is (partieel) wilsonbekwaam en de laatste jaren staat de sector in het teken van deïnstitutionalisering. Ook moet worden voorkomen dat teveel de nadruk wordt gelegd op het zelfbeschikkingsrecht van cliënten. Enige vorm van ondersteuning zal altijd nodig zijn.

Legemaate heeft een aantal criteria geformuleerd aan de hand waarvan de negatieve effecten van een juridische regeling kunnen worden beoordeeld. ${ }^{30}{ }^{\star 0}$ Het betreft de volgende criteria: de aanleiding tot een juridische interventie, de vorm en inhoud van de gekozen interventie, in relatie tot het doel, de aard en de structuur van het terrein waarop de interventie is gericht en de gevolgen van de interventie. Deze criteria zullen in ogenschouw moeten worden genomen, alvorens het besluit wordt genomen een regeling in te voeren. Daarnaast is het van belang dat de effecten van een regeling worden meegenomen." Op deze manier kan worden voorkomen dat ongewenste vormen van juridisering ontstaan. Daarvan is sprake als een juridische regeling onvoldoende aansluit op de praktijk en zelfs contraproductief gaat werken. ${ }^{2}$ Hulpverleners kunnen zich gaan verzetten tegen een wettelijke regeling en op zoek gaan naar mogelijkheden om bepaalde bepalingen te omzeilen.

\subsection{Rechtsbeginselen in de verstandelijk gehandicaptenzorg}

\subsubsection{Inleiding}

Rechtsbeginselen vormen het fundament van het recht. Kelk beschouwt rechtsbeginselen 'als het zenuwstelsel van het recht, omdat zij nauw verbonden zijn met het

39 Legemaate 1994b, p. 15-22.

40 Van Wijmen formuleert een aantal criteria die betrekking hebben op de consistentie oftewel samenhang van wetgeving, maar kunnen ook in een bredere context worden gezien en worden gebruikt om een oordeel te geven over de relevantie van wetgeving in de sector verstandelijk gehandicaptenzorg. F.C.B. van Wijmen, "Consistentie van kwaliteitsregulering: ook een kwestie van kwaliteit", in: J.C.J. Dute en F.C.B. van Wijmen, Consistentie van wetgeving in de gezondheidszorg, Antwerpen-Groningen: Intersentia 1998.

41 Steeds vaker bevat wetgeving met betrekking tot de gezondheidszorg een bepaling, waarin is vereist dat een wet regelmatig moet worden geëvalueerd. In Artikel 71 Wet Bopz is bepaald dat de Wet Bopz elke vijf jaar moet worden geëvalueerd.

42 J.C.J. Dute, "De juridische context van de geestelijke gezondheidszorg", in: J.M.G. A. Graste en D. M.J, Baudien (red.), Waardenvol werk: ethiek in de geestelijke gezondheidszorg, Assen: Van Gorcum 2000b, p. 170. 
doel en de functie van het recht." Rechtsbeginselen hebben niet dezelfde betekenis als rechtsregels. Een individu kan in beginsel geen juridische aanspraken ontlenen aan een rechtsbeginsel. Dit verandert zodra een rechtsbeginsel wordt uitgewerkt in een rechtsregel. Dit kunnen grondrechten en regelingen van civiel-, straf- en bestuursrechtelijke aard zijn. Rechtsbeginselen mogen dan niet dezelfde werking hebben als een rechtsregel, dit betekent nog niet dat zij buiten het rechtssysteem staan. Het gehele rechtssysteem kan worden gezien als een uitwerking van rechtsbeginselen. ${ }^{4}$

In deze studie wordt, vanwege de bijzondere situatie van mensen met een verstandelijke handicap, de aandacht gericht op een speciaal rechtsbeginsel: het recht op ontplooiing. Elementen van dit rechtsbeginsel zijn terug te vinden in drie andere rechtsbeginselen die in deze studie centraal staan: het zelfbeschikkingsrecht, het beschermingsbeginsel en het recht op goede zorg. Ook is het rechtsbeginsel gepositiveerd in diverse verdragen (Verdrag inzake de rechten van het kind) en de Grondwet (artikel 22 lid $3 \mathrm{Gw}$ ). Het rechtsbeginsel recht op ontplooiing kenmerkt zich door zowel de nadruk te leggen op sociale als klassieke elementen die terug te voeren zijn op de drie eerdergenoemde beginselen. Het beschermingsbeginsel is met name op het individu gericht. Het gaat ervan uit dat individuen beschermd moeten worden tegen gevaren van buitenaf en tegen gevaren die zij zelf veroorzaken. Het zelfbeschikkingsrecht is gebaseerd op de gedachte dat individuen zelf kunnen bepalen hoe zij aan hun leven invulling geven. Dit beginsel heeft ook een sociale kant. De vrijheid van een individu wordt begrensd door de vrijheid van anderen. ${ }^{45}$ Het rechtsbeginsel recht op goede zorg benadrukt dat individuen in de gezondheidszorg aanspraak moeten kunnen maken op kwalitatief goede zorg. Het recht op goede zorg krijgt in deze studie een andere insteek dan het bekende rechtsbeginsel 'recht op gezondheidszorg': het vertoont geen kenmerken van een sociaal grondrecht, maar eerder van een individueel grondrecht. Het gaat met name om de wijze waarop invulling wordt gegeven aan het begrip zorg. ${ }^{46}$ De paternalistische visie wordt losgelaten en maakt plaats voor een modernere invulling. Hulpverleners verlenen goede zorg, als zij inzichtelijk, verantwoord en in gesprek met de cliënt handelen. Elke vorm van zorg dient, althans voor zover mogelijk is, bij te dragen aan de ontplooiing van een cliënt. Ontplooiing kan worden bereikt door gelijktijdig bescherming en

43 C. Kelk, "Rechtsbeginselen en het Gezondheidsrecht", Tijdschrift voor Gezondheidsrecht (14) 1990-2, p. 112.

44 Dute 2000a, p. 26.

45 Legemaate 1991, p. 205-206.

46 Het begrip zorg kan ook worden vervangen door ondersteuning. Een aspect van ondersteuning is zorg. 
zelfbeschikking van cliënten in ogenschouw te nemen. Deze unieke combinatie is terug te vinden in het rechtsbeginsel goede zorg. $v$

\subsubsection{Zelfbeschikking}

Het zelfbeschikkingsrecht als wijsgerig principe gaat uit van de uniciteit van de mens die altijd anders is dan ieder ander mens, een inherente waardigheid heeft en onvoorwaardelijk respect verdient. Wordt dit principe losgelaten, dan kan de mens worden beschourd als een object of een ding dat voorwerp wordt van manipulatie. "s

De mens komt als mens een zelfbeschikkingsrecht toe." Dit betekent niet dat rechtstreeks een beroep kan worden gedaan op dit recht. Het zelfbeschikkingsrecht is niet afdwingbaar, maar kan worden beschouwd als een rechtsbeginsel. In de Nederlandse gezondheidszorg neemt het zelfbeschikkingsrecht een belangrijke plaats in. Diverse patiëntenwetten, waaronder de Wgbo en de Wet Bopz, vormen een uitwerking van dit rechtsbeginsel. De achterliggende gedachte van het zelfbeschikkingsrecht is dat mensen vrij zijn om te beslissen hoe zij hun leven willen inrichten. Dit uitgangspunt geldt ook voor mensen met een verstandelijke handicap, ondanks het feit dat zij lang niet allemaal in staat zijn om hun zelfbeschikkingsrecht volledig uit te oefenen. Leenen merkt in dit kader op dat ook hun zelfbeschikkingsrecht moet worden gerespecteerd en alles in het werk dient te worden gesteld het zelfbeschikkingsrecht zich naar de mate van het mogelijke te laten verwezenlijken. ${ }^{50}$

Juist in de verstandelijk gehandicaptenzorg is het van groot belang dat het zelfbeschikkingsrecht tot zijn recht komt. Mensen met een verstandelijke handicap verblijven gedurende een lange periode in een voorziening, waarbij ze zijn aangewezen op ondersteuning van verschillende hulpverleners. Roscam Abbing ${ }^{51}$ en Kelk ${ }^{52}$ hebben in de jaren tachtig van de vorige eeuw reeds om aandacht gevraagd voor de rechtspositie van patiënten die in instituten zijn opgenomen.

47 Het recht op goede zorg en het recht op ontplooiing zijn onlosmakelijk met elkaar verbonden: zonder goede zorg is het niet haalbaar om het recht op ontplooiing te verwezenlijken in de zorg voor mensen met een verstandelijke handicap.

48 H.J.J. Leenen, Mensen, rechten, instituties en de staat in de gezondheidszorg (afscheidscollege UvA), Alphen aan den Rijn: Samson H.D. Tjeenk Willink 1990, p. 10.

49 Leenen 2000 , p. 32.

50 Leenen 2000, p. 32.

51 Roscam Abbing 1983.

52 Kelk, 1985 
Beide auteurs waren in die tijd negatief gestemd over de zorg die in instituten werd verleend. Dit is voor een deel te verklaren doordat de vele patiëntenwetten, die als doel hebben het bieden van individuele rechtsbescherming aan patiënten, pas in de jaren negentig van de vorige eeuw in werking zijn getreden. Daarnaast vond de zorg voornamelijk plaats in instituten, die nauwelijks nog vergelijkbaar zijn met de huidige instituten. Tegenwoordig bestaan deze steeds meer uit kleinschalige woningen. Ook verschuift de zorg naar voorzieningen buiten het instituut.

'Speciale aandacht is nodig voor de rechtspositie van de patiēnt, geplaatst in een door de institutionalisering extra afhankelijke positie, waarbij inbreuk op essentiële grondrechten dreigt. De jurist heeft hierbij een speciale beschermende rol te veroullen zowel ten aanzien van de arts, door hem te behoeden voor te gemakkelijke beslissingen, als ook ter bescherming van de patiënt, die recht heeft op een eigen wilsbeschikking, op een eigen oordeel omtrent leven en dood. 53

Het blijft echter een feit dat een verblijf in een voorziening mensen met een verstandelijke handicap kwetsbaar en afhankelijk maakt. Bovendien is regelmatig sprake van uitoefening van dwang en drang. Daarbij moet ervoor worden gewaakt dat het zelfbeschikkingsrecht van cliënten niet al te gemakkelijk terzijde wordt geschoven. Ook mensen met een verstandelijke handicap willen, ieder op hun eigen manier, richting geven aan hun leven en beslissingen kunnen nemen. In het recht geldt het uitgangspunt dat een ieder zijn wil kan bepalen, tenzij het tegendeel wordt aangetoond. Voorkomen moet worden dat van het omgekeerde wordt uitgegaan. Het is onredelijk om aan beslissingen van mensen met een verstandelijke handicap onevenredig hoge eisen te stellen. ${ }^{54}$ Indien binnen de verstandelijk gehandicaptenzorg niet voldoende waarde wordt gehecht aan het zelfbeschikkingsrecht, bestaat het gevaar dat cliënten objecten worden die gemakkelijk voorwerp zijn van manipulatie, aldus Leenen. ${ }^{55}$

\section{Grenzen aan het zelfbeschikkingsrecht}

Het zelfbeschikkingsrecht is geen absoluut recht maar is gebonden aan bepaalde grenzen. De mens leeft in een sociale context waarbij hij rekening dient te houden met andere mensen. Het gaat om zelfbeschikking door alle mensen. ${ }^{56}$ Een beperking van het zelfbeschikkingsrecht dient te voldoen aan strenge eisen, aangezien het uitgangspunt van dit rechtsbeginsel - elk individu kan zelf beslissen

53 Roscam Abbing 1983, p. 15.

54 Leenen 2000, p. 35.

55 Leenen 1990, p. 10.

56 Leenen 2000 , p. 34. 
over datgene wat er met hem gebeurt - zoveel mogelijk in stand gehouden moet worden. Leenen onderscheidt vier beperkingen van het zelfbeschikkingsrecht." De eerste is het zelfbeschikkingsrecht van anderen. Daamaast mag een individu bij de uitoefening van zijn zelfbeschikkingsrecht geen schade veroorzaken aan anderen. Een derde grond voor beperking is het algemeen belang. Tot slot vormt ongerechtvaardigde ongelijkheid tussen mensen of het reguleren van machtsverhoudingen ook een grond om het zelfbeschikkingsrecht te beperken.

In de verstandelijk gehandicaptenzorg zullen de eerste twee beperkingsgronden regelmatig aan de orde zijn. Hulpverleners zullen trachten te voorkomen dat door het handelen van een cliënt schade wordt veroorzaakt aan anderen. Dit betekent ook dat de invulling van het zelfbeschikkingsrecht, afhankelijk van de situatie, zal verschillen. Een cliënt kan wellicht heel goed zelf bepalen wat voor een soort werk hij wil doen, waar en met wie hij wil wonen zonder dat hij schade veroorzaakt aan andere cliënten. Tegelijkertijd kan deze cliënt worden beperkt in de uitoefening van zijn zelfbeschikkingsrecht als het gaat om zaken als zelfstandig fietsen of omgang met respectievelijk vrouwen of mannen omdat hij op deze terreinen een gevaar voor anderen kan zijn. Deze gedachtegang sluit ook aan bij het recht op ontplooiing. Het zelfbeschikkingsrecht van een cliënt moet in het kader van zijn verdere ontwikkeling op zoveel mogelijk terreinen in stand worden gehouden. Zodra diens handelen schade veroorzaakt aan andere cliënten, mag een hulpverlener ingrijpen. De vrijheid en ontplooiing van de ene cliënt wordt op deze manier gewaarborgd door de vrijheid en ontplooiing van de andere cliënt op dat moment te beperken. ${ }^{56}$

Op het eerste gezicht zijn de eerder genoemde beperkingen van het zelfbeschikkingsrecht erg ruim geformuleerd. Om te voorkomen dat te snel een inbreuk wordt gemaakt op het zelfbeschikkingsrecht, dient de motivering sterker te zijn naarmate de inbreuken meer de intieme sfeer en de lichamelijke en geestelijke integriteit raken. Daarbij zijn van belang de criteria van subsidiariteit, proportionaliteit en effectiviteit. Hieronder wordt verstaan dat een inbreuk op het zelfbeschikkingsrecht pas aan de orde is als er geen ander alternatief voor handen is, er een redelijke verhouding bestaat tussen het doel van de inbreuk en het gevolg ervan en de inbreuk wordt beëindigd zodra de noodzaak daartoe niet meer aanwezig is. Legemaate wijst op een andersoortige beperking van het zelfbeschikkingsrecht die niet direct is af te leiden uit de vier hiervoor genoemde

57 Leenen 2000, p. 36.

58 In paragraaf 3.3.3 wordt duidelijk gemaakt dat in de zorg voor mensen met een verstandelijke handicap, naast gevaar voor anderen, bescherming voor de cliënt zelf een belangrijke reden kan zijn om in te grijpen in het zelfbeschikkingsrecht van cliënten. Van belang is dat deze beperkingen een bijdrage leveren aan de ontplooiing van cliënten. 
gronden. De achterliggende gedachte van het zelfbeschikkingsrecht is dat een individu, die dit recht uitoefent, ook in staat moet zijn om met betrekking tot het onderwerp van de beslissing zijn wil te bepalen. Is dit niet het geval, dan kan de zelfbeschikking niet worden gerealiseerd door de persoon zelf. De besluitvorming zal op zo'n moment op een andere wijze moeten verlopen. ${ }^{s}$ In de verstandelijk gehandicaptenzorg zal deze beperking zich regelmatig voordoen. Dit betekent niet dat de betreffende cliënt op dat moment geen zelfbeschikkingsrecht meer heeft. Dit recht, en dat geldt ook voor andere rechten, kan een individu nooit worden afgenomen, ook niet als een vertegenwoordiger als plaatsvervanger optreedt.

In de psychiatrie wordt benadrukt dat hulpverleners, als onderdeel van goed hulpverlenerschap, moeten proberen om de uitoefening van het zelfbeschikkingsrecht van patiënten te herstellen. ${ }^{\infty}$ Een psychiatrische patiënt is over het algemeen tijdelijk verhinderd in de uitoefening van zijn rechten.

'Het is het doel van de geestelijke gezondheidszorg zo snel mogelijk de patiënt in een situatie te brengen dat hij weer over zijn eigen wil kan beschikken, dat hij weer over zichzelf kan beslissen. ${ }^{21}$

Een verstandelijke handicap is, in tegenstelling tot een psychiatrische aandoening, niet tijdelijk van aard. Er is niet sprake van een ziekte die is te genezen door een tijdelijke opneming in een instituut. Mensen met een verstandelijke handicap verblijven veelal voor het leven in een bepaalde voorziening. Het is een illusie om in de verstandelijk gehandicaptenzorg te spreken over een herstel van de uitoefening van het zelfbeschikkingsrecht. Dit betekent echter niet dat mensen met een verstandelijke handicap niet in staat zijn om een ontwikkeling door te maken. Het komt geregeld voor dat een cliënt een bepaalde groei doormaakt: hij verhuist van een instituut naar een kleinere woonvoorziening of een zelfstandige woonvorm. De mogelijkheden van een cliënt met een verstandelijke handicap moeten echter niet worden overschat. Tonkens wijst erop dat het belangrijk is dat de samenleving reëel blijft ten aanzien van de mogelijkheden van mensen met een verstandelijke handicap. Het burgerschapsparadigma heeft ook zijn onvolkomenheden. Het blijft immers gaan om mensen met blijvende beperkingen en bepaalde kenmerken, waardoor zij zich onderscheiden van niet-gehandicapten. ${ }^{62}$

59 Legemaate 1991, p. 205-206.

60 Legemaate 1991, p. 207.

61 Roscam Abbing 1983, p. 15.

62 Tonkens 1999. 
Het burgerschapsparadigma moet echter juist wel breed in de verstandelijk gehandicaptenzorg doorwerken. Ook mensen met een meervoudige ernstige verstandelijke handicap vallen onder dit paradigma. De essentie daarvan is dat burgers met meer beperkingen aanspraak kunnen maken op meer ondersteuning. Het uiteindelijk doel is bij alle cliënten hetzelfde: het doormaken van een ontwikkeling, in de zin van totale afhankelijkheid naar meer zelfbeschikking. Per cliënt zal deze ontwikkeling verschillen. Het zal ook onontkoombaar zijn dat het zelfbeschikkingsrecht van mensen met een verstandelijke handicap van tijd tot tijd wordt beperkt. Vanuit de gedachte van ontplooiing is het van belang dat deze tijdelijke beperkingen, zoals afzonderen of fixeren van een cliënt, niet langer duren dan noodzakelijk is. Op deze wijze kunnen cliënten in de verstandelijk gehandicaptenzorg weer zo snel mogelijk (een deel van) hun zelfbeschikkingsrecht uitoefenen.

\section{Zelfbeschikkingsrechtdoctrine in de verstandelijk gehandicaptenzorg}

In de vier eerder genoemde beperkingsgronden van Leenen komt niet aan de orde wat er met het zelfbeschikkingsrecht van een individu gebeurt zodra sprake is van gevaar voor de cliënt zelf. Dit motief vormt in de verstandelijk gehandicaptenzorg regelmatig een reden om het zelfbeschikkingsrecht te beperken. Het kan gaan om automutilerend gedrag, gedragsproblemen, de kans om 's nachts uit bed te vallen en diverse situaties waarin een cliënt niet kan overzien welke gevolgen zijn handelen heeft, zoals het omgaan met geld. De mate waarin een hulpverlener zal ingrijpen, hangt voor een groot deel samen met de wilsbekwaamheid van een cliënt. Als een cliënt in staat is om zelf een beslissing te nemen, mag zijn zelfbeschikkingsrecht niet worden beperkt. De situatie verandert zodra andere cliënten door het gedrag van een cliënt in gevaar worden gebracht. Maar geldt dit ook als sprake is van gevaar voor de cliënt zelf? Mag een hulpverlener dan ook ingrijpen in het zelfbeschikkingsrecht van een cliënt? In de samenleving is het geaccepteerd dat mensen diverse sporten beoefenen waaraan grote risico's verbonden zijn. Denk daarbij aan bergbeklimmen, skiën of parachutespringen. Vanwege het zelfbeschikkingsrecht is het niet toegestaan om mensen te verbieden deze sporten uit te oefenen. Dit recht is zodanig ingeburgerd in onze maatschappij dat mensen vrij zijn om te doen en laten wat ze willen. Ook als dit betekent dat mensen zichzelf in een gevaarlijke situatie brengen. Zo lang als andere mensen daarbij geen gevaar lopen kunnen geen beperkingen worden opgelegd. Wel is van belang in dat mensen willens en wetens handelen. De vraag is echter of ook in de verstandelijk gehandicaptenzorg aan dit criterium kan worden vastgehouden. Wat gebeurt er als een cliënt zichzelf willens en wetens verwondt? Mag een hulpverlener dan ingrijpen? Van een bergbeklimmer 
mag worden verwacht dat hij zich realiseert wat de gevolgen van zijn sport kunnen zijn. Van de Klippe spreekt van onaanvaardbare uitholling van het zelfbeschikkingsrecht als de overheid ook op zo'n moment besluit in te grijpen.63 Het standpunt dat individuen zelf mogen bepalen of zij zich willen blootstellen aan bepaalde gevaren, benadrukt het idee van negatieve zelfbeschikking.

'Het zelfbeschikkingsrecht omvat ook de negatieve zelfbeschikking: beperking van fundamentele rechten is niet toelaatbaar op grond van schade die mensen aan zichzelf toebrengen of dreigen toe te brengen. Uitgangspunt is dat mensen die in staat zijn tot waardering van hun belang de ruimte moeten krijgen om zelf dit belang in te vullen.' ${ }^{\prime 4}$

In eerste instantie moeten ook mensen met een verstandelijke handicap de gelegenheid krijgen om zich bloot te stellen aan bepaalde gevaren, mits zij willens en wetens handelen en geen schade veroorzaken aan anderen. Berghmans betoogt echter dat zelfbeschikking, oftewel autonomie, niet het enige relevante morele handelingsprincipe is voor hulpverleners. ${ }^{\circ 5}$ Ook weldoen is van belang. Hieronder wordt verstaan dat hulpverleners goed doen, in de meest positieve zin van het woord. Het gevolg van weldoen is dat het zelfbeschikkingsrecht van een cliënt terzijde kan worden geschoven om te voorkomen dat een cliënt een gevaar vormt voor zichzelf. Hiermee lijkt Berghmans te beweren dat hulpverleners goede redenen kunnen hebben om ook bij wilsbekwame cliënten in te grijpen. Hij onderscheidt echter verschillende verschijningsvormen van paternalistisch handelen. Onder sterk paternalistisch handelen wordt verstaan het beperken van het zelfbeschikkingsrecht van een wilsbekwaam persoon. Van zwak paternalistisch handelen is sprake wanneer geen rekening wordt gehouden met de wensen, keuzen of acties van een cliënt omdat deze vanwege problemen in zijn functioneren de gevolgen van zijn handelen niet kan overzien. ${ }^{66}$ Paternalistisch handelen dient ook in de verstandelijk gehandicaptenzorg, beperkt te blijven tot zwak paternalistisch handelen. In deze sector is een deel van de cliënten minder in staat om naar eigen inzicht te handelen. Deze cliënten zijn (gedeeltelijk) wilsonbekwaam. Vanuit dit kader is het gerechtvaardigd dat een hulpverlener ingrijpt in het zelfbeschikkingsrecht van een cliënt teneinde de kans op schade voor de cliënt te voorkomen. Daarbij geldt een aanvullende voorwaarde: de beperking in de vrijheid moet een bijdrage leveren aan het welzijn van de betrokkene oftewel de ontwikkelingsmogelijkheden van een cliënt.

63 Van de Klippe 1997, p. 205.

64 Laurs 1988, p. 134.

65 R.L.P. Berghmans, Om bestwil paternalisme in de psychiatrie. Een gezondheidsethische studie, Amsterdam: Thesis publishers 1992, p. 245.

66 Berghmans 1992, p. 26-27. 
Toch dienen ook in de zorg voor mensen met een verstandelijke handicap cliënten zoveel mogelijk de ruimte te krijgen om zelfstandig keuzes te maken, ook als het gaat om beslissingen waarbij risico's kunnen ontstaan voor de persoon zelf. In de rechtspraak wordt deze benadering onderschreven. Uit een uitspraak van de Rechtbank Middelburg van 25 april 2002 kan worden afgeleid dat gevaar voor de cliënt zelf minder ruimte geeft om met dwang in te grijpen dan gevaar voor anderen. In dit geval betrof het een vrouw met een borderlinestoornis en suicidaal gedrag. De Rechtbank constateert dat de vrouw over voldoende realiteitsbesef beschikt en in staat is tot vrije wilsbepaling, ondanks haar stoornis. Een gedwongen verblijf in een psychiatrisch ziekenhuis zou dan ook geen recht doen aan haar zelfbeschikkingsrecht. ${ }^{6}$ De situatie verandert als een hulpverlener onvoldoende overtuigd is van de wilsbekwaamheid van een cliënt. Een hulpverlener heeft het recht om zwak paternalistisch op te treden als een cliẻnt wilsonbekwaam is. Het probleem dat zich hierbij voordoet is dat wilsonbekwaamheid onvoldoende geoperationaliseerd is waardoor hulpverleners geneigd zijn om, wellicht onterecht, zwak paternalistisch op te treden. Deze wijze van handelen is, mede gezien de onduidelijkheid die bestaat over wilsonbekwaamheid, alleen gerechtvaardigd als een hulpverlener zijn optreden kan uitleggen aan derden en, voor zover mogelijk is, aan de betreffende cliënt. Daarnaast mag een hulpverlener ook ingrijpen als het handelen van een cliënt leidt tot gevaar voor anderen. In het laatste geval is het niet van belang of een cliënt wilsbekwaam dan wel wilsonbekwaam is. Ook nu dienen stringente criteria in acht te worden genomen. Het mag niet zo zijn dat mensen met een verstandelijke handicap als een 'gevaarlijke' groep worden beschouwd. Cliënten vormen in het algemeen eerder een gevaar voor zichzelf dan voor anderen.

\subsubsection{Bescherming}

In paragraaf 3.3.2 is aan de orde gesteld onder welke voorwaarden het zelfbeschikkingsrecht van een cliënt kan worden beperkt. Van de Klippe beschouwt zelfbeschikking en bescherming als twee kanten van dezelfde medaille: 'In de begrenzing van de uitoefening van het zelfbeschikkingsrecht komt het beschermingsbeginsel tot uitdrukking ${ }^{\prime 6}$ In de juridische literatuur wordt zelden een eenduidige omschrijving gegeven van het beschermingsbeginsel. Feitelijk betekent dit beginsel dat cliënten in hun vrijheid worden beperkt teneinde hen optimale bescherming te bieden. Hulpverleners hebben verschillende redenen om cliënten in bescherming te nemen. De bescherming kan zich richten op het algemeen belang, op de belangen van derden of op de cliënt zelf die bijzondere bescherming

67 Rechtbank Middelburg, 25 april 2002, BJ 2002, 55, m.nt. J. Legemaate.

68 Van de Klippe 1997, p. 205. 
behoeft. In deze studie wordt uitgegaan van een enge definitie van het beschermingsbeginsel: de vrijheid van een cliënt wordt beperkt om de cliënt te beschermen tegen zichzelf. ${ }^{\oplus}$ Deze beschrijving vertoont veel overeenkomsten met artikel $11 \mathrm{Gw}$. De strekking van dit artikel is dat individuen beschermd moeten worden tegen inbreuken van buitenaf die het lichaam raken. Te denken valt aan een lichamelijk onderzoek of de toepassing van vrijheidsbeperkende maatregelen. Een hulpverlener mag beide vormen, een lichamelijk onderzoek dan wel een vrijheidsbeperkende maatregel, alleen verrichten als de uitvoering op een wettelijke grondslag berust of als een cliënt toestemming heeft gegeven.

In de regelingen curatele, beschermingsbewind en mentorschap is deze enge betekenis van het beschermingsbeginsel ook terug te vinden. Cliënten die hun belangen niet kunnen behartigen of die zichzelf schade toebrengen, kunnen een vertegenwoordiger toegewezen krijgen. ${ }^{70}$ Daarnaast bevat ook de Wgbo een bepaling, waarin het beschermingsbeginsel tot uitdrukking komt.

Verzet de patiënt zich tegen een verrichting van ingrijpende aard waarvoor een persoon als bedoeld in de leden 2 of 3 toestemming heeft gegeven, dan kan de verrichting slechts worden uitgevoerd indien zij kennelijk nodig is teneinde ernstig nadeel voor de patiënt te voorkomen.' (art. 7:464 lid 6 BW)

Zelfbeschikking en bescherming zijn twee kanten van dezelfde medaille die, mede vanwege de bijzondere positie waarin mensen met een verstandelijke handicap zich bevinden, op zichzelf niet voldoende zijn voor een adequate rechtspositie van mensen met een verstandelijke handicap. Pas als sprake is van een gepast samenspel, kan een positieve bijdrage worden geleverd aan de rechten van mensen met een verstandelijke handicap. In de ethiek wordt de tegenstelling tussen zelfbeschikking en bescherming aangeduid met autonomie en paternalisme. Paternalisme betekent dat een hulpverlener ingrijpt in iemands vrijheid van handelen, dat wordt gerechtvaardigd met redenen die uitsluitend verwijzen naar het welzijn, het goede, het geluk, de behoeften en belangen of waarden van degene op wie dwang wordt uitgeoefend. ${ }^{71}$ Een vraag die zich regelmatig voordoet is of een hulpverlener de autonomie van een cliënt moet respecteren of dat hij de cliënt moet beschermen tegen nadelige gevolgen van zijn han-

69 Bescherming van het algemeen belang en belangen van derden (oftewel de bescherming van de maatschappij) is terug te vinden in de begrenzing van het zelfbeschikkingsrecht (paragraaf 3.3.2).

70 Tegelijkertijd worden derden ook beschermd door het benoemen van een wettelijk vertegenwoordiger.

71 Dworkin, G., The theory and practice of autonomy, Cambridge: Cambridge University Press 1988, p. 121-129. 
delen. Als een hulpverlener voor de tweede optie kiest, wordt een cliënt de mogelijkheid ontnomen om te leren van zijn handelen. Een cliënt zal niet ondervinden welke consequenties zijn handelen heeft. Deze conflicten doen zich regelmatig voor bij cliënten met een Prader-Willi syndroom. Als deze cliẻnten alle vrijheid wordt geboden, is de kans groot dat zij door hun ongeremde eetgedrag te zwaar worden. In de ethiek wordt de oplossing gezocht in een model dat uitgaat van relationele autonomie. Dit model zou beter passen in de verstandelijk gehandicaptenzorg dan een model dat teveel de nadruk legt op zelfbepaling en onafhankelijkheid. ${ }^{2}$ Als autonomie wordt opgevat in termen van negatieve vrijheid, ligt het accent op non-interventie: een individu mag niet worden gehinderd door anderen bij de invulling van zijn leven. De enige voorwaarde is dat hij met zijn handelen anderen niet schaadt. Relationele autonomie sluit meer aan bij positieve vrijheid: het vergroten van de handelingsvrijheid en keuzevrijheid staat voorop. Het gaat niet zozeer om de vraag of een individu in staat is om beslissingen te nemen maar om datgene wat een individu met zijn keuzen tot stand brengt. ${ }^{73}$ Zelfbeschikking maakt plaats voor zelfontplooiing. Dit vereist een andere houding van de hulpverlener: in plaats van afstandelijkheid zijn begrip, betrokkenheid, steun en waar nodig kritiek vereist. ${ }^{7}$ De cliënt verlangt een actievere houding van de hulpverlener. Widdershoven en Berghmans verwoorden de rol van de hulpverlener als volgt:

Niet alleen het respecteren van reeds bestaande autonomie is diens morele opdracht, maar ook het realiseren van autonomie waar deze tekortschiet, of waar belemmeringen bestaan. Het gaat niet uitsluitend om het handhaven (of beschermen) van de handelingsvrijheid van de cliënt, maar tevens om het vergroten van de mogelijkheden om greep te krijgen op en zin te ervaren in de eigen situatie. 75

Het voorgaande laat zien dat zelfbeschikking en bescherming, mits vanuit een juist perspectief toegepast, beide van betekenis zijn voor de rechtspositie van verstandelijk gehandicapten. Dit kan betekenen dat ingrijpen in de vrijheid van een cliënt op bepaalde momenten noodzakelijk is. Deze inbreuken in de vrijheid van een cliënt behoren een duidelijk doel te dienen. Niet elke inbreuk is gerechtvaardigd. Bovendien zijn het nog altijd de rechten van cliënten die worden be-

72 R.H. van Hooren et al, "Autonomy and intellectual disability", Journal of Intellectual Disability Research (46) 2002-7, p. 560-568.

73 Berlin 1996.

74 Widdershoven, Berghmans en Welie 2003, p. 329.

75 G. Widdershoven en R. Berghmans, "Autonomie in de hulpverlening", in: J. Graste en D. Baudien, Waardenvol Werk, Assen: Van Gorcum 2000, p. 57. 
perkt. In dit kader kan ook worden verwezen naar het exceptiebeginsel. Leenen 76 omschrijft dit beginsel als volgt:

\section{'(...) Bij de toepassing van een zelfbeschikkingbeperkende maatregel op een individuele} burger wegens diens persoonlijke toestand is extra zorgouldigheid vereist. Een dergelijke uitzondering moet worden beheerst door dezelfde norm waarop zij een uitzondering is en de werking van de norm waarop zij een uitzondering is moet zo veel mogelijk worden gehandhaafd.'

Leenen beoogt met het exceptiebeginsel te benadrukken dat bescherming van een cliënt uiteindelijk tot doel heeft om de zelfbeschikking van een cliënt te herstellen. Om dit doel te bereiken moet elke beschermende maatregel voldoen aan het proportionaliteits-, het subsidiariteits- en het effectiviteitsbeginsel. De betekenis van het exceptiebeginsel werkt ook door in het normatief kader van deze studie. Elke vorm van bescherming dient te voldoen aan strikte criteria.

Een aanvulling op het exceptiebeginsel van Leenen is dat bescherming ook een wezenlijke functie moet vervullen, met name in de verstandelijk gehandicaptenzorg. Niet elke inbreuk zal gerechtvaardigd zijn. Om een uitspraak te kunnen doen over de juistheid van bescherming is doorslaggevend welke intentie hulpverleners hebben als zij een cliënt beschermen. In eerste instantie zullen hulpverleners de bedoeling hebben om gevaar voor de cliënt af te afwenden. Het bieden van bescherming aan cliënten dient evenwel in een bredere context te worden gezien. Bescherming dient ook een bijdrage te leveren aan de ontplooiing van cliënten. Berghmans ${ }^{7}$ spreekt in dit kader over opvoedkundig paternalisme. Paternalistisch handelen is bij kinderen gerechtvaardigd. Als het goed is laten ouders zich in hun handelen leiden door het belang van het kind, dat een toekomstgeoriënteerd aspect heeft. Het handelen van ouders is gericht op de ontwikkeling van hun kind. Berghmans geeft tegelijkertijd aan dat opvoedkundig paternalisme moeilijker wordt bij mensen met een verstandelijke handicap, waarvan het ontwikkelingspotentieel gering is of ontbreekt. Mensen met een verstandelijke handicap maken echter wel degelijk een bepaalde ontwikkeling door. De mate van ontwikkeling verschilt per cliënt. Bescherming kan een bijdrage leveren aan de ontplooiing van cliënten. In deze studie wordt deze benadering functionele bescherming genoemd. Het is belangrijk dat cliënten niet om verkeerde redenen worden beschermd maar dat daadwerkelijk een bijdrage wordt geleverd aan de rechtspositie van cliënten. Het gaat tenslotte om inbreuken op het zelfbeschikkingsrecht van cliënten. Daarnaast wordt met functionele

76 Leenen 2000, p. 37.

77 Berghmans 1992, p. 129-130. 
bescherming een verbinding gelegd tussen bescherming en zelfbeschikking. Blankman voegt hieraan toe dat in het kader van de ontwikkeling van cliënten, bescherming op maat moet worden geboden. Bescherming heeft in zijn ogen een aanvullende functie: 'Slechts voor zover dat noodzakelijk is, dienen beschermende maatregelen te worden genomen. De noodzakelijke bescherming ligt bij iedere cliënt anders en hangt af van de individuele mate van mondigheid en de eigen mogelijkheden.' In eerste instantie dient uitgegaan te worden van de restcapaciteit van een cliënt. Alleen waar nodig dient het recht in te grijpen en te ondersteunen.

Op grond van het voorafgaande kan een aantal criteria worden geformuleerd waaraan bescherming van cliënten dient te voldoen:

1. Het betreft een cliënt die niet kan overzien welke gevolgen zijn handelen heeft.

2. Er is sprake van een onveilige situatie voor de cliënt zelf."

3. Bescherming voldoet aan de criteria van subsidiariteit, proportionaliteit ${ }^{* 0}$ en effectiviteit.

4. Bescherming gaat gepaard met grote zorgvuldigheid: de noodzaak van bescherming moet worden beargumenteerd en in het zorgplan worden vastgelegd.

5. Bescherming levert een bijdrage aan de ontplooiing van de cliënt."

\subsubsection{Goede zorg}

In artikel 22 lid 1 van de Grondwet is vastgelegd dat 'de overheid maatregelen treft ter bevordering van de volksgezondheid'. Dit artikel geeft invulling aan het recht op gezondheidszorg. De overheid heeft de verplichting om aan cliënten kwalitatief goede, betaalbare en beschikbare gezondheidszorg te bieden. Het recht op gezondheidszorg is, in tegenstelling tot artikel $10 \mathrm{Gw}$ en $11 \mathrm{Gw}$, een sociaal grondrecht. Cliënten kunnen niet rechtstreeks een beroep doen op artikel $22 \mathrm{Gw}$. De overheid heeft slechts een inspanningsverplichting naar cliënten toe. Verdedig-

78 K. Blankman, "Recht en gezondheid. Menswaardigheid en rechtsbescherming van geestelijk gehandicapten", in: K. Blankman en J.E. Doek (red.), Recht en gezondheid: liber Amicorum Mr. Oscar P.F. Oldenburg, Amsterdam: VU Uitgeverij 1992, p. 42-43.

79 Het begrip gevaar is met opzet vermeden. In de zorg voor mensen met een verstandelijke handicap biedt dit begrip te weinig ruimte om een cliënt te beschermen tegen zichzelf (zie verder hoofdstuk 5, 6 en 7).

80 De beschermingsmaatregel dient in verhouding te staan tot het doel van bescherming: een bijdrage leveren aan de ontplooiing van een cliënt.

81 Dit laatste criterium is, in tegenstelling tot de andere vier criteria, niet duidelijk terug te vinden in de literatuur. 
baar is dat cliënten in de care sector meer rechten kunnen ontlenen aan artikel 22 Gw. Laurs nuanceert het idee dat het recht op gezondheidszorg geen afdwingbare verplichtingen in het leven roept. Hij is van mening dat het recht op gezondheidszorg als een afdwingbaar individueel recht moet worden beschouwd..$^{2}$ Ter motivering wordt verwezen naar de relatie tussen het recht op zelfbeschikking en het recht op gezondheidszorg. Beide rechten zijn als het ware complementair: ze vullen elkaar aan en hebben als doel om het zelfbeschikkingsrecht van een cliënt te vergroten. Veel psychiatrische patiënten beschikken niet over het vermogen om hun zelfbeschikkingsrecht uit te oefenen. In dat kader kan het recht op gezondheidszorg een belangrijke bijdrage leveren. Daarnaast heeft het recht op gezondheidszorg ook een functie in relatie tot de toepassing van vrijheidsbeperking. Zonder het aanbod van een in kwalitatief opzicht goede zorg is vrijheidsbeperking van psychiatrische patiënten niet te rechtvaardigen, aldus Laurs. De toepassing van vrijheidsbeperking dient gepaard te gaan met adequate hulpverlening: deskundig personeel, voldoende personeel en een verantwoorde toepassing van vrijheidsbeperking. De gedachtegang van Laurs kan worden doorgetrokken naar cliënten met een verstandelijke handicap. Zonder deskundige ondersteuning zijn veel cliënten met een verstandelijke handicap niet in staat om hun zelfbeschikkingsrecht uit te oefenen. Legemaate merkt op dat ook veel somatische patiënten het vermogen missen om hun zelfbeschikkingsrecht adequaat uit te oefenen. Het zou vanuit dit kader onterecht zijn om cliënten met een verstandelijke handicap een grotere claim op het recht op gezondheidszorg toe te kennen. Toch zijn er diverse argumenten voor deze stelling. Somatische patiënten zijn voor een kortere periode opgenomen, kunnen over het algemeen genezen van hun aandoening en zijn minder afhankelijk van hulpverleners dan cliënten in de verstandelijk gehandicaptenzorg die over het algemeen gedurende hun hele leven afhankelijk zijn van hulpverleners.

Het recht op gezondheidszorg krijgt in de praktijk ook steeds meer het karakter van een afdwingbaar grondrecht waardoor in toenemende mate de vrijblijvendheid van artikel $22 \mathrm{Gw}$ afneemt. ${ }^{83}$ Dit blijkt onder meer uit een uitspraak van de Centrale Raad van Beroep d.d. 24 juli 2002.84 Ouders vorderden bij hun verzekeraar een deel van de eigen bijdrage terug die in rekening was gebracht voor hun zoon die jarenlang in een psychiatrisch ziekenhuis was verzorgd. Er zou geen sprake zijn van goede zorg: de geboden zorg was ver onder de maat. De verzekeraar heeft op grond van de AWBZ een controlerende taak als het gaat om de kwaliteit van de door zorgaanbieders verstrekte zorg. De Raad oordeelde dat

82 Laurs 1988, p. 139-140.

83 Leenen 2000, p. 27.

84 Centrale Raad van Beroep Utrecht d.d. 24 juli 2002. Zaaknr: 01/253, 02/2337 AWBZ. 
deze zorg niet overeenkwam met de zorg waarop de verzekerde overeenkomstig de AWBZ recht heeft. Het besluit, waarin door de verzekeraar een eigen bijdrage was opgelegd, diende te worden vernietigd.

Deze uitspraak is ook van betekenis voor de verstandelijk gehandicaptenzorg. Cliënten die vinden dat de geboden zorg onder maat is, kunnen zich in de toekomst tot de rechter wenden. Daarbij is wel van belang dat beide partijen een invulling kunnen geven aan kwaliteit van zorg. Voor de verstandelijk gehandicaptenzorg bestaan vooralsnog geen algemeen geaccepteerde criteria, op grond waarvan een oordeel kan worden gegeven over de geboden kwaliteit van zorg. Naast het recht op gezondheidszorg kan ook worden gesproken van het 'recht op goede zorg'. Het begrip zorg heeft in deze studie een brede betekenis. In relatie tot de verstandelijk gehandicaptenzorg kan onder zorg ook worden verstaan het bieden van ondersteuning. Dit begrip is afkomstig uit de sociale wetenschappen. Van Gennep relateert ondersteuning aan volwaardig burgerschap:

Mensen met een verstandelijke handicap krijgen zodanige ondersteuning, dat zij met hun beperkingen toch als volwaardig burger in de samenleving kunnen functioneren."

Door te spreken over ondersteuning neemt de sector verstandelijk gehandicaptenzorg afstand van de traditionele invulling van het begrip zorg., ${ }^{* 6}$ Ondersteuning heeft tot doel een cliënt een volwaardige plaats in de samenleving te bieden. Het begrip ondersteuning gaat van andere vooronderstellingen uit dan het begrip zorg. Onder ondersteuning wordt verstaan het toegang geven van de betrokken persoon tot voor hem belangrijke kennis, middelen en relaties die nodig zijn om in de samenleving te kunnen wonen, werken en recreëren.' ${ }^{\prime 7}$ In beginsel wordt gestreefd naar een zo groot mogelijke zelfstandigheid. Daarnaast gaat het echter ook om emotie, relatie en participatie. Met behulp van ondersteuning krijgt een cliënt de kans om normale ervaringen op te doen zoals het maken van keuzes, het aangaan van relaties en het ondernemen van diverse activiteiten. ${ }^{8 B}$ De mo-

85 A.Th.G. van Gennep en G. van Hove, "Zijn het burgerschapsparadigma en inclusie dan niet bruikbaar voor mensen met een ernstige verstandelijke handicap? Kanttekeningen bij een zorgelijke ontwikkeling", Nederlands Tijdschrift voor de Zorg aan verstandelijk gehandicapten (26) 2000-4, p. 252.

86 De essentie van de traditionele invulling van zorg is dat zorg de activiteiten van de cliënt overneemt. Het begrip zorg is ook een medisch georiënteerd begrip. Ondersteuning is meer een pedagogisch begrip.

87 A.Th.G. van Gennep, Paradigma-verschuiving in de visie op zorg voor mensen met een verstandelijke handicap (inaugurale reden Universiteit Maastricht), Maastricht: 1997 a, p. 25-26.

88 Van Gennep en Van Hove 2000, p. 252. 
derne invulling van zorg vertoont overigens veel overeenkomsten met ondersteuning. De nadruk wordt niet meer gelegd op wat betrokkene niet kan, maar op het bevorderen van de empowerment van cliënten.

Het rechtsbeginsel recht op goede zorg kan worden beschouwd als een toespitsing van het recht op gezondheidszorg. ${ }^{00}$ Het accent ligt op het bieden van kwalitatief goede zorg en minder op de beschikbaarheid en bereikbaarheid van zorg. ${ }^{\text {" }}$ Kwalitatief goede zorg is zorg die individueel gericht is en bijdraagt aan de ontplooiing van cliënten. Dit betekent ook dat het recht op goede zorg veel verwantschap vertoont met individuele grondrechten, hetgeen van het recht op gezondheidszorg niet gezegd kan worden. Daarnaast dient de hulpverlener zijn handelen inzichtelijk te maken en verantwoording af te leggen aan derden. Kelk voegt hieraan toe dat 'het recht op goede zorg ook te beschouwen is als een intentieverklaring van de wijze waarop de patiënt vanwege het instituut waar hij verblijft zal worden verzorgd, begeleid, behandeld en tegemoet wordt getreden. ${ }^{12}$ Goede zorg heeft echter ook een materieel aspect. Om goede zorg mogelijk te maken moeten cliënten een beroep kunnen doen op voorzieningen en voldoende gekwalificeerd personeel.

Het rechtsbeginsel goede zorg is inmiddels ook verankerend in wetgeving. In dit verband kunnen worden genoemd de Kwaliteitswet zorginstellingen (Kwz) en de Wet op de beroepen in de individuele gezondheidszorg (Wet big) die bet. be. grip verantwoorde zorg hanteren.

'De zorgaanbieder biedt verantwoorde zorg aan. Onder verantwoorde zorg wordt verstaan zorg van goed niveau, die in ieder geval doeltreffend, doelmatig en patiëntgericht wordt verleend en die afgestemd is op de reële behoefte van de patiënt.' (art. $2 \mathrm{Kwz}$ )

'Degene die in een register als bedoeld in artikel 3 staat ingeschreven of die een beroep uitoefent waarvan de opleiding krachtens artikel 34, eerste lid, is geregeld of aangewezen,

89 Het begrip zorg is volop in ontwikkeling en is niet meer alleen gericht op het verzorgen en verplegen van cliënten. Van den Brink onderscheidt zes dimensies aan zorg: verpleging en lichamelijke verzorging, opvang en bescherming, ontplooiing en ontwikkeling, praktische en huishoudelijke hulp, troost en sociale steun, organisatie en regie. Zorg bij mensen met een verstandelijke handicap richt zich met name op de persoonlijke ontplooiing en minder op verpleging en bescherming, aldus Van den Brink (G. F.M. van den Brink, Een schaars goed: de betekenis van zorg in de hedendaagse levensloop, Utrecht: NIZW 1999, p. 13-24).

90 Dit recht valt uiteen in drie aspecten: kwaliteit van zorg, bereikbaarheid van de gezondheidszorg en financiële toegankelijkheid van de gezondheidszorg.

91 Kelk 1990, p. 114-115.

92 Kelk 1985, p. 28-30. 
en die zijn beroep uitoefent anders dan in het kader van een instelling als bedoeld in de Kwaliteitswet zorginstellingen, organiseert zijn beroepsuitoefening op zodanige wijze en voorziet zich zodanig van materieel, dat een en ander leidt of redelijkerwijze moet leiden tot verantwoorde zorg.' (art. 40 lid 1 Wet big)

Daarnaast kan worden verwezen naar het begrip goed hulpverlenerschap, dat wordt genoemd in de Wgbo.

De hulpverlener moet bij zijn werkzaamheden de zorg van een goed hulpoerlener in acht nemen en handelt daarbij in overeenstemming met de op hem rustende verantwoordelijkheid, voortvloeiende uit de voor hulpverleners geldende professionele standaard.' (art. 7:453 BW)

\subsubsection{Goede zorg en de zorgethiek}

Het rechtsbeginsel goede zorg krijgt meer betekenis door de invulling die in de zorgethiek aan het begrip goede zorg wordt gegeven. Goed hulpverlenerschap betekent dat een hulpverlener verantwoordelijk is voor het bieden van goede zorg, aldus Widdershoven c.s. ${ }^{3}$ Goede zorg neemt in de zorgethiek een centrale plaats in. In de zorgethiek wordt goede zorg beschouwd als een moreel gezichtspunt op hulpverlenerschap. Kenmerken zijn het tegemoetkomen aan de zorgbehoeften van de cliënt, de verantwoordelijkheid van een hulpverlener om in te grijpen, het uitvoeren van zorg en checken of zorg ook wordt ontvangen door een cliënt. Verkerk omschrijft goede zorg als zorg die op aandachtige, verantwoordelijke, competente en responsieve wijze wordt gegeven en ontvangen. Zij benadrukt dat de zorgrelatie tussen een hulpverlener en een cliënt dialogisch van aard is. ${ }^{94} 95$ Widdershoven c.s. zijn van mening dat de uitgangspunten van goede zorg op gespannen voet staan met zelfbeschikking. In de Wgbo en de Wet Bopz wordt sterk de nadruk gelegd op het recht op zelfbeschikking. Het uitgangspunt van de Wgbo is dat een cliënt wordt beschouwd als een volwaardige gesprekspartner die, op basis van volledige informatie, in alle vrijheid toestemming dient te geven voor een behandeling. In de Wet Bopz is bepaald dat een hulpverlener alleen mag ingrijpen in het zelfbeschikkingsrecht van een cliënt als sprake is van gevaar voor de cliënt of anderen. Tegelijkertijd veronderstelt goede zorg volgens ethici ook weer niet dat alle aandacht voor het zelfbeschikkings-

\section{Widdershoven, Berghmans en Welie 2003, p. 330-332.}

94 M. A. Verkerk, "Over drang als goed zorgen - een zorgethische beschouwing", Tijdschrift voor Geneeskunde en ethiek (11) 2001-4, p. 103.

95 Deze definitie van goede zorg is afgeleid van J. Tronto, Moral boundaries: a political argument for an ethic of care, New York/London: Routledge 1993. 


\section{Hoofdstuk 3}

recht verkeerd zou zijn. Verkerk is van mening dat respect voor autonomie een belangrijk wapen is tegen de macht en overheersing waar cliënten in de zorg mee te maken krijgen:

Te lang en te vaak zijn cliënten geconfronteerd gewoest met - goedbedoelde - paternalistische handelingen van hulpverleners. Het inzetten van het respect voor individuele autonomie als belangrijke waarde werkt daarom als een soort van wapen tegen zorg als macht en overheersing. Een belangrijk wapen (...) in die zorgpraktijken waar mensen al kwetsbaar en afhankelijk zijn en zich ook als zodanig gedragen. $\%$

Toch blijven ethici over het algemeen kritisch ten opzichte van het zelfbeschikkingsrecht in relatie tot goede zorg. Teveel aandacht voor het recht op zelfbeschikking zou tot gevolg hebben dat veel cliënten verstoken blijven van goede zorg, aldus diverse ethici. De Wet Bopz wordt veelvuldig als voorbeeld genoemd. Deze wet zou uitgaan van een te nauw kader, waardoor hulpverleners niet de mogelijkheid hebben om naar eigen inzicht in te grijpen in het zelfbeschikkingsrecht van cliënten. Voor een deel is dit een terechte keuze van de wetgever. Het gaat immers om vrijheidsbeperkende maatregelen die verstrekkende gevolgen kunnen hebben voor de rechtspositie van cliënten. Een belangrijke functie van het recht is om op zo'n moment de vrijheid van een cliënt te waarborgen.

De kritiek van ethici is voor een deel terecht. Eerder in dit hoofdstuk zijn de verschillende functies van het recht uiteengezet. Naast het waarborgen van de vrijheid, heeft het recht ook de functie om cliënten te beschermen en te ondersteunen. Het is de vraag of de huidige wetgeving aan deze functies van het recht tegemoetkomt. Het vermoeden bestaat dat bepaalde cliënten, ten onrechte, aan hun lot worden overgelaten. In de zorgethiek wordt de oplossing gezocht in meer betrokkenheid van de hulpverlener. De cliënt zou meer gebaat zijn bij begrip, betrokkenheid, steun en waar nodig ook kritiek van de hulpverlener. $\mathrm{Al}$ deze elementen vormen tezamen het concept goede zorg. In de literatuur worden begrippen als betutteling, overbescherming en paternalisme regelmatig in één adem genoemd met goede zorg. Goede zorg heeft echter een bredere betekenis dan paternalisme. Goede zorg vereist een actieve houding van een hulpverlener. Hij moet inspelen op de situatie en rekening houden met de mogelijkheden van een cliënt. ${ }^{97}$ Op een bepaald moment kan het noodzakelijk zijn dat een hulpverlener een beslissing van een cliënt overruled. Paternalisme betekent dat een hulpverlener het beter meent te weten. Vanuit het oogpunt van goede

96 Verkerk 2001, p. 101-102.

97 Verkerk 2001, p. 105. 
zorg dient een hulpverlener niet alleen een beslissing te nemen voor een cliënt omdat hij het beter meent te weten, maar ook om de cliënt verder op weg te helpen.\% Als het uitgangspunt van goede zorg ook wordt gehanteerd in relatie tot vrijheidsbeperking, zou dit betekenen dat hulpverleners in een eerder stadium mogen ingrijpen. Nu mag een hulpverlener pas in een latere fase ingrijpen, teneinde de inbreuken op het zelfbeschikkingsrecht tot een minimum te beperken. In de verstandelijk gehandicaptenzorg is dit geen gepast uitgangspunt. Veel cliënten zijn niet of nauwelijks in staat om hun rechten zelfstandig uit te oefenen. Cliēnten hebben juist baat bij ondersteuning teneinde zich verder te kunnen ontplooien. Hulpverleners zouden meer ruimte moeten krijgen om vrijheidsbeperking toe te passen dan onder het huidige juridische kader mogelijk is. Daar moet wel een juiste rechtsbescherming tegenover staan, om te voorkomen dat hulpverleners te gemakkelijk ingrijpen in de vrijheid van cliënten. Het gevaar is altijd aanwezig dat goede zorg ontaardt in oververzorging en betutteling. Kelk verstaat onder oververzorging 'een overmatige, overdreven zorgverlening die neerkomt op verstikking van de initiatieven van cliënten, betutteling, bevoogding en zelfs kleinering. Hulpverleners verliezen op zo'n moment het belang van de cliènt uit het $o \circ .^{\prime m}$ Om oververzorging te voorkomen, is het van belang dat hulpverleners het zelfbeschikkingsrecht van cliënten erkennen. Respect voor de rechten van cliënten is een middel om te voorkomen dat cliënten ondergeschikt raken aan macht en overheersing van hulpverleners.

\section{Het recht op bijzondere zorg of meer zorg?}

In de context van het recht op zorg wordt ook over het recht op bijzondere zorg gesproken. ${ }^{100}$ Mensen met een verstandelijke handicap hebben in beginsel dezelfde rechten als andere burgers in de samenleving. In de praktijk betekent dit nog niet dat mensen met een verstandelijke handicap ook voldoende zorg ontvangen. In de gezondheidszorg wordt met name veel ruimte geboden aan cure. Voortdurend worden nieuwe medicijnen en behandelingsmethoden ontwikkeld. Deze ontwikkelingen komen maar in beperkte mate ten goede aan de verstandelijk gehandicaptenzorg. In beginsel is het recht op gezondheidszorg een sociaal grondrecht hetgeen betekent dat cliënten niet oneindig een beroep kunnen doen op dit recht. Het moet echter mogelijk zijn om voor bepaalde groepen in de samenleving een uitzondering te maken. Vanuit deze gedachte kent Leenen de overheid, op het gebied van de verstandelijk gehandicaptenzorg, een extra ver-

\footnotetext{
98 Widdershoven en Berghmans 2000, p. 55-57.

99 Kelk 1985, p. 29.
}

100 J.C.M. Willems, "Opvoedingsondersteuning moet vroeger, massaler en massiever", in: Recht op zorg van het gehandicapte kind, Utrecht: William Schrikker Stichting 2003, p. 9-14. 
antwoordelijkheid toe. De overheid dient ervoor te zorgen dat mensen met een verstandelijke handicap voldoende aanspraak kunnen maken op voorzieningen, zodanig dat zij hun achterstand kunnen inlopen dan wel kunnen compenseren. In dit kader is het rechtvaardig dat mensen met een verstandelijke handicap meer zorg toebedeeld krijgen. Leenen verwijst hiervoor naar het begrip sociale rechtvaardigheid:

'Sociale rechtoaardigheid bestaat niet uit het lenigen van iedere individuele nood, maar uit het op een zo eerlijk mogelijke wijze lenigen van alle noden. Evenals chronische zieken, verpleeghuispatiënten en psychisch gestoorde bejaarden, zullen mensen met een verstandelijke handicap als groep bij de verdeling van de voor de gezondheidszorg beschikbare middelen meer moeten worden erkend.' 101

Naast sociale rechtvaardigheid benadrukt Leenen ook het compensatiebeginsel. Dit beginsel is een nadere concretisering van het gelijkheidsbeginsel en heeft tot doel om de aanwezige ongelijkheid tussen burgers te verminderen. Mensen met een verstandelijke handicap zijn over het algemeen minder in staat om hun zelfbeschikkingsrecht uit te oefenen. Zij zullen daardoor ook moeilijker een beroep kunnen doen op het recht op zorg. Het compensatiebeginsel gaat van de gedachte uit dat bji de verdeling van gezondheidszongousnzzianinger eer groztraandeel moet gaan naar degene die de meeste ondersteuning nodig hebben. Dit betekent dat ongelijkheid bij de verdeling van de gezondheidszorgvoorzieningen wordt gebruikt om ongelijkheid in gezondheid te verminderen. Op deze manier draagt het recht op zorg ook bij aan de verwezenlijking van het recht op zelfbeschikking. ${ }^{102}$ De Commissie Keuzen in de Zorg komt in de jaren negentig van de vorige eeuw tot dezelfde conclusie. In het rapport kiezen en delen geeft zij aan welke voorzieningen noodzakelijk zijn in de gezondheidszorg. Voorzieningen zijn noodzakelijk als zij zorg garanderen voor leden van de samenleving die niet voor zichzelf kunnen zorgen. Door middel van zorg wordt deelneming aan de samenleving weer mogelijk. ${ }^{103}$ Het burgerschapsmodel gaat van vrijwel dezelfde gedachtegang uit. Zorg wordt in dit model vervangen door ondersteuning. Mensen met een verstandelijke handicap zijn burgers met dezelfde rechten en plichten als ieder ander. Dit betekent echter nog niet dat mensen met een ver-

101 H.J.J. Leenen, "De verstandelijk gehandicapte in het gezondheidsrecht", in: W.A.L. van Leeuwen (red.), Vademecum Zorg voor Verstandelijk Gehandicapten, Houten/Diegem: Bohn Stafleu Van Loghump. 1993, p. 1800-11.

102 H.J.J. Leenen, "Gelijkheid en ongelijkheid in de gezondheidszorg", Tijdschrift voor Gezondheidsrecht (8) 1984-2, p. 53-68.

103 Commissie Keuzen in de zorg, Kiezen en Delen: een rapport van de commissie Keuzen in de zorg, Den Haag: Albani 1991. 
standelijke handicap ook daadwerkelijk in staat zijn om zelfstandig deel te nemen aan de maatschappij. De intensiteit van ondersteuning zal per cliënt moeten verschillen.

Op grond van artikel $22 \mathrm{Gw}$ is de overheid verantwoordelijk voor het recht op zorg. Artikel $22 \mathrm{Gw}$ richt zich niet specifiek op bijzondere zorg voor bepaalde groepen in de samenleving. Het Verdrag inzake de rechten van het kind (VRK) besteedt speciale aandacht aan mensen met een verstandelijke handicap. Het VRK bevat, naast het recht op gezondheidszorg, tevens een artikel waarin wordt benadrukt dat gehandicapte kinderen recht hebben op bijzondere zorg. Gehandicapte kinderen hebben op grond van het VRK recht op gezondheidszorg en voorzieningen die voor de behandeling van ziekte en het herstel van de gezondheid noodzakelijk zijn. Daarnaast kunnen zij, op grond van artikel 23 van het verdrag, ook aanspraak maken op bijzondere zorg. Het doel van bijzondere zorg is dat 'het kind een zo volledig mogelijke integratie in de maatschappij en persoonlijke ontwikkeling bereikt, met inbegrip van zijn of haar culturele en intellectuele ontwikkeling' (artikel 23 lid 3 VRK).

Hoewel de inhoud van het VRK specifiek van toepassing is op kinderen, verdient het aanbeveling om de strekking van artikel 23 ook van toepassing te verklaren op volwassen (verstandelijk) gehandicapten. Niet alleen kinderen met een verstandelijke handicap, maar ook volwassen mensen met een verstandelijke handicap dienen recht te hebben op bijzondere zorg of, om te spreken in termen van deze studie, extra ondersteuning waar nodig is. Het bereiken van de leeftijdsgrens van 18 jaar betekent geenszins dat mensen met een verstandelijke handicap geen behoefte meer hebben aan zorg.

Door het VRK ook van toepassing te verklaren op volwassen cliënten met een verstandelijke handicap mag overigens niet de indruk worden gewekt dat mensen met een verstandelijke handicap in deze studie worden gelijkgesteld met kinderen. Dit neemt niet weg dat er ook goede redenen bestaan om toch een parallel te trekken met kinderen. Uit tabel 1 van hoofdstuk 1 kan worden afgeleid dat, hoewel cliënten een volwassen leeftijd hebben bereikt, hun verstandelijke vermogen veelal niet boven de leeftijd van 12 jaar uitkomt. Ook de inhoud van een ander artikel ondersteunt de gedachte om een vergelijking te maken tussen kinderen en cliënten met een verstandelijke handicap. In artikel 5 VRK is bepaald dat kinderen recht hebben op 'passende leiding en begeleiding op een wijze die verenigbaar is met de zich ontwikkelende vermogens van het kind'. De strekking van dit artikel sluit aan bij de uitgangspunten in de verstandelijk gehandicaptenzorg: een cliënt met een verstandelijke handicap dient recht te hebben op een vorm van ondersteuning die aansluit bij zijn mogelijkheden.

Willems is van mening dat de rechten van het kind in internationale wetgeving, waaronder het Verdrag inzake de rechten van het kind, goed zijn vastgelegd. Daarentegen is de inhoud van het verdrag, waarin een aantal essentiële rechten zijn vastgelegd, nog niet opgenomen in de Nederlandse Grondwet. Hij heeft 
voorgesteld om artikel $22 \mathrm{Gw}$ uit te breiden met een extra lid, waarvan de inhoud betrekking zou hebben op extra zorg voor kinderen. Deze zorg, bestaande uit leiding en begeleiding en gemeenschapszorg, is noodzakelijk om de ontwikkeling van kinderen te kunnen garanderen. ${ }^{104}$ Het voorstel van Willems kan een bredere betekenis krijgen door niet alleen te spreken over kinderen, maar over gehandicapten in het algemeen.

In het Verdrag inzake de rechten van het kind wordt gesproken over bijzondere zorg. Dit begrip hoeft naar mijn mening niet in de Grondwet te worden opgenomen. Het is niet relevant of mensen met een verstandelijke handicap bijzondere zorg krijgen, maar of ze ook daadwerkelijk meer zorg kunnen krijgen. In het kader van het burgerschapsparadigma is het uitgangspunt dat alle burgers gelijkwaardig zijn aan elkaar. Voorkomen moet worden dat in categorieën wordt gedacht. Elke burger heeft recht op (goede) zorg. De mate waarin gebruik wordt gemaakt van dit recht zal per individu verschillen. Mensen met een verstandelijke handicap kunnen pas als gelijkwaardige en volwaardige burgers worden beschouwd als zij voldoende aanspraak kunnen maken op zorg (ondersteuning).

\subsubsection{Ontplooiing}

Het recht op ontplooiing is het vierde rechtsbeginsel dat in deze studie centraal staat. Het recht op ontplooiing, dat tot nu toe in de gezondheidszorg onderbelicht is gebleven, kan worden beschouwd als een 'integraal beginsel'. Hierin zijn elementen van de andere drie rechtsbeginselen die in deze studie centraal staan, terug te vinden. Deze rechtsbeginselen komen beter tot hun recht als rekening wordt gehouden met de uitgangspunten van het recht op ontplooiing. Gezamenlijk kan op deze manier een optimale bijdrage worden geleverd aan de rechtspositie van mensen met een verstandelijke handicap. Het recht op ontplooiing gaat ervan uit dat mensen met een verstandelijke handicap, ondanks hun handicap, de mogelijkheid wordt geboden om zich (verder) te ontwikkelen. In de jeugdzorg wordt al langer de nadruk op dit rechtsbeginsel gelegd. In het verleden werden jeugdigen voornamelijk gezien als object van zorg, waarbij behandeling en bescherming centraal stonden. In de vorige eeuw is het besef doorgedrongen dat bescherming plaats dient te maken voor het creëren van ontwikkelingsmogelijkheden. De Langen beschouwt het recht op ontplooiing als de grondslag voor de jeugdzorg. Iedere jeugdige heeft recht op zo optimaal mo-

104 Willems 2003, p. 9-14. 
gelijke ontplooiingskansen. Uit deze grondslag vloeien een aantal grondrechten voort, aldus De Langen. 105106

Ook Willems beschouwt het recht op ontplooing als een belangrijk recht(sbeginsel) in de jeugdzorg. ${ }^{100} \mathrm{Hij}$ spreekt in dat kader over het recht op persoonswording. Dit recht wordt ook wel een 'paraplurecht' genoemd, oftewel een beginsel dat verwijst naar een bundel van rechten, waaronder het recht op ontplooiing, het recht op begeleiding en het recht op opvoedingsondersteuning, welke aan het kind toekomen dan wel dienen toe te komen. Om het recht op persoonswording veilig te kunnen stellen, maakt Willems gebruik van een driedeling van rechten. Hij noemt allereerst beschermingsrechten, die van belang zijn voor het recht op minimale persoonswording. Beschermingsrechten vormen de smalste basis waarop ontplooiing tot volwaardig lid van de samenleving mogelijk is. Daarnaast zijn welzijnsrechten, ook wel genoemd het recht op optimale persoonswording, van belang voor de ontplooiing van kinderen. Beide vormen van rechten, beschermingsrechten en welzijnsrechten, kunnen niet los worden gezien van zelfbepalingsrechten, waarbij het kind als subject van rechten wordt beschouwd.

Niet alleen in de jeugdzorg wordt het accent gelegd op ontplooing. Een vergelijkbare ontwikkeling is gaande in de verstandelijk gehandicaptenzorg. Van Gennep wijst erop dat deze sector zich niet meer alleen moet richten op tekorten van cliënten. Een cliënt moet de mogelijkheid krijgen om ervaringen op te doen in gewone situaties. Zorg heeft plaatsgemaakt voor ondersteuning. Naast overeenkomsten zijn er echter ook verschillen tussen de jeugdzorg en de verstandelijk gehandicaptenzorg. Willems legt de nadruk op de persoonswording van kinderen. Door middel van beschermingsrechten en welzijnsrechten is het uiteindelijke doel in de jeugdzorg dat kinderen, naarmate ze ouder worden, steeds meer een beroep kunnen gaan doen op hun zelfbepalingsrechten. Hoewel goede zorg ook een bijdrage levert aan het vergroten van de mogelijkheden van cliënten met een verstandelijke handicap, is het zelfbeschikkingsrecht in deze sector niet het uiteindelijke doel ervan. In deze studie staat de gedachte centraal dat de rechtspositie van mensen met een verstandelijke handicap niet voldoende ge-

105 M. de Langen, Recht voor jeugdigen: een onderzoek naar rechten en rechtsbeginselen in het jeugdrecht (diss. Utrecht), Alphen aan den Rijn: Samsom Uitgeverij 1973, p. 16.

106 Overigens wordt in artikel 22 lid $3 \mathrm{Gw}$ gesproken over 'ontplooiing': de overheid dient voorwaarden te scheppen voor maatschappelijke en culturele ontplooiing en vrijetijdsbesteding.

107 Willems, J.C.M., Wie zal de opvoeders opvoeden? Kindermishandeling en het recht van kinderen op persoonswording (diss. Maastricht), Den Haag: T.M.C. Asser Press 1999. 
waarborgd wordt als zelfbeschikking en bescherming als (enige) uitgangspunten worden beschouwd. Cliënten bereiken zelden, in tegenstelling tot kinderen, een moment waarop ze zelfstandig invulling kunnen gaan geven aan hun leven. Vanuit deze optiek zijn het 'blijvend kinderen'. Deze visie zit verwerkt in het recht op ontplooiing. Dit recht is niet een middel tot zelfbeschikking, maar eerder een uitgangspunt dat altijd centraal dient te staan in deze sector. Het gaat om cliënten die zich gedurende hun hele leven zullen blijven ontwikkelen.

Van Dale verstaat onder zelfontplooiing 'het verder ontwikkelen, bevorderen van de eigen geestelijke groei', In welke mate cliënten werkelijk een geestelijke groei kunnen doormaken, zal onder meer afhankelijk zijn van organische afwijkingen en de intensiteit van ondersteuning. Het begrip geestelijke groei heeft in de verstandelijk gehandicaptenzorg een andere betekenis dan gebruikelijk is. Mensen met een verstandelijke handicap zullen, ondanks het doormaken van een bepaalde ontwikkeling, niet minder verstandelijk gehandicapt worden. Het is dan ook beter om te spreken van persoonlijke groei. Mensen met een verstandelijke handicap zijn wel in staat om, ondanks hun handicap, bepaalde vaardigheden en attitudes te leren en kennis op te doen waardoor ze beter kunnen functioneren in de maatschappij. Het recht op ontplooiing lijkt enigszins op het recht op opvoeding. Onder opvoeding wordt verstaan dat een kind wordt voorbereid op een zelfstandig bestaan in de samenleving. Van een kind wordt verwacht dat hij vanaf zijn achttiende levensjaar volwassen is en in staat is om zijn eigen keuzes te maken. Ook mensen met een verstandelijke handicap die de leeftijd van achttien jaar bereiken zijn volgens de wet volwassen. Het bereiken van de leeftijdsgrens van 18 jaar betekent echter niet dat zij ook geestelijk volwassen zijn. Veel cliënten zullen ook na hun $18^{e}$ zijn aangewezen op ondersteuning.

Het gegeven dat een cliënt gebruik maakt van ondersteuning mag hem niet belemmeren in zijn ontwikkeling, integendeel. De kern van het recht op ontplooiing is dat een hulpverlener zorgvuldig afweegt op welke wijze hij een optimale bijdrage kan leveren aan de verdere ontwikkeling (ontplooiing) van een cliënt. In dat kader kan ondersteuning verschillende vormen aannemen. Op bepaalde momenten kan het noodzakelijk zijn dat een cliënt wordt beschermd. Niet elke vorm van bescherming is per definitie verkeerd. Het recht op zorg, het recht op bescherming en het zelfbeschikkingsrecht zijn uiteindelijk gezamenlijk gericht op de ontplooiing van cliënten. Dit betekent ook dat ontplooiing van een cliënt niet wordt belemmerd door het bieden van bescherming. Juist op het moment dat een cliënt niet in staat is om zijn eigen belangen te waarborgen, dient het recht adequate voorzieningen te treffen teneinde een cliënt zo goed mogelijk te laten functioneren in de maatschappij. Laurs gaat nog verder door te beweren dat 'de zelfontplooiing van mensen ernstig wordt geschaad als hun belangen onbe- 
schermd blijven. ${ }^{106}$ Zonder adequate bescherming is de kans groot dat de belangen van wilsonbekwame patiënten worden geschaad. Overigens is het wel van belang dat, ondanks bescherming, de zelfbeschikking van de cliënt zoveel mogelijk blijft behouden. Het recht op zelfbeschikking betekent in beginsel dat een hulpverlener de keuzes van een cliënt zoveel mogelijk moet respecteren en dat hij terughoudend moet zijn met het opleggen van vrijheidsbeperking. In de verstandelijk gehandicaptenzorg wordt een hulpverlener regelmatig geconfronteerd met cliënten die niet of minder in staat zijn tot het maken van keuzes. Op zo'n moment mag een hulpverlener zich minder terughoudend opstellen en wordt van hem verwacht dat hij zijn uiterste best doet om het zelfbeschikkingsrecht van deze cliënten zoveel mogelijk te bevorderen. Uiteraard moet worden voorkomen dat hulpverleners hun visie te gemakkelijk opleggen aan de cliënt, waardoor de mening van de cliënt naar de achtergrond verdwijnt. Een hulpverlener dient te allen tijde de rechten van een cliënt te respecteren. Reeds eerder is het exceptiebeginsel aan de orde gesteld. Het uitgangspunt van dit beginsel is dat het zelfbeschikkingsrecht alleen beperkt mag worden als tegelijkertijd in de beperking herstel van zelfbeschikking tot uitdrukking komt, aldus Leenen. ${ }^{109}$ Het recht op ontplooiing is onder meer uitgewerkt in de Verklaring van de Rechten van Mensen met een verstandelijke handicap. Het begrip ontplooiing wordt in de toelichting van het recht op goede begeleiding genoemd.

Mensen met een verstandelijke handicap moeten in staat gesteld worden om hun vaardigheden te ontwikkelen en hun potentiële mogelijkheden tot ontplooiing te brengen. Daarom hebben zij recht op onderwijs en begeleiding. Net als mensen zonder handicap hebben zij recht op medische zorg. ${ }^{110}$

Ook in de preambule van de Verklaring over de Rechten van de Gehandicapte Mens wordt gerefereerd aan het begrip ontplooiing:

'(...) De gehandicapte mens dient bij te worden gestaan in de ontplooiing van zijn mogelijkheden op de meest verschillende gebieden en om zijn integratie in het normale leven zoveel mogelijk te bevorderen.'

108 Laurs 1988, p. 131.

109 Leenen 2000 , p. 37.

110 Verklaring van de Rechten van Mensen met een verstandelijke handicap, GA Res. 2856 (XXVI) of 20 December 1971, UN Doc. A/8429 (1971).

111 Verklaring over de Rechten van de Gehandicapte Mens, GA Res. 3447 (XXX) of 9 December 1975, UN Doc. A/10034 (1975). 
De inhoud van de Verklaringen van de Verenigde Naties zijn slechts richtinggevend voor de rechtspositie van cliënten in Nederland. Beiden hebben geen verbindende werking. Dat geldt ook voor het Handvest van de grondrechten van de Europese Unie, waarin wordt gesproken over het bevorderen van de zelfstandigheid van personen met een handicap: ${ }^{112}$

'De Unie erkent en eerbiedigt het recht van personen met een handicap op maatregelen die beogen hun zelfstandigheid, hun maatschappelijke en beroepsintegratie en hun deelname aan het gemeenschapsleven te bewerkstelligen.' "13

Cliënten kunnen meer rechten ontlenen aan het Verdrag inzake de rechten van het kind (VRK) en het Evrm. Beide verdragen hebben directe werking. In Nederland bepaalt de rechter of een verdragsbepaling, die naar haar inhoud een ieder kan verbinden, rechtstreekse werking heeft. ${ }^{1 \mu}$ Dit geldt onder meer voor artikel 8 Evrm waarin is vastgelegd dat elke burger recht heeft op een gezinsleven. Daarnaast kunnen bepalingen uit het VRK, waaronder artikel 23, worden ingelezen in artikel 3 en 8 van het Evrm zolang als jurisprudentie over de directe werking van deze bepalingen ontbreekt."11

In het VRK en het Evrm wordt slechts op indirecte wijze verwezen naar het recht op ontplooiing. Eén van de basisprincipes van het Verdrag inzake de rechten van het kind (VRK) is dat kinderen recht op ontwikkeling hebben. De overheid moet zich inspannen om de ontwikkeling van kinderen te stimuleren. Dit basisprincipe is in artikel 23 lid 1 van het Verdrag nader uitgewerkt:

'De staten die partij zijn, erkennen dat een geestelijk of lichamelijk gehandicapt kind een volwaardig en behoorlijk leven dient te hebben, in omstandigheden die de waardigheid van het kind verzekeren, zijn zelfstandigheid bevorderen en zijn actieve deelneming aan het gemeenschapsleven vergemakkelijken. ${ }^{716}$

112 Overigens is het Handvest in december 2000 wel goedgekeurd door de Raad van Ministers. Het is met name een moreel document, waar het Europees Hof naar kan verwijzen.

113 Handvest van de Grondrechten van de Europese Unie (2000), Europese Unie, artikel 26.

114 In artikel $93 \mathrm{Gw}$ is bepaald dat bepalingen van verdragen (Evrm) die naar haar inhoud een ieder kunnen verbinden (dus rechtstreekse werking hebben), verbindende kracht hebben nadat ze zijn bekendgemaakt. Of een bepaling ook daadwerkelijk rechtstreeks werkend is, wordt aan de rechter overgelaten.

115 Willems 1999, p. 157.

116 Verdrag inzake de rechten van het kind (1989), Trb. 1990, 170, artikel 23 lid 1. 
Artikel 8 Evrm vertoont enige verwantschap met het recht op ontplooiing. Op grond van dit artikel heeft een ieder recht op respect voor zijn privé-, familie- en gezinsleven. Legemaate wijst er terecht op dat dit artikel bepalend is voor de ontplooiingsmogelijkheden van individuen. Artikel $8 \mathrm{Evrm}$ mag alleen worden beperkt als voldaan is aan één van de beperkingsgronden, waaronder de bescherming van de gezondheid of bescherming van de rechten en vrijheden van anderen. ${ }^{17}$

Artikel $10 \mathrm{Gw}$ en $11 \mathrm{Gw}$ kunnen worden beschouwd als een nadere uitwerking van artikel 8 Evrm. Daarnaast wordt in artikel 22 lid $3 \mathrm{Gw}$ speciale aandacht besteed aan het bevorderen van de ontplooiing(smogelijkheden) van individuen. In dit artikel wordt gesproken over maatschappelijke en culturele ontplooiing en vrijetijdsbesteding. Dit is een globale beschrijving die met name is gericht op de ontplooiing van mensen in de zin van deelname aan culturele evenementen en de mogelijkheid om een hobby te beoefenen. De ontplooiing van mensen met een verstandelijke handicap gaat echter veel verder. Het gaat om deelname aan het gemeenschapsleven. Ook mensen met een verstandelijke handicap verlangen naar een (betaalde) baan, naar een salaris, naar een woning in de wijk teneinde als volwaardig burger deel te kunnen nemen aan de samenleving. In Europese en internationale wetgeving zijn aanknopingspunten te vinden die meer richting geven aan het basisbeginsel van ontplooiing. Goede voorbeelden zijn artikel 23 van het VRK en artikel 26 van het Handvest van de Grondrechten van de Europese Unie. Een soortgelijke bepaling dient in de Nederlandse Grondwet te worden opgenomen, teneinde - dringender dan nu het geval is - te benadrukken en te waarborgen dat mensen met een verstandelijke handicap de kans moeten krijgen om zich op alle gebieden te ontplooien in de samenleving.

\subsection{Beschouwing}

In dit hoofdstuk is het normatief kader uiteengezet voor de rechtspositie van mensen met een verstandelijke handicap. Verschillende aspecten zijn aan de orde gekomen: de plaats van het recht, juridisering en rechtsbeginselen. Het recht op ontplooiing neemt een centrale plaats in. Dit rechtsbeginsel is niet alleen bepalend voor de invulling van de overige rechtsbeginselen en basisrechten, maar geeft ook richting aan de betekenis van het recht en de visie inzake juridisering in de verstandelijk gehandicaptenzorg.

Aan het einde van de vorige eeuw is een aantal wetten tot stand gekomen, die ook van betekenis is voor de sector verstandelijk gehandicaptenzorg. Hulpverleners zullen, mede op grond van deze wetgeving, zorgvuldiger moeten omgaan

117 L. Legemaate, "Evrm", in: Sluijters, B. e.d. (red.), Gezondheidsrecht: tekst en commentaar, Deventer: Kluwer 1999. 
met de rechten van mensen met een verstandelijke handicap. Daar komt bij dat mensen met een verstandelijke handicap, in tegenstelling tot patiënten in de somatiek en de psychiatrie, niet snel een beroep zullen doen op hun rechten. Als een cliënt niet of nauwelijks in staat is om zijn rechten te claimen en ook niet zijn beklag doet over een beperking van zijn rechten, moet een hulpverlener hem tegemoetkomen. Hij moet kunnen rechtvaardigen waarom hij op een bepaald moment ervoor kiest om de rechten van een cliënt te beperken. De beperking moet inzichtelijk zijn, worden medegedeeld aan de cliënt en/of zijn vertegenwoordiger en moet worden vastgelegd in het zorgplan. Dit alles betekent dat een bepaalde vorm van juridisering in de verstandelijk gehandicaptenzorg onvermijdelijk en noodzakelijk is. Het is een gegeven dat mensen met een verstandelijke handicap afhankelijk zijn van hulpverleners. Deze afhankelijkheid wordt ook wel omschreven in termen van macht. Tussen een cliënt en een hulpverlener bestaat een ongelijke verhouding, aangezien een cliënt altijd afhankelijk zal zijn van de (kennis van de) hulpverlener. Naast afhankelijkheid zijn er nog andere factoren die juridisering noodzakelijk maken. Cliënten krijgen gedurende hun verblijf regelmatig te maken met toepassingen van vrijheidsbeperkende maatregelen. Deze beperkingen kunnen uit het oogpunt van een onveilige situatie voor de cliënt zelf of vanwege gevaar voor anderen noodzakelijk zijn, maar kunnen ook verband houden met de aanwezigheid van andere cliënten of organisatorische factoren. Zonder het recht, zouden cliënten overgeleverd zijn aan de goedbedoelde intenties van hulpverleners. In het verleden is gebleken dat de zorg niet geheel vrij is van misstanden en schendingen van rechten. Het recht dient op zulke momenten cliënten te beschermen. Ethici zijn van mening dat het rechtendiscours zich niet teveel moet bemoeien met de verstandelijk gehandicaptenzorg. Juridisering zou in hun ogen de huidige zorg transformeren in een vorm van zorg waar andere normen de boventoon gaan voeren. Bovendien zou er geen ruimte meer zijn voor het morele karakter van de hulpverlening. Volgens ethici verlangt het recht van hulpverleners dat zij een andere houding innemen, waardoor het verlenen van zorg en ondersteuning naar de achtergrond wordt verschoven. De kritiek van ethici is niet terecht. Het recht geeft grenzen aan en verlangt van hulpverleners zich transparant op te stellen. Op deze manier wordt voorkomen dat rechten van cliënten onnodig en onterecht worden beperkt. Een andere houding van hulpverleners kan, in tegenstelling tot wat ethici beweren, juist leiden tot een verbetering van de rechtspositie van verstandelijk gehandicapten. Om te voorkomen dat alsnog sprake is van negatieve effecten van juridisering, moet het recht aansluiting zoeken bij de specifieke kenmerken van de verstandelijk gehandicaptenzorg. Daarnaast moet echter ook de aandacht verschuiven naar het recht op ontplooiing.

In het gezondheidsrecht nemen het recht op zelfbeschikking en het recht op bescherming een centrale plaats in. Regelmatig leidt de toepassing van deze beginselen tot dilemma's in de verstandelijk gehandicaptenzorg. Het komt de rechts- 
positie van cliënten niet ten goede als teveel nadruk wordt gelegd op bescherming of op zelfbeschikking. Het is van groot belang dat in deze sector beide beginselen in een juiste verhouding worden toegepast, teneinde de mogelijkheden van mensen met een verstandelijke handicap optimaal tot ontplooiing te laten komen. Het rechtsbeginsel goede zorg dient in functie te staan van beide beginselen, bescherming en zelfbeschikking. Dit rechtsbeginsel veronderstelt betrokkenheid van de hulpverlener, ondersteuning en bescherming waar nodig. In de lijn van het burgerschapsparadigma dient elke cliënt de mogelijkheid te krijgen om deel te nemen aan de samenleving. Om dit te kunnen bereiken is het van belang dat cliënten aanspraak kunnen maken op extra ondersteuning. Juist deze ondersteuning vormt de sleutel tot het burgerschap. Het vierde rechtsbeginsel dat in deze studie centraal staat is het recht op ontplooiing. Dit rechtsbeginsel vormt de concretisering van de drie eerder genoemde rechtsbeginselen. Elke vorm van goede zorg, waar vrijheidsbeperking ook deel van kan uitmaken, dient bij te dragen aan de ontplooiing van cliënten. Dit uitgangspunt geldt ook als gevaar voor anderen de aanleiding vormt om de vrijheid van een cliènt te beperken. Deze kan zoveel mogelijk tot uitdrukking worden gebracht bij de uitvoering van de vrijheidsbeperkende maatregel (het voorkomen van langdurige toepassingen van vrijheidsbeperking, gedurende de toepassing ervan in contact blijven met de cliënt en voortdurend op zoek gaan naar alternatieven).

In de volgende hoofdstukken zal de lijn, die in dit hoofdstuk is neergezet, worden doorgetrokken. In de uitwerking van het thema vrijheidsbeperking zal het recht op ontplooiing als toetssteen fungeren. Worden cliënten in hun vrijheid beperkt teneinde hun mogelijkheden zoveel als mogelijk is te kunnen ontplooien? Daarnaast kan uit het empirische onderzoek blijken of onder hulpverleners sprake is van een toegenomen bewustwording van rechten. De voorbeelden uit de praktijk laten ook zien of de angst van ethici - juridisering in de verstandelijk gehandicaptenzorg gaat ten koste van de zorgverlening aan de cliënt terecht is. Uiteraard kleven er ook nadelen aan juridisering. Als juridisering te grote vormen aanneemt, bestaat het gevaar dat de gehele sector wordt gekoloniseerd door het recht. Daarnaast zal juridisering de zorg gaan tegenwerken zodra sprake is van wetgeving die niet aansluit bij de kenmerken van de sector. Het recht heeft echter niet de intentie om de zorg in de weg te lopen. De juiste balans dient te worden gevonden: niet teveel aandacht voor het recht, maar ook niet te weinig. Het blijft immers gaan om een kwetsbare groep mensen waarbij wel van belang is dat hun mogelijkheden zoveel mogelijk tot ontplooiing worden gebracht.

Door de nadruk te leggen op het recht op ontplooiing en het recht op goede zorg wordt uitgegaan van een breder normatief kader. Beide beginselen trachten de tekortkomingen van het huidige juridisch kader in de verstandelijk gehandicaptenzorg op te heffen. Tegelijkertijd betekent de introductie van beide beginselen niet, dat alle dilemma's in de zorg voor mensen met een verstandelijke 
Hoofdstuk 3

handicap verdwijnen. Het recht alleen is niet toereikend om hulpverleners bewust te maken van de rechten van mensen met een verstandelijke handicap. Ook in de professionele standaard van hulpverleners dient de rechtspositie van cliënten en de consequenties die deze heeft voor het handelen van hulpverleners een centrale plaats in te nemen. 


\section{Goed hulpverlenerschap}

\subsection{Inleiding}

In de zorg voor mensen met een verstandelijke handicap vervullen als regel een persoonlijk begeleider, ${ }^{1}$ een arts $^{2}$ en een gedragsdeskundige een belangrijke rol: zij verlenen de meest directe zorg aan cliënten. De toepassing van vrijheidsbeperkende maatregelen maakt ook onderdeel uit van deze zorg (ondersteuning). De verschillende beroepsgroepen zijn bij het toepassen van vrijheidsbeperking gebonden aan de norm van goed hulpverlenerschap. Deze open norm is vastgelegd in de Wgbo (artikel 7:453 BW). De wetgever heeft bewust gekozen voor een open normering. De bedoeling is dat het veld zelf invulling en inhoud geeft aan goed hulpverlenerschap. Het uitgangspunt van goed hulpverlenerschap is dat elke hulpverlener een eigen verantwoordelijkheid heeft ten aanzien van zijn handelen. Deze verantwoordelijkheid is nader uitgewerkt in de professionele standaard waaronder wordt verstaan 'het geheel van regels en normen waarmee een hulpverlener bij het uitoefenen van zijn werkzaamheden rekening behoort te houden'. ${ }^{3}$ Elke hulpverlener heeft een eigen professionele standaard, die mede nader wordt vormgegeven door de beroepsgroep waartoe hii behoort. De professionele standaard van een AVG heeft doorgaans een medische insteek. Dit kan niet worden gezegd van de professionele standaard van een persoonlijk begeleider. Binnen deze beroepsgroep ligt het accent meer op het verrichten van niet-medische handelingen. Een persoonlijk begeleider wordt voortdurend geconfronteerd met een grote variëteit aan niet-medische handelingen, waarbij de nadruk ligt op het ondersteunen van cliënten met een verstandelijke handicap. Een terugkerend dilemma is de reikwijdte van de verantwoordelijkheid van een persoonlijk begeleider. Waar ligt de grens tussen enerzijds beschermen en anderzijds vrij laten? De professionele standaard van een persoonlijk begeleider biedt de ruimte om dit dilemma uit te werken.

Recente ontwikkelingen, waaronder de aandacht voor het burgerschapsmodel en de inwerkingtreding van diverse patiëntenwetten, zijn van invloed op de inhoud van de professionele standaard van hulpverleners. In het normatief kader (hoofdstuk 3) wordt benadrukt dat het bieden van goede zorg, gericht op het tot

1 Zie voor een omschrijving van de taken en de achtergrond van een persoonlijk begeleider paragraaf 1.7 .

2 Dit kan een arts voor verstandelijk gehandicapten (AVG) zijn of een huisarts.

3 J. Legemaate, "De zorg van een goed hulpverlener, in relatie tot de professionele standaard", in: J. Legemaate (red.), De Wgbo: van tekst naar toepassing, Houten/Diegem: Bohn Stafleu Van Loghum 1998, derde druk, p. 12. 
ontplooiing brengen van de mogelijkheden van een cliënt, het centrale uitgangspunt dient te zijn. Hulpverleners dienen evenwel over bepaalde kwaliteiten te beschikken om deze zorg ook daadwerkelijk te kunnen bieden aan cliënten. Deze kwaliteiten zullen in het kader van goed hulpverlenerschap nader moeten worden uitgewerkt voor de verschillende beroepsgroepen. Goede zorg vereist niet dat hulpverieners zich, uit respect voor het zelfbeschikkingsrecht van cliënten, terughoudend opstellen. Van hulpverleners wordt verwacht dat zij een actieve houding innemen om de mogelijkheden van cliënten te benutten en waar mogelijk ook te vergroten. Dit principe geldt ook als vrijheidsbeperking aan de orde is: vrijheidsbeperking dient de ontplooiing van cliënten niet in de weg te staan.

Centraal in dit hoofdstuk staat goed hulpverlenerschap vanuit het perspectief van een persoonlijk begeleider, aangezien hij verantwoordelijk is voor de dagelijkse ondersteuning van cliènten. Bovendien is hij het eerste aanspreekpunt voor een cliënt en zijn vertegenwoordiger als er vragen of problemen zijn over de geboden ondersteuning. Allereerst wordt in paragraaf 4.2 de juridische betekenis van goed hulpverlenerschap uiteengezet. In paragraaf 4.3 wordt goed hulpverlenerschap in de context van de verstandelijk gehandicaptenzorg beschreven. Vervolgens komt in paragraaf 4.4 tot 4.6 een drietal aspecten aan bod, op grond waarvan de professionele standaard nader kan worden ingevuld: verantwoordelijkheden van de persoonlijk begeleider (paragraaf 4.4), kwaliteitsnormen en kwaliteitsbeleid in de sector verstandelijk gehandicaptenzorg (paragraaf 4.5) en richtlijnen in de zorg voor mensen met een verstandelijke handicap (paragraaf 4.6). Het hoofdstuk wordt afgesloten met een beschouwing (paragraaf 4.7).

\subsection{De juridische betekenis van goed hulpverlenerschap}

In de Wgbo is geregeld dat 'de hulpverlener bij zijn werkzaamheden de zorg van een goed hulpverlener in acht moet nemen en daarbij moet handelen in overeenstemming met de op hem rustende verantwoordelijkheid, voortvloeiende uit de voor hulpverleners geldende professionele standaard' (artikel 7:453 BW). De strekking van deze bepaling is 'dat de hulpverlener die zorg moet betrachten, die een redelijk bekwame vakgenoot in dezelfde omstandigheden zou hebben betracht', aldus een passage uit de Memorie van Toelichting (MvT). In artikel 7:453 BW worden twee belangrijke begrippen geïntroduceerd: goed hulpverlener ${ }^{5}$ en professionele standaard.

5 In de praktijk wordt meestal gesproken over 'goed hulpverlenerschap'. 
De wetgever hanteert een brede definitie van goed hulpverlenerschap. In de MvT wordt opgemerkt dat het goed hulpverlenerschap ruim geinterpreteerd moet worden; alle normen met betrekking tot behoorlijke hulpverlening vallen er (...) onder.' De invulling ervan wordt overgelaten aan de praktijk en de rechtspraak. Goed hulpverlenerschap heeft een 'dubbele' betekenis. Ten eerste wordt het handelen van een hulpverlener begrensd door goed hulpverlenerschap. Hij dient bij de uitoefening van zijn werkzaamheden rekening te houden met de rechten van de cliënt en andere maatschappelijke normen. Het gaat dan niet alleen om rechten die in de Wgbo zijn vastgelegd, maar ook om andere regelgeving zoals de Wet Bopz, de Wet big en de Kwaliteitswet zorginstellingen. Naast wetgeving zijn ook van belang de adviezen van de Inspectie voor de Gezondheidszorg, waaruit een gedragslijn voor hulpverleners is af te leiden. Onder goed hulpverlenerschap wordt ook verstaan dat een hulpverlener verantwoordelijk is voor zijn handelen. Het blijft mogelijk dat hij een verzoek van een cliënt en/of een vertegenwoordiger naast zich neerlegt indien hij van mening is dat het bieden van een bepaalde vorm van ondersteuning in strijd is met de zorg van een goed hulpverlener.

De term professionele standaard wordt, als het over medici gaat, in de gezondheidsrechtelijke literatuur doorgaans onderverdeeld in twee componenten: de medisch-professionele standaard waartoe normen, regels en ervaringen uit de beroepsgroep worden gerekend en het andere gedeelte van de professionele standaard dat bestaat uit het nakomen van de rechten van de cliënt en andere maatschappelijke normen. ${ }^{7}$ Leenen omschrijft de medisch-professionele standaard als 'het zorgouldig volgens de inzichten van de medische wetenschap en ervaring handelen als een redelijk bekwaam arts van gelijke medische categorie in gelijke omstandigheden met middelen die in redelijke verhouding staan tot het concreet behandelingsdoel. ${ }^{\prime}$ Dit gedeelte van de professionele standaard behoort tot de autonomie van een hulpverlener, hetgeen betekent dat een hulpverlener zelf verantwoordelijk is voor de invulling ervan. ${ }^{9}$ De medisch-professionele standaard wordt overigens vormgegeven door de beroepsgroep en niet door de individuele hulpverlener.

6 Kamerstukken II 1990/91, 21 561, nr. 6, p. 60.

7 Deze twee componenten moeten in de context van de Wgbo worden gelezen. Deze wet legt de nadruk op het verrichten van handelingen op het gebied van de geneeskunst (artikel 7:446 BW lid 1 en lid 2). Deze wet is ook van toepassing in de verstandelijk gehandicaptenzorg (zie ook paragraaf 1.2).

8 H.J.J. Leenen., Handboek gezondheidsrecht, Deel II Gezondheidszorg en recht, vierde herziene druk, Houten/Diegem: Bohn Stafleu Van Loghum 2002, p. 41-42.

9 In dit kader wordt ook wel gesproken over medisch-professionele autonomie i.p.v. professionele autonomie van een hulpverlener. J.H. Hubben, "Professionele autonomie: grenzen en dynamiek", in: J.H. Hubben, en H.D.C. Roscam 
In de gezondheidsrechtelijke literatuur wordt de medisch-professionele standaard verder ingevuld. Een hulpverlener dient zich te houden aan de grenzen van zijn kennen en kunnen, dient te handelen in overeenstemming met de wetenschap, dient primair te handelen in het belang van de cliënt, dient te handelen in overeenstemming met de geldende ethiek, dient rekening te houden met de belangen van de samenleving en de instelling waarbinnen hij werkzaam is en dient het oordeel van degenen die met hem samenwerken serieus te nemen. ${ }^{10} \mathrm{De}$ beroepsgroep is niet volledig autonoom op het gebied van het ontwikkelen van beroepsnormen. De wetgever kan, mede op grond van het algemeen belang, regels opleggen ten aanzien van het medisch handelen. ${ }^{\text {II }}$ In de Wet Bopz is bepaald dat een cliènt tegen zijn wil kan worden behandeld als hij een gevaar vormt voor zichzelf of anderen. De hulpverlener is uiteindelijk degene die beslist of een cliënt ook daadwerkelijk wordt behandeld tegen zijn wil. Het andere gedeelte van de professionele standaard, de rechten en maatschappelijke normen, valt buiten het bereik van de hulpverlener: deze normen worden opgelegd aan hulpverleners.

Naast medici hebben ook niet-primair medisch georiënteerde beroepen, zoals een persoonlijk begeleider, een eigen professionele standaard die richting geeft aan het handelen in de praktijk. De voornaamste taak van een persoonlijk begeleider bestaat uit het ondersteunen van cliënten met een verstandelijke handicap. Deze kerntaak vormt het uitgangspunt voor de verdere invulling van de professionele standaard van een persoonlijk begeleider. In de concrete uitwerking zal het accent komen te liggen op het verrichten van niet-medische handelingen, ${ }^{12}$ waardoor in plaats van de medisch-professionele standaard beter kan worden gesproken van 'de professionele standaard van een persoonlijk begeleider'. Een gedeelte daarvan behoort tot de verantwoordelijkheid van de beroepsgroep, het andere gedeelte wordt ingevuld door juridische en maatschappelijke normen. ${ }^{13}$

Abbing (red.), Gezondheidsrecht in perspectief, 25 jaar Vereniging voor Gezondheidsrecht, Utrecht: De Tijdstroom 1993, p. 66-67.

10 W.B. van der Mijn, Wie stelt de dokter de wet?, Deventer: Kluwer 1983, p. 10-13.

11 Hubben 1993, p. 67.

12 Dit betekent allerminst dat hulpverleners ook recht en ethiek naar zich gaan toetrekken. Deze gebieden blijven tot de verantwoordelijkheid van de wetgever behoren.

13 De wetgever spreekt alleen over het begrip professionele standaard (artikel 7:453 BW). Van Reijsen pleit ervoor om uitsluitend het begrip professionele standaard te hanteren als verzamelnaam voor normen die kunnen worden afgeleid uit de regelgeving en algemeen aanvaarde maatschappelijke normen, de jurisprudentie en de normering gesteld door beroepsbeoefenaren. Op deze wijze wordt voorkomen dat de nadruk komt te liggen op medische kennis en normering door beroepsgroepen (P.P.M. van Reijsen, Medisch-professionele auto- 
Tabel 7

Professionele standaard van een persoonlijk begeleider

\begin{tabular}{l|l} 
& $\begin{array}{l}\text { Normen afkomstig van de beroepsgroep: } \\
\text { kennis en ervaring op het gebied van } \\
\text { het ondersteunen van cliënten met een } \\
\text { verstandelijke handicap }\end{array}$ \\
\hline $\begin{array}{l}\text { Professionele standaard van een } \\
\text { persoonlijk begeleider }\end{array}$ & $\begin{array}{l}\text { Normen afkomstig van de wetgever en de } \\
\text { maatschappij: } \\
\text { rechten van cliènten en maatschappe- } \\
\text { lijke normen }\end{array}$
\end{tabular}

Een ruime benadering van goed hulpverlenerschap

Volgens Leenen wordt met goed hulpverlenerschap in de Wgbo alleen de medisch-professionele standaard bedoeld, temeer daar het bij de rechten van de cliënt en andere maatschappelijke normen gaat om normen die extern worden opgelegd en die zonder meer moeten worden opgevolgd.14 De medischprofessionele standaard is gebaseerd op medische kennis en medische ervaring van hulpverleners. Leenen verwijst ter motivering naar de parlementaire behandeling van de Wgbo waarin een omschrijving wordt gegeven van de medischprofessionele standaard. Een kernpunt daarin is dat de handeling medisch geïndiceerd moet zijn met het oog op een concreet behandelingsdoel en dat er een rechtstreekse relatie moet zijn tussen de ziekteverschijnselen en de toe te passen diagnostische methoden en tussen de diagnose en de toe te passen therapie. ${ }^{15}$ Dit betekent ook dat het handelen van een hulpverlener wordt bepaald door de 'inzichten van de medische wetenschap en de ervaring die de beroepsgroep met

mering door beroepsgroepen (P.P.M. van Reijsen, Medisch-professionele autonomie en gezondheidsrecht (diss. Nijmegen), Lelystad: Koninklijke Vermande 1999, p. 22-23). De samenvoeging van de niet-medische en medisch-professionele standaard mag echter niet tot gevolg hebben dat hulpverleners ook de gebieden recht en ethiek naar zich toe gaan trekken. Zowel de wetgever als de hulpverlener behouden ieder een eigen verantwoordelijkheid. In dat kader kan toch beter worden gesproken over twee aparte onderdelen, die samen inhoud geven aan de professionele standaard van een hulpverlener in de sector verstandelijk gehandicaptenzorg.

14 Leenen 2000, p 187.

15 Kamerstukken II 1992-93, 21 561, nr. 15, p. 10-11. 
medische handelingen heeft opgedaan'. ${ }^{16}$ Ook de beoordeling van niet-medische aspecten moet worden geplaatst in een medisch referentiekader. ${ }^{17}$

Leenen formuleert, mede op basis van rechtspraak, een aantal aanvullende beroepsnormen die zijn eerder omschreven uitspraken over de juridische betekenis van goed hulpverlenerschap nuanceren: ${ }^{15}$ de zorg moet van een behoorlijk niveau zijn en daarnaast behoren pijnbestrijding en het begeleiden van de cliënt ook tot de taken van een hulpverlener. De inhoud van deze niet-medische normen varieert per beroepsgroep en illustreert dat de medisch-professionele standaard van medici niet alleen gebaseerd is op medische kennis. ${ }^{19} \mathrm{Er}$ is ook voldoende ruimte voor onder meer de ethiek, belangen van derden en niet-medische taken zoals het begeleiden en verzorgen van cliënten. Leenen merkt echter wel op dat 'de beoordeling van de niet-medische aspecten van de beslissing van de arts wordt bepaald door en is gebonden aan zijn medische deskundigheid.' Hij wijst erop dat het handelen van een hulpverlener altijd moet passen in een medisch referentiekader. ${ }^{20}$

De uitleg die door Leenen wordt gegeven aan de medisch-professionele standaard kan niet zonder meer worden vertaald naar de professionele standaard van hulpverleners die werkzaam zijn in de verstandelijk gehandicaptenzorg, om de eenvoudige reden dat in deze sector het accent niet ligt op het bieden van medische hulpverlening. Een persoonlijk begeleider moet ook begrijpen wat er in een cliënt omgaat, hij moet diens taal spreken en op de juiste momenten ondersteuning bieden. Met name in de verstandelijk gehandicaptenzorg, waar de nadruk niet ligt op medisch handelen, zal een hulpverlener vanuit een breder, niet-medisch, perspectief moeten beoordelen wat verantwoord is.

Legemaate ${ }^{21}$ gaat ook uit van een ruimere benadering. Uit zijn omschrijving van de professionele standaard komt naar voren dat goed hulpverlenerschap meer is dan alleen een technisch goede hulpverlening. Een goede hulpverlener gaat in gesprek met de cliënt en probeert de autonomie van de cliënt, die schade heeft opgelopen door opneming in een instituut, zoveel mogelijk te herstellen. ${ }^{22}$ Ook

16 Leenen 2002, p. 34.

17 Onder niet-medische aspecten verstaat Leenen 'bij de individuele patiënt gelegen factoren' (Leenen 2002, p. 40).

18 Leenen 2002, p. 37-40.

19 In de gezondheidszorg wordt vaak gedacht dat technische deskundigheid van een hogere orde is dan bijvoorbeeld vaardigheid in pijnbestrijding en begeleiding (Leenen 2002, p. 39).

20 Leenen 2002, p. 40.

21 Legemaate 1998.

22 E.B.-van Veen, "Beter gezondheidsrecht - enkele beschouwingen naar aanleiding van goed recht", in: J.C.J. Dute, J.K.M. Gevers en G.R.J. de Groot (red.), 
wordt van hulpverleners verwacht dat zij in hun dagelijkse werkzaamheden rekening houden met wettelijke bepalingen. Voorwaarde is echter wel dat de wetgever, op zijn beurt, bij het ontwerpen van wetgeving rekening houdt met de specifieke kenmerken van de sector waarop de wetgeving betrekking heeft. Pas dan zal sprake kunnen zijn van 'goed recht'. Legemaate spreekt over één professionele standaard die niet alleen betrekking heeft op technische aspecten van de beroepsuitoefening, maar ook normen bevat betreffende de relatie met de cliënt en maatschappelijke zorgvuldigheidseisen. Daartoe behoren zowel regels die door de wetgever en de rechter zijn geformuleerd (recht van buiten) als normen uit de beroepsgroep zelf (recht van binnen). Tussen beide vormen van recht vindt ook interactie plaats. ${ }^{23}$ Het recht van buiten bevat een aantal open normen, waaronder goed hulpverlenerschap, die het mogelijk maken om regels uit de beroepsgroep te gebruiken bij het vinden en vormen van recht. Op deze manier hebben hulpverleners de mogelijkheid om het recht te sturen en nader in te vullen. Daarbij moet worden bedacht dat de grenzen van het recht van buiten niet kunnen worden overschreden door het recht van binnen. Legemaate wijst erop dat ook het recht (de personen en instanties die belast zijn met toezicht en handhaving daarvan) een eigen verantwoordelijkheid behoudt: 'de normen en regels van de verschillende beroepsgroepen moeten voortdurend kritisch worden getoetst'.2 De (eigen) professionele standaard van een hulpverlener reikt niet zo ver, dat daaronder ook sterilisatie, abortus op niet-medische indicatie en euthanasie vallen. Een hulpverlener moet zich ten aanzien van deze ingrijpende beslissingen beroepen op maatschappelijke en juridische normering en regeling. ${ }^{25}{ }^{26} \mathrm{Het}$ is de taak van de wetgever om voor deze ingrijpende (medische) handelingen bescherming te bieden aan cliënten. Dit geldt te meer als het gaat om cliënten die minder in staat zijn om op te komen voor hun belangen. $\mathrm{Zij}$ verdienen extra bescherming, teneinde de relatie tussen de hulpverlener en de cliënt meer in balans te brengen.

Omzien naar de toekomst, Houten/Diegem: Bohn Stafleu van Loghum 2002b, p. 27.

23 Legemaate 1994b, p. 49.

24 Legemaate 1994b, p. 49.

25 Leenen 2002, p. 32.

26 Hulpverleners mogen deze beslissingen niet uitvoeren op grond van hun eigen normen en waarden. Het wordt een ander verhaal als het gaat om sterilisatie of abortus op grond van een medische indicatie. In dat geval beroept een hulpverlener zich op zijn eigen (medisch-) professionele standaard. 


\subsection{Goed hulpverlenerschap in de zorg voor mensen met een verstande- lijke handicap}

In hoofdstuk 1 (paragraaf 1.2) werd al aandacht besteed aan de Wgbo, waarin ook de norm goed hulpverlenerschap is vastgelegd. Deze wet legt de nadruk op het verrichten van geneeskundige handelingen. ${ }^{z}$ In de zorg voor mensen met een verstandelijke handicap staat echter het bieden van ondersteuning centraal. Een strikte interpretatie van de reikwijdte van de Wgbo heeft tot gevolg dat de sector verstandelijk gehandicaptenzorg niet onder deze wet valt. ${ }^{28}$ De norm goed hulpverlenerschap is echter ook zonder de Wgbo van betekenis in de verstandelijk gehandicaptenzorg. Elke hulpverlener heeft een eigen verantwoordelijkheid die door de wensen van een cliënt of een vertegenwoordiger niet opzij kan worden gezet. ${ }^{29}$ Goed hulpverlenerschap is een beroepsnorm die door elke hulpverlener in de gezondheidszorg in acht genomen moet worden. De Wgbo heeft ertoe geleid dat deze norm sinds 1 april 1995 ook in de wet is vastgelegd, waardoor hulpverleners en ook cliënten zich kunnen beroepen op artikel 7:453 BW.

\section{De invulling van goed hulpverlenerschap in de verstandelijk gehandicaptenzorg}

Aan de hand van de definities van Legemaate ${ }^{30}$ en Leenen $^{31}$ is het mogelijk om een voorstelling van goed hulpverlenerschap te maken. In de verstandelijk gehandicaptenzorg is deze norm nog niet voor alle beroepsgroepen in voldoende mate ingevuld. Dit geldt met name voor een persoonlijk begeleider. Diens professionele standaard is, in tegenstelling tot de professionele standaard van een AVG, nog nauwelijks gedefinieerd. Een arts kan terugvallen op richtlijnen, rapporten en nota's die opgesteld zijn door de beroepsgroep waartoe hij behoort. Een aanzienlijk deel daarvan heeft betrekking op technische normen en regels van het vak. Op grond van deze kennis kan een arts beoordelen of hij de juiste

27 Onder handelingen op het gebied van de geneeskunst worden verstaan: 'alle verrichtingen (...) rechtstreeks betrekking hebbende op een persoon en ertoe strekkende hem van een ziekte te genezen, hem voor het ontstaan van een ziekte te behoeden of zijn gezondheidstoestand te beoordelen, dan wel deze verloskundige bijstand te verlenen (artikel 7:446 lid 2a BW) en andere dan de onder a bedoelde handelingen, rechtstreeks betrekking hebbende op een persoon, die worden verricht door een arts of tandarts in die hoedanigheid' (artikel 7:446 lid $2 \mathrm{~b}$ BW).

28 In paragraaf 1.2 is echter ook uiteengezet dat de Wgbo analoog kan worden toegepast in de sector verstandelijk gehandicaptenzorg.

29 Leenen 2000, p. 187.

30 Legemaate 1998.

31 Leenen 2000 en Leenen 2002. 
diagnose heeft gesteld en of de behandeling correct is uitgevoerd..$^{x}$ Ook voor persoonlijk begeleiders zijn verscheidene richtlijnen beschikbaar. Het merendeel van deze richtlijnen heeft betrekking op medische verrichtingen, zoals het toepassen van voorbehouden handelingen. Goed hulpverlenerschap is in de verstandelijk gehandicaptenzorg evenwel meer dan alleen het correct uitvoeren van technische handelingen. De dagelijkse werkzaamheden van een persoonlijk begeleider bestaan ook uit het ondersteunen van cliënten.

Naast richtlijnen bieden ook de Wgbo en de Wet Bopz aanknopingspunten om goed hulpverlenerschap van een persoonlijk begeleider nader in te vullen. De vertaling van deze wetten naar de sector verstandelijk gehandicaptenzorg verloopt niet zonder problemen. De Wgbo kan analoog worden toegepast in de verstandelijk gehandicaptenzorg. Voor de Wet Bopz ligt dit anders. Hoewel deze wet ook van toepassing is in de verstandelijk gehandicaptenzorg, is de inhoud ervan minder geschikt voor deze sector. Het accent ligt in deze wet te veel op 'niet ingrijpen', waardoor het gevaar dreigt dat cliënten aan hun lot worden overgelaten. Het is terecht dat het zelfbeschikkingsrecht van cliënten met een verstandelijke beperking wordt gerespecteerd. Cliënten zijn echter niet altijd in staat om dit recht zelfstandig uit te oefenen. $\mathrm{Zij}$ hebben ook behoefte aan ondersteuning in termen van het burgerschapsparadigma. ${ }^{30}$

Ook in de zorgethiek zijn aanknopingspunten te vinden om goed hulpverlenerschap van persoonlijk begeleiders meer inhoud te geven. Tronto meent dat een goede hulpverlener aandachtig, verantwoordelijk en competent is.$^{34}$ Het doel van het bieden van zorg is om de mogelijkheden van cliënten te vergroten. Van een hulpverlener wordt verwacht dat hij een cliënt op een juiste manier ondersteunt, zodanig dat een cliënt meer inzicht krijgt in zijn eigen situatie en mogelijkheden, aldus Verkerk. ${ }^{35}$ Goede zorg legt de nadruk op het respecteren van de positieve vrijheid van cliënten. Het uitgangspunt is niet langer zelfbeschikking, maar zelfontplooiing. ${ }^{36}$ Hiermee is niet gezegd dat respect voor het zelfbeschik-

32 Legemaate 1998, p. 15-16.

33 Voorstanders van de Wet Bopz zullen zeggen dat de Wet Bopz gericht is op het voorkomen van gevaar en niet op het bieden van 'goede zorg', waar andere wetten voor zijn. Deze opmerking gaat niet op voor de verstandelijk gehandicaptenzorg. Deze sector is niet gebaat bij een wet die alleen maar gericht is op het wegnemen van 'gevaar'.

34 J.C. Tronto, Moral Boundaries: a political argument for an ethic of care, New York/London: Routledge 1993, p. 136 en M. Verkerk, "A care perspective on coercion and autonomy", Bioethics (13) 1999-3/4, p. 366.

35 Verkerk 1999, p. 367.

36 Widdershoven, Berghmans en Welie 2003, p. 329 en zie ook hoofdstuk 3 van dit boek. 
kingsrecht een verkeerd uitgangspunt is. Al eerder in deze studie is aangegeven dat dit uitgangspunt in de zorg voor mensen met een verstandelijke handicap niet voldoende is (hoofdstuk 3 ). Veel cliënten in deze sector zijn niet in staat om hun zelfbeschikkingsrecht zelfstandig uit te oefenen. Goede zorg kan de mogelijkheden van cliënten bevorderen en daardoor ook de zeggenschap over hun eigen leven vergroten. Vanzelfsprekend moet ervoor worden gewaakt dat goede zorg niet ontaardt in paternalisme. Hiervan is sprake als een hulpverlener de intentie heeft om een cliënt wel te doen zonder daarbij rekening te houden met de actuele wensen, keuzen en acties van de betrokken cliënt. ${ }^{x z}$ De hulpverlener is oprecht van mening dat door zijn handelen het belang en het welzijn van de cliënt beter wordt behartigd dan wanneer hij de cliënt zijn gang laat gaan. Het uitgangspunt van goede zorg is niet dat de hulpverlener het beter meent te weten dan de cliënt zelf. De hulpverlener heeft veel meer de rol van adviseur. Belangrijk is dat de voorkeur van de hulpverlener niet aan de cliënt wordt opgelegd, maar dat in onderling overleg een beslissing wordt genomen..$^{36}$

In het kader van goede zorg zijn hulpverleners op bepaalde momenten genoodzaakt om de vrijheid van een cliënt te beperken. In lang niet alle gevallen is helder op grond van welke normen hij mag ingrijpen in de vrijheid van een cliënt met een verstandelijke handicap. Ook wetgeving biedt op dit punt niet in alle gevallen duidelijkheid. Een hulpverlener is bij vrijheidsbeperking gebonden aan de beginselen van effectiviteit, proportionaliteit en subsidiariteit. De toepassing van deze beginselen kan echter een wettelijke bepaling niet opzij zetten. ${ }^{39}$ Dwangbehandeling en de toepassing van middelen of maatregelen zijn geregeld in artikel 39 en 40 Wet Bopz. Dit geldt echter niet voor alle beperkingen die een hulpverlener oplegt aan een cliënt. Veel van deze beperkingen worden doorgaans zonder een wettelijke grondslag toegepast. ${ }^{40} \mathrm{Aan}$ de hand van de beginselen effectiviteit, proportionaliteit en subsidiariteit kan een hulpverlener toch beoordelen of het rechtvaardig is om in te grijpen in het zelfbeschikkingsrecht van een cliënt. ${ }^{41}$

37 Berghmans 1992, p. 46.

38 Widdershoven, Berghmans en Welie 2003, p. 331.

39 T.P.J.C. Widdershoven, "Psychiatrie en recht: de Wet Bopz en psychiatrie. Kanttekeningen bij een regeling", Preadvies Vereniging voor Gezondheidsrecht, Utrecht: 2003, p. 24.

40 In hoofdstuk 5, 6 en 7 wordt nader ingegaan op deze problematiek, die voor een groot deel samenhangt met de beperkte reikwijdte van de Wet Bopz.

41 De gedachte achter deze drie beginselen is dat een beroep wordt gedaan op de creativiteit van een hulpverlener. Het is lang niet altijd noodzakelijk om een cliënt af te zonderen of te fixeren. Een hulpverlener kan ook gebruik maken van minder ingrijpende interventies. Op deze manier kunnen effectiviteit, proporti- 
Het effectiviteitsbeginsel vereist dat de interventie effectief is. Onder een interventie wordt verstaan een afspraak waar een cliènt zich aan moet houden of een maatregel die wordt opgelegd aan een cliënt. Deze afspraken en maatregelen hebben als gemeenschappelijk kenmerk dat zij leiden tot een beperking van de vrijheid. Effectief betekent dat de interventie voor zover mogelijk is bijdraagt aan de ontwikkeling van een cliënt. Dit betekent ook dat de beperking alleen mag worden opgelegd als deze daadwerkelijk in het belang van de cliënt is. De interventie mag niet om andere redenen worden opgelegd (vanwege een tekort aan personeel of vanwege de aanwezigheid van één cliënt met moeilijk gedrag). In bepaalde situaties is het echter onvermijdelijk dat andere cliënten door het handelen van een cliënt in een gevaarlijke situatie belanden. Het beperken van de vrijheid van een cliënt is op dat moment niet in zijn belang, maar in het belang van anderen. Van belang is dat bij de uitvoering van de maatregel zoveel mogelijk rekening wordt gehouden met het effectiviteitsbeginsel. Als blijkt dat een interventie geen effect meer heeft, dient deze beëindigd te worden.

Een interventie dient niet alleen effectief te zijn maar ook proportioneel. Dit betekent dat de zwaarte van de interventie in redelijke verhouding moet staan tot de het beoogde doel. Het doel van een interventie kan zijn het verminderen van gevaar. Er zijn echter gradaties aan te brengen in gevaar. Dit geldt ook voor de middelen die worden ingezet om gevaar te verminderen. Een cliënt die in ernstige mate automutileert rechtvaardigt de toepassing van een zwaardere interventie dan een cliënt die af en toe een grote mond opzet tegenover een hulpverlener.

Tot slot moet een interventie ook voldoen aan het subsidiariteitsbeginsel. Een hulpverlener moet kiezen voor de minst ingrijpende interventie. Een cliënt, die andere cliënten dermate lastig valt dat hij een gevaar vormt voor anderen, kan worden afgezonderd in een afzonderingsruimte. Er zijn echter ook andere mogelijkheden denkbaar, die minder ingrijpend zijn voor de cliënt zijn. Een oplossing kan zijn om met de cliënt te gaan wandelen.

De sector verstandelijk gehandicaptenzorg is gebaat bij een verdere aanscherping van goed hulpverlenerschap. Dit geldt met name voor de functie van persoonlijk begeleider. Zijn professionele standaard dient op een dusdanige wijze te worden uitgewerkt, dat hij meer handvatten aangereikt krijgt. Het betreft onder meer een nadere invulling van verantwoordelijkheden, kwaliteitsnormen, opleidingseisen en richtlijnen. Van belang is dat elke cliënt de juiste vorm en intensi-

onaliteit en subsidiariteit een rol spelen bij de verduidelijking van het begrip goed hulpverlenerschap. Een persoonlijk begeleider kan ter motivering van een (goede) beslissing verwijzen naar een of meer van deze criteria. 
teit van ondersteuning krijgt. In de volgende drie paragrafen worden de volgende aspecten nader uitgewerkt: ${ }^{2}$

1. De (reikwijdte van de) verantwoordelijkheden van een persoonlijk begeleider.

2. Kwaliteitsnormen en kwaliteitsbeleid in de sector verstandelijk gehandicaptenzorg.

3. Richtlijnen in de sector verstandelijk gehandicaptenzorg.

\subsection{Verantwoordelijkheden van een persoonlijk begeleider}

Begin 2001 deden zich in de verstandelijk gehandicaptenzorg een aantal incidenten voor. De Inspectie ontving binnen een maand vier meldingen van verbrandingen door te heet badwater ${ }^{*}$ In één van de gevallen overleed een cliënt aan de gevolgen ervan." De Rechtbank bevond de betrokken medewerker schuldig, maar legde geen straf op. Het betrof een (onervaren) medewerker die was vergeten om na het schoonmaken van het bad de thermostaatknop terug te draaien. Bovendien had hij nagelaten om de temperatuur van het badwater te controleren.

Deze incidenten brachten een discussie op gang over de reikwijdte van de verantwoordelijkheden van medewerkers in de verstandelijk gehandicaptenzorg. Bovendien werd de rol van richtlijnen onder de aandacht gebracht. In de stichting waar de schuldig bevonden werknemer werkzaam was ontbrak een protocol voor het baden van cliënten met een (ernstige) meervoudige verstandelijke handicap. Volgens de Rechtbank kon wel worden uitgegaan van een vast gebruik namelijk dat na het reinigen van een bad, de thermostaatknop wordt teruggedraaid en het water handmatig wordt gecontroleerd. Vanwege de ernstige (deels voorzienbare) risico's die verbonden zijn aan het baden van een cliënt, mocht van de medewerker worden verwacht dat hij handelde conform het vaste gebruik. Mede gezien het feit dat de medewerker onvoldoende geschoold was in de zorg en weinig ervaring had met het baden van cliënten werd hem uiteindelijk geen straf opgelegd. Doorslaggevend was ook dat binnen de stichting sprake was van een hoge werkdruk en bovendien adequate til- en hulpmiddelen ont-

42 Uiteraard zijn deze drie aspecten ook van belang voor de professionele standaard van andere disciplines waaronder een AVG en een gedragsdeskundige, Het accent ligt echter op de professionele standaard van een persoonlijk begeleider, aangezien de persoonlijk begeleider de meest directe ondersteuning biedt aan cliënten.

43 Inspectie voor de Gezondheidszorg, Circulaire naar aanleiding van verbrandingen in de gehandicaptenzorg, Den Haag: 2001.

44 Rechtbank Middelburg 17 april 2002, TvGr 2003/11. 
braken. Opvallend is dat de stichting ondanks het ontbreken van een badprotocol en de slechte werkomstandigheden geen blaam trof. Kennelijk achtte de Rechtbank de werknemer, ondanks zijn ontoereikende opleiding, ook in deze situatie verantwoordelijk voor de geleverde zorg. ${ }^{\text {* }}$

In de zorg voor mensen met een verstandelijke handicap worden persoonlijk begeleiders dagelijks geconfronteerd met vragen over hun verantwoordelijkheden. Deze vragen spelen niet alleen bij het baden van cliënten maar doen zich ook voor bij de toepassing van vrijheidsbeperking. In veel gevallen biedt de professionele standaard uitkomst. De achtergronden en opleidingen van persoonlijk begeleiders lopen echter zeer uiteen waardoor het niet eenvoudig is om voor deze beroepsgroep een eenduidig omschreven professionele standaard te ontwikkelen. De beroepsgroep kan worden onderverdeeld in verpleegkundigen en verzorgenden en werknemers met een agogische opleiding, zoals sociaal pedagogische hulpverleners. Verpleegkundigen en verzorgenden kunnen terugvallen op een algemene beroepscode die is opgesteld door NU'91. Ook de Nederlandse Vereniging voor Sociaal Pedagogisch Hulpverleners (NVSPH) kent een algemene beroepscode. Persoonlijk begeleiders met een verpleegkundige achtergrond kunnen sinds kort ook terugvallen op een beroepscode die specifiek voor de verstandelijk gehandicaptenzorg is geschreven. De Algemene Vergadering voor Verpleegkundigen en Verzorgenden (AVVV) heeft de competenties van basisverpleegkundigen in de verstandelijk gehandicaptenzorg beschreven. ${ }^{46}$ Positief is dat in deze omschrijving ook aandacht wordt besteed aan de Wet Bopz. Daarnaast is binnen de NVSPH onlangs een functiegroep voor verstandelijk gehandicapten opgericht. Een geschikt thema voor deze functiegroep zou kunnen zijn de verantwoordelijkheden van een persoonlijk begeleider aangaande de toepassing van vrijheidsbeperking.

Aanvullend moet in de opleiding (meer) stil worden gestaan bij de verantwoordelijkheden en taken van een persoonlijk begeleider. Het een sluit het ander niet uit. ${ }^{*}$ De uitspraak van de Rechtbank Middelburg ${ }^{48}$ illustreert dat in de sector

45 In dit geval betrof het een strafzaak. Daarmee is nog niet veel gezegd over de verantwoordelijkheid van de stichting. Dit neemt niet weg dat de schuld - in de zin van causaliteit tussen de tekortkoming van de hulpverlener en de veroorzaakte schade - redelijk snel is aangenomen door de rechter.

46 AVVV, Beroepscompetentie profiel basisverpleegkundige verstandelijk gehandicaptenzorg, Utrecht: 2004.

47 Hetzelfde kan worden gezegd over de functie van een pedagoog en een psycholoog: zowel in de opleiding als in een beroepscode moet meer duidelijkheid worden gegeven over welke taken en verantwoordelijkheden een pedagoog of een psycholoog heeft in de verstandelijk gehandicaptenzorg. Binnen de NIP en NVO zijn aparte secties yoor werkenden in de gehandicaptenzorg actief. Op dit 
verstandelijk gehandicaptenzorg ook werknemers werkzaam zijn die niet opgeleid zijn voor een baan in de zorg." Dit betekent dat in instituten, willen zij over voldoende geschikt personeel blijven beschikken, voldoende aandacht moet worden besteed aan de (om- en bij)scholing van medewerkers. Deze initiatieven kunnen niet voorkomen dat alsnog bepaalde risico's optreden. De rechterlijke macht hanteert echter een strikt beleid, waaruit kan worden afgeleid dat door hulpverleners en/of voorzieningen al het mogelijke moet worden gedaan om risico's in de zorg voor mensen met een verstandelijke handicap te voorkomen. In recente jurisprudentie worden grote gevolgen verbonden aan het overtreden van een veiligheidsnorm. Van belang is dat medewerkers op de hoogte zijn van de geldende veiligheidsnormen. Blok spreekt zelfs over een 'al langere tijd gehanteerde ruimere toerekening en omkering van de bewijslast bij overtreding van een veiligheidsnorm'so

In een uitspraak van de Rechtbank Breda d.d. 20 augustus 2002 werd een ziekenhuis veroordeeld tot het betalen van schadevergoeding aan de nabestaanden van een overleden patiënt, die suïcide pleegde door van een flatgebouw te springen, nadat ze toestemming had gekregen om tijdens de bewegingstherapie alleen naar het toilet te gaan. ${ }^{51}$ De rechter oordeelde dat het ziekenhuis een veiligheidsnorm had geschonden door de patiënt in strijd met het beleid zonder begeleiding buiten de afdeling te laten. Het ziekenhuis gaf toe dat het algemeen behandelbeleid en de daarbij behorende begeleiding nog onvoldoende zijn vastgelegd en geprotocolleerd. Ook bestond onder het personeel nog weinig bekendheid met landelijke richtlijnen en protocollen. De rechter nam in deze zaak redelijk snel aan dat sprake zou zijn van causaal verband tussen het overtreden van de veiligheidsnorm en de gevolgen die dit heeft gehad voor de patiënt. Een vergelijkbare casus deed zich een paar jaar eerder voor in Heiloo. ${ }^{52}$ Ook daar werd het ziekenhuis veroordeeld tot het betalen van schadevergoeding nadat een vrijwillig opgenomen patiënt een dag voor zijn ontslag in de ogen van de rechter onterecht door verpleegkundigen, zonder overleg met de dienstdoend psychiater, naar huis werd gestuurd. De patiënt verbleef met toestemming van de psychiater elders. In de nacht voor zijn vertrek kwam hij dronken naar het ziekenhuis. Ook was hij agressief en neerslachtig. Uiteindelijk is de patiënt weer

moment wordt gezamenlijk gewerkt aan een beroepsprofiel voor psychologen en pedagogen die werkzaam zijn in de verstandelijk gehandicaptenzorg.

48 Rechtbank Middelburg 17 april 2002, TvGr 2003/11.

49 In veel gevallen is het ook een bewuste keuze van het management om vanwege problemen met het budget te kiezen voor ongeschoolde werknemers.

50 Rechtbank Breda 20 augustus 2002, BJ 2002, 49, m.nt. A. Blok.

51 Rechtbank Breda 20 augustus 2002, BJ 2002, 49, m.nt. A. Blok.

52 Hoge Raad 16 juni 2000, kBJ 2000, 54, m.nt. Zuijderhoudt. 
met een taxi naar zijn motel vertrokken. Vervolgens stichtte de patiënt 's nachts brand. De rechter oordeelde dat 'de verpleging niet heeft gehandeld met de zorgvuldigheid die van redelijk handelende verpleegkundigen in de gegeven omstandigheden mocht worden verwacht.' Het ziekenhuis erkende dat het beleid in dergelijke situaties niet is vastgelegd in regels."s

In beide casus veronderstelt de rechter dat sprake is van causaliteit tussen de tekortkoming van hulpverleners en/of het ziekenhuis en de veroorzaakte schade. De rechter merkt op dat het ontbreken van een duidelijk behandelbeleid en richtlijnen voor verantwoordelijkheden van de verschillende hulpverleners bepalend zijn voor het leveren van verantwoorde zorg en goed hulpverlenerschap. Tegelijkertijd lijkt hij over het hoofd te zien dat in beide casus sprake is van vrijwillig opgenomen cliënten. Alleen cliënten die onvrijwillig zijn opgenomen mogen (tegen hun wil) in hun bewegingsvrijheid worden beperkt. Als een vrijwillig opgenomen cliënt aangeeft niet langer opgenomen te willen zijn, heeft hij het recht om de instelling te verlaten. Aangezien de Wet Bopz in beide casus niet aan de orde is, zijn er grenzen aan de verantwoordelijkheid van de betrokken medewerkers. Maar ook los van de vraag of de Wet Bopz of de Wgbo van toepassing is, dient altijd te worden beoordeeld of medewerkers volgens de normen van goed hulpverlenerschap (artikel 7:453 BW) hebben gehandeld en/of sprake is van verantwoorde zorg (artikel $2 \mathrm{Kwaliteitswet} \mathrm{zorginstellingen).} \mathrm{Blok} \mathrm{merkt}$ in de noot bij het arrest over de patiënt die suïcide pleegde op dat 'het nog een hele dobber is om getoetst aan deze vage normeringen (goed hulpverlenerschap en verantwoorde zorg) een toerekenbare tekortkoming te bewijzen, zeker bij het uiterst moeilijk voorspelbare risico dat suïide nu eenmaal vormt. ${ }^{\prime 4}$ De strekking van haar betoog is dat een te ruime toerekening en omkering van de bewijslast geen goede ontwikkelingen zijn in de gezondheidszorg. Het is een illusie om te denken dat medewerkers elk risico kunnen uitsluiten.

Zuijderhoudt concludeert in zijn noot onder het arrest van de Hoge Raad van 16 juni 2000 dat het voorkomen van risico's ook niet ten koste moet gaan van de (bewegings)vrijheid van cliënten: 'vooral moet ervoor gewaakt worden dat het arrest niet verkeerd gelezen en uitgelegd wordt in dier voege dat na jarenlange, moeitevolle strijd voor een minder paternalistische, minder bevoogdende psychiatriess de patiënten de rekening gaan betalen in de vorm van allerhande restricties door de hulpverlening opge-

53 De uitspraken die hier worden aangehaald hebben betrekking op de zorg die wordt verleend in een ziekenhuis. De strekking van deze uitspraken kan echter ook worden vertaald naar de zorg voor mensen met een verstandelijke handicap.

54 Rechtbank Breda 20 augustus 2002, BJ 2002, 49, m.nt. A. Blok.

55 Op de plaats van psychiatrie kan ook worden gelezen verstandelijk gehandicaptenzorg. 
legd om de aansprakelijkheid van het instituut nog draaglijk te houden (...). Zuijderhoudt raakt met zijn opmerking een gevoelig punt. Ook in de verstandelijk gehandicaptenzorg is men afgestapt van het 'bestwil-criterium'. In het kader van het burgerschapsparadigma wordt van een persoonlijk begeleider verwacht dat hij een andere invulling geeft aan zijn taken. Hij neemt niet meer vóór de cliënt een beslissing maar biedt een cliënt, indien nodig, ondersteuning bij het nemen van beslissingen. Hieronder wordt ook verstaan dat een persoonlijk begeleider de keuze van een cliënt moet respecteren als daar bepaalde risico's aan verbonden zijn. Het behoort echter tot diens verantwoordelijkheid om deze risico's proportioneel te houden met de intentie van de handeling (het vergroten van de zelfstandigheid van een cliënt). Daarvoor is van belang dat een persoonlijk begeleider de risico's nader kan omschrijven. ${ }^{56}$ Verantwoordelijkheid heeft immers ook betrekking op het afleggen van rekenschap over de geboden ondersteuning. In dat kader wordt ook van een hulpverlener verwacht dat hij inzichtelijk maakt welke zorgvuldigheidseisen in acht zijn genomen: heeft hij een andere hulpverlener geconsulteerd? Heeft hij een cliënt en/of zijn vertegenwoordiger voldoende ingelicht over de mogelijke risico's? Is een oordeel gegeven over de mate van wilsonbekwaamheid van de cliënt? Bestond er gevaar voor andere cliënten of derden? Gaat het om een eenmalig risico? Draagt de handeling, ondanks het rísico, bij aan het vergroten van de zelfstandigheid van de cliënt? Op deze manier kan een hulpverlener aantonen dat hij zich voldoende heeft ingespannen om de risico's voor de cliënt aanvaardbaar te houden.

Ook in de Tweede Kamer is veel aandacht besteed aan de eerder genoemde incidenten. Aan de orde kwam de vraag in hoeverre een medewerker verantwoordelijk is voor zijn handelingen. Bovendien vroegen enkele kamerleden zich af wie verantwoordelijk gesteld kan worden voor de gebeurtenissen in de stichting, waar een cliënt overleed aan verbrandingen veroorzaakt door te heet badwater. De toenmalige Staatssecretaris van VWS, Vliegenthart, antwoordde dat een instituut zelf de normen voor verantwoorde zorg dient vast te stellen. Van een instituut wordt verwacht dat het risico's inventariseert en op grond daarvan richtlijnen en protocollen opstelt, waardoor soortgelijke incidenten kunnen wor-

56 Een cliënt mag zelfstandig reizen. Van tevoren moet wel geïnventariseerd zijn welke risico's zich kunnen voordoen. Het mag niet zo zijn dat de cliënt geen rekening houdt met het andere verkeer en niet alleen een gevaar vormt voor zichzelf maar ook voor andere deelnemers in het verkeer. Een ander risico kan zich voordoen als cliënten de kans lopen om zwanger te worden. Dit risico zal met alle betrokkenen, waaronder de cliënt, goed door gesproken moeten worden. Maar, ook een cliënt dient de mogelijkheid te hebben om 'bewust' te kiezen voor het ouderschap. 
den voorkomen. ${ }^{57}$ De staatssecretaris lijkt hiermee te suggereren dat instituten verantwoordelijk zijn voor dergelijke incidenten en niet de medewerker zelf, tenzij sprake is van verwijtbare nalatigheid van de medewerker. 5 De rechter in Middelburg gaf echter aan dat de medewerker schuldig was. ${ }^{9}$

In de nabije toekomst zal de vraag 'Wat is een aanvaardbaar risico voor een cliënt?' nog meer centraal komen te staan. Een oorzaak is de reeds ingezette individualisering van de zorg, waarvan ook de modernisering van de AWBZ deel uitmaakt. Steeds minder cliënten zullen gebruik maken van 24-uurs zorg in een instituut. Cliënten hebben de mogelijkheid om op grond van een $\mathrm{Pgb}$ langer thuis te wonen. Ook zullen cliënten in nieuwe woonvormen terechtkomen, waar niet langer 24 uur een hulpverlener aanwezig zal zijn. In dit kader is van belang dat een hulpverlener de grenzen van zijn verantwoordelijkheden kent. Wat overblijft is dat hij de (mogelijke) risico's in kaart brengt en dat de risico's van een aanvaardbaar niveau ${ }^{60}$ zijn. Mocht dit laatste niet het geval zijn, dan behoort het tot de gezamenlijke verantwoordelijkheid van een hulpverlener en de woonvoorziening waar de cliënt verblijft om een oplossing te zoeken voor de problematiek. Er zal een keuze moeten worden gemaakt tussen meer ondersteuning of overplaatsing naar een andere voorziening, als de gevraagde ondersteuning op de locatie niet kan worden geboden. In de lijn van de Kwaliteitswet zorginstellingen mag van voorzieningen worden verwacht dat zij deze grenzen in hun beleid vastleggen. Een dergelijk beleid creëert meer duidelijkheid voor de cliënt, zijn vertegenwoordiger en de medewerkers die werkzaam zijn in de voorziening. Tevens wordt op deze manier (indirect) inhoud gegeven aan de professionele standaard van hulpverleners die werkzaam zijn in de zorg voor mensen met een verstandelijke handicap.

57 Aanhangsel Handelingen II 2001-02, p. 1291-1292.

58 Als het gaat om verwijtbare nalatigheid van een big-geregistreerde beroepsbeoefenaar kan ook een tuchtprocedure worden gestart. Dit is alleen mogelijk als het gaat om een verpleegkundige, een (AVG) arts of een gezondheidszorgpsycholoog.

59 Het ging in dit geval wel om een strafrechterlijke procedure en niet om een civielrechtelijke procedure. In het laatste geval zou naar alle waarschijnlijkheid de uitspraak luiden dat de instelling en niet de werknemer aansprakelijk is (Rechtbank Middelburg 17 april 2002, TvGr 2003/11).

60 Wat een aanvaardbaar niveau is moet voor elke cliënt individueel worden bepaald. Deze afweging vindt plaats in overleg met de cliënt, de vertegenwoordiger en alle disciplines die betrokken zijn bij de ondersteuning die wordt verleend. 


\subsection{Kwaliteitsnormen en kwaliteitsbeleid in de sector verstandelijk gehan- dicaptenzorg}

In artikel 2 van de Kwaliteitswet zorginstellingen (Kwz) is vastgelegd dat de zorgaanbieder 'verantwoorde zorg' aanbiedt. Hieronder moet worden verstaan zorg van een goed niveau die in ieder geval doeltreffend, doelmatig en cliëntgericht wordt verleend en die is afgestemd op de reële behoefte van de cliënt. Het is niet eenvoudig om het begrip verantwoorde zorg te operationaliseren. In de verpleeghuiszorg is in 2001 een lijst met tien indicatoren voor verantwoorde zorg opgesteld. ${ }^{61}$ Deze indicatoren hebben betrekking op de zorginhoud en kwaliteit van de inzet van het personeel. Deze lijst kan worden gebruikt om te beoordelen of in een verpleeghuis sprake is van situaties die door partijen als onverantwoord worden beschouwd. Een vergelijkbare lijst ontbreekt tot nu toe in de zorg voor mensen met een verstandelijke handicap. ${ }^{62}$

Op grond van de Kwz hebben zorgaanbieders een eigen verantwoordelijkheid voor het ontwikkelen van normen voor verantwoorde zorg. Daartoe behoren ook normen die betrekking hebben op het personeelsbeleid. Het badincident dat leidde tot de dood van een cliënt en strafvervolging van een hulpverlener, laat zien dat de deskundigheid van het personeel ook bepalend is voor het leveren van verantwoorde zorg. Zorgaanbieders mogen echter zelf bepalen op welke wijze zij invulling geven aan het personeelsbeleid. $\mathrm{Zij}$ hoeven vooralsnog geen rekening te houden met bepaalde opleidingseisen voor persoonlijk begeleiders.

61 Inspectie voor de gezondheidszorg, Evaluatierapport Zorgen in de Zomer, Den Haag: 2000a. Het betreft onder meer de volgende indicatoren: structurele afwijkingen van het met de cliënt besproken individuele zorgplan, dreigende concessies t.a.v. het zorgplan m.b.t. risicovolle en/of gezondheidsbedreigende situaties, het niet bereikbaar en oproepbaar zijn van de verpleegkundige deskundigheid voor de functie verpleeghuiszorg gedurende 24 uur per dag 7 dagen per week, het niet bereikbaar en oproepbaar zijn van een verpleeghuisarts voor de functie verpleeghuiszorg gedurende 24 uur per dag 7 dagen per week, het niet tenminste 1 keer per week aanbieden van groepsgewijze recreatieve activiteiten aan cliënten en het ontbreken van permanente aanwezigheid van een geïnstrueerd persoon voor het toezicht t.b.v. psychogeriatrische geïndiceerde cliënten in huiskamers.

62 Werveling, de beroepsvereniging voor verpleegkundigen en verzorgenden in de zorg voor mensen met een verstandelijke handicap, werkt sinds 2001 samen met de AVVV, algemene vergadering verpleegkundigen en verzorgenden, aan een signaleringsinstrument voor minimale kwaliteit van zorg. Vooralsnog is het signaleringsinstrument in de sector verstandelijk gehandicaptenzorg alleen bedoeld voor afdelingen voor cliënten met een meervoudige (ernstige) verstandelijke handicap. 
Sinds de jaren negentig is het uitgangspunt voor het kwaliteitsbeleid 'professionele zelfregulering'. ${ }^{3}$ In het Model Kwaliteitssysteem Gehandicaptenzorg zijn enkele kwaliteitsnormen vastgelegd voor de verstandelijk gehandicaptenzorg, ${ }^{4}$ In dit model wordt niet verwezen naar opleidingseisen of kwaliteitsnormen van hulpverleners in de verstandelijk gehandicaptenzorg. Dit is nog een braakliggend terrein in deze sector. ${ }^{-5}$ De Inspectie voor de Gezondheidszorg constateert in het jaarrapport $2001^{\circ}$ dat in de gehandicaptenzorg geen normering bestaat voor kwantiteit en kwaliteit van personeel.

In de gehandicaptenzorg wordt niet systematisch, op grond van bestaande zorgoragen onderbouwd aan welke kwaliteitseisen de benodigde personeelsformatie moet voldoen. Dat leidt tot problemen in het primaire proces. Dit blijkt uit het algemeen toezicht in de gehandicaptenzorg en komt ook naar voren uit bijvoorbeeld meldingen over cliënten in de zorg, die verbrandingen opliepen doordat ze werden blootgesteld aan te heet badwater. $*$

De gewenste kwantitatieve bezetting is duidelijk, aldus de Inspectie. Dit geldt echter niet voor de kwalitatieve eigenschappen van het personeel. Niet helder is of het personeel specifieke opleidingen of achtergronden nodig heeft: verpleegkundig, verzorgend of agogisch? De Inspectie beschouwt het niet als haar taak om deze normen te ontwikkelen en legt de verantwoordelijkheid bij het veld. Ook de brancheorganisatie VGN is terughoudend. $\mathrm{Zij}$ wil vooralsnog niet verder gaan dan het creëren van randvoorwaarden en laat het ontwikkelen van normen over aan het veld. De Inspectie belemmert op deze manier de uitvoering van haar eigen werkzaamheden. Door het ontbreken van kwaliteitsnormen kan zij niet de benodigde informatie over het veld verzamelen; een belangrijke voorwaarde voor de Inspectie om haar functies goed te kunnen vervullen. Tegelijkertijd is het niet de taak van de Inspectie om normen voor het veld te gaan ontwikkelen.

De evaluatie van de Kwaliteitswet zorginstellingen laat zien dat het veld onvoldoende de verantwoordelijkheid op zich heeft genomen om normen te ontwik-

63 J. Smits, "Het recht op kwaliteit", Markant, (8), 2003-2, p. 13.

64 Vereniging Gehandicaptenzorg Nederland, Model Kwaliteitssysteem Gehandicaptenzorg, Utrecht: 2000.

65 De Nederlandse vereniging van artsen voor verstandelijk gehandicapten (NVAVG) heeft in 1999 opleidingseisen opgesteld. Sinds 8 februari 2000 is het medisch specialisme arts voor verstandelijk gehandicapten (AVG) erkend, http://www.nvavg.nl.

66 Inspectie voor de Gezondheidszorg, Jaarrapport Inspectie voor de Gezondheidszorg 2001, Den Haag 2002c, p. 69-70.

67 Inspectie voor de Gezondheidszorg 2002c, p. 69. 
kelen voor verantwoorde zorg. ${ }^{\star \infty}$ Deze wet heeft tot nu toe onvoldoende geleid tot een actieve, integrale aanpak van kwaliteit door het veld. Met de komst van deze wet zijn de erkenningsnormen op grond van de Ziekenfondswet en de $\mathrm{Al}$ gemene Wet Bijzondere Ziektenkosten (AWBZ) komen te vervallen. Hierin was bepaald dat in elk instituut altijd een verpleegkundige aanwezig moest zijn. Zorgaanbieders mogen nu zelf bepalen op welke wijze zij verantwoorde zorg bieden aan cliënten. Het zou echter goed zijn als de verstandelijk gehandicaptenzorg inzichtelijk zou maken wat zij onder 'goede zorg' verstaat, over welke kennis en vaardigheden hulpverleners moeten beschikken, welke disciplines essentieel zijn in de sector en hoe de onderlinge verhouding moet zijn tussen de verschillende disciplines. ${ }^{\omega}$ De ontwikkeling van dergelijke normen draagt ook bij aan het verduidelijken van de professionele standaard van de verscheidene beroepsgroepen in de verstandelijk gehandicaptenzorg. Tevens dient de sector stil te staan bij de vraag wat de achtergrond moet zijn van zorgverleners in deze sector. Mede naar aanleiding van het badincident rees de vraag of alle zorgverleners verpleegkundigen moeten zijn. Op afdelingen waar verpleegtechnische handelingen verricht moeten worden, verdient het aanbeveling om de aanwezigheid van een verpleegkundige te garanderen. De praktijk leert dat slechts voor een klein deel van alle handelingen in de verstandelijk gehandicaptenzorg de aanwezigheid van verpleegkundigen vereist is. Het merendeel van de handelingen is gericht op het bieden van ondersteuning aan cliënten. Ook dan zijn echter bepaalde vaardigheden vereist. Om te kunnen werken met een tillift moet een hulpverlener over enige vaardigheden beschikken en kennis hebben van het bijbehorende protocol. Dit geldt ook voor het toepassen van vrijheidsbeperkende maatregelen.

Het is de verantwoordelijkheid van een instituut om aan de hand van kwaliteitsnormen na te gaan of hulpverleners over voldoende kennis en vaardigheden beschikken om ondersteuning te bieden aan cliënten. ${ }^{70} \mathrm{Zijlstra}$ wijst er terecht op dat hulpverleners in de zorg voor mensen met een verstandelijke beperking, ongeacht hun achtergrond, moeten beschikken over bepaalde vaardigheden. Dit geldt te meer als sprake is van cliënten met een (ernstige) meervoudige handicap. 'Personen met meerooudige beperkingen hebben zorgverleners nodig die gericht zijn op de persoon en niet op zijn onmogelijkheden. Dit vereist wel degelijk een bepaald den-

Kamerstukken II 2002/03, 28 439, nr. 1.

69 J. de Koning, "Hoezo ongekwalificeerd?", Markant, (6), 2001-8, p. 22.

70 In dit kader wordt ook wel gesproken over competentiemanagement. Onder competentie wordt verstaan de kennis, de vaardigheden en de ervaring waarover een medewerker beschikt. Per functie in de sector verstandelijk gehandicaptenzorg kan een bepaald competentieprofiel worden opgesteld. Dit zijn competenties die nodig zijn om een functie goed uit te kunnen oefenen. 
kniveau en er dient een bepaalde beroepshouding te worden ontwikkeld die gericht is op het leren kennen van de persoon in tegenstelling tot een houding die alleen maar gericht is op het zo goed mogelijk verzorgen en/of ontwikkelen. Permanente scholing is hierbij van belang. Deze permanente scholing dient aan te sluiten bij de leerbehoeften, leerstijlen en de motivatie tot leren bij de zorgverleners. ${ }^{n}$ Een actieve betrokkenheid van het management is een vereiste om het niveau van het personeel op peil te houden, aldus Zijlstra. ${ }^{72}$ Deze betrokkenheid kan nog meer gestalte krijgen door het aanbieden van (bij)scholing. Op deze manier blijft de kwaliteit van het personeel op een verantwoorde manier gewaarborgd. ${ }^{23}$ Beroepsverenigingen kunnen op hun beurt actief aan de slag gaan met het beschrijven van de competenties van hun leden. Deze beschrijvingen kunnen als uitgangspunt dienen voor de (bij)scholing die in en ook buiten instellingen wordt gegeven aan hulpverleners. ${ }^{74}$

De sector verstandelijk gehandicaptenzorg bevindt zich nog in een beginstadium van het formuleren van kwaliteitsnormen. Geen enkele partij lijkt het voortouw te willen nemen in het ontwikkelen van deze normen. Mede naar aanleiding van de incidenten heeft in 2002 een eerste overleg plaatsgevonden tussen de Inspectie en de VGN over het ontwikkelen van kwaliteitsnormen voor het personeel in de verstandelijk gehandicaptenzorg. Het is belangrijk dat het veld bij deze overlegvormen wordt betrokken. Op deze manier blijft het veld ook verantwoordelijk voor de kwaliteit van zorg. Ondanks deze initiatieven lijkt het alsof het geduld van de overheid opraakt. In een brief van de Staatssecretaris van VWS, naar aanleiding van de evaluatie van de Kwaliteitswet zorginstellingen, wordt een harde lijn ingezet. ${ }^{75}$ Legemaate spreekt zelfs van een trendbreuk in het

71 R. Zijlstra, Dansen met olifanten. Een onderzoek naar de implementatie van het opvoedingsprogramma in de zorg voor mensen met ernstige meervoudige beperkingen (diss. Groningen), Stichting Kinderstudies: Groningen 2003, p. 162.

72 Zijlstra 2003, p. 162.

73 De Wet big heeft ook als taak om de kwaliteit van medewerkers te bewaken. De artikel 3 beroepen, waartoe AVG'en, gezondheidszorgpsychologen en verpleegkundigen behoren, worden geacht de opleidingseisen en deskundigheidsgebieden nader bij AMvB te regelen. De deskundigheidsgebieden zijn voor artsen en verpleegkundigen op vrij globale wijze reeds in de Wet big omschreven.

74 Naast de AVVV, die het beroepscompetentieprofiel heeft beschreven van de basisverpleegkundige in de verstandelijk gehandicaptenzorg (AVVV, 2004) is ook Werveling (de beroepsvereniging voor verpleegkundigen en verzorgenden in de verstandelijk gehandicaptenzorg) bezig met het beschrijven van de competenties van verpleegkundigen in de zorg voor mensen met een ernstige meervoudige verstandelijke handicap.

Kamerstukken II 2002/03, 28 439, nr. 2. 
beleid van de overheid. ${ }^{76}$ Als het veld niet zelf de verantwoordelijkheid op zich wil nemen, dient de overheid in te grijpen, aldus de staatssecretaris. Zo wordt opgemerkt dat 'de eis dat zorg van een kwalitatief verantwoord niveau is, niet langer vrijblijvend mag zijn'. Reeds eerder plaatste de Minister van VWS in het kabinetsstandpunt op de evaluatie Kwaliteitswet zorginstellingen een aantal kanttekeningen:?

'De tegenhanger van het kaderkarakter van de Kwaliteitswet is zelfregulering. Deze zelfregulering moet dan wel in de praktijk plaatsvinden. Hier ontbreekt volgens de evaluatie nog het nodige aan. Indien niet binnen afzienbare tijd sterker en met duidelijke resultaten gestalte wordt gegeven aan deze verantwoordelijkheid, dan zal ik op een aantal punten mijn beleid scherper vastleggen.

'(...) de veldpartijen moeten meer energie steken in de ontwikkeling van veldnormen en kwaliteitssystemen. Dat dat hard nodig is, zie ik als de belangrijkste conclusie van de evaluatie. De Inspectie kan hierbij een positieve rol spelen, door deze ontwikkeling te volgen en waar nodig te stimuleren, signaleren en corrigeren."

De Staatssecretaris van VWS komt met een aantal aanbevelingen met als inzet een betere naleving van de Kwaliteitswet zorginstellingen en betere waarborgen voor goede zorg. Het veld behoudt zijn eigen verantwoordelijkheid, maar wordt meer aangesproken op het publiekelijk verantwoording afleggen over kwaliteit en doelmatigheid van de geleverde zorg. Om aan deze taak te kunnen voldoen wordt het voor zorgaanbieders nog belangrijker om kwaliteitsnormen te ontwikkelen, op grond waarvan de Inspectie kan beoordelen of sprake is van verantwoorde zorg. Ook in het rapport 'de Staat van de gezondheidszorg' is deze harde lijn terug te vinden. Indien zorgaanbieders zich onvoldoende inzetten voor het ontwikkelen van een adequaat kwaliteitsbeleid, zal de Inspectie mogelijk overgaan tot het opleggen van sancties. ${ }^{70}$

De gewijzigde koers van de overheid is niet onbegrijpelijk. Ondanks de verantwoordelijkheid van het veld behoudt de overheid een eigen verantwoordelijkheid ten aanzien van de kwaliteit van zorg in de verstandelijk gehandicaptenzorg. Zij kan, mede op grond van artikel $22 \mathrm{Gw}$, eisen stellen en voorwaarden scheppen, welke voor de kwaliteit van zorg bevorderlijk zijn, en toezicht uitoefenen. Het is voor de rechtspositie van cliënten ook noodzakelijk dat de overheid deze verantwoordelijkheid op zich neemt. Naarmate het veld op dit gebied

\section{Legemaate 2003a, p. 15-16.}

77 Kamerstukken II 2002/03, 28 439, nr. 1.

78 Inspectie voor de Gezondheidszorg, Staat van de gezondheidszorg 2002, Kwaliteitsborging in zorginstellingen: intentie, wet en praktijk, Den Haag: 2002d. 
minder initiatief onderneemt, zal de overheid niet kunnen volstaan met alleen maar indirecte regelingen. 7 ?

In de Tweede Kamer zijn ook geluiden hoorbaar dat de kwaliteit in de verstandelijk gehandicaptenzorg dusdanig te wensen overlaat, dat ingrijpen van de overheid noodzakelijk is. In november 2000 heeft toenmalig kamerlid Dankers naar aanleiding van de zorgkloof in de sector verstandelijk gehandicaptenzorg (met name voor mensen met een intensieve zorgvraag) een motie ingediend waarin zij verzoekt om een concreet meerjarenplan voor de kwaliteitsverbetering van de zorg voor mensen met een meervoudige en/of complexe handicap. ${ }^{*}$ Belangrijke punten zijn het uitbreiden van consulententeams, meer begeleiders per groep en het verkleinen van de samenlevingsgroepen. In de motie wordt aan de minister gevraagd of binnen drie jaar de kwaliteit op het gewenste niveau kan worden gebracht. Uit de reactie van de toenmalige Staatssecretaris van VWS kan worden opgemaakt dat het de taak van de overheid is om in de zorgsector 'actief te participeren in discussies over indringende kwaliteitsvragen van zorg en daaraan zonodig leiding te geven', ${ }^{81} \mathrm{Zij}$ benadrukt echter ook dat zorgverleners een eigen verantwoordelijkheid hebben als het gaat om het bieden van goede zorg. De beleidsmaatregelen die de overheid rond deze thematiek neemt, liggen voornamelijk op het gebied van stimulering en facilitering (o.a deskundigheidsbevordering door middel van expertisecentra, bekostiging naar zorgzwaarte, samenwerkingsverbanden en het realiseren van meer mogelijkheden voor dagbesteding). Inmiddels zijn er vijf regionale centra voor Consultatie en Expertise opgericht. ${ }^{82}$ De maatregelen zijn een stap in de goede richting, maar zullen zonder de medewerking van het veld hun doel voorbij schieten.

\subsection{Richtlijnen in de zorg voor mensen met een verstandelijke handicap}

De professionele standaard van een persoonlijk begeleider kan ook worden uitgewerkt aan de hand van bronnen waarvan een aantal specifiek door de beroepsgroep zijn opgesteld. ${ }^{83}$ Daartoe behoren naast beroepscodes en gedragsregels, vakinhoudelijke en technische regels en regels betreffende specifieke ethi-

79 H.J.J. Leenen en H.D.C. Roscam Abbing, Bestuurlijk gezondheidsrecht, Alphen aan den Rijn/Brussel: Samsom H.D. Tjeenk Willink 1986, p. 57-58.

80 Kamerstukken II 2000-01, 27 401, nr. 10.

81 DBG/OAG-2129481, Brief aan de vaste commissie voor volksgezondheid, welzijn en sport.

82 Deze centra voor consultatie en expertise zijn bedoeld voor cliënten met bijzondere zorgvragen.

83 E.-B. van Veen, De Wgbo: de betekenis voor de hulpverleners in de gezondheidszorg, derde gewijzigde druk, Lelystad: Koninklijke Vermande 2002a, p. 25-27. 
sche kwesties, ook richtlijnen. ${ }^{44}$ Richtlijnen zijn instrumenten voor beroepsbeoefenaren om verantwoorde zorg te leveren. ${ }^{\mathrm{s}}$ Het vaststellen van richtlijnen is geen exclusieve aangelegenheid van de beroepsgroepen voor persoonlijk begeleiders. Ook in voorzieningen voor verstandelijk gehandicaptenzorg worden richtlijnen ontwikkeld. Daarnaast zijn de Inspectie voor de Gezondheidszorg, de Gezondheidsraad en het Kwaliteitsinstituut voor de Gezondheidszorg CBO op dit gebied actief. Deze richtlijnen hebben, anders dan de richtlijnen van de beroepsgroepen, een breder bereik: zij dienen te worden nageleefd door alle beroepsgroepen die werkzaam zijn in de zorg voor mensen met een verstandelijke handicap.

\subsubsection{Richtlijnen van beroepsgroepen en voorzieningen voor mensen met een ver- standelijke handicap}

De afgelopen jaren zijn in de zorg voor mensen met een verstandelijke handicap diverse richtlijnen ontwikkeld. In deze sector is met name de NVAVG actief. Deze beroepsgroep houdt zich voornamelijk bezig met het opstellen van richtlijnen die gericht zijn op diagnostiek en medische problematiek. ${ }^{86}$ Ook de beroepsvereniging voor verpleegkundigen en verzorgenden in de zorg voor mensen met een verstandelijke handicap (Werveling) beoogt de kennis en ervaring van haar leden (persoonlijk begeleiders) te vergroten met het doel de kwaliteit van zorg te verbeteren. $\mathrm{Zij}$ wil deze doelstelling onder meer bereiken door het ontwikkelen van richtlijnen en veldnormen. De afgelopen jaren heeft Werveling meegewerkt aan de richtlijn vrijheidsbeperkende maatregelen ${ }^{87}$ en aan een signaleringsinstrument om de kwaliteit van zorg in een instelling te meten. ${ }^{88}$ Daarnaast wil zij de deskundigheid van het verpleegkundig en verzorgend personeel verder profes-

84 Richtlijn wordt hier gebruikt als verzamelbegrip voor protocol, voorschrift, richtlijn, regeling, standaard, advies en beslisboom.

85 F.C.B. van Wijmen, "Richtlijnen voor verantwoorde zorg. Over de betekenis van standaardisering voor patiënt, professional en patiëntenzorg", Preadvies Vereniging voor gezondheidsrecht, Utrecht: $2000 \mathrm{~b}, \mathrm{p} .75$.

86 Enkele voorbeelden van NVAVG consensusrichtlijnen zijn: richtlijnen voor farmacologische sedatie bij mensen met een verstandelijke handicap, epilepsie bij mentale retardatie, richtlijnen voor diagnostiek en behandeling, wetenschappelijke verantwoording, prikaccidentenprotocol, preventie van Hepatitis $B$ in de zorg voor mensen met een verstandelijke handicap.

87 Kwaliteitsinstituut voor de gezondheidszorg CBO en Verpleegkundig Wetenschappelijke Raad, Het gebruik van vrijheidsbeperkende interventies in de zorg. Een richtlijn voor verpleegkundigen en verzorgenden in een multidisciplinaire omgeving, Utrecht: 2001. 
sionaliseren. Opvallend is dat het alleen gaat om het verder ontwikkelen van specifieke deskundigheid voor verpleegkundige ondersteuning aan mensen met een verstandelijke handicap. Werveling wil het specialisme 'meervoudig complex gehandicapten' als officieel beroepsdeelprofiel realiseren. Hiermee wil zij het belang van verpleging voor de zorg aan gehandicapten op de agenda plaatsen. De afgelopen jaren is het aantal verpleegkundigen in de sector teruggebracht van 70.000 naar $29.000 . "$ Werveling is niet de enige beroepsgroep die actief is op het gebied van het verbeteren van kwaliteit van zorg, ook de AVVV zet zich in om de kwaliteit van verpleegkundigen en verzorgenden in de sector verstandelijk gehandicaptenzorg te verbeteren. $\mathrm{Zij}$ heeft samen met het Trimbos instituut een signaleringsinstrument ontworpen om de kwaliteit van zorg aan cliënten met een (ernstige) meervoudige handicap te kunnen bepalen. ${ }^{\infty}$ Verpleegkundigen en verzorgenden kunnen aan de hand van dit instrument inzichtelijk maken of zij minimale zorg verlenen aan hun cliënten.

Niet alleen beroepsgroepen ontwikkelen richtlijnen. Hulpverleners dienen ook rekening te houden met richtlijnen die in de voorzieningen worden opgesteld. De inhoud hiervan is zeer uiteenlopend en heeft onder meer betrekking op de toepassing van vrijheidsbeperking, hygiëne of voorbehouden handelingen. De Wet Bopz kent echter nog meer begrippen, die in een richtlijn kunnen worden uitgewerkt. Genoemd kunnen worden verzet, wilsbekwaamheid en gevaar. Een richtlijn biedt ook de mogelijkheid om vast te leggen op welke wijze dwangbehandeling of middelen of maatregelen kunnen worden toegepast. De wetgever laat bijvoorbeeld in het midden of een hulpverlener voor de toepassing van dwangbehandeling een second opinion moet aanvragen. Ook wordt geen termijn voor dwangbehandeling genoemd. In artikel 38 lid 3 Wet Bopz is de mogelijkheid opgenomen dat bij AMvB nader wordt bepaald welke behandelingsmiddelen of - maatregelen niet mogen worden toegepast in het kader van dwangbehandeling. Tot nu toe heeft de wetgever niet van deze mogelijkheid gebruik gemaakt. Door middel van zelfregulering kan het veld met richtlijnen komen waarin bijvoorbeeld de toepassing van bepaalde handelingen - zoals EAT - wordt uitgesloten.

\subsubsection{Overige richtlijnen}

De Inspectie heeft de afgelopen jaren een aantal adviezen uitgebracht die specifiek van toepassing zijn op de sector verstandelijk gehandicaptenzorg. Deze adviezen, die in de vorm van referentiekaders, richtlijnen, circulaires of discussie-

89 C.Carbo, "Professionalisering van beroepsbeoefenaren. De knop is nog niet overal om", Markant (8), 2003-9, p. 26-28.

http://www.avvv.nl 
nota's zijn verschenen, zijn niet bindend, maar hebben wel de status van een zwaarwegend advies." ${ }^{\prime \prime}$ Ook vervullen zij in de rechtspraak een belangrijke rol., Persoonlijk begeleiders, maar ook artsen en gedragsdeskundigen, kunnen uit deze adviezen normen afleiden om het begrip goed hulpverlenerschap in de verstandelijk gehandicaptenzorg nader in te vullen. De adviezen gaan niet zover, dat heel gedetailleerd wordt beschreven op welke wijze hulpverleners met bepaalde problematiek om moeten gaan. Uit de keuze van onderwerpen blijkt ook dat de Inspectie zich beperkt tot risicovolle en ingrijpende handelingen:

- Risico's bij het gebruik van de Zweedse band in de gehandicaptenzorg ${ }^{3}$

- Advies sterilisatie van mensen met een verstandelijke handicap ${ }^{9}$

- Protocol Electro Aversie Therapie (EAT) ${ }^{5}$

- Circulaire naar aanleiding van verbrandingen in de gehandicaptenzorg\%

Hulpverleners in de sector verstandelijk gehandicaptenzorg kunnen ook terugvallen op adviezen van de Gezondheidsraad. In 2002 heeft de Gezondheidsraad een advies geschreven over 'Anticonceptie voor mensen met een verstandelijke handicap'." Centraal staat de vraag welke afwegingen een rol spelen als hulpverleners worden geconfronteerd met een verzoek tot anticonceptie, waartoe ook sterilisatie behoort, voor een cliënt met een verstandelijke handicap. Een positief aspect van het advies is dat bij het besluitvormingsproces niet alleen de arts wordt betrokken, maar ook een gedragsdeskundige.

In het advies wordt de nadruk gelegd op 'ouderschapscompetentie'. Een cliënt met een verstandelijke handicap is niet geschikt voor het ouderschap als het ouderschap een te zware last legt op zijn functioneren en als er een grote kans bestaat dat het kind ten gevolge van tekortschietende opvoedingsvaardigheden ernstige

91 Legemaate 1998, p. 22.

92 Hoge Raad 27 juni 1986, NJ 1987, 898 en Rechtbank's Hertogenbosch 6 oktober 1999, kBJ 2000, 30.

93 Inspectie voor de Gezondheidszorg, Risico's bij het gebruik van de Zweedse band in de gehandicaptenzorg, Den Haag: 2002a.

94 Inspectie voor de Gezondheidszorg, Sterilisatie mensen met een verstandelijke handicap. Herzien advies van de Inspectie voor de Gezondheidszorg, Den Haag: 1998.

95 Landelijke Evaluatie Commissie EAT, Protocol Electro Aversie Therapie, Rijswijk: 1997.

96 Inspectie voor de Gezondheidszorg, Circulaire naar aanleiding van verbrandingen in de Gehandicaptenzorg, Den Haag: 2001.

97 Gezondheidsraad, Anticonceptie voor mensen met een verstandelijke handicap, Den Haag: 2002, nr.14. 
schade zal ondervinden. Hierom mag het zelfbeschikkingsrecht van een cliënt ook worden beperkt als sprake is van 'ernstig nadeel' voor anderen."

De kern van het advies van de Gezondheidsraad is dat ook cliënten met een verstandelijke handicap, in de lijn van het burgerschapsparadigma, de ruimte moeten krijgen om hun kinderwens te vervullen. Dit standpunt van de Gezondheidsraad lijkt voorbij te gaan aan de gedachte dat juist in het kader van het burgerschapsparadigma ook stil moet worden gestaan bij de mogelijkheden van cliënten en de mate waarin deze mogelijkheden door middel van ondersteuning verder tot ontwikkeling kunnen worden gebracht. Het zelfbeschikkingsrecht is niet het enige uitgangspunt waar in de verstandelijk gehandicaptenzorg rekening mee moet worden gehouden. Ook het beschermingsbeginsel speelt in deze sector een rol. In de lijn van hoofdstuk 3 ligt het in de rede dat het zelfbeschikkingsrecht van een cliënt in bepaalde situaties, waaronder als sprake is van een kinderwens, wordt beperkt. Er zijn tal van situaties denkbaar waarin het voorkomen van een kinderwens een grotere bijdrage zal leveren aan de ontplooiing van cliënten dan wanneer de kinderwens in de praktijk wordt gerealiseerd. In dat kader is wel van belang dat de inbreuk op het zelfbeschikkingsrecht voldoet aan de eerder genoemde eisen van eisen van effectiviteit, proportionaliteit en subsidiariteit. Het mag niet zo zijn dat hulpverleners al bij voorbaat een kinderwens van een cliënt ontmoedigen en daarbij overstappen op de meest ingrijpende vorm van anticonceptie: sterilisatie.

Vanuit het oogpunt van goed hulpverlenerschap verdient het aanbeveling dat samen met de cliënt en andere disciplines de huidige situatie van een cliënt in kaart wordt gebracht en zorgvuldig wordt afgewogen welke optie in het belang van de cliënt is en bijdraagt aan zijn ontplooiingsmogelijkheden. Op deze manier wordt het zelfbeschikkingsrecht van cliënten ook zo veel mogelijk in stand gehouden.9

98 In de Wgbo bestaat in het kader van dwangbehandeling alleen ruimte voor 'ernstig nadeel voor de cliënt zelf' (artikel 7:465 lid 6 BW). De Wet Bopz gaat wel uit van een ruimer criterium: gevaar voor de cliënt zelf of voor anderen (artikel 38 lid 5 Bopz).

99 In het standpunt op het advies 'Anticonceptie voor mensen met een verstandelijke handicap' stelt de Staatssecretaris van VWS een ontmoedigingsbeleid voor. Daarnaast wordt voorgesteld om protocollen en richtlijnen op te stellen waarbij getoetst kan worden of een cliënt in staat is tot verantwoord ouderschap (IBE/E2472312). 


\subsubsection{Problemen rond het formuleren van richtlijnen}

Hoewel in de zorg voor mensen met een verstandelijke handicap diverse richtlijnen zijn ontwikkeld, is een aantal essentiële begrippen nog altijd niet nader uitgewerkt. Persoonlijk begeleiders moeten regelmatig 'verzet' van cliënten interpreteren. In de praktijk ontbreekt een duidelijke omschrijving van dit begrip. Andere begrippen die om een nadere uitwerking vragen zijn ernstig nadeel voor de cliënt en wilsonbekwaamheid. De afgelopen jaren zijn diverse pogingen ondernomen om criteria te ontwikkelen voor wilsonbekwaamheid. ${ }^{100}$ Deze pogingen hebben tot nu toe nog niet geleid tot een bruikbare richtlijn. In de laatste evaluatie van de Wet Bopz wordt nogmaals bevestigd dat het veld zeer gebaat zou zijn bij een richtlijn op dit gebied. In het eindrapport luidt één van de aanbevelingen: 'de overheid behoort onderzoek te stimuleren naar begripsverheldering ter zake van de wilsonbekwaamheid en naar het ontwikkelen van richtlijnen voor de operationalisering en de praktische toepassing van de criteria voor wilsonbekwaamheid in de context van de Wet Bopz en andere gezondheidswetten. ${ }^{10 t}$ De vraag is echter of het haalbaar is om een richtlijn voor deze ingewikkelde materie te ontwikkelen. Het verleden heeft laten zien dat het uitermate lastig is om inhoudelijke criteria te formuleren. ${ }^{102}$ Het is ook onduidelijk welke partij deze criteria moet gaan ontwikkelen. Het veld lijkt in een impasse te zitten. Legemaate wijst erop dat het veld niet de ruimte benut die het krijgt om bij te dragen aan de ontwikkeling en interpretatie van normen. Hij spreekt zelfs over gemiste kansen die het risico

100 M.C.I.H. Biesaart en J.H. Hubben, Beoordeling van wilsonbekwaamheid bij mensen met een verstandelijke handicap, Nijmegen: KU Nijmegen, Faculteit der Rechtsgeleerdheid 1997; M.C.I.H. Biesaart en J.H. Hubben, Methodiek voor de vaststelling van wilsonbekwaamheid bij mensen met een verstandelijke handicap, Nunspeet: Bestuurscentrum Stichting Philadelphia Zorg en Utrecht: Vereniging Gehandicaptenzorg Nederland 2000; Ministerie van Justitie, Handreiking voor de beoordeling van wilsbekwaamheid. Den Haag: 1994.

101 Begeleidingscommissie evaluatie Wet Bopz, Evaluatie Wet Bopz, Deelonderzoek 10-10: Conclusies en aanbevelingen van de begeleidingscommissie, Den Haag: ZonMw 2002, p. 45

102 Hulpverleners kunnen in de praktijk echter niet zonder criteria voor wilsonbekwaamheid. De kans is groot dat hulpverleners zich laten leiden door hun eigen belangen. Door middel van criteria kan het besluitvormingsproces ten aanzien van wilsonbekwaamheid inzichtelijker worden gemaakt (S.P.K. Welie, "Wilsbekwaamheid in de gezondheidszorg", in: P.J. van Koppen et al. (red.). Het recht van binnen: psychologie van het recht, Deventer; Kluwer 2002, p. 86-90). Een belangrijke vraag is of de nadruk moet blijven liggen op het zoeken naar 'materiele criteria' of dat het accent moet gaan verschuiven naar 'procedurele criteria'. Het ontwikkelen van materiele criteria lijkt onbegonnen werk. 
van een intensivering van bemoeienis van de overheid en andere toezichthouders doen toenemen. ${ }^{103}$

Een grotere inmenging van de overheid is terecht als het gaat om dreigende situaties. Als de zorg onder een bepaald niveau komt, moet de overheid de mogelijkheid hebben om in te grijpen. Tegelijkertijd is het geen goede ontwikkeling als de overheid volledig de regie in handen neemt. Het verlenen van ondersteuning aan cliënten dient een verantwoordelijkheid te zijn van zowel het veld als de overheid. Beide partijen zouden zich meer gezamenlijk moeten inspannen om een nadere invulling te geven aan wettelijke begrippen. Voorkomen moet worden dat de wetgever het veld met te vage begrippen opzadelt. ${ }^{104}$ Vage begrippen, die bovendien niet aansluiten bij de specifieke eigenschappen van de sector verstandelijk gehandicaptenzorg, kunnen ook leiden tot onverschilligheid bij het veld. De Wet Bopz is daar een goed voorbeeld van. Hulpverleners hebben aan een aantal begrippen uit deze wet (waaronder verzet en gevaar) een eigen invulling gegeven. Tegelijkertijd is het onvermijdelijk dat bepaalde wettelijke begrippen niet tot in detail worden uitgewerkt door de wetgever. Een voorbeeld is het begrip vrijheidsbeperking: onduidelijk is wat allemaal onder dit begrip valt. Behalve dat dit begrip in overleg met het veld nog nader kan worden omschreven, is het veel belangrijker dat hulpverleners kunnen verantwoorden dat de maatregel die zij hebben toegepast ook daadwerkelijk noodzakelijk was. Hiervan is sprake als deze heeft bijgedragen aan de ontwikkeling van een cliënt. Ook dit aspect behoort tot goed hulpverlenerschap.

Om te verhinderen dat hulpverleners in de nabije toekomst worden overspoeld met (nieuwe) begrippen, normen en richtlijnen, dienen zij stappen te ondernemen. In het rapport Signalering Ethiek en Gezondheid van de Raad voor de Volksgezondheid en Zorg wordt ook gewezen op het belang van het ontwikkelen van nieuwe vormen van professionaliteit. ${ }^{105}$ Hulpverleners zullen hun eigen positie moeten bepalen in het centrale dilemma dat zich nu voordoet in deze sector: ruimte geven voor zelfbeschikking enerzijds en bieden van bescherming

103 Legemaate 2003a, p. 15.

104 Kastelein merkt in haar inaugurale rede op dat de overheid zoveel mogelijk de zaken concreet moet regelen; geen globale juridische normen indien niet noodzakelijk. Ook moet de overheid bij onderwerpen waarover geen consensus bestaat niet teveel vertrouwen op zelfregulering. W.R. Kastelein, Patiëntenwetgeving: bureaucratie of bescherming? Toetsing van (evaluatie van) patiëntenwetgeving (inaugurale rede Nijmegen), Lelystad: Koninklijke Vermande 2002.

105 Schuurman, M.L.H., "Zelfbeschikking en eigen verantwoordelijkheid van mensen met een verstandelijke handicap", in: Raad voor de Volksgezondheid en Zorg, Signalering Ethiek en Gezondheid, Zoetermeer: 2003, p. 80. 
en professionele begeleiding anderzijds. Het ontwikkelen van richtlijnen kan hierbij een belangrijk hulpmiddel zijn.

\subsection{Beschouwing}

In deze beschouwing staat een tweetal vragen centraal. De eerste vraag luidt: ' In hoeverre is goed hulpverlenerschap vastgelegd in een juridisch kader? De tweede vraag is: 'In hoeverre wordt in het juridische kader, ten aanzien van goed hulpverlenerschap, rekening gehouden met de specifieke eigenschappen van de verstandelijk gehandicaptenzorg?'

In hoeverre is goed hulpverlenerschap vastgelegd in een juridisch kader?

In de zorg voor mensen met een verstandelijke handicap heeft elke hulpverlener, waaronder ook een persoonlijk begeleider, een eigen verantwoordelijkheid ten aanzien van zijn handelen. Deze is uitgewerkt in een professionele standaard, die wordt vormgegeven door de beroepsgroep waarvan hij deel uitmaakt. De professionele standaard van een hulpverlener is te beschouwen als een uitwerking van het begrip goed hulpverlenerschap (artikel 7:453 BW). Elke hulpverlener dient de zorg van een goed hulpverlener te betrachten: bij de uitoefening van zijn beroep dient hij enerzijds rekening te houden met ethische, juridische en maatschappelijke normen, anderzijds behoudt hij een eigen verantwoordelijkheid die gebaseerd is op kennis en ervaring van zijn beroepsgroep.

In de gezondheidsrechtelijke literatuur zijn verschillende opvattingen te vinden over goed hulpverlenerschap. Leenen verstaat onder goed hulpverlenerschap (in de zin van artikel 7:453 BW) alleen de 'medisch-professionele standaard'. Hij maakt een onderscheid tussen de professionele standaard die is gebaseerd op normen die extern worden opgelegd en de medisch-professionele standaard die is gebaseerd op wetenschappelijke kennis en ervaring die in de praktijk is opgedaan. Dit onderscheid benadrukt dat de bemoeienis van de wetgever niet onbegrensd is; een hulpverlener behoudt een eigen verantwoordelijkheid. Deze visie over goed hulpverlenerschap kan ook worden doorgetrokken naar de zorg voor mensen met een verstandelijke handicap. Elke beroepsgroep die in deze sector werkzaam is heeft een professionele standaard, waarvan een deel wordt ingevuld door de beroepsgroep zelf. Dit geldt ook voor een persoonlijk begeleider. Een duidelijk omschreven professionele standaard verstevigt zijn positie en biedt meer tegenwicht aan andere hulpverleners die in deze sector werkzaam zijn: artsen en gedragsdeskundigen. Al eerder is opgemerkt dat een persoonlijk begeleider een belangrijke functie vervult in de zorg voor mensen met een verstandelijke handicap. Hij is betrokken bij de dagelijkse ondersteuning aan cliënten en vormt het aanspreekpunt voor de cliënt, zijn vertegenwoordiger en andere hulpverleners die betrokken zijn bij de ondersteuning die wordt geboden. Een nader omschreven professionele standaard kan ertoe bijdragen dat inzichte- 
lijk wordt gemaakt welke taken tot het domein behoren van een persoonlijk begeleider, in hoeverre een persoonlijk begeleider verantwoordelijk is voor zijn handelen (bijvoorbeeld ten aanzien van de toepassing van vrijheidsbeperking) en aan welke opleidingseisen een persoonlijk begeleider moet voldoen.

De professionele standaard van een persoonlijk begeleider is, in tegenstelling tot die van medici, doorgaans niet medisch georiënteerd. Voor deze beroepsgroep is het van belang dat van een andere benadering wordt uitgegaan: een persoonlijk begeleider heeft maar een beperkte medische kennis. De nadruk die in het verleden werd gelegd op het bieden van medische zorg behoort inmiddels tot het verleden. Aan het einde van de vorige eeuw is mede door het burgerschapsparadigma de aandacht verschoven naar het bieden van ondersteuning. Het handelen van een persoonlijk begeleider staat voornamelijk in het teken van het tot ontplooiing brengen van de mogelijkheden van cliènten. Uiteraard valt in bepaalde situaties niet te ontkomen aan het verlenen van (medische) zorg. ${ }^{100} \mathrm{De}$ beroepsverenigingen van een persoonlijk begeleider (Werveling, de AVVV en de NVSPH) hebben de afgelopen jaren bepaald niet stil gezeten. $\mathrm{Er}$ is inmiddels genoeg materiaal verzameld om een begin te maken met het invullen van de professionele standaard van een persoonlijk begeleider. De inhoud van het materiaal binnen Werveling en de AVVV beperkt zich nog wel tot de medische deskundigheid: het gaat voornamelijk om het verder ontwikkelen van de specifieke deskundigheid van verpleegkundige ondersteuning aan mensen met een verstandelijke handicap. ${ }^{100}$ In de praktijk gaat het echter veel meer om het ondersteunen van cliënten bij hun dagelijkse bezigheden. Persoonlijk begeleiders lopen tegen vragen aan die te maken hebben met de reikwijdte van hun verantwoordelijkheden. Regelmatig moet een afweging worden gemaakt tussen het in bescherming nemen van en het loslaten van een cliënt.

Blijkbaar is het niet eenvoudig om dergelijke (niet-medische) problematiek nader te omschrijven in een professionele standaard van een persoonlijk begeleider. Dit vormt te meer een reden voor persoonlijk begeleiders om mede in het kader van goed hulpverlenerschap hun handelen te verantwoorden aan derden. Bij afwezigheid van richtlijnen is het belangrijk dat een persoonlijk begeleider kan aantonen dat hij heeft gehandeld met de zorgvuldigheid die van 'redelijk handelende persoonlijk begeleiders' in de gegeven omstandigheden mocht worden verwacht. Onder zorgvuldigheid wordt verstaan dat hij zich bekwaam achtte om in de gegeven situatie te handelen, overleg heeft gepleegd met de cliënt en/of

106 Dit geldt met name voor cliënten met een (zeer) ernstige meervoudige verstandelijke handicap.

107 Dit neemt niet weg dat er ook andere ontwikkelingen gaande zijn: de richtlijn vrijheidsbeperkende maatregelen en een signaleringsinstrument om de kwaliteit van zorg in een instelling te meten. 
vertegenwoordiger, een collega of andere disciplines heeft geraadpleegd en verslag heeft gedaan in het zorgplan van de cliënt. De criteria subsidiariteit, proportionaliteit en effectiviteit kunnen bij het nemen van beslissingen een ondersteunende rol spelen. Deze werkwijze bevordert dat de verschillende stappen die zijn gezet toetsbaar zijn voor derden waaronder de cliënt, de vertegenwoordiger, andere hulpverleners en de Inspectie. Het veld dient ook aan de slag te gaan met het nader invullen van de professionele standaard van persoonlijk begeleiders. Het management van een voorziening is mede verantwoordelijk voor het bijscholen van personeel, voor het afbakenen van verantwoordelijkheden van hulpverleners en voor het opstellen van richtlijnen als het gaat om risicovolle handelingen zoals het separeren of fixeren van een cliënt.

De wetgever stelt zich terughoudend op als het gaat om de invulling van goed hulpverlenerschap: in de Wgbo, de Wet big en de Kwaliteitswet zorginstellingen wordt de verantwoordelijkheid voor goede zorg neergelegd bij de voorzieningen voor verstandelijk gehandicaptenzorg en de hulpverleners die in deze sector werkzaam zijn. Er zijn echter ook signalen dat de wetgever zich steeds meer gaat bemoeien met het veld. Deze bemoeienis begrenst de mogelijkheden van zelfregulering. De evaluatie van de Kwaliteitswet zorginstellingen laat zien dat het veld onvoldoende de verantwoordelijkheid neemt om normen te ontwikkelen voor verantwoorde zorg overeenkomstig artikel $2 \mathrm{Kwz}$. De Minister en de Staatssecretaris van VWS hebben aangegeven dat de overheid, indien het veld niet haar verantwoordelijkheid neemt, tot maatregelen zal overgaan. $\mathrm{Zij}$ heeft de mogelijkheid om, mede op grond van artikel $22 \mathrm{Gw}$, eisen te stellen en voorwaarden te scheppen teneinde de kwaliteit van zorg te garanderen en op een hoger peil te brengen.

Ook de rechter heeft de afgelopen jaren een aantal uitspraken gedaan die bepalend zijn voor de invulling van goed hulpverlenerschap. ${ }^{108}$ De rechter spreekt zich steeds nadrukkelijker uit over de verantwoordelijkheid van een hulpverlener dan wel een voorziening. De strekking van deze uitspraken is dat een hulpverlener bepaalde kwaliteiten moet bezitten. Ook dient het management van een voorziening zorg te dragen voor de beschikbaarheid van adequate richtlijnen en goede werkomstandigheden (opleiding, voldoende hulpmiddelen, gekwalificeerd personeel). Op grond van de Kwaliteitswet zorginstellingen kan het management verantwoordelijk worden gehouden voor het kwaliteitsbeleid in een voorziening. Daarnaast kunnen de verschillende beroepsgroepen op dit gebied een bijdrage leveren. $\mathrm{Zij}$ kunnen vastleggen over welke kwaliteiten zij dienen te beschikken, welke verantwoordelijkheden zij behoren te hebben en over welke

108 Rechtbank Middelburg 17 april 2002, TvGr 2003/11, Rechtbank Breda 20 augustus 2002, BJ 2002, 49, m.nt. A. Blok. 
kennis zij beschikken. Een voorziening kan deze knowhow meenemen in haar kwaliteitsbeleid. Als een voorziening op dit punt in gebreke blijft kan de overheid ingrijpen. De Kwaliteitswet zorginstellingen geeft de minister de bevoegdheid een schriftelijke aanwijzing te geven (artikel 7 lid $1 \mathrm{Kwz}$ ) en de Inspectie de bevoegdheid een schriftelijk bevel uit te vaardigen (artikel 7 lid $4 \mathrm{Kwz}$ ). Ondanks dat het veld (nog) onvoldoende initiatieven toont op het gebied van kwaliteitsbeleid en het nader invullen van professionele standaarden, mag het niet zo zijn dat de overheid deze verantwoordelijkheid geheel op zich gaat nemen. Hulpverleners, waaronder persoonlijk begeleiders, zullen temidden van alle ontwikkelingen die gaande zijn, hun eigen positie moeten (blijven) bepalen. De rol van de overheid dient zich te beperken tot het stimuleren en, indien nodig, het ondersteunen van de ontwikkelingen die in het veld gaande zijn.

In hoeverre wordt in het juridische kader, ten aanzien van goed hulpverlenerschap, rekening gehouden met de specifieke eigenschappen van de verstandelijk gehandicaptenzorg? Mede ten gevolge van de gewijzigde visie in de verstandelijk gehandicaptenzorg wordt van hulpverleners verwacht dat zij een andere invulling geven aan goed hulpverlenerschap. Een belangrijk aspect van het burgerschapsparadigma is het verlenen van ondersteuning aan cliënten. De juiste vorm en intensiteit van ondersteuning biedt een cliënt de mogelijkheid om zich verder te ontwikkelen. De wijze waarop invulling wordt gegeven aan ondersteuning vereist bepaalde vaardigheden van een hulpverlener. Van belang is dat hij zorgvuldig en inzichtelijk handelt. Een goed hulpverlener dient een cliënt op de juiste momenten los te laten. Op andere momenten biedt hij gepaste ondersteuning aan cliënten. Deze wijze van handelen is niet vastgelegd in wetgeving, maar dient een hulpverlener (of zijn beroepsgroep) zich eigen te maken en doet een beroep op zijn creativiteit. Deze moet er toe leiden dat het spanningsveld tussen bescherming en zelfbeschikking niet meer centraal staat: een persoonlijk begeleider voldoet pas echt aan de norm van goed hulpverlenerschap als hij het dilemma tussen bescherming en zelfbeschikking weet te vermijden.

Een persoonlijk begeleider krijgt in zijn dagelijkse werkzaamheden ook te maken met wetgeving: de inhoud van de Wet Bopz en de Wgbo maken onderdeel uit van zijn professionele standaard. De wetgever heeft met de invoering van de Wet Bopz afstand genomen van het bestwil-criterium. Deze wet legt het accent op het zelfbeschikkingsrecht van cliënten. Hulpverleners mogen de vrijheid van cliënten beperken, mits voldaan is aan het gevaarscriterium. Dit criterium is echter niet eenvoudig te operationaliseren in de zorg voor mensen met een verstandelijke handicap. ${ }^{109}$ Een strikte interpretatie van gevaar staat het verlenen

109 In hoofdstuk 5, 6 en 7 wordt nader ingegaan op deze problematiek. 
van goede zorg in de weg. Cliënten hebben behoefte aan zorg, oftewel aan ondersteuning in termen van het burgerschapsparadigma. Goed hulpverlenerschap omvat in de zorg voor mensen met een verstandelijke handicap meer dan niet ingrijpen en geen bemoeienis hebben met de cliënt. Het gevaar is wel aanwezig dat hulpverleners zich teveel gaan bemoeien met een cliënt waardoor de vrijheid van cliënten op bepaalde momenten onnodig wordt beperkt. Deze wijze van handelen leidt niet tot goede zorg, maar eerder tot paternalistisch handelen. Het is niet gepast als cliënten alle risico's worden ontnomen. Twee recente uitspraken laten echter het tegendeel zien. ${ }^{110}$ De rechter lijkt in deze uitspraken terug te willen gaan naar het bestwil-criterium. Hij gaat echter nog een stap verder. Van hulpverleners wordt verwacht dat zij beletten dat cliënten worden blootgesteld aan risico's. In beide arresten werd de causaliteit tussen het overtreden van de veiligheidsnorm en de gevolgen die dit heeft gehad voor de cliënt vrij snel aangenomen. Beide uitspraken dragen echter niet bij aan een juiste invulling van goed hulpverlenerschap in de sector verstandelijk gehandicaptenzorg. Ook het bieden van goede zorg komt op deze manier in het gedrang. Enerzijds mogen hulpverleners als gevolg van de Wet Bopz niet te snel ingrijpen in het zelfbeschikkingsrecht van cliënten, anderzijds komt uit jurisprudentie naar

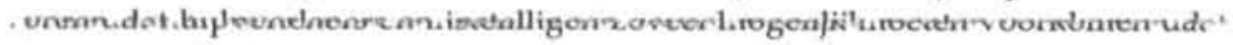
cliënten worden blootgesteld aan risico's, wat leidt tot strikte veiligheidsnormen. Dit dilemma kan niet door het veld alleen worden opgelost. Het is voor hulpverleners onmogelijk om cliënten te beschermen tegen alle denkbare risico's. Dit kan niet de bedoeling zijn goed hulpverlenerschap en is ook niet bevorderlijk voor de ontplooiing van cliënten.

De veranderingen die gaande zijn in de zorg voor mensen met een verstandelijke handicap vragen aldus om een andere houding van hulpverleners, die nader uitgewerkt moet worden in hun professionele standaard. Samen met alle partijen in het veld (de Inspectie, de brancheorganisatie VGN en de verschillende beroepsgroepen) moet worden bekeken over welke kwaliteiten hulpverleners in de verstandelijk gehandicaptenzorg dienen te beschikken om aan de verwachtingen te kunnen voldoen. Het formuleren van kwaliteitseisen voorkomt niet dat incidenten in de zorg aan mensen met een verstandelijke handicap in de toekomst zijn uitgesloten. Daarvoor is meer nodig. Een belangrijke taak is weggelegd voor het management van een voorziening, die op grond van de Kwaliteitswet zorginstellingen verantwoordelijk is voor het bieden van verantwoorde zorg. Om hulpverleners bewust te maken van de risico's die zich kunnen voordoen in de zorg voor mensen met een verstandelijke handicap is voort-

110 Rechtbank Breda 20 augustus 2002, BJ 2002, 49, m.nt. A. Blok en Hoge Raad 16 juni 2000, kBJ 2000, 54, m.nt. Zuijderhoudt. 
durende (bij)scholing onontbeerlijk. Daarin kan aandacht worden besteed aan richtlijnen, het voorkomen van risico's, wetgeving en het inzichtelijk maken van verantwoordelijkheden binnen een instituut of woonvoorziening. Deze inspanningen van het management kunnen een belangrijke bijdrage leveren aan de concrete uitwerking van goed hulpverlenerschap in de verstandelijk gehandicaptenzorg.

Goede scholing is ook om andere redenen belangrijk in deze sector. Het werven van goed gekwalificeerd personeel is niet eenvoudig en is nog al te vaak een budgetkwestie. De oplossing wordt regelmatig gezocht in het aannemen van minder gekwalificeerd personeel, dat overigens zeer gemotiveerd is om aan de slag te gaan. Om te voorkomen dat zich incidenten zullen voordoen is het belangrijk dat deze mensen een goede scholing krijgen en op de hoogte worden gebracht van bestaande (interne) richtlijnen en andere relevante (interne) documenten. Een ander punt van aandacht is het vasthouden van het gekwalificeerd personeel. Alleen dan is het mogelijk om op een adequate wijze invulling te geven aan goed hulpverlenerschap en alleen dan zal een positieve bijdrage kunnen worden geleverd aan de verdere ontplooiing van cliënten. Dit aspect dient ook onderdeel uit te maken van het kwaliteitssysteem in een voorziening en moet door het management worden meegenomen bij de verdere vormgeving van het (kwaliteits)beleid. 



\section{Vrijheidsbeperking: een juridische analyse}

\section{$5.1 \quad$ Inleiding}

In hoofdstuk 3 is uiteengezet dat het zelfbeschikkingsrecht ook binnen de verstandelijk gehandicaptenzorg een belangrijke rol vervult. Inbreuken op dit recht zijn alleen gerechtvaardigd indien zij op een wettelijke grondslag berusten.' Dit geldt ook voor de toepassing van vrijheidsbeperking, die juridisch gezien een schending van het zelfbeschikkingsrecht is. Door vrijheidsbeperking wordt de speelruimte van een cliënt om zelf keuzes te maken begrensd. Dit betekent echter niet dat elke inbreuk op het zelfbeschikkingsrecht als negatief moet worden beschouwd. Vrijheidsbeperking dient, althans voor zover mogelijk, een bijdrage te leveren aan de ontplooiing(smogelijkheden) van een cliënt.

De Wet Bopz legitimeert het gebruik van vrijheidsbeperking in de zorg voor mensen met een verstandelijke handicap. In deze wet staan twee waarden centraal: het recht op zelfbeschikking en het recht op bescherming. Tussen deze twee waarden is altijd een zekere spanning aanwezig. Het uitgangspunt van de Wet Bopz is om een evenwicht te vinden tussen zelfbeschikking en bescherming. ${ }^{2}$ De eerste doelstelling van de Wet Bopz is het respecteren van het zelfbeschikkingsrecht van onvrijwillig opgenomen cliënten. Een inbreuk op het zelfbeschikkingsrecht is alleen toegestaan onder bijzondere omstandigheden. Daarnaast beoogt de Wet Bopz de interne rechtspositie van onvrijwillig opgenomen cliënten te waarborgen. Het zorgplan, dwangbehandeling, toepassing van middelen of maatregelen in noodsituaties, huisregels, beperkingen in de bewegingsvrijheid en een klachtenregeling maken onderdeel uit van de interne rechtspositie.

De IGZ heeft in 1997 een onderzoek uitgevoerd naar vrijheidsbeperkende maatregelen in de zorg voor mensen met een verstandelijke handicap in relatie tot de Wet Bopz. ${ }^{3}$ De resultaten daarvan laten zien dat bij één op de vier mensen met

1 Artikel 10 Grondwet: een ieder heeft behoudens bij of krachtens de wet te stellen beperkingen, recht op eerbiediging van zijn persoonlijke levenssfeer.

Artikel 11 Grondwet: ieder heeft behoudens bij of krachtens de wet te stellen beperkingen, recht op onaantastbaarheid van zijn lichaam. Artikel 15 lid 1 Grondwet: buiten de gevallen bij of krachtens de wet bepaald mag niemand zijn vrijheid worden ontnomen.

2 Ministerie Volksgezondheid, Welzijn en Sport en Ministerie van Justitie, Kabinetsstandpunt Evaluatie van de Wet Bopz, Rijswijk: 1997, p. 11-12.

3 Inspectie voor de Gezondheidszorg, Zorg onder beperking: vrijheidsbeperkende maatregelen in de zorg voor mensen met een verstandelijke handicap in relatie tot de 
een verstandelijke handicap, die in een instituut wonen, vrijheidsbeperkende maatregelen worden toegepast. Vier jaar later blijkt op grond van een deelrapport van de evaluatie van de Wet Bopz' dat bij één op de zes cliënten van instituten voor verstandelijk gehandicaptenzorg ${ }^{5}$ vrijheidsbeperkende maatregelen worden toegepast. In verhouding tot een aantal jaren geleden is sprake van een afname. Het werkelijk aantal toepassingen van vrijheidsbeperkingen bij mensen met een verstandelijke handicap ligt evenwel hoger, aangezien beide onderzoeken alleen betrekking hebben op instituten met een Bopz-aanmerking. Ook in gvt'en komt vrijheidsbeperking voor. ${ }^{6}$

In dit hoofdstuk wordt het huidige juridische kader voor de toepassing van vrijheidsbeperking uiteengezet. Er wordt nog geen oplossing aangereikt voor de knelpunten die in dit hoofdstuk worden geconstateerd. In paragraaf $5.2 \mathrm{zal}$ het begrip vrijheidsbeperking juridisch nader worden uiteengezet. Wat is de wettelijke grondslag voor toepassing van vrijheidsbeperking? Wat wordt verstaan onder vrijheidsbeperking volgens de wet? Bij wie mag vrijheidsbeperking worden toegepast? Welke vormen van vrijheidsbeperking zijn er? Welke normen dienen in acht genomen te worden als sprake is van toepassing van vrijheidsbeperking bij mensen met een verstandelijke handicap? Hoofdstuk 5 wordt afgesloten met een beschouwing. In zowei dit hoofd'stuk ai's in hoofdstuk 6 figt de nadruk op de toepassing van vrijheidsbeperking in een institutionele setting. De Wet Bopz is immers alleen van toepassing in instituten. In hoofdstuk 7 worden de contouren geschetst van een alternatieve regeling voor de toepassing van vrijheidsbeperking in de verstandelijk gehandicaptenzorg. Deze regeling strekt zich niet alleen uit tot de intramurale setting, maar heeft een grotere reikwijdte.

\section{$5.2 \quad$ Vrijheidsbeperking}

De notie van vrijheid (en de beperking daarvan) is niet als zodanig terug te vinden in de Nederlandse wetgeving. In artikel 15 van de Grondwet komt het recht op bewegingsvrijheid aan de orde. Op grond van dit artikel mag niemand van zijn vrijheid worden beroofd buiten de gevallen die bij of krachtens de wet zijn bepaald. In deze studie wordt onder vrijheidsbeperking verstaan 'iedere ingreep

wet Bopz en Bopz-indicatiestelling in de verstandelijk gehandicaptenzorg, Rijswijk: 1997.

4 Arends, Blankman en Frederiks 2002.

5 Met instituten wordt in dit hoofdstuk bedoeld: instituten met een Bopz-aanmerking.

6 Noordelijk Centrum voor Gezondheidsvraagstukken, Onderzoeksrapport vrijheidsbeperkende maatregelen, Groningen: Noordelijk Centrum voor Gezondheidsvraagstukken 1997. Zie verder ook hoofdstuk 6 van dit boek. 
die de individuele grondrechten van mensen met een verstandelijke handicap beperkt'. Een beperking van een individueel grondrecht leidt uiteindelijk tot een inbreuk op de vrijheid van een individu met een verstandelijke handicap. Een beperking van een individueel grondrecht leidt uiteindelijk tot een inbreuk op de vrijheid van een individu met een verstandelijke handicap. Tot de individuele grondrechten, die in het geding zijn, behoren het recht op privacy (artikel 10 $\mathrm{Gw}$ ), het recht op lichamelijke integriteit (artikel $11 \mathrm{Gw}$ ) en het recht op bewegingsvrijheid (artikel $15 \mathrm{Gw}$ ). De hier gehanteerde definitie van vrijheidsbeperking beperkt zich niet tot een smalle definitie. In de verstandelijk gehandicaptenzorg komt een breed scala aan vrijheidsbeperkende maatregelen voor. De beperking van individuele grondrechten van mensen met een verstandelijke handicap begint reeds bij een opname in een voorziening. De beperkingen breiden zich verder uit tijdens het verblijf in een voorziening, waar een cliënt te maken krijgt met een breed scala aan vrijheidsbeperkingen, variërend van het beperken van alcoholgebruik en roken tot het afzonderen op de eigen kamer of in een afzonderingsruimte. Het hanteren van een smalle definitie van vrijheidsbeperking, uit respect voor het zelfbeschikkingsrecht van cliënten, is niet toereikend in deze sector. Vanuit het burgerschapsparadigma is het belangrijk dat ook de (op het eerste gezicht) minder ingrijpende vormen van vrijheidsbeperking worden benoemd. Voor een cliënt met een matige verstandelijke handicap zijn zaken als het mogen kiezen tussen thee of koffie, het aantal boterhammen en zonder begeleiding naar zijn werk mogen gaan in meer of mindere mate bepalend voor zijn verdere ontwikkeling. Dit neemt niet weg dat er redenen kunnen zijn waarom de desbetreffende cliënt ook op deze gebieden in zijn vrijheid moet worden beperkt. Het gevaar bestaat dat met een smalle definitie deze vormen van vrijheidsbeperking, die niet worden benoemd in de Wet Bopz, buiten het zicht van derden en zonder legitieme reden plaatsvinden. In hoofdstuk 7 wordt in het kader van de alternatieve regeling uitgebreider ingegaan op het begrip vrijheidsbeperking.

Naast vrijheidsbeperking' spreekt het Evrm ook over 'vrijheidsbeneming' (artikel 5 Evrm), waaronder een ernstige inbreuk op het recht op vrijheid van een cliënt wordt verstaan. Voorbeelden zijn een onvrijwillige opname in een instituut of een langdurige afzondering. Het Europese Hof heeft criteria ontwikkeld om te beoordelen of sprake is van vrijheidsbeneming of vrijheidsbeperking. Dit onderscheid is van belang, omdat op grond van artikel 5 lid 4 Evrm bij de toepassing van vrijheidsbeneming de toegang tot de rechter verzekerd moet zijn. Opvallend is dat in de Wet Bopz de rechter alleen wordt betrokken bij de opneming van cliënten. Als een cliënt zich daarentegen verzet tegen een dwangbe- 
handeling, die al maanden voortduurt, wordt niet een oordeel gevraagd aan de rechter. ${ }^{8}$ In dit proefschrift wordt in beginsel alleen de term vrijheidsbeperking gehanteerd, waaronder ook ernstige inbreuken op het recht op vrijheid worden verstaan.

Bij de toepassing van vrijheidsbeperking is het niet relevant waar de beperking plaatsvindt en wie de beperking toepast. Hulpverleners, kunnen de vrijheid van cliënten begrenzen door het toepassen van fysieke middelen, waartoe fixeren en afzonderen worden gerekend, als door het toedienen van medicijnen, voedsel of vocht. Daarnaast kan ook sprake zijn van het toepassen van indirecte middelen oftewel psychische dwang.' Evenmin is belangrijk wat de intentie van vrijheidsbeperking is. In de zorg voor mensen met een verstandelijke handicap wordt vanuit verschillende invalshoeken de vrijheid van een cliënt beperkt: het bieden van bescherming, somatische redenen, pedagogische redenen of het voorkomen van gevaar. Deze maatregelen hebben uiteindelijk allemaal hetzelfde gevolg: het beperken van de vrijheid van een cliënt.

In de verstandelijk gehandicaptenzorg kan een onderscheid worden gemaakt tussen wettelijke maatregelen en niet-wettelijke maatregelen die leiden tot inbreuken op de individuele rechten van cliënten met een verstandelijke handicap. De Wet Bopz maakt diverse vormen van vrijheidsbeperking mogelijk die op een continuüm kunnen worden geplaatst: huisregels, beperkingen in de bewegingsvrijheid, dwangbehandeling en middelen of maatregelen in het kader van een noodsituatie. ${ }^{10}$ Deze vormen kunnen nader worden onderverdeeld in vrijheidsbeperkende maatregelen en dwangmiddelen. ${ }^{12}$ Vrijheidsbeperkende maatregelen zijn huisregels en beperkingen in het recht op bewegingsvrijheid, het recht op bezoek, het recht op telefoonverkeer en het recht op vrije briefwisseling. Afzonderen, separeren, fixatie, het toedienen van medicatie en voeding en vocht

8 De rechter kan wel achteraf worden betrokken bij de toepassing van vrijheidsbeperking: een onvrijwillig opgenomen cliënt heeft de mogelijkheid om een klacht in te dienen tegen dwangbehandeling of de toepassing van middelen of maatregelen (artikel 41 lid 1 Bopz). Indien deze klacht ongegrond wordt verklaard kan hij zich tot de rechter wenden (artikel 41 lid 11 Bopz).

9 Psychische dwang betekent dat aan een cliënt duidelijk wordt gemaakt dat het achterwege laten of juist vertonen van bepaald gedrag ernstige nadelige consequenties kan hebben voor hem.

10 De Krankzinnigenwet bevatte in tegenstelling tot de Wet Bopz geen bepalingen over de interne rechtspositie van de onvrijwillig opgenomen patiënt.

11 Legemaate 1991, p. 271.

12 A. Frijlink, In vrijheid beperkt: een gezondheidsrechtelijk onderzoek naar vrijheidsbeperkende maatregelen in psychiatrische ziekenhuizen, zwakzinnigeninrichtingen en psychogeriatrische verpleeghuizen, Maastricht: Rijksuniversiteit Limburg 1991, p. 6. 
onder dwang vallen onder dwangmiddelen. Dwangbehandeling komt in deze indeling niet voor, maar kan ook worden geplaatst onder dwangmiddelen. De mogelijkheid bestaat om een maatregel als afzondering met toestemming van de cliënt op te nemen in het zorgplan. Vervolgens kan het noodzakelijk zijn dat deze afspraak, vanwege verzet van de cliènt, onder dwang wordt toegepast.

Het onderscheid tussen vrijheidsbeperkende maatregelen en dwangmiddelen is enigszins kunstmatig aangezien beperkingen in het recht op bewegingsvrijheid ook onder dwang opgelegd kunnen worden. Daarnaast bestaat de mogelijkheid om dwangmiddelen met toestemming van de cliënt en/of vertegenwoordiger in het zorgplan op te nemen. In deze studie wordt het onderscheid tussen vrijheidsbeperkende maatregelen en dwangmiddelen dan ook losgelaten en wordt alleen gesproken over 'vrijheidsbeperkende maatregelen' of 'vrijheidsbeperking'. Vrijheidsbeperking is ruimer dan hetgeen de Wet Bopz mogelijk maakt: naast de eerder beschreven wettelijke vormen van vrijheidsbeperking zijn nog vele andere maatregelen mogelijk die de vrijheid van cliënten beperken. Daarbij valt te denken aan begeleidingsafspraken, dwangmaatregelen op grond van de Wgbo, pedagogische maatregelen en niet-wettelijke maatregelen, waaronder wordt verstaan toepassingen van vrijheidsbeperking bij vrijwillig opgenomen cliènten of cliënten die niet in een Bopz-instituut verblijven. Daarnaast wordt de vrijheid van cliënten ook beperkt door onder meer de bouw van een voorziening ${ }^{13}$ en diverse wettelijke voorschriften. De wetgever rekent ook een voorziening voor verstandelijk gehandicaptenzorg tot de publieke ruimte hetgeen een aantal extra vrijheidsbeperkende maatregelen met zich meebrengt. ${ }^{14}$ Dit alles betekent dat de vrijheid van cliënten op talloze manieren kan worden beperkt. Slechts een deel van alle vrijheidsbeperkende maatregelen is terug te voeren op de Wet Bopz.

Vrijheidsbeperking kan verder worden onderverdeeld in gewenste en ongewenste vrijheidsbeperking. Over het algemeen wordt vrijheidsbeperking geassocieerd met onvrijwilligheid. Een cliënt of een vertegenwoordiger kan echter ook in-

13 Een goede bouwkundige opzet (eenpersoonskamers en een beperkte groepsgrootte) kan veel noodsituaties voorkomen in de verstandelijk gehandicaptenzorg. Daarnaast is gehorigheid een knelpunt dat in de nieuwbouw van voorzieningen extra aandacht verdient (Inspectie voor de Gezondheidszorg, De uitvoering van de Wet Bopz vraagt meer aandacht. De resultaten van vier thematische onderzoeken op het terrein van de Wet bijzondere opnemingen in psychiatrische ziekenhuizen (Wet Bopz), Den Haag: 2004, p. 29 en bijlage 7).

14 Op grond van de Tabakswet (Stb. 2002, 201) geldt in publiek toegankelijke ruimtes van instellingen in de gezondheidszorg een rookverbod (artikel $10 \mathrm{Ta}$ bakswet). Roken is alleen toegestaan in daartoe speciaal aangewezen en ingerichte, besloten ruimtes. Het rookverbod geldt ook voor woonvoorzieningen, zoals gezinsvervangende tehuizen. 
stemmen met de toepassing van een vrijheidsbeperkende maatregel, zoals het afsluiten van een slaapkamerdeur gedurende de nacht. Er is dan sprake van gewenste vrijheidsbeperking. Deze instemming ontneemt, met name in de verstandelijk gehandicaptenzorg, niet volledig het vrijheidsbeperkende karakter ervan. ${ }^{15}$ Het blijft immers gaan om inbreuken op individuele rechten van cliënten. Een cliënt stemt in om in een ruimte te worden opgesloten, maar kan er zelf niet uit of een cliënt wordt gefixeerd in een stoel, waardoor hij niet meer vrij kan rondlopen. Uiteraard wordt de maatregel rechtmatiger als een cliënt en/of vertegenwoordiger toestemming verleent voor de inbreuk. Het feit dat een cliënt, die toestemming verleent voor vrijheidsbeperking, achteraf instemt met de maatregel of zelf verzoekt om een maatregel verzachten de toepassing ervan, maar mogen er niet toe leiden dat hulpverleners een vrijbrief krijgen om vrijheidsbeperking toe te passen. Een hulpverlener zal uiterst zorgvuldig om moeten gaan met de instemming die de cliënt verleent. Het gaat immers om zeer kwetsbare cliënten, die niet altijd hun wil duidelijk kenbaar kunnen maken. Er is pas sprake van een volkomen gewenste vrijheidsbeperking als een wilsbekwame cliënt instemt met een vrijheidsbeperkende maatregel en ook de ruimte krijgt om de maatregel op te heffen op het moment dat hij niet meer akkoord gaat met de situatie.

\subsection{Criteria en motieven voor de toepassing van vrijheidsbeperking}

De wettelijke grondslag voor de toepassing van vrijheidsbeperking bij mensen met een verstandelijke handicap is gelegen in de Wet Bopz. De voorloper van de Wet Bopz, de Krankzinnigenwet, bevatte geen nadere bepalingen over de interne rechtspositie. Tot 1974 ging men ervan uit dat een gedwongen opname tevens dwangbehandeling rechtvaardigde. In zowel 1974 als $1975^{16}$ verschenen twee arresten van de Hoge Raad waarin de rechter oordeelde dat het enkele feit dat iemand gedwongen opgenomen is onvoldoende grond oplevert om hem tegen zijn wil te behandelen. De Wet Bopz borduurt voort op dit standpunt van de Hoge Raad. Hieronder worden enkele algemene criteria en motieven voor de toepassing van vrijheidsbeperking nader beschouwd. Een aantal van deze criteria en motieven, waaronder het institutionele karakter, onvrijwillige opneming, proportionaliteit, subsidiariteit en effectiviteit en het gevaarscriterium zijn vast-

15 In de jurisprudentie wordt deze opvatting niet altijd onderschreven. De president van de Rechtbank Amsterdam oordeelde dat een elektroshockconvulsietherapie niet beschouwd hoeft te worden als vrijheidsbeperking als blijkt dat de betreffende cliënt instemt met de maatregel. Op zo'n moment wordt het inbreukmakende karakter van de maatregel hieraan ontnomen (Rechtbank Amsterdam 20 september 1990, NJ 1992, 612).

HR 14 juni 1974, NJ 1974, 436 en HR 15 april 1975, NJ 1975, 288. 
gelegd in de Wet Bopz. De andere motieven die worden genoemd zijn ook aan de orde in de zorg voor mensen met een verstandelijke handicap, maar zijn niet eenvoudig terug te vinden in het huidige juridische kader voor de toepassing van vrijheidsbeperking.

\subsubsection{Institutionele karakter}

De Wet Bopz is alleen van toepassing op instituten voor verstandelijk gehandicaptenzorg met een Bopz-aanmerking. Dit betekent dat vrijheidsbeperking in beginsel alleen mag worden toegepast in instituten en niet in andere voorzieningen zoals gezinsvervangende tehuizen, dagverblijven, beschermd wonen of wooninitiatieven die opgezet worden op grond van het Persoonsgebonden budget $(\mathrm{Pgb})$. Hetzelfde kan worden gezegd van de thuissituatie. ${ }^{17}$

\subsubsection{Onvrijwillige opneming}

In instituten voor verstandelijk gehandicaptenzorg verblijven rond de 37.000 mensen met een verstandelijke handicap. ${ }^{18}$ De Wet Bopz is maar op een klein gedeelte van deze 37.000 cliënten van toepassing. Alleen cliënten die via een inbewaringstelling, een rechterlijke machtiging of een artikel $60 \mathrm{Bopz}$-indicatie zijn opgenomen, vallen onder de reikwijdte van de Wet Bopz. ${ }^{19}$ Deze cliënten hebben de juridische status 'onvrijwillig' en zijn op grond van een extra wettelijke waarborg, namelijk via de rechter of via een indicatie-commissie, opgenomen in een instituut voor verstandelijk gehandicaptenzorg. De overige cliënten dragen de status van 'vrijwillig.' De tweede evaluatie van de Wet Bopz $z^{20}$ laat zien dat, op grond van de gegevens van de deelnemende instituten waarvan de totale populatie 28.207 cliënten betrof, maar liefst $70 \%$ van de cliënten vrijwillig opgenomen is. Vrijheidsbeperking mag, formeel gezien, slechts bij zo'n $30 \%$ van de cliënten

17 Het Ministerie van VWS heeft te kennen gegeven om de mogelijkheden voor het verkrijgen van een Bopz-aanmerking te verruimen. In 2004 zal IGZ vermoedelijk met een aantal kwaliteitscriteria komen, waar instituten aan moeten voldoen om een Bopz-aanmerking aan te vragen. Het kan gaan om een instituut, een afdeling of een locatie van een instituut. Het is nog onduidelijk of een gvt hiervoor ook in aanmerking komt.

18 Bartels 2002.

19 De Inspectie heeft op grond van artikel $63 \mathrm{Bopz}$ wel de taak om te waken voor de belangen van alle personen wier geestvermogens zijn gestoord. Hiertoe behoren ook vrijwillig opgenomen cliënten. De Inspectie ziet toe dat deze cliënten op een verantwoorde wijze worden behandeld, verpleegd, verzorgd en bejegend.

20 Arends, Blankman en Frederiks 2002, p. 89-91. 
worden toegepast. Het grote aantal vrijwillig opgenomen cliënten is te verklaren doordat onder de Krankzinnigenwet alleen psychiatrische patiënten gedwongen opgenomen werden. Opneming van mensen met een verstandelijke handicap vond (op een enkele uitzondering na) vrijwillig plaats. ${ }^{21}$ Door de komst van de Wet Bopz is de procedure van onvrijwillige opneming nu ook op de verstandelijk gehandicaptenzorg van toepassing. Dit betekent dat cliënten die onder de Krankzinnigenwet nog vrijwillig waren opgenomen, nu opnieuw geïndiceerd moeten worden door een indicatiecommissie. Niet alle instituten zijn daar even voortvarend mee aan de slag gegaan..$^{2}$ De Inspectie heeft eind 2001 een brief naar Vereniging Gehandicaptenzorg Nederland gestuurd, waarin zij aangeeft dat nog teveel cliënten zonder de juiste juridische status in een instituut verblijven. In deze brief stelt de Inspectie voor om de cliënten, waarbij mogelijk een Bopz-indicatie moet worden afgegeven, op een snelle en verantwoorde wijze te indiceren. In totaal zou het gaan om 7000 indicaties. Aan deze inhaalslag kleeft ook een negatief aspect. Het doet vermoeden dat instituten, zodra zij voldaan hebben aan het verzoek van de Inspectie, een vrijbrief hebben om vrijheidsbeperking toe te passen bij cliënten met een Bopz-indicatie.

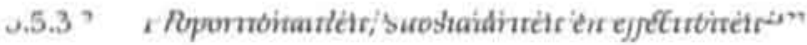

Om rechtmatig vrijheidsbeperking toe te passen dient aan drie beginselen te zijn voldaan: proportionaliteit, subsidiariteit en effectiviteit. ${ }^{24}$ Het proportionaliteitsbeginsel vereist dat sprake moet zijn van een redelijke verhouding tussen het doel (het verminderen van het gevaar) en het middel (de vrijheidsbeperkende maatregel) dat wordt ingezet. Subsidiariteit betekent dat het minst ingrij-

21 Onder de Krankzinnigenwet is incidenteel een rechter ingeschakeld voor de opneming van een cliënt met een verstandelijke handicap, HR 18 mei 1984, NJ 1984, 514 en HR 28 juni 1985, NJ 1985, 852.

22 Arends, Blankman en Frederiks 2002, p. 89-91.

23 In deze context wordt niet gesproken over 'doelmatigheid'. Deze term wordt ook geassocieerd met efficiëntie: er dient een gunstige verhouding te zijn tussen de baten en lasten die voortvloeien uit de toepassing van vrijheidsbeperking. In dit proefschrift wordt niet gesproken over doelmatigheid maar is gekozen voor de term 'effectiviteit', ook wel doeltreffendheid genoemd. Het gaat immers om de vraag of een toepassing van vrijheidsbeperking ook daadwerkelijk een bijdrage levert aan de ondersteuning van cliënten. Doeltreffendheid is ook een van de zes kwaliteitseisen die worden genoemd in de nota 'Zicht op wetgeving' (Handelingen II 1990-1991, 22 008, nrs. 1-2, p. 23 e.v.).

24 Deze criteria zijn ook terug te vinden in artikel 38 lid 5 Bopz: dwangbehandeling is alleen toegestaan als dit 'volstrekt noodzakelijk' is om gevaar af te wenden. 
pende alternatief gekozen moet worden. In plaats van separatie kan bijvoorbeeld ook gekozen worden voor een minder ingrijpend alternatief zoals een wandeling maken met de cliènt. Effectiviteit betekent dat een vrijheidsbeperkende maatregel niet langer mag duren dan noodzakelijk is. Als de maatregel geen effect meer heeft, dient deze te worden gestaakt.

\subsubsection{Motieven voor de toepassing van vrijheidsbeperking}

In de literatuur worden verschillende motieven genoemd voor de toepassing van vrijheidsbeperking. De belangrijkste zijn: gevaar, bescherming, behandeling en handhaving van de orde. ${ }^{25}$ Aan dit rijtje kunnen voor de verstandelijk gehandicaptenzorg de motieven 'opvoeden' en 'straffen en belonen' worden toegevoegd.

a) Het gevaarsmotief. Pas als sprake is van gevaar, veroorzaakt door een geestesstoornis van de cliënt, bestaat er een reden om aan de cliënt vrijheidsbeperking op te leggen. Gevaar op zichzelf is niet voldoende voor de toepassing van vrijheidsbeperking. Er moet een causaal verband bestaan tussen de geestelijke stoornis - de verstandelijke handicap - en het gevaar. De Wet Bopz maakt onderscheid tussen het gevaarscriterium voor opneming en het gevaarscriterium voor de toepassing van vrijheidsbeperking gedurende het verblijf van een cliënt. Oorspronkelijk was het gevaarscriterium voor opneming algemeen geformuleerd. Onder gevaar werd verstaan 'een gevaar voor zichzelf, voor anderen of voor de algemene veiligheid van personen of goederen' (artikel 1 lid 1 sub f). Het criterium is, mede op grond van de jurisprudentie, door een wetswijziging nader omschreven. ${ }^{27}$ Deze bij amendement toegevoegde wijziging werd als volgt toegelicht: '(...) Het begrip gevaar wordt nader omschreven conform de jurisprudentie van de Hoge Raad. De beschrijving belemmert de ontwikkeling van de verdere jurisprudentie niet, maar geeft aan de praktijk meer houvast'. ${ }^{28}$ Het gevaarscriterium, waarvan sprake moet zijn als bij een gedwongen opgenomen cliënt vrijheidsbeperking wordt toegepast, was tot 1 januari 2004 strikter dan het gevaarscriterium uit artikel 1 lid 1 sub f Bopz. In artikel 38 lid 5 Bopz werd gesproken over 'ernstig gevaar voor de cliënt, voortoloeiende uit de stoornis van de geestvermogens'. De wetgever wilde daarmee de drempel voor het toepassen van dwangbehandeling verhogen. De intentie was dat, mede uit respect voor het zelfbe-

25 Frijlink 1991, p. 68-78.

26 Legemaate 1991, p. 282-273.

27 Wet van 22 juni 2000 , Stb. 292, op 1 december 2000 in werking getreden bij Besluit van 2 oktober 2000, Stb. 420.

28 Kamerstukken II 1999-00, 26 257, nr. 8. 
schikkingsrecht van cliënten, een hulpverlener niet te snel over mocht gaan tot het toepassen van vrijheidsbeperking. Bij nader inzien heeft de wetgever toch besloten om 'ernstig' te laten vervallen, omdat het criterium 'ernstig gevaar' onvoldoende ruimte zou geven aan hulpverleners om in te grijpen waar dat nodig is. ${ }^{29}$

b) Het beschermingsmotief. In de verstandelijk gehandicaptenzorg is bescherming van de cliënt nog een veel gebruikt motief. Cliënten worden beschermd tegen bijvoorbeeld situaties in het verkeer, valgevaar of zelfverwonding. Beschermende maatregelen worden veelal permanent toegepast. In de praktijk is er geen duidelijk verschil tussen het gevaarsmotief en het beschermingsmotief. Deze onduidelijkheid wordt deels veroorzaakt doordat niet alleen het doel van de maatregel, maar ook de vorm van de maatregel bij beide motieven hetzelfde kunnen zijn. Theoretisch gezien is wel een onderscheid te maken. ${ }^{30} \mathrm{Bij}$ bescherming gaat het hoofdzakelijk om bescherming van de cliënt zelf, terwijl het gevaarsmotief wordt geïnterpreteerd als gevaar voor zichzelf en gevaar voor anderen. Het gevaarsmotief in de Wet Bopz biedt evenwel ook ruimte voor het beschermingsmotief. Onder gevaar wordt immers ook verstaan 'gevaar voor de cliënt zelf'. Toch zal het niet eenvoudig zịn om op grond van het beschermingsmotier een chiënt op te nemen. Als een cliënt lijdt aan een stoornis van de geestvermogens maar geen gevaar oplevert in de zin van de Wet Bopz, is het vrijwel onmogelijk om hem op te nemen. Dat het beter zou zijn om deze cliënt op te nemen doet daar niets aan af. In dit kader biedt artikel $60 \mathrm{Bopz}$ nog een uitweg: opname is mogelijk indien dit noodzakelijk is omdat de cliënt zich tengevolge van zijn stoornis van de geestvermogens niet buiten een instituut kan handhaven. In dit geval hoeft niet sprake te zijn van gevaar. De enige voorwaarde die de wet stelt is dat de cliënt geen bereidheid tot en geen bezwaar toont tegen opneming.

c) Het behandelingsmotief. Vrijheidsbeperkende maatregelen en dwangmiddelen kunnen ook in het kader van de behandeling worden toegepast en in het zorgplan worden opgenomen. Daarvoor dient een cliënt en/of vertegenwoordiger toestemming te geven. De hulpverlener moet ervan overtuigd zijn dat de cliënt instemt met het zorgplan en zich daar niet tegen verzet. Vrijheidsbeperkende maatregelen die in het zorgplan zijn opgenomen dienen een therapeutisch doel te hebben: ${ }^{31}$ ze zijn gericht op een verbetering

29 Wet van 13 juli 2002, Stb. 431, op 1 januari 2004 in werking getreden bij Besluit van 4 november 2003, Stb. 467 (zie ook paragraaf 5.4.1).

30 Frijlink 1991, p. 69-71.

31 Deze eis geldt niet voor de toepassing van middelen of maatregelen in het kader van een noodsituatie (artikel 39 Wet Bopz). 
van de stoornis oftewel het verminderen van storend gedrag van een cliënt. In de verstandelijk gehandicaptenzorg is het moeilijk om te spreken over een therapeutisch doel. Een verstandelijke handicap is een blijvende handicap die door het inzetten van een bepaalde behandeling niet weggenomen kan worden. Wel is het mogelijk om de handicap en eventueel daarbij horende gedragsproblemen beter hanteerbaar te maken voor de cliënt en zijn omgeving. Ook bij dit motief zijn de criteria van effectiviteit, proportionaliteit en subsidiariteit aan de orde. Als een vrijheidsbeperkende maatregel niet meer bijdraagt aan het verbeteren van de situatie van een cliênt, moet de toepassing worden gestaakt. Daarnaast wordt van de hulpverlener verwacht dat hij, ook al heeft de cliënt en/of de vertegenwoordiger toestemming verleend, voortdurend op zoek gaat naar minder ingrijpende alternatieven.

d) Het handhaven van de orde. Het leven in een groep leidt onvermijdelijk tot beperkingen in de vrijheid van de afzonderlijke leden van de groep. Elke groep, afdeling of woning in een instituut voor verstandelijk gehandicaptenzorg heeft bepaalde afspraken vastgelegd in huisregels. Voor de rechtspositie van een cliënt is het belangrijk dat huisregels niet te ver gaan. Maatregelen met een therapeutisch doel horen thuis in een individueel zorgplan en niet in de huisregels. De orde kan ook worden gehandhaafd door individuele beperkingen in de bewegingsvrijheid op te leggen. Deze beperkingen moeten in verhouding staan tot het gevaar dat door de cliënt wordt veroorzaakt. Het is niet rechtmatig om aan een cliënt een beperking op te leggen die niet noodzakelijk zou zijn als ęen andere cliënt niet op de groep zou verblijven. Daarbij valt te denken aan het afsluiten van kasten en deuren omdat een cliënt de gewoonte heeft om alles op te eten wat in huis is. Een mogelijke oplossing is om cliënten, die geen gevaar veroorzaken, een eigen sleutel van kasten en deuren te geven zodat zij niet onterecht in hun vrijheid worden beperkt.

e) Opvoedingsmotief. In de verstandelijk gehandicaptenzorg neemt de gedragsdeskundige, naast de arts voor verstandelijk gehandicapten (AVG), een belangrijke plaats in. De gedragsdeskundige houdt zich bezig met het verder ontwikkelen van de cliënt en probeert daarbij te voorkomen dat de cliënt een gevaar veroorzaakt voor zichzelf of voor anderen. Vrijheidsbeperking wordt in dit kader toegepast teneinde de ontwikkeling van de cliënt te bevorderen. Vanuit het opvoedingsmotief kan het noodzakelijk zijn om een cliënt apart te zetten, bijvoorbeeld omdat hij de situatie niet 
aankan en op zijn kamer tot rust moet komen. ${ }^{32}$ Een onderscheid kan worden gemaakt tussen pedagogisch handelen en orthopedagogisch handelen. Onder pedagogisch handelen wordt verstaan het begeleiden van een cliënt bij zijn ontwikkeling van volstrekte afhankelijkheid naar zelfstandigheid en het uitoefenen van verantwoordelijkheid zolang en zover een cliënt daartoe in staat is. Doel hiervan is de cliënt in te voeren in de normen en waarden van de samenleving en hem tot een verantwoordelijk, autonoom mens te vormen. ${ }^{33}$ In een voorziening voor verstandelijk gehandicaptenzorg neemt de hulpverlener de opvoedingsrol van de ouders op zich. Orthopedagogisch handelen houdt zich meer bezig met gedrags-, leer- en ontwikkelingsproblemen waarbij de in zijn ontwikkeling belemmerde cliënt wordt opgevoed.

f) Straffen en belonen. Een onderdeel van opvoeden en orthopedagogisch handelen is het belonen van goed gedrag en het straffen van verkeerd gedrag. De grens tussen strafmaatregelen en vrijheidsbeperkende maatregelen is niet helder aan te geven. ${ }^{M}$ In de Wet Bopz is geen bepaling te vinden die betrekking heeft op het toepassen van negatieve sancties in de vorm van vrijheidsbeperking. Het is juridisch gezien onjuist als een vrijheidsbeperkende maatregel een strafkarakter krijgt, in dat geval schiet vrijheidsbeperking zijn doel voorbij en handelt een hulpverlener niet meer rechtmatig. ${ }^{.5}$ In het belonen van cliënten zit ook een vrijheidsbeperkend element. Van cliënten wordt een bepaald gedrag vereist, om aanspraak te kunnen maken op de beloning. Gedragsdeskundigen handelen echter vanuit een andere visie dan juristen. Het straffen en belonen wordt als een wezenlijk onderdeel van de opvoeding en behandeling beschouwd. Onder straf

32 In de verstandelijk gehandicaptenzorg ook wel genoemd een 'time-out'. De time-out is van oorsprong een behandelingsinstrument. In de gedragstherapie wordt een time-out gebruikt om de koppeling tussen gedrag en voor de cliënt (ongewenste) consequenties te voorkomen. In de praktijk wordt de term inmiddels ook gebruikt voor vormen van kortdurende afzondering.

33 M. van Ooyen-Houben e.a., Richtlijn Wet Bopz en pedagogische maatregelen in de kinder- en jeugdpsychiatrie, Utrecht: GGZ Nederland i.s.m. het Trimbosinstituut 1999.

34 C. de Groot en M. Donker, Evaluatie Wet Bopz, Deelonderzoek 10-6: De Wet Bopz in de kinder-en jeugdpsychiatrie, Den Haag: ZonMw 2002.

35 In de Nota van toelichting behorende bij het Besluit rechtspositieregelen Bopz (Besluit van 3 november 1993, Stb. 563, p. 5) wordt opgemerkt dat vrijheidsbeperkende maatregelen zoals huisregels geen strafkarakter mogen hebben, maar als doel moeten hebben om een einde te maken aan de verstoring van de orde. Bovendien moet in het zorgplan worden ingespeeld op het storend gedrag van de cliënt. 
de opvoeding en behandeling beschouwd. Onder straf wordt verstaan het toedienen van een nare, vervelende prikkel die direct dient te volgen op ernstig ongewenst gedrag van een cliënt'.6 Het doel van deze handeling is dat het ongewenst gedrag van een cliënt afneemt. De visie van een gedragsdeskundige verschilt daarin dat het straffen van cliënten niet direct wordt beschouwd als een inbreuk op de lichamelijke integriteit en het recht op vrijheid van cliënten. Gedragsdeskundigen lijken minder oog te hebben voor de wijze waarop een bepaald resultaat voor een cliënt wordt bereikt. Het toepassen van dwang kan leiden tot meer vrijheid voor een cliènt. Voor hulpverleners weegt op dat moment het laatste het zwaarst en niet de toepassing van dwang, aldus Van Wijmen en Te Braake. ${ }^{x}$ Om een oordeel te kunnen geven over de rechtmatigheid van straffen en belonen van cliënten is het van belang dat het handelen van een hulpverlener in een redelijke verhouding staat tot het verwachte resultaat. ${ }^{35}$ Als vrijwel het gehele leven van een cliënt gereguleerd wordt door middel van straffen en belonen is niet meer sprake van de vereiste proportionaliteit. Dit geldt ook als de straf of de beloning niet in verhouding staat tot het te verwachten resultaat.

\subsection{Vormen van vrijheidsbeperking}

Een aantal vormen van vrijheidsbeperking is vastgelegd in de Wet Bopz. Het betreft dwangbehandeling, middelen of maatregelen, huisregels en beperkingen in het recht op bewegingsvrijheid.

\subsubsection{Dwangbehandeling}

Van dwangbehandeling is sprake als het zorgplan wordt uitgevoerd, ondanks het ontbreken van toestemming van de cliënt en/of vertegenwoordiger of ondanks verzet van de cliënt en/of vertegenwoordiger tegen (een deel van) de reeds afgesproken inhoud van het zorgplan (artikel 38 lid 5 Wet Bopz). Voor de komst van de Wet Bopz was dwangbehandeling niet toegestaan in instituten voor verstandelijk gehandicaptenzorg aangezien een wettelijke basis daarvoor ontbrak. ${ }^{39}$ Het was wel mogelijk om onder de noemer van overmacht in te grijpen en daarmee een noodsituatie te voorkomen. De wettelijke grondslag voor dwangbehandeling is thans artikel 38 lid 5 Bopz.

36 P. Adriaans en P. Duker, Behandeling van probleemgedrag bij zwakzinnigen, Rotterdam: Lemniscaat 1973, p. 37.

37 F.C.B. van Wijmen en Th.A.M. te Braake, "Token economy en rechten van patiënten", Maandblad geestelijke volksgezondheid (44) 1989-10, p. 1088.

38 Van Wijmen en Te Braake 1989, p. 1082.

39 Hof Arnhem 12 juli 1988, NJ 1989, 761. 
Dwangbehandeling is gericht op verbetering en genezing van de stoornis waar een cliënt aan lijdt. De Wet Bopz verstaat onder een geestesstoornis ook een 'verstandelijke handicap'. Een hulpverlener dient in een geneeskundige verklaring, die vereist is om een voorlopige machtiging of een IBS af te geven, een keuze te maken uit een lijst met 18 verschillende stoornissen, waaronder ook een verstandelijke handicap. ${ }^{40}$ In de verstandelijk gehandicaptenzorg is het evenwel niet passend om te spreken over een genezing van de stoornis, aangezien mensen met een verstandelijke handicap niet te genezen zijn van hun beperking. Dwangbehandeling zal er niet toe kunnen leiden dat de stoornis wordt weggenomen. Wel kan een omgeving worden gecreëerd, waarin de stoornis zich op een zodanig niveau stabiliseert, dat het gevaar wordt weggenomen. Daarnaast is het mogelijk om psychische problemen en gedragsproblemen van een cliënt te verminderen." Met name mensen met een lichte verstandelijke handicap worden opgenomen vanwege hun psychische en/of gedragsstoornissen.

De Wet Bopz regelt twee vormen van dwangbehandeling. De eerste vorm kan zich voordoen als bij de totstandkoming van het zorgplan geen overeenstemming wordt bereikt tussen de hulpverlener en de cliënt en/of vertegenwoordiger. In beginsel wordt het zorgplan in overleg met de cliënt en/of vertegenwoordiger opgesteld. Het kan echter gebeuren dat de cliënt en/of vertegenwoordiger zodanig van mening verschillen met de voor de behandeling verantwoordelijke persoon over de inhoud van het zorgplan dat geen overeenstemming wordt bereikt. De tweede vorm van dwangbehandeling kan zich voordoen bij de uitvoering van het zorgplan. Beide partijen zijn in beginsel tot een akkoord gekomen over de inhoud van het zorgplan. Echter, op het moment dat het zorgplan wordt uitgevoerd, verzet de cliënt en/of vertegenwoordiger zich daartegen of een onderdeel ervan. In beide gevallen is pas sprake van dwangbehandeling als de behandelaar alsnog besluit de behandeling voort te zetten. Op grond van artikel 38 lid $5 \mathrm{Bopz}$ mag de behandeling alleen worden voortgezet als deze behandeling volstrekt noodzakelijk is om gevaar af te wenden. De wetgever heeft rondom dwangbehandeling de begrippen gevaar en verzet opengelaten en laat daarmee de invulling aan het veld over. Ook zegt de wet niets over de duur van de dwangbehandeling en laat zij in het midden welke middelen wel of niet ingezet mogen worden in het kader van dwangbehandeling.

40 Bijlage 1-3, Regeling van de Minister van VWS van 28 oktober 2003, nr. GVM2419898, Stcrt. 217, houdende vaststelling van modellen Bopz (Regeling vaststelling modellen Bopz).

41 Nota van toelichting bij het Besluit van 3 november 1993, Stb. 561, p. 3. 


\section{Geonar}

Dwangbehandeling heeft tot doel het afwenden van gevaar. Oorspronkelijk vereiste de wet 'ernstig gevaar'. Dit is een strikter criterium dan het criterium dat bij een gedwongen opneming van een cliënt wordt gehanteerd." Recentelijk is ernstig gevaar gewijzigd in gevaar. Deze wijziging betekent een verruiming van het gevaarscriterium." Een reden voor deze wijziging is de consistentie van wetgeving, aldus de Minister van VWS." Het criterium voor dwangbehandeling wordt in het vervolg gelijkgesteld met het criterium voor dwangopneming. De wijziging van artikel 38 lid 5 Bopz strookt echter niet met de motivering die de regering tijdens de parlementaire behandeling van het wetsontwerp Bopz aanvoerde. Van de Klippe maakt duidelijk dat de regering toentertijd bewust heeft gekozen voor een ontkoppeling van dwangopneming en dwangbehandeling: een onvrijwillige opneming rechtvaardigt nog geen dwangbehandeling. Dwangbehandeling is pas aan de orde als voldaan is aan de vereisten van een 'aangescherpt gevaarscriterium'. Daarnaast gaat het om gevaar dat de cliënt binnen het instituut veroorzaakt en is dwangbehandeling alleen toegestaan in zeer ernstige situaties. Met genoemde wetswijziging lijkt de regering afstand te hebben genomen van haar eerder ingenomen standpunt dat een onvrijwillige opneming nog geen dwangbehandeling rechtvaardigt. Legemaate vindt de koerswijziging van de Kamer en ministers stuitend. ${ }^{46}$ Volgens de Minister van VWS kunnen veel cliënten, nadat ze gedwongen zijn opgenomen, niet worden behandeld omdat zij niet voldoen aan het criterium van ernstig gevaar. ${ }^{47}$ Legemaate vreest echter dat door het schrappen van het woordje 'ernstig', de drempel voor hulpverleners aanzienlijk wordt verlaagd om dwang toe te passen: een dwangopneming is voldoende om ook dwangbehandeling te mogen toepassen bij cliënten. Deze redenering is bijna letterlijk terug te vinden in de intentie die de indieners van het amendement voor ogen hadden: 'De opname is eigenlijk bedoeld om onder dwang het behandelplan te vervolgen.' ${ }^{48}$

Het kan natuurlijk niet de bedoeling van een wet zijn om onvrijwillig opgenomen cliënten gedurende hun verblijf aan hun lot over te laten vanwege het feit

42 Artikel 2 Bopz resp. artikel 20 Wet Bopz spreken over 'gevaar' resp. 'onmiddellijk dreigend gevaar' als voorwaarde voor opneming.

43 Wet van 13 juli 2002, Stb. 431, p. 7, op 1 januari 2004 in werking getreden bij Besluit van 4 november 2003, Stb. 467.

44 Handelingen II 2001-02, 6 september 2001, p. 99-6222.

45 Van de Klippe 1997, p. 75-76.

46 Rechtbank Middelburg 30 augustus 2001, BJ 2001, 61, m.nt. J. Legemaate, p. 257258.

47 Handelingen II 2001-02, 6 september 2001, p. 99-6222.

48 Handelingen II 2001-02, 5 september 2001, p. 68-6175. 
dat hulpverleners op grond van de Bopz niet of nauwelijks mogen ingrijpen. Deze wijze van handelen strookt niet met het bieden van goede zorg aan cliënten. Tegelijkertijd mag het ook niet zo zijn dat te lichte eisen worden gesteld aan de criteria van dwangbehandeling. Dwangbehandeling in de verstandelijk gehandicaptenzorg heeft veelal een ingrijpender karakter dan onvrijwillige opneming, die op dat moment noodzakelijk is omdat de betreffende cliënt zich niet meer kan handhaven buiten de instelling. ${ }^{4}$ Dwangbehandeling heeft doorgaans een langdurig karakter. Daarnaast is het voor hulpverleners niet eenvoudig om vast te stellen of een cliënt het eens dan wel oneens is met de toepassing ervan. Elke toepassing van dwangbehandeling dient dan ook, ongeacht of in artikel 38 lid 5 Bopz wordt gesproken over ernstig gevaar dan wel gevaar, te voldoen aan de criteria van subsidiariteit, proportionaliteit en effectiviteit.

De beoogde wetswijziging is terecht wat betreft de onmacht van hulpverleners om bij bepaalde cliënten, die al heel lang zijn opgenomen en onder de huidige omstandigheden geen uitzicht hebben op verbetering, niet te mogen ingrijpen, omdat het gevaar van cliënten niet dermate ernstig is dat een dwangbehandeling gerechtvaardigd is. Daarentegen moet worden belet dat een onvrijwillige opneming automatisch leidt tot dwangbehandeling, aangezien deze laatste opvatting niet getuigt van veel respect voor de rechten van cliënten. Zowel Legemaate als De Roode vrezen dat hulpverleners in de toekomst minder moeite zullen doen om met de cliënt tot overeenstemming te komen over (een deel van) het zorgplan, aangezien dwangbehandeling eerder toegestaan zal zijn.50 Ook Dijkers voorspelt dat de drempel voor dwangbehandeling lager wordt. ${ }^{51} \mathrm{Hij}$ relativeert deze uitspraak enigszins door erop te wijzen dat dwangbehandeling, ook na het schrappen van het woord 'ernstig', nog steeds moet voldoen aan strenge criteria. Dwangbehandeling is slechts toegestaan als dat 'volstrekt noodzakelijk' is (artikel 38 lid 5 Bopz), waarin de criteria subsidiariteit, proportionaliteit en effectiviteit terug te vinden zijn. Bovendien moet het gaan om gevaar dat, ondanks opneming, bestaat in een instituut.

49 Blankman beschouwt de opneming als een beslissing binnen een zorgtraject. De opneming is gericht op voortgaande behandeling en verzorging van cliënten. $K$. Blankman, Psychiatrie en recht. Rechtsbescherming bij vrijheidsbeneming in de sectoren verstandelijk gehandicaptenzorg en psychogeriatrie, Preadvies Vereniging voor Gezondheidsrecht, Utrecht 2003, p. 81-82.

50 Rechtbank Middelburg 30 augustus 2001, BJ 2001, 61, m.nt. J. Legemaate, p. 258 en R.P. de Roode, De interne rechtspositie in de psychiatrie, Praktijkreeks Bopz, deel 2. Den Haag: Koninklijke Vermande 2003, p. 46.

51 W. Dijkers, "Wijzigingen van de Wet Bopz: de stand van zaken begin 2002", Trema (24) 2002-4, p. 167. 
Een hulpverlener moet bij de toepassing van dwangbehandeling rekening houden met een aantal wettelijke vereisten. Dwangbehandeling mag alleen dat gedeelte van het zorgplan betreffen dat volstrekt noodzakelijk is om het gevaar af te wenden. Van belang is dat gevaar wordt veroorzaakt door de geestesstoornis van de cliënt. Zodra het gevaar verdwenen is, dient de dwangbehandeling gestaakt te worden. In de jurisprudentie is gevaar (voorheen ernstig gevaar) omschreven als gevaar voor de cliënt zelf en voor anderen. De Roodes maakt onderscheid tussen sociale, psychische en psychiatrische invaliditeit, latent gevaar, gevaar voor de cliënt zelf en gevaar voor anderen. In tegenstelling tot de toepassing van middelen of maatregelen hoeft niet sprake te zijn van een acuut gevaar. Een hulpverlener mag ook preventief ingrijpen.

De afgelopen jaren is een aantal uitspraken verschenen over (ernstig) gevaar. In een uitspraak van 21 maart $1995^{\circ 3}$ verstaat de Rechtbank Den Bosch onder gevaar 'een voortdurende achteruitgang van de cliënt, noodzakelijkerwijze leidende tot de dood of ernstige invaliditeit van de betrokkene'. In een andere uitspraak wordt de kans op uitputting, gevaar voor verwaarlozing, verhongering of uitdroging gelijkgesteld aan gevaar. ${ }^{\mathbf{4}}$ Beide uitspraken laten zien dat gevaar zich niet hoeft te openbaren als een 'acute noodtoestand'. Gevaar is ook aan de orde wanneer een cliënt agressie oproept bij medecliënten ${ }^{55}$ of de gezondheid van anderen door dreigend of agressief gedrag aantast. ${ }^{56}$ Niet elke vorm van agressie vormt overigens een reden om dwangbehandeling bij een cliënt toe te passen. Schoppen, krabben en slaan van het personeel vormen volgens de Rechtbank Leeuwarden geen gevaar in de zin van artikel 38 lid 5 Bopz, aangezien 'het gedrag zich alleen voordeed als het verzet van de cliënt tegen dwangmedicatie werd genegeerd'. ${ }^{57}$ De legitimatie voor dwangbehandeling komt te vervallen op het moment dat hulpverleners ervan overtuigd zijn dat het gevaar is geweken.

\section{Verzet}

De behandeling in het kader van artikel 38 lid 5 Bopz wordt uitgevoerd onder verzet van de cliënt en/of vertegenwoordiger. ${ }^{56}$ Verzet is in de Wet Bopz niet nader geoperationaliseerd. In de literatuur is wel een aantal handreikingen te

52 De Roode 2003, p. 37-40.

53 Rechtbank Den Bosch 21 maart 1994, niet gepubliceerd.

54 Rechtbank Roermond 26 mei 1994, BJ 27.

55 Rechtbank Den Bosch 6 april 1995, BJ 102.

56 Rechtbank Amsterdam 20 maart 1995, BJ 145.

57 Rechtbank Leeuwarden 25 februari $2000, k B J 2000,34$.

58 De behandeling wordt toch uitgevoerd, als de cliënt zich verzet, maar de vertegenwoordiger toestemming heeft verleend. 
vinden. ${ }^{59} \mathrm{Zo}$ is bij de interpretatie van verzet niet doorslaggevend of de cliënt wilsbekwaam is. Ook verzet van wilsonbekwame cliënten dient serieus genomen te worden. ${ }^{60}$

Het komt erop neer dat elke vorm van verzet als verzet moet worden geïnterpreteerd. In de kamerstukken wordt een toelichting gegeven op het begrip verzet. ${ }^{11}$ Hieruit kan worden afgeleid dat voor de interpretatie van verzet naar het feitelijk gedrag van de cliënt moet worden gekeken, waarbij gelet dient te worden op verbale en non-verbale uitingen. Ook verzet van een wilsonbekwame cliënt dient in beginsel als verzet te worden beschouwd..$^{62}$ Indien een hulpverlener twijfelt over de vraag of sprake is van verzet, zal de cliënt de 'benefit of the doubt' moeten krijgen. ${ }^{6}$

Sinds de invoering van de Wet Bopz heeft noch de wetgever, noch de brancheorganisatie VGN het begrip verzet, in het kader van de Wet Bopz, nader uitgewerkt. Het is wel mogelijk om een aantal criteria af te leiden uit de gedragscode van de Nederlandse Vereniging voor Artsen in de zorg voor verstandelijk gehandicapten (NVAVG ${ }^{(4)}{ }^{.5}$ De NVAVG heeft verzet nader uitgewerkt in het kader van de Wet medisch-wetenschappelijk onderzoek met mensen (Wmo) en komt tot een aantal criteria:

1. Verzet zal multidisciplinair moeten worden vastgesteld op basis van het gedrag van een cliënt.

2. Verzet kan zowel aan verbaal als non-verbaal gedrag worden afgemeten.

59 Voor de sector verpleeg- en verzorgingshuizen heeft het Ministerie van Volksgezondheid, Welzijn en Sport in 2002 een drietal voorlichtingsbrochures over de Wet Bopz uitgebracht. In deze brochures wordt ook aandacht besteed aan een nadere omschrijving van verzet.

60 C.J. van de Klippe, "Behandeling en dwangtoepassing: de artikelen 38 en 39 Bopz", in: P.J.H. Laurs, Handboek opneming en verblijf, Arnhem: Gouda Quint 1994, p. B7-57.

61 Kamerstukken II 1980-81, 11 270, nr. 17, p. 19 en Kamerstukken II 1991-92, 21 239, nr. 20, p. 9 (MvA)

62 R.B.M. Keurentjes, De Wet Bopz: de betekenis van de wet voor de beroepsbeoefenaren in de geestelijke gezondheidszorg, vijfde herziene druk, Den Haag: Koninklijke Vermande 2003, p. 139.

63 Kamerstukken 11 1991-1992 21 239, nr. 20, p.9 (MvA).

64 De afkorting NVAVG vervangt de verouderde afkorting NVAZ.

65 NVAZ, "Gedragscode voor artsen bij beoordeling van verzet bij mensen met een verstandelijke handicap in het kader van de Wet Medisch-Wetenschappelijk Onderzoek met Mensen", Tijdschrift van de Vereniging van Artsen in de Zwakzinnigenzorg (17) 1999-3, p. 13-15. 
3. Verzet moet worden afgezet tegen de achtergrond van de cliënt (m.b.v. zijn levensgeschiedenis).

4. Verzet is met name aan de orde als sprake is van afwijkend gedrag.

5. Verzet kan het beste worden beoordeeld door hulpverleners die de cliënt kennen, zodat zij aan specifiek gedrag een bepaalde waarde kunnen toekennen.

Uit de criteria van de NVAVG kan worden afgeleid dat een hulpverlener beter een oordeel kan geven over verzet naarmate hij de cliënt beter kent. In de verstandelijk gehandicaptenzorg zal het niet gemakkelijk zijn om aan dit criterium te voldoen. Cliënten krijgen te maken met veel verschillende hulpverleners.

De gedragscode van de NVAVG is een stap in de goede richting als het gaat om de operationalisering van het begrip verzet. Het begrip dient echter nog verder te worden uitgewerkt zodat ook afstand kan worden genomen van het 'bestwilcriterium'. Met de komst van de Wet Bopz is het bestwilcriterium vervangen door het gevaarscriterium. Pas als sprake is van gevaar, mag een cliënt tegen zijn wil worden behandeld. Aangezien verzet nog niet nader omschreven is, is de kans groot dat verzet van cliënten wordt genegeerd en hulpverleners, overigens met de beste bedoelingen, de behandeling voortzetten. Deze wijze van handelen druist in tegen het recht op zelfbeschikking. Daarentegen zal rechtsbescherming ook haar doel voorbij schieten als hulpverleners het gedrag van met name wilsonbekwame cliënten te snel als verzet interpreteren, waardoor bepaalde vrijheidsbeperkende maatregelen aan een cliënt worden onthouden met alle gevolgen van dien. ${ }^{66}$

\section{Grenzen aan dwangbehandeling}

De Wet Bopz kent geen maximum periode voor de toepassing van dwangbehandeling. Uit de parlementaire stukken valt op te maken dat dwangbehandeling voortgezet kan worden voor zover dat volstrekt noodzakelijk is om gevaar af te wenden. ${ }^{67}$ De wetgever zal niet de bedoeling hebben gehad om dwangbehandeling maanden te laten voortduren. ${ }^{68}$ Artikel 56 lid 1b Bopz geeft aan dat

66 T.P.J.C. Widdershoven, "Artikel 38" (supplement 2), in: P.J.H. Laurs, Handboek opneming en verbliif, Arnhem: Gouda Quint 1996, p. C1/ Art. 38-904-910.

67 Kamerstukken II 1990-91, 21 239, nr. 6, p. 19.

68 Uit gegevens van IGZ blijkt dat de duur van dwangbehandeling in de verstandelijk gehandicaptenzorg veelal geen kwestie is van enkele dagen, maar van maanden of zelfs jaren. In de periode van 1998-2002 zijn 932 dwangbehandelingen beëindigd en lopen nog 688 dwangbehandelingen. De gemiddelde duur van de beëindigde dwangbehandelingen bedraagt 239 dagen en van de 
hulpverleners niet verder dan een maand mogen vooruitkijken: het zorgplan dient elke maand geëvalueerd en zo mogelijk aangepast te worden. Er zijn situaties denkbaar waarbij gevaar ook na een maand nog aanwezig is. Door middel van tussentijdse evaluaties en de reeds eerder genoemde criteria subsidiariteit, proportionaliteit en effectiviteit zal ook dan getracht moeten worden om de inbreuken op de rechten van cliënten met een verstandelijke handicap zo veel mogelijk te beperken. Helaas kan niet iedere keer worden voldaan aan deze criteria. Door een gebrek aan personeel wordt niet altijd de minst ingrijpende vorm van dwangbehandeling gekozen. In een uitspraak van de Rechtbank Maastricht erkent de rechter dat instituten door een tekort aan middelen worden beperkt in hun keuze van dwangmiddelen: 'als er wel voldoende keuzemogelijkheden zijn, zou niet overgegaan zijn tot het afsluiten van de kamer'. ${ }^{\circ}$

Artikel 38 lid 5 Bopz biedt de mogelijkheid om bij Algemene Maatregel van Bestuur bepaalde therapeutische middelen uit te sluiten van dwangbehandeling. Tot nu toe is daar nog geen gebruik van gemaakt waardoor allerlei middelen therapeutisch ingezet kunnen worden, inclusief de middelen en maatregelen die in artikel $39 \mathrm{Bopz}$ worden genoemd. De vraag is echter of separatie en afzondering een therapeutisch doel kunnen hebben en of een langdurige toepassing van beide middelen niet op gespannen voet staat met de eerder genoemde beginselen effectiviteit, subsidiariteit en proportionaliteit. In een uitspraak van 25 augustus 1994 oordeelde de rechter dat separatie ook als therapeutisch middel ingezet kan worden. ${ }^{70}$ Dit in tegenstelling tot het standpunt van de Tweede Kamer daterend uit 1980: 'het is onjuist te stellen dat dwangmiddelen mogen worden toegepast in het kader van het behandelingsplan. Behandelingsplannen zijn gericht op de vooruitgang of ten minste op het voorkomen van achteruitgang van de cliënt en op de vermindering van zijn geestelijke stoornis. ${ }^{71}$

Een middel dat raakt aan de grenzen van dwangbehandeling is Elektro Aversietherapie (EAT). ${ }^{n}$ Een Landelijke Evaluatie Commissie EAT heeft in 1997 een

nog lopende dwangbehandelingen 1172 dagen. De gemiddelde duur van de dwangbehandelingen in de periode 1998-2002 bedraagt daarmee 635 dagen.

69 Rechtbank Maastricht, 20 januari 1999, kBJ 1999, 63, m.nt. red.

70 Rechtbank Middelburg 25 augustus 1994, reknr. 73/94, niet gepubliceerd.

71 Kamerstukken $I I$ 1980-81, 11 270, nr. 17, p. 20.

72 EAT onderscheidt zich van Electro Convulsie Therapie (ECT), dat een gangbaar begrip is in de psychiatrie. ECT is een behandeling waarbij een epileptisch insult (convulsie) wordt opgewekt. Zie voor verdere informatie over ECT het proefschrift van Van de Klippe, 1997, p. 189-194. Daarentegen bestaat EAT uit het toedienen van korte elektrische prikkels, toegediend via elektrodes op de ledematen, die als aversief worden ervaren om ongewenst gedrag te verminde- 
protocol opgesteld over de toepassing van EAT in de verstandelijk gehandicaptenzorg. ${ }^{3}$ Op grond van dit protocol is EAT alleen toegestaan bij mensen met een verstandelijk handicap die ernstige gedragsproblemen hebben. Tevens benadrukt de commissie dat de toepassing ervan tot een minimum beperkt moet blijven. Het middel mag pas worden ingezet als andere behandelmethoden niet het gewenste resultaat opleveren. EAT wordt verder beschouwd als een ongebruikelijke methode die niet tot het 'gewone arsenaal van behandeling en begeleiding' mag worden gerekend. Aangezien EAT ook niet wordt beschouwd als een medische behandeling, kan het middel ook onder de verantwoordelijkheid van een gedragsdeskundige worden toegepast. Een arts of een gedragsdeskundige dient zorgvuldig af te wegen wat goed is voor een cliënt: niet behandelen, met alle gevolgen van dien, of pijnprikkels toedienen met kans op verbetering. Meininger spreekt in dit kader over een paradox: 'vrijheidsbelemmering vindt plaats met het bewuste oogmerk van een uiteindelijke vergroting van de vrijheid van de persoon. 74

\subsubsection{Middelen of maatregelen}

Naast dwangbehandeling spreekt de Wet Bopz ook over dwang ter overbrugging van tijdelijke noodsituaties. Dwang heeft in dit kader geen therapeutische intentie: ${ }^{75}$ er is sprake van een beveiligingsintentie gericht op het opheffen van een noodsituatie die is ontstaan. ${ }^{76} \pi$ In de Nota van toelichting bij het Besluit middelen en maatregelen Bopz ${ }^{7 / 5}$ wordt gesteld dat in de verstandelijk gehandicaptenzorg noodsituaties minder vaak voor zullen komen dan in de psychiatrie, omdat het gedrag van mensen met een verstandelijke handicap doorgaans meer voorspelbaar is. ${ }^{79}$ De wetgever lijkt te suggereren dat door de juiste middelen of

ren. Toepassing van EAT vindt onder meer plaats bij mensen met een verstandelijke handicap die zichzelf ernstig verwonden.

73 Landelijke Evaluatie Commissie EAT, Protocol Electro Aversie Therapie, Rijswijk: 1997.

74 H.P. Meininger, "Ethische implicaties van electro-aversie therapie: overwegingen naar aanleiding van een casus", Nederlands Tijdschrift voor de zorg aan verstandelijk gehandicaptenzorg (25) 1992-4, p. 206-219.

75 Onder therapeutische intentie wordt verstaan dwang die is gericht op verbetering/genezing van de stoornis waaraan een cliënt lijdt.

76 T.P.J.C. Widdershoven, "Artikel 39 Bopz (supplement 10)", in: P.J.H. Laurs, Handboek opneming en verbliif, Arnhem: Gouda Quint 2000, p. C1/ Art. 39-23.

77 Van de Klippe 1994, p. B7-50-56.

78 Nota van toelichting bij het Besluit van 3 november 1993, Stb. 563, p. 3.

79 Een uitzondering dient gemaakt te worden voor mensen met een verstandelijke handicap met psychische en/of gedragsproblemen. 
maatregelen op te nemen in het zorgplan een noodsituatie voorkomen kan worden. Ook in de verstandelijk gehandicaptenzorg doen zich evenwel onvoorzienbare omstandigheden voor. Op zo'n moment zal een voorziening moeten worden getroffen, die mogelijk niet is vastgelegd in het zorgplan.

\section{Noodsituatie}

In de Nota van toelichting bij het Besluit middelen en maatregelen Bopz ${ }^{80}$ wordt van een noodsituatie gesproken 'als de cliënt onverwacht zodanig psychotisch functioneert dat dit leidt tot gevaar voor de cliënt zelf of voor anderen' of 'als meer dan de normale kans bestaat dat een dergelijke situatie zich zal gaan voordoen.' Het begrip noodsituatie wordt door deze omschrijving wel erg opgerekt. Uit de jurisprudentie kan worden opgemaakt dat ook een dreigende noodsituatie onder de definitie van noodsituatie valt. ${ }^{81}$ Van de Klippe merkt op dat dit concept ontstaan is in een tijd waarin dwangbehandeling verboden was en de rechter naar mogelijkheden zocht om noodzakelijk geachte dwang te legitimeren. ${ }^{n 2}$ De gedachte was dat met de komst van de Wet Bopz het begrip noodsituatie waarschijnlijk strikter zou worden gedefinieerd. De Wet Bopz biedt voldoende aanknopingspunten om bij mogelijke dreiging van gevaar het zorgplan met therapeutische middelen aan te passen teneinde het gevaar weg te nemen. Frijlink heeft in haar onderzoek alle jurisprudentie rondom het begrip noodsituatie tot 1991 bestudeerd. Daaruit blijkt dat het begrip noodsituatie betrekking heeft op de aard van het gevaar en de duur van de situatie. Gevaar is aanwezig als sprake is van onaanvaardbare risico's voor de lichamelijke integriteit van de cliënt of anderen. Het toepassen van een dwangmiddel wordt niet gerechtvaardigd door het werkrooster van het personeel of een tekort aan personeel. ${ }^{\circ 0}$

\section{Viif verschillende middelen of maatregelen}

De middelen of maatregelen die in het kader van artikel 39 Bopz kunnen worden toegepast worden in artikel 2 van het Besluit middelen en maatregelen Bopz genoemd: ${ }^{: 4}$ afzondering, separatie, fixatie, het toedienen van medicatie onder dwang en toediening van vocht en voeding onder dwang.

In de toelichting bij dit besluit worden de middelen of maatregelen nader beschreven.

1. Afzondering: een cliënt wordt ingesloten in een daarvoor speciaal bestemde eenpersoonskamer, die prikkelarm is ingericht en als regel een bed,

80 Nota van toelichting bij het Besluit van 3 november 1993, Stb. 563, p. 3.

81 President Rechtbank Alkmaar 3 mei 1989, TvGr 1989/57.

82 Van de Klippe 1994, p. B7-90-96.

83 Frijlink 1991, p. 49.

84 Besluit middelen en maatregelen Bopz van 3 november 1993, Stb. 563. 
een stoel, een kledingkast en wasgelegenheid bevat. Gedurende afzondering dient er doorlopend toezicht te zijn. Afzondering op de eigen kamer met de deur op slot, is formeel niet toegestaan. De afzonderingruimte dient te voldoen aan de eisen van het College Bouw Ziekenhuisvoorzieningen (CBZ). ${ }^{85}$

2. Separatie: een cliënt wordt voor intensieve afzondering ingesloten in een afzonderlijke, speciaal daarvoor bestemde en ingerichte ruimte, een separeerverblijf. Daarbij moet voldaan zijn aan de richtlijnen van het CBZ.

3. Fixatie: naast vastbinden wordt onder fixatie elke vorm van vasthouden verstaan waardoor de betrokkene in zijn bewegingen wordt belemmerd. Hulpmiddelen bij fixatie zijn Zweedse banden, onrustband, tafelblad, diepe stoel en bedhekken.

4. Onder dwang toedienen van medicatie: het gaat hierbij om medicijnen die ingezet worden ter overbrugging van een noodsituatie. Medicijnen met een langdurige werking zijn niet toegestaan.

5. Onder dwang toedienen van vocht en voeding: deze vorm doet zich zelden voor. Het valt echter niet uit te sluiten dat gevaar voor uitdroging ontstaat voordat het zorgplan is aangepast.

Separatie is niet toegestaan binnen de psychogeriatrie. Dit lijkt anders voor de verstandelijk gehandicaptenzorg waarbij separatie van tijd tot tijd nodig kan zijn

85 Het College Bouw Ziekenhuisvoorzieningen heert criteria opgesteld waaraan een afzonderingsruimte moet voldoen. College Bouw Ziekenhuisvoorzieningen, Bouwkundig-functionele maatstaven ten behoeve van nieuwbouwplannen voor afzonderingsvoorzieningen in de verstandelijk gehandicaptenzorg, Rapportnummer 075, Utrecht: 1999. Daarnaast heeft het College basiskwaliteitseisen voor separeer- en afzonderingsruimtes geformuleerd. Deze kunnen worden beschouwd als een aanvulling op de maatstaven (College Bouw Ziekenhuisvoorzieningen, Separeer-en afzonderingsruimtes, Bouwmaatstaven voor nieuwbouw, Utrecht: 2003).

86 Het College Bouw Ziekenhuisvoorzieningen heeft criteria opgesteld waaraan een separatieruimte moet voldoen. College Bouw voor Ziekenhuisvoorzieningen, Bouwkundig-functionele maatstaven ten behoeve van nieuwbouwplannen voor separeervoorzieningen in de geestelijke gezondheidszorg, Rapportnummer 074, Utrecht: 1999. Het betreft onder meer de volgende criteria: de inrichting van een separeerkamer dient tot een minimum beperkt te blijven. Indien een bed aanwezig is, kan het noodzakelijk zijn om dit aan de vloer te bevestigen. Ook mogen geen scherpe of uitstekende objecten aanwezig zijn. De ruimte moet over daglicht kunnen beschikken en een acceptabel uitzicht bieden. 
bij cliënten die ernstige gedragsproblemen hebben, aldus de Nota van toelichting bij het Besluit van 3 november 1997.87

\section{Duur}

De vijf vormen van middelen of maatregelen mogen niet langer dan zeven dagen worden toegepast. Na deze periode van zeven dagen moet het zorgplan in overeenstemming met de cliënt en/of vertegenwoordiger worden aangepast. Dit heeft tot gevolg dat de betreffende middelen of maatregelen na zeven dagen opgenomen kunnen worden in het zorgplan. Indien geen overeenstemming wordt bereikt over het aanpassen van het zorgplan, kunnen de middelen of maatregelen in de vorm van dwangbehandeling worden voortgezet voor een langere periode dan zeven dagen indien dit volstrekt noodzakelijk is om gevaar voor de cliënt of anderen te voorkomen. Dit betekent dat de termijn van zeven dagen voor onbepaalde tijd verlengd kan worden.

\section{Onderscheid artikel 38 en artikel 39}

Hoewel de wet over twee verschillende vormen van dwang spreekt, namelijk artikel 38-dwang en artikel 39-dwang, is dit juridische onderscheid in de praktijk moeilijk bruikbaar en dient naar een ander criterium te worden gezocht. De onduidelijkheid wordt mede veroorzaakt door het feit dat de vijf middelen of maatregelen ook in het kader van artikel 38 Bopz toegepast kunnen worden. De geest van de Wet Bopz is echter dat inbreuken op het zelfbeschikkingsrecht tot een minimum worden beperkt. Op grond van artikel 56 lid1b Bopz mag de hulpverlener niet verder vooruit kijken dan 1 maand. Dit betekent dat langdurige separaties, fixaties en afzonderingen elke maand opnieuw bekeken moeten worden.

\section{Beschermende maatregelen}

Hoewel beschermende maatregelen niet voorkomen in de Wet Bopz, is het begrip nog steeds verankerd in de verstandelijk gehandicaptenzorg. ${ }^{88}$ De Inspectie omschreef in het verleden beschermende maatregelen als 'verpleegkundige maatregelen, waarmee de ernstige verplegings- en zorgbehoeftige cliënt beschermd wordt tegen lichamelijk letsel.' Deze maatregelen hoefden van de Inspectie niet geregistreerd te worden. ${ }^{89}$ Een voorbeeld van een beschermende

87 Nota van toelichting bij het Besluit van 3 november 1993, Stb. 563, p. 5.

88 M.F. Wesseling, Evaluatie wet Bopz, Deelonderzoek 7: Interne rechtspositie verstandelijk gehandicapten: gevaarlijk zelfstandig?, Rijswijk: Ministerie VWS 1996, p. 16-17 en Arends, Blankman, Frederiks 2002.

89 Geneeskundige Inspectie voor de Geestelijke Volksgezondheid, Referentiekader algemene zwakzinnigeninrichtingen, Rijswijk: 1990. 
maatregel is het fixeren van een cliënt in bed om te voorkomen dat hij valt of het fixeren van een cliënt in een rolstoel vanwege epilepsie. Bij deze maatregelen zou de intentie van de maatregel niet vrijheidsbeperking zijn, maar bescherming oftewel de aanleiding voor de beperking in de vrijheid vormt niet het gedrag van de cliënt maar een lichamelijke beperking. ${ }^{90}$ Met de invoering van de Wet Bopz is niet meer van belang wat de intentie van vrijheidsbeperking is, maar is de aard van de maatregel bepalend." Het plaatsen van een bedhek wordt ook als een middel of maatregel beschouwd als de maatregel bedoeld is om te voorkomen dat een cliënt uit bed valt.

\section{Medische maatregelen}

In de praktijk moeten hulpverleners rekening houden met twee wettelijke regimes: de Wet Bopz als het gaat om het behandelen van stoornissen en de Wgbo voor de behandeling van somatische aandoeningen. De problemen ontstaan bij toepassingen van middelen of maatregelen die zich in een grijs gebied bevinden; zij zitten tussen de Wgbo en de Wet Bopz in. Een cliënt krijgt een tafelblad voor zijn rolstoel om te voorkomen dat hij uit zijn stoel valt vanwege epileptische aanvallen of een cliënt krijgt premedicatie van de tandarts. Als artsen deze middelen of maatregelen onder de Wgbo plaatsen, valt de toepassing ervan buiten het toezicht van de Inspectie. Een middel of maatregel in het kader van de Wgbo kent immers niet het wettelijke vereiste van registreren en melden. Deze maatregelen - een bedhek, een Zweedse band of een tafelblad - zijn vergelijkbaar met middelen of maatregelen die op grond van de Wet Bopz worden toegepast: er is sprake van een inbreuk op de vrijheid van cliënten. De Wgbo vormt niet het juiste juridische kader voor deze maatregelen. Deze wet bevat, in tegenstelling tot de Wet Bopz, onvoldoende waarborgen voor de toepassing van vrijheidsbeperkende maatregelen. Een onderscheid tussen Bopz-maatregelen en Wgbomaatregelen leidt bovendien tot verwarring op de werkvloer.

\section{Pedagogische maatregelen}

Naast beschermende en medische maatregelen is de pedagogische maatregel een gangbaar begrip binnen de verstandelijk gehandicaptenzorg. Deze maatregelen beogen het gedrag te beïnvloeden en zijn gericht op de ontwikkeling van de mogelijkheden van de cliënt. ${ }^{92}$ Het gaat onder meer om maatregelen die gedrag inperken, grenzen stellen, contact met anderen beperken, invulling van vrije tijd beperken of maatregelen waarbij bepaalde taken verplicht uitgevoerd moeten

90 Wesseling 1996, p. 16-17.

91 T.P.J.C Widdershoven 2000, p. C1/Art. 39-74-80.

92 Frijlink 1991, p. 64. 
worden. ${ }^{93}$ Widdershoven merkt terecht op dat waar dergelijke interventies het karakter hebben van een middel of maatregel de normering van de Wet Bopz in acht genomen moet worden. ${ }^{.4}$ Teneinde probleemgedrag van cliënten aan te pakken, wordt veelvuldig gebruik gemaakt van een 'time-out'. Deze methode heeft veel weg van de maatregel afzonderen. Volgens de Wet Bopz is afzonderen alleen toegestaan in een afzonderingsruimte die voldoet aan de vereisten van het CBZ. In een handboek voor pedagogen van Adriaans en Duker uit 1973 is te lezen dat verschillende ruimten in aanmerking komen voor een time-out zoals de linnenkamer, de garderobe en de slaapkamer. In hetzelfde boek is de volgende passage opgenomen: 'De methode moet niet worden beschouwd als een strafmaatregel, maar als een maatregel waardoor bekrachtiging van het probleemgedrag wordt voorko$m e n . O m$ deze reden is het niet per se nodig dat een cliënt het apart zetten als onaangenaam ervaart. Het kan zelfs voorkomen dat een cliënt plezier ervaart als het apart wordt gezet." $"$ s

De normen van de Wet Bopz zijn ook van toepassing als pedagogische maatregelen het karakter krijgen van één van de beperkingen die gedefinieerd zijn in artikel 40 lid 3 Bopz. ${ }^{* 6}$ Ter illustratie: een cliënt die in een aparte ruimte moet eten of een cliënt die alleen op afgesproken tijdstippen de woonkamer in mag komen. In de kinder- en jeugdpsychiatrie zijn hulpverleners ook bekend met het begrip pedagogische maatregelen. Het Trimbos-instituut heeft een richtlijn opgesteld over de toepassing van de Wet Bopz in de kinder- en jeugdpsychiatrie." Het doel van de richtlijn is om aan te geven welke handelingen in het kader van huisregels, opvoeding en behandeling zonder speciale voorwaarden mogen worden toegepast en welke handelingen aan wettelijke vereisten dienen te voldoen. De term pedagogische maatregel wordt in het rapport bewust niet genoemd vanwege de onduidelijkheid die rond dit begrip bestaat. In de richtlijn wordt de volgende indeling van interventies onderscheiden: handelingen in het kader van handhaving van huisregels, handelingen in het kader van opvoeding en handelingen in het kader van behandeling,98 Zodra de interventies het karakter van een Bopz-maatregel krijgen, dienen de normen van de Wet Bopz in acht te worden

93 A.M. Ingelse komt tot de volgende indeling van pedagogische maatregelen: beperkende, opleggende en faciliterende maatregelen (niet gepubliceerd). T.P.J.C. Widdershoven 2000, p. C1/Art. 39-74-80.

95 Adriaans en Duker, p. 42-43.

96 Pedagogische maatregelen raken soms nauw aan beperkingen in het recht op bewegingsvrijheid, artikel 40 lid 3 Wet Bopz. Het onderscheid tussen beide maatregelen is niet helder te maken.

97 Ooyen-Houben e.a., 1999.

98 Orthopedagogisch handelen wordt als onderdeel van de behandeling beschouwd. 
genomen. ${ }^{\infty}$ Voor zover pedagogische maatregelen niet onder de Wet Bopz vallen, is er nog altijd de toets van goed hulpverlenerschap waaraan voldaan moet worden (artikel 7:453 BW). ${ }^{100}$ De Wet Bopz vereist dat vrijheidsbeperkende maatregelen alleen toegepast worden als sprake is van gevaar dat wordt veroorzaakt door een geestesstoornis. In de kinder- en jeugdpsychiatrie handelt een goed opvoeder in veel gevallen om bestwil, waardoor het gevaarscriterium ruimer wordt geïnterpreteerd dan juridisch gezien toelaatbaar is. Daarnaast is niet eenvoudig vast te stellen in hoeverre gedragsproblemen te maken hebben met de geestesstoornis van de cliënt. De geluiden die hoorbaar zijn in de kinder- en jeugdpsychiatrie zijn vergelijkbaar met de situatie die zich in de verstandelijk gehandicaptenzorg voordoet in orthopedagogische instituten die formeel gezien onder de Wet Bopz vallen. In beide sectoren bestaat een grijs gebied, waarbij het niet duidelijk is of sprake is van opvoedkundige (pedagogische) maatregelen of Bopz-maatregelen. Dit geldt met name voor pedagogische maatregelen waar sancties of beloningen aan verbonden zijn. ${ }^{101}$ Deze maatregelen raken nauw aan de Wet Bopz: zelden stemt een cliënt in met een dergelijke maatregel. Vanuit de visie van een gedragsdeskundige is echter niet direct sprake van een straf. Deze werkwijze wordt verdedigd op grond van de norm goed hulpverlenerschap. Het is echter ook verdedigbaar dat deze maatregelen onder het regime van de Wet Bopz vallen. De gevolgen van het opleggen van een straf zijn dermate ingrijpend, dat sprake is van een vrijheidsbeperkende maatregel.

\subsubsection{Huisregels}

Artikel 37 Bopz gaat over huisregels: 'Huisregels bevatten geen andere regelen dan die nodig zijn voor een ordelijke gang van zaken in het psychiatrisch ziekenhuis. Zij beperken de vrijheid van handelen van de patiënt niet verder dan voor een dergelijke gang van zaken nodig is. ${ }^{\prime 20}$ Huisregels gelden in beginsel alleen voor cliënten die met een IBS, RM of een Bopz-indicatie zijn opgenomen.

99 De drie verschillende vormen van interventies worden in gedeeld in een aantal categorieën. Zodra een jongere zijn afspraken 'trendmatig' niet nakomt krijgen de handelingen van de hulpverlener steeds meer het karakter van de vrijheidsbeperkende maatregelen die zijn vastgelegd in de Wet Bopz.

100 T.P.J.C. Widdershoven 2000, p. C1/Art. 39-74-80.

101 Enkele voorbeelden zijn: een cliënt moet eten in de keuken omdat hij storend gedrag vertoont naar andere cliënten toe, een cliënt belonen met een sigaar indien hij zich aan de gemaakte afspraken houdt, een cliënt kan tijdens de koffie niet van de koekjes afblijven en moet afkoelen op de gang met de gangdeur op slot en een cliënt wil niet mee doen aan corvee en moet gaan nadenken op zijn kamer.

102 Besluit rechtspositieregelen Bopz, 3 november 1993, Stb. 651, artikel 3. 
In de kamerstukken wordt evenwel opgemerkt dat 'huisregels voor alle - ook de vrijwillig opgenomen - cliënten gelden'. ${ }^{100}$ Deze visie wordt onderschreven door een uitspraak van de Rechtbank Den Bosch ${ }^{104}$ waarin de rechter aangeeft dat huisregels ook van toepassing zijn op vrijwillig opgenomen cliënten. Door vrijwillig op een afdeling te verblijven wordt de cliënt geacht de huisregels te accepteren en zich daaraan ook te onderwerpen. Indien de cliënt zich niet met de regels kan verenigen staat het hem vrij zijn verblijf in het ziekenhuis te beëindigen, aldus de Rechtbank in Den Bosch. De strekking van deze uitspraak is niet verdedigbaar in de verstandelijk gehandicaptenzorg. Vrijwillig opgenomen cliënten verblijven in een voorziening, omdat zij zich doorgaans niet zonder ondersteuning kunnen handhaven buiten de voorziening. Daar komt bij dat zij weinig andere mogelijkheden hebben om naartoe te gaan. In de eerste evaluatie van de Wet Bopz geven onderzoekers aan dat de interne rechtspositie van onvrijwillig opgenomen cliënten beter is geworden ten opzichte van vrijwillig opgenomen cliënten. In theorie hoeven huisregels pas aan de wet te voldoen als op de groep onvrijwillig opgenomen cliënten verblijven. Om deze situatie te beëindigen is voorgesteld om artikel 37 lid 1 en 4 Bopz van toepassing te verklaren op alle afdelingen van instituten. ${ }^{105} \mathrm{Op}$ deze manier gelden huisregels voor alle cliẻnten van instituten, voor zover dat al niet gebeurt, en wordt voorkomen dat huisregels pas worden aangepast nadat een cliënt met een IBS, RM of een Bopzindicatie is opgenomen.

\section{Inhoud huisregels}

De wetgever geeft in artikel 37 Bopz het kader aan voor huisregels. In artikel 40 Bopz staan enkele andere beperkingen genoemd zoals beperkingen in het recht op bewegingsvrijheid. Huisregels mogen deze beperkingen niet uitbreiden. In verband hiermee is bepaald dat 'huisregels alleen die beperkingen kunnen aanbrengen in de vrijheid van handelen van een cliënt die nodig zijn om een instituut een geordende samenleving te doen zijn.'106 In de Nota van toelichting worden enkele voorbeelden genoemd: bezoektijden, slaaptijden, tijdstippen waarop mag worden getelefoneerd, pauzetijden, besteding van vrije tijd, verbod tot het aangaan van seksuele relaties, gebruik van alcohol en drugs, agressief gedrag en maatregelen ter voorkoming van geluidsoverlast. ${ }^{107}$ Toch bestaat er nog ondui-

103 Kamerstukken II 1980-81, 11 270, nr. 17, Nota n.a.v. het eindverslag, p. 71.

104 Rechtbank Den Bosch, 8 oktober 1990, rolnummer 565/90.

105 Wesseling 1996, p. 45.

106 Nota van toelichting bij het Besluit van 3 november 1993, Stb. 561, p. 3

107 Nota van toelichting bij het Besluit van 3 november 1993, Stb. 561, p. 3 
delijkheid over wat wel en niet in een huisregel thuis hoort. ${ }^{100}$ Dit werd onlangs geillustreerd in een uitspraak van 16 juli 2001 van de Rechtbank Den Bosch. ${ }^{10 \%}$ Een cliënt had een klacht ingediend over de huisregels van de afdeling van een psychiatrische instelling. Zij achtte de regels in strijd met haar bewegingsvrijheid. Volgens de geldende huisregels dienen cliënten tijdens therapietijden en ook tijdens activiteiten, zoals koffie-en theedrinken, binnen te blijven. Aan deze regels ligt een therapeutische doelstelling ten grondslag. In het verleden werden op deze huisregels uitzonderingen gemaakt voor de cliënt in kwestie. Deze uitzonderingen waren inmiddels ingetrokken waardoor de huisregels weer op haar van toepassing waren. De klacht werd ongegrond verklaard, aangezien het huisregels betrof en geen beperkingen in het recht op bewegingsvrijheid. In de Wet Bopz is bepaald dat klagen ex artikel 41 Bopz niet van toepassing is op klachten over huisregels. In zijn noot stelt Widdershoven terecht dat in dit arrest huisregels niet het juiste middel zijn om dergelijke afspraken in vast te leggen. Het geëigende instrument voor therapeutische doelstellingen is het zorgplan. ${ }^{110}$

\section{Voorwaarden}

Huisregels behoren niet meer te zijn dan regels die nodig zijn om met elkaar in een groep te leven. Zij horen bij het verblijf in een instituut. Van de cliënt wordt, zodra hij opgenomen is, verlangd dat hij deze regels naleeft, ondanks het feit dat huisregels over het algemeen eenzijdig worden vastgesteld. Indien een cliënt zich niet aan de huisregels houdt mogen daar consequenties aan worden verbonden. Deze maatregelen mogen geen strafkarakter hebben maar moeten gericht zijn op het beëindigen van de verstoring." ${ }^{.11}$

Het zorgplan biedt de mogelijkheid om nadere beperkingen vast te leggen die samenhangen met de geestesstoornis van de cliënt. Het is ook mogelijk om in het zorgplan voor een cliënt een uitzondering te maken op de huisregels, met andere woorden bepaalde huisregels worden in individuele gevallen niet van toepassing verklaard, verruimd of aangescherpt in het zorgplan. Op grond van de

108 GGZ Nederland heeft een model-huisreglement opgesteld (GGZ Nederland, Model-huisreglement, Utrecht: 1999). Hierin is vastgelegd welke onderwerpen in huisregels kunnen worden geregeld en welke niet. De Inspectie acht het wenselijk dat ook in de andere sectoren, de verstandelijk gehandicaptenzorg en de psychogeriatrie een vergelijkbaar document wordt opgesteld (IGZ 2004, p. 1213).

109 Rechtbank Den Bosch, 6 maart 2001, BJ 2001, 48, m.nt. T.P.J.C. Widdershoven.

110 Rechtbank Den Bosch, 6 maart 2001, BJ 2001, 48, m.nt. T.P. J.C. Widdershoven.

111 Nota van toelichting bij het Besluit van 3 november 1993. Stb. 561, p. 5 . 


\section{Hoofdstuk 5}

Wet Bopz $\mathrm{z}^{112}$ en de literatuur ${ }^{113}$ kunnen de volgende voorwaarden worden geformuleerd:

1. Huisregels gelden voor alle cliënten van een instituut (vrijwillig en onvrijwillig opgenomen).

2. Cliënt en/of vertegenwoordiger wordt zo spoedig mogelijk na opname over de huisregels geïnformeerd. ${ }^{114}$

3. Huisregels gaan niet verder dan nodig is om een ordelijke gang van zaken binnen een instituut te handhaven.

4. Huisregels mogen de fundamentele rechten ${ }^{115}$ van een cliënt niet verder beperken dan nodig is voor een ordelijke gang van zaken binnen een instituut.

5. In huisregels moet een redelijke verhouding bestaan tussen het doel en de inhoud van de regel.

6. Individuele beperkingen horen thuis in het zorgplan van een cliënt.

7. Huisregels kunnen beperkt of opgeheven worden via het zorgplan van een cliënt.

8. Beperkingen in het recht op bewegingsvrijheid ${ }^{116}$ horen niet thuis in de huisregels, maar in het zorgplan.

9. Huisregels dienen voortdurend geëvalueerd te worden, indien mogelijk samen met de cliënten.

10. Huisregels mogen geen sancties bevatten.

\subsubsection{Beperking in het recht op bewegingsvrijheid}

Dwangbehandeling en de toepassing van middelen of maatregelen zijn van ingrijpende aard. Dit geldt echter evenzeer voor beperkingen in het recht op bewegingsvrijheid (artikel 40 lid $3 \mathrm{Bopz}$ ). Ook zij tasten het zelfbeschikkingsrecht van cliënten aan. Beperkingen in het recht op bewegingsvrijheid dienen samen te hangen met de geestesstoornis van de cliënt en vormen vaak een aanvulling

112 Artikel 37 Bopz en Besluit rechtspositieregelen Bopz van 3 november 1993, Stb. 561.

$113 \mathrm{~J}$. Legemaate, "Opneming en behandeling krachtens een behandelingsovereenkomst", in: P.J.H. Laurs, Handboek opneming en verbliif, Arnhem: Gouda Quint 1996, p. B1-25.

114 Artikel 37 lid 3 Wet Bopz schrijft voor dat de voor de behandeling verantwoordelijke persoon zorgt draagt dat de cliënt een mondelinge toelichting ter zake ontvangt van de huisregels.

115 Onder fundamentele rechten wordt verstaan: ontvangen en verzenden van post, ontvangen van bezoek, vrijheid van beweging en vrij telefoonverkeer.

116 Bijvoorbeeld het afsluiten van een groepsruimte, de gang, de buitendeur. 
op of een aanscherping van de huisregels van de afdeling of de woning. De Wet Bopz schrijft voor in welke situaties de beperkingen opgelegd mogen worden:

a) Indien naar het oordeel van de voor de behandeling verantwoordelijke persoon van de uitoefening van het recht op bewegingsvrijheid ernstige nadelige gevolgen moeten worden gevreesd voor de gezondheidstoestand van de cliënt.

b) Indien dit ter voorkoming van verstoring van de orde in het ziekenhuis, zoals die in de huisregels is beschreven, of ter voorkoming van strafbare feiten noodzakelijk is.

Beperkingen in het recht op bewegingsvrijheid dienen per individu bepaald te worden en mogen niet het karakter hebben van een middel of maatregel, waarvoor striktere criteria gelden. In de jurisprudentie hanteert de rechter evenwel ook vrij strenge normen voor de toepassing van beperkingen in het recht op bewegingsvrijheid. In een arrest van 23 december 1988 van het Hof Den Bosch werden de opgelegde beperkingen, te weten het slechts in nachtgoed gekleed mogen gaan, het niet in eigen beheer mogen bewaren van post, het niet mogen schrijven van brieven en de afwezigheid van lectuur in de isolatiekamer, uitsluitend gerechtvaardigd door een noodtoestand, namelijk suicidegevaar en het gevaar voor brandstichting. Het Hof onderstreept dat de behandelaar zich bij elke maatregel dient af te vragen of deze geïndiceerd is uit therapeutisch oogpunt dan wel onvermijdelijk is vanwege een noodtoestand. Het onthouden van een sigaret mag nimmer louter als strafmaatregel opgelegd worden, aldus het Hof. ${ }^{117}$

Hulpverleners dienen alle beperkingen nauwkeurig vast te leggen in het zorgplan. Artikel 40 lid 3 Bopz illustreert dat een gedwongen opneming nog niet betekent dat de cliënt ook op een gesloten afdeling dient te verblijven. Pas als is voldaan aan een van de voorwaarden die genoemd worden in artikel 40 lid 3 Bopz mag een cliënt op een gesloten afdeling worden geplaatst. ${ }^{118}$ De beperkingen in het recht op bewegingsvrijheid hebben betrekking op het hele instituutsterrein. Voorbeelden van beperkingen ex artikel 40 lid 3 Bopz zijn beperkte tijden waarop een cliënt naar buiten mag gaan, op bepaalde tijden niet de woonkamer mogen betreden of onder begeleiding naar therapie gaan.

\section{Overige beperkingen in het kader van artikel 40 Wet Bopz}

In artikel $40 \mathrm{Bopz}$ wordt naast de beperkingen in het recht op bewegingsvrijheid nog een aantal andere beperkingen genoemd. Het betreft beperkingen in het

117 Hof Den Bosch, 23 december 1988, TvGr. 1989/43.

118 Keurentjes 2003, p. 106. 
recht op bezoek, het recht op vrij telefoonverkeer en het recht op briefgeheim. Deze beperkingen gelden alleen voor cliënten die via een RM of een IBS opgenomen zijn en niet voor cliënten met een Bopz-indicatie. Ook hier gelden weer de eerdergenoemde criteria van effectiviteit, proportionaliteit en subsidiariteit. Elke beperking die in artikel $40 \mathrm{Bopz}$ genoemd wordt dient gemotiveerd te worden door de behandelaar.

\subsection{Waarborgen rondom vrijheidsbeperking}

Vrijheidsbeperking dient, mede gezien de grote gevolgen die de toepassing ervan kan hebben voor het zelfbeschikkingsrecht van cliënten, te zijn omgeven door strikte waarborgen. In artikel 38 en $39 \mathrm{Bopz}$ zijn geen waarborgen te vinden die betrekking hebben op de toepassing van vrijheidsbeperking. Beide artikelen vermelden onder welke omstandigheden een middel of maatregel mag worden toegepast, maar gaan niet in op de vraag op welke wijze een middel of maatregel moet worden uitgevoerd. In het Besluit middelen en maatregelen Bopz ${ }^{119}$ wordt in de toelichting opgemerkt dat goede zorg met zich meebrengt dat bij afzondering doorlopend toezicht aanwezig is. Daarnaast dient een hulpverlener op grond van goed hulpverlenerschap op een verantwoorde wijze om te gaan met vrijheidsbeperking. Hij kan daarbij onder meer gebruik maken van richtlijnen en adviezen van de Inspectie en de brancheorganisatie VGN. Ook dient steeds rekening te worden gehouden met de beginselen effectiviteit, proportionaliteit en subsidiariteit (paragraaf 5.3).

\section{Verantwoordelijke arts}

Het behandelplan wordt in overleg met de cliënt of de vertegenwoordiger opgesteld door de 'voor de behandeling verantwoordelijke persoon' (artikel 38 lid 2 Bopz). In de toelichting op artikel $38 \mathrm{Bopz}$ wordt opgemerkt dat dit niet altijd een arts hoeft te zijn, maar ook een gedragsdeskundige of een persoonlijk begeleider kan zijn. Als het echter gaat om toepassingen van middelen of maatregelen wordt nadrukkelijk de behandelend arts genoemd als degene die uiteindelijk de beslissing neemt. ${ }^{120} \mathrm{Bij}$ afwezigheid van de arts is de vervanger verantwoordelijk. Als een arts niet terstond aanwezig kan zijn is het afdelingshoofd of diens vervanger de aangewezen persoon om de beslissing te nemen. De geneesheer-directeur is uiteindelijk eindverantwoordelijk voor de zorg die binnen een instituut wordt geboden aan cliënten. Deze functie zal over het algemeen ingevuld worden door een arts. Binnen de verstandelijk gehandicaptenzorg bestaat veel kritiek op deze eis aangezien het niet meer zou passen bij de ontwikkelin-

119 Nota van toelichting bij het Besluit van 3 november 1993, Stb. 563, p. 4.

120 Nota van toelichting bij het Besluit van 3 november 1993, Stb. 563, p. 4. 
gen binnen de sector. In het verleden overheerste in de verstandelijk gehandicaptenzorg het medische model, waarin de arts veel bevoegdheden had. Sinds geruime tijd is dit model losgelaten en hebben ook andere disciplines, waaronder gedragsdeskundigen, verantwoordelijkheden gekregen binnen een instituut. ${ }^{121}$ Ondanks deze ontwikkelingen blijven artsen in de verstandelijk gehandicaptenzorg een belangrijke positie innemen. Dit geldt met name in relatie tot de Wet Bopz. De NVAVG heeft een model taakomschrijving Bopz-arts opgesteld. ${ }^{12}$ Andere beroepsgroepen, zoals het Nederlands Instituut van Psychologen (NIP) en de Nederlandse Vereniging van pedagogen en onderwijskundigen (NVO), blijven op dit gebied achter waardoor de functie van een gedragsdeskundige in relatie tot de Wet Bopz onduidelijk blijft.

\section{Registreren}

Op grond van artikel 57 Bopz dient de geneesheer-directeur ervoor zorg te dragen dat elke toepassing van een middel of maatregel in een noodsituatie intern wordt geregistreerd. Daarbij dient de reden van de toepassing vermeld te worden. De inhoud van het register bestaat uit afschriften van formulieren die aan de Inspectie in het kader van een noodsituatie ex artikel 39 Bopz zijn gezonden. ${ }^{12}$ Daarnaast dient elke toepassing van dwangbehandeling en een middel of maatregel in het kader van artikel 39 Bopz bijgehouden te worden in het patiëntendossier (artikel 56 lid 1e, f Bopz). Het registeren van vrijheidsbeperking in een register en in dossiers van cliënten kunnen naast wettelijke verplichtingen ook worden beschouwd als onderdelen van goed hulpverlenerschap. Daarnaast mag, in het kader van de Kwaliteitswet zorginstellingen, van instituten worden verwacht dat zij als onderdeel van hun kwaliteitsbeleid over een intern registratiesysteem beschikken. Gegevens uit dit systeem kunnen worden gebruikt om het beleid ten aanzien van vrijheidsbeperking zonodig aan te passen.

121 Gedragsdeskundigen voeren aan dat vrijheidsbeperkende maatregelen in eerste instantie gevolgen hebben voor de psyche of beleving van de betrokken cliënt. Het behoort in hun ogen niet tot het domein van de arts om hierover een beslissing te nemen. Een arts kan 'alleen maar' over de somatische aspecten oftewel de veiligheid van de maatregel oordelen.

122 NVAVG, Model taakomschrijving Bopz-arts in de zorg voor mensen met een verstandelijke handicap, 2002.

123 Artikel 3 Regeling kennisgeving en toepassing dwangbehandeling en middelen of maatregelen en registratie middelen of maatregelen Bopz, 4 juni 2002, Stcrt. 109. Lw.tr. 1 september 2002 (Stb. 2002, 363). 


\section{Melden aan de Inspectie}

De Inspectie houdt toezicht op de toepassingen van vrijheidsbeperking door middel van de meldingen die van instituten binnenkomen. De geneesheer-directeur dient bij aanvang en bij beëindiging van dwangbehandeling en bij aanvang van middelen of maatregelen melding te maken bij de inspecteur (artikel 38 lid 6 respectievelijk artikel 39 lid 3 Bopz). Hij dient daarbij gebruik te maken van de meldingsformulieren die opgenomen zijn in de Regeling kennisgeving en toepassing dwangbehandeling en middelen of maatregelen en registratiemiddelen of maatregelen. ${ }^{124}{ }^{125}$ Artikel 39 Bopz geeft in tegenstelling tot artikel 38 lid 7 Bopz niet aan wat de Inspectie moet doen met de meldingen over middelen of maatregelen. Een melding over dwangbehandeling dient in elk geval door de Inspectie na afloop van de behandeling getoetst te worden op een zorgvuldige toepassing. ${ }^{126}$

\section{Goed hulpverlenerschap}

Voor goed hulpverlenerschap is vereist dat een hulpverlener op een verantwoorde wijze omgaat met de toepassing van vrijheidsbeperking. Het handelen van een hulpverlener wordt begrensd door zijn professionele standaard. Artikel 7:453 BW zegt immers dat 'de hulpverlener bij zijn werkzaamheden de zorg van een goed hulpverlener in acht moet nemen en daarbij moet handelen in overeenstemming met de op hem rustende verantwoordelijkheid, voortvloeiende uit de voor de hulpverleners geldende professionele standaard.' De professionele standaard van een hulpverlener wordt nader ingevuld door middel van wetgeving, jurisprudentie, richtlijnen en adviezen waardoor inzichtelijk wordt welke handelingen een hulpverlener mag verrichten en op welke wijze hij deze mag uitvoeren. Rondom de toepassing van vrijheidsbeperking in de verstandelijk gehandicaptenzorg bestaan nog veel on-

124 Artikel 1 en 2 Regeling kennisgeving en toepassing dwangbehandeling en middelen of maatregelen en registratie middelen of maatregelen Bopz, 4 juni 2002, Stcrt. 109. I.w.tr. 1 september 2002 (Stb. 2002, 363).

125 De verplichting tot het melden van beëindiging van middelen of maatregelen is bij de desbetreffende wetswijziging abusievelijk niet in de wettekst terechtgekomen. Bij een volgende wetswijziging zal deze omissie worden rechtgezet. In de tussentijd is in de Regeling kennisgeving en toepassing dwangbehandeling en middelen of maatregelen en registratie middelen of maatregelen Bopz een extra bijlage (IV) opgenomen om alsnog aan de verplichting te voldoen.

126 Tegelijkertijd hoeft een deel van de Bopz-gegevens niet aan de Inspectie gemeld te worden. Het betreft: middelen of maatregelen-akkoord, beperking vrijheden wat betreft bezoek, telefoonverkeer en beweging (artikel 40) en toepassingen van vrijheidsbeperking bij vrijwillig opgenomen cliënten (IGZ, Melden in het kader van de Wet Bopz aan de Inspectie voor de Gezondheidszorg, 2002b). 
duidelijkheden. De professionele standaard van de verschillende beroepsgroepen die werkzaam zijn in de verstandelijk gehandicaptenzorg biedt nog onvoldoende aanknopingspunten om op een verantwoorde wijze om te gaan met vrijheidsbeperking bij cliënten. Dit geldt met name voor persoonlijk begeleiders en gedragsdeskundigen (zie ook hoofdstuk 4). Recentelijk heeft de Inspectie een advies uitgebracht over het gebruik van de Zweedse band in de verstandelijk gehandicaptenzorg. Daarnaast is, in samenwerking met het CBO en de Verpleegkundig Wetenschappelijke Raad, een richtlijn verschenen over het gebruik van vrijheidsbeperkende maatregelen. Beide documenten bevatten waardevolle informatie op grond waarvan hulpverleners een nadere invulling kunnen geven aan goed hulpverlenerschap.

\section{Advies van de Inspectie over het gebruik van de Zweedse band}

Tijdens een debat in de Tweede Kamer, begin 2002, onderschrijt de toenmalige Minister van VWS dat zij op de hoogte is van situaties waarin cliënten worden vastgebonden op een zodanige wijze dat dit risico's met zich meebrengt. ${ }^{12} \mathrm{De}$ Inspectie heeft in 2002 een rapport gepubliceerd over de risico's die verbonden zijn aan het gebruik van de Zweedse band in de verstandelijk gehandicaptenzorg. De belangrijkste conclusies zijn: ${ }^{128}$

- $\quad$ Bij 7\% van de cliënten in instituten wordt de Zweedse band gebruikt.

- Binnen de gehandicaptenzorg gebeuren regelmatig (bijna) ongelukken met de Zweedse band.

- Hulpverleners zijn zich onvoldoende bewust van de risico's die verbonden zijn aan het gebruik van de Zweedse band.

- De belangrijkste reden om de Zweedse band toe te passen bij cliënten is het voorkomen van vallen.

- Zorgverleners die de Zweedse band toepassen beschikken zelden over een gebruiksaanwijzing of een protocol betreffende het gebruik ervan.

In het rapport worden ook enkele aanbevelingen gedaan teneinde de fisico's bij het gebruik van de Zweedse band terug te dringen. Van zorgaanbieders wordt verwacht dat zij een protocol hebben om de Zweedse band op een verantwoorde manier toe te passen. ${ }^{129}$ In dit protocol moet worden aangegeven wie verantwoordelijk is voor de beslissing, of gekeken is naar alternatieven en dient een risico-inventarisatie per cliënt te worden gemaakt. Daarnaast moeten afspraken

127 Handelingen II 2001-02, 22 januari 2002, p. 40-2950-2952.

128 Inspectie voor de gezondheidszorg, Risico's bij het gebruik van de Zweedse band in de gehandicaptenzorg, Den Haag: 2002a.

129 VGN heeft inmiddels een raamprotocol over het gebruik van onrustbanden in de gehandicaptenzorg uitgebracht (2002). 
zijn gemaakt over de wijze waarop toezicht wordt gehouden op een cliënt die wordt gefixeerd.

\section{Het gebruik van vrijheidsbeperkende interventies in de zorg}

Niet alleen een arts of een gedragsdeskundige, maar ook verpleegkundigen en verzorgenden krijgen te maken met situaties waarbij het noodzakelijk is om vrijheidsbeperkende maatregelen toe te passen. Eind 2001 heeft het $C B O$ en de Verpleegkundig Wetenschappelijke Raad ${ }^{130}$ een richtlijn opgesteld, waarin het besluitvormingsproces en het uiteindelijk gebruik van vrijheidsbeperkende maatregelen is uiteengezet. Deze richtlijn heeft tot doel een praktisch handvat te bieden aan verpleegkundigen en verzorgenden bij het toepassen van vrijheidsbeperkende maatregelen in alle intramurale settings van de gezondheidszorg.

Een aantal fasen wordt onderscheiden op grond waarvan verpleegkundigen en verzorgenden de informatie kunnen verzamelen die nodig is om op verantwoorde wijze de vrijheid van cliënten te beperken. ${ }^{131}$ De richtlijn dient op de werkvloer nog nader uitgewerkt en aangepast te worden aan de specifieke eigenschappen van de sector en locatie waar de richtlijn gebruikt gaat worden. Instituten zijn mede op grond van het Model Kwaliteitssysteem Gehandicaptenzorg $^{12}$ verplicht om de toepassing van vrijheidsbeperkende maatregelen volgens een vastgestelde werkwijize uit te voeren. Het Model Kwaliteitssysteem schrijft voor dat inzichtelijk moet zijn op welke wijze tot besluitvorming wordt gekomen ten aanzien van de toepassing van vrijheidsbeperkende maatregelen.

\subsection{Vrijheidsbeperking bij een artikel 60 Bopz-indicatie}

Vrijheidsbeperking mag op grond van de Wet Bopz alleen worden toegepast bij cliënten die onvrijwillig zijn opgenomen. Mensen met een verstandelijke handicap kunnen op drie verschillende manieren onvrijwillig worden opgenomen in een instituut, namelijk via een IBS, een RM of een Bopz-indicatie. Een onvrijwil-

130 Kwaliteitsinstituut voor de gezondheidszorg CBO en Verpleegkundig Wetenschappelijke Raad, Het gebruik van vrijheidsbeperkende interventies in de zorg. Een richtlijn voor verpleegkundigen en verzorgenden in een multidisciplinaire omgeving, Utrecht: 2002.

131 Het betreft de volgende fasen: is sprake van een gevaarlijke of risicovolle situatie, het verzamelen van informatie over het gevaar, het zoeken naar alternatieven voor vrijheidsbeperkende maatregelen, overleg met betrokkenen, is de vrijheidsbeperkende maatregel noodzakelijk, toepassing van de vriiheidsbeperkende maatregel en verslaglegging van het besluit, waarbij de achtergronden en overwegingen worden vermeld.

132 Vereniging Gehandicaptenzorg Nederland, Model Kwaliteitssysteem Gehandicaptenzorg, Utrecht: 2000, p. 42. 
lige opneming via een Bopz-indicatie is pas in een later stadium toegevoegd aan het wetsvoorstel Bopz. Nadat het ingediende wetsvoorstel Bopz ${ }^{13}$ in 1983 was aangenomen door de Tweede Kamer, gaven diverse partijen aan dat zij zich hier niet in konden vinden. Ook de Eerste Kamer uitte bezwaar. De kritiek had niet direct te maken met het feit dat de verstandelijk gehandicaptenzorg, in tegenstelling tot de Krankzinnigenwet, onder de reikwijdte van de Wet Bopz was gebracht, maar eerder met de verwachte werklastvermeerdering voor de rechterlijke macht. ${ }^{14}$ Het uitgangspunt van het wetsvoorstel was dat elke cliënt die niet bereid is tot opneming met een RM of een IBS opgenomen moet worden. In de verstandelijk gehandicaptenzorg kan een aanzienlijk aantal cliënten niet of moeilijk aangeven of zij bezwaar hebben tegen een opneming dan wel bereid zijn om opgenomen te worden. Onder de Krankzinnigenwet verbleef deze groep cliënten vrijwillig in instituten. De regering heeft deze kritiek serieus genomen en een novelle bij de Tweede Kamer ingediend die vervolgens in 1991 is aanvaard. ${ }^{135}$ In deze novelle is het ruime bereidheidscriterium voor de verstandelijk gehandicaptenzorg en psychogeriatrie losgelaten en vervangen door een strikter bezwaarcriterium. Pas als een cliënt zich nadrukkelijk verzet tegen opname dient een RM te worden aangevraagd. Indien hij echter geen blijk geeft van bereidheid en zich ook niet verzet tegen opneming, verloopt de opneming via een artikel 60 Bopz-indicatie.

Diverse juristen hebben hun oordeel gegeven over de toevoeging van de Bopznovelle en de gevolgen die deze heeft voor de rechtspositie van mensen met een verstandelijke handicap. ${ }^{136}$ Artikel $15 \mathrm{Gw}$ en artikel 5 Evrm vereisen dat een onafhankelijke instantie, bij voorkeur de rechter, betrokken moet zijn bij een beslissing die vrijheidsbeneming tot gevolg heeft. ${ }^{137}$ Het is de vraag of een proce-

133 Kamerstukken II 1970-71, 11 270, nrs. 1-3.

134 J. Krul-Steketee, "Waarborgt de Bopz de rechtspositie van demente bejaarden en zwakzinnigen?", Het Ziekenhuis (23) 1993-10, p. 458-463.

135 Handelingen II 1991-92, 17 december 1991, nr. 38, p. 2450-2451.

136 Krul-Steketee 1993, p. 458-463, H. van de Klippe, "De Bopz op het Binnenhof: bijna uitbehandeld", MGv Maandblad Geestelijke Volksgezondheid (47) 1992-3, p. 243-257, A. Frijlink en Th.A.M. te Braake, "Opneming in een zwakzinnigen- of verpleeginrichting: Bopz-novelle", Nederlands Juristenblad (65) 1990-24, p. 955 961, J. Krul-Steketee, "De Bopz-novelle, mede bezien vanuit het Evrm", Tijdschrift voor Gezondheidsrecht (16) 1992-5, p. 268-277, P.J.H. Laurs, "Wat de Bopz in petto heeft voor de psychogeriatrie en de gehandicaptenzorg", Het Ziekenhuis (22) $1992-12$, p. 594-598.

137 De rechter hoeft overigens niet elke toepassing van vrijheidsbeneming van tevoren te toetsen. Van belang is dat een cliënt de toepassing van vrijheidsbeneming achteraf kan laten toetsen door een rechter (artikel 5 lid 4 Evrm). 
dure bij een indicatiecommissie hieraan voldoet. Krul-Steketee beschouwt een artikel 60 opneming in een instituut voor verstandelijk gehandicaptenzorg niet als vrijheidsbeneming maar als een vorm van noodzakelijke zorgverlening, waarvoor het Evrm geen speciale wettelijke regeling vereist. ${ }^{138}$ Deze redenering is mede gebaseerd op het gevaarscriterium voor artikel 60 opneming. De Wet Bopz formuleert het gevaarscriterium als volgt: 'De noodzaak van opneming en verblijf in een zwakzinnigeninrichting is aanwezig, indien de betrokkene zich ten gevolge van de stoornis van de geestvermogens niet buiten de inrichting kan handhaven (artikel 60 lid 4 Bopz).' Krul-Steketee stelt dat een artikel 60 Bopz-indicatie alleen maar dient om vrijheidsbeperking, die tijdens het verblijf mogelijk noodzakelijk is, te legitimeren. ${ }^{139}$ Vooruitlopend op de toepassing van vrijheidsbeperking tijdens het verblijf, worden alle wilsonbekwamen bij voorbaat al onder de Wet Bopz geplaatst. $\mathrm{Zij}$ pleit ervoor om de procedure tot opneming van cliënten, die geen blijk geven van bereidheid en evenmin verzet tonen, uit de Wet Bopz te halen en te laten verlopen via een vertegenwoordiger. De Wgbo zou daar voldoende mogelijkheden voor bieden. Krul-Steketee heeft voor een deel gelijk. Veel instituten indiceren en masse hun vrijwillig opgenomen cliënten, zodat voor het geval het nodig mocht zijn, vrijheidsbeperkende maatregelen kunnen worden toegepast. ${ }^{140}$ De vraag is echter of artikel 60 cliënten uit de Wet Bopz moeten worden gehaald. De Wgbo biedt, in verhouding tot de Wet Bopz, minder waarborgen en is eigenlijk niet bedoeld voor het toepassen van vrijheidsbeperking. Frijlink en Te Braake hebben, in tegenstelling tot Krul-Steketee, een ander oordeel over de Bopz-novelle. Zij vinden het niet aanvaardbaar dat de rechtsbescherming van mensen met een verstandelijke handicap en psychogeriatrische patiënten afwijkt van die van psychiatrische patiënten. Elke opneming die het karakter heeft van onvrijwilligheid dient voorafgaand door een rechter getoetst te worden. ${ }^{141}$ Dit standpunt komt overeen met de conclusies van deelonderzoek 2 Evaluatie Wet Bopz, waarin Van Ginneken voorstelt om een speciale rechtbankkamer in te stellen voor de verstandelijk gehandicaptenzorg en psychogeriatrie. Elke cliënt die

138 Krul-Steketee 1992, p. 268-277

139 Krul-Steketee 1993, p. 458-463.

140 IGZ heeft in oktober 2001 een brief gestuurd naar VGN met het verzoek om medewerking te verlenen aan het herindiceren van vrijwillig opgenomen cliënten die opgenomen zijn in instituten met een Bopz-aanmerking. Een aanzienlijk aantal van deze cliënten is nog niet in het bezit van een artikel 60 -indicatie, terwijl bij deze cliënten wel vrijheidsbeperking wordt toegepast. Dit is in strijd met de huidige wet- en regelgeving en schaadt de rechtsbescherming van cliënten, aldus de Inspectie. Overigens is een deel van de vrijwillig opgenomen cliënten reeds voor de invoering van de Wet Bopz opgenomen.

141 Frijlink en Te Braake 1990, p. 955-961. 
niet vrijwillig instemt met opneming, wordt door deze rechtbankkamer beoordeeld. Daarmee vervalt het onderscheid tussen een RM en een Bopz-indicatie..$^{12}$ Het is echter nog maar de vraag of met dit voorstel de beoogde interne rechtsbescherming voor mensen met een verstandelijke handicap wordt gecreeerd. Veel cliënten in de verstandelijk gehandicaptenzorg zullen onder het voorstel van Van Ginneken nog steeds vrijwillig worden opgenomen. Het is veel belangrijker om de aandacht te verplaatsen naar de interne rechtspositie. Eerdere onderzoeken hebben laten zien dat op de werkvloer geen onderscheid wordt gemaakt tussen de verschillende juridische statussen die cliënten hebben gekregen bij opneming. 10

Duidelijk is dat de Wet Bopz een uitzondering maakt voor een grote groep cliënten binnen de verstandelijk gehandicaptenzorg. Vanuit het oogpunt van rechtsbescherming is het terecht dat deze groep onder de Wet Bopz is gebracht. De Wet Bopz bevat een aantal waarborgen die ook bij wilsonbekwame cliënten met een verstandelijke handicap in acht genomen moeten worden. De interne rechtspositie van artikel 60 cliënten blijft een punt van aandacht, met name omdat bij deze groep cliënten vrijheidsbeperkende maatregelen niet kortdurend worden toegepast. Uit artikel 38 lid 3 Bopz valt op te maken dat het zorgplan is bedoeld om de geestesstoornis van een cliënt zodanig te verbeteren dat het gevaar wordt weggenomen. Deze doelstelling is niet realistisch bij artikel 60 cliënten, ook niet als sprake is van vrijheidsbeperking. Het gevolg is dat vrijheidsbeperkende maatregelen structureel in plaats van incidenteel worden toegepast. In de toekomst zal bekeken moeten worden of cliënten met een Bopz-indicatie onder de Wet Bopz moeten blijven vallen of dat zij onder een andere regeling moeten worden ondergebracht. ${ }^{14}$

\subsection{Vrijheidsbeperking bij vrijwillig opgenomen cliënten}

De Inspectie heeft in 2002 een bulletin uitgebracht inzake het 'melden in het kader van de Wet Bopz aan de Inspectie voor de Gezondheidszorg'. Hierin staat

142 P. P. J. N. van Ginneken, Evaluatie Wet Bopz, Deelonderzoek 10-2: Externe rechtspositie in de psychogeriatrie en de verstandelijk gehandicaptensector, Den Haag: ZonMw 2002.

143 Blankman lijkt in zijn preadvies ook deze kant op te gaan. Hij stelt voor om het onderscheid tussen de externe en interne rechtspositie te laten vervallen. Een opneming in een instituut voor verstandelijk gehandicaptenzorg beschouwt hij als een bijzondere vorm van vrijheidsbeperking (Blankman 2003).

144 In hoofdstuk 7 wordt uitgebreider ingegaan op dit punt. In dit hoofdstuk wordt een alternatieve regeling voor de toepassing van vrijheidsbeperking uiteengezet. 
dat 'de toepassing van dwangbehandeling en de toepassing van middelen of maatregelen in het kader van een noodsituatie alleen mogelijk zijn bij patiënten die met een IBS, een RM of een Bopz-indicatie zijn opgenomen en met inachtneming van artikel 38 respectievelijk artikel 39 Bopz. " 45 Op grond van de Wet Bopz is het niet toegestaan om vrijheidsbeperking toe te passen bij vrijwillig opgenomen cliënten. Dwangbehandeling mag pas worden toegepast als een RM of een Bopz-indicatie is afgegeven. Een IBS-procedure moet in gang worden gezet, als de toepassing van middelen of maatregelen in het kader van een noodsituatie noodzakelijk is of dwangbehandeling nodig is. De rechter hanteert een andere benadering dan de Inspectie. De jurisprudentie laat zien dat het ook mogelijk is om bij vrijwillig opgenomen cliënten vrijheidsbeperking toe te passen.

\section{Jurisprudentie}

In de afgelopen jaren heeft de rechter zich diverse malen uitgesproken over vrijheidsbeperking bij vrijwillig opgenomen cliënten. Juridisch gezien is vrijheidsbeperking bij deze groep cliënten niet toegestaan. De Grondwet (artikel 10, 11 en 15) en het Europees verdrag voor de rechten van de mens (artikel 5 Evrm) vereisen een wettelijke grondslag voor vrijheidsbeneming en inbreuken op de lichamelijke integriteit van mensen. Deze wettelijke grondslag wordt geboden door de Wet Bopz. De onderstaande jurisprudentie laat zien dat vrijheidsbeperking ook buiten het wettelijke regime van de Wet Bopz voorkomt.

Een 29-jarige man verblijft vrijwillig in een instituut voor verstandelijk gehandicaptenzorg. Regelmatig wordt ter afwending van gevaar separatie toegepast, nu eens met instemming van betrokkene, dan weer met verzet. Er wordt een voorlopige machtiging gevorderd voor het kunnen toepassen van deze separatie. De Rechtbank oordeelt, dat in dit geval geen voorlopige machtiging is vereist, nu het verzet zich niet richt tegen voortduring van het verbliif in het instituut en het verzet tegen de separatie steeds kortdurend is. Betrokkene geniet weliswaar geringere rechtsbescherming dan degenen die onvrijwillig of na beoordeling van een indicatiecommissie in het instituut zijn opgenomen, zo overweegt de Rechtbank, maar deze leemte kan niet worden opgevuld door de ingrijpende en veelal langdurige maatregel van de voorlopige machtiging toe te passen. Het is aan de wetgever om de interne rechtspositie van cliënten in gevallen als deze te verbeteren. De voorlopige machtiging wordt niet afgegeven. In de noot wordt opgemerkt dat dwanginterventie ten aanzien van een vrijwillig in een instituut voor verstandelijk gehandicaptenzorg of psychogeriatrisch verpleeghuis verblijvende persoon zonder rechterlijke machtiging kan plaatsvinden. Basis hiervan is artikel 7:466 lid 1 BW.146

145 IGZ 2002b, p. 19.

146 Rechtbank Alkmaar, 10 februari 1998, kBJ 1998, 43, m.nt. W. Dijkers. 
Betrokkene verblijft al jaren vrijwillig in een instituut voor verstandelijk gehandicaptenzorg. Regelmatig is in verband met agressief gedrag separatie vereist, hetgeen meestal gebeurt met instemming van betrokkene. Het komt echter ook voor, dat betrokkene zich tegen deze separatie verzet, maar achteraf daarmee instemt. De Rechtbank wijst de vordering tot het verlenen van een voorlopige machtiging af op grond van het feit dat het verzet zich niet richt tegen het verbliif als zodanig, maar tegen de separaties. Ook overweegt de Rechtbank dat ondanks het feit dat frequentie en duur van de separaties toenemen, betrokkene hiermee lijkt in te stemmen. ${ }^{10}$ ?

In bovenstaande uitspraken vond de Rechtbank het niet noodzakelijk om de juridische status van de cliënten te wijzigen in een onvrijwillige opname. De jurisprudentie is op dit punt echter niet consistent. In de uitspraak van 10 februari 1998 van de Rechtbank Alkmaar is de rechter van mening dat de status van een vrijwillig opgenomen man in een instituut voor verstandelijk gehandicaptenzorg niet omgezet hoeft te worden in die van een onvrijwillig opgenomen cliènt. Dwanginterventies kunnen blijkbaar ook zonder een rechterlijke machtiging plaatsvinden. ${ }^{14}$ De juridische basis daarvoor is te vinden in de artikelen 7:465 lid $6 \mathrm{BW}$ en 7:466 lid $1 \mathrm{BW} .{ }^{10}$ Bovendien is het verzet in deze casus niet gericht tegen het verblijf maar tegen de toepassing van een middel of maatregel. Een jaar later wordt in een andere uitspraak (Rechtbank Den Bosch, 6 oktober 1999, kB) 2000,30 ) wel een voorlopige machtiging verleend teneinde dwangbehandeling mogelijk te maken. In deze zaak ging het om het toepassen van stroomstoten (EAT) bij een vrijwillig opgenomen cliënt met een verstandelijke handicap. Er

Artikel 7:466 lid 1 BW luidt: 'is op grond van artikel 7:465 BW voor het uitvoeren van een verrichting uitsluitend de toestemming van een daar bedoelde persoon in plaats van die patiënt vereist, dan kan tot de verrichting zonder die toestemming worden overgegaan indien de tijd voor het vragen van die toestemming ontbreekt aangezien onverwijlde uitvoering van de verrichting kennelijk nodig is teneinde ernstig nadeel voor de patiënt te voorkomen.'

147 Rechtbank Alkmaar, 1 februari 2000, kBJ 2000, 43, m.nt. red.

148 Deze trend doet zich ook voor in de psychiatrie: Rechtbank Arnhem, 6 november 2001, BJ 2002, 15, m.nt. redactie.

149 Zie ook Rechtbank Amhem, 6 november 2001, BJ 2002, 15, m.nt. redactie waarin wordt tegengesproken dat de Wgbo geschikt is voor dwangbehandeling. In deze uitspraak wordt opgemerkt dat de Wet Bopz, in tegenstelling tot de Wgbo, een op die situatie toegesneden rechtsbescherming bevat. Het zou in strijd zijn met de bedoeling van de wetgever om vrijwillig opgenomen patiënten minder rechtsbescherming te bieden dan de Bopz-patiënten. De artikelen 7:465 lid 6 en 7:466 lid 1 BW werden door de rechter niet geschikt geacht voor dwangbehandeling. 
werd verondersteld dat betrokkene zich verzette tegen de behandeling. In deze casus is onduidelijk of is nagegaan of de Wgbo in dit geval ook een oplossing kon bieden.

Onderstaande casus betreffen beide een omzetting van een vrijwillige opneming in een onvrijwillig opneming.

Betrokkene verblijft op basis van vrijwilligheid in een instituut voor verstandelijk gehandicaptenzorg. Hoewel hij niet van plan is definitief uit het instituut te vertrekken, is sprake van verzet daar betrokkene zich bepaalde interventies niet laat welgevallen, door bijvoorbeeld lang weg te blijven. Naar het oordeel van de Rechtbank is onder deze omstandigheden, hoewel betrokkene niet van plan is om definitief te vertrekken, sprake van verzet als bedoeld in artikel $3 \mathrm{Bopz}$. Het doel van de machtiging is primair om betrokkene tegen zijn wil in zijn kamer te kunnen opsluiten teneinde te beletten dat hij ongewenst seksueel contact aangaat met vrouwen en kinderen. De advocaat van betrokkene bepleit een opneming via de indicatiecommissie. Dit is echter niet mogelijk vanwege het verzet dat betrokkene toont. Bovendien heeft betrokkene, ook met een opneming via artikel 60 Bopz, de vrijheid om zich aan dwang te onttrekken door het instituut te verlaten. Een artikel 60 opneming legitimeert immers niet een daadwerkelijke vrijheidsberoving. De Rechtbank in deze casus verleent de voorlopige machtiging. ${ }^{150}$

De Officier van Justitie stelt een vordering in tot het verlenen van een voorlopige machtiging voor een behandeling met stroomstoten (EAT) van een vrijwillig opgenomen cliënt met een verstandelijke handicap. Zonder deze behandeling zou de cliënt zich verwonden als gevolg van een geestesstoornis. In aanmerking nemende dat met de cliënt geen communicatie mogelijk is en gelet op de aard van de behandeling, wordt verondersteld dat cliënt zich tegen de therapie verzet. De Rechtbank overweegt dat de nodige bereidheid als bedoeld in artikel 2 lid 3 sub a Bopz ontbreekt en dat de handelwijze van het instituut is aan te merken als een gedwongen behandeling in de zin van artikel 38 lid 5 Bopz. De voorlopige machtiging wordt verleend. In de noot wordt gewezen op de mogelijkheden van de Wgbo en artikel 42 Bopz. Via artikel 42 Bopz kan de Inspectie aan de rechter alsnog de vraag voorleggen of de behandeling, waartegen de cliënt zich verzet, noodzakelijk is, Op deze wijze hoeft niet de omweg van de voorlopige machtiging gevolgd te worden teneinde de vraag naar de geoorloofdheid van de dwangbehandeling aan de rechter voor te kunnen leggen. Voor toepassing van artikel 42 Bopz is wel vereist dat een artikel 60 opneming heeft plaatsgevonden. 152

De Inspectie gaat ervan uit dat middelen of maatregelen alleen toegepast mogen worden bij onvrijwillig opgenomen cliënten. Een uitzondering op dit uitgangs-

150 Rechtbank Amsterdam, 30 oktober 1998, kBJ 1999, 5, m.nt. T.P. J.C. Widdershoven

151 Rechtbank Den Bosch, 6 oktober 1999, $k$ BJ 2000, 30, m.nt. K. Blankman 
punt, zo meent de Inspectie, doet zich voor als sprake is van een incidentele toepassing van een middel of maatregel bij een vrijwillig opgenomen cliënt. ${ }^{15}$ In geval van een noodsituatie kan het noodzakelijk zijn om een middel of maatregel toe te passen. Formeel moet in zo'n situatie eerst de juridische status van een cliënt worden aangepast aan de omstandigheden. Echter, in bepaalde gevallen geldt de regel nood breekt wet. Mocht het vervolgens niet bij een incidentele situatie blijven, dan dient de juridische status van de cliënt alsnog, met het oog op vervolgacties, aangepast te worden. ${ }^{15}$ De Wet Bopz biedt aan onvrijwillig opgenomen cliënten een aantal procedurele waarborgen waar vrijwillig opgenomen cliënten geen aanspraak op kunnen maken. Naast de mogelijkheid voor cliënten om gebruik te maken van de speciale klachtenprocedure heeft een instituut ook de verplichting om de handelingen te melden aan de Inspectie.

Op grond van de jurisprudentie kan worden geconcludeerd dat in bepaalde gevallen vrijheidsbeneming ook buiten het regime van de Wet Bopz om toegepast mag worden. Bovendien doet de Rechtbank Alkmaar (10 februari 1998) de volgende uitspraak: 'Betrokkene geniet weliswaar geringere rechtsbescherming dan degenen die onvrijwillig of na beoordeling van een indicatiecommissie in de inrichting zijn opgenomen, maar deze leemte kan niet worden opgeould door de ingrijpende en veelal langdurige maatregel van de voorlopige machtiging toe te passen in bovenvermelde situaties. Het is aan de wetgever om de interne rechtspositie in gevallen als deze te verbeteren.' In de noot bij de uitspraak van 6 oktober 199914 wordt een aantal visies uiteengezet op de vraag of een machtiging verleend mag worden met als doel dwangbehandeling. Widdershoven pleit voor een dubbele toetsing, wanneer de machtiging bedoeld is om dwangbehandeling te legitimeren. De rechter moet niet alleen toetsen of aan de grond voor opneming is voldaan maar hij dient ook na te gaan of de voorwaarden voor dwangbehandeling aanwezig zijn. ${ }^{155}$ Blank-

152 Arends, Blankman en Frederiks, 2002, p. 38.

153 Uit een uitspraak van de Rechtbank Amsterdam blijkt dat ook bij structurele toepassingen geen rechterlijke machtiging noodzakelijk is. Het betrof hier een vrouw die op vrijwillige basis was opgenomen en van tijd tot tijd, zonder haar instemming, gesepareerd moest worden. Ze maakte geen aanstalten om het psychiatrisch ziekenhuis te verlaten. Bovendien had ze tijdens een zitting aangegeven geen bezwaar te hebben tegen separatie in het geval haar behandelaars dat noodzakelijk achten.

154 Rechtbank Den Bosch, 6 oktober 1999, kBJ 2000, 30, m.nt. K. Blankman.

155 In de uitspraak van 6 oktober 1999, $k$ BJ 2000, 30, heeft de rechter deze dubbele toetsing uitgevoerd. De rechter overweegt niet alleen of de nodige bereidheid voor opneming en verblijf ontbreekt maar ook of de dwangbehandeling, EAT, volstrekt noodzakelijk is om gevaar voor anderen af te wenden. Deze dubbele toetsing is ook aan de orde in de psychiatrie: Rechtbank Arnhem, 21 november 
man daarentegen is van mening dat pas overgegaan moet worden op een dubbele toetsing als duidelijk is dat de Wgbo geen uitkomst biedt. Het argument dat de Wet Bopz meer rechtsbescherming biedt (artikel 41 Bopz klachtregeling) is niet overtuigend omdat dit voordeel wegvalt tegen het nadeel dat de cliënt zijn bewegingsvrijheid kwijtraakt. Blankman prefereert eerst naar de Wgbo te kijken omdat door de dubbele toetsing het gevaar ontstaat dat de schotten tussen opneming en behandeling dreigen te vervagen. Een oordeel over de geoorloofdheid van de dwangbehandeling kan uiteindelijk ook via artikel 42 Bopz verlopen zonder daarvoor de procedure van een voorlopige machtiging te moeten doorlopen. De mening van zowel Widdershoven als Blankman bevatten een kern van waarheid. In de praktijk komt het geregeld voor dat dwangbehandeling plaatsvindt bij vrijwillig opgenomen cliënten. Aangezien deze cliënten zich niet verzetten tegen het verblijf in een instituut, is een voorlopige machtiging eigenlijk niet aan de orde. Van Ginneken merkt terecht op dat de huidige Wet Bopz thans niet goed in elkaar zit. Deze wet biedt geen oplossing voor situaties waarin de cliënt enerzijds bereid is om zijn verblijf te continueren in een instituut maar anderzijds niet bereid is bloot te worden gesteld aan vrijheidsbeperkende maatregelen. ${ }^{156}$ Het huidige systeem van de Wet Bopz zit zodanig in elkaar, dat eerst de juridische status moet worden aangepast, alvorens overgegaan kan worden tot het meer inhoudelijke gedeelte oftewel de toepassing van vrijheidsbeperkende maatregelen. Hieruit blijkt dat de Wet Bopz met name gericht is op opneming van cliënten. De benodigde ondersteuning kan pas worden geboden aan cliënten, als zij in het bezit zijn van de juiste juridische status. Van Ginneken kiest dan ook voor een andere oplossing. Als een cliënt vrijwillig is opgenomen behoort het tot de taak van een hulpverlener om alles op alles te zetten om geen dwangbehandeling te hoeven toepassen. Hij zal moeten proberen de cliënt te overtuigen en te motiveren om dwangbehandeling te voorkomen. ${ }^{157}$ In de psychiatrie zal de kans groter zijn dat een hulpverlener de situatie kan voorleggen aan de cliënt. Dit neemt echter niet weg dat ook in de verstandelijk gehandicaptenzorg met cliënten en vertegenwoordigers kan worden overlegd en gezamenlijk op zoek kan worden gegaan naar alternatieven.

De Hoge Raad schept meer duidelijkheid over de toepassing van vrijheidsbeperking bij vrijwillig opgenomen cliënten. ${ }^{158}$ Uit een arrest van 2 november 2001 kan worden afgeleid dat dwangbehandeling in een Bopz-locatie 'in beginsel' de rechtsbescherming verdient van de Wet Bopz. Dit is op zich een terechte con-

2001, BJ 2002, 16; Rechtbank Den Haag, 15 september 2000, kBJ 2000, 65, m.nt. redactie; Hoge Raad, 2 november 2001, BJ 2002, 1, m.nt. T.P. Widdershoven.

156 Rechtbank Roermond, 24 november 1999, kBJ 2000, 13, m.nt. Van Ginneken.

157 Rechtbank Roermond, 24 november 1999, kBJ 2000, 13, m.nt. Van Ginneken.

158 Hoge Raad, 2 november 2001, BJ 2002, 1, m.nt. T.P.J.C. Widdershoven. 
statering. Het blifft echter omslachtig dat deze rechtsbescherming pas kan worden geboden nadat een voorlopige machtiging (of een Bopz-indicatie) is afgegeven.

\section{Wgbo versus Wet Bopz}

De Wgbo heeft betrekking op geneeskundige handelingen en is op het eerste gezicht niet het juiste kader voor vrijheidsbeperking. De intentie van een geneeskundige handeling is, in tegenstelling tot handelen in het kader van de Wet Bopz, niet het wegnemen of verminderen van een geestesstoornis. Onvrijwillig opgenomen cliënten krijgen te maken met de Wgbo als het gaat om handelingen die gericht zijn op het genezen van somatische aandoeningen. Handelingen die worden verricht door de tandarts of de arts van een instituut, zoals het toedienen van een griepprik, worden door de Wgbo genormeerd. Het toepassen van vrijheidsbeperking kan onderdeel uitmaken van een somatische behandeling, zoals het fixeren van een cliënt tijdens zijn genezingsproces. Wilsbekwame cliënten kunnen hiervoor zelf toestemming geven. Indien een cliënt wilsonbekwaam is, mag de vertegenwoordiger plaatsvervangend toestemming geven voor de behandeling. Vrijheidsbeperkende maatregelen, die worden vastgelegd in het zorgplan, hoeven in beginsel niet te voldoen aan de eis dat zij noodzakelijk zijn om ernstig nadeel bij de cliënt te voorkomen. Immers, met toestemming van de cliënt en vertegenwoordiger kan bijna alles worden vastgelegd in het zorgplan. Dit geldt ook voor de Wet Bopz, mits cliënt en vertegenwoordiger zich niet verzetten tegen de inhoud van het zorgplan. ${ }^{159}$

In die gevallen dat een wilsbekwame cliënt zich onder de Wgbo verzet, biedt de Wgbo geen ruimte voor behandeling (artikel 7:465 lid $6 \mathrm{BW}$ ). Dwangbehandeling onder de Wgbo is alleen mogelijk bij wilsonibekwame cliënten. Als een wilsonbekwame cliënt zich verzet tegen een verrichting van ingrijpende aard kan deze handeling slechts uitgevoerd worden indien zij 'kennelijk nodig is teneinde ernstig nadeel voor de cliënt te voorkomen.' ${ }^{160}$ Dit is een belangrijk onderscheid met de Wet Bopz, waarbij het niet uitmaakt of een cliënt wilsbekwaam dan wel wilsonbekwaam is. Dwangbehandeling op grond van artikel 38 lid 5 Bopz is in beide gevallen mogelijk, mits sprake is van gevaar. Een ander verschil tussen de Wgbo en de Wet Bopz is de legitimatie van dwangbehandeling. De Wet Bopz spreekt over 'gevaar' voor de cliënt zelf of derden in tegenstelling tot de Wgbo waar sprake moet zijn van een 'ernstig nadeel'. Weliswaar is ernstig nadeel voor meer interpretaties vatbaar, het gaat onder de Wgbo alleen over

159 Er moet uiteraard wel sprake zijn van een therapeutisch doel.

160 Artikel 7:465 lid 6 BW. 
nadeel voor de cliënt zelf en niet over nadeel voor derden. ${ }^{161}$ Widdershoven wijst er nadrukkelijk op dat artikel 7:465 lid $6 \mathrm{BW}$ niet geschikt is voor het onder dwang uitvoeren van (een deel van) het Bopz-zorgplan, of het onder dwang toepassen van een behandeling die er op is gericht de psychische stoornis te verbeteren zodat gevaar wordt weggenomen. ${ }^{162}$ Ook Dijkers is van mening dat de Wgbo niet geschikt is voor toepassingen van vrijheidsbeperking in het kader van de Wet Bopz. Hij maakt nadrukkelijk onderscheid tussen de Wgbo en de Wet Bopz. De belangrijkste reden daarvoor is dat de Wgbo als uitgangspunt heeft dat in vrijheid een contract wordt gesloten tussen een cliënt en een hulpverlener. ${ }^{163}$ Dit kan niet worden gezegd van een Bopz-maatregel: cliënt en hulpverlener zijn in dat geval tot elkaar veroordeeld. Voor beide partijen bestaat weinig ruimte voor vrijheid. De behandeling staat in het teken van een dusdanige verbetering van de stoornis, dat daarmee het gevaar wordt weggenomen. ${ }^{164}$

Gezien de verschillen tussen de Wgbo en de Wet Bopz is het alleen onder strikte voorwaarden toegestaan om dwang toe te passen buiten het Bopz-kader om. Dwangbehandeling dient beperkt te blijven tot een tijdelijke situatie. Daarbij moet (zo spoedig mogelijk) overeenstemming bestaan tussen de cliënt en/of de vertegenwoordiger en de hulpverlener. Zonder toestemming van de cliënt en/of de vertegenwoordiger zal dwangbehandeling alleen kunnen worden gerechtvaardigd door 'de zorg yan een goed hulpverlener', ${ }^{105}$ Een hulpverlener kan op grond van zijn goed hulpverlenerschap van oordeel zijn dat de toepassing van dwangbehandeling absoluut noodzakelijk is en voorrang verdient boven nietbehandelen. De Wet Bopz, wellicht niet in de huidige vorm, blijft echter een meer geëigend kader voor dwang. Op grond van deze wet dient een vrijheidsbeperkende maatregel intern geregistreerd te worden en dient de Inspectie op de hoogte te worden gebracht. Ook heeft de cliënt de mogelijkheid om een klacht in te dienen bij een Bopz-klachtencommissie op grond van artikel $41 \mathrm{Bopz}$ wanneer hij het niet eens is met de toepassing van vrijheidsbeperking. De Wgbo bevat geen vergelijkbare bepalingen.

Naast oneigenlijk gebruik van de Wgbo komt het ook voor dat de Wet Bopz oneigenlijk wordt gebruikt. In een uitspraak van de Rechtbank Zwolle ${ }^{166}$ werd een voorlopige machtiging verleend om een vrijwillig in een psychiatrische woon-

161 T.P.J.C. Widdershoven, 'Artikel 38, supplement 2', in: P.J.H Laurs, Handboek opneming en verbliif, Deventer: Gouda Quint 1996, p. C1-1031-1032.

162 Widdershoven 1996, p. C1/Art. 38-1031-1154.

163 W. Dijkers, Doen en laten in de Bopz-machtigingsprocedure. Een onderzoek naar juridische posities (diss. Groningen), Den Haag: SDU Uitgevers BV, p. 215.

164 Besluit rechtspositieregelen van 3 november 1993, Stb. 561.

165 Van Veen 2002, p. 117-120.

166 Rechtbank Zwolle, 25 januari 2000, kBJ 2000, nr. 53, m.nt. R.P. de Roode. 
voorziening verblijvende diabetespatiënt te doen opnemen in een psychiatrisch ziekenhuis. Deze patiënt weigerde, onder invloed van zijn stoornis, om een aantal open wonden te laten verzorgen. In de noot wordt door De Roode opgemerkt dat artikel 7:465 lid $6 \mathrm{BW}$ in verhouding tot de Wet Bopz te weinig waarborgen biedt voor de toepassing van vrijheidsbeperkende maatregelen: de Wet Bopz kent een betere rechtsbescherming ${ }^{107}$ In dit geval ging het echter om het behandelen van wonden. Deze somatische behandeling kan tegen de wil van de cliènt worden uitgevoerd als sprake is van ernstig nadeel voor de cliënt en als de cliënt in kwestie wilsonbekwaam is. ${ }^{108}$ Aan beide voorwaarden was voldaan. Toch besloot de rechter om een voorlopige machtiging toe te kennen aan de patiënt. Deze machtiging legitimeert hulpverleners echter nog niet om over te gaan tot dwangbehandeling. Daarvoor dient sprake te zijn van gevaar. Bovendien moet de behandeling bijdragen aan het verbeteren van de geestesstoornis. Tevens kan de behandeling van de somatische aandoening alleen binnen de muren van een instituut met een Bopz-aanmerking plaatsvinden. Hiertoe behoort niet een afdeling van een algemeen ziekenhuis.

Recente jurisprudentie laat zien dat het (oneigenlijk) gebruik van de Wet Bopz ter waarborging van somatische zorg inmiddels door verschillende Bopz-rechters wordt toegestaan. ${ }^{109}$ Niet in alle gevallen is echter sprake van een oneigenlijk gebruik van de Wet Bopz. De uitspraak van 13 november 2002 van de Rechtbank Amsterdam illustreert dat toepassing van de Wet Bopz bij de behandeling van somatische aandoeningen in bepaalde situaties ertoe kan bijdragen dat de cliënt, die in eerste instantie een somatische behandeling weigerde, gaat meewerken aan de behandeling ervan. Door behandeling van de geestesstoornis kan de cliënt de noodzaak van de behandeling gaan inzien en zich alsnog bereid verklaren om mee te werken aan de behandeling van dé somatische aandoening. In

167 Het is echter nog maar de vraag of de Wet Bopz een zoveel betere rechtsbescherming biedt: bij toepassing van de Wgbo kan de cliënt gebruik maken van het klacht- en tuchtrecht. Ook kunnen in het kader van de kwaliteitswetgeving eisen worden gesteld ter waarborging van een zorgvuldige toepassing van vrijheidsbeperking.

168 De Inspectie noemt als voorbeeld een wilsonbekwame cliënt die op grond van de Wgbo tegen zijn wil wordt behandeld voor suikerziekte om hem te behoeden voor ernstig nadeel of een cliënt die een noodzakelijke somatische behandeling weigert op basis van een waan. Beide patiënten behoren onder de Wgbo te worden behandeld en niet onder de Wet Bopz, aldus de Inspectie (IGZ 2002b, p. 19-20).

169 Rechtbank Amsterdam, 13 november 2002, BJ 2003, 49; Rechtbank Amsterdam, 23 januari 2003, BJ 2003, 50; Rechtbank Middelburg, 18 maart 2003, BJ 2003, 56, m.nt. J.C.J. Dute. 
deze uitspraak wordt de Wet Bopz indirect gebruikt: door een cliënt onvrijwillig op te nemen en te behandelen aan zijn stoornis kan uiteindelijk ook de somatische aandoening worden behandeld. Het is echter nog maar de vraag of de weigering van de cliënt ook daadwerkelijk wordt veroorzaakt door de geestesstoornis. ${ }^{100}$ Dute doet de suggestie dat de wetgever deze jurisprudentie, voor zover deze leidt tot een oneigenlijk gebruik van de Wet Bopz, een halt moet toeroepen. Een andere optie is dat de Hoge Raad zich gaat buigen over deze, niet eenvoudige, materie. ${ }^{11}$

\section{Verantwoorde zorg}

Voortbordurend op de toon die de rechter in de uitspraak van 10 februari 1998 heeft gezet, is in de zomer van 2000 een rapport verschenen over criteria voor verantwoord handelen bij vrijheidsbeperkende interventies. ${ }^{172}$ Dit rapport is een antwoord op de vraag van de Minister van VWS om criteria te ontwikkelen voor het operationaliseren van het begrip verantwoord handelen in situaties waarin vrijheidsbeperkende maatregelen nodig zijn. In het rapport wordt gesproken over een uitbreiding van de reikwijdte van de Wet Bopz, oftewel een algemene zorgwet aangepast aan de ontwikkelingen in het zorgbeleid en het zorgveld welke ook van toepassing is op semi-murale en extramurale zorgvormen. De minister erkent hiermee dat vrijheidsbeperkende maatregelen niet alleen voorkomen in instellingen waarop de Wet Bopz van toepassing is, maar ook daarbuiten. In afwachting van een nieuwe of gewijzigde wettelijke regeling moeten de kwaliteitscriteria uit het rapport als leidraad dienen voor het toepassen van vrijheidsbeperkende maatregelen. Over de Wgbo wordt opgemerkt dat deze wet onvoldoende wettelijke basis biedt voor het legitimeren van het handelen van hulpverleners bij meer structurele vrijheidsbeperkende maatregelen.

170 In de uitspraak van 13 november 2002 (BJ 2002, 49) wordt het causale verband tussen de stoornis en het gevaar als volgt gemotiveerd: ' (...) Uit de omstandigheid dat betrokkene in het zeer recente verleden zich nog wel wilde laten bestralen en dat dit in een periode was dat zij minder psychotisch was, kan de conclusie worden getrokken dat haar huidige standpunt dat zij niet bestraald wil worden, wordt ingegeven door haar stoornis en de daarmee gepaard gaande psychose (....).

171 Rechtbank Middelburg, 18 maart 2003, BJ 2003, 56, m.nt. J.C.J. Dute.

172 Inspectie voor de Gezondheidszorg, Criteria voor verantwoord handelen bij vrijheidsbeperkende maatregelen, Den Haag: $2000 \mathrm{~b}$. 


\subsection{Vrijheidsbeperking buiten Bopz-instituten}

De Wet Bopz heeft een beperkte reikwijdte en is uitsluitend van toepassing op instituten voor verstandelijk gehandicaptenzorg. Dit leidt ertoe dat een sociowoning wel onder de reikwijdte van de wet valt en een gvt niet, terwijl de populatie cliënten niet veel van elkaar verschilt. In de parlementaire geschiedenis wordt deze keuze van de wetgever niet helder gemotiveerd. ${ }^{m}$ Krul-Steketee vraagt zich dan ook terecht af waarom het soort voorziening in de verstandelijk gehandicaptenzorg de vorm van rechtsbescherming bepaalt. ${ }^{174}$

De afgelopen jaren heeft een aantal onderzoeken het vermoeden bevestigd dat vrijheidsbeperkende maatregelen ook buiten instituten worden toegepast. In 1997 heeft het NCvG ${ }^{175}$ in opdracht van de Inspectie een onderzoek verricht naar de toepassing van vrijheidsbeperkende maatregelen in settings welke niet onder de Wet Bopz vallen, waaronder gvt'en. Het onderzoek leverde een aantal opvallende resultaten op. Afzonderen en het beperken in de bewegingsvrijheid komen regelmatig voor in gvt'en. De reden van deze toepassingen is vooral de bescherming van de cliënt, de omgeving en het personeel. Ook worden deze vrijheidsbeperkende maatregelen geregeld als sanctie opgelegd. Daarnaast is opmerkelijk dat hoe vaker in een setting een vrijheidsbeperkende maatregel voorkomt, hoe eerder het personeel van mening is dat deze handelingen zijn toegestaan.

Recente ontwikkelingen in de verstandelijk gehandicaptenzorg bevorderen de toepassing van vrijheidsbeperkende maatregelen buiten instituten. Sinds 1 april 2000 is de uitraaskamer onder de Wet voorzieningen gehandicaptenzorg gebracht. Artikel 1, lid 1c Wvg bepaalt dat 'tot de woonvoorziening wordt ook een uitraaskamer gerekend, waaronder wordt verstaan een verblijfsruimte waarin een gehandicapte die, vanwege een gedragsstoornis ernstig ontremd gedrag vertoont, zich kan afzon-

173 In de brochure 110 vragen over de Wet Bopz (Ministerie VWS en Geneeskundige Inspectie voor de geestelijke volksgezondheid, 1994) wordt toegelicht waarom gvt'en en dagverblijven niet onder de Wet Bopz vallen, terwijl daar ook vrijheidsbeperking plaatsvindt: 'de Bopz is bedoeld voor 24-uurs opvang. Wellicht is het zinvol na een aantal jaren ervaring met de Bopz, toch de Bopz op een aantal van deze instellingen van toepassing te laten zijn. Deze kwestie zal bij de evaluatie van de wet - die binnen drie jaar na invoering moet plaatsvinden - aan de orde komen.' (p. 7-8).

174 J. Krul-Steketee, "De reikwijdte van de Bopz-novelle", Nederlands Juristenblad (65) 1990-29, p. 1160-1161.

175 Noorderlijk Centrum voor Gezondheidsvraagstukken 1997; R.H. Bakker, L.J. Tiesinga, P. Gassman en Th. W.N. Dassen, "Vrijheidsbeperkende maatregelen in niet Bopz aangemerkte instellingen. Gelegaliseerde dwang of gedwongen legalisering?", Tijdschrift voor sociale Geneeskunde (80) 2002-7, p. 455-462. 
deren of tot rust kan komen'. Deze nieuwe mogelijkheid roept een aantal vragen op. Hoe verhoudt deze voorziening zich tot de Wet Bopz? In hoeverre oefent de Inspectie toezicht uit op deze vrijheidsbeperkende maatregel? Wie is verantwoordelijk voor het uitvoeren van deze vrijheidsbeperkende maatregel? De huidige Wet Bopz houdt vooralsnog geen rekening met dit soort initiatieven.

In het kabinetsstandpunt naar aanleiding van de eerste evaluatie van de Wet $B o p z^{176}$ geeft het kabinet aan dat zij het niet wenselijk acht om de werkingssfeer van de Wet Bopz uit te breiden naar gvt'en. Zij motiveert haar standpunt als volgt: 'Een got beoogt niet vierentwintig uur per etmaal verbliif te bieden, maar bewoners te stimuleren en te begeleiden bij een zo zelfstandig mogelijk bestaan. Het is mede daarom naar zijn aard een voorziening waarin geen sprake dient te zijn van gedwongen opname dan wel gedwongen verblijf. Bovendien horen in een got geen vrijheidsbeperkende middelen en maatregelen te worden toegepast.' Dit standpunt wordt een paar jaar later losgelaten. De Minister van VWS heeft in januari 2002 erkend dat vrijheidsbeperkende maatregelen ook buiten instituten worden toegepast. Op grond van deze bevindingen is de minister tot de conclusie gekomen dat, mede in het kader van de modernisering van de AWBZ, de Wet Bopz wellicht meer persoonsgericht in plaats van instituutsgericht moet worden. ${ }^{17}$ Daarnaast heeft het Ministerie van VWS aan het Instituut voor Beleid en Management van de Erasmus IIniversiteit Rotterdam de ondracht gegeven om te onderzoeken in hneverre in niet-Bopz-locaties behoefte bestaat aan een wettelijk kader voor de toepassing van vrijheidsbeperking. Dit onderzoek heeft in 2003 plaatsgevonden. De resultaten bevestigen de bevindingen uit eerdere onderzoeken. In bijna alle voorzieningen voor verstandelijk gehandicaptenzorg komen toepassingen van vrijheidsbeperking voor. In gvt'en wordt gebruik gemaakt van afzondering, medicatie, belmatten en de deur op slot. Daarnaast zijn ook logeerhuizen, kinderdagverblijven en dagverblijven voor ouderen bekend met toepassingen van vrijheidsbeperking. ${ }^{178}$

176 Ministerie Volksgezondheid, Welzijn en Sport en Ministerie van Justitie, Kabinetsstandpunt Evaluatie van de Wet Bopz, Rijswijk: 1997, p. 42.

177 Handelingen 1122 januari 2002, p. 40-2950-2952.

178 L.A.P. Arends en R. Dursun, Vrijheidsbeperkende maatregelen bij psychogeriatrische patiënten en verstandelijk gehandicapten op niet-Bopz-plaatsen, Rotterdam: Instituut Beleid en Management Gezondheidszorg Erasmus Medisch Centrum/Erasmus Universiteit Rotterdam (in opdracht van het Ministerie van VWS) 2004 (nog niet gepubliceerd). 


\subsection{Beschouwing}

In deze beschouwing staat een tweetal vragen centraal. De eerste vraag luidt: 'In hoeverre is vrijheidsbeperking vastgelegd in een juridisch kader?' De tweede vraag luidt: 'In hoeverre wordt in het juridische kader, ten aanzien van de toepassing van vrijheidsbeperking, rekening gehouden met de specifieke eigenschappen van de verstandelijk gehandicaptenzorg?'

In hoeverre is vijheidsbeperking vastgelegd in een juridisch kader?

In 1994 is de Wet Bopz in werking getreden. Deze wet legitimeert de toepassing van vrijheidsbeperking. Ook de verstandelijk gehandicaptenzorg valt onder de reikwijdte van deze wet. De Wet Bopz gaat uit van een enge invulling van vrijheidsbeperking. Huisregels, beperkingen in het recht op bewegingsvrijheid, dwangbehandeling en middelen of maatregelen zijn de vier vormen van vrijheidsbeperking die zijn toegestaan. De Wet Bopz hanteert het uitgangspunt dat het beperken van de vrijheid van cliënten alleen mogelijk is als sprake is van 'gevaar'. Daarbij doet de intentie van de maatregel niet ter zake. Elke maatregel die leidt tot een inperking van de vrijheid van een cliënt, dient te worden verantwoord en dus te voldoen aan de vereisten van de Wet Bopz. Daarmee beoogt de Wet Bopz de interne rechtspositie van cliënten optimaal te beschermen.

Strikt genomen is vrijheidsbeperking alleen toegestaan bij cliënten die onvrijwillig zijn opgenomen in instituten met een Bopz-aanmerking. De jurisprudentie laat echter zien dat, onder bepaalde omstandigheden, ook vrijheidsbeperking bij vrijwillig opgenomen cliënten is toegestaan. De rechter verwijst daarbij naar de Wgbo. Op grond van artikel 7:465 lid 6 BW bestaat de mogelijkheid om, bij ernstig nadeel voor de wilsonbekwame cliënt, diens verzet terzijde te schuiven en de behandeling toch uit te voeren. De Wgbo is echter niet de juiste weg om vrijheidsbeperking toe te passen. Deze wet is bedoeld voor somatische handelingen. Indien een cliënt zich verzet tegen een somatische handeling, bijvoorbeeld een griepspuit, mag de hulpverlener de behandeling onder bepaalde voorwaarden uitvoeren: het betreft een verrichting van ingrijpende aard, de cliënt is wilsonbekwaam en niet behandelen veroorzaakt een ernstig nadeel voor de cliënt. Daarnaast dient ook de vertegenwoordiger van de cliënt, indien aanwezig, toestemming te geven voor de verrichting.

De Wgbo is slechts geschikt om tijdelijk of in een noodsituatie vrijheidsbeperking toe te passen. Deze wijze van handelen is ook in overeenstemming met goed hulpverlenerschap. Tegelijkertijd vereist goed hulpverlenerschap dat vrijheidsbeperking op een verantwoorde wijze plaatsvindt. De Wgbo biedt niet voldoende waarborgen hiervoor. De Wet Bopz, wellicht niet in de huidige vorm, is een meer geëigend kader voor vrijheidsbeperking. Indien dwangbehandeling bij vrijwillig opgenomen cliënten plaatsvindt vereist de Wet Bopz dat de juridische status van de cliënt wordt aangepast. Het is de vraag of deze aanpassing van de 
juridische status voldoende is om de interne rechtspositie van mensen met een verstandelijke handicap optimaal te waarborgen. De Rechtbank van Alkmaar (10 februari 1998) is bovendien van mening dat de leemte bij vrijwillig opgenomen cliënten niet kan worden opgevuld door een doorgaans ingrijpende en langdurige maatregel als een voorlopige machtiging.

De Wet Bopz legt de nadruk op opneming van cliënten in een instituut voor mensen met een verstandelijke handicap. Dit blijkt ook uit het gegeven dat vrijheidsbeperking pas mag worden toegepast, nadat een Bopz-indicatie of een voorlopige machtiging is aangevraagd. In deze wet wordt onvoldoende aandacht besteed aan de waarborgen rondom de toepassing van vrijheidsbeperking (de interne rechtspositie). Een juiste juridische status betekent nog niet dat cliënten voldoende beschermd worden tegen inbreuken op hun vrijheid. Op grond van de Wet Bopz is de hulpverlener verplicht om dwangbehandeling en middelen of maatregelen in het kader van een noodsituatie te melden aan de Inspectie en intern te registreren. De wet zegt echter niets over de wijze waarop hulpverleners deze middelen of maatregelen dienen toe te passen. Ook laat zij in het midden welke maatregelen niet mogen worden toegepast in het kader van dwangbehandeling en noemt zij geen termijn voor dwangbehandeling, in tegenstelling tot vrijheidsbeperking in het geval van een noodsituatie welke niet langer dan zeven dagen mag duren. Het behoort tot de taak van professionals om open normen nader in te vullen. Deze normen kunnen vervolgens onderdeel gaan uitmaken van de professionele standaard van artsen, gedragsdeskundigen en persoonlijk begeleiders.

Het is dan ook van groot belang dat de criteria proportionaliteit, subsidiariteit en effectiviteit in relatie tot de toepassing van vrijheidsbeperking nader worden uitgewerkt. Op deze manier wordt ook vrijheidsbeperking bij vrijwillig opgenomen cliënten genormeerd. De uitwerking van deze criteria hoeft niet noodzakelijkerwijs wettelijk te worden vormgegeven. Ze kunnen ook worden uitgewerkt via zelfregulering. Een hulpverlener dient aan te kunnen tonen dat de toepassing van een vrijheidsbeperkende maatregel een laatste redmiddel is, waarvoor geen ander en minder ingrijpend alternatief voorhanden is. Verder dient er een redelijke verhouding te bestaan tussen de inbreuk op de vrijheid van een cliënt en het doel van deze inbreuk. Tot slot dient de toepassing van een vrijheidsbeperkende maatregel gestaakt te worden, zodra duidelijk is dat de maatregel niet meer het gewenste effect heeft of een minder ingrijpend alternatief voorhanden is.

In hoeverre wordt in het juridische kader, ten aanzien van de toepassing van vrijheidsbeperking, rekening gehouden met de specifieke eigenschappen van de verstandelijk gehandicaptenzorg?

Het juridische kader voor vrijheidsbeperking in de verstandelijk gehandicaptenzorg is voornamelijk de Wet Bopz. Deze wet kent een lange geschiedenis. De 
verstandelijk gehandicaptenzorg is pas in een later stadium onder de reikwijdte van de wet gebracht. De implementatie van de Wet Bopz in de verstandelijk gehandicaptenzorg verloopt, ruim 10 jaar na invoering, nog steeds niet op de wijze die de wetgever in 1994 voor ogen had. ${ }^{17}$ De Wet Bopz wordt beschouwd als een wet die eigenlijk voor de psychiatrie is geschreven. Ook in de titel van de wet wordt verwezen naar de psychiatrie: 'Wet bijzondere opnemingen in psychiatrische ziekenhuizen'.

Een aantal redenen is te noemen op grond waarvan het huidige juridische kader tekort schiet voor de verstandelijk gehandicaptenzorg:

- Volgens de Wet Bopz is de toepassing van vrijheidsbeperking gericht op het verbeteren van de stoornis. Op grond van artikel le Bopz en het Besluit administratieve bepalingen Bopz $z^{100}$ wordt onder een geestelijke stoornis ook verstaan een verstandelijke handicap. In de verstandelijk gehandicaptenzorg is de zorg niet gericht op het verbeteren van de stoornis. Er is veel meer sprake van het stabiliseren van de stoornis. Een verstandelijke handicap is immers een blijvende stoornis. Wel is het mogelijk om psychische en/of gedragsproblemen te voorkomen of te verminderen. De Wet Bopz spreekt ook over een therapeutische doelstelling. Daarvan zal in de verstandelijk gehandicaptenzorg niet of nauwelijks sprake zijn.

- In de verstandelijk gehandicaptenzorg is het veel moeilijker dan in de psychiatrie om achter de eigenlijke wil van een cliënt te komen. Verzet een cliënt zich bewust tegen de toepassing van vrijheidsbeperking? Stemt een cliënt in met het zorgplan waarin vrijheidsbeperkende maatregelen zijn opgenomen? In de sector ontbreken eenduidige criteria om wils(on)bekwaamheid en verzet bij een cliënt vast te stellen.

- De essentie van de Wet Bopz is dat slechts tijdelijk middelen of maatregelen worden toegepast. Zodra het gevaar geweken is, dient de maatregel gestopt te worden. In de zorg voor verstandelijk gehandicapten ligt het accent op structurele of langdurige toepassingen van middelen of maatregelen. Een aanzienlijk deel van de vrijheidsbeperkende maatregelen wordt toegepast via de constructie middel of maatregel akkoord. Deze middelen of maatregelen zijn opgenomen in het zorgplan waarmee cliënt en/of vertegenwoordiger hebben ingestemd. Het gevaar bestaat dat bij de toepassing ervan niet altijd serieus wordt omgegaan met het verzet van een cliënt. Daarnaast hoeft de toepassing niet te worden gemeld bij de Inspectie.

179 Dit wordt ook onderschreven door de empirische gegevens, die in het kader van dit onderzoek zijn verzameld (hoofdstuk 6).

180 Besluit administratieve bepalingen Bopz van 2 april 2001, Stb. 214 (bijlage 1-4). 
- Er is een grijs gebied van behandelen, ${ }^{181}$ waarin het onduidelijk is of de Wet Bopz of de Wgbo van toepassing is. Op grond van de Wet Bopz mag een hulpverlener vrijheidsbeperkende maatregelen tegen de wil van een cliënt toepassen indien sprake is van gevaar. Verwarrend is dat de Wgbo ook een mogelijkheid biedt om dwangbehandeling toe te passen. Indien een wilsonbekwame cliënt zich tegen een behandeling verzet, mag de behandeling worden voortgezet als sprake is van ernstig nadeel voor de cliënt. De Wgbo is echter niet het juiste kader om vrijheidsbeperkende maatregelen toe te passen. Deze wet is gericht op somatische behandelingen. Indien een vrijwillig of onvrijwillig opgenomen cliënt zich verzet tegen een behandeling bij de tandarts of geen operatie wil ondergaan, kan hij toch tegen zijn wil worden behandeld indien hij wilsonbekwaam is en ernstig nadeel te verwachten is van zijn beslissing. De Wgbo wordt echter ook gebruikt om vrijheidsbeperkende maatregelen toe te passen bij vrijwillig opgenomen cliënten. Indien een cliënt instemt met de toepassing van vrijheidsbeperking is er nog niets aan de hand. De situatie verandert zodra sprake is van verzet. De jurisprudentie op dit gebied is niet altijd even consistent. De rechter achtte het in een aantal gevallen toelaatbaar dat middelen of maatregelen ook bij vrijwillig opgenomen cliènten werden toegepast, onder de vlag van de Wgbo. Deze toepassing mist de waarborgen die de Wet Bopz aan cliënten biedt. De Wgbo kent, in tegenstelling tot de Wet Bopz, niet de eis dat de toepassingen van vrijheidsbeperkingen worden geregistreerd en gemeld aan de Inspectie. Daarnaast kent de wet geen speciale klachtregeling. Uiteraard hebben vrijwillig opgenomen cliënten wel de mogelijkheid om via het reguliere klachtrecht een klacht in te dienen.

- De Wet Bopz heeft onvoldoende greep op alle vrijheidsbeperkende maatregelen. Vrijheidsbeperking is in de verstandelijk gehandicaptenzorg veel ruimer dan de Wet Bopz mogelijk maakt. Hulpverleners maken veelvuldig gebruik van een breed scala aan vrijheidsbeperkende maatregelen. Een cliënt met een verstandelijke handicap die in een Bopz-instituut verblijft krijgt te maken met begeleidingsafspraken, huisregels, pedagogische maatregelen, beschermende maatregelen, middelen of maatregelen en beperkingen in de bewegingsvrijheid. De Wet Bopz is in beginsel alleen van toepassing op middelen of maatregelen die worden toegepast omdat sprake is van gevaar voor de cliënt of voor anderen. Deze middelen of maatregelen moe-

181 In het kader van de Wet Bopz wordt gesproken over behandelen. In de verstandelijk gehandicaptenzorg is het echter gepaster om te spreken over handelen aangezien niet sprake is van het behandelen oftewel genezen van een verstandelijke handicap. Er is eerder sprake van het bieden van ondersteuning aan cliënten. 
ten bij verzet van een cliënt geregistreerd en gemeld worden aan de Inspectie. In de zorg voor mensen met een verstandelijke handicap is het gevaarscriterium niet altijd toereikend. Ook vanuit het oogpunt van opvoeding, het bieden van bescherming als ook het begeleiden en ondersteunen van cliënten dient de vrijheid van een cliënt te kunnen worden beperkt. De Wet Bopz legitimeert niet de toepassing van beschermende en pedagogische maatregelen.

- De Wet Bopz heeft een institutioneel karakter. Een aanzienlijk aantal cliënten met een verstandelijke handicap is niet woonachtig in een instituut. Van de 110.000 mensen met een verstandelijke handicap wonen er maar liefst 73.000 thuis, zelfstandig of in een andere woonvorm. Vrijheidsbeperkende maatregelen komen niet alleen voor in Bopz-instituten, maar ook daarbuiten. De Wet Bopz is daar echter niet van toepassing.

- Onder de Krankzinnigenwet, de voorloper van de Wet Bopz, waren vrijwel alle cliënten in instituten voor verstandelijk gehandicaptenzorg vrijwillig opgenomen. Een groot deel van deze cliënten is nog steeds vrijwillig opgenomen. De Wet Bopz is echter niet van toepassing op deze cliënten, ook niet als bij deze groep cliënten vrijheidsbeperking wordt toegepast.

Naast het zelfbeschikkingsrecht ook goede zorg als uitgangspunt?

Bovenstaande punten maken duidelijk waarom de Wet Bopz niet het geschikte kader is voor de verstandelijk gehandicaptenzorg. In de Wet Bopz wordt onvoldoende rekening gehouden met de specifieke eigenschappen van de verstandelijk gehandicaptenzorg. Het is goed dat de Wet Bopz beperkingen in de vrijheid van cliënten tot een minimum wil beperken.middelen of maatregelen mogen niet zo maar worden toegepast. Het gaat immers om ingrijpende maatregelen met verstrekkende gevolgen voor cliënten. De nadruk ligt daarbij sterk op het zelfbeschikkingsrecht van cliënten. Ook mensen met een verstandelijke handicap hebben recht op zelfbeschikking. In de zorg voor mensen met een verstandelijke handicap hebben hulpverleners echter te maken met cliënten die minder in staat zijn om dit recht zelfstandig uit te oefenen. Om ervoor te zorgen dat cliënten de zorg of ondersteuning krijgen waar ze recht op hebben, dient naast het zelfbeschikkingsrecht ook ruimte te zijn voor goede zorg. Bepaalde vormen van vrijheidsbeperking zijn noodzakelijk vanuit het oogpunt van goede zorg. Handelen vanuit goede zorg betekent dat cliënten in hun vrijheid worden beperkt, om uiteindelijk een bepaalde ontwikkeling te kunnen doormaken. Soms is het noodzakelijk om een cliënt in het begin te ondersteunen en te begeleiden door middel van strikte afspraken en regels. Vanuit dit oogpunt is het legitiem om de vrijheid van een cliënt te beperken. Bescherming wordt ingezet om uiteindelijk meer vrijheid te bereiken. Belangrijk is wel dat goede zorg gepaard gaat met een adequate rechtsbescherming. Als in het juridische kader meer mogelijkheden worden gecreëerd om in te grijpen in de vrijheid van cliënten, moeten daar wel 


\section{Hoofdstuk 5}

waarborgen tegenover staan. Goede zorg betekent allesbehalve dat cliënten vanwege een tekort aan personeel, een tekort aan tijd of andere niet-legitieme redenen worden beperkt in hun vrijheid. Alvorens in hoofdstuk 7 nader wordt ingegaan op een alternatieve regeling, waarin de nadruk ligt op goede zorg en rechtsbescherming, wordt in het volgende hoofdstuk (6) een beschrijving gegeven van de wijze waarop in de dagelijkse praktijk van de zorg voor mensen met een verstandelijke handicap wordt omgegaan met vrijheidsbeperking. 


\section{Vrijheidsbeperking in de praktijk}

\subsection{Inleiding}

In het vorige hoofdstuk is vrijheidsbeperking vanuit een juridische invalshoek beschreven. In dit hoofdstuk wordt uiteengezet hoe in de praktijk van de zorg voor mensen met een verstandelijke handicap wordt omgegaan met vrijheidsbeperking. De resultaten zijn gebaseerd op het empirische onderzoek dat in het kader van deze studie is uitgevoerd in drie verschillende voorzieningen voor verstandelijk gehandicaptenzorg. Het onderzoek bestond uit observaties, interviews en dossieronderzoek. Daarnaast wordt ook gebruik gemaakt van de resultaten van de tweede evaluatie van de Wet Bopz, die bestond uit: een schriftelijke enquête, interviews en een dossieronderzoek. Zowel de mening van de persoonlijk begeleider, de vertegenwoordiger als de cliënt worden weergegeven en geillustreerd door citaten. ${ }^{1}$ Het hoofdstuk wordt afgesloten met een beschouwing waarin de knelpunten die in de praktijk zijn geconstateerd nogmaals de revu passeren. In hoofdstuk 7 wordt nader ingegaan op deze knelpunten en wordt een voorstel gedaan voor een alternatieve regeling.

\subsection{Casuïstiek uit de praktijk}

Hieronder worden vijf verschillende casus gepresenteerd. ${ }^{2}$ Aan de hand hiervan moet duidelijk worden hoe divers de rol van vrijheidsbeperking is in de zorg voor mensen met een verstandelijke handicap. Ook wordt aan de orde gesteld dat in de praktijk nauwelijks een onderscheid wordt gemaakt tussen een vrijwillig en een onvrijwillig opgenomen cliënt. Vrijwel elke cliënt met een verstandelijke handicap die opgenomen is in een voorziening heeft te maken met vrijheidsbeperking. De mate waarin dat gebeurt verschilt per cliënt. De motieven die ten grondslag liggen aan de toepassing van vrijheidsbeperking kunnen variëren van behandelen, opvoeden, het bieden van bescherming tot het voorkomen van gevaar of het handhaven van de orde. In een aantal casus komt ook de onmacht van de hulpverleners naar voren. Ze willen graag de huidige situatie doorbreken, maar vanwege een tekort aan personeel, een tekort aan tijd of het

1 Ook is een aantal citaten van artsen en gedragsdeskundigen in het verhaal verwerkt. Deze citaten komen voornamelijk uit interviews die in het kader van de tweede evaluatie van de Wet Bopz hebben plaatsgevonden.

2 De vijf casus komen uit het empirische materiaal dat is verzameld in de drie verschillende voorzieningen. 
ontbreken van hulp van een consulententeam ${ }^{3}$ kan het soms niet op een andere manier.

\section{Casus 1: Strak dagprogramma}

Cliënt $\mathrm{V}, 4$ vrijwillig opgenomen, dient zich elke dag aan een strak dagprogramma te houden. Het schema biedt de cliënt zekerheid. Zonder dit programma ontstaat er teveel spanning voor de cliënt. Hij moet duidelijk weten waar hij aan toe is. Hij houdt ervan om voortdurend zijn grenzen te verleggen. Dit programma probeert dat gedrag zoveel mogelijk te voorkomen, aldus een passage uit het zorgplan.

Een fragment uit het schema:

16:00 terug van werk: koffie en 1 sigaar

16:50 verplicht douchen

17:00 eten in de eigen kamer

18.00 nieuws kijken

18.30 verplicht wandelen

19.00 treinkamer

21.30 evaluatie op kantoor, bij goed gedrag 1 sigaar

22.00 inleveren rookwaar en deur van slaapkamer op slot

Als cliënt $\mathrm{V}$ moeilijk gedrag vertoont wordt hem een crisisprogramma aangeboden. Aan het einde van de dag wordt met cliënt $\mathrm{V}$ de dag doorgenomen. Als hij zich goed heeft gedragen krijgt hij als beloning een extra sigaar. De vrijheidsbeperking bestaat voornamelijk uit allerlei afspraken die met de cliënt zijn gemaakt. Binnen deze afspraken kan hij redelijk zijn eigen gang gaan. In de groep waar cliënt $\mathrm{V}$ verblijft, wonen voornamelijk cliënten met autisme en gedragsproblemem.

\section{Casus 2: Beschermende maatregelen}

Cliënt $W$ heeft een ernstige verstandelijke handicap en is vrijwillig opgenomen. Volgens het zorgplan worden bij deze cliënt geen middelen of maatregelen toegepast. In het zorgplan staat wel genoteerd dat beschermende maatregelen worden toegepast. Cliënt $W$ draagt in de rolstoel een heupband ter bescherming van zichzelf vanwege epilepsieaanvallen. Als hij wordt vervoerd draagt hij voetenbandjes om te voorkomen dat zijn voeten ergens tussenkomen. Tot slot heeft hij

3 In Nederland is mede naar aanleiding van de schokkende beelden van Jolanda Venema, vastgebonden aan een verwarmingselement, een landelijk systeem van consultatie ontstaan. Aanleiding voor consultatie zijn uitzichtloze situaties waarin cliënten met emstige gedragsproblemen zich kunnen bevinden.

De namen van de cliënten zijn geanonimiseerd. 
bedhekken ter bescherming van zichzelf. Tegen deze maatregelen verzet de cliënt zich niet en zijn ouders hebben toestemming verleend. Vrijheidsbeperking vindt bij deze cliēnt plaats vanuit het motief beschermen.

\section{Casus 3: Kamertraining en het bepalen van grenzen}

Met cliënt $X$, vrijwillig opgenomen, gaat het de laatste jaren steeds beter. Werd hij voorheen voortdurend afgezonderd, de laatste tijd is dat niet of nauwelijks meer aan de orde. Hij woont echter nog steeds binnen een vrij gesloten groep met cliënten die individuele begeleiding krijgen, hetgeen inhoudt dat deze cliënten voornamelijk op hun kamer de dag doorbrengen. Dit wordt in een van de deelnemende instituten ook wel kamerbegeleiding of kamertraining genoemd. Cliënt $\mathrm{X}$ heeft echter behoefte aan sociale contacten. De afdeling waar hij woont vindt hij af en toe net een gevangenis. Ondanks het feit dat hij steeds meer vrijheid krijgt, is het nog altijd de begeleiding die de grenzen bepaalt waarbinnen hij mag functioneren. Hij heeft op zijn kamer een bord hangen met daarop exact aangegeven wat en wanneer plaatsvindt. De afgelopen maanden is het programma al in zijn voordeel aangepast. Hij mag op bepaalde tijden alleen gaan wandelen en de deur naar de woonkamer staat nu vaker open. Echter als de deur naar de woonkamer dicht is, mag hij er niet in. Op dat moment krijgt een andere cliënt individuele begeleiding in de woonkamer. Op diverse momenten wordt de vrijheid van cliënt $X$, volgens zijn eigen zienswijze, onterecht beperkt, aangezien hij in tegenstelling tot andere cliënten wel behoefte heeft om zich vrij te kunnen bewegen tussen zijn eigen kamer en de woonkamer. Andere cliënten van de groep belemmeren deze vrijheid.

\section{Casus 4: Huisregels}

Een aantal cliënten van een sociowoning, geniet veel vrijheid. De enige vorm van vrijheidsbeperking waar zij zich aan moeten houden zijn de huisregels.

1. Als cliënten ergens naar toe gaan, afmelden bij personeel en medecliënten.

2. Als er bezoek komt voor iemand, kleding aanhouden en niet in pyjama erbij komen zitten.

3. Bij het draaien van muziek rekening houden met de andere cliënten.

4. Nette manieren aan tafel tijdens het eten.

5. Niet de post van elkaar openen.

6. Niet ongevraagd de kamer van andere cliënten betreden.

\section{Casus 5: Bijzonder zorgplan}

Bij cliënt $Z$, vrijwillig opgenomen, is al vier jaar geleden een bijzonder zorgplan opgesteld. Dit plan wordt echter nog steeds niet uitgevoerd, omdat de uitspraak van het consulententeam nog niet is gehonoreerd. Om het plan uit te kunnen voeren is meer begeleiding nodig. Het doel van het zorgplan is om gedurende de dag meer structuur aan te brengen. Op dit moment zijn er veel lege momen- 
ten op een dag. Cliënt $\mathrm{Z}$ moet vanwege zijn moeilijke gedrag deze lege momenten op zijn kamer doorbrengen. In de woonkamer verblijven op drukke momenten nog zeven andere cliënten. Cliënt $\mathrm{Z}$ wordt van de andere cliënten onrustig waardoor het gevaar bestaat dat hij met meubilair gaat gooien. Het gevolg is dat hij, soms onterecht, op zijn kamer wordt opgesloten. Een hulpverlener merkt over cliënt $Z$ op dat 'als je hem echt tot zijn recht wilt laten komen dan is één op één begeleiding nodig.' Het nieuwe zorgplan houdt weliswaar veel afspraken in en een strak dagprogramma, maar levert uiteindelijk meer vrijheid voor de cliënt op aangezien hij niet meer zo vaak op zijn kamer hoeft te verblijven.

\section{Een beschouwing over deze vijf casus}

De casus laten zien dat vrijheidsbeperking ook buiten het juridische kader plaatsvindt: in alle vijf de situaties was sprake van vrijheidsbeperking bij een cliènt met de juridische status vrijwillig. Veel van deze beperkingen zijn met toestemming van cliënt en/of vertegenwoordiger opgenomen in het zorgplan. In casus 1 heeft de vertegenwoordiger ingestemd met het dagprogramma en het crisisprogramma, dat in werking treedt als cliënt $\mathrm{V}$ moeilijk gedrag gaat vertonen. Onduidelijk is echter wat onder moeilijk gedrag moet worden verstaan. Hiermee wordt hoogstwaarschijnlijk bedoeld dat cliënt $\mathrm{V}$ zich gaat verzetten tegen het dagprogramma. Vanaf dat moment is de cliënt het niet meer eens met een deel van het zorgplan en mag het reguliere programma, conform de Wet Bopz, niet meer worden uitgevoerd. Ook niet als sprake is van gevaar. Dwangbehandeling is in beginsel niet toegestaan bij vrijwillig opgenomen cliënten. De Wgbo biedt hiertoe geen mogelijkheden. Bovendien is verzet niet te ondervangen in een overeenkomst. De Wgbo en ook de Wet Bopz bevatten ieder een speciale bepaling over verzet. In de praktijk wordt regelmatig afgeweken van deze regels. Dit leidt ertoe dat het crisisprogramma uit casus 1 gewoon ingaat vanaf het moment dat cliënt $\mathrm{V}$ moeilijk gedrag gaat vertonen. Zodra de cliënt weer rustig is, wordt overgestapt op het reguliere dagprogramma.

Een aantal van de opgelegde maatregelen, die in de casus aan bod komen, wordt door hulpverleners pedagogische maatregelen genoemd. Volgens hulpverleners vallen deze maatregelen niet onder de Wet Bopz. Daarnaast valt een maatregel als kamertraining moeilijk te plaatsen onder de Wet Bopz. De vraag is of de Wet Bopz bedoeld is voor de toepassing van zulke ingrijpende en langdurige maatregelen. Mensen met een verstandelijke handicap worden, ongeacht hun status, in de dagelijkse zorg onderworpen aan diverse vormen van vrijheidsbeperking. Daarbij lijkt het niet relevant te zijn waar de cliënt met een verstandelijke handicap verblijft. Ook een cliënt in een gvt of een vrijwillig opgenomen cliënt krijgt te maken met vrijheidsbeperking. Op deze manier ontstaat een grijs gebied, waarvoor geen gepast wettelijk kader bestaat. 
De casus maken ook duidelijk dat een deel van de vrijheidsbeperkende maatregelen kan worden voorkomen. Dit komt enerzijds door een tekort aan financiële middelen en de groepsgrootte, anderzijds doordat hulpverleners zich nog onvoldoende bewust zijn van de beperkingen die zij opleggen aan cliënten. Juist in zulke situaties is het van belang dat hulpverleners zich realiseren dat zij de rechten van cliënten ten onrechte beperken. Uit casus 5 komt naar voren dat het personeel zich wel realiseert dat de rechten van cliënt 5 ten onrechte worden beperkt. Een instituut beschikt echter niet over voldoende middelen om een adequate oplossing te vinden voor de huidige situatie. Het lijkt erop dat bepaalde omstandigheden in een instituut leiden tot situaties die eigenlijk voorkomen hadden moeten worden.

Tegelijkertijd kan worden opgemerkt dat wetgeving ook belemmerend kan werken. In bepaalde situaties willen hulpverleners vanuit het oogpunt van goede zorg de vrijheid van een cliënt beperken. Een voorbeeld is een cliënt, die in een locatie buiten het instituut woont en regelmatig wegloopt. Om te voorkomen dat de cliënt 's nachts buiten gaat dwalen, wordt door de begeleiders voorgesteld om een slot te plaatsen op de deur van de kamer van de cliënt. Op grond van de Wet Bopz is deze beperking van de vrijheid niet toegestaan. De cliënt woont immers niet (meer) in het instituut met een Bopz-aanmerking. ${ }^{5}$ Het handelen van een hulpverlener wordt op zo'n moment beperkt door een wettelijk kader dat niet altijd even cliëntvriendelijk is.

\subsection{De rol van vrijheidsbeperking in de praktijk}

Noodzaak van vrijheidsbeperking

Persoonlijk begeleiders hebben een ambivalente huuding ten aanzien van de toepassing van vrijheidsbeperking. Aan de ene kant realiseren zij zich dat cliënten zich aan allerlei opgelegde regels moeten houden zoals achter gesloten deuren wonen en niet de vrijheid hebben om te doen en laten wat ze willen. Aan de andere kant beseffen zij ook dat deze maatregelen bij bepaalde cliënten nodig zijn uit het oogpunt van veiligheid en bescherming. Een kenmerk van mensen met een verstandelijke handicap is dat zij een blijvende beperking hebben. Deze beperking kan met zich mee brengen dat enige mate van vrijheidsbeperking noodzakelijk is. Verschillende voorbeelden daarvan zijn reeds gegeven in paragraaf 6.2. Kortom, het lijkt alsof vrijheidsbeperking in bepaalde gevallen noodzakelijk is om mensen met een verstandelijke handicap een zo prettig mogelijk leven te geven.

5 Een cliënt kan overigens ook in een locatie woonachtig zijn, die behoort tot het instituut. 
'Bepaalde cliënten moeten achter gesloten deuren zitten, dat is voor hun eigen veiligheid, maar ik kan me toch wel voorstellen dat sommige cliënten zoiets hebben van, wij hebben ook het recht om hier in de woonkamer te zitten, het recht van vrijheid. Echter de cliënten kunnen er zonder ons niet uit.' (persoonlijk begeleider)

Soms zijn de beperkingen die opgelegd worden niet direct noodzakelijk, maar is er geen andere oplossing voorhanden. Dit kan zo nu en dan tot een botsing van belangen leiden. De vrijheid van de ene cliënt wordt beperkt door de aanwezigheid van een andere cliënt.

'De kamers zien er niet echt vrolijk uit, liever gezegd eerder kaal. De kamer van T. zag er echt heel leuk uit. Echter met de komst van een nieuwe cliënt, was de inrichting van $T$. na een dag al kapot. $R$. kan niet tegen prikkels en omdat beide cliënten de kamer delen moet $T$. het onderspit delven. Ook vanwege een andere cliënt moest de huiskamer veel soberder worden.' (persoonlijk begeleider)

Voor een buitenstaander komen de vrijheidsbeperkingen die worden opgelegd niet altijd prettig over. Diverse vertegenwoordigers vragen zich af of alle beperkingen die worden opgelegd ook daadwerkelijk nodig zijn. Ze weten echter niet hoe het anders moet. In veel gevallen overheerst de gedachte dat de begeleiding uiteindelijk wel het beste met de cliënten voor zal hebben.

Het is heel moeilijk om te bepalen of al deze beperkingen op de rechten van A. echt nodig zijn. Het zal wel voor zijn eigen bestwil zijn, maar dat kan ik niet beslissen of overzien. Daarvoor heb je medisch inzicht nodig en daar heeft de begeleiding een betere kijk op dan de familie. Ik weet ook niet of $A$. dit ook als een beperking ziet.' (vertegenwoordiger)

Daarnaast is het lastig om als onderzoeker zicht te krijgen op wat de cliënten zelf vinden van de vrijheidsbeperkingen. Cliënten met ernstige gedragsproblemen en een (zeer) ernstige verstandelijke handicap waren niet in staat om over dit onderwerp te communiceren. Een cliënt met een lichte tot matige verstandelijke handicap kon in het onderzoek heel goed onder woorden brengen dat hij in zijn vrijheid wordt beperkt. Een aantal jaren geleden werd hij nog regelmatig afgezonderd. Op dit moment gaat het veel beter met hem en hoeft hij niet zo vaak meer afgezonderd te worden. Wel, krijgt hij nog een aantal beperkingen opgelegd waar hij het niet altijd mee eens is.

'I $k$ vind het leuk dat ik vooruitgegaan ben. Ik mag nu langer werken, ik mag mu shag halen bij het tankstation. Deze dingen mocht ik eerst niet. Verder mag ik alleen wandelen op bepaalde tijden. Ik vind het niet leuk dat ik al om 21.20 uur moet gaan slapen. Ik zou wel wat langer op willen blijven. Op mijn kamer kijk ik geen TV meer. Ik mag ook geen vuur op mijn kamer en ik weet waarom. Daar heb ik zelf voor gezorgd.' (cliënt) 


\subsubsection{Wettelijke vormen van vrijheidsbeperking in de praktijk}

In de dagelijkse praktijk van de zorgveriening aan mensen met een verstandelijke handicap komen verschillende vormen van vrijheidsbeperking voor. De Wet Bopz spreekt over de volgende vormen van vrijheidsbeperking:

1. Dwangbehandeling

2. Middelen of maatregelen

3. Huisregels

4. Beperkingen in het recht op bewegingsvrijheid

Naast deze vier wettelijke vormen komen in deze sector ook niet-wettelijke vormen van vrijheidsbeperking voor. Dit zijn allereerst vormen van vrijheidsbeperking die niet direct terug te voeren zijn op de vier vormen van vrijheidsbeperking die de Wet Bopz onderscheidt. Daarnaast wordt vrijheidsbeperking ook toegepast bij vrijwillig opgenomen cliënten en cliënten die buiten instituten verblijven. De Wet Bopz is niet van toepassing in deze settings.

\subsubsection{Dwangbehandeling}

Dwangbehandeling is een begrip dat in de praktijk niet zo veel bekendheid geniet. Dit geldt met name voor de eerste variant van dwangbehandeling, inhoudende dat er geen overeenstemming bereikt kan worden over het opstellen van het zorgplan. Toch komt het in de praktijk voor dat cliënten en/of vertegenwoordigers het niet eens zijn over de inhoud van een zorgplan.

Voorafgaande aan een zorgplanbespreking informeer ik ouders altijd, waardoor het zelden gebeurt dat ouders het niet eens zijn met het zorgplan.' (persoonlijk begeleider)

Vertegenwoordigers stemmen meestal in met het zorgplan. Ze hebben begrip voor de situatie. Er wonen hier meer mensen, wat kan leiden tot ander gedrag dan in de thuissituatie. Je hebt ook niet altijd evenveel tijd, waardoor ook het gedrag van de cliënt anders kan zijn dan thuis waar hij alle aandacht kreeg. Je moet echter wel goed uitleggen waarom bepaalde maatregelen nodig zijn.' (persoonlijk begeleider)

Dwangbehandeling kan zich ook voordoen als een cliënt bij de uitvoering van het zorgplan niet volgens de gemaakte afspraken behandeld wil worden. De behandeling mag in dat geval alleen worden toegepast als sprake is van gevaar voor de cliënt of anderen. De resultaten van de tweede evaluatie van de Wet Bopz laten zien dat deze situatie zich nog minder vaak voordoet dan de eerste vorm van dwangbehandeling. Dit hangt voor een groot deel samen met de interpretatie van het begrip verzet. 


\section{Verzet}

Veel cliënten verzetten zich niet of nauwelijks meer doordat zij reeds een lange periode in een instituut verblijven en kenmerken van hospitalisatie vertonen. Een ander herkenbaar probleem is dat onderscheid gemaakt kan worden tussen verzet in de zin van de Wet Bopz en verzet in de zin van tegenstribbelen, waarbij het de vraag is of hulpverleners hierop in moeten gaan. In de interviews geven hulpverleners aan dat niet elk verzet als verzet wordt geïnterpreteerd. Tevens geven zij aan dat bij elke vorm van separatie en afzondering wel sprake is van enige vorm van tegenwerking. Cliënten zijn op het moment van de toepassing van de maatregel zo boos dat zij zich tegen (bijna) alles lijken te verzetten. Op zo'n moment geven hulpverleners aan dat zij geen redelijk gesprek meer kunnen voeren met een cliënt. Achteraf kan blijken dat een cliënt alsnog instemt met de maatregel en is er van verzet geen sprake meer. Deze bevindingen wijken af van de uitleg die de wetgever aan verzet geeft: elk verzet dient te worden geïnterpreteerd als verzet.

'Cliënten willen ook vaak die veiligheid voor henzelf waarborgen en voor anderen. Als zij inzien wat voor een gevaar zij voor de groep veroorzaken, begrijpen ze vaak ook heel goed waarom wij bepaalde dingen doen zoals afzonderen.' (persoonlijk begeleider)

Het wordt als een gemis ervaren dat het begrip verzet niet nader is geoperationaliseerd voor de sector verstandelijk gehandicaptenzorg. Hulpverleners nemen vooralsnog niet het voortouw. $\mathrm{Zij}$ verschuilen zich achter de vraag wie de criteria voor verzet moeten uitwerken. Is het een taak van de wetgever, de brancheorganisatie VGN of het veld? Naast hospitalisatie van cliënten vertonen ook hulpverleners tekenen van hospitalisatie waardoor niet elk verzet als verzet wordt beschouwd. De Inspectie gaat er vanuit dat ook feitelijk verzet ${ }^{6}$ als verzet beschouwd moet worden en dat elk verzet gemeld moet worden zodat het handelen inzichtelijk wordt.

'Hoe definieer je verzet? Daar hebben we regelmatig hele discussies over. We hebben voor verzet geen duidelijke criteria.' (arts)

Hulpverleners hanteren bewust of onbewust toch bepaalde criteria bij de beoordeling van verzet. Wilsbekwaamheid is een van die criteria. Als een cliënt wilsonbekwaam is of een matige tot (zeer) ernstige verstandelijke handicap heeft

6 Onder feitelijk verzet wordt verstaan verzet dat niet wordt verwoord door een cliènt, maar dat wel uit het gedrag van een cliënt is af te leiden. 
wordt verzet al snel als geen verzet beschouwd. Daarentegen wordt verzet van een wilsbekwame cliënt over het algemeen serieuzer genomen.

'Tk spreek pas van verzet als iemand van hoog niveau is,' (arts)

In de praktijk gehanteerde criteria voor de operationalisatie van verzet zijn dat verzet heftig, invoelbaar en herhaald moet zijn, oftewel één keer verzet is nog geen verzet.

'Een laag niveau cliënt wil van de afdeling af. Er is echter een gesloten deur. Bij nader inzien blijkt dat de cliënt alleen maar door de deur wil omdat er iets achter de deur staat dat van hem is. De arts moet zich hier iets bij kumnen voorstellen.' (arts)

Ondanks deze criteria blijft de interpretatie van verzet voor een groot deel ook afhankelijk van de medewerker die op dat moment op de groep werkt. Zijn visie is op dat moment doorslaggevend.

'Of het als verzet gezien wordt is heel erg afhankelijk van de persoon die met deze cliënt werkt.' (persoonlijk begeleider)

\subsubsection{Middelen of maatregelen}

De Wet Bopz spreekt over vijf verschillende vormen van middelen of maatregelen: afzondering, separatie, 7 fixatie, dwangmedicatie en toediening van voeding en vocht onder dwang. Daarvan worden afzondering en fixatie het vaakst toegepast. Het komt maar zelden voor dat een middel of maatregel in het kader van een noodsituatie wordt toegepast. Veel middelen of maatregelen zijn met toestemming van de cliënt en of vertegenwoordiger opgenomen in het zorgplan onder de constructie 'middel of maatregel akkoord'. Ook is opvallend dat middelen of maatregelen ongeacht de status van de cliënt (vrijwillig of onvrijwillig) worden toegepast.

\section{Afzonderen}

Op een aantal woningen, met name waar cliënten met gedragsproblemen verblijven, wordt het af en toe noodzakelijk geacht om cliënten af te zonderen. Niet alle gebouwen beschikken nog over een afzonderingsruimte. Conform het beleid van de Inspectie is een deel van deze ruimtes een paar jaar geleden afgebroken. De afzonderingsruimtes die nog wel in gebruik zijn voldoen lang niet allemaal

7 In deze paragraaf wordt niet nader ingegaan op separatie. Deze vorm kwam nauwelijks ter sprake in de onderzochte instituten. Veel instituten beschikken ook niet meer over een separeerruimte. 
aan alle wettelijke eisen. Cliënten kunnen echter wel baat hebben bij afzonderen, aldus de mening van persoonlijk begeleiders, artsen en gedragsdeskundigen. Met name cliënten met een verstandelijke handicap en autisme kunnen in een afzonderingsruimte tot rust komen.

Vroeger had ieder paviljoen een eigen afzonderingsruimte. In de jaren tachtig is dit er uitgegaan. De ruimtes zijn allemaal slaapkamers geworden. Sinds de invoering van de Wet Bopz is er wel weer behoefte aan afzonderingsruimtes.' (arts)

Afzonderen mag volgens de Wet Bopz alleen plaatsvinden in een afzonderingsruimte. Bij gebrek aan een afzonderingsruimte wordt in de eigen slaapkamer afgezonderd. Ten aanzien van de vraag of afzonderen op de eigen kamer ook een geschikte oplossing is, lopen de meningen uiteen. Een eigen kamer kan een negatieve lading krijgen als een cliënt daar voortdurend wordt afgezonderd, aldus de mening van een persoonlijk begeleider. Aan de andere kant doet een eigen kamer prettiger aan dan een afzonderingsruimte.

'Er is geen aparte ruimte om iemand af te zonderen. Als je $P$. wilt afzonderen, dan weet je niet meer wat je met hem moet doen, dan breekt hij echt letterlijk de boel af, dan gaat hij naar zijn eigen kamer.' (persoonlijk begeleider)

'Een cliënt gaat af en toe naar zijn kamer. Hij wordt's morgens wel eens boos tijdens het scheren en dan wordt hij naar zijn kamer gestuurd. De deur gaat dan niet dicht. Hij gaat dan op zijn bed zitten en dan vraag je na een tijdje, kun je weer lief zijn? Het is niet echt afzonderen. Hij snapt het wel.' (persoonlijk begeleider)

Een cliënt die in het verleden veelvuldig werd afgezonderd, weet goed waarom hij nog steeds van tijd tot tijd naar een afzonderingsruimte wordt gebracht.

'Als mij iets niet bevalt, word ik boos en giftig. Personeel komt er dan bij. Ik kan dan niet weglopen en de deur is dan op slot.' (cliënt)

\section{Fixatie}

Bepaalde cliënten worden vanwege hun onrustige gedrag gefixeerd tijdens bijvoorbeeld het slapen. In woningen waar mensen met een (zeer) ernstige verstandelijke handicap verblijven worden cliënten regelmatig gefixeerd. De redenen daarvoor lopen uiteen van het voorkomen van automutileren tot het tegengaan van vallen uit een rolstoel tijdens een epilepsieaanval. In de meeste gevallen wordt als motief genoemd het bieden van veiligheid. 
'Er worden niet echt veel mensen opgesloten. Een cliënt slaapt wel op een aparte kamer op de gang, met een Zweedse band om. Dat is vamuit vroeger, vanwege zijn agressieve gedrag.' (persoonlijk begeleider)

\section{Overige middelen of maatregelen}

Bij het toedienen van medicatie doen zich weinig problemen voor, aldus de geìnterviewde persoonlijk begeleiders. De meeste cliënten nemen hun medicijnen trouw in. Het komt zelden voor dat dwangmedicatie nodig is. Een enkele keer is het noodzakelijk om de medicijnen door de pap te mengen omdat een cliënt slikproblemen heeft of moeten de medicijnen via een depot toegediend worden.

'Een enkele keer zijn er problemen met de toediening van medicijnen. Bij mensen met een (zeer) ernstige verstandelijke handicap wordt er wel eens wat in de pap gestopt. Bij mensen met een matige tot lichte verstandelijke handicap doe ik dat niet. Als een cliènt geen medicijnen wil probeer je het later nog eens. Lukt het dan nog niet, dan doe je het alsnog door de pap.' (arts)

In de geinterviewde instituten blijkt in een aantal gevallen sprake te zijn van veelvuldig medicijngebruik. Een aantal cliënten bleek na het afbouwen van de medicatie ook heel goed zonder alle medicijnen te kunnen. Er was zelfs een cliënt die zelf zijn medicatie heeft laten veranderen.

\section{Gevaar}

Middelen of maatregelen kunnen in het kader van dwangbehandeling toegepast worden bij Bopz-cliënten als sprake is van gevaar. De beoordeling van gevaar is, net als verzet, mede afhankelijk van de persoon die óp dat moment in de woning werkt. Relevante factoren zijn hoe veel jaren de begeleider al op de groep werkt, met hoeveel personeelsleden hij in een woning werkt en hoeveel dagen hij in de betreffende week al gewerkt heeft. Als een begeleider al meer dan zes dagen achter elkaar gewerkt heeft, daalt zijn incasseringsvermogen waardoor een potentieel dreigende situatie eerder als gevaar ingeschat zal worden. Bovendien is belangrijk dat iedereen, zowel de cliënten als het personeel, zich in een woning veilig voelt.

'Voor de een is een tikje gewoon een tikje en voor een ander is een tikje al behoorlijk over de schreef gaan.' (persoonlijk begeleider)

Gevaar doet zich voor als sprake is van fysieke agressie in de zin van automutileren of als cliënten gaan gooien met attributen zoals hete thee of messen, aldus de geïnterviewde persoonlijk begeleiders. Van gevaar is ook sprake als cliënten uit het raam (dreigen te) springen of als cliënten personeel of medecliënten gaan slaan. Tegelijkertijd geven persoonlijk begeleiders ook aan dat de omschrijving 
van gevaar in de Wet Bopz te beperkt is voor de sector verstandelijk gehandicaptenzorg. Als zij strikt volgens de wettelijke omschrijving te werk gaan, kunnen zij op diverse momenten niet ingrijpen. Daarnaast laten de resultaten van de enquête, die in het kader van de tweede evaluatie van de Wet Bopz is gehouden, zien dat in meer dan $80 \%$ van de instituten middelen of maatregelen vanuit het beschermingsmotief worden toegepast. Slechts een enkeling verwijst naar het gevaarsmotief.

'Op grond van de Wet Bopz beperk je alleen als er sprake is van gevaar. Je hebt in deze sector echter meer legitieme mogelijkheden nodig om de vrijheid te beperken van cliënten. Bijvoorbeeld vanuit pedagogische overwegingen, dat doe je bij kinderen ook.' (orthopedagoog)

'Het komt wel eens voor dat een cliënt heel hard zit te gillen in de woonkamer. Op een gegeven moment besluiten we dan toch om haar maar af te zonderen. Er is dan niet echt sprake van gevaar.' (persoonlijk begeleider)

Gevaarlijke situaties kunnen ook worden voorkomen. Persoonlijk begeleiders geven aan dat zij altijd zeer alert moeten zijn. Meestal zien ze het gevaar van tevoren aankomen. Zodra cliënten onrustig worden of afwijkend gedrag gaan vertonen is het moment aangebroken om in te grijpen. Een cliënt kan uit de groep worden gehaald of een begeleider kan met de cliënt gaan wandelen teneinde een gevaarlijke situatie te voorkomen.

'Bij sommige cliënten helpt het om ze op de eigen kamer te zetten en vervolgens de sleutel om te draaien.' (persoonlijk begeleider)

In de meeste gevallen is er een duidelijke verklaring voor de situatie. Om deze te kunnen achterhalen is het belangrijk dat het personeel de cliënt goed kent. Het komt echter geregeld voor dat een ervaren persoonlijk begeleider met een invalkracht of een nieuw personeelslid moet werken.

'Laatst heeft een cliënt mij gebeten. Hij is niet iemand waar je bang voor hoeft te zijn. Maar je moet wel in je achterhoofd houden dat, als er wat aan de hand is, hij gevaarlijk kan worden.' (persoonlijk begeleider)

\section{Middelen of maatregelen akkoord}

Middelen of maatregelen worden niet alleen bij gevaar toegepast, maar kunnen ook onderdeel uitmaken van het zorgplan. De Inspectie heeft jaren geleden de term middelen of maatregelen akkoord geïntroduceerd. In de sector verstandelijk gehandicaptenzorg is deze term een veel gebezigd begrip; dit kwam nadrukkelijk naar voren in de interviews. Als een cliënt en/of zijn vertegenwoordi- 
ger op een eerder moment instemt met de toepassing van bepaalde middelen of maatregelen, wordt deze afspraak als middel of maatregel akkoord opgenomen in het zorgplan. Als een cliënt zich vervolgens verzet tegen een middel of maatregel akkoord, mag op grond van de Wet Bopz de behandeling alleen worden uitgevoerd bij gevaar. Bovendien moet de cliënt in het bezit zijn van de juiste juridische status: onvrijwillig.

Een risico dat verbonden is aan middelen of maatregelen akkoord is dat de toepassing van middelen of maatregelen buiten het toezicht van de Inspectie plaatsvindt en op deze manier eindeloos kan doorgaan. In de interviews met persoonlijk begeleiders, en ook vertegenwoordigers, kwam naar voren dat een middel of maatregel akkoord soms jarenlang in het zorgplan blijft opgenomen, ook als het betreffende middel of maatregel al lang niet meer nodig is.

Th ben verbaasd dat separeren nog in het zorgplan staat. In het verleden is mijn dochter wel cens gesepareerd, maar dat is nu niet meer nodig.' (vertegenwoordiger)

Uit de interviews met onder meer persoonlijk begeleiders, artsen en gedragsdeskundigen bleek ook dat sommige regionale inspecteurs een keer in de drie maanden een overzicht toegestuurd wensen te krijgen van alle middelen of maatregelen akkoord. Dit verzoek is echter niet gebaseerd op de Wet Bopz, waardoor instituten niet verplicht zijn om deze overzichten op te sturen. Lang niet alle geïnterviewde instituten gaven aan dat zij middelen of maatregelen akkoord registreren. ${ }^{*}$

\subsubsection{Huisregels}

Elke woning of afdeling geeft op zijn eigen manier invulling aan huisregels. Soms zijn huisregels inzichtelijk voor iedereen en schriftelijk vastgelegd. Huisregels zijn ook aan verandering onderhevig. Gold vroeger de regel dat elke cliënt op een bepaald tijdstip naar bed moest gaan, inmiddels is deze huisregel in een aantal instituten afgeschaft. Cliënten mogen opblijven in de woonkamer of op hun eigen kamer TV kijken nadat het personeel naar huis is gegaan. Deze verandering geldt nog niet voor alle cliënten. Er zijn altijd cliënten, met name als het gaat om mensen met een (zeer) ernstige verstandelijke handicap, die geholpen moeten worden bij het naar bed gaan. Deze cliënten worden naar bed gebracht voordat het personeel naar huis gaat.

8 Bovendien blijkt uit een bulletin van de Inspectie voor de gezondheidszorg 'Melden in het kader van de Wet Bopz aan de Inspectie voor de Gezondheidszorg' (2002b) dat middelen of maatregelen akkoord onder Bopz-gegevens vallen die niet aan de Inspectie hoeven te worden gemeld (p. 36). 
'Ik ga om 23 uur naar bed. Dat mag ik zelf weten. In mijn vorige huis moest ik al om 22 uur gaan slapen. Het is fijn dat het hier niet meer zo streng is.' (cliënt)

'Onlangs was er een incident met een cliënt. De cliënt was nog TV aan het kijken op zijn eigen kamer. De nachtdienst wilde dat hij zijn TV uitdeed. De cliënt werd boos en vervolgens neemt de nachtdienst contact op met mij dat de cliënt in kwestie lastig is.' (persoonlijk begeleider)

Huisregels worden veelal gelijkgesteld met algemene regels. Aangezien cliënten met andere cliënten samenwonen, geven begeleiders aan dat het noodzakelijk is om bepaalde omgangsregels op te stellen.

'In principe mogen de cliënten alles zelf beslissen. Ze moeten echter wel rekening houden met elkaar. Er wonen zes cliënten in dit huis. Je kunt hier niet tot 12 uur in de avond muziek draaien. Dan moet je ergens anders gaan wonen. De meeste normen en waarden die in de maatschappij gelden, zijn ook hier van toepassing.' (persoonlijk begeleider)

We hebben wel huisregels, maar dat zijn eigenlijk gewoon meer algemene regels en niet afgesproken regels. Bijvoorbeeld dat bezoek altijd mag komen, wanneer er gebeld moet worden naar familie, altijd alles opbergen en cliënten mogen niets op hun kamer achterlaten waarmee ze zich kunnen bezeren als ze gaan slapen.' (persoonlijk begeleider)

Op een aantal groepen geldt de regel dat tijdens het eten geen TV of muziek aan mag staan. In de praktijk wordt deze regel niet zo strikt toegepast door het personeel. Daarnaast worden regels omtrent het rookbeleid genegeerd.

De huisregels staan mooi op papier genoteerd. De regel met roken werkt echter al niet. Officieel mag er alleen in de hoek gerookt worden. Het is hun huis en wij werken hier. $P$. is astmatisch en daar zou rekening mee gehouden moeten worden. Maar, personeel en cliënten roken toch in het gedeelte waar niet de rookverwijderaar hangt.' (vertegenwoordiger)

Familieleden zijn in beginsel altijd welkom om langs te komen. In veel gevallen wordt wel aan familie gevraagd om van tevoren te bellen zodat personeel kan beoordelen of het uitkomt dat familieleden op bezoek komen.

'De regel geldt dat bezoek altijd welkom is, maar ze moeten wel altijd van tevoren bellen. De situatie kan soms zodanig zijn, dat het niet uitkomt dat familie langskomt. Bijoorbeeld als B. zich net helemaal heeft onder gesmeerd. Daarnaast willen familieleden dat er iemand van het personeel bij het bezoek aanwezig is. Vanwege een stukje veiligheid. Maar dat is niet altijd mogelijk.' (persoonlijk begeleider) 
De huisregels worden niet altijd bekend gemaakt aan de vertegenwoordigers.

Deze regels zijn niet bekend gemaakt aan mij als mentor. Het zal wel ergens liggen. Ik krijg regelmatig post maar dit soort dingen zit daar niet bij. Zo van dat en dat mag allemaal niet, daar wordt weinig over verteld.' (vertegenwoordiger)

Over het algemeen probeert een instituut de huisregels tot een minimum te beperken. Dit geldt met name in woningen waar het mogelijk is om de huisregels te bespreken met de cliënten tijdens bijvoorbeeld een cliëntenvergadering.

De huisregels zijn minimaal, gepoogd wordt deze tot een minimum te beperken. De huisregels worden ook van tijd tot tijd doorgenomen met de cliënten. (persoonlijk begeleider)

Vanuit de cliënten ligt er nu de vraag om de bedtijden te veranderen. Dat betekent dat het management de werktijden moet gaan veranderen' (persoonlijk begeleider)

Cliēnten zijn het overigens niet altijd eens met de huisregels.

Tk vind het niet leuk dat begeleiders steeds komen zeuren dat de muziek te hard staat. Dat ligt gewoon aan de muziek, hoe deze is opgenomen. Andere cliènten kunnen toch niet klagen over de muziek, zij zitten opgesloten op hun kamer.' (cliënt)

\subsubsection{Beperkingen in het recht op bewegingsurijheid}

Uit de eerste evaluatie van de Wet Bopz kwam naar yoren dat vrijwel niemand in de praktijk spreekt over 'beperkingen in het recht op bewegingsvrijheid.' Bovendien geeft men in de praktijk aan dat er naast beperkingen van de bewegingsvrijheid ook sprake is van algemene vrijheidsbeperkingen. ${ }^{9}$ Voorbeelden van algemene vrijheidsbeperkingen zijn: koelkast op slot, maximaal 3 sigaretten per dag, geen eigen bankpasje. Ook in de tweede evaluatie van de Wet Bopz komt naar voren dat het begrip in de praktijk niet of nauwelijks wordt gehanteerd. In zorgplannen wordt de term begeleidingsafspraken of overige beperkende maatregelen gebruikt. ${ }^{10}$ In interviews met vertegenwoordigers en persoonlijk begeleiders werd gesproken over 'aparte regels voor cliënten die genoteerd staan in het zorgplan'. Hoewel persoonlijk begeleiders in de interviews een groot deel van de beperkingen konden benoemen, realiseerden zij zich ook dat niet alle beperkingen ergens genoteerd staan. Dit betreft met name beperkingen die

9 Wesseling 1996, p. 17-18.

10 Arends, Blankman en Frederiks 2002, p. 87. 
voor een grotere groep cliënten tegelijkertijd gelden zoals de koelkast op slot, buitendeur op slot en tuinhekje op slot. Uit de interviews komt naar voren dat een aantal regionale inspecteurs het zeer op prijs stelt dat hen, naast de meldingen van dwangbehandeling en middelen of maatregelen, ook eens per jaar een overzicht van alle beperkingen in het recht op bewegingsvrijheid wordt gestuurd.

Als strikt wordt vastgehouden aan de definitie van beperkingen in het recht op bewegingsvrijheid, valt een groot deel van de beperkingen die in de zorg voor mensen met een verstandelijke handicap wordt toegepast buiten de definitie. De beperkingen in het recht op bewegingsvrijheid kunnen op grond van het empirische onderzoek onderverdeeld worden in:

A. beperkingen in vrijheid om een ruimte te verlaten dan wel te betreden; voorbeelden zijn niet zonder toestemming naar buiten gaan, op bepaalde momenten niet de woonkamer in, deurverklikkers, vaste kamermomenten, afkoelen in de tussenkamer, time-out, tussendeur dicht, keuken niet betreden, hand-in-hand begeleiding, gesloten afdeling.

B. beperking in vrijheid om te beschikken over bepaalde voorwerpen; voorbeelden zijn koelkast op slot, sigarettenschema, bestek achter slot en grendel, een keer in de week bellen, mobiele telefoon inleveren, geen huisdieren, geen vuur ìn eigen berleer, kileulingk'ast' op sibr, penner anfemen, al! cohol beperking, alleen gebeurtenissen vertellen aan cliënt die binnen een voor hem overzichtelijke tijd plaatsvinden.

C. beperkingen in het aangaan van contacten; voorbeelden zijn het verbieden van onderlinge relaties, geen contact met ouders en niet naar activiteiten.

D. overige zoals een gestructureerd dagprogramma/schema

\section{A. Beperkingen in vrijheid om een ruimte te verlaten dan wel te betreden}

In instituten, maar ook in sociowoningen en gvt'en worden cliënten beperkt in de vrijheid om een bepaalde ruimte te verlaten dan wel te betreden. Bepaalde afdelingen zijn de hele dag gesloten, sommige cliënten verblijven de hele dag op hun kamer, andere cliënten mogen wel vrij rondlopen maar kunnen niet weglopen omdat er een hek om de tuin zit. Deze beperkingen zijn vaak het gevolg van de aanwezigheid van andere cliënten.

'Er is op dit moment een cliënt van de buren aanwezig, waardoor de voordeur op slot moet. Er is geen zicht op zijn gedrag. Dit heeft echter ook weer gevolgen voor de andere cliënten. Hun vrijheid wordt ook beperkt.' (persoonlijk begeleider)

Cliènten vinden het niet prettig om in hun vrijheid beperkt te worden. Ze geven aan dat ze graag wat meer vrijheden zouden willen hebben, bijvoorbeeld de stad ingaan of bij een vriendin op bezoek gaan. 
Tk mag op dinsdag, twoensdag en zondagavond niet weg. Ik zou ook graag 1 keer per week naar een vriendin toe willen gaan. Dat is eigenlijk best wel shit, dat het niet kan.' (cliënt)

De beperkingen in vrijheid hangen ook samen met de diensten van het personeel. Op bepaalde groepen geldt de regel dat zodra het personeel 's avonds naar huis gaat, de cliënten de huiskamer moeten verlaten.

Tk vind het niet leuk dat ik al om 21.20 uur moet gaan slapen. Ik wil wel langer opblijven. Op mijn kamer kijk ik geen TV meer.' (cliënt)

Vertegenwoordigers verschillen onderling van mening over de beperkingen die opgelegd worden aan de cliënten. Het is heel lastig om te bepalen of al deze beperkingen ook daadwerkelijk nodig zijn.

'Als je de deuren niet goed op slot doet en alles open zou laten dan zou er een levensbedreigende situatie ontstaan voor P. Hij ziet geen gevaar. Hij is ooit in het hoofigebouw van acht meter hoog uit een raam gesprongen. Dat is goed afgelopen, maar hij ziet daar geen gevaar van in. Als je alles afsluit is het inderdaad een vripheidsbeperkende situatie, maar wel een situatie die voor $P$. noodzakelijk is.' (vertegenwoordiger)

Daarnaast kunnen vertegenwoordigers moeilijk inschatten wat de cliënt zelf vindt van de beperking.

'Een beperking is ook weer dat hij op zijn eigen kamer moet eten. Dat is een gevolg van het feit dat hij in een groep woont. Hij zou graag samen in de woonkamer eten. Maar of hij dat als een tekortkoming ziet is nog maar de vraag.' (vertegenwoordiger)

Een deel van de beperkingen wordt als 'normaal' beschouwd aangezien vertegenwoordigers deze beperkingen ook thuis hanteren.

'Hij mag niet gaan en staan waar hij wil. Hij mag maar 10 minuten onder de douche. Hij mag niet fietsen wanneer hij dat wil. Het feit dat hij ook geen bier mag overdag, is niet vreemd. Als H. bij mij thuis is mag hij dat ook niet.' (vertegenwoordiger)

B. Beperkingen om te beschikken over bepaalde voorwerpen

In de interviews zijn diverse voorbeelden ter sprake gekomen waaruit blijkt dat cliënten beperkt worden om vrij te beschikken over bepaalde voorwerpen. Het achterliggende motief van deze beperkingen is vaak bescherming. Op veel groepen wordt het eten achter slot en grendel bewaard en de sigaretten door de begeleiding beheerd. Andere voorbeelden zijn: kledingkast op slot, geen sleutel hebben, bestek achter slot en grendel, cliēnten krijgen per week een bedrag aan 
zakgeld, alleen op een bepaalde dag telefoneren en alleen in het weekend een alcoholische drank nuttigen.

'Hij had vroeger een geldpotje. Daar kon hij van alles meedoen. Dat heeft hij nu niet meer. De reden zal ook wel een soort bescherming zijn. Betekent wel dat hij daardoor weer beperkt wordt. Hij krijgt nu alleen nog maar geld als hij sigaretten gaat kopen. Hij kan niet een patatje of zo kopen. Dat is zielig, maar aan de andere kant geeft hij zijn geld ook zomaar uit. Hij heeft inmiddels geleerd om niet meer om geld te zeuren, ook niet als hij met zijn zus op pad is.' (vertegenwoordiger)

De beperkingen worden regelmatig aan alle cliënten in een woning opgelegd omdat bijvoorbeeld één cliënt al het eten opeet.

'Doordat $P$. hier op de groep woont, zijn alle spullen van de groep afgehaald zoals planten. Hij zou dat allemaal kapot maken. Maar, het gevolg is wel dat de groep ook voor de andere cliënten een stuk kaler wordt gemaakt.' (persoonlijk begeleider)

Bovengenoemde beperkingen zijn overigens niet in alle huizen noodzakelijk. Persoonlijk begeleiders zijn zeer creatief in het zoeken naar alternatieven. Indien de voorraadkasten, vanwege het eetgedrag van een cliënt, voor iedereen worden afgesloten bestaat de mogelijkheid om aan de andere cliënten een sleutel te geven zodat zij wel toegang hebben tot het eten en drinken in de kasten.

Ook worden niet alle beperkingen als een beperking gezien. Veel beperkingen worden als vanzelfsprekend beschouwd en door cliënten veelal ook zo ervaren. Pas na doorvragen en het noemen van voorbeelden kwamen begeleiders, cliënten en vertegenwoordigers met voorbeelden.

'In de vorige woning was er ook een cliënt die alles opat en opdronk. Met het gevolg dat de kasten allemaal op slot moesten. Ik vind het als moeder logisch dat bier en koffie etc. achter slot en grendel zit. Dat moet thuis ook gebeuren.' (vertegenwoordiger)

\section{Beperking in het aangaan van contacten}

Naast de eerdergenoemde beperkingen worden cliënten van een instituut in een aantal gevallen beperkt in het aangaan van contacten. Familieleden zijn echter op een kleine uitzondering na altijd welkom. In een gvt gelden soms speciale afspraken ten aanzien van het aangaan van contacten. Zo mogen de kinderen van een cliënt alleen op bezoek komen als dit van tevoren is afgesproken met de begeleiding. Ook komt het voor dat afspraken worden gemaakt over relaties en vriendschappen.

Ik heb mu een half jaar verkering. Ik heb hem via het werk leren kennen. Ik wil met hem samenwonen. Dat we ergens gaan wonen en dat de leiding 1 of 2 keer per week langs- 
komt. Nu nog niet, nog maar mee wachten. Er zijn nu met de leiding afspraken gemaakt over wanneer ik mijn vriend mag zien. ' (cliënt)

Persoonlijk begeleiders denken wisselend over het verbieden van vriendschappen. Soms kan het echt niet anders en moet ter voorkoming van vervelende dingen of omdat sprake is van een aanzienlijk niveauverschil de relatie of vriendschap worden beëindigd.

Hij heeft net een relatie achter de rug. Er was een niveauverschil in de relatie. Zij had ook veel meer behoefte aan hem, dan hij aan haar. We hebben ons in het begin daar wel mee bemoeid. Er zijn toen afspraken gemaakt met de leiding en zijn vriendin.' (persoonlijk begeleider)

De begeleiding heeft niet het recht om vriendschappen van cliënten te verbieden. Er is wel eens een discussie geweest onder de begeleiding. Maar, ik bliif er bij dat het niet een taak of een recht van de begeleiding is om daar iets over te zeggen. Ik waarschuw cliënten wel, maar verbied niets.' (persoonlijk begeleider).

\section{Een gestructureerd dagprogramma/schema}

Een aantal cliënten heeft een dagprogramma. Daarin staat aangegeven wat de cliēnt op welk tijdstip gaat doen. Zo'n strak schema biedt de cliënt duidelijkheid en houvast maar beperkt tegelijkertijd diens bewegingsvrijheid. Allereerst wordt hij beperkt in zijn vriiheid om een ruimte te verlaten of te betreden. Een onderdeel van een dagprogramma is vaak dat de cliënt bepaalde gedeeltes van de dag op zijn kamer moet doorbrengen. Daarnaast heeft hij niet de vrije beschikking over voorwerpen zoals sigaretten/sigaren. Deze worden veelal volgens een vast schema of gedoseerd uitgereikt aan de cliënt. Tot slot is een cliënt door een gestructureerd dagprogramma beperkt in het aangaan van contacten met andere mensen binnen of buiten een instituut.

\subsubsection{Niet-wettelijke vormen van vrijheidsbeperking in de praktijk}

Naast de wettelijk toegestane vormen van vrijheidsbeperking, komen in de verstandelijk gehandicaptenzorg ook niet-wettelijke vormen van vrijheidsbeperking voor. Hiermee wordt bedoeld dat vrijheidsbeperking niet op grond van de Wet Bopz wordt toegepast; vrijheidsbeperking wordt toegepast in voorzieningen die geen Bopz-aanmerking hebben of bij vrijwillig opgenomen cliënten. In beide gevallen is de Wet Bopz niet van toepassing. Daarnaast worden in de verstandelijk gehandicaptenzorg ook pedagogische maatregelen en maatregelen met het oog op straffen en belonen toegepast. Geen van beide motieven noemt de Wet Bopz. 


\subsubsection{Pedagogische maatregelen}

Naast middelen of maatregelen worden pedagogische, medische of beschermende maatregelen veelvuldig in de verstandelijk gehandicaptenzorg gebruikt. Dit onderscheid draagt niet bij aan een verheldering van het begrip middel of maatregel. De Wet Bopz kent alleen de vijf eerder genoemde middelen of maatregelen. Pedagogische maatregelen worden onderscheiden van Bopz-middelen of maatregelen. Enkele voorbeelden zijn: een cliënt moet op zijn kamer tot rust komen omdat hij tijdens het koffiedrinken niet rustig kan blijven zitten in de woonkamer of een cliënt wordt naar zijn kamer gestuurd omdat hij geen zin heeft in corvee. Daarnaast komt het veelvuldig voor dat afspraken over roken worden gemaakt. Hulpverleners geven aan dat zij het onderscheid tussen pedagogische maatregelen en Bopz-middelen of maatregelen in stand houden, omdat het gevaarscriterium te weinig handvatten biedt voor de sector verstandelijk gehandicaptenzorg.

'Het is goed dat er een onderscheid wordt gemaakt tussen beschermende, pedagogische en reguliere middelen of maatregelen. In onze sector mag je officieel alleen beperken als er sprake is van gevaar maar er zijn tal van andere legitieme momenten om de vrijheid van cliënten te beperken.' (orthopedagoog)

Pedagogische maatregelen worden niet nauwkeurig intern geregistreerd en aan de Inspectie gemeld. Dit beeld wordt bevestigd door de schriftelijke enquête die in het kader van de tweede evaluatie van de Wet Bopz verstuurd is naar alle instituten voor verstandelijk gehandicaptenzorg. Onder de geretourneerde enquêtes bevond zich ook een aantal orthopedagogische instituten die in de kantlijn van de enquête opvallende uitspraken deden. Deze instituten hebben een Bopz-aanmerking en vallen daarmee onder de Wet Bopz.

'De Wet Bopz is bij ons niet van toepassing. Daarover hebben we met de Inspectie afspraken gemaakt.'

Wij passen alleen pedagogische maatregelen toe en noteren deze in het zorgplan. Van dwangbehandeling en noodsituaties in de zin van de Wet Bopz is geen sprake.'

\section{'Middelen of maatregelen komen alleen voor vanuit pedagogisch oogpunt'}

Het standpunt van een aantal orthopedagogische instituten is dat zij vanuit de pedagogiek werken. De Inspectie voor de gezondheidszorg (IGZ) maakt de vergelijking met instituten voor verstandelijk gehandicaptenzorg die ook van mening zijn dat de Wet Bopz niet op hen van toepassing is, omdat zij vanuit het beschermingsidee werken. In principe hoeven pedagogische maatregelen niet gemeld te worden aan de Inspectie, aangezien deze vorm van vrijheidsbeper- 
king niet onder de Wet Bopz valt. Het probleem is echter dat pedagogische middelen nauw raken aan Bopz-middelen of maatregelen. Binnen de sector verstandelijk gehandicaptenzorg is niet duidelijk wat het verschil is tussen pedagogische maatregelen en middelen of maatregelen in het kader van de Wet Bopz. Een orthopedagogisch instituut stelt in de kantlijn van de geretoumeerde enquête de vraag: waar leg je de grens tussen middelen of maatregelen en pedagogische maatre. gelen? Hoe ver kun je opvoedkundig gaan?

Inmiddels heeft het Trimbos-instituut een richtlijn opgesteld over de toepassing van de Wet Bopz in de kinder-en jeugdpsychiatrie. "Deze richtlijn is ook meegenomen in de evaluatie van de Wet Bopz. De evaluatie laat zien dat de richtlijn tot veel onduidelijkheid leidt in de kinder- en jeugdpsychiatrie. ${ }^{12}$ Een veel gehoorde klacht is dat hulpverleners van mening zijn dat zij, in vergelijking met ouders, veel minder mogen. Een ouder mag een kind naar zijn kamer sturen of verbieden dat hij met bepaalde personen omgaat. Het juridische kader, waartoe ook de Wet Bopz behoort, zou te stringent zijn voor de kinder- en jeugdpsychiatrie. Hetzelfde kan gezegd worden over de verstandelijk gehandicaptenzorg. Orthopedagogen voelen zich belemmerd in hun handelen.

\subsubsection{Begeleidingsafspraken: straffen en belonen}

Naast beperkingen in het recht op bewegingsvrijheid, huisregels, middelen of maatregelen komt het een enkele keer voor dat cliënten een straf opgelegd krijgen. Deze vorm van vrijheidsbeperking komt ook voor in gvt'en. De Wet Bopz is niet bedoeld voor deze vorm van vrijheidsbeperking.

'Zelden is er hier in huis ruzie. Eén cliënt kan er echter wcl wat van. Hij krijgt dan de hele dag keukendienst. Hij heeft net weer twee dagen keukendienst gehad omdat hij zich niet correct gedragen had. Het gebeurt ook wel eens dat hij in de keuken moet eten. Hij hoeft echter niet opgesloten te worden.' (persoonlijk begeleider)

Het uitdelen van straffen kan verschillende vormen aannemen. Een persoonlijk begeleider merkt op dat geld afpakken van cliënten geen juiste straf is. Bovendien heeft de straf vaak niet de beoogde werking. Cliënten worden door de maatregel op het verkeerde been gezet.

'Tk pak niet graag geld af. Dat zorgt erooor dat I. niet meer kan roken en dan gaat hij bijoorbeeld geld stelen of andere manieren bedenken om toch aan zijn geld te komen. Dat is ook machtsgebruik en dan dwing je mensen om verkeerde dingen te gaan doen. Een regel die goed helpt is om hem te verbieden uit te gaan. Dat is een behoorlijke straf

11 Van Ooyen-Houben e.a. 1999.

12 De Groot en Donker 2002. 
voor hem. Ik vraag dan wel altijd aan hem of hij vindt dat hij deze straf verdiend heeft.' (persoonlijk begeleider)

Naast het straffen van cliënten wordt goed gedrag van cliënten beloond. Eén van de cliënten moet zich elke avond bij de begeleiding melden. Vervolgens wordt samen met de cliënt de dag doorgesproken aan de hand van een checklist. Bij goed gedrag wordt hij beloond met een extra sigaar.

Hij heeft elke dag om half 10 een gesprek met de begeleiding. Hij vertelt dan wat hij die dag gedaan heeft en of hij alles goed gedaan heeft. Dan volgt er een sigaar als beloning.' (vertegenwoordiger)

\subsubsection{Vrijheidsbeperking buiten Bopz-instituten}

Bij de cliënten die in een sociowoning of in een gvt wonen is nauwelijks sprake van vrijheidsbeperkende maatregelen, aldus de mening van persoonlijk begeleiders. Toch doen zich situaties voor die dicht tegen vrijheidsbeperkende maatregelen aanzitten. De Wet Bopz is wel van toepassing in sociowoningen maar niet in gvt'en. In de onderzochte woonvormen is nauwelijks verschil in populatie.

'Hier is nooit sprake van vrijheidsbeneming in de zin van mensen opsluiten en dergelijke. In de nevenvestigingen moet wel zo nu en dan worden opgetreden en moeten cliënten naar hun kamer worden gestuurd.' (persoonlijk begeleider)

Ook in een sociowoning of gvt wordt af en toe ruzie gemaakt. Cliënten kunnen dit soms zelf oplossen zonder dat mensen apart gezet hoeven te worden.

'Er wordt wel ruzie gemaakt. De leiding hoeft dan niet tussen beide te komen. We lossen het vaak zelf op. Ik loop meestal weg of ga naar mijn kamer.' (cliënt)

In andere gevallen moet de begeleiding optreden. Cliënten worden naar hun kamer gestuurd om af te koelen.

'Het enige wat gebeurt is dat mensen naar hun kamer worden gestuurd. Zo van ga iij maar naar je kamer toe en om half zes mag je weer beneden komen. De reden is dan vaak afkoelen.' (persoonlijk begeleider)

Hoewel de Wet Bopz niet van toepassing is in gvt'en, wordt in deze setting ook met huisregels gewerkt. Een aantal huisregels is nodig vanwege de aanwezigheid van een bepaalde cliënt.

'Cliënten moeten melden wie er blijft slapen en wie niet. Dat geldt ook als ze iemand mee naar huis nemen. Rondom alcohol is een aantal regels opgesteld. Aangezien één cliënt bij 
ons erg veel drinkt, ligt alcohol achter slot en grendel. In het weekend liggen enkele bierflesjes in de koelkast.' (persoonlijk begeleider)

Cliēnten van een gvt of een sociowoning zijn meestal op de hoogte van de meeste huisregels.

'Geen brood meer na zes uur. Deze regel is nodig omdat bepaalde mensen daar misbruik aan hebben gemaakt. Koekjes zijn er wel elke dag en chips alleen in het weekend. Als je tweggaat zeggen waar je naartoe gaat. Als de begeleiding weggaat, hoef je niet naar bed. le mag nog op je kamer of in de woonkamer TV kijken. Het is je eigen verantwoordelijkheid dat je de volgende dag wel weer vroeg op moet. Als de begeleiding weg is, alleen opendoen voor bekenden.' (cliënt)

'Om 22 uur moet de muziek uit. Ik mag ook niet teveel bier. Als je meer wilt mag je bier op je kamer hebben. Als het dan een keer fout gaat mag het niet meer. le mag na het eten nog naar buiten, maar er is hier niet veel te doen. Je mag ook later slapen, maar het is wel slim om op tijd te gaan slapen.' (cliënt)

\subsubsection{Vrijheidsbeperking bij vrijwillig opgenomen cliënten}

Wettelijk gezien mag vrijheidsbeperking alleen toegepast worden bij onvrijwillig opgenomen cliënten. Uit het empirische onderzoek komt naar voren dat bij de toepassing van vrijheidsbeperking nauwelijks onderscheid wordt gemaakt tussen een cliënt die vrijwillig is opgenomen en een cliẻnt die onvrijwillig is opgenomen. Een deel van deze middelen of maatregelen wordt met toestemming van de cliënt en/of vertegenwoordiger opgenomen in het zorgplan. Daarnaast vindt ook toepassing van vrijheidsbeperking plaats in situaties waarbij sprake is van verzet van een vrijwillig opgenomen cliënt. Instituten geven zelf aan waarom zij geen onderscheid maken tussen Bopz-cliënten en niet-Bopz-cliënten:

- Een instituut heeft geen cliënten met een Bopz-status.

- Een groot deel van de cliënten moet nog worden geherindiceerd.

- Vanuit de visie op zorg geldt geen onderscheid.

- Alle cliënten zijn in de praktijk wilsonbekwaam.

- Bij beide groepen cliënten gelden dezelfde zorgvuldigheidseisen.

- De Wet Bopz is in principe op alle cliënten van toepassing, ook al ontbreekt de indicatie.

- Er worden ook middelen of maatregelen bij niet-Bopz cliënten toegepast.

- De zorg wordt gegeven vanuit een individueel zorgplan, dat elke cliënt heeft.

- Personeel weet niet of cliënten wel of niet Bopz-geïndiceerd zijn.

- Alle cliënten worden in de geest van de wet behandeld.

- Middelen of maatregelen worden ook bij vrijwillig opgenomen cliënten toegepast, deze cliënten staan op de wachtlijst voor herindicatie. 
- Verschil tussen een Bopz en niet Bopz-cliënt is slechts administratief.

- Het uitgangspunt is, ongeacht de status, leveren van kwalitatief goede zorg.

De bovenstaande opmerkingen roepen de vraag op of de toepassing van vrijheidsbeperking bij elke cliënt op een verantwoorde wijze plaatsvindt. De Wet Bopz kent een aantal waarborgen voor de toepassing van vrijheidsbeperking. Deze zijn echter niet van toepassing op vrijwillig opgenomen cliënten.

\subsection{Alternatieven voor vrijheidsbeperking}

Sommige persoonlijk begeleiders realiseren zich dat de rechten van mensen met een verstandelijke handicap in een aantal gevallen onnodig worden beperkt.

'Als ze meer individuele aandacht en hand-in-hand-begeleiding zou krijgen, hoeft ze minder vaak in de afzonderingsruimte gezet te worden' (persoonlijk begeleider)

'Als hij geen activiteiten en geen vast programma heeft, neemt zijn probleemgedrag aanzienlijk toe' (persoonlijk begeleider)

Instituten nemen diverse initiatieven om het aantal middelen of maatregelen terug te dringen. In een instituut wordt een deel van het probleemgedrag aangepakt door beter in te spelen op het gehoor van cliënten en visuele problemen. Goede zorgprogramma's, voldoende aandacht en personeel kunnen ook een groot deel van de escalaties voorkomen.

Hij laat een opbouw aan spanningen zien. Wij gaan met hem wandelen, knuffelen en stoeien om maar te voorkomen dat de situatie escaleert.' (persoonlijk begeleider)

'Een cliënt slaat altijd bij het afdrogen. Een alternatief is hem een handdoek in zijn handen te geven.' (persoonlijk begeleider)

Daarnaast doen instituten regelmatig een beroep op consulententeams zodra sprake is van een uitzichtloze situatie: een cliënt moet bijvoorbeeld meer dan 20 uur per week gefixeerd worden. Het duurt soms jaren voordat een aanvraag voor een bijzonder zorgplan, waarin wordt gevraagd om extra personeel, wordt gehonoreerd. In de tussentijd doen zich schrijnende en pijnlijke situaties voor, waar ook vertegenwoordigers weinig verbetering in kunnen aanbrengen. Het enige wat zij kunnen doen is berusten in de tijdelijke oplossing en hopen dat de situatie binnenkort verbetert. 
Met het bijzondere zorgplan is al een aantal jaren niets gedaan. Het ligt klaar, maar er gebeurt niets mee. Tegentwoordig laten ze haar vier of viif keer per dag rusten in de afzonderingsruimte.' (vertegenwoordiger)

Afdelingen zijn soms al jaren gewend om volgens een bepaalde manier te werk te gaan. De komst van een nieuw personeelslid kan verbeteringen brengen. Zo kan worden besloten om het gebruik van Zweedse banden af te bouwen. Na een paar maanden blijkt vervolgens dat een deel van de $Z$ weedse banden niet meer nodig is.

Toen ik begon met werken waren er meer mensen met een Zweedse band en de deur op slot. Nu, vijf jaar later is er, mede door mijn beleid, veel veranderd.' (persoonlijk begeleider)

Een aantal keren werd door persoonlijk begeleiders en vertegenwoordigers opgemerkt dat het aantal middelen of maatregelen drastisch zou kunnen dalen als in bouwkundig opzicht het een en ander zou veranderen. Cliënten zouden bijvoorbeeld allemaal een eigen kamer moeten krijgen. Daarnaast is ook de groepsgrootte bepalend voor het aantal toegepaste middelen of maatregelen, zeker als het gaat om cliẻnten met ernstige gedragsproblemen. Tot nu toe bestaan de meeste groepen nog uit acht of meer cliënten.

\subsection{Registreren en melden}

In kader van de tweede evaluatie van de Wet Bopz kregen alle instituten voor verstandelijk gehandicaptenzorg de vraag voorgelegd om gegevens in te vullen over het aantal toepassingen van middelen of maatregelen in het kader van dwangbehandeling en noodsituaties bij zowel Bopz-cliënten als niet-Bopzcliënten in het jaar 2000. Een aanzienlijk aantal instituten was niet in staat om hiervan een overzicht te geven. Instituten gaven als reden op dat toepassingen van middelen of maatregelen handmatig geteld moeten worden, aantallen worden alleen in een dagelijkse rapportage bijgehouden, een centraal registratiesysteem ontbreekt of men is bezig met het opzetten van een nieuw registratiesysteem. Daarnaast registreert elk instituut op zijn eigen manier de toepassingen van vrijheidsbeperking.

'Als iemand drie keer gefixeerd wordt op een dag, wordt deze maatregel drie keer genoteerd' (staffunctionaris kwaliteit).

'Als een cliënt tien keer per dag een maatregel krijgt opgelegd, wordt dit drie keer per dag gemeld: ochtenddienst, middagdienst en avonddienst.' (persoonlijk begeleider) 
Instituten geven ook aan dat niet alle hulpverleners zich realiseren welke gevolgen hun handelen heeft voor de vrijheid van cliënten. Hierdoor wordt een deel van de vrijheidsbeperkende maatregelen niet geregistreerd.

Ik ben ervan overtuigd dat op groepen veel meer gebeurt. Men is zich daar echter veel minder bewust van wat men daadwerkelijk doet.' (persoonlijk begeleider)

Op grond van de Wet Bopz is de geneesheer-directeur ${ }^{13}$ verantwoordelijk voor het melden van dwangbehandeling en noodsituaties aan de Inspectie. In de praktijk wordt lang niet alles gemeld.

'Ik zou nooit durven zeggen dat alles gemeld wordt. Maar, het zit hier wel fors ingeramd.' (arts)

'Alle meldingen van dwang en nood gaan eerst naar de arts. Deze beslist of en wat er gemeld gaat worden.' (persoonlijk begeleider)

'Als mensen zich verzetten worden ze toch naar hun kamer gestuurd. Daar verzetten ze zich altijd tegen. Dit wordt niet gemeld, maar is een middel of maatregel akkoord. Als het verzet heftig is, wordt er wel gemeld.' (persoonlijk begeleider)

Bij de meldingen naar de Inspectie toe is ook de zwaarte van de maatregel van invloed. De meldingen van dwangbehandeling en noodsituaties verlopen via een landelijk formulier, ontwikkeld door de IGZ. Op dit formulier kunnen niet de middelen of maatregelen worden ingevuld die bij vrijwillig opgenomen cliënten worden toegepast. Toch bleek uit interviews dat instituten deze toepassingen wel melden. Dit verloopt meestal via een aparte brief aan de Inspectie. Het gaat

13 Op grond van de Wet Bopz dient de functie van geneesheer-directeur ingevuld te worden door een arts (artikel 1 lid 3 Wet Bopz). De praktijk van de verstandelijk gehandicaptenzorg laat een ander beeld zien: in veel gevallen is binnen een voorziening geen arts aanwezig en wordt de functie van geneesheer-directeur ingenomen door een gedragsdeskundige. De NVAVG heeft recentelijk een nota opgesteld over de taken en bevoegdheden van een geneesheer-directeur en eerste geneeskundige, een term die ook wordt gebruikt in de verstandelijk gehandicaptenzorg. Onder een eerste geneeskundige wordt verstaan de arts die verantwoordelijk is voor de algemene gang van zaken op medisch gebied. Hij is niet verantwoordelijk voor Bopz-aangelegenheden. Een Bopz-arts is belast is met taken en bevoegdheden in het kader van de Wet Bopz (NVAVG, De cerste geneeskundige taken en verantwoordelijkheden in de zorg voor mensen met een verstandelijke handicap, 2003). 
dan vaak om eenmalige toepassingen van dwangbehandeling waarbij een instituut het niet nodig vindt om de juridische status van de cliënt te veranderen. Soms komt het voor dat de juridische status van de cliënt nog niet is aangepast en er toch middelen of maatregelen toegepast moeten worden.

'Als er bijzonderheden zijn, wordt er bijzonder verslag bij de melding gedaan. Bijvoorbeeld een cliënt verzet zich normaal gesproken nooit tegen separeren en nu wel.' (persoonlijk begeleider)

Een cliënt die vrijwillig opgenomen is werd laatst een of twee keer gefixeerd wegens het overlijden van zijn moeder. Deze situatie is, vergezeld van een brief, gemeld aan de Inspectie.' (arts)

Inspecteurs maken, per regio, verschillende afspraken met het veld. In de ene regio wil de inspecteur elke maand op de hoogte worden gebracht van het aantal toepassingen van dwang en middelen of maatregelen. In andere regio's ontvangen inspecteurs om de drie maanden een overzicht van alle middelen of maatregelen, inclusief de middelen of maatregelen die in het zorgplan staan. Op deze lijst staan ook middelen of maatregelen die bij vrijwillig opgenomen cliènten zijn toegepast. Instituten registreren dikwijls middelen of maatregelen los van de juridische status die een cliënt heeft. De Inspectie doet tot nu toe weinig met deze overzichten.

Ondanks de administratieve rompslomp die het registreren en melden met zich meebrengt, delen de instituten de mening dat registeren en melden noodzakelijk is. Op grond van het overzicht van middelen of maatregelen wordt inzichtelijk wat zich binnen een instituut op het gebied van vrijheidsbeperking voordoet. Het bijhouden van alle middelen of maatregelen wordt ook als een onderdeel van het kwaliteitssysteem beschouwd. Instituten erkennen dat nog meer gedaan kan worden met de interne registraties. Het beleid van een instituut dient erop gericht te zijn om het aantal middelen of maatregelen terug te dringen. Daarnaast benadrukken instituten dat registreren en melden zinvoller wordt, als de Inspectie daadwerkelijk iets doet met de gegevens. Het heeft weinig zin om gegevens naar de Inspectie te sturen omdat 'het moet'.

'Het is bij bepaalde cliënten wel een administratieve rompslomp. Daar loop je wel eens tegenaan. Je kunt echter op grond van de registratie ook gericht feedback geven.' (persoonlijk begeleider)

\subsection{De Wet Bopz een geschikt kader?}

De Wet Bopz vormt het juridische kader voor vrijheidsbeperking. Hulpverleners mogen alleen vrijheidsbeperkende maatregelen toepassen indien voldaan is aan 
de voorwaarden die deze wet stelt. Over het algemeen zijn persoonlijk begeleiders goed te spreken over de Wet Bopz. Door de komst van deze wet wordt vaker stil gestaan bij de toepassing van vrijheidsbeperking, wordt zorgvuldiger gewerkt en meer gezocht naar alternatieven. Oftewel de geest van de wet is goed. Collega's worden ook eerder aangesproken als de vrijheid van een cliënt onnodig beperkt wordt en andere oplossingen voorhanden zijn.

'De Wet Bopz is een goede wet. Het gaat toch om het opleggen van vrijheidsbeperkingen. Dat moet je niet zelf bepalen, daar moet een vorm van toezicht en verantwoording voor zijn. Als begeleider heb je toch een soort machtspositie ten aanzien van de cliënten.' (persoonlijk begeleider)

Met de komst van deze wet zijn alle beperkingen opnieuw aan de orde gesteld: waarom moet iemand zoveel naar de time-out kamer? Zijn er geen andere mogelijkheden denkbaar? De Wet Bopz heeft ons toch eens aan het denken gezet.' (persoonlijk begeleider)

'De Wet Bopz is een goede wet. Het gaat uiteindelijk om vrijheidsbeperking en daar kun je in een instituut voor mensen met een verstandelijke handicap misbruik van maken. Deze wet dwingt je om na te denken over vrijheidsbeperking en om de maatregelen te beperken als dat nodig is.' (persoonlijk begeleider)

Ook op afdelingen waar cliënten met een (zeer) ernstige verstandelijke handicap verblijven laat men zich positief uit over de Wet Bopz, al loopt het personeel wel tegen een aantal interpretatieproblemen op. Er worden middelen of maatregelen toegepast, maar de reden van toepassing komt niet overeen met de bedoeling van de wet. Bepaalde cliënten hebben middelen of maatregelen nodig omdat ze anders uit hun bed of stoel vallen wegens epilepsie. Dit zijn beschermende maatregelen, waarbij de reden van toepassing op het somatische vlak ligt.

'Het enige wat hier beperkt wordt, is de toepassing van beschermende maatregelen. De pedagoog komt een keer in het jaar langs om te kijken of deze maatregelen nog nodig zijn. Je mag namelijk niet zomaar iemand vastbinden.' (persoonlijk begeleider)

\section{Kanttekeningen}

Ondanks de positieve indruk die hulpverleners hebben van de Wet Bopz, is toch een aantal kanttekeningen te maken. De Wet Bopz zou teveel voor de psychiatrie geschreven zijn, waardoor enkele begrippen zoals geneesheer-directeur, behandelplan en gevaar niet inpasbaar zijn in de verstandelijk gehandicaptenzorg. In deze paragraaf wordt een aantal kanttekeningen en problemen die specifiek zijn voor de sector verstandelijk gehandicaptenzorg nader toegelicht. Op grond van deze kanttekeningen kan (voorlopig) worden geconcludeerd dat de Wet Bopz 
niet in alle opzichten het juiste juridische kader is voor de toepassing van vrijheidsbeperking in de sector verstandelijk gehandicaptenzorg.

1. Verschillen tussen mensen met een verstandelijke handicap, Vrijheidsbeperking komt bij vrijwel elk niveau van verstandelijke handicap voor: zowel bij cliënten met een (zeer) ernstige verstandelijke handicap als bij cliënten met een matige tot lichte verstandelijke handicap. De achterliggende reden voor de toepassing ervan is gevaar. Bij cliënten met een (zeer) ernstige verstandelijke handicap dient gevaar geïnterpreteerd te worden als gevaar om uit bed te vallen, gevaar om zichzelf te verwonden ${ }^{14}$ en gevaar om uit een stoel te vallen. Vrijheidsbeperkende maatregelen die bij mensen met een verstandelijke handicap met gedragsproblemen worden toegepast zijn van een ander kaliber: er is niet alleen sprake van gevaar voor de cliënt zelf maar er kan ook sprake zijn van gevaar voor anderen en voor goederen. In woningen waar cliënten met ernstige gedragsproblemen verblijven kan het noodzakelijk zijn om hen af te zonderen. Deze maatregel betekent dikwijls een grote inbreuk op de lichamelijke integriteit. Belangrijk is dat in deze situaties rekening wordt gehouden met de criteria effectiviteit, proportionaliteit en subsidiariteit.

2. Noodzaak van handelen. Persoonlijk begeleiders geven aan dat, hoe ingrijpend bepaalde maatregelen ook zijn, het vaak niet anders kan. Zonder de toepassing van deze maatregelen zijn cliënten niet of nauwelijks in de hand te houden. Door het toepassen van beperkingen, als een vaste dagstructuur of regelmatig kamermomenten, ${ }^{15}$ zijn cliënten in staat om redelijk te functioneren. Hun vrijheid wordt als het ware functioneel beperkt met het doel om binnen diens beperkte vrijheid toch nog enige mate van autonomie te hebben. Deze wijze van handelen strookt niet geheel met de uitgangspunten van de Wet Bopz. Deze wet gaat ervan uit dat cliënten zo min mogelijk in hun vrijheid worden beperkt. Vrijheidsbeperkende maatregelen mogen alleen worden opgelegd bij gevaar.

3. Alternatieven. Hoewel persoonlijk begeleiders aangeven dat ze vaak geen andere oplossing kunnen bedenken voor vrijheidsbeperkende maatregelen, zijn diverse situaties denkbaar waarin het anders zou kunnen. Een deel van de vrijheidsbeperkende maatregelen wordt onbewust en routinematig toegepast. Door het onderwerp vrijheidsbeperking bespreekbaar te maken realiseren persoonlijk begeleiders, maar ook vertegenwoordigers, zich dat in

14 Gevaar om zichzelf te verwonden moet evenwel ook weer niet te licht worden opgevat. Automutilatie, zelfverwondend gedrag, kan worden beschouwd als een zeer ernstige gedragsstoornis.

15 Het begrip kamermoment is geen term die in de Wet Bopz wordt genoemd, maar is 'vakjargon'. 
de dagelijkse omgang met cliënten veel beperkingen overbodig zijn. Sommige beperkingen wordt onbewust toegepast en andere zijn al lang niet meer nodig maar worden toch nog steeds toegepast. Factoren als tijdgebrek, tekort aan personeel en ondeskundig personeel spelen ook een rol. Vanwege tijdgebrek krijgen cliënten niet elk moment van de dag voldoende begeleiding. Dat betekent dat ze niet naar buiten kunnen of niet van hun kamer gehaald worden. De praktijk laat zien dat intensieve begeleiding ${ }^{16}$ bij cliënten met ernstige gedragsproblemen een deel van de vrijheidsbeperkende maatregelen kan voorkomen.

4. Goed hulpverlenerschap. In het eindrapport van de tweede evaluatie van de Wet Bopz plaatst de begeleidingscommissie de opmerking dat een operationalisering van het begrip 'de zorg van een goed hulpverlener' noodzakelijk is. ${ }^{17} \mathrm{Ze}$ wijst met name op situaties waarbij de toepassing van maatregelen nodig is om een cliënt te beschermen. Veel van deze middelen of maatregelen worden toegepast onder de vlag van de Wgbo. Daarnaast zijn hulpverleners onvoldoende op de hoogte van de juridische status van cliënten, waardoor ook bij vrijwillig opgenomen cliënten vrijheidsbeperking wordt toegepast. Het rapport laat zien dat hulpverleners niet dagelijks bezig zijn met de regels die in de Wet Bopz staan. Er wordt getracht zo goed mogelijke zorg te leveren. De ene keer zijn daar meer afspraken en beperkingen voor nodig dan de andere keer. De vraag doet zich dan ook voor of het noodzakelijk is om alle vrijheidsbeperkingen onder de Wet Bopz te plaatsen. Een hulpverlener dient zich immers, behalve de Wet Bopz, ook te houden aan de norm van goed hulpverlenerschap op grond van de Wgbo. Pas als sprake is van gevaar komt de Wet Bopz om de hoek kijken. De grens tussen handelen in het kader van de Wet Bopz en handelen in het kader van de Wgbo is zeer moeilijk aan te geven. Uit de interviews komt naar voren dat persoonlijk begeleiders ook spreken in termen van het bieden van bescherming, opvoeden en pedagogisch handelen. Deze termen kent de Wet Bopz niet. Een voorbeeld daarvan is het reguleren van sigaretten of van geld. Dit zijn pedagogische maatregelen, die veelvuldig worden toegepast. De vraag is of deze vrijheidsbeperkende maatregelen onder het regime van de Wet Bopz vallen of dat de toepassing vanuit een ander kader gelegitimeerd kan worden.

5. Vrijwillig opgenomen cliënten. Een aanzienlijk aantal cliënten van instituten voor verstandelijk gehandicaptenzorg is vrijwillig opgenomen. De resultaten van de tweede evaluatie van de Wet Bopz laten zien dat van de 100 in-

16 Onder intensieve begeleiding wordt verstaan 1:1 begeleiding oftewel één begeleider voor één cliënt.

17 Begeleidingscommissie evaluatie Wet Bopz 2002, p. 51. 
stituten die meewerkten aan de evaluatie, in maar liefst $35 \%$ van deze instituten geen Bopz-cliënten verblijven. Daarnaast heeft van de ruim 28.000 cliènten, die in deze 100 instituten wonen, slechts $30 \%$ een Bopz-status. Dit betekent dat Bopz-cliēnten $(30 \%)$ over $65 \%$ van de Bopz-instituten zijn verspreid. De instituten die aangeven geen Bopz-cliënten te hebben, vallen allen onder de Wet Bopz. Ze staan immers op de lijst met Bopz-aanmerkingen." Dit hoge percentage instituten zonder Bopz-cliënten is voor een deel toe te schrijven aan de werkwijze van de indicatiecommissies.

'Als ik een aanvraag de deur uit doe, geef ik de redenen aan waarom ik deze aanvraag tot een indicatie wens. Daarmee bepaal ik of het om een Bopz-indicatie gaat. Het indicatieorgaan bepaalt ook, maar het hangt er wel vanaf wie de indicatie doet. Laatst was er een maatschappelijk werkster die de indicatie moest doen. Deze per. soon wist niet wat de Wet Bopz was' (arts).

Een deel van de huidige populatie is reeds opgenomen voor de invoering van de Wet Bopz. Deze zittende cliënten zijn nog niet allemaal in aanmerking gekomen voor een herindicatie. Sommige instituten zijn nog steeds bezig met een inhaalslag. De indicatiecommissies die verantwoordelijk zijn voor artikel $60 \mathrm{Bopz}$-indicaties hebben een grote achterstand. Andere instituten laten de huidige situatie voortbestaan, waardoor veel cliënten hun vrijwillige status houden. Dat is in strijd met de wet aangezien ook bij deze cliënten vrijheidsbeperkende maatregelen voorkomen. In dit verband dringt zich dan ook de vraag op wat de toegevoegde waarde van een Bopzindicatie is? Volgens de Wet Bopz mogen alleen middelen of maatregelen worden toegepast bij onvrijwillig opgenomen cliënten.

'Externe toetsing vind ik heel belangrijk oftewel dat een onafhankelijk iemand mee kijkt. In de praktijk stelt het echter weinig voor. Als instituut zijnde kun je zelf bepalen wie je aanwijst voor een herindicatie. Wij hebben de cliënten uitgekozen waarbij frequent middelen of maatregelen worden toegepast.' (directeur)

De Inspectie is er voorstander van dat elke cliënt die wordt opgenomen, zonder IBS of RM, via een artikel 60 Bopz wordt geïndiceerd. Met een Bopz-indicatie moeten instituten verantwoording afleggen aan de Inspectie. Een indicatie kan ervoor zorgen dat de werkvloer zich nog meer gaat realiseren waar men mee bezig is en welke inbreuken men makkt op grondrechten van cliënten, aldus de Inspectie. De werkvloer is echter nauwelijks 
op de hoogte van de juridische status van cliënten. Hulpverleners houden bij de toepassing van vrijheidsbeperking weinig tot geen rekening met de juridische status van cliënten.

6. Terminologie van Wet Bopz. Diverse keren wordt door respondenten benadrukt dat een aantal begrippen uit de Wet Bopz niet geschikt is voor de sector verstandelijk gehandicaptenzorg. Veel genoemd wordt de functie van geneesheer-directeur. Op grond van de Wet Bopz is de arts degene die eindverantwoordelijk is voor het gehele Bopz-beleid. Het is ook de arts die dwangbehandeling en noodsituaties moet melden aan de Inspectie. Deze wijze van handelen vloeit voort uit het medische model, waarbij de arts binnen een instituut voor verstandelijk gehandicaptenzorg een vooraanstaande positie innam. De sector verstandelijk gehandicaptenzorg heeft het medische model echter al een aantal decennia achter zich gelaten. Naast de arts heeft de gedragsdeskundige zijn intrede gedaan in deze sector. Geïnterviewden gaven aan dat de functie van een gedragsdeskundige in de Wet Bopz meer gewicht zou moeten krijgen.

Artikel 38 lid 3 Bopz heeft betrekking op het behandelingsplan. Deze term is na de vorige evaluatie gewijzigd in zorgplan. Het doel van het zorgplan is om de geestesstoornis te verbeteren en daardoor het gevaar weg te nemen. Binnen de verstandelijk gehandicaptenzorg is deze doelstelling meestal niet haalbaar. Een cliënt met een verstandelijke handicap ondervindt problemen in het functioneren en is (levenslang) aangewezen op ondersteuning. Wel is het mogelijk dat deze functioneringsproblemen door een adequate ondersteuning in een latere levensfase afnemen. Dit is echter niet mogelijk bij mensen met een (zeer) ernstige verstandelijke handicap.

Het begrip verzet levert ook veel problemen op in de sector verstandelijk gehandicaptenzorg. De resultaten van het onderzoek laten zien dat in instituten dwangbehandeling niet vaak voorkomt. Een mogelijke oorzaak is dat het personeel verzet niet als verzet interpreteert. Persoonlijk begeleiders en artsen geven in interviews aan dat zij verzet van wilsonbekwame cliënten anders interpreteren dan verzet van cliënten met een lichte verstandelijke handicap. Het gevolg hiervan is dat de behandeling die, ondanks het verzet van een cliënt, wordt uitgevoerd niet als dwangbehandeling wordt beschouwd.

7. Middel of maatregel akkoord. Ondanks het feit dat dwangbehandeling en noodsituaties gemeld moeten worden aan de Inspectie, wordt een deel van de middelen of maatregelen buiten het toezicht van de Inspectie toegepast op basis van de constructie middel of maatregel akkoord. Deze vorm van vrijheidsbeperking staat, na toestemming van cliënt en/of vertegenwoordiger, in het zorgplan genoteerd. Geïnterviewden geven aan dat bij de toe passing van deze middelen of maatregelen niet altijd serieus wordt omgegaan met het verzet van de cliënt. Uit het dossieronderzoek en interviews 
blijkt bovendien dat middelen of maatregelen, ook nadat ze niet meer van toepassing zijn, in het zorgplan blijven staan. Deze wijze van handelen leidt ertoe dat de interne rechtspositie van cliënten slechter is dan de Wet Bopz beoogt.

8. Grijs gebied. In het eindrapport van de tweede evaluatie van de Wet Bopz wordt ook de verhouding tussen de Wgbo en Wet Bopz aan de orde gesteld. Aanbeveling 33 luidt: 'de overheid behoort het veld te informeren over de verhouding tussen de Wet Bopz en de Wgbo, alsmede over de mogelijkheden en beperkingen van beide wetten waar het gaat om dwangtoepassing en vrijheidsbeperkende maatregelen'.19 Binnen de verstandelijk gehandicaptenzorg bestaat een grijs gebied, waarbij het onduidelijk is of de Wet Bopz dan wel de Wgbo van toepassing is. Naast middelen of maatregelen in het kader van gevaar worden ook middelen of maatregelen om medische redenen toegepast. $\mathrm{De}$ ze maatregelen zijn eerder onder de Wgbo te plaatsen dan onder de Wet Bopz. Te denken valt aan een bedhek, een helm of een tafelblad. Deze maatregelen worden toegepast op afdelingen die veel overeenkomsten hebben met verpleeghuisachtige settings.

'Sommige middelen of maatregelen zitten tussen de Wet Bopz en de Wgbo in, bijvoorbeeld als je een tafelblad voor een rolstoel doet om te voorkomen dat iemand valt. In zo'n geval is sprake van de Wgbo.' (arts).

9. Belemmerende werking van de Wet Bopz. Vanuit het oogpunt van goed hulpverlenerschap en het bieden van verantwoorde zorg kunnen hulpverleners niet zonder het toepassen van vrijheidsbeperking. Uit interviews met hulpverleners kan worden afgeleid dat vrijheidsbeperking op bepaalde momenten noodzakelijk is, teneinde in een later stadium meer vrijheid voor de cliënt te garanderen. Bepaalde cliënten kunnen niet zonder structuur, andere cliënten moeten tegen zichzelf worden beschermd en weer andere cliënten moeten beperkt worden in hun vrijheid omdat ze een gevaar vormen voor anderen. Reeds eerder is opgemerkt dat de Wet Bopz van een zeer strikt kader uitgaat. Vrijheidsbeperkende maatregelen zijn alleen toegestaan als sprake is van gevaar. In de verstandelijk gehandicaptenzorg kunnen hulpverleners niet altijd uit de voeten met dit, in hun ogen, te beperkte kader. In een eerder aangehaald citaat (paragraaf 6.3.2.1) werd opgemerkt dat naast gevaar, zich nog tal van andere legitieme momenten voordoen om in te grijpen in de vrijheid van cliënten.

19 Begeleidingscommissie evaluatie Wet Bopz 2002, p. 46. 


\subsection{Beschouwing}

In deze beschouwing staat een tweetal vragen centraal. De eerste vraag luidt: In hoeverre wordt in de praktijk van de zorg voor mensen met een verstandelijke handicap ten aanzien van de toepassing van vrijheidsbeperking rekening gehouden met het juridische kader?' Deze vraag valt uiteen in twee subvragen: 'Is de toepassing van vrijheidsbeperking in de praktijk van voldoende waarborgen voorzien?' 'Zijn hulpverleners zich in de praktijk voldoende bewust van het juridische kader of wordt deze genegeerd?' De tweede vraag luidt: 'In hoeverre hangen knelpunten rondom de toepassing van vrijheidsbeperking bij mensen met een verstandelijke handicap samen met de specifieke eigenschappen van de praktijk van de verstandelijk gehandicaptenzorg?'

In hoeverre wordt in de praktijk van de zorg voor mensen met een verstandelijke handicap ten aanzien van de toepassing van vrijheidsbeperking rekening gehouden met het juridische kader?

Wat als eerste opvalt in de resultaten van het praktijkonderzoek is dat hulpverleners op de werkvloer nauwelijks onderscheid maken tussen vrijwillig en onvrijwillig opgenomen cliënten. $\mathrm{Zij}$ geven aan dat ze regelmatig niet op de hoogte zijn van de juridische status van een cliënt. $\mathrm{Zij}$ beschouwen het verschil tussen een Bopz-cliënt en een niet-Bopz-cliënt slechts van administratieve aard. Voor elke cliënt gelden dezelfde zorgvuldigheidseisen en het uitgangspunt is het leveren van kwalitatief goede zorg, ongeacht de status van de cliënt. Het onderzoek laat ook zien dat maar liefst $70 \%$ van alle cliënten vrijwillig in instituten verblijft. Dit betekent dat bij een aanzienlijk aantal cliënten geen vrijheidsbeperkende maatregelen mogen worden toegepast. De praktijk laat een ander beeld zien: middelen of maatregelen worden wel degelijk bij vrijwillig opgenomen cliënten toegepast. Deze groep cliënten valt niet onder het wettelijk regime van de Wet Bopz. Op deze manier ondervinden zij niet de voordelen van de Wet Bopz (klachtrecht, toezicht Inspectie).

De sector verstandelijk gehandicaptenzorg heeft meer dan 10 jaar de tijd gekregen om aan de slag te gaan met de Wet Bopz. Nog altijd staat deze wet bloot aan veel kritiek. Ook orthopedagogische instituten vallen onder de reikwijdte van de Wet Bopz. Toch geven zij aan dat deze wet niet van toepassing is op hun cliënten. In deze setting is het motief voor vrijheidsbeperking niet gevaar maar opvoeden (pedagogisch handelen). Het gevolg is dat de toegepaste middelen of maatregelen, die wel degelijk leiden tot een inbreuk op de vrijheid van cliënten, niet worden beschouwd als vrijheidsbeperking en ook niet worden gemeld bij de Inspectie. Een soortgelijk motief wordt aangevoerd door hulpverleners die werkzaam zijn op afdelingen waar cliënten met een (zeer) ernstige verstandelijke handicap verblijven. Ook op deze afdelingen is het noodzakelijk om vrijheidsbeperkende maatregelen toe te passen. Over het algemeen staan deze maatregelen genoteerd in het zorgplan. Het betreft voornamelijk het fixeren van cliënten 
teneinde te voorkomen dat ze uit hun rolstoel of bed vallen of zichzelf verwonden. Het motief van deze maatregelen is het bieden van bescherming aan cliënten. Volgens veel hulpverleners valt dit handelen niet onder de Wet Bopz. Maar ook hier is sprake van een inbreuk op de vrijheid van cliënten.

Het voorafgaande laat zien dat vrijheidsbeperking in de praktijk veel ruimer wordt toegepast dan de Wet Bopz toelaat. Op grond van deze wet mag de vrijheid van een cliënt alleen worden beperkt als sprake is van gevaar. In de sector verstandelijk gehandicaptenzorg wordt de vrijheid van cliënten niet alleen beperkt op grond van gevaar. Een cliënt die heel hard zit te gillen, kan op een gegeven moment naar zijn kamer worden gestuurd of zelfs voor een bepaalde tijd worden afgezonderd. In dit geval is niet sprake van gevaar in de zin van de Wet Bopz. Bescherming, opvoeden, straffen en belonen vormen redenen om de vrijheid van een cliënt te beperken, waarbij lang niet altijd sprake is van gevaar voor zichzelf of voor anderen. Daarnaast wordt het begrip beperkingen in de bewegingsvrijheid in de praktijk zeer ruim geïnterpreteerd. Aan de hand van de vele voorbeelden die in het kader van deze studie zijn verzameld, kunnen beperkingen worden ingedeeld in beperkingen in vrijheid om een ruimte te verlaten dan wel te betreden, beperkingen om te beschikken over bepaalde voorwerpen, beperkingen in het aangaan van contacten en gestructureerde dagprogramma's en schema's.

Een deel van de beperkingen die in de praktijk voorkomen is beslist noodzakelijk voor de eigen veiligheid van cliënten of voor de veiligheid van anderen. Voor buitenstaanders is het moeilijk in te schatten of al deze beperkingen ook echt noodzakelijk zijn. Vertegenwoordigers vinden het lastig om hierover een oordeel te geven. Cliënten zelf zijn het ook niet altijd eens met de beperkingen die worden opgelegd. Daar komt bij dat veel cliënten niet kunnen verwoorden wat zij van de beperkingen vinden.

Is de toepassing van vrijheidsbeperking in de praktijk voorzien van voldoende waarborgen?

De Wet Bopz kent een aantal waarborgen voor de rechtspositie van mensen met een verstandelijke handicap. Allereerst dient een cliënt kort na opneming in te stemmen met zijn zorgplan. Indien hij daartoe niet in staat is, geeft een vertegenwoordiger toestemming. In dit zorgplan kunnen vrijheidsbeperkende maatregelen worden opgenomen.

Een cliënt behoudt altijd het recht om zich te verzetten tegen het zorgplan. Alleen als sprake is van gevaar mag een hulpverlener het verzet van een cliënt naast zich neerleggen. In alle andere gevallen dient hij verzet van een cliënt te respecteren. De Wgbo kent een soortgelijke regeling, zij het dat onder deze wet verzet van een wilsbekwame patiënt altijd moet worden gehonoreerd.

Uit deze studie lijkt naar voren te komen dat slechts in een enkel geval sprake is van dwangbehandeling. Blijkbaar verzetten cliënten zich vrijwel nooit tegen een 
vrijheidsbeperkende maatregel en zijn vertegenwoordigers het vrijwel altijd eens met de toepassing ervan. Dit is een te voorbarige conclusie. De resultaten laten ook zien dat grote onduidelijkheid bestaat over de begrippen verzet en wilsonbekwaamheid. Hulpverleners hebben moeite met de interpretatie van verzet. Dit geldt met name bij verzet van wilsonbekwame cliënten. Het gevolg is dat veel verzet niet als verzet wordt geïnterpreteerd waardoor niet snel sprake zal zijn van dwangbehandeling. Het merendeel van de maatregelen is vastgelegd in het zorgplan. Persoonlijk begeleiders, artsen maar ook vertegenwoordigers geven aan dat in de meeste gevallen wordt ingestemd met het zorgplan. Slechts een enkele keer komt het voor dat beide partijen niet tot overeenstemming komen. Een andere waarborg is het intern registreren en het melden van middelen of maatregelen en dwangbehandeling bij de Inspectie. Het melden verloopt nog niet zoals de Wet Bopz deze voor ogen heeft. Veel meldingen belanden niet op het bureau van de Inspectie. Daarnaast zijn er nog weinig instituten die een goed intern registratiesysteem hebben opgezet. Dit alles hangt samen met het feit dat hulpverleners zich nog onvoldoende realiseren dat zij vrijheidsbeperkende maatregelen toepassen bij cliënten. Een pedagogische maatregel, een bedhek of een Zweedse band, wordt niet beschouwd als vrijheidsbeperking in de zin van de Wet Bopz. Daarnaast registreren en melden instituten ieder op hun eigen manier. Voor het ene instituut is drie keer fixeren van een cliënt op een dag slechts één melding naar de Inspectie toe. Een ander instituut maakt er drie meldingen van. Toepassingen van vrijheidsbeperking bij vrijwillig opgenomen cliënten hoeven in principe niet te worden gemeld bij de Inspectie. De overheid gaat ervan uit dat vrijheidsbeperking bij deze groep cliënten niet aan de orde is. Dit is echter een verkeerde veronderstelling, aangezien een groot aantal cliënten onterecht vrijwillig verblijft in een instelling. Ook maakt het personeel nauwelijks onderscheid tussen vrijwillig en onvrijwillig opgenomen cliënten. Dit verklaart wellicht waarom sommige instituten ook toepassingen van vrijheidsbeperking bij vrijwillig opgenomen cliënten melden aan de Inspectie.

Het gevolg van dit alles is dat de Inspectie voor de Gezondheidszorg haar taken uitoefent op grond van onvoldoende informatie. De vraag is echter of de Inspectie haar taken, die gericht zijn op individuele rechtsbescherming, moet handhaven naast haar andere taken die betrekking hebben op kwaliteitsbewaking en -bevordering binnen instituten. Uit de empirische gegevens komt naar voren dat instituten niet nauwkeurig melden aan de Inspectie, ook omdat niet duidelijk is wat de Inspectie met de gegevens doet. De rol van de Inspectie moet echter ook niet worden overschat. Het is niet reëel om van de Inspectie te verwachten dat zij elke melding van dwang of toepassing van middelen of maatregelen ook daadwerkelijk toetst. Veel belangrijker is dat de Inspectie zich bezig gaat houden met algemene kwaliteitsbewaking. Deze taak vloeit ook voort uit de Kwaliteitswet zorginstellingen. Elk instituut is verplicht om een kwaliteitssysteem op te zetten. Een niet onbelangrijk onderdeel van het kwaliteitssysteem is het interne 
registratiesysteem. Daarnaast kan de Inspectie steekproefsgewijs cliënten individueel blijven toetsen, waarbij ze waakt voor langdurige toepassingen van dwangbehandeling.

Instituten vertonen zelf op het gebied van kwaliteitssystemen nog te weinig initiatief. Weliswaar verzamelen ze diverse gegevens over cliënten, in de praktijk gebeurt daar nog weinig mee. Het is ook een taak van het management om aan te geven wat ze met de interne registratie wil bereiken. Het registreren van vrijheidsbeperking kan zeer informatief zijn, met name voor het ontwikkelen van gericht beleid. Met een duidelijke visie ten aanzien van vrijheidsbeperking kan gezocht worden naar alternatieven en wordt voorkomen dat instituten zich verschuilen achter een tekort aan personeel of bouwkundige gebreken. Op bepaalde momenten is het echter niet te voorkomen dat vrijheidsbeperking plaatsvindt. De rechter heeft in een uitspraak van 20 januari $1999^{\circ}$ erkend dat bij de toepassing van vrijheidsbeperkende maatregelen ook rekening dient te worden gehouden met de beperkte middelen die een instituut ter beschikking heeft en de daarmee samenhangende tekorten in het personeel. Hopelijk zijn niet nog meer van deze uitspraken te verwachten. De bouw van een voorziening, een tekort aan personeel of ongekwalificeerd personeel mag nooit een reden vormen voor de toepassing van vrijheidsbeperking.

Een belangrijk onderdeel van goed hulpverlenerschap is dat instituten en hulpverleners voortdurend op zoek moeten gaan naar alternatieven voor vrijheidsbeperking. Voorkomen moet worden dat een niet adequaat (be)handelingsaanbod leidt tot langdurige vrijheidsberoving zonder perspectief op verbetering. Nog altijd komt het voor dat cliënten voor een langere periode afgezonderd worden in een kale kamer. De reden van deze afzondering is dat het personeel met de handen in het haar zit en niet weet hoe het anders moet. Aanvragen voor bijzondere zorgplannen worden niet altijd gehonoreerd en mede vanwege te grote groepen en te weinig personeel ontbreekt een alternatief.

Zijn hulpverleners zich in de praktijk voldoende betwust van het juridische kader of wordt deze genegeerd?

De Wet Bopz heeft hulpverleners aan het denken gezet. Hulpverleners gaan bewuster en zorgvuldiger om met vrijheidsbeperking. Het kan echter nog veel beter. In een van de interviews erkende een persoonlijk begeleider dat in de woningen veel meer gebeurt dan bekend is. Hulpverleners zijn zich nog onvoldoende bewust van alle beperkingen die worden opgelegd aan cliënten. In dat kader kunnen hulpverleners twee houdingen aannemen:

20 Rechtbank Maastricht, 20 januari 1999, kBJ 1999, 63. 
1. Hulpverleners realiseren zich dat de rechten van cliënten worden beperkt. $\mathrm{Zij}$ beseffen ook dat dit in een aantal gevallen anders kan. Het ontbreekt echter aan voldoende alternatieven.

2. Hulpverleners realiseren zich niet welke gevolgen hun handelen heeft voor de rechtspositie van mensen met een handicap. Zij zijn van mening dat zij juist handelen.

Hulpverleners van de tweede categorie zijn nog onvoldoende aan het denken gezet door de Wet Bopz. Zij realiseren zich niet dat de vrijheid van cliënten door hun handelen wordt beperkt. Daar komt bij dat persoonlijk begeleiders in deze studie regelmatig de vergelijking maakten met hun eigen thuissituatie. Kinderen moeten zich thuis ook aan allerlei regels en afspraken houden. De verhouding tussen ouders en kinderen is evenwel van een andere orde dan de verhouding tussen persoonlijk begeleiders en cliënten. Het betreft in het laatste geval een professionele verhouding en geen privé-aangelegenheid. Cliënten maken niet vrijwillig de keuze om in een voorziening te gaan wonen, waarbij ze afhankelijk zijn van zeer veel verschillende hulpverleners. Bovendien verlaten kinderen meestal het ouderlijk huis zodra ze volwassen zijn in tegenstelling tot cliënten die over het algemeen hun gehele leven zijn aangewezen op anderen. Deze argumenten pleiten ervoor om vrijheidsbeperkende maatregelen inzichtelijk te maken en, voor zover mogelijk is, tot een minimum te beperken.

Voor hulpverleners van de eerste categorie geldt een ander verhaal. Zij zijn zich (meer) bewust van hun handelen en staan vaker stil bij de gevolgen die dit heeft voor de vrijheid van cliënten. Het ontbreekt echter nog aan alternatieven teneinde het aantal vrijheidsbeperkende maatregelen terug te dringen. Gedacht kan worden aan een vol dagprogramma, meer individuele aandacht, het voorkomen van escalaties door met een cliënt te gaan wandelen, een bijzonder zorgplan en een inventarisatie maken van alle vrijheidsbeperkende maatregelen.

In hoeverre hangen knelpunten rondom de toepassing van vrijheidsbeperking bij mensen met een verstandelijke handicap samen met de specifieke eigenschappen van de praktijk van de verstandelijk gehandicaptenzorg?

Het empirische onderzoek laat zien dat, hoewel deze factoren niet letterlijk zijn genoemd door hulpverleners, een tekort aan personeel, de bouw van de voorzieningen en aandacht en tijd van personeel van invloed zijn op het aantal vrijheidsbeperkende maatregelen dat wordt toegepast in de sector verstandelijk gehandicaptenzorg.

Een deel van deze maatregelen zou niet meer nodig zijn als voorzieningen zodanig worden aangepast dat kleinere groepsruimtes ontstaan en cliënten, die daar prijs op stellen, een eigen kamer toebedeeld krijgen. Veel cliënten moeten nu nog een kamer delen met andere cliënten. Dit heeft niet alleen gevolgen voor hun privacy, maar ook voor het aantal vrijheidsbeperkende maatregelen. Hulp- 
verleners geven aan dat het probleemgedrag van cliënten afneemt, naarmate de groepen kleiner zijn. Daarnaast is de personele bezetting ook van invloed op de toepassing van vrijheidsbeperking. Uit het onderzoek komt naar voren dat het niet eenvoudig is om het aantal vrijheidsbeperkingen terug te dringen, zonder voldoende (gekwalificeerd) personeel.

Het gaat echter te ver om te beweren dat het aantal vrijheidsbeperkende maatregelen geheel afhankelijk is van de factor personeel. Naast de kwantiteit van personeel speelt ook de attitude van het personeel een belangrijke rol. Zolang hulpverleners onvoldoende stil staan bij de maatregelen die zij opleggen, zal het aantal maatregelen niet of nauwelijks afnemen. Alleen in die situaties dat er geen andere oplossing voor handen is en de beperking bovendien een bijdrage levert aan de ontplooiingsmogelijkheden van een cliënt, mag worden ingegrepen in de vrijheid van een cliënt. Vanuit deze gedachtegang worden langdurige toepassingen van vrijheidsbeperkingen, zonder perspectief op verbetering, niet toelaatbaar geacht.

In beperkte mate valt niet te ontkomen aan vrijheidsbeperking. Ieder individu wordt dagelijks geconfronteerd met vrijheidsbeperkende maatregelen. Een reiziger in de trein is gebonden aan bepaalde regels, een gast in een hotel moet zich aan bepaalde voorschriften houden. Tussen het reizen per trein of het verblijf in een hotel en het verblijf in een instituut voor verstandelijk gehandicaptenzorg zit echter wel een belangrijk verschil. Een cliënt met een verstandelijke handicap kiest er over het algemeen niet vrijwillig voor om samen met andere mensen in een huis te gaan wonen. In dat kader is het van belang dat hulpverleners zich voortdurend realiseren welke gevolgen hun handelen heeft voor de rechtspositie van cliënten. Toepassingen van vrijheidsbeperkende maatregelen moeten worden verantwoord ten opzichte van de cliënt en/of zijn vertegenwoordiger en andere hulpverleners. Van belang is dat een positieve bijdrage wordt geleverd aan de rechtspositie van mensen met een verstandelijke handicap. Tot slot mag niet onopgemerkt blijven dat, ondanks de toegenomen kennis over de achtergronden van het gedrag van mensen met een verstandelijke handicap, de kennis van het huidige personeel lang niet altijd toereikend zal zijn om het gedrag van cliënten op een zodanige wijze te kunnen duiden dat passende ondersteuning of begeleiding wordt geboden.

In het volgende hoofdstuk wordt, gebaseerd op de bevindingen van hoofdstuk 5 en 6, een voorstel gedaan voor een alternatieve regeling voor vrijheidsbeperking in de verstandelijk gehandicaptenzorg. In dit voorstel is ook een aantal elementen terug te vinden van het normatief kader, dat in hoofdstuk 3 is uiteengezet. Naast goede zorg ligt de nadruk op (het recht op) ontplooiing: elke toepassing van vrijheidsbeperking dient, voor zover mogelijk is, bij te dragen aan de ontplooiing van de betrokken cliënt. 



\section{Een alternatieve regeling voor vrijheidsbeperking in de verstandelijk gehandicaptenzorg}

\section{$7.1 \quad$ Inleiding}

De beschouwingen van hoofdstuk 5 en 6 bevatten voldoende aanknopingspunten om te veronderstellen dat de primaire doelstelling van de Wet Bopz - het beschermen van de rechtspositie van onvrijwillig opgenomen cliënten - in instituten voor verstandelijk gehandicaptenzorg niet optimaal wordt gerealiseerd. Vrijheidsbeperking is in beginsel alleen mogelijk bij cliënten die onvrijwillig zijn opgenomen in een instituut met een Bopz-aanmerking. De praktijk laat evenwel een ander beeld zien. Vrijheidsbeperking vindt overal plaats, ongeacht de locatie en de juridische status van een cliënt, waardoor de huidige rechtsbescherming van cliënten duidelijk te wensen overlaat.

De Ministers van VWS en Justitie hebben op 5 april 2002 het evaluatierapport Wet Bopz aangeboden aan de Tweede Kamer. In de aanbiedingsbrief deed de toenmalige Minister van VWS de belofte dat het kabinetsstandpunt op korte termijn naar de Tweede Kamer zou worden toegezonden. In het voorjaar van 2004 was deze er nog altijd niet. ${ }^{1}$ Uit de reactie van de Staatssecretaris van VWS op het rapport 'Dementerenden en de Wet Bopz' kan evenwel worden opgemakt dat de bewindslieden voornemens zijn om een ander juridisch kader voor te bereiden voor de sectoren verstandelijk gehandicaptenzorg en psychogeriatrie. ${ }^{23}$ Vlak na het verschijnen van het evaluatierapport heeft de VGN wel haar

1 In antwoorden op kamervragen over het mogelijke gebruik van separeercellen in de geestelijke gezondheidszorg geeft de Staatssecretaris van VWS aan dat 'naar verwachting het kabinetsstandpunt op de resultaten van de tweede evaluatie van de Wet Bopz in april 2004 aan de Ministerraad wordt voorgelegd' (2030406830).

2 Kamerstukken II 2003/03, 28 850, nrs. 1-2, p. 40 (Rapport Dementerenden en de Wet Bopz, Algemene Rekenkamer). De staatssecretaris geeft in haar reactie aan dat 'het lijkt alsof de sector psychogeriatrie, evenals de verstandelijk gehandicaptenzorg, niet goed uit de voeten kan met de begrippen van de wet. Ten aanzien van de aanbeveling om de mogelijkheid en wenselijkheid te onderzoeken van een wettelijk kader dat beter aansluit bij de specifieke kenmerken van beide sectoren (...) zijn de signalen uit de praktijk voldoende helder.'

3 In het voorjaar van 2004 is binnen het Ministerie van VWS een project van start gegaan voor het ontwikkelen van een andere wettelijke regeling voor het opnemen van mensen met een verstandelijke handicap of dementie en het toepassen van vrijheidsbeperking in de zorg voor mensen met een verstandelijke han- 
standpunt kenbaar gemaakt.4 $\mathrm{Zij}$ is voorstander van het afschaffen van een separate Bopz-indicatie voor de groep 'geen bereidheid, geen bezwaar'. Ook beveelt zij aan dat in de verstandelijk gehandicaptenzorg de functie van een onafhankelijke cliëntenvertrouwenspersoon wordt ingevoerd. De VGN heeft verder als haar opvatting kenbaar gemaakt dat zij niet instemt met het ontwerpen van een nieuwe wettelijke regeling. $\mathrm{Zij}$ prefereert het voortbestaan van de huidige Wet Bopz, ook omdat het veld juist gewend is geraakt aan de inhoud van deze wet. Het invoeren van een nieuwe wet zou een tijdrovende kwestie zijn. De implementatie van de Wet Bopz heeft ook een aantal jaren in beslag genomen, aldus de VGN.

In deze studie wordt afstand genomen van de Wet Bopz. Beargumenteerd wordt waarom niet kan worden volstaan met slechts enkele aanpassingen van deze wet. De voorkeur gaat uit naar een alternatieve regeling voor de Wet Bopz in de verstandelijk gehandicaptenzorg. ${ }^{5}$ In de afgelopen jaren zijn diverse publicaties verschenen over de werking van de Wet Bopz in deze sector. De algemene lijn daarin is dat de huidige Wet Bopz geen geschikt juridisch kader is voor deze sector. De begeleidingscommissie van de tweede evaluatie van de Wet Bopz concludeert dat 'acht jaren ervaring met de Wet Bopz uitwijst, dat de rechtsbescherming die de wet de gbgb-groep beoogt te bieden, niet of maar in zeer beperkte mate wordt gerealiseerd. (...) De begeleidingscommissie verwacht niet dat in deze sectoren een zodanige aanpassing kan worden gerealiseerd dat wet en praktijk veel dichter bij elkaar komen te liggen. (...) Naarmate een wettelijke regeling verder weg ligt van de opvattingen, de ervaringen en het ethisch besef van de hulpverleners die de regeling moeten toepassen, nemen de kansen op een succesvolle implementatie van de regeling af." Ook Blankman komt in zijn preadvies voor de Vereniging voor Gezondheidsrecht over 'de rechtsbescherming bij vrijheidsbeneming in de sectoren verstandelijk gehandicaptenzorg en psychogeriatrie' tot het oordeel dat de uitgangspunten van de Wet Bopz als juist worden ervaren, maar dat de uitwerking ervan niet landt in

dicap en psychogeriatrie. De uitkomsten van dit project kunnen uitmonden in een wetsvoorstel of leiden tot aanpassingen van het bestaande juridische kader (de Wet Bopz).

5 Deze alternatieve regeling is overigens ook bedoeld voor de sector psychogeriatrie. Samen met mr. L. Arends is het initiatief ontstaan om, mede naar aanleiding van de tweede evaluatie van de Wet Bopz, een voorzet te geven voor een alternatieve regeling voor de sectoren verstandelijk gehandicaptenzorg en psychogeriatrie. In deze studie wordt de sector psychogeriatrie buiten beschouwing gelaten. Deze sector komt aan bod in het proefschrift van Arends over de rechtspositie van de psychogeriatrische patiënt dat eind 2004 zal verschijnen. Begeleidingscommissie evaluatie Wet Bopz 2002, p. 50. 
de praktijk.' Hij schetst in zijn preadvies de contouren van een andere rechtsbeschermingsregeling. Ter motivering verwijst Blankman naar de resultaten van de tweede evaluatie van de Wet Bopz.

\subsection{De noodzaak van een alternatieve regeling}

In deze studie is al diverse keren betoogd dat de Wet Bopz niet de beoogde rechtsbescherming biedt aan cliënten in instituten met een Bopz-aanmerking. Op het eerste gezicht lijkt de oorzaak te liggen bij de juridische status van cliënten in de verstandelijk gehandicaptenzorg. Slechts een klein deel van de opgenomen diènten heeft een Bopz-indicatie en is dus onvrijwillig opgenomen. De overige diënten (ongeveer 70\%) verblijven 'vrijwillig' in een instituut met een Bopzaanmerking. ${ }^{8}$ Een groot deel van deze cliẽnten heeft geen Bopz-indicatie," Instituten laten na om voor deze groep een Bopz-indicatie aan te vragen, ook omdat onduidelijkheden bestaan over de interpretatie van 'geen bereidheid, geen bezwaar'. Arends geeft aan dat daarmee de rechtspositie van vrijwillig opgenomen diềnten wordt uitgehold, omdat de extra bescherming van de Wet Bopz op hen niet van toepassing is. ${ }^{10}$

Een vrijwillig opgenomen cliënt stemt vrijwel nooit in met de toepassing van vrijheidsbeperking. Als een hulpverlener op een bepaald moment toch besluit om vrijheidsbeperking toe te passen kan de rechtsbescherming, die de Wet Bopz alleen aan onvrijwillig opgenomen cliënten biedt, slechts worden geboden via een Bopz-indicatie." De rechtspraak laat geen eenduidige lijn zien terzake van de toepassing van vrijheidsbeperking bij vrijwillig opgenomen cliënten. Niet in alle gevallen hoeft de juridische status te worden gewijzigd in een onvrijwillige opneming. De Rechtbank Alkmaar stelt: '(...) De leemte kan niet worden opgevuld door de ingrijpende en veelal langdurige maatregel van de voorlopige machtiging toe te passen. Het is aan de wetgever om de interne rechtspositie in gevallen als deze te verbete-

7 Blankman 2003, p. 78.

8 Arends, Blankman en Frederiks 2002, p. 89-90.

9 Na de invoering van de Wet Bopz in 1994 moesten veel cliënten geherindiceerd worden. Zij waren voor de komst voor de Wet Bopz vrijwillig in een instituut opgenomen. Na 1994 kwam een gedeelte van deze groep cliënten in aanmerking voor een Bopz-indicatie. Veel instituten hebben deze 'inhaalslag' (nog altijd) niet uitgevoerd.

10 L.A.P. Arends, "De interne rechtspositie van psychogeriatrische patiènten in verpleeg- en verzorgingshuizen", Tijdschrift voor Gerontologie en Geriatrie (34) 2003-2, p. 71.

11 Als een cliënt zich niet alleen verzet tegen de toepassing van vrijheidsbeperking, maar ook tegen zijn verblijf dient een voorlopige machtiging te worden aangevraagd. 
ren. ${ }^{72}$ Een arrest van de Hoge Raad van 2 november $2001^{13}$ schept meer duidelijkheid over de toepassing van vrijheidsbeperking bij vrijwillig opgenomen cliënten. De strekking van dit arrest is dat dwangbehandeling in een Bopzlocatie de rechtsbescherming verdient van de Wet Bopz. Toch wordt ook enige ruimte opengelaten voor eigen interpretatie: een gedwongen behandeling is ten aanzien van vrijwillig opgenomen cliënten in een Bopz-locatie 'in beginsel' niet mogelijk, aldus de conclusie van de Advocaat-generaal Langemeijer. ${ }^{14}$

Het kunstmatige onderscheid in de praktijk tussen onvrijwillig en vrijwillig opgenomen cliënten vormt niet de enige reden om te kiezen voor een alternatieve regeling. De praktijk laat ook zien dat de waarborgen die de Wet Bopz biedt aan onvrijwillig opgenomen cliënten door hulpverleners niet altijd zorgvuldig worden toegepast. Het gaat om het registreren en melden van vrijheidsbeperking, de termijnen van dwangbehandeling en middelen of maatregelen, de motieven voor de toepassing van vrijheidsbeperking, de toegankelijkheid van de Bopzklachtencommissie en de interpretatie van verzet en wilsonbekwaamheid. Een aantal van deze punten hangt samen met het gegeven dat de Wet Bopz oorspronkelijk is geschreven voor de psychiatrie.

Een ander punt van kritiek is dat de Wet Bopz alleen van toepassing is op de intramurale zorg. Aangetoond is dat ook buiten instituten vrijheidsbeperking wordt toegepast: ${ }^{15}$ in een gvt, in een thuissituatie en in een dagverblijt. Dit betekent dat op dit moment de plaats van verblijf bepalend is voor de mate van rechtsbescherming. Gezien de huidige ontwikkelingen - PGB, modernisering AWBZ en deconcentratie - gaan in de nabije toekomst steeds meer cliënten buiten een instituut wonen. De Wet Bopz houdt vooralsnog geen rekening met deze veranderingen.

Niet alle genoemde knelpunten zijn specifiek voor de verstandelijk gehandicaptenzorg. De eerder genoemde tekortkomingen zijn echter van dien aard dat een nieuwe regeling voor deze sector gerechtvaardigd is. De begeleidingscommissie van de tweede Bopz-evaluatie pleit niet voor een nieuwe regeling. $\mathrm{Zij}$ stelt voor om de groep cliënten, die noch bereidheid noch verzet toont tegen opneming in een instituut, de zogenaamde gbgb-groep, onder te brengen in de Wgbo. ${ }^{16}$ Los

12 Rechtbank Alkmaar 22 januari 1998, kBJ 1998, 43, m.nt. W. Dijkers.

13 HR 2 november 2001, BJ 2002, 1, m.nt. T.P.J.C. Widdershoven.

14 Langemeijer verwijst daarbij naar de Wgbo: artikel 7:450, 7:465 en 7:466 BW.

15 Zie hoofdstuk 6 (Vrijheidsbeperking in de praktijk) van dit boek; IGZ, 1997; Wesseling, 1996; Noordelijk Centrum voor Gezondheidsvraagstukken 1997; Arends en Dursun 2004 (nog niet gepubliceerd).

16 De mening van de begeleidingscommissie wijkt op dit punt af van de conclusies die in deelrapport drie worden gepresenteerd (Begeleidingscommissie evaluatie Wet Bopz 2002, p. 35 en p. 50-52). 
van de vraag of de Wgbo voldoende rechtsbescherming biedt aan cliënten, die niet goed in staat zijn om hun eigen belangen te behartigen, blijven instituten in het voorstel van de begeleidingscommissie te maken hebben met verschillende wettelijke kaders. Het voorstel leidt tot een driedeling: cliënten die zich verzetten tegen opneming vallen onder de Wet Bopz, gbgb-cliënten vallen onder een soort Wgbo-plus ${ }^{17}$ en vrijwillig opgenomen cliènten vallen onder de Wgbo.

Bovendien is de Wgbo niet geschikt voor de toepassing van vrijheidsbeperking. Bepaalde vormen van vrijheidsbeperking vallen binnen het bereik van artikel 5 Evrm en vereisen een rechterlijke toetsing. De Wgbo is met name bedoeld voor somatische verrichtingen die de hulpverlener en de cliënt en/of vertegenwoordiger in onderling overleg zijn overeengekomen. De toepassing van vrijheidsbeperking is van een ander kaliber dan het verrichten van een lichamelijk onderzoek, het ondergaan van een operatie of een jaarlijkse controle bij de tandarts. Toepassing van vrijheidsbeperking onder de Wgbo impliceert ook een zekere mate van vrijwilligheid. Als een cliënt (onder het regime van de Wgbo) besluit om het instituut te verlaten, mag de hulpverlener hem niet tegenhouden. ${ }^{10}$

De conclusie is dat de Wet Bopz niet de gewenste (interne) rechtsbescherming biedt aan cliënten in de verstandelijk gehandicaptenzorg. Daarbij zijn de volgende overwegingen van belang:

1. De Wet Bopz benadrukt de externe rechtspositie van cliënten. ${ }^{19}$ Zodra een cliënt is opgenomen, komt er geen rechter of indicatiecommissie meer aan te pas. Een onvrijwillig opgenomen cliënt heeft wel de mogelijkheid om op grond van artikel 41 Bopz lid 1 een klacht in te dienen maar in de praktijk wordt van deze mogelijkheid nauwelijks gebruik gemaakt. De toepassing van vrijheidsbeperking kan, in tegenstelling tot de opname van cliënten, behoorlijk ingrijpend zijn. Eerder werd al opgemerkt dat de gemiddelde

17 De begeleidingscommissie stelt voor om de gbgb-groep uit de Bopz te halen. Dit mag er niet toe leiden dat deze cliënten rechtspositioneel 'vogelvrij' worden. Een aantal voorwaarden moet in acht worden genomen waaronder een regeling voor de objectieve vaststelling van de (wils)onbekwaamheid, een regeling op grond waarvan een vertegenwoordiger van de cliënt uit de gbgb-groep instemt met de opneming en een operationalisering van verzet (Begeleidingscommissie evaluatie Wet Bopz 2002, p. 51).

18 Dit geldt overigens ook voor een cliënt met een Bopz-indicatie: als hij aangeeft dat hij weg wil, kan niemand hem tegenhouden. De enige oplossing is het aanvragen van een rechterlijke machtiging.

19 De Wet Bopz wordt ook wel een 'opnamewet' genoemd. 
duur van dwangbehandeling in de verstandelijk gehandicaptenzorg 627 dagen bedraagt. ${ }^{20}$

2. Uit de wettelijke systematiek volgt dat bij vrijwillig opgenomen cliënten geen vrijheidsbeperkende maatregelen mogen worden toegepast. Pas als vrijwillig opgenomen cliënten een Bopz-indicatie of een voorlopige machtiging (als zij zich ook verzetten tegen het verblijf) hebben mag overgegaan worden tot de toepassing van vrijheidsbeperking. Deze studie illustreert echter dat vrijheidsbeperking veelvuldig voorkomt bij cliënten die vrijwillig zijn opgenomen. De wijze van handelen die de Wet Bopz en in beginsel ook de Hoge Raad ${ }^{21}$ voorschrijven - vrijheidsbeperking is pas mogelijk nadat een cliënt in het bezit is van de juiste juridische status - is omslachtig.

3. Aangezien vrijheidsbeperking bij vrijwillig opgenomen cliënten niet onder de reikwijdte van de Wet Bopz valt, kunnen deze cliënten ook geen aanspraak maken op de waarborgen die de Wet Bopz biedt.

4. In de verstandelijk gehandicaptenzorg komt het veelvuldig voor dat vrijheidsbeperkende maatregelen, met toestemming van de cliënt en/of vertegenwoordiger, (structureel) worden opgenomen in het zorgplan. ${ }^{22} \mathrm{Op}$ grond van de Wet Bopz mogen vrijheidsbeperkende maatregelen alleen in het zorgplan worden opgenomen als ze een therapeutisch doel hebben in de zin van het wegnemen van de stoornis. ${ }^{23}$ In de zorg aan mensen met een verstandelijke handicap is deze doelstelling niet haalbaar. De wetgever komt in de nota van toelichting behorende bij het Besluit rechtspositieregelen Bopz tot dezelfde conclusie 'als het gaat om verstandelijk gehandicapten (...) zal van verbetering van de stoornis slechts in die zin sprake kunnen zijn dat het gaat om het creëren van een omgeving waarin de stoornis zich (...) op een zodanig niveau stabiliseert dat het gevaar wordt weggenomen. Het gaat immers veelal om mensen met onherstelbare ontwikkelingsgebreken of chronische ziektebeelden'. ${ }^{24}$

5. De waarborgen die de Wet Bopz biedt aan onvrijwillig opgenomen cliënten zijn niet van toepassing op vrijheidsbeperkende maatregelen die in het zorgplan zijn vastgelegd. De Inspectie hoeft niet op de hoogte te worden

20 Zie hoofdstuk 5, paragraaf 5.4: de verschillende vormen van vrijheidsbeperking.

21 HR 2 november 2001, BJ 2002, 1, m.nt. T.P.J.C. Widdershoven.

22 Voorbeeld 1: elke dag wordt cliënt vastgebonden met een Zweedse band. Cliënt en of vertegenwoordiger zijn akkoord.

Voorbeeld 2: in het zorgplan is afgesproken dat cliënt wordt afgezonderd zodra hij moeilijk gedrag gaat vertonen. Cliënt verzet zich niet tegen de toepassing van de maatregel.

23 Artikel 38 lid 3 Bopz.

24 Nota van toelichting bij het Besluit van 3 november 1993, Stb. 561, p. 3. 
gebracht, noch hoeven deze toepassingen intern geregistreerd te worden. In de Wet Bopz is slechts de eis opgenomen dat het zorgplan elke maand wordt geèvalueerd om te voorkomen dat vrijheidsbeperkende maatregelen met instemming van de cliënt en/of vertegenwoordiger in het zorgplan blijven staan, ook nadat ze niet meer nodig zijn. ${ }^{25}$

6. Ondanks toestemming van de cliënt en/of vertegenwoordiger behoudt een cliënt het recht om zich te verzetten tegen de toepassing van (een deel van) het zorgplan. In de praktijk wordt verzet zelden geconstateerd door hulpverleners. $\mathrm{Zij}$ achten de uitleg van de wetgever, dat iedere vorm van verzet als verzet dient te worden beschouwd, in de praktijk niet haalbaar en ook niet reëel. In het negeren van verzet schuilt het gevaar dat niet voldaan hoeft te worden aan de waarborgen die in de Wet Bopz zijn neergelegd. Het begrip verzet dient nader te worden geoperationaliseerd, waarbij rekening wordt gehouden met de specifieke kenmerken van de sector verstandelijk gehandicaptenzorg.

7. Behalve over verzet bestaat ook - nog steeds - onduidelijkheid over wilsonbekwaamheid. Dit begrip vervult naast verzet een cruciale rol in de Wet Bopz. Is een cliënt in staat om toestemming te geven voor zijn zorgplan, waar vrijheidsbeperkende maatregelen in zijn opgenomen? Het ontbreekt echter nog steeds aan duidelijke criteria voor wilsonbekwaamheid. ${ }^{26}$

8. Onder de Wgbo is het ook mogelijk om in het kader van dwangbehandeling vrijheidsbeperking toe te passen. Hulpverleners worstelen in de praktijk met de vraag welke vormen van vrijheidsbeperking in dat geval mogelijk zijn. Herhaaldelijk worden maatregelen genomen die gericht zijn op het behandelen van somatische aandoeningen, maar die naar hun aard toch vrijheidsbeperkend zijn. ${ }^{2}$ Deze vormen van vrijheidsbeperking vallen bui-

25 Als afspraken over de toepassing van een middel of maatregel in het zorgplan blijven staan, ook als de toepassing niet meer aan de orde is, wordt alvast ingespeeld op toekomstige situaties. Als de toepassing toch weer noodzakelijk blijkt te zijn kan de maatregel direct worden toegepast. Dit wordt anders als de cliënt en/of vertegenwoordiger verzet tonen. In dat geval wordt voorkomen dat sprake is van een noodmaatregel. De toepassing is immers in het zorgplan vastgelegd.

26 De vraag is echter of het haalbaar is om zowel voor verzet als wilsonbekwaamheid inhoudelijke criteria op te stellen. Voor een groot deel behoort het ontwikkelen van dergelijke criteria tot de verantwoordelijkheid van de verschillende beroepsgroepen die werkzaam zijn in de zorg voor mensen met een verstandelijke handicap.

27 Enkele voorbeelden: om een oogwond goed te laten genezen worden de armen van een cliënt gefixeerd, een cliënt krijgt premedicatie als hij naar de tandarts 
ten het toezicht van de Inspectie. Vooralsnog is ten aanzien van dergelijke behandelingen toestemming van de cliënt en/of zijn vertegenwoordiger vereist. ${ }^{28}$

9. Vrijheidsbeperking komt niet meer alleen binnen de muren van een intramurale setting voor. De ondersteuning aan cliënten met een verstandelijke handicap verschuift steeds meer naar buiten de muren van de instituten. De Wet Bopz is onvoldoende toegesneden op deze nieuwe ontwikkelingen in de zorg en kan ook niet zozeer worden opgerekt dat zij ook extramuraal van toepassing zal zijn.

10. Hulpverleners zijn op grond van de Wet Bopz verplicht om dwangbehandeling en de toepassing van middelen of maatregelen te melden bij de Inspectie. De gegevens van dit onderzoek en ook het Bopzis-registratiesysteem illustreren dat sprake is van onderrapportage. Van het aantal toepassingen in noodsituaties wordt slechts een zeer laag percentage aan de Inspectie gemeld. Op deze manier blijft het ook voor de Inspectie onduidelijk hoe vaak en hoe lang middelen of maatregelen daadwerkelijk worden toegepast.

\subsection{Uitgangspunten alternatieve regeling}

Het voorstel 'alternatieve regelgeving voor vrijheidsbeperking in de verstandelijk ge. handicaptenzorg ${ }^{29}{ }^{30}$ gaat uit van de gedachte dat een wettelijke regeling die de toepassing van vrijheidsbeperking in de verstandelijk gehandicaptenzorg reguleert niet alleen het accent dient te leggen op het zelfbeschikkingsrecht, zoals in de Wet Bopz het geval is, maar ook de relatie met andere beginselen tot uitdrukking moet brengen. Daarbij zijn twee beginselen met name van belang, te weten goede zorg en rechtsbescherming.

gaat of een cliënt met epilepsie wordt in een rolstoel vastgezet om te voorkomen dat hij valt.

28 Nota van toelichting bij het Besluit van 3 november 1993, Stb. 561, p. 3-4.

29 Het voorstel in dit proefschrift is een bewerking van de 'alternatieve regelgeving voor de Wet Bopz in de psychogeriatrie en verstandelijk gehandicaptenzorg: een Wet verantwoorde toepassing vrijheidsrechten?', dat is geschreven door mr. L.A.P. Arends en mw. mr. drs. B.J.M. Frederiks en op een invitational conference, d.d. 20 november 2002 , in Utrecht is voorgelegd aan deskundigen uit het veld van de psychogeriatrie en verstandelijk gehandicaptenzorg.

30 L.A.P. Arends en B.J.M. Frederiks, Hersenschimmen? Een beschoutving over de noodzaak van nieuwe wetgeving naar aanleiding van de tweede Wet Bopz-evaluatie interne rechtspositie van psychogeriatrische patiënten en verstandelijk gehandicapten, Tijdschrift voor gezondheidsrecht (27) 2003-2, p. 80-92. 


\section{Goede zorg}

In de Wet Bopz wordt te eenzijdig de nadruk gelegd op het zelfbeschikkingsrecht. Hulpverleners mogen alleen ingrijpen als sprake is van gevaar. In de verstandelijk gehandicaptenzorg zijn cliënten echter minder in staat om hun zelfbeschikkingsrecht uit te oefenen." Voor de ontplooiing van deze cliênten zou het beter zijn als de hulpverlener een ondersteunende rol vervult, wat ook kan betekenen dat hij ingrijpt in de vrijheid van een cliënt. Een mogelijke oplossing is om het zelfbeschikkingsrecht meer te relateren aan andere (rechts)beginselen, waaronder goede zorg.

Het beginsel van goede zorg heeft de afgelopen jaren aan gezag gewonnen, als reactie en in aanvulling op de zelfbeschikkingsdoctrine. Goede zorg is gericht op het zoveel mogelijk versterken van de zelfbeschikking of autonomie van de cliênt. In hoofdstuk 3 is echter ook aan de orde gesteld dat het een utopie is om te veronderstellen dat cliënten met behulp van ondersteuning in de nabije toekomst geheel zelfstandig kunnen gaan functioneren. Op een enkele uitzondering na, zullen veel cliënten altijd afhankelijk zijn van anderen. Dit betekent dat goede zorg in de verstandelijk gehandicaptenzorg eerder gericht is op het bevorderen van de ontplooiing van cliënten dan het realiseren van zelfbeschikking. De nadruk ligt daarbij op steun van de omgeving en interactie met de cliënt. ${ }^{3}$ Hulpverleners dienen cliënten actief te ondersteunen bij het maken van keuzes waarmee ze zich kunnen identificeren en die in hun leven betekenisvol zijn. ${ }^{33}$ Binnen deze context dienen interventies te worden uitgevoerd in het belang van de cliënt om de autonomie te versterken, in plaats van deze te bedreigen. ${ }^{34}$ Dat kan in de eerste plaats gebeuren door de cliënt zoveel mogelijk te begeleiden en te ondersteunen. Daarnaast kan het ook betekenen dat ingrijpen tegen de wil van de cliënt, of zonder dat deze zich heeft kunnen uitspreken, geboden is. ${ }^{35}$ In dit kader vormen vrijheidsbeperkende maatregelen ook een onderdeel van goede zorg. Deze maatregelen kunnen een bijdrage leveren aan het herstellen of vergroten van de autonomie van de cliënt. ${ }^{36}$ In diverse patiëntenwetten wordt verwezen naar goede zorg. In artikel 7:453 BW is bepaald dat de hulpverlener de

\footnotetext{
31 Zie ook paragraaf 3.3.2 van dit proefschrift.

32 Schuurman 2003, p. 78.

33 Widdershoven, Berghmans en Welie 2003, p. 325-338.

34 M. Verkerk, "A care perspective on coercion and autonomy", Bioethics (13) 1999. 3/4, p. 358-368.

35 Widdershoven, Berghmans en Welie 2003, p. 329.

36 M.H.N. Schermer, "Drang en informele dwang in de zorg", in: Centrum voor ethiek en gezondheid. Signalering Ethiek en Gezondheid. Raad voor de Volksgezondheid en Zorg, Zoetermeer 2003, p. 42-43.
} 
zorg van een goed hulpverlener in acht moet nemen. Ook artikel $2 \mathrm{Kwz}$ en artikel 40 lid 1 Wet big geven invulling aan goede zorg.

\section{Rechtsbescherming}

In de verstandelijk gehandicaptenzorg gaat het doorgaans om cliënten die niet of minder goed in staat zijn om hun eigen belangen te behartigen. Regelgeving dient daarom goede zorg te bevorderen, maar moet daarnaast ook voldoende rechtsbescherming bieden. Onder rechtsbescherming wordt in dit verband verstaan een nauwkeurige omschrijving van rechten van mensen met een verstandelijke handicap en procedures om deze rechten tot gelding te brengen. Hieronder wordt ook verstaan dat inzichtelijk wordt gemaakt onder welke omstandigheden een inbreuk mag of in het kader van goede zorg zelfs moet worden gemaakt. Het is echter niet mogelijk om alles wettelijk vast te leggen.

Een kenmerk van de alternatieve regeling is dat meer verantwoordelijkheden worden gelegd bij de werkvloer waardoor een persoonlijk begeleider de ruimte krijgt om goede zorg te bieden aan cliënten. Een onderdeel van goede zorg is de toepassing van vrijheidsbeperking. Om te waarborgen dat persoonlijk begeleiders op de juiste wijze omgaan met de ruimte die hen wordt geboden is het van belang dat zij zich bewust zijn van hun handelen en deze achteraf kunnen verantwoorden. Deze werkwijze vloeit ook voort uit het principe van goed hulpverlenerschap. In dat kader is het van belang dat situaties, waarin vrijheidsbeperking aan de orde is, zichtbaar en toetsbaar zijn. Vrijheidsbeperkingen kunnen allereerst in het zorgplan worden vastgelegd. Daarnaast biedt een intern kwaliteitssysteem mogelijkheden om toezicht te houden op vrijheidsbeperking. Elke toepassing van vrijheidsbeperking dient te worden gemeld bij de interne toetsingscommissie vrijheidsbeperking. Tot slot is van belang dat er een mogelijkheid is om het recht te handhaven op het moment dat rechten geschonden zijn. Bij al deze punten dient rekening te worden gehouden met het feit dat cliënten met een verstandelijke handicap veelal niet of nauwelijks in staat zijn om zelf te ageren indien een inbreuk op hun rechten wordt gemaakt. De introductie van de functie cliëntenvertrouwenspersoon is in dit kader zeer wenselijk. Onderzoek laat zien dat onder cliënten (en ook vertegenwoordigers) onduidelijkheid bestaat over de mogelijkheden die er zijn om te klagen. ${ }^{37}$ Een cliëntenvertrouwenspersoon kan cliënten wijzen op de verschillende mogelijkheden die het recht biedt om een klacht in te dienen en waar nodig kunnen zij ook steun bieden aan cliënten. Haag: ZonMw 2002, p. 8-9. 
De inhoud van de volgende paragraaf (7.4) beperkt zich tot een uiteenzetting van de uitgangspunten van een alternatieve regeling voor de toepassing van vripheidsbeperking in de verstandelijk gehandicaptenzorg. De gedachte is dat eerst consensus dient te bestaan over de contouren van een nieuwe regeling, alvorens overgaan kan worden tot het in detail uitwerken van de regeling.

\subsection{Inhoud alternatieve regeling}

\section{Toepassing van vrijheidsbeperking (VB)}

Twee uitgangspunten: 'goede zorg en rechtsbescherming'

De kem van de alternatieve regeling:

1. Het onderscheid tussen vrijwillig en onvrijwillig opgenomen cliënten vervalt. Dit betekent dat vrijheidsbeperking in beginsel bij elke cliènt mogelijk is. Een opneming in een voorziening is een bijzondere vorm van vrijheidsbeperking. Hiermee vervalt ook het onderscheid tussen de interne en exteme rechtspositie.

2. Het begrip vrijheidsbeperking wordt verruimd: pedagogische maatregelen, beperkingen in de bewegingsvrijheid, beschermende maatregelen en middelen of maatregelen vallen onder dit begrip. De intentie van de maatregel is niet langer bepalend. Het gaat om de gevolgen van een maatregel: alle maatregelen die de vrijheid van cliënten beperken, vallen onder de regeling.

3. Het locatiegebonden karakter vervalt: vrijheidsbeperking kan in beginsel overal plaatsvinden. Bij AMvB kan worden bepaald op welke plaatsen vrijheidsbeperking niet mogelijk is en aan welke vereisten voldaan moet zijn om vrijheidsbeperking te mogen toepassen.

De inhoud van de alternatieve regeling voor een verantwoorde toepassing van vrijheidsbeperking in de verstandelijk gehandicaptenzorg wijkt op een aantal essentiële punten af van de huidige regeling (de Wet Bopz). Alleen op deze manier kan worden tegemoet gekomen aan de bezwaren die genoemd zijn in paragraaf 7.2. Een belangrijk verschil met de huidige regeling is dat het onderscheid tussen de externe en interne rechtspositie komt te vervallen. Ook wordt uitgegaan van een ruimer criterium, waardoor ook pedagogische maatregelen en beschermende maatregelen onder de alternatieve regeling vallen. De toepassing van vrijheidsbeperking is niet meer afhankelijk van de juridische status van een cliënt, de plaats waar hij verblijft of de reden van toepassing. Elke toepassing van vrijheidsbeperking moet voldoen aan dezelfde voorwaarde: noodzaak. Daarbij is het niet van belang of de cliënt onvrijwillig is opgenomen of dat hij zelfstandig en vrijwillig in een flat woont of in een instituut verblijft.

In de alternatieve regeling wordt een onderscheid gemaakt tussen materiële en procedurele normen. Materiële normen hebben betrekking op de inhoudelijke crite- 
ria voor vrijheidsbeperking. In de alternatieve regeling wordt niet meer gesproken over gevaar dat wordt veroorzaakt door een geestesstoornis, maar over de noodzaak van vrijheidsbeperking: 'Een vrijheidsbeperking vindt niet plaats, dan nadat de noodzaak van de toepassing ervan is vastgesteld'. Onder noodzaak wordt ook verstaan of een toepassing van vrijheidsbeperking voldoet aan de eisen van subsidiariteit, proportionaliteit en effectiviteit.

De Wet Bopz bevat diverse andere materiële normen, die bewust niet nader zijn uitgewerkt door de wetgever. Het veld heeft de afgelopen jaren de gelegenheid gekregen om begrippen als wilsonbekwaamheid, verzet en gevaar nader in te vullen. Het begrip gevaar is de afgelopen jaren door de jurisprudentie behoorlijk uitgekristalliseerd. Dit geldt echter niet voor een begrip als wilsonbekwaamheid. In de alternatieve regeling krijgt de regionale toetsingscommissie vrijheidsbeperking een rol in deze. Een cliënt, eventueel bijgestaan door een cliëntenvertrouwenspersoon, kan zich tot deze commissie wenden als hij zich verzet tegen opneming, beschouwd als een bijzondere vorm van vrijheidsbeperking, en de toepassing van vrijheidsbeperking. De regionale toetsingscommissie vrijheidsbeperking heeft als taak om te beoordelen of de toepassing van vrijheidsbeperking voldoet aan de zorgvuldigheidseisen. Eén van deze eisen is of 'de hulpverlener de overtuiging heeft dat de betrokken cliënt wilsonbekwaam is'. Indien de cliënt alsnog wilsbekwaam wordt verklaard, mag de toepassing van vrijheidsbeperking niet tegen zijn wil worden toegepast.

Ook beoordeelt de commissie op grond van meldingsformulieren, die door de interne toetsingscommissie vrijheidsbeperking worden doorgestuurd, dan wel op individueel verzoek of de toepassingen van (ernstige vormen van) vrijheidsbeperking voldoen aan een aantal zorgvuldigheidseisen (zie verder paragraaf 7.4.2). Door middel van deze externe toetsing wordt meer inzicht verkregen in vrijheidsbeperking en wordt systematisch aandacht besteed aan het beleid rond vrijheidsbeperking. Daarnaast behoudt de wetgever de mogelijkheid om door middel van een $\mathrm{AMvB}$ het initiatief te nemen om normen te ontwikkelen, indien het veld of de toetsingscommissie dit nalaat.

De procedurele normen hebben betrekking op de besluitvorming ten aanzien van de toepassing van vrijheidsbeperking. In de alternatieve regeling wordt, anders dan in de Wet Bopz, niet alleen aan de verantwoordelijkheden van de arts aandacht besteed maar ook aan de verantwoordelijkheden van de gedragsdeskundige. Andere procedurele normen zijn op welke wijze de voortgang van de toepassing van vrijheidsbeperking wordt getoetst en ook kenbaar wordt gemaakt aan de cliënt, zijn vertegenwoordiger en de Inspectie. In de Wet Bopz is niets bepaald over de maximale duur van dwangbehandeling. De alternatieve regeling stelt als procedurele norm dat elke dwangbehandeling die langer dan een jaar duurt moet worden getoetst door de regionoale toetsingscommissie. De Wet Bopz schrijft ook geen second opinion voor. In de alternatieve regeling moet de hulpverlener, als de vertegenwoordiger van een wilsonbekwame cliënt niet in- 
stemt met de toepassing van vrijheidsbeperking of afwezig is, een second opinion vragen aan een arts of een gedragsdeskundige, ook om ervoor te zorgen dat geen alternatieven over het hoofd worden gezien. Het vragen van een second opinion behoort ook tot de zorgvuldigheidseisen die de regionale toetsingscommissies hanteren om te kunnen beoordelen of een toepassing van vrijheidsbeperking zorgvuldig plaatsvindt (paragraaf 7.4.2).

Daarnaast bevat de alternatieve regeling normen voor de wijze waarop vrijheidsbeperking wordt geregistreerd in een kwaliteitssysteem (in de alternatieve regeling kwaliteit en transparantie genoemd), welke mogelijkheden een cliënt en/of vertegenwoordiger heeft om een toepassing van vrijheidsbeperking te laten toetsen door een externe commissie en op welke wijze de functie van een clièntenvertrouwenspersoon ingevuld moet worden.

\subsubsection{De kern van de alternatieve regeling}

Het onderscheid tussen vrijwillig en onvrijwillig vervalt

Het onderscheid tussen vrijwillig en onvrijwillig opgenomen cliënten komt in de alternatieve regeling te vervallen. Opneming in een voorziening is een bijzondere vorm van vrijheidsbeperking en wordt daarmee beschouwd als een onderdeel van de ondersteuning die wordt geboden aan cliënten. Elke cliēnt die is opgenomen in een voorziening kan te maken krijgen met de toepassing van vrijheidsbeperking, mits voldaan is aan de voorwaarden die worden genoemd in de alternatieve regeling. ${ }^{38}$

In de alternatieve regeling verschuift het zwaartepunt naar de interne rechtspositie. De Wet Bopz benadrukt voornamelijk de externe rechtspositie: de Wet Bopz wordt ook wel gekarakteriseerd als een opnamewet. ${ }^{39}$ Cliënten kunnen wel onvrijwillig worden opgenomen, maar kunnen daarna niet verder worden behandeld als ze niet meewerken. Deze wijze van handelen komt tegemoet aan het zelfbeschikkingsrecht van cliënten, maar getuigt tegelijkertijd niet van goede zorg, waar elke onvrijwillig opgenomen cliënt ook recht op heeft. ${ }^{* 0}$ Daar komt bij

38 Een relevante vraag is, ook met het oog op de ontschotting van de zorg, wanneer een cliënt onder de regeling valt en wanneer niet. Het betreft cliënten met een verstandelijke handicap die door het RIO zijn geïndiceerd voor een van de zeven functies van de AWBZ.

39 Door huidige ontwikkelingen, waaronder de voorwaardelijke machtiging en het wijzigen van ernstig gevaar in gevaar, krijgt de Wet Bopz ook kenmerken van een behandelwet. De nadruk blijft echter liggen op een opnamewet.

40 Zie hoofdstuk 3 (een normatief kader voor de interne rechtspositie van mensen met een verstandelijke handicap) voor een uitvoerige omschrijving van 'recht op goede zorg'. 
dat elke onvrijwillige opneming wordt getoetst door een rechter of een indicatiecommissie. Dit kan niet gezegd worden van de toepassing van vrijheidsbeperkende maatregelen in een instituut. Deze maatregelen hoeven alleen aan de Inspectie te worden gemeld als sprake is van dwangbehandeling of de toepassing van middelen of maatregelen in een noodsituatie.

De nadruk die in de alternatieve regeling wordt gelegd op de interne rechtspositie heeft nog een ander doel: het verbeteren van de interne rechtspositie van cliënten. In de verstandelijke gehandicaptenzorg vormt de opneming van een cliënt niet het ultieme doel, maar gaat het veel meer om de ondersteuning die moet worden geboden tijdens het verblijf in een voorziening. In tegenstelling tot in de psychiatrie, is het in de sector verstandelijk gehandicaptenzorg minder relevant om een onderscheid te maken tussen de interne en externe rechtspositie van onvrijwillig opgenomen cliënten. Zowel de interne als de externe rechtspositie maken onderdeel uit van een groter geheel en moeten ook zijn voorzien van dezelfde waarborgen. Blankman wijst erop dat de opneming niet moet worden gezien als een geïsoleerd moment maar als een noodzakelijk onderdeel van een hulpverleningstraject. De opneming is niet gericht op het wegnemen van het gevaar dat wordt veroorzaakt door een verstandelijke beperking, maar vormt het startpunt voor de ondersteuning en de begeleiding. ${ }^{41}$ Blankman maakt in dit verband een vergelijking met de regeling van ondertoezichtstelling van minderjarigen (artikel 1:254 BW e.v.). De kinderrechter kan besluiten om een minderjarige onder toezicht te stellen en eventueel ook uit huis te plaatsen als een goede verzorging ontbreekt en de noodzaak daartoe is vastgesteld. De ondertoezichtstelling en de uithuisplaatsing vormen geen doel op zich, maar zijn noodzakelijk in het belang van een goede verzorging en opvoeding (artikel 1:261 lid 1 BW). Door het onderscheid tussen vrijwillig en onvrijwillig opgenomen cliënten te laten vervallen wordt een oplossing geboden voor het probleem dat op de werkvloer nauwelijks een onderscheid wordt gemaakt tussen vrijwillig en onvrijwillig opgenomen cliënten. Bovendien zijn zeer veel cliënten, bijna $70 \%$ van alle cliënten die in een instituut wonen, vrijwillig opgenomen. ${ }^{42}$

Opneming heeft zeer ingrijpende gevolgen voor de cliënt: de cliënt dient zich aan te passen aan de gebruiken van de voorziening, zijn bewegingsvrijheid wordt beperkt en hij moet een gedeelte van zijn privacy inleveren. Veel opnemingen zijn voor een langere periode of zelfs definitief en vragen daarom om een zorgvuldige afweging. Op grond van de Wet Bopz mag een hulpverlener pas overgaan tot het toepassen van vrijheidsbeperking als een cliënt de status onvrijwillig heeft. In veel gevallen is dit een omslachtige procedure. Voordeel is

42 Arends, Blankman en Frederiks 2003, p. 89-90. 
wel dat een indicatiecommissie zich buigt over de aanvraag van een Bopz-indicatie of dat de rechter toetst of er een grond aanwezig is om een rechterlijke machtiging af te geven.

Uit het evaluatieonderzoek komt evenwel naar voren dat tegen de huidige Bopzindicatiecommissies een aantal zwaarwegende bezwaren bestaan. Door de begeleidingscommissie is geconstateerd dat de rechtsbescherming die de procedure van art. 60 Bopz beoogt te bieden, in de praktijk uitermate gering dan wel niet of nauwelijks aanwezig is: ${ }^{30}$

- De indicatiecommissies hanteren een begrip verzet dat beperkter is dan de wetgever heeft bedoeld.

- De indicatiecommissies voeren de Bopz-toets niet uit kort voordat betrokkene kan worden opgenomen, maar in de regel al enige maanden eerder.

- De indicatiecommissies delen betrokkene lang niet altijd schriftelijk en mondeling mee dat hij zich tegen opneming kan verzetten.

- De indicatiecommissies toetsen vaak niet (of niet expliciet) of betrokkene zich buiten de instelling zou kunnen handhaven.

- De indicatiecommissies leggen het Bopz-oordeel zelden vast en delen het vaak niet aan betrokkene mede.

De conclusie van de begeleidingscommissie is dat van een rechtsbeschermend effect van de indicatiecommissies nauwelijks sprake is. Ook twijfelt zij er sterk aan of het veranderingsvermogen van de indicatiecommissies zodanig is dat in de toekomst dit rechtsbeschermende effect alsnog kan optreden. In het evaluatierapport wordt niet genoemd dat de indicatiecommissies een achterstand hebben bij het afgeven van indicaties, waardoor zich in instituten veel gedoogsituaties voordoen: hulpverleners passen toch vrijheidsbeperkende maatregelen toe, in afwachting van een Bopz-indicatie.

In de alternatieve regeling blijft van de bezwaren die hierboven staan weergegeven er nog één relevant: het onvoldoende toetsen of de betrokkene zich nog buiten de instelling kan handhaven. Dit wordt op de volgende manier ondervangen. De commissie is niet meer - voor zover dat in de huidige wetgeving al het geval was - de eerste beoordelaar van de noodzaak tot opneming, dat wordt nu een arts, respectievelijk een gedragsdeskundige. In de voorgestelde procedure doet de indicatiecommissie ${ }^{44}$ dit werk als onafhankelijk orgaan over en kan daar, naast de behandelaar, op worden aangesproken door de regionale toet-

\section{Begeleidingscommissie evaluatie Wet Bopz 2002, p. 28-30.}

44 In het voorstel wordt de voorkeur gegeven aan het RIO als indicatiecommissie, omdat dit een bestaand orgaan is. Dit neemt niet weg dat deze functie ook door een andere instantie kan worden ingevuld, als die daartoe meer geëquipeerd blijkt. 
singscommissie vrijheidsbeperking, ook omdat opneming wordt beschouwd als een bijzondere vorm van vrijheidsbeperking. Daarnaast heeft de Inspectie bevoegdheden om in te grijpen of om opheldering te vragen. Ter verbetering van de kwaliteit van de door het indicatieorgaan te nemen beslissingen kan bij $\mathrm{AMvB}$ worden vastgelegd dat een indicatiecommissie zodanig dient te zijn samengesteld dat zij een deskundig oordeel kan geven over de wilsbekwaamheid van de cliënt en de noodzaak tot opneming.

\section{De procedure van bijzondere vrijheidsbeperking: opneming}

Alvorens een cliënt wordt opgenomen in een voorziening wordt door een (onafhankelijke) arts of een (onafhankelijke) gedragsdeskundige vastgesteld of sprake is van een noodzaak daartoe. ${ }^{45}$ Het begrip noodzaak wordt later in deze paragraaf toegelicht. Vervolgens dient de arts of de gedragsdeskundige een verzoek in bij het Regionaal Indicatieorgaan (RIO) om de desbetreffende cliënt op te nemen. Het RIO start alleen een procedure als door de arts of gedragsdeskundige een uitspraak is gedaan over de wilsbekwaamheid van de cliënt en toestemming is gevraagd aan de cliënt en/of vertegenwoordiger. Dit betekent overigens niet dat deze ook hoeven in te instemmen met de vrijheidsbeperkende maatregel: ook bij verzet van een cliënt en/of vertegenwoordiger kan de vrijheid van een cliënt worden beperkt.

In de alternatieve regeling wordt van een aantal mogelijkheden uitgegaan:

1. De cliënt is wilsbekwaam en geeft toestemming voor opneming: ook dan is sprake van vrijheidsbeperking. Het is immers uitermate lastig om vast te stellen of de cliënt ook daadwerkelijk wilsbekwaam is en of hij vrijwillig instemt met de opneming.

2. De cliënt is wilsbekwaam, maar geeft geen toestemming. In dit geval vindt, hoewel er een noodzaak voor opneming is, toch geen opneming plaats. Een arts kan in dit geval een second opinon vragen aan een onafhankelijke arts of gedragsdeskundige over de wilsbekwaamheid van de cliënt. 464

45 Bij voorkeur is de arts of de gedragsdeskundige die een oordeel geeft over de wils(on)bekwaamheid van de betrokken cliënt niet degene die reeds betrokken is bij de ondersteuning van de cliënt.

46 Er zal een uitzondering moeten worden gemaakt voor wilsbekwame cliënten die een gevaar vormen voor andere cliënten of hulpverleners. Het Regionaal Indicatieorgaan (RIO) moet in dit geval een mogelijkheid hebben om een cliênt te beperken in zijn vrijheid. Van belang is dat gevaar voor anderen niet te ruim wordt geinterpreteerd, waardoor toch nog via een achterdeur een mogelijkheid wordt gecreëerd om wilsbekwame cliënten op te nemen.

47 In deze situatie is niet sprake van vrijheidsbeperking. Het zal echter in deze situatie niet eenvoudig zijn om vast te stellen of een cliënt 'weloverwogen' be- 
3. De cliënt is wilsonbekwaam. In dit geval wordt de vertegenwoordiger om toestemming gevraagd:

a. De vertegenwoordiger stemt in met opneming, de cliènt wordt opgenomen.

b. De vertegenwoordiger stemt in met opneming maar de cliënt blijft zich verzetten: de cliënt, eventueel bijgestaan door een cliëntenvertrouwenspersoon, kan zich wenden tot de regionale toetsingscommissie vrijheidsbeperking.

4. De vertegenwoordiger stemt niet in met opneming: het RIO meldt de situatie bij de regionale toetsingscommissie vrijheidsbeperking, die vervolgens toetst of de opneming voldoet aan de zorgvuldigheidseisen.

5. De vertegenwoordiger is afwezig: het RIO meldt de situatie bij de regionale toetsingscommissie vrijheidsbeperking die vervolgens toetst of de opneming voldoet aan de zorgvuldigheidseisen.

Ook in de alternatieve regeling blijft wilsbekwaamheid een cruciaal begrip. De hulpverlener, in dit geval een arts of gedragsdeskundige, is verantwoordelijkheid voor de bepaling van wilsbekwaamheid. Als een cliënt wilsonbekwaam is, mag de vertegenwoordiger vervangende toestemming verlenen voor een opneming in een voorziening, ook als de cliënt verzet toont. In het laatste geval geldt als aanvullende voorwaarde dat de cliënt (of de cliëntenvertrouwenspersoon) de mogelijkheid heeft om zich te wenden tot de regionale toetsingscommissie vrijheidsbeperking. Van belang is dat sprake is van een zorgvuldige en verantwoorde afweging. Als een cliënt daarentegen wilsbekwaam ter zake is, mag de opneming geen doorgang vinden als de cliënt niet instemt met de opneming. Dit geldt ook als toch sprake is van een noodzaak voor toepassing van vrijheidsbeperking (lees in dit geval opneming). De vraag is of deze wijze van handelen tegemoet komt aan het beginsel van goede zorg. De kans bestaat dat wilsbekwame cliënten, hoewel er een noodzaak voor opneming bestaat, aan hun lot worden overgelaten. Deze wijze van handelen staat haaks op de uitgangspunten van goede zorg, die ervan uitgaan dat ingrijpen op bepaalde momenten geboden is om een cliënt verder te helpen. Het is evenwel de vraag of deze situatie zich vaak zal voordoen: een arts of een gedragsdeskundige stelt vast dat er een noodzaak voor opneming is, maar de cliënt in kwestie is wilsbekwaam en niet bereid om opgenomen te worden.

Deze procedure in de alternatieve regeling omtrent opneming wijkt af van de huidige regeling in de Wet Bopz, waarin nog is bepaald dat verzet van een wils-

sluit om niet opgenomen te worden, hoewel er een noodzaak aanwezig is voor opneming. 
bekwame cliënt kan worden overruled, mits sprake is van gevaar voor de cliënt zelf of anderen. Hetzelfde geldt voor dwangbehandeling: een wilsbekwame cliënt kan ook tegen zijn wil worden behandeld. Blankman wijst er op dat dwangbehandeling bij wilsbekwame cliënten niet mogelijk moet zijn, ook gezien het Evrm. ${ }^{48}$ Dijkers en Widdershoven lijken tot dezelfde conclusie te komen." Dwangbehandeling bij een wilsbekwame cliënt leidt al snel tot schending van artikel 3 Evrm en artikel 8 Evrm. ${ }^{30} \mathrm{Zij}$ stellen de vraag waarom de wetgever in de Wet Bopz een uitzonderingspositie heeft gecreëerd. De Wgbo biedt immers geen mogelijkheden om wilsbekwame cliënten tegen hun wil te behandelen. Een uitzondering dient te worden gemaakt voor wilsbekwame cliënten die een gevaar voor anderen zijn. Op dat moment moet het RIO de mogelijkheid hebben om een cliënt toch op te nemen als hij niet instemt met opneming.

Een wilsonbekwame cliënt kan zijn verzet tegen opneming tonen. In de praktijk wordt verzet van een wilsonbekwame cliënt regelmatig overruled. ${ }^{51}$ Vanuit het oogpunt van goede zorg is het inderdaad niet reëel om elke vorm van verzet ook als zodanig te beschouwen. Van belang is evenwel dat verzet van een cliënt niet te gemakkelijk terzijde wordt geschoven. Ook de mening van een wilsonbekwame cliënt moet worden meegewogen. Een hulpverlener zal op zoek moeten gaan naar de achterliggende reden van verzet: waarom wil een cliënt niet wonen op deze plek? Waarom vertoont een cliënt gedragsproblemen? In de alternatieve regeling wordt aan een wilsonbekwame cliënt, indien hij zich verzet tegen opneming, de mogelijkheid geboden om zich te wenden tot de regionale toetsingscommissie vrijheidsbeperking. Cliënten zullen deze stap niet zo gauw zelf zetten. $\mathrm{Zij}$ kunnen zich laten bij staan door een cliëntenvertrouwenspersoon. Een cliënt kan bij de regionale toetsingscommissie vrijheidsbeperking allereerst bestrijden dat hij wilsonbekwaam ter zake is. Daarnaast kan hij aangeven dat hij het niet eens is met de toepassing van vrijheidsbeperking waarvoor zijn vertegenwoordiger toestemming heeft gegeven. Daarnaast heeft de cliëntenvertrouwenspersoon, bij aanhoudend verzet van een wilsonbekwame cliënt, de mogelijkheid om zich te wenden tot deze commissie (zie verder paragraaf 7.4.1, een regeling van individueel toezicht en bijstand).

48 Blankman 2003, p. 100-101.

49 W. Dijkers en T.P.J.C. Widdershoven, De Wet Bopz, artikelsgetwijs commentaar (losbladig), Den Haag: Koninklijke Vermande 2002, p. C1-992-998.

50 Zie ook EHRM 24 september 1992 (Herczegfalvy tegen Oostenrijk), NJ 1993, 523.

51 Hulpverleners maken bewust of onbewust toch gebruik van bepaalde criteria bij de beoordeling van verzet. Wilsbekwaamheid is een van deze criteria. Verzet van een wilsonbekwame cliënt wordt al snel als geen verzet beschouwd (Arends, Blankman en Frederiks 2003, p. 75-76). 
Nadat een cliënt is opgenomen dient de zorgaanbieder een aantal normen in acht te nemen die betrekking hebben op kwaliteit en transparantie. Deze normen gelden ook voor cliënten die instemmen met vrijheidsbeperking. De zorgaanbieder moet elke toepassing van vrijheidsbeperking registreren en regelmatig evalueren. $\$$ Deze verplichting geldt ook voor de bijzondere vorm van vrijheidsbeperking: de opneming. In het kader van de Wet Bopz is het niet gebruikelijk dat een Bopz-indicatie regelmatig wordt geẽvalueerd. Cliënten krijgen doorgaans, zonder een tussentijdse toetsing, levenslang een Bopz-indicatie. Daarnaast biedt de Wet Bopz ook de mogelijkheid om een rechterlijke machtiging voor vijf jaar af te geven (artikel 17 lid 4 Bopz). Dit gebrek aan rechtsbescherming wordt in de alternatieve regeling tenietgedaan door instituten de verplichting op te leggen minimaal een keer per jaar de opneming te evalueren. Als een wilsonbekwame cliënt zich nadrukkelijk verzet tegen zijn verblijf in een instituut verdient het aanbeveling dat de opneming frequenter wordt geëvalueerd. Hetzelfde geldt voor ingrijpende vormen van vrijheidsbeperking.

\section{Een ruime betekenis van vrijheidsbeperking}

Het begrip vrijheidsbeperking krijgt een ruimere betekenis dan onder de huidige Wet Bopz: 'Vrijheidsbeperking is iedere ingreep die de individuele rechten beperkt'. In hoofdstuk 5 (paragraaf 5.2) is toegelicht dat het hanteren van een smalle definitie van vrijheidsbeperking, uit respect voor het zelfbeschikkingsrecht van cliënten, niet toereikend is in deze sector. Naast de bekende vormen van vrijheidsbeperking die in de Wet Bopz worden genoemd wordt de vrijheid van cliënten op tal van andere momenten beperkt. Het gevaar bestaat dat met een smalle definitie deze vormen van vrijheidsbeperking, die niet worden benoemd in de Wet Bopz, buiten het zicht van derden en zonder legitieme reden plaatsvinden.

De definitie van vrijheidsbeperking kan worden verfijnd door te spreken over 'elke inbreuk die de zelfstandigheid van een cliënt met een verstandelijke handicap beperkt'.53 Naast middelen of maatregelen, dwangbehandeling en beperkingen in de bewegingvrijheid vallen ook pedagogische maatregelen, beschermende maatregelen, dagschema's en opneming in een voorziening onder het begrip. Belang-

52 Deze vormen van vrijheidsbeperking mogen pas worden toegepast als voldaan is het aan het criterium 'noodzaak'. In alle andere gevallen mogen cliënten niet worden beperkt in hun vrijheid.

53 Het blijft echter, ook na het aanbrengen van details, een zeer ruime definitie die in het kader van wetgeving verder verfijnd zal moeten worden. Een ruime definitie van vrijheidsbeperking heeft als gevolg dat zeer veel vormen van vrijheidsbeperking onder het toeziend oog van de wetgever worden uitgevoerd. 
rijk is dat de intentie van de maatregel niet langer bepalend is. ${ }^{54}$ Het gaat om de gevolgen van een maatregel: alle maatregelen die de vrijheid van cliënten beperken, vallen onder de regeling. Op deze manier wordt een ander bezwaar van de Wet Bopz ondervangen, namelijk het niet van toepassing verklaren van de Wet Bopz door vrijheidsbeperking te labelen als pedagogische maatregel. De intentie van de maatregel mag dan van een andere aard zijn, dit betekent nog niet dat niet sprake zou zijn van vrijheidsbeperking..5

Een grotere reikwijdte heeft als nadeel dat de handhaafbaarheid van de regeling complexer wordt. Het is denkbaar dat aan minder ingrijpende vormen van vrijheidsbeperking geringere eisen worden gesteld. Deze maatregelen hoeven minder frequent te worden geregistreerd dan maatregelen als separatie en fixatie. Vooralsnog is er niet voor gekozen om gradaties aan te brengen in de vrijheidsbeperkende maatregelen. Dit betekent dat het beperken van alcoholgebruik of het aantal boterhammen gelijk is aan het fixeren van een cliënt. Vanuit het perspectief van een cliënt kunnen beide vormen van vrijheidsbeperking van ingrijpende aard zijn. Dit maakt het extra lastig om een indeling aan te brengen. Het is echter wel mogelijk om een onderscheid aan te brengen in de duur van de toepassing van vrijheidsbeperking. In hoofdstuk 5 is gebleken dat de gemiddelde duur van dwangbehandeling in de verstandelijk gehandicaptenzorg meer dan 600 dagen bedraagt. In de alternatieve regeling is niet geregeld hoe lang een vrijheidsbeperkende maatregel mag duren. Om toch enige vorm van gradatie aan te brengen moet elke vrijheidsbeperkende maatregel, die langer dan een jaar duurt, door de zorgaanbieder worden gemeld aan de regionale toetsingscom-

54 Onder de Wet Bopz is ook de intentie van de maatregel niet langer bepalend voor de vraag of sprake is van vrijheidsbeperking. Toch wordt in de praktijk nog steeds een onderscheid gemaakt tussen beschermende en pedagogische maatregelen enerzijds en maatregelen in de zin van de Wet Bopz anderzijds. Voor een deel wordt dit veroorzaakt door het criterium 'gevaar' dat in de ogen van hulpverleners een te nauw criterium is: zowel beschermende als pedagogische maatregelen hebben niet het oogmerk om 'gevaar' te voorkomen. De introductie van het begrip 'noodzaak' moet een einde maken aan deze discussie.

De Groot en Donker zijn van mening dat pedagogische maatregelen geen vrijheidsbeperkende maatregel zijn in de zin van de Wet Bopz: zij hebben een opvoedkundig karakter en hangen niet samen met de stoornis van een cliènt. Tegelijkertijd merken beide auteurs ook op dat sommige van de in de praktijk toegepaste sancties (pedagogische maatregelen) niet proportioneel zijn of op onrechtmatige gronden worden toegepast en daarmee te beschouwen zijn als middelen of maatregelen dan wel vrijheidsbeperkingen (De Groot en Donker 2002, p. 67-69). 
missie vrijheidsbeperking." Deze commissie toetst in elke individuele situatie of voldaan is aan de grond van de toepassing: er moet sprake zijn van een noodzaak.

Niet elke vrijheidsbeperkende maatregel die langer dan een jaar duurt wordt voorgelegd aan de regionale toetsingscommissie vrijheidsbeperking. Het moet gaan om een fysieke beperking in de vrijheid of om medicatie. Hierdoor worden alcoholrestricties (vooralsnog) niet meegenomen in de definitie. ${ }^{57}$ Dit betekent overigens niet dat de mening van de cliënt in deze volledig buiten beschouwing wordt gelaten. Indien een cliënt aangeeft dat hij een bepaalde vrijheidsbeperkende maatregel als zeer ingrijpend ervaart, dienen de strikte criteria die voor emstige vrijheidsbeperkingen worden toegepast, ook in dit individuele geval te worden gehanteerd.

Dijkers merkt naar aanleiding van een uitspraak van het Europese Hof op dat elke vrijheidsbeperkende maatregel de mogelijkheid inhoudt dat minder vrijheden worden toegestaan en dat cliënten korter worden gehouden. ${ }^{5 *}$ In deze uitspraak besliste het Hof dat een onvrijwillige plaatsing van een demente vrouw in een verpleeghuis niet te beschouwen is als vrijheidsbeneming. In het Evrm wordt een onderscheid gemaakt tussen vrijheidsbeneming in de zin van artikel 5 Evrm en vrijheidsbeperking in de zin van artikel 2 van het Vierde Protocol bij het Evrm. In de praktijk is het niet eenvoudig om een onderscheid te maken. Het Hof spreekt van een glijdende schaal. De specifieke situatie van de desbetreffende cliënt en de aard, de duur, de gevolgen en de wijze van tenuitvoerlegging van de maatregel in kwestie zijn bepalend. Het Hof wijst er op dat meer rechtsbescherming nodig is, naarmate de maatregel meer het karakter van vrijheidsbeneming krijgt. Uiteindelijk oordeelde het Hof dat riet sprake is van vrijheidsbeneming omdat de demente vrouw niet gedwongen was opgenomen, bewegingsvrijheid genoot en zij contacten met de buitenwereld kon aangaan. ${ }^{9}$ Als

56 Dit betekent ook dat elke maatregel die langer dan een jaar duurt een ernstige vrijheidsbeperking wordt genoemd.

57 Deze definitie dient door het veld nader te worden omschreven. Het begrip medicatie kan ruim worden opgevat en kan variẻren van gedwongen medicatie tot medicatie die in de pap wordt gestopt.

58 Europees Hof voor de Rechten van de Mens 26 februari 2002, BJ 2002, 20, m.nt. W. Dijkers.

59 Deze conclusie vormt nog geen (voldoende) reden om te besluiten dat gbgbgroep uit de Wet Bopz wordt gehaald. Elke opneming van een demente vrouw moet opnieuw worden beoordeeld. De situatie is afhankelijk van de omstandigheden waaronder iemand is opgenomen: als een cliënt gedwongen op een afdeling verblijft, de afdeling afgesloten is en vrijheidsbeperkende maatregelen 
dezelfde cliënt op een gesloten afdeling zou verblijven, of als (continu) vrijheidsbeperkende maatregelen zouden worden toegepast, kan de opneming wellicht wel als vrijheidsbeneming in de zin van art. 5 Evrm worden gekwalificeerd. Of nu sprake is van vrijheidsbeperking of vrijheidsbeneming, beide vormen vallen onder de alternatieve regeling. Het enige verschil is dat bij de toepassing van ernstige vrijheidsbeperkingen extra waarborgen in acht moeten worden genomen.

Een ander verschil met de Wet Bopz is dat een beperking in de vrijheid van een cliënt, die met instemming van de cliënt of vertegenwoordiger plaatsvindt, ook als vrijheidsbeperking wordt beschouwd. Een uitzondering op deze regel is alleen gerechtvaardigd als een cliënt, die zelf instemt om in zijn vrijheid te worden beperkt, ook zelf de controle behoudt over de toepassing ervan en zelf kan bepalen wanneer de maatregel wordt gestaakt. Onder de huidige Wet Bopz worden veel vrijheidsbeperkende maatregelen met instemming van de cliënt en/of vertegenwoordiger toegepast. Een veel gebruikte methode is 'middel of maatregel akkoord': vrijheidsbeperkende maatregelen worden met toestemming opgenomen in het zorgplan. De empirische resultaten in hoofdstuk 6 illustreren dat vertegenwoordigers soms geen andere keuze hebben dan om in te stemmen met de inhoud van het zorgplan. Ook kunnen vraagtekens worden gezet bij de toestemming van een cliënt. Het is niet eenvoudig om vast te stellen of een cliënt wilsbekwaam ter zake is. In de Wet Bopz hoeven middelen of maatregelen die in het zorgplan zijn opgenomen niet te worden geregistreerd en ook niet aan de Inspectie kenbaar te worden gemaakt zolang als de cliënt en of de vertegenwoordiger geen verzet toont. De vraag of een beperking al dan niet zonder verzet van de cliënt plaatsvindt, doet niet af aan de plicht van de zorgverlener om zorgvuldigheid en transparantie te betrachten bij de toepassing ervan. Een dergelijke opstelling is vereist vanwege de kwetsbaarheid van de groep cliënten waarmee hulpverleners te maken hebben.

\section{Vrijheidsbeperking kan overal plaatsvinden}

Het locatiegebonden karakter van de toepassing van vrijheidsbeperking bij cliënten met een verstandelijke handicap komt te vervallen. Vrijheidsbeperking kan onder de alternatieve regeling in beginsel overal plaatsvinden. Deze bepaling ondervangt een belangrijk en veel genoemd bezwaar van de Wet Bopz. De rechtspositie van (onvrijwillig opgenomen) cliënten wordt onder de Wet Bopz bepaald door de plek waar zij verblijven. Een cliënt die in een instelling met een Bopzaanmerking verblijft, heeft op papier een betere rechtspositie dan cliënten die in

worden opgelegd kan opneming wel als vrijheidsbeneming worden beschouwd (en onder de reikwijdte van de Wet Bopz vallen). 
een gvt wonen, in een zelfstandige woonvoorziening of nog thuis wonen. In de laatst genoemde voorzieningen geldt de Wet Bopz niet. Toch vindt ook daar vrijheidsbeperking plaats. De Wet Voorzieningen Gehandicaptenzorg (Wvg) maakt het mogelijk dat in de thuissituatie een uitraaskamer wordt gecreëerd. Noch de Inspectie, noch de hulpverlener is bevoegd om toezicht te houden op dergelijke toepassingen van vrijheidsbeperking. In de alternatieve regeling kan bij AMvB worden bepaald waar vrijheidsbeperking niet toegestaan is. De grond voor deze uitsluiting is te vinden in de extra veiligheidsmatregelen die voor de toepassing van bepaalde vormen van vrijheidsbeperking getroffen moeten worden. Deze veiligheidsmaatregelen kunnen niet op elke locatie worden genomen.

Een ander punt van aandacht is dat de zorg voor mensen met een verstandelijke handicap zich de laatste jaren steeds meer heeft verschoven van institutionele zorgvormen naar trans- en extramurale zorg. Deze trend maakt zelfs onderdeel uit van actief overheidsbeleid (substitutie) en sluit bovendien aan op de wens van veel cliënten om zo lang mogelijk thuis te kunnen verblijven. Daarnaast zijn per 1 april 2003 de schotten tussen de verschillende sectoren - verpleging en verzorging, gehandicaptenzorg en geestelijke gezondheidszorg - in de gezondheidszorg komen te vervallen. Ten gevolge van de modemisering van de AWBZ kunnen zorgaanbieders AWBZ-breed zorg in natura gaan leveren. Dit betekent dat een cliënt met een verstandelijke handicap ook zorg kan krijgen in een verzorgingshuis, een verpleeghuis of een aanleunwoning. Het doel van de modernisering AWBZ is dat het aanbod van zorg tot meer kwaliteit en kwantiteit leidt. De zorg wordt vanaf 1 april 2003 functiegericht geïndiceerd. De functies zijn zo geschreven dat de zorg, die opgebouwd kan zijn uif verschillende functies, in drie sectoren (gehandicaptenzorg, verpleging en verzorging en geestelijke gezondheidszorg $)^{61}$ kan worden aangeboden. Een alternatief voor de Wet Bopz dient aan te sluiten bij deze ontwikkelingen. Het wordt met de huidige ontwikkelingen steeds moeilijker om het instellingsgebonden karakter van de wet vast te houden.

60 Een voorbeeld: een cliënt mag alleen worden gefixeerd als er voldoende toezicht is op de toepassing en gebruik wordt gemaakt van fixatiemateriaal, dat voorgeschreven is door de sector. Ook moet elke hulpverlener in de voorziening op de hoogte zijn van het fixatieprotocol.

61 Nota van Toelichting bij het Besluit van 25 oktober 2002, Stb. 527, p. 23. 


\subsubsection{De toepassing van vrijheidsbeperking onder de alternatieve regeling}

Toepassing van vrijheidsbeperking:

Bij wie: bij elke cliënt in de verstandelijk gehandicaptenzorg, mits hij toestemming verleent voor de toepassing ervan. Bij het ontbreken van toestemming is, ondanks de noodzaak, in beginsel geen vrijheidsbeperking mogelijk. De alternatieve regeling biedt in dit geval nog een aantal mogelijkheden: vervangende toe. stemming van de vertegenwoordiger bij wilsonbekwaamheid van een cliënt en bij afwezigheid van een vertegenwoordiger of indien deze geen toestemming verleent dient overleg plaats te vinden met een onafhankelijke arts of gedragsdeskundige en wordt de cliëntenvertrouwenspersoon geïnformeerd.

Waar: vrijheidsbeperking kan overal worden toegepast, mits 'bekwame' hulpverleners aanwezig zijn om een verantwoorde toepassing van vrijheidsbeperking te garanderen.

Wanneer: als vrijheidsbeperking 'noodzakelijk' is voor het welzijn van de cliënt. De toepassing van vrijheidsbeperking past binnen de ondersteuning die wordt geboden aan cliënten en moet een bijdrage leveren aan de ontplooiing van cliënten. Noodzakelijk betekent een verruiming van het huidige criterium gevaar. Vrijheidsbeperking blijft evenwel een ultimum remedium. Belangrijk is dat de beperking voldoet aan het proportionaliteits-, subsidiariteits- en effectiviteitsbeginsel. Deze criteria bieden overigens ook de ruimte om te handelen als sprake is van gevaar voor anderen.

Wie beslist: het oordeel over de toepassing van vrijheidsbeperking is aan de hulpverlener. Dit kan een arts of een gedragsdeskundige zijn. Deze hoeft niet altijd zelf de beslissing te nemen maar kan ook een opdracht tot vrijheidsbeperking aan een ander geven. Vereist is dan wel dat deze persoon bekwaam is en de mogelijkheid heeft om terug te vallen op de deskundigheid van een arts of gedragsdeskundige.

Waarborgen: in de alternatieve regeling is een aantal bepalingen ten aanzien van transparantie en kwaliteit opgenomen. Elke toepassing (en beëindiging) van vrijheidsbeperking met of zonder instemming van de cliënt en/of vertegenwoordiger, wordt gemeld bij de interne toetsingscommissie vrijheidsbeperking en dient regelmatig te worden geëvalueerd. Deze commissie is verplicht om de ernstige vormen van vrijheidsbeperking door te sturen naar de regionale toetsingscommissies vrijheidsbeperking. Daarnaast wordt de cliënt bijgestaan door een cliëntenvertrouwenspersoon en kan de cliënt, de vertegenwoordiger, de cliëntenvertrouwenspersoon en ook de zorgverlener zich in individuele gevallen wenden tot de regionale toetsingscommissie vrijheidsbeperking. Hoewel de rechter niet direct wordt betrokken bij de opneming en het verblijf van cliënten, is de toegang tot de rechter gewaarborgd. Een cliënt, een vertegenwoordiger, een cliëntenvertrouwenspersoon en de zorgaanbieder behouden de mogelijkheid om zich te wenden tot de rechter als het oordeel van de regionale toetsings: 
commissie vrijheidsbeperking in het nadeel van de desbetreffende partij is (civielrecht of tuchtrecht). Daamaast blijt de mogelijkheid bestaan om een klacht in te dienen bij de klachtencommissie. ${ }^{2}$ as

\section{Bij wie mag vrijheidsbeperking worden toegepast?}

Vrijheidsbeperking mag in beginsel bij elke cliènt worden toegepast. De alternatieve regeling maakt geen onderscheid meer tussen de externe en interne rechtspositie. Het uitgangspunt is dat een cliènt en/of zijn vertegenwoordiger eerst toestemming moet geven voor een vrijheidsbeperkende maatregel die noodzakelijk is alvorens een cliënt wordt beperkt in zijn vrijheid. Deze systematiek is ook terug te vinden in de Wgbo en de Wet Bopz. In eerste instantie moet een hulpverlener op basis van toereikende informatie toestemming vragen aan de cliënt. Een belangrijk verschil met de huidige Wet Bopz is, dat het vrijheidsbeperkende karakter van de maatregel niet verdwijnt als een cliënt toestemming geeft. Ook nu blijft de alternatieve regeling van toepassing. Als daarentegen een vertegenwoordiger van een wilsonbekwame cliënt geen toestemming verleent danwel ontbreekt, kan de vrijheid van een cliēnt alleen worden beperkt als daar een noodzaak toe is en een aantal extra waarborgen is gerealiseerd: de cliëntenvertrouwenspersoon kan worden betrokken bij de beslissing, een second opinion dient te worden aangevraagd en de cliënt en/of vertegenwoordiger kan zich wenden tot regionale toetsingscommissie vrijheidsbeperking inzien zij het niet eens zijn met een toepassing van vrijheidsbeperking.

Een onderscheid kan worden gemaakt tussen wilsbekwame en wilsonbekwame cliënten. Zodra de noodzaak van de toepassing van vrijheidsbeperking is vastgesteld, wordt toestemming aan de cliënt gevraagd. Indien een wilsbekwame

62 Op grond van artikel 1 lid $1 \mathrm{e}$ Wkcz kan door een klager (cliënt, vertegenwoordiger of een cliëntenvertrouwenspersoon) worden geklaagd over een gedraging. Hieronder wordt verstaan 'enig handelen of nalaten alsmede het nemen van een besluit dat gevolgen heeft voor een cliënt'. Deze bepaling bevat niet een beperking. Over elk handelen of nalaten kan worden geklaagd: ook over onzorgvuldig handelen aangaande de toepassing van vrijheidsbeperking. De uitspraak van de klachtencommissie is niet bindend. Ook bestaat er geen beroepsmogelijkheid. Als de klacht ongegrond wordt verklaard en is de klager het daar niet mee eens dan kan hij alsnog naar de rechter toestappen.

63 Op grond van artikel 1 lid $4 \mathrm{Wkcz}$ is de Wkcz niet van toepassing op klachten van onvrijwillig opgenomen cliënten, voor zover deze overeenkomstig een bijzondere wettelijke regeling door een klachtencommissie kunnen worden behandeld. Met de alternatieve regeling komt echter de Bopz-klachtencommissie te vervallen. Ook vervalt het onderscheid tussen onvrijwillig en vrijwillig opgenomen cliënten. 
cliënt geen toestemming verleent mag een hulpverlener, ondanks de vastgestelde noodzaak, de vrijheid van deze cliënt niet beperken. Deze wijze van handelen druist op het eerste gezicht in tegen het beginsel van goede zorg. Het zal hoogstwaarschijnlijk niet snel gebeuren dat een wilsbekwame cliënt niet wil inzien dat vrijheidsbeperkende maatregelen noodzakelijk zijn. Op zo'n moment kan worden getwijfeld aan de wilsbekwaamheid van een cliënt. ${ }^{64}$ Van belang is dat een hulpverlener nauwkeurig nagaat wat de redenen zijn van deze weigering en/of de cliënt ook begrijpt wat de consequenties van deze weigering zijn. Een hulpverlener kan de mening van een andere arts of gedragsdeskundige in zijn beslissing betrekken, in het kader van een second opinion. ${ }^{65}$

Zodra mogelijk sprake is van wilsonbekwaamheid van een cliënt, wordt van de hulpverlener verwacht dat hij de nodige zorgvuldigheid betracht. De grens tussen wilsbekwaamheid en wilsonbekwaamheid is niet eenvoudig vast te stellen. In het zorgplan moet worden gemotiveerd waarom de desbetreffende cliënt wilsonbekwaam is. Daarnaast moet aan de vertegenwoordiger van de cliënt vervangende toestemming worden gevraagd voor de toepassing van vrijheidsbeperking. Indien de vertegenwoordiger geen toestemming verleent of indien de cliënt geen vertegenwoordiger heeft, mag de vrijheidsbeperking uitsluitend na overleg met een onafhankelijke arts of gedragsdeskundige ${ }^{66}$ plaatsvinden en nadat de cliëntenvertrouwenspersoon op de hoogte is gesteld. Een wilsonbekwame

64 De uitkomsten van een beslissing mogen echter niet doorslaggevend zijn voor de bepaling van wilsbekwaamheid. Een cliënt is niet automatisch wilsonbekwaam als hij een bepaalde vorm van ondersteuning weigert. Hij kan daarvoor gegronde redenen hebben.

65 Hierbij moet ook rekening worden gehouden met gevaar voor anderen. Onder noodzaak wordt ook verstaan 'gevaar voor derden'. In deze betekenis draagt vrijheidsbeperking niet direct bij aan het welzijn en de ontwikkeling van de cliënt, maar worden derden in bescherming genomen. Van belang is dat bij de uitvoering van de maatregel rekening wordt gehouden met de ontwikkeling van cliënten.

66 In de Varbanov-uitspraak is door het Europees Hof voor de Rechten van de Mens bepaald dat, mede op grond van artikel 5 lid 1e Evrm, vrijheidsbeneming niet mag plaatsvinden zonder dat een geneeskundige verklaring is opgesteld door een medisch specialist, een psychiater. Alleen als de onmogelijkheid daarvan aannemelijk is, kan de verklaring door een andere medicus worden opgesteld (Europees Hof voor de Rechten van de Mens 5 oktober 2000, BJ 2001, 36, m.nt. W. Dijkers). In de verstandelijk gehandicaptenzorg is het gebruikelijk dat een (onafhankelijke) AVG of een gedragsdeskundige om advies wordt gevraagd. Op grond van de Varbanov-uitspraak zou dit eigenlijk een psychiater moeten zijn. 
diènt behoudt daarnaast de mogelijkheid om zich te wenden tot de regionale toetsingscommissie vrijheidsbeperking om de wilsonbekwaamheidsverklaring en/of de toepassing van vrijheidsbeperking te laten toetsen. De cliënt kan daarbij worden ondersteund door de cliëntvertrouwenspersoon. Op deze manier blijft verzet van een wilsonbekwame cliënt een rol van betekenis spelen. Het initiatief wordt echter neergelegd bij de cliēnt en zijn cliëntenvertrouwenspersoon. Belangrijk voor hulpverleners is dat zij kunnen aantonen dat zij zeer zorgvuldig te werk zijn gegaan.

Er kan zich ook een noodsituatie voordoen, waarin het vragen van toestemming niet kan worden afgewacht. In dat geval kan de vrijheidsbeperking tijdelijk worden toegepast zonder toestemming te vragen aan de cliënt en/of zijn vertegenwoordiger. De toestemmingsprocedure wordt in dit geval uitgevoerd zodra de cliënt weer aanspreekbaar is of, als de cliënt wilsonbekwaam is, de vertegenwoordiger op de hoogte is gesteld.

\section{Waar mag vrijheidsbeperking worden toegepast?}

Vrijheidsbeperking kan in beginsel overal worden toegepast, mits bekwame hulpverleners aanwezig zijn en de zorgvuldigheideisen in acht worden genomen. Het uitgangspunt in de alternatieve regeling is dat elke cliënt, onafhankelijk van de plaats waar hij is opgenomen, recht heeft op dezelfde mate van bescherming. Dit betekent dat de reikwijdte van de alternatieve regeling in verhouding tot de Wet Bopz aanzienlijk wordt uitgebreid. Hulpverleners mogen op veel meer plaatsen dan nu het geval is, vrijheidsbeperking toepassen. Het is echter bepaald niet nieuw voor de verstandelijk gehandicaptenzorg dat ook buiten instituten vrijheidsbeperking wordt toegepast. In de huidige situatie wordt veel gedoogd en door de vingers gezien. ${ }^{67}$ Ook de Inspectie en de Minister van VWS zijn op de hoogte van deze toepassingen. In de zomer van 2000 heeft de Inspectie een rapport uitgebracht over criteria voor verantwoord handelen bij vrijheidsbeperkende interventies. ${ }^{6}$ In het rapport wordt gesproken over een uitbreiding van de reikwijdte van de Wet Bopz, in de zin van een algemene zorgwet die is aangepast aan de ontwikkelingen in het zorgbeleid en het zorgveld en die ook van toepassing is op semi-murale en extramurale zorgvormen. Hiermee wordt erkend dat vrijheidsbeperking niet alleen voorkomt in de situaties die de Wet Bopz bestrijkt, maar ook daarbuiten. Twee jaar later, in januari 2002, ziet

\footnotetext{
67 Zie ook hoofdstuk 6 van dit boek; Noordelijk Centrum voor Gezondheidsvraagstukken 1997 en Arends en Dursun 2004 (nog niet gepubliceerd).

68 Inspectie voor de Gezondheidszorg, Criteria voor verantwoord handelen bij vrijheidsbeperkende maatregelen, Den Haag: $2000 \mathrm{~b}$.
} 
ook de Minister in dat vrijheidsbeperkende maatregelen buiten instituten plaatsvinden. ${ }^{\oplus}$

Hoewel vrijheidsbeperking in beginsel overal kan worden toegepast, wordt de mogelijkheid gecreëerd om voor bepaalde toepassingen bij AMvB een uitzondering te maken, indien in verband met de veiligheid van de cliënt extra maatregelen moeten worden getroffen. Denkbaar is dat in een thuissituatie of in een zelfstandige woonruimte niet voldoende toezicht kan worden geboden als een cliënt wordt gefixeerd gedurende de nacht. Ook vereisen de maatregelen afzondering en separatie een aantal veiligheidsmaatregelen die niet overal kunnen worden geboden. Een voorziening behoudt overigens altijd de mogelijkheid om bepaalde vormen van vrijheidsbeperking niet toe te passen. Door zelf aan te geven waar de grenzen van zorg liggen, kan het gebeuren dat een risicovolle handeling als separatie niet wordt toegepast binnen een bepaalde voorziening. Ook kan een voorziening besluiten om bepaalde cliënten niet op te nemen, als zij van mening is dat onder het personeel onvoldoende kennis aanwezig is waardoor deze cliënten niet de ondersteuning kunnen krijgen die zij nodig hebben. Dergelijke beslissingen maken onderdeel uit van het kwaliteitsbeleid in een voorziening en worden vastgelegd in het zorgplan van een cliënt. Van belang is dat een voorziening binnen de mogelijkheden die zij ter beschikking heeft, goede zorg biedt aan cliënten.

\section{Wanneer mag vrijheidsbeperking worden toegepast?}

In de alternatieve regeling wordt niet meer gesproken over gevaar, veroorzaakt door een geestesstoornis. Er wordt uitgegaan van een noodzakelijkheidscriterium, waarbij in aanmerking wordt genomen of vrijheidsbeperking effectief is, in verhouding staat tot het doel dat beoogd wordt en er geen redelijk alternatief is met een minder ingrijpend karakter. ${ }^{70}$ Dit criterium sluit beter aan bij de aard van de cliënten en de zorg die geboden wordt in de verstandelijk gehandicaptenzorg dan het gevaarscriterium uit de Wet Bopz. Vrijheidsbeperking moet ook worden gezien in het kader van de ondersteuning die wordt geboden aan cliënten. Bepaalde maatregelen kunnen een bijdrage leveren aan de verdere ontplooiing van cliënten. De vrijheid van cliënten wordt als het ware functioneel beperkt met het doel om binnen een (tijdelijke) beperkte vrijheid toch nog enige mate van autonomie te hebben. Deze wijze van handelen strookt niet met de uitgangspunten van de Wet Bopz.

Onder noodzakelijk wordt verstaan dat een vrijheidsbeperkende maatregel uit het oogpunt van het welzijn van de cliënt wordt toegepast. Het is niet de bedoe-

69 Handelingen 1122 januari 2002, p. 40-2950-2952.

70 De vrijheidsbeperkende maatregel is ook niet langer gericht op het verminderen van een stoornis. 
ling dat met deze omschrijving wordt teruggegaan naar een paternalistische visie op het handelen van een hulpverlener. De reden dat een cliënt in zijn vrijheid wordt beperkt is niet alleen dat de hulpverlener denkt dat dit beter is voor hem. Onder welzijn van een cliënt wordt ook verstaan dat vrijheidsbeperking, althans waar mogelijk, een bijdrage moet leveren aan de ontplooiing van cliënten. Het gaat om redenen die zo dicht mogelijk bij de cliënt liggen. Het criterium noodzaak betekent niet dat een cliënt vanwege een tekort aan personeel mag worden beperkt in zijn vrijheid. Als cliënten op grond van verkeerde redenen worden beperkt in hun vrijheid, dient de Inspectie hiervan door hulpverleners, vertegenwoordigers of de cliëntenvertrouwenspersoon onverwijld op de hoogte te worden gebracht. Het begrip noodzaak dient echter wel ruimte te laten voor gevaar voor derden. In deze betekenis draagt vrijheidsbeperking niet direct bij aan het welzijn en de ontwikkeling van de cliënt, maar worden derden in bescherming genomen. ${ }^{n} \mathrm{Bij}$ de uitvoering van de maatregel kan alsnog rekening worden gehouden met de ontwikkeling van cliënten.

In het kader van de vertaling van het begrip goede zorg naar de praktijk van het toepassen van vrijheidsbeperkingen wordt met deze regeling, in vergelijking met de Wet Bopz, meer ruimte gegeven aan hulpverleners om cliënten te beperken in hun vrijheid. Vrijheidsbeperking blijft echter ook onder de alternatieve regeling een ultimum remedium. In de zorg voor verstandelijk gehandicapten is het onvermijdelijk dat beperkingen van de vrijheid plaatsvinden. Uitgangspunt dient daarbij te zijn dat die beperkingen alleen worden toegepast als er geen andere oplossing is. Aan de andere kant móet een vrijheidsbeperking ook worden toegepast als dit uit het oogpunt van goede zorg noodzakelijk is, bijvoorbeeld ter bescherming van iemands veiligheid. Als een beperking onvermijdelijk is, moet worden gezocht naar een manier die het minst ingrijpend is voor de betrokken cliënt. Tegenover meer mogelijkheden om vrijheidsbeperking toe te passen staat een regeling die meer inzicht biedt in het handelen van een hulpverlener. Van een hulpverlener wordt verwacht dat hij zijn handelen achteraf kan verantwoorden.

De toepassing van vrijheidsbeperking moet aan een aanvullende voorwaarde voldoen: de toepassing moet verantwoord zijn. Het begrip verantwoord is een operationalisering van goede zorg, maar wordt verder niet omschreven in de

71 Leenen onderscheidt een aantal grenzen, op grond waarvan een inbreuk in het zelfbeschikkingsrecht van een cliënt is gerechtvaardigd: de eerste grens wordt bepaald door het zelfbeschikkingsrecht van anderen; rechten van anderen beperken het zelfbeschikkingsrecht van een cliënt. De tweede grens kenmerkt zich doordat de uitoefening van het zelfbeschikkingsrecht niet tot schade bij anderen mag leiden. Het algemeen belang prevaleert in dit geval boven het individueel belang van een cliënt (Leenen 2000, p. 36-37). 
alternatieve regeling. ${ }^{2}$ Het gebruik van open normen is in deze alternatieve regeling niet te voorkomen. De wetgever heeft de taak om randvoorwaarden te creëren. De beslissing wat in een concreet geval goede zorg is en wanneer er een noodzaak voor de toepassing van vrijheidsbeperking aanwezig is, is vooral een zorginhoudelijke beslissing. Het is een taak van het veld om deze begrippen door middel van standaarden, protocollen en gedragsregels nader uit te werken. De brancheorganisatie VGN en de beroepsverenigingen (NVO, NIP, NVAVG, NVSPH, AVVV en Werveling) kunnen hierbij een rol spelen. Indien het veld onvoldoende initiatieven ontwikkelt op dit gebied, kan de wetgever bij AMvB nadere regels stellen.

Wie beslist over de toepassing van vrijheidsbeperking?

In de alternatieve regeling wordt het oordeel over de toepassing van vrijheidsbeperking aan de hulpverlener overgelaten. Dit kan een arts of een gedragsdeskundige zijn. In de Wet Bopz komt de gedragsdeskundige niet voor. ${ }^{73}$ De toepassing van vrijheidsbeperking vereist echter de kennis van beide disciplines. Artsen en gedragsdeskundigen zullen gezamenlijk, met behulp van hun beroepsverenigingen, moeten vaststellen op welke wijze hun bevoegdheden nader gestalte krijgen. Onder de Wet Bopz is een hulpverlener niet verplicht om in bepaalde situaties een second opinion te vragen aan een collega-arts of gedragsdeskundige. De alternatieve regeling kent deze verplichting wel. Mede in het kader van goed hulpverlenerschap moet een hulpverlener in de situatie dat geen toestemming kan worden verkregen van een vertegenwoordiger een second opinion vragen aan een collega (een arts of een gedragsdeskundige). ${ }^{74}$ Als een

72 In het rapport van Arends en Dursun (2004) is een aantal aanknopingspunten te vinden voor een nadere omschrijving van verantwoorde zorg. Zo moet sprake zijn van een juiste verantwoordelijkheidheidstoedeling, voldoende deskundigheid van betrokken hulpverleners, een inzichtelijke en zorgvuldige procedure, de waarborg van voldoende toezicht, transparantie en toetsbaarheid van toepassingen, het ontwikkelen van een actief beleid om vrijheidsbeperkingen zoveel mogelijk te voorkomen en te beperken en een mogelijkheid tot rechtshandhaving indien er rechten geschonden zijn.

73 Wel wordt op grond van artikel 38 lid 2 Wet Bopz het zorgplan van een cliënt opgesteld door de 'voor de behandeling verantwoordelijke persoon'. Dit kan ook een gedragsdeskundige zijn.

74 Niet ondenkbaar is dat eisen worden gesteld aan een second opinion. Op bepaalde momenten zal het voeren van een telefonisch gesprek met een andere arts/gedragsdeskundige voldoende zijn. Dit zal echter niet in alle situaties voldoende zijn, zeker als het gaat om ernstige vormen van vrijheidsbeperking. 
wilsbekwame cliënt geen toestemming geeft voor vrijheidsbeperking, hoewel er een noodzaak is voor de toepassing ervan, kan een hulpverlener uit het oogpunt van goed hulpverlenerschap ook besluiten om een onafhankelijke collega te betrekken bij zijn beslissing.

De bevoegde arts of gedragsdeskundige hoeft de vrijheidsbeperking niet zelf toe te passen. Hij kan hiertoe ook een opdracht geven aan iemand die bekwaam is om die opdracht uit te voeren volgens een systeem analoog aan dat van de Wet big." De arts of de gedragsdeskundige blijft eindverantwoordelijk. De persoon aan wie de opdracht wordt gegeven, hoeft geen professional te zijn. Het is denkbaar dat een ouder van een cliënt die nog thuis woont elke avond een Zweedse band aanlegt of onder dwang medicatie toedient. Van belang is dat een arts of een gedragsdeskundige op de achtergrond aanwezig is en ervan overtuigd is dat de ouder bekwaam is om deze verrichtingen uit te voeren. Een ouder heeft niet de bevoegdheid om alle mogelijke vormen van vrijheidsbeperking in de thuissituatie toe te passen, vanwege de extra veiligheidsmaatregelen die ten aanzien van bepaalde vormen van vrijheidsbeperking nodig zijn.

Welke waarborgen biedt de alternatieve regeling rondom de toepassing van vrijheidsbeperking?

In de alternatieve regeling wordt de nadruk gelegd op kwaliteit en transparantie ten aanzien van de toepassing van vrijheidsbeperking. Elke toepassing van vrijheidsbeperking dient met enige regelmaat te worden geëvalueerd. ${ }^{76}$ De Kwaliteitswet zorginstellingen (Kwz) geeft aan zorgaanbieders de opdracht om een kwaliteitssysteem te ontwikkelen. ${ }^{7}$ Dit systeem moet worden uitgebreid met een registratiesysteem, met als doel om toezicht te houden op vrijheidsbeperking. De gegevens die worden verzameld zijn geschikt om na te gaan of zowel op indivi-

Sommige beslissingen kunnen niet worden genomen, zonder dat een tweede arts of gedragsdeskundige de cliënt in kwestie heeft gezien en/of gesproken.

75 Hoofdstuk IV van de Wet big omvat de regeling 'voorbehouden handelingen' (o.a. injectie en electroconvulsieve therapie). Een voorbehouden handeling mag in beginsel alleen worden uitgevoerd door een arts, een tandarts of een verloskundige (artikel 36 Wet big). Een andere hulpverlener, bijvoorbeeld een persoonlijk begeleider, mag deze verrichtingen ook uitvoeren mits hij een opdracht heeft gekregen van één van deze hulpverleners om de voorbehouden handelingen zelfstandig te mogen uitvoeren (artikel 35 Wet big). Andere voorwaarden zijn dat de hulpverlener bekwaam moet zijn om de opdracht uit te voeren en de aanwijzingen van zijn opdrachtgever moet opvolgen.

76 Het is denkbaar dat ernstige vormen van vrijheidsbeperking frequenter worden geëvalueerd.

77 Artikel $4 \mathrm{~K}$ waliteitswet zorginstellingen. 
dueel als beleidsmatig niveau een zorgvuldige afweging plaatsvindt met betrekking tot de toepassing van vrijheidsbeperking. Daarnaast dient het registratiesysteem zich te ontwikkelen tot een krachtig kwaliteitsinstrument dat kan worden ingezet om het aantal vrijheidsbeperkingen zoveel mogelijk terug te dringen. Naast een registratiesysteem maakt ook de interne toetsingscommissie vrijheidsbeperking onderdeel uit van het kwaliteitssysteem. Deze commissie houdt toezicht op het registratiesysteem, waar meldingen over vrijheidsbeperking binnenkomen.

In de alternatieve regeling verschilt de rol van de Inspectie van de rol die zij inneemt in de Wet Bopz. De Inspectie komt meer op afstand te staan. De nadruk komt te liggen op de eigen verantwoordelijkheid van zorgaanbieders. Elke zorgaanbieder is verplicht om een intern registratiesysteem voor vrijheidsbeperking te ontwikkelen en een interne toetsingscommissie vrijheidsbeperking in te stellen. Beide instrumenten dwingen een zorgaanbieder om verantwoording af te leggen over de kwaliteit van de geleverde zorg. Indien de zorgaanbieder dit nalaat, heeft de Inspectie op grond van de Kwz de taak om in te grijpen. Deze wet biedt hiervoor voldoende instrumenten ${ }^{78}$ In hoofdstuk 4 is echter ook aan de orde gekomen dat de Kwz niet goed functioneert. De uitkomsten van de eerste evaluatie van de Kwz vormden voor de Staatssecretaris van VWS aanleiding om met een aantal aanbevelingen te komen met als inzet een betere naleving van de wet en tevens betere waarborgen voor goede zorg. ${ }^{7}$ In dit kader onderstreept de staatssecretaris de rol van de Inspectie. In het licht van de geconstateerde tekortkomingen ten aanzien van de borging van kwaliteit acht zij het raadzaam dat inspecteurs strenger en zonodig ook repressiever optreden naar voorzieningen toe. Wenselijk zou zijn dat de Inspectie de bevoegdheid krijgt om bestuurlijke boetes op te leggen aan voorzieningen die zich onvoldoende inspannen om de kwaliteit van zorg te borgen, ${ }^{\infty 0}$

De Inspectie krijgt jaarlijks, ook als onderdeel van het kwaliteitsjaarverslag (artikel $5 \mathrm{Kwz}$ ), van elke zorgaanbieder een overzicht van het aantal toegepaste vrijheidsbeperkingen toegestuurd. In hoofdstuk 6 is gebleken dat instituten erkennen dat meer gedaan kan worden met de interne registratie. Het beleid van een instituut dient erop gericht te zijn om het aantal middelen of maatregelen terug

78 Op grond van artikel 7 lid 1 Kwaliteitswet zorginstellingen mag de minister de zorgaanbieder een schriftelijke aanwijzing geven als deze in onvoldoende mate of op onjuiste wijze de kwaliteit van zorg systematisch bewaakt. De Inspectie kan op grond van hetzelfde artikel (lid 4) onder bepaalde voorwaarden een schriftelijk bevel geven. Daarnaast is de minister ook bevoegd om bestuursdwang toe te passen (artikel $14 \mathrm{~K}$ waliteitswet zorginstellingen).

80 Kamerstukken II 2002/03, 28 439, nr. 2, p. 7. 
te dringen. Het registratiesysteem kan hierbij een rol van betekenis spelen. Instituten geven echter ook aan dat intern registreren en melden aan de Inspectie zinvoller wordt als de Inspectie daadwerkelijk iets doet met de gegevens. Van de Inspectie kan, ook gezien de personele bezetting, niet worden verlangd dat zij elke individuele melding toetst. Voor een groot deel ligt deze verantwoordelijkheid bij de zorgaanbieder zelf. De rol van de Inspectie is in de tweede evaluatie Wet Bopz aan de orde gesteld. Een van de uitkomsten van dit deelonderzoek is dat in het veld een grote waarde wordt toebedeeld aan de toezichthoudende rol van de Inspectie. ${ }^{\text {s1 }}$ Tegelijkertijd wordt opgemerkt dat de Inspectie twee verschillende toezichtstaken heeft - taken op het gebied van de algemene kwaliteitsbewaking en die op het gebied van de individuele rechtsbescherming - die moeilijk met elkaar te combineren zijn. De resultaten van het deelonderzoek laten zien dat de individuele rechtsbescherming niet optimaal wordt gerealiseerd. Een voor de hand liggende oplossing is om het apparaat van de Inspectie uit te breiden. In de alternatieve regeling is ervoor gekozen om een interne toetsingscommissie vrijheidsbeperking in te stellen. Deze commissie krijgt de taak om individuele toepassingen van vrijheidsbeperking te toetsen. Daarnaast krijgt ook de cliëntenvertrouwenspersoon ${ }^{n}$ een taak inzake de individuele toetsing van vrijheidsbeperking. Zowel aan de Inspectie als aan de cliëntenvertrouwenspersoon wordt jaarlijks verslag gedaan van het aantal vrijheidsbeperkingen. De cliëntenvertrouwenspersoon kan aan de hand van deze gegevens toetsen hoe de situatie bij cliënten ervoor staat, meedelen aan cliënten welke rechten zij hebben en mogelijk een klacht voorbereiden met een cliënt. Deze wijze van handelen is niet gebruikelijk bij de patiëntenvertrouwenspersoon in de psychiatrie waarvan wordt verwacht dat hij een lijdelijke rol vervult. Ook is denkbaar dat in de alternatieve regeling een bepaling, vergelijkbaar met artikel 63 Wet Bopz, wordt opgenomen waarin is bepaald dat de Inspectie de bevoegdheid heeft om te allen tijde individuele gegevens van een cliënt op te vragen. ${ }^{33}$ Hierin kan ook worden opgenomen dat de Inspectie de mogelijkheid heeft om op aanwijzing van een

81 Legemaate, Arends en Van 't Riet 2002, p. 113.

82 De inhoud van de functie cliëntenvertrouwenspersoon wordt in de volgende paragraaf uiteengezet.

83 Deze bevoegdheid is mede gebaseerd op de Algemene wet bestuursrecht (Awb), waarin een aantal bepalingen zijn opgenomen die betrekking hebben op toezicht op de naleving: artikel 5:12, 5:13, 5:15, 5:16, 5:17 en 5:20. Op grond van deze bepalingen is een toezichthouder (waaronder een inspecteur) bij of krachtens enig wettelijk voorschrift bevoegd om een plaats te betreden zonder toestemming, inlichtingen te vorderen en inzage te vorderen van gegevens en bescheiden. Een ieder is verplicht aan een toezichthouder alle medewerking te verlenen. 
vertegenwoordiger of een cliëntenvertrouwenspersoon nader onderzoek te verrichten.

\section{Een regeling van individueel toezicht en bijstand}

Een belangrijk onderdeel van de alternatieve regeling is de introductie van een cliëntenvertrouwenspersoon die een spilfunctie vervult in de individuele rechtsbescherming. In de conclusies en aanbevelingen van de begeleidingscommissie wordt opgemerkt dat de begeleidingscommissie het 'bijzonder teleurstellend vindt dat de uitkomsten van de eerste evaluatie en de naar aanleiding daarvan door de regering gedane uitlatingen nog niet hebben geleid tot enige verbetering van het klachtrecht. De introductie van een onafhankelijke patiëntenvertrouwenspersoon of een daarmee vergelijkbare functionaris in de zorg voor verstandelijk gehandicapten verdient naar de mening van de begeleidingscommissie de hoogste prioriteit'. ${ }^{4}$

In de psychiatrie heeft een cliënt recht op bijstand van een patiëntenvertrouwenspersoon (pvp). De taken en bevoegdheden van deze functionaris zijn uitgewerkt in een besluit ${ }^{35}$ behorende bij de Wet Bopz. Ook heeft de Stichting Patiëntenvertrouwenspersoon Geestelijke Gezondheidszorg (Stichting PVP) een taakomschrijving opgesteld. ${ }^{56}$ De pvp is verantwoordelijk voor een adequate klachtenbegeleiding en -bemiddeling, informatiebegeleiding en processignalering en vervult een aantal algemene taken waaronder het onderhoud met de behandelaars van een cliënt als sprake is van een conflict. Nadat in 1994 de Wet Bopz van kracht is geworden, heeft de Stichting PVP een aantal aanvullende gedragsregels opgesteld. ${ }^{87}$ Wat opvalt in deze gedragsregels is dat een pvp hoofdzakelijk op verzoek van een cliënt ondersteuning biedt. De pvp onderneemt alleen op eigen initiatief actie als hij een onaanvaardbare situatie constateert en de betrokken cliënt niet in staat is om een klacht te verwoorden. Bovendien behoort het verlenen van advies en bijstand aan vertegenwoordigers niet tot de taken van een pvp. De functie van een pvp is primair gericht op het ondersteunen van individuele cliënten. In de gedragsregels pvp is de volgende passage opgenomen: 'Indien een vertegenwoordiger aangeeft namens cen cliënt een beroep op de pop te doen of een klacht uit over diens positie, verifieert de pop of de cliënt ondersteuning wenst. Zo ja, dan beschouwt hij de cliënt verder als hulpvrager en handelt dienovereenkomstig. Zo nee, dan onderneemt hij geen verdere actie tenzij sprake is van een onaanvaardbare situatie'.

84 Begeleidingscommissie evaluatie Wet Bopz 2002, p. 37.

85 Besluit patiëntenvertrouwenspersoon Bopz, 3 november 1993, Stb. 565.

86 Stichting Patiëntenvertrouwenspersoon Geestelijke Gezondheidszorg, Taakomschrijving patiëntenvertroutwenspersoon, Utrecht, 1982.

87 Stichting Patiëntenvertrouwenspersoon Geestelijke Gezondheidszorg, Gedragsregels patiëntenvertrouwenspersoon, Utrecht, 1999. 
Uit de resultaten van het evaluatieonderzoek van de Wet Bopz $z^{\text {ss }}$ komt naar voren dat de functie van een cliëntenvertrouwenspersoon op een aantal punten dient te verschillen van de functie van een pvp. In tegenstelling tot in de psychiatrie is de cliënt minder in staat om zijn eigen wensen kenbaar te maken. Dit geldt ook voor het onder woorden brengen van een klachtwaardige situatie. Een cliëntenvertrouwenspersoon zal zich naar cliënten toe proactiever moeten opstellen. Hij moet zelf naar cliënten toe gaan en uitleggen wat hij kan betekenen voor hen. Daarnaast heeft hij net als de pvp een signaleringsfunctie. Deze functie is met name van belang voor wilsonbekwame cliënten die geen vertegenwoordiger of familie hebben. Zodra een clièntenvertrouwenspersoon van mening is dat in een bepaalde situatie niet sprake is van verantwoorde zorg mag hij de zorgaanbieder hiervan op de hoogte brengen en aanbevelingen tot verbetering doen.

Een andere oplossing voor onmondige cliènten is om, in tegenstelling tot de functieomschrijving van een pvp, de cliëntenvertrouwenspersoon ook toegankelijk te maken voor de vertegenwoordiger. De kans is echter groot dat een cliëntenvertrouwenspersoon in een moeilijke situatie belandt als hij zowel de belangen van de vertegenwoordiger als die van de cliënt moet behartigen. In de alternatieve regeling is de functie van een cliëntenvertrouwenspersoon alleen bedoeld voor cliënten, juist ook als een cliënt niet voor zichzelf kan opkomen. Hiervoor zijn verschillende redenen te noemen. De belangrijkste reden is die van partijdigheid. Voor elke partij moet duidelijk zijn welke belangen een cliëntenvertrouwenspersoon behartigt. Daarnaast is niet eenvoudig vast te stellen of een cliënt in een bepaalde situatie wilsonbekwaam is. Voorkomen moet worden dat een cliëntenvertrouwenspersoon met een vraag van een vertegenwoordiger aan de slag gaat, zonder dat hij overtuigd is van het feit dat de cliënt wilsonbekwaam ter zake is. Er zijn uiteraard ook situaties denkbaar waarin het evident is dat een cliënt wilsonbekwaam is. Mocht een vertegenwoordiger in dit geval een klacht hebben over de verzorging dan bestaat uiteraard altijd de mogelijkheid om deze klacht neer te leggen bij de cliëntenvertrouwenspersoon die vervolgens kan besluiten om alsnog een nader onderzoek in te stellen. Ook kan hij de vertegenwoordiger doorverwijzen naar andere instanties of personen.

Bij wilsbekwame cliënten (of liever gezegd cliënten die een vertegenwoordiger hebben, maar in dit geval toch wilsbekwaam kunnen worden beschouwd) ligt deze situatie ingewikkelder. Alleen na toestemming van de cliënt, mag een cliëntenvertrouwenspersoon een klacht van een vertegenwoordiger in behandeling nemen. De cliënt wordt echter bij de afhandeling van de klacht als hulpvrager beschouwd en niet de vertegenwoordiger. Een vertegenwoordiger beschikt over

88 Legemaate, Arends en Van't Riet 2002, p. 85-92. 
diverse andere mogelijkheden om een klacht neer te leggen: MEE (voorheen SPD), het Informatie- en klachtenbureau gezondheidszorg (IKG) of de klachtenfunctionaris in de voorziening. Een ander argument is dat jonge cliënten juist los willen of kunnen komen van hun vertegenwoordiger. Dit laat de praktijk ook zien. ${ }^{89}$ Een cliëntenvertrouwenspersoon heeft als doel om de rechtspositie van een cliënt tegenover zijn vertegenwoordiger te verstevigen. Dit betekent ook dat een cliëntenvertrouwenspersoon niet zonder de toestemming van een cliënt gegevens mag uitwisselen met een (wettelijk) vertegenwoordiger. Hiermee wordt ook de privacy van cliënten gerespecteerd. De invoering van een cliëntenvertrouwenspersoon, die zich alleen richt op de ondersteuning van cliënten, betekent in veel voorzieningen een cultuuromslag. Op diverse momenten in deze studie komt naar voren dat de zorgaanbieder nog steeds de neiging heeft om belangrijke zaken zoals het zorgplan alleen te bespreken met de vertegenwoordiger. De cliënt wordt nog te weinig erkend als volwaardig gesprekspartner. Ook zijn zorgaanbieders nog onvoldoende gewend aan het idee om in conflicten met cliënten en vertegenwoordigers achter de mening van de cliënt te gaan staan.

Een vraag die nog niet aan de orde is gesteld is of een cliëntenvertrouwensper-

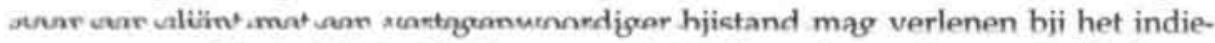
nen van een klacht bij de klachtencommissie. Een uitspraak van de klachtencommissie patiëntenvertrouwenspersonen ${ }^{\circ}$ maakt duidelijk dat een patiënt niet met de hulp van een patiëntenvertrouwenspersoon een klacht mag indienen zonder dat de wettelijk vertegenwoordiger is geïnformeerd. De klachtencommissie motiveert haar uitspraak door erop te wijzen dat een cliënt, die een mentor of een curator heeft, onbevoegd is om zonder toestemming van zijn vertegenwoordiger een rechtshandeling te verrichten betreffende zijn verzorging, verpleging, behandeling en begeleiding. ${ }^{91}$ In dit geval was de vertegenwoordiger

89 Het 'Project cliëntenvertrouwenspersonen' vindt plaats in opdracht van de provincie Zuid-Holland. Het doel is om te komen tot de ontwikkeling en verbreding van een uniform model van een cliëntenvertrouwenspersoon in de zorg voor verstandelijk gehandicapten.

90 Klachtencommissie Patiëntenvertrouwenspersonen, 26 mei 2000, BJ 2001, 16, m.nt. J. Hubben.

91 Een uitspraak van het regionaal tuchtcollege te Eindhoven $(2002 / 133)$ houdt dezelfde lijn aan als die van de klachtencommissie. In deze uitspraak luidt het oordeel dat een onder curatele gestelde niet een klacht mag indienen bij het tuchtcollege: 'gezien het bepaalde in artikel 1: 381 lid 2 BW was klager ten tijde van het indienen van de klacht onbekwaam om rechtshandelingen te verrichten voor zover de wet niet anders bepaalt. Uit deze handelingsonbekwaamheid vloeit voort de onbekwaamheid tot het aanspannen van procedures, waaronder 
niet op de hoogte gebracht van de klacht die ingediend zou worden bij een klachtencommissie van een psychiatrische instelling. Deze wijze van handelen wijkt af van de gedragsregels die zijn opgesteld door de Stichting PVP, waarin is bepaald dat 'de pop zich laat leiden door de wens van de cliënt. Hij neemt zonder diens toestemming geen contact op met de vertegenwoordiger' en 'hij laat zich leiden door hoe de cliënt zelf zijn belang ziet'. Hubben merkt in de bijbehorende noot op dat de klachtencommissie over het hoofd heeft gezien dat de curandus en de onder mentorschap gestelde wel een zelfstandig klachtrecht toekomt. Hij verwijst daarbij naar artikel $8: 21$ lid 2 Awb waarin is bepaald dat onbekwamen zelf in rechte kunnen optreden 'indien zij tot cen redelijke waardering van hun belangen in staat kumnen worden geacht'. Daarnaast wijst hij op het persoonlijke karakter van het klachtrecht. Een vertegenwoordiger dient ook zijn grenzen te kennen. Dit geldt met name als het gaat om persoonlijke beslissingen, waaronder het indienen van een klacht."

In de alternatieve regeling wordt afstand genomen van de aanbevelingen die de klachtencommissie in de bovengenoemde uitspraak heeft gedaan. Elke cliënt moet de mogelijkheid hebben om samen met een cliëntenvertrouwenspersoon een klacht in te dienen, zonder dat de vertegenwoordiger hiervan op de hoogte hoeft te worden gebracht. Dit geldt ook als het gaat om een wettelijk vertegenwoordiger. Een cliëntenvertrouwenspersoon verdedigt immers de belangen van een cliënt en niet die van een vertegenwoordiger. Deze benadering toont respect voor de rechtspositie van cliënten met een verstandelijke handicap. Bovendien is het indienen van een klacht niet te beschouwen als een rechtshandeling waarvoor een curator of mentor toestemming moet verlenen..$^{93}$ Wilsonbekwame cliënten, met of zonder vertegenwoordiger, behouden te allen tijde de mogelijkheid om te klagen.

Artikel 2 lid 4 Wet klachtrecht cliënten zorgsector biedt aan cliëntenvertrouwenspersonen de mogelijkheid om namens een wilsonbekwame cliënt een klacht in te dienen. Op grond van dit artikel mag een klacht alleen door of namens een cliënt worden ingediend. De wetgever gaat uit van een ruime benadering en heeft vooralsnog geen aansluiting gezocht bij de Wgbo, waarin een rangorde van vertegenwoordigers wordt gehanteerd. Namens de cliënt kunnen klagen een wettelijk vertegenwoordiger van de cliënt, een persoon die door de cliënt zelf is aangewezen en een zaakwaarnemer van de cliënt. Niet ondenkbaar

ook tuchtrechtelijke procedures. Niet is gebleken van toestemming van de curator tot het indienen van de onderhavige klacht (...)'.

92 Het onderwerp van een klacht kan zeer persoonlijk zijn (relaties). Denkbaar is ook dat een cliënt een klacht indient over een onderwerp waarover hij van mening verschilt met zijn vertegenwoordiger.

93 Kamerstukken II 1993-94, 23 040, nr. 5, p. 23 (MvA). 
is dat in het laatste geval een cliëntenvertrouwenspersoon optreedt namens de wilsonbekwame cliënt, mits daar een redelijke grond voor bestaat (artikel 6:198 BW). Als een wilsonbekwame cliënt een vertegenwoordiger heeft, is het raadzaam dat een cliëntenvertrouwenspersoon deze persoon eerst benadert, alvorens hij besluit alsnog een klacht in te dienen. Een vertegenwoordiger heeft immers ook de mogelijkheid om een klacht in te dienen.

Een ander punt van aandacht vormt de wijze waarop op dit moment invulling wordt gegeven aan de klachtencommissies in voorzieningen. De huidige Bopzklachtencommissie blijkt in deze sector te hoogdrempelig te zijn voor cliënten en vertegenwoordigers. ${ }^{94}{ }^{95}$ Een cliëntenvertrouwenspersoon kan een deel van deze problematiek wegnemen, door een cliënt te informeren over de mogelijkheden die hij heeft om een klacht in te dienen. Ook kan hij de cliënt bijstand verlenen bij het indienen van een klacht. Daarnaast verdient het aanbeveling dat hoge eisen worden gesteld aan de leden van de klachtencommissies. De Wet Bopz heeft nu alleen als vereiste dat de commissie uit minimaal drie leden moet bestaan, waarvan alleen de voorzitter onafhankelijk is. ${ }^{96}$ Naast onafhankelijkheid is ook van belang dat de leden over voldoende deskundigheid beschikken om een oordeel te kunnen geven over onderwerpen als wilsonbekwaamheid of de toepassing war wrijheidshyperking . In dit kader is het nodig om nadere eisen te stellen die verdergaan dan de Wet Bopz doet."

$\mathrm{Al}$ eerder in deze paragraaf is benadrukt dat in de alternatieve regeling de nadruk ligt op kwaliteit en transparantie. Hiermee moet worden voorkomen dat door een ruimere interpretatie van de wet een vrijbrief zou ontstaan voor het (onbeperkt) toepassen van vrijheidsbeperking. Van belang is dat elke vrijheidsbeperkende maatregel inzichtelijk wordt gemaakt en wordt verantwoord. Om

94 Begeleidingscommissie evaluatie Wet Bopz 2002, p. 36-37.

95 Een probleem is dat deze Bopz-commissies gelieerd zijn aan de instelling waardoor cliënten en vertegenwoordigers mede vanwege hun 'afhankelijke positie' minder snel geneigd zullen zijn om een klacht in te dienen.

96 In het Besluit klachtenbehandeling Bopz (2 april 2001, Stb. 214) is in artikel 4 bepaald dat de voorzitter van de klachtencommissie onafhankelijk dient te zijn. De Bopz-klachtencommissie bestaat uit minimaal drie leden, waaronder een voorzitter, een jurist en een orthopedagoog.

97 De uitkomsten van de tweede evaluatie Wet Bopz laten zien dat aan de kwaliteit en deskundigheid van de commissieleden wordt getwijfeld, zowel door kritische volgers van de commissies (de pvp'en) als door sommige commissieleden zelf O. Legemaate, Het klachtrecht van de Wet Bopz: geschiedenis en toekomst, in: P.J.P. Baart, P.W.H.M. Francissen, L.A. van Kleef-Deelen, S. Stulp en M. Zijp (red.), Handboek Cliẽntenparticipatie, Houten/Diegem: Bohn Stafleu Van Loghum, 2003b). 
deze doelstelling te kunnen bereiken dient elke voorziening te beschikken over een gedegen kwaliteitsbeleid. Een onderdeel hiervan vormt de 'interne toetsingscommissie vrijheidsbeperking'. Deze multidisciplinaire commissie toetst de interne meldingen van vrijheidsbeperking. Het betreft het begin en beëindiging van een vrijheidsbeperkende maatregel. In de commissie nemen in ieder geval plaats een arts, een gedragsdeskundige, een kwaliteitsfunctionaris/beleidsmedewerker en een of meerdere persoonlijk begeleiders. Hulpverleners zijn verplicht om alle vormen van vrijheidsbeperking ${ }^{*}$ intern te melden. Het betreft ook vormen van vrijheidsbeperking waarvoor een cliënt en/of zijn vertegenwoordiger toestemming heeft gegeven. Het is tevens de taak van de interne commissie om de overzichten van toepassingen regelmatig terug te koppelen naar de woningen. Ook dient regelmatig evaluatie plaats te vinden van de maatregelen.

Naast een interne toetsingscommissie vrijheidsbeperking wordt een regionale toetsingscommissie vrijheidsbeperking ingevoerd. ${ }^{\infty}$ Deze commissie heeft als voornaamste taak om de meldingen van ernstige vormen van vrijheidsbeperking regelmatig te toetsen. De interne toetsingscommissie vrijheidsbeperking stuurt twee keer per jaar een overzicht naar de regionale toetsingscommissie vrijheidsbeperking. In dit overzicht zijn alleen de ernstige vormen van vrijheidsbeperking opgenomen. Deze toepassingen worden aan de hand van een meldingsformulier doorgegeven. Op dit formulier staat een aantal zorgvuldigheideisen genoemd. Onder een ernstige vorm van vrijheidsbeperking wordt in dit proefschrift verstaan: 'een fysieke beperking in de vrijheid die langer dan een jaar duurt of de toepassing van medicatie die langer dan een jaar duurt'. Hierdoor vallen alcoholrestricties (vooralsnog) buiten de definitie.

\section{Taken regionale toetsingscommissie vrijheidsbeperking}

De regionale commissie houdt zich niet alleen bezig met meldingen van de interne toetsingscommissie vrijheidsbeperking. $\mathrm{Zij}$ heeft drie taken:

1. Het toetsen van de opneming van cliënten (als bijzondere vorm van vrijheidsbeperking) in die gevallen dat de vertegenwoordiger geen toestemming verleent of afwezig is. In dit geval stuurt het RIO een meldingsformulier naar de regionale toetsingscommissie vrijheidsbeperking. Daarnaast kan een cliënt en/of zijn cliëntenvertrouwenspersoon de toetsingscommissie om een oordeel vragen (met name ten aanzien van het oordeel

98 Het uitgangspunt is een brede definitie van vriiheidsbeperking. Daarvoor is wel van belang dat binnen de voorziening eenduidigheid bestaat over wat wel en niet onder dit begrip wordt geplaatst.

99 Deze wijze van toetsing vertoont overeenkomsten met de regionale toetsingscommissies euthanasie zoals deze voorkomen in de Wet toetsing levensbeëindiging op verzoek en hulp bij zelfdoding (Stb. 2001, 194). 
van het RIO over de mate van wilsonbekwaamheid van een cliënt, waardoor de cliënt niet zelf toestemming mag geven voor de toepassing van vrijheidsbeperking). Ook in dit geval wordt een meldingsformulier ingevuld.

2. Het toetsen van ernstige vormen van vrijheidsbeperking tijdens het verblijf van een cliënt in een voorziening. ${ }^{100}$ Deze toetsing vindt plaats aan de hand van meldingsformulieren. Twee keer per jaar worden deze formulieren door de interne toetsingscommissie vrijheidsbeperking doorgestuurd naar de regionale toetsingscommissie vrijheidsbeperking. Daarnaast kan de interne commissie buiten deze termijnen om een melding doen waarvoor mogelijk een extra vergadering wordt ingelast.

3. Het op verzoek van een hulpverlener, een vertegenwoordiger, een $\mathrm{cvp}^{101}$ of een cliënt ${ }^{102}$ toetsen van toepassingen van vrijheidsbeperking. Reden kan zijn dat een cliënt zich nadrukkelijk verzet tegen de toepassing van een maatregel. Ook kan een maatregel die buiten de definitie van ernstige vrijheidsbeperking valt, toch dermate ingrijpend zijn (vanuit het perspectief van de cliënt) dat deze wordt voorgelegd aan de commissie. Ook voor deze vormen van vrijheidsbeperking dient een meldingsformulier te worden ingevuld. De cliënt kan bij het invullen van het formulier worden geholpen door de cvp. Een andere mogelijkheid is dat hij de melding mondeling komt toelichten bij (een deel van de) commissie of dat de commissie naar de voorziening toe komt.

100 Indien in een thuissituatie op verzoek van de cliënt en/of zijn familieleden door hulpverleners ondersteuning wordt geboden valt ook de thuissituatie onder deze regeling.

101 Het feit dat een cliënt een vertegenwoordiger heeft, mag niet verhinderen dat een cliëntenvertrouwenspersoon zich wendt tot de regionale toetsingscommissie vrijheidsbeperking. Vergelijk in dit kader artikel 42 van de Wet Bopz waarin is bepaald dat de inspecteur, die van mening is dat een cliënt die zich verzet tegen de toepassing van een behandeling, niet in staat kan worden geacht gebruik te maken van het Bopz-klachtrecht, een verzoekschrift kan indienen ter verkrijging van de beslissing van de rechter over de noodzaak van de behandeling waartoe tegen de cliënt zich verzet. Een cliëntenvertrouwenspersoon moet ook de mogelijkheid krijgen om zich bij wilsonbekwaamheid van een cliënt, vanuit het oogpunt van individuele rechtsbescherming, te wenden tot de regionale toetsingscommissie vrijheidsbeperking.

102 Ook als een cliënt een vertegenwoordiger heeft, kan hij zich wenden tot de regionale toetsingscommissie vrijheidsbeperking, al dan niet bijgestaan door een cliëntenvertrouwenspersoon. 


\section{Samenstelling regionale commissie}

De regionale toetsingscommissie vrijheidsbeperking wordt multidisciplinair samengesteld: een arts (bij voorkeur een AVG), een gedragsdeskundige, een ethicus en een jurist (tevens voorzitter van de commissie). Vergelijkbaar met de regionale toetsingscommissie euthanasie in het kader van de Wet toetsing levensbeëindiging op verzoek en hulp bij zelfdoding komen er vijf regionale commissies, bij voorkeur in Groningen, Arnhem, Haarlem, Rijswijk, Zuid-Holland en's-Hertogenbosch.

\section{Toetsingsprocedure}

De toetsing vindt plaats aan de hand van meldingsformulieren. Uit deze formulieren zal duidelijk moeten worden of vrijheidsbeperking zorgvuldig heeft plaatsgevonden. Ook (de toetsing van) de opneming van cliënten ${ }^{100}$ en de vormen van vrijheidsbeperking die op verzoek van derden worden getoetst, dienen aan deze eisen te voldoen. ${ }^{104}$

Het betreft de volgende zorgvuldigheideisen:

1. De hulpverlener (een arts of gedragsdeskundige kan als eindverantwoordelijke worden beschouwd) is van mening dat de toepassing van vrijheidsbeperking noodzakelijk is voor het welzijn van de cliënt. Dit betekent dat de toepassing van vrijheidsbeperking past binnen de ondersteuning die wordt geboden aan de desbetreffende cliënt en een bijdrage moet leveren aan zijn ontplooiing.

103 De term hulpverlener komt in de meldingsformulieren van het RIO niet voor. In dat geval wordt gesproken van 'indicatieorgaan'.

104 Het is moeilijk om van te voren een schatting te maken van het aantal meldingen dat bij de regionale toetsingscommissie binnen zal komen: in 2002 waren er 89 meldingen van IBS en RM en 311 meldingen van dwangbehandeling en noodsituaties in de verstandelijk gehandicaptenzorg. $48,4 \%$ van de meldingen van dwangbehandeling waren binnen twee weken weer beëindigd (Inspectie voor de Gezondheidszorg, Jaarrapport Bopz 2002, Den Haag: 2003). In dit voorstel worden echter ook toepassingen van vrijheidsbeperking gemeld die met toestemming van de cliënt al langer dan een jaar voortduren. In dat kader is het van belang dat het begrip 'ernstige vorm van vrijheidsbeperking' door het veld helder en eenduidig wordt afgebakend. Daarnaast dient de interne toetsingscommissie vrijheidsbeperking een actieve rol te vervullen: door middel van een actief beleid bestaande uit intensieve toetsing, evaluatie en aandacht voor alternatieven kan worden voorkomen dat de regionale commissie wordt overbelast. Ter vergelijking: in $\mathbf{2 0 0 2}$ kwamen bij de regionale toetsingscommissie euthanasie 1882 meldingen van euthanasie en hulp bij zelfdoding binnen (Regionale toetsingscommissie euthanasie, Jaarverslag, 2003). 
2. De hulpverlener heeft de cliënt en/of vertegenwoordiger geïnformeerd over de vrijheidsbeperkende maatregel.

3. De hulpverlener heeft de overtuiging dat de betrokken cliënt wilsonbekwaam is om toestemming te geven voor vrijheidsbeperking.

4. De cliënt is wilsbekwaam maar vormt een gevaar voor derden.

5. De hulpverlener heeft toestemming van de vertegenwoordiger voor de toepassing van vrijheidsbeperking of heeft, bij het ontbreken van toestemming, in ieder geval geprobeerd om toestemming te verkrijgen van de cliënt en/of vertegenwoordiger.

6. De hulpverlener heeft nader onderzoek verricht naar (mogelijk) verzet van de cliënt .

7. De hulpverlener is van mening dat er geen (minder ingrijpende) alternatieven zijn.

8. Er is sprake van een verantwoorde toepassing van vrijheidsbeperking. Hieronder wordt verstaan dat degene die de maatregel uitvoert hiertoe ook bekwaam is. Een risicovolle handeling, waaronder fixatie, mag niet door elke persoonlijk begeleider of familielid worden uitgevoerd. De arts of gedragsdeskundige blijft vooralsnog eindverantwoordelijk. ${ }^{105}$

9. De hulpverlener heeft een andere, onafhankelijke arts of gedragsdeskundige geraadpleegd.

10. De toepassing van vrijheidsbeperking wordt regelmatig geëvalueerd.

11. Er is doorlopend toezicht op risicovolle toepassingen van vrijheidsbeperking (fixatie en separatie).

12. De hulpverlener heeft de overtuiging dat de cliënt zich niet buiten de voorziening kan handhaven. ${ }^{100}$

13. De vrijheidsbeperkende maatregel voldoet aan de vereisten van proportionaliteit en effectiveit.

Aan deze lijst kunnen in een later stadium nog zorgvuldigheidseisen worden toegevoegd. Ook is denkbaar dat de lijst nog verder wordt verfijnd.

\section{Rechtsgevolgen toetsing}

Als de regionale toetsingscommissie vrijheidsbeperking oordeelt dat sprake is van onzorgvuldig handelen bij opneming, brengt zij het RIO hiervan op de hoogte. Het RIO zal vervolgens, afhankelijk van het oordeel van de regionale toetsingscommissie vrijheidsbeperking, een nieuw besluit moeten nemen.

105 Zorgvuldigheidseisen 8, 10 en 11 zijn niet van toepassing als sprake is van een toetsing van een opneming van een cliënt.

106 Zorgvuldigheideis 12 is alleen van toepassing als sprake is van een toetsing van een opneming van een cliènt. 
Als de regionale toetsingscommissie vrijheidsbeperking oordeelt dat sprake is van onzorgvuldig handelen bij de toepassing van ernstige vormen van vrijheidsbeperking, wordt het oordeel gemeld aan de Inspectie. De Inspectie kan vervolgens op grond van de Kwaliteitswet zorginstellingen maatregelen nemen. Daamaast kan de Inspectie ook tuchtrechtelijke stappen ondernemen. In dat geval moet sprake zijn van verwijtbaar handelen van een individuele beroepsbeoefenaar (een arts, een gezondheidszorgpsycholoog of een verpleegkundige). De Inspectie toetst daarnaast of de voorziening voldoet aan de eisen van de Kwaliteitswet zorginstellingen. Een onderdeel van het kwaliteitsbeleid van een voorziening vormt het instellen van een interne toetsingscommissie vrijheidsbeperking. Tevens kan de regionale toetsingscommissie aan de Inspectie doorgeven dat bepaalde voorzieningen vrijwel nooit melden en/of onzorgvuldig melden.

Tegen het eindoordeel van de regionale toetsingscommissie vrijheidsbeperking kan door een cliënt, al dan niet bijgestaan door een cliëntenvertrouwenspersoon, een vertegenwoordiger, een hulpverlener en een cliëntenvertrouwenspersoon geen beroep worden ingediend. De regionale toetsingscommissie vrijheidsbeperking moet vooral worden beschouwd als een kwaliteitsinstrument. Het zorgvuldig toetsen van (ernstige vormen van) vrijheidsbeperking bevordert dat in een voorziening systematisch aandacht wordt besteed aan het kwaliteitsbeleid rondom de toepassing van vrijheidsbeperking. Uiteraard staat wel de weg naar de rechter open (civielrecht of tuchtrecht). Daarnaast kan een cliënt, een vertegenwoordiger of een cliëntenvertrouwenspersoon zich wenden tot de klachtencommissie van de voorziening.

\section{Rol klachtencommissie en IGZ}

De (Bopz)klachtencommissies zullen naast de toetsingscommissies in stand worden gehouden. De tweede evaluatie Wet Bopz heeft echter laten zien dat deze commissies te hoogdrempelig zijn voor cliënten en vertegenwoordigers, waardoor weinig klachten bij deze commissie terecht komen. De samenstelling en deskundigheid van de commissie kan hier verandering in brengen. Ook kan een cvp'er de cliënt wijzen op de mogelijkheid om een klacht in te dienen.

Ook de Inspectie behoudt een rol in de alternatieve regeling. Haar taak is echter niet langer het toetsen en bewaken van de individuele rechtspositie van cliënten, maar het bewaken van het kwaliteitsbeleid ten aanzien van vrijheidsbeperking. Het kwaliteitsbeleid omvat o.a. een interne toetsingscommissie vrijheidsbeperking, een registratiesysteem, scholing en een visie op vrijheidsbeperking. Ook krijgt de Inspectie jaarlijks in het kader van de alternatieve regeling (en ook de Kwaliteitswet zorginstellingen) van elke voorziening een jaarverslag toegezonden, waarin een onderdeel wordt gewijd aan de toepassingen van vrijheidsbeperking en de wijze waarop invulling wordt gegeven aan de plichten die samenhangen met de interne toetsingscommissie vrijheidsbeperking. Daarnaast 
behoudt de Inspectie de mogelijkheid om individuele gegevens van een cliënt op te vragen (mede gebaseerd op artikel 5:20 Awb). Ook kan zij tijdens thematisch toezicht vragen naar individuele toepassingen van vrijheidsbeperking.

De Inspectie komt ook in beeld als op grond van een melding bij de regionale toetsingscommissie vrijheidsbeperking blijkt dat in een voorziening niet zorgvuldig wordt gehandeld als het gaat om de toepassing van vrijheidsbeperking. De Kwaliteitswet zorginstellingen bevat een aantal instrumenten die ingezet kunnen worden. ${ }^{100}$

Daarnaast kan de regionale toetsingscommissie vrijheidsbeperking aan de Inspectie doorgeven dat een bepaalde voorziening niet of nauwelijks meldt of niet nauwkeurig meldt. Op grond van de Kwaliteitswet zorginstellingen kan de Inspectie de voorziening aanspreken op haar 'gebrekkige' kwaliteitsbeleid. Ook kan zij in haar thematisch onderzoek aandacht besteden aan het meldingsbeleid van voorzieningen en de wijze waarop invulling wordt gegeven aan de plichten die samenhangen met de interne commissie toetsing vrijheidsbeperking.

\section{Voordelen regionale toetsingscommissies vrijheidsbeperking}

De wijze van externe toetsing die in de alternatieve regeling wordt voorgesteld, biedt een aantal voordelen:

1. In tegenstelling tot de Wet Bopz, wordt ook tijdens de toepassing van vrijheidsbeperking een toetsingsmoment ingebouwd. Ernstige vormen van vrijheidsbeperking, die langer dan een jaar duren, moeten worden gemeld bij de regionale toetsingscommissie vrijheidsbeperking. In de Wet Bopz wordt een toepassing van dwangbehandeling en/of noodsituatie alleen bij aanvang gemeld en bij beëindiging weer afgemeld bij de Inspectie.

2. Er ontstaat meer openheid en controle over vrijheidsbeperking. Vrijheidsbeperking heeft ook een positieve kant, mits de toepassing ervan voldoet aan de zorgvuldigheidseisen.

3. In voorzieningen voor verstandelijk gehandicaptenzorg ontstaat meer systematische aandacht voor het kwaliteitsbeleid van vrijheidsbeperking.

4. Er vindt een multidisciplinaire toetsing plaats, waarbij naast een jurist en een ethicus ook mensen uit de praktijk betrokken zijn.

5. De structuur bestaande uit een interne toetsingscommissie vrijheidsbeperking, een externe regionale toetsingscommissie vrijheidsbeperking en de Inspectie biedt meer mogelijkheden om de rechtspositie van cliënten met een verstandelijke handicap te beschermen. Uiteindelijk is het de bedoeling

107 De evaluatie Kwaliteitswet zorginstellingen laat evenwel zien dat het huidige ínstrumentarium van de Inspectie niet toereikend is. De minister spreekt de wens uit dat inspecteurs meer mogelijkheden krijgen om strenger en repressiever op te treden naar voorzieningen toe (Kamerstukken II 2002/03, 28 439, nr. 2). 
dat in de voorziening zelf, door een gedegen intern kwaliteitsbeleid, de toepassingen van vrijheidsbeperking inzichtelijk worden gemaakt, worden verantwoord en dat op zoek wordt gegaan naar alternatieven. Op deze manier zullen steeds minder meldingen doorgestuurd hoeven te worden naar de externe regionale commissies.

6. Er komt meer duidelijkheid over de begrippen noodzaak, verzet, wilsonbekwaamheid en ernstige vrijheidsbeperking.

Met de komst van een cliëntenvertrouwenspersoon, een interne toetsingscommissie vrijheidsbeperking en een regionale toetsingscommissie vrijheidsbeperking wordt ruimschoots invulling gegeven aan het aspect rechtsbescherming. Van belang is ook dat, in tegenstelling tot de Wet Bopz, de mogelijkheden van rechtsbescherming open staan voor alle cliënten waarbij vrijheidsbeperking aan de orde is.

\subsubsection{Plaats van de regeling}

De alternatieve regeling voor de toepassing van vrijheidsbeperking in de verstandelijk gehandicaptenzorg kan op diverse manieren worden ingepast in het huidige juridische kader. Er zijn verschillende scenario's denkbaar:

- De huidige Wet Bopz handhaven. Het gaat vooral om het nader invullen van begrippen zoals verzet en gevaar.

- De Wet Bopz aanpassen voor de sector verstandelijk gehandicaptenzorg. Een groot deel van de beperkingen die toegepast worden, ondervangt de Wet Bopz immers niet.

- De sector verstandelijk gehandicaptenzorg uit de Wet Bopz halen en onderbrengen in de Wgbo.

- De alternatieve regeling, naast de Wet Bopz, vormgegeven door zelfregulering.

- De Wet Bopz laten plaats maken voor een alternatieve regeling, waarbij het accent niet langer ligt op het moment van opname, maar op het behandelen en het verzorgen van cliënten. Het instellingsgebonden karakter van de wet komt te vervallen.

De voorkeur gaat in deze studie uit naar het laatste scenario. In paragraaf 7.2 luidde de conclusie dat de Wet Bopz niet de gewenste interne rechtspositie biedt aan mensen met een verstandelijke handicap. Een alternatieve regeling voor de toepassing van vrijheidsbeperking biedt, in tegenstelling tot (het aanpassen van) de Wet Bopz, meer mogelijkheden om deze rechtspositie te verbeteren. In de volgende paragrafen zullen echter eerst de voor- en nadelen van de andere sce- 
nario's de revue passeren. ${ }^{108}$ Uit de vele nadelen die worden genoemd, mag duidelijk worden dat de keuze voor een alternatieve regeling de meest voor de hand liggende optie is. ${ }^{109}$

\subsubsection{De alternatieve regeling ondergebracht in de Wet Bopz}

Het aanpassen van de Wet Bopz voor de sector verstandelijk gehandicaptenzorg heeft twee belangrijke voordelen. Allereerst hoeft het veld niet opnieuw kennis te maken met een andere wet. De uitkomsten van de eerste en tweede evaluatie onderschrijven dat hulpverleners achter de doelstellingen van de Wet Bopz staan en redelijk op de hoogte zijn van de inhoud van deze wet. Daarnaast is een voordeel dat het aanpassen van de Wet Bopz niet veel tijd in beslag hoeft te nemen. Voor de sector verstandelijk gehandicaptenzorg zal echter een groot deel van de huidige Wet Bopz moeten worden uitgeschakeld om de gewenste veranderingen door te kunnen voeren. De artikelen 38 en 39 Bopz zullen moeten worden gewijzigd, aangezien het begrip gevaar in artikel 38 lid 5 Bopz niet meer van toepassing is. Daarnaast zal het onderscheid tussen opneming en verblijf komen te vervallen. Dit betekent dat hoofdstuk 1 en 2 van de Wet Bopz moeten worden ondergebracht in hoofdstuk 3 , de interne rechtspositie van onvrijwillig opgenomen cliënten. De rechten die evenwel in hoofdstuk 3 worden genoemd gaan ook gelden voor vrijwillig opgenomen cliënten, hetgeen ook een aantal wijzigingen vereist. Het zal geen eenvoudige opgave zijn om al deze wijzigingen in te passen in de Wet Bopz.

\subsubsection{De alternatieve regeling ondergebracht in de Wgbo of Wgbo-plus}

Het is ook mogelijk dat de alternatieve regeling (gedeeltelijk) wordt ondergebracht in de Wgbo. De begeleidingscommissie evaluatie Wet Bopz deelt deze zienswijze. In het eindrapport is te lezen dat 'de beperkingsaspecten inzake de categorie geen bereidheid geen bezwaar niet zodanig zijn dat de vereiste rechtsbescherming alleen via de toepassing van de Wet Bopz gerealiseerd kan worden'. ${ }^{110}$ Blijkbaar is de begeleidingscommissie van mening dat cliënten met een Bopz-indicatie niet op een dusdanige manier in hun vrijheid worden beperkt dat een behoorlijke rechtsbescherming in de zin van de Wet Bopz is vereist. Dezelfde benadering is

108 Het eerste scenario, het handhaven van de huidige Wet Bopz zonder aanpassingen, wordt verder niet besproken. In hoofdstuk 5 en 6 zijn voldoende aanknopingspunten te vinden, op grond waarvan geconcludeerd kan worden dat dit scenario niet de voorkeur verdient.

109 Zie ook B.J.M. Frederiks en J.C.J. Dute, Evaluatie Wet Bopz: Interne rechtspositie verstandelijk gehandicapten, Nederlands Tijdschrift voor de zorg aan verstandelijk gehandicapten (28) 2002-3, p. 153-154.

110 Begeleidingscommissie evaluatie Wet Bopz 2002, p. 50. 
terug te vinden in de eerder aangehaalde uitspraak van het Europese Hof, $\mathrm{m}$ waarin het Hof oordeelde dat de plaatsing van een demente vrouw in een verpleeghuis onder de gegeven omstandigheden niet te beschouwen is als een vrijheidsbeneming in de zin van artikel 5 Evrm. Het Hof onderbouwt haar oordeel door te wijzen op het belang van de opname voor de vrouw, de ambivalente houding van de vrouw tegen de opname en het gegeven dat de vrouw zich na opname vrij kon bewegen en sociale contacten met de buitenwereld kon onderhouden. Al deze aspecten wijzen erop dat slechts sprake is van vrijheidsbeperking.

De begeleidingscommissie komt met het voorstel om cliënten die geen bereidheid en geen bezwaar tonen, de zogenaamde gbgb-groep, uit de Wet Bopz te halen. Deze benadering zou tot een betere aansluiting van de praktijk op de rechtspositieregeling van de cliënt leiden. Om te voorkomen dat de rechtspositie van deze cliënten minder adequaat wordt gewaarborgd, komt de begeleidingscommissie met een aantal aanvullende voorwaarden: ${ }^{112}$

1. Een regeling voor de objectieve vaststelling van de (wils)onbekwaamheid.

2. Een regeling op grond waarvan een vertegenwoordiger van de cliènt instemt met de opneming.

3. Een operationalisering van het begrip verzet.

4. Een zorgvuldige check, zowel kort voor de opneming als regelmatig gedurende het verblijf, op de aanwezigheid van verzet.

5. Een operationalisering van goed hulpverlenerschap.

6. Een goede regeling van het klachtrecht.

7. Een adequaat toezicht door de Inspectie

8. De ontwikkeling van een adequaat en transparant kwaliteitsbeleid inzake de zorg voor cliënten uit de gbgb-groep.

Met deze beoogde aanpassingen komt de gbgb-groep onder de Wgbo te vallen. Er wordt ook wel gesproken over een soort 'Wgbo-plus' aangezien een aantal aspecten van de Wgbo wordt aangescherpt.

De begeleidingscommissie stelt, naast het aanpassen van huidige wetgeving, een andere oplossing voor: het ontwerpen van een nieuwe wettelijke regeling. Het voordeel hiervan is dat de gehele sector verstandelijk gehandicaptenzorg onder een en dezelfde regeling kan worden geplaatst, hetgeen meer duidelijkheid creëert voor de hulpverleners in deze sector. Een mogelijk nadeel is dat het reali-

111 Europees Hof voor de Rechten van de Mens, 26 januari 2002, BJ 2002, 20, m.nt. W. Dijkers.

112 Bovenstaande punten dienen respectievelijk in de Wet Bopz (punt 1, 2, 4, 6 en 7), de Wgbo (punt 5) en de Kwaliteitswet zorginstellingen (punt 8) te worden uitgewerkt. De punten 5 en 8 lenen zich meer voor zelfregulering. 
seren van een nieuwe wet meer tijd in beslag neemt dan het verwezenlijken van de acht bovengenoemde voorwaarden, aldus de begeleidingscommissie. Aanpassing zal evenwel ook veel tijd in beslag nemen. In het eerste evaluatierapport van de Wet Bopz wordt al gesproken over het operationaliseren van het begrip verzet en het verbeteren van de regeling van het klachtrecht. Tot op heden zijn deze verbeteringen nog niet gerealiseerd. De functie cliëntenvertrouwenspersoon is, in tegenstelling tot in de psychiatrie, nog steeds niet verplicht in de verstandelijk gehandicaptenzorg. Ook is al eerder opgemerkt dat het begrip wilsonbekwaamheid niet eenvoudig is te operationaliseren. Wilsonbekwaamheid en verzet vormen echter wel de kern van de Wgbo-plus. Zodra duidelijk is dat een cliënt zich verzet tegen de toepassing van vrijheidsbeperking, valt hij alsnog onder de Wet Bopz. Daarnaast wordt in de door de begeleidingscommissie voorgestelde regeling over het hoofd gezien dat niet elke cliënt wordt bijgestaan door een vertegenwoordiger. De regeling zou in elk geval moeten worden aangevuld met het oordeel van een onafhankelijke commissie die de opneming van een cliënt toetst. Bovendien moet als voorwaarde worden toegevoegd dat een hulpverlener, bij het ontbreken van een vertegenwoordiger of indien geen toestemming van een vertegenwoordiger kan worden verkregen voor het toepassen van vrijheidsbeperking tijdens het verblijf van een cliënt, een second opinion aanvraagt.

Hoewel de begeleidingscommissie geen uitgesproken voorkeur heeft voor het aanscherpen van de Wgbo dan wel het ontwerpen van een nieuwe wettelijke regeling, lijkt de voorkeur uit te gaan naar de eerste optie. Nadelig aan deze keuze is het onderscheid dat ontstaat tussen vrijwillig opgenomen cliënten, de gbgb-groep en cliënten die zich verzetten tegen opneming en verblijf in een instituut. De keuze voor een alternatieve regeling voorkomt dit. Een ander nadeel van een Wgbo-plus is dat gbgb-cliënten adequate rechtsbescherming wordt onthouden. De Wgbo is bedoeld voor (geneeskundige) verrichtingen die tussen een cliënt en een hulpverlener worden overeengekomen en biedt geen ruimte voor de toepassing van vrijheidsbeperking, ook niet als de vertegenwoordiger instemt met de toepassing ervan. ${ }^{11}$ De toepassing van vrijheidsbeperking vraagt om een adequate regeling, die geen onderscheid maakt tussen vrijheidsbeperking die met instemming van de cliënt en/of vertegenwoordiger is toegepast en vrij-

113 De Wgbo bevat een bepaling voor vrijheidsbeperking: als een wilsonbekwame cliënt zich verzet tegen een verrichting van ingrijpende aard waarvoor een vertegenwoordiger toestemming heeft verleend, kan de verrichting toch worden uitgevoerd indien zij kennelijk nodig is teneinde ernstig nadeel voor de cliënt te voorkomen (artikel 7:465 lid 6 BW). Het gaat in dit geval om 'verzet tegen somatische handelingen' zoals het ondergaan van een operatie. Het wegnemen van een stoornis staat niet centraal. 
heidsbeperking die tegen de wil van een cliënt en of vertegenwoordiger wordt uitgevoerd. Beide vormen vragen om dezelfde waarborgen, aangezien met name bij cliënten met een verstandelijke handicap moeilijk in te schatten is of de cliënt (en ook de vertegenwoordiger) daadwerkelijk vrijwillig en weloverwogen instemt met de toepassing ervan. De interpretatie van de begrippen verzet en wilsonbekwaamheid blijft een lastig vraagstuk voor hulpverleners in deze sector.

Een ander nadeel van een Wgbo-plus regeling is dat, vergelijkbaar met de uitspraak van het Hof, ${ }^{4}$ het begrip vrijheidsbeperking nog altijd eng wordt geïnterpreteerd. Het Hof spreekt ook wel over een glijdende schaal: naarmate de maatregel meer richting vrijheidsbeneming verschuift, is meer rechtsbescherming gewenst. Op grond van deze uitspraak vallen cliënten met een Bopz-indicatie als het gaat om extra rechtsbescherming buiten de boot. Deze wijze van handelen strookt niet met de bevindingen die in hoofdstuk 6 zijn gepresenteerd. De empirische analyse maakt duidelijk dat ook cliënten met een Bopz-indicatie te maken krijgen met ingrijpende vrijheidsbeperkende maatregelen die kunnen variëren van begeleidingsafspraken tot het afzonderen en fixeren van cliënten. Een gbgb-cliënt die op een gesloten afdeling verblijft en waarbij voortdurend vrijheidsbeperkende maatregelen worden toegepast behoort gezien het ingrijpende en permanente karakter van de opneming aanspraak te kunnen maken op waarborgen die ook gelden voor cliënten die zich verzetten tegen opneming en verblijf. Het Hof kwam tot een ander oordeel dat overigens niet door alle rechters werd gedeeld. Rechter Louciades geeft in zijn dissenting opinion aan dat een opneming in een verpleeghuis, vanwege het ingrijpende karakter, om meer rechtsbescherming vraagt. Bovendien geeft hij aan dat de vraag of sprake is van vrijheidsbeneming niet afhankelijk mag zijn van de vraag of maatregel al dan niet wordt toegepast in het belang van de cliënt. Het gegeven dat de maatregel om bestwil plaatsvindt, ontneemt niet het vrijheidsbeperkende karakter ervan. Louciades wil voorkomen dat cliënten, die niet kunnen aangeven of zij bezwaar maken tegen opname dan wel bereid zijn opgenomen te worden, een deel van hun rechtsbescherming mislopen. Deze gedachtegang is ook terug te vinden in de alternatieve regeling.

\subsubsection{De alternatieve regeling vormgegeven door zelfregulering}

In de vorige paragrafen is de nadruk gelegd op wetgeving. De alternatieve regeling kan een plaats krijgen in de Wet Bopz of in een soort Wgbo-plus. Een andere optie is om de alternatieve regeling vorm te geven door middel van zelfre-

114 Europees Hof voor de Rechten van de Mens 26 januari 2002, BJ 2002, 20, m.nt. W. Dijkers. 
gulering. Twee belangrijke voordelen van zelfregulering zijn dat een grotere betrokkenheid ontstaat van het veld en een betere aansluiting wordt verkregen op het handelingsperspectief van hulpverleners en de specifieke eigenschappen van de sector verstandelijk gehandicaptenzorg. ${ }^{115}$ Een ander voordeel is dat de contouren van een alternatieve regeling sneller gestalte zullen krijgen als wordt gekozen voor zelfregulering. Tegenover deze voordelen staat ook een aantal nadelen. Zelfregulering mag dan tot meer betrokkenheid onder het veld leiden, de bindende werking die wetgeving met zich meebrengt ontbreekt. In de praktijk zal zowel de normering als de handhaving juridisch een zwakke basis hebben. ${ }^{116}$ Een ander nadeel van zelfregulering is dat hulpverleners gebonden blijven aan de Wet Bopz. Belangrijke aspecten van de alternatieve regeling zijn dat het begrip vrijheidsbeperking wordt opgerekt, vrijheidsbeperking in beginsel overal kan worden toegepast en het onderscheid tussen vrijwillig en onvrijwillig opgenomen cliënten vervalt. Het zal niet gemakkelijk zijn om deze aspecten in de praktijk toe te passen, zolang zij niet conform de huidige regels zijn.

In de afgelopen jaren heeft een aantal initiatieven op het gebied van vrijheidsbeperking door middel van zelfregulering gestalte gekregen. Een goed voorbeeld is het project Kwaliteit van Dwang en Drang ${ }^{117}$ waarin GGZ Nederland in samenwerking met het instituut voor Gezondheidsethiek in Maastricht een aantal kwaliteitscriteria heeft geformuleerd voor het toepassen van dwang en drang in de psychiatrie. Een vergelijkbaar project is begin 2004 van start gegaan voor de sector verstandelijk gehandicaptenzorg. De kwaliteitscriteria, die vanuit de praktijk worden ontwikkeld, kunnen uiteindelijk worden beschouwd als een aanvulling op of een nadere uitwerking van de begrippen die in de Wet Bopz worden gebezigd en kunnen uiteindelijk een voorzet geven voor een alternatieve regeling. Bovendien kunnen de uitkomsten van een soortgelijk project worden gebruikt voor het ontwikkelen van een standaard voor deze sector en onderdeel uitgaan maken van de professionele standaard van de verschillende beroepsgroepen. ${ }^{118}$ Het $\mathrm{CBO}$ heeft in samenwerking met de Verpleegkundige Weten-

115 F.C.B. van Wijmen en J.C.J. Dute, "Wet- en regelgeving als sturingsinstrumenten in de gezondheidszorg, in: J.C.J. Dute en H.E.G.M. Hermans (red.), Regulering van de gezondheidszorg, Maarssen: Elsevier gezondheidszorg 2000a, p. 52.

116 Van Wijmen en Dute 2000a, p. 52-53.

117 R.L.P. Berghmans e.a., Kwaliteit van dwang en drang in de psychiatrie, Utrecht/ Maastricht: Instituut voor Gezondheidsethiek, Universiteit Maastricht en GGZ Nederland 2001.

118 Op 1 januari 2004 is het project ' $k$ waliteitscriteria voor vrijheidsbeperking in de verstandelijk gehandicaptenzorg' van start gegaan. Het project wordt uitgevoerd vanuit het Gouverneur Kremers Centrum in samenwerking met de sectie 
schappelijke Raad een richtlijn ontwikkeld voor verpleegkundigen en verzorgenden in de gezondheidszorg waarin het besluitvormingsproces en het gebruik van vrijheidsbeperkende maatregelen is uiteengezet. ${ }^{119}$ Deze richtlijn wordt in een vervolgtraject aangepast aan de specifieke eigenschappen van de sector verstandelijk gehandicaptenzorg en de locatie waar de richtlijn toegepast gaat worden.

\subsubsection{De alternatieve regeling in een afzonderlijke wet}

Met de komst van een alternatieve regeling komt de Wet Bopz voor de gehele sector verstandelijk gehandicaptenzorg te vervallen. In de vorige paragraaf is aangegeven dat de regeling eventueel ook door zelfregulering kan worden vormgegeven. Voordelig aan deze keuze is dat de alternatieve regeling op korte termijn ingevoerd zou kunnen worden. Dit voordeel weegt echter niet op tegen het belangrijkste nadeel van zelfregulering: de bindende werking van wetgeving ontbreekt. Een denkbare oplossing is dat het veld, vooruitlopend op een nieuwe wet, aan de slag gaat met het ontwikkelen van kwaliteitscriteria voor de toepassing van vrijheidsbeperking in de verstandelijk gehandicaptenzorg. Op deze manier wordt het veld gestimuleerd om bewuster om te gaan met vrijheidsbeperking. Mogelijke hiaten in de Wet Bopz kunnen door middel van zelfregulering nader worden ingevuld. Naast initiatieven in het veld heeft de wetgever als taak om, mede gezien de resultaten van de tweede evaluatie Wet Bopz, een allereerste aanzet te geven voor een alternatieve regeling. Aangezien dit geen eenvoudige onderneming is, is het niet ondenkbaar dat een groep gezondheidsjuristen het voortouw gaat nemen. De eerste contouren van een alternatieve wetgeving zijn, tijdens een invitational conference op 20 november 2002, ${ }^{120}$ voorgelegd aan deskundigen uit de verstandelijk gehandicaptenzorg. Onder de aanwezigen bestond voldoende draagvlak voor een alternatieve regeling.

Vooruitlopend op het standpunt inzake de uitkomsten van de tweede evaluatie Wet Bopz heeft de staatssecretaris van VWS te kennen gegeven open te staan voor een nieuw juridisch kader voor de sector verstandelijk gehandicaptenzorg. ${ }^{121}$ Inmiddels is binnen het Ministerie van VWS een project van start gegaan

gezondheidsrecht en de sectie gezondheidsethiek en wijsbegeerte en wordt gefinancierd door vijf zorginstellingen en de VGN.

119 Kwaliteitsinstituut voor de gezondheidszorg CBO en Verpleegkundig Wetenschappelijke Raad 2002.

120 L.A.P. Arends en B.J.M. Frederiks, Alternatieve regelgeving voor de Wet Bopz in de psychogeriatrie en verstandelijk gehandicaptenzorg: Een Wet verantwoorde toepassing vrijheidsrechten?, Invitational conference, Utrecht, 20 november 2002.

121 Kamerstukken II 2003/03, 28 850, nrs. 1-2, p. 40 (Rapport Dementerenden en de Wet Bopz, Algemene Rekenkamer). 
voor het ontwikkelen van een andere wettelijke regeling als het gaat om het toepassen van vrijheidsbeperking bij mensen met een verstandelijke handicap en dementie. Vooralsnog is onduidelijk is of het gaat om een geheel nieuw wettelijk kader of slechts het aanpassen van het huidige juridische kader, de Wet Bopz.

Belangrijk voor het veld is dat in een nieuwe zorgwet meer ruimte ontstaat voor de toepassing van vrijheidsbeperking. Vanuit het oogpunt van goede zorg is vrijheidsbeperking niet alleen aan de orde als sprake is van gevaar. Meer ruimte voor hulpverleners betekent niet dat vrijheidsbeperking te pas en te onpas mag worden toegepast bij cliënten. De wetgever behoudt ook onder de alternatieve regeling de verantwoordelijkheid om de randvoorwaarden voor de toepassing van vrijheidsbeperking aan te geven. Binnen deze kaders wordt hulpverleners de ruimte geboden om te bepalen wanneer zij vrijheidsbeperking noodzakelijk achten. Daarvoor is het essentieel dat begrippen zoals noodzaak, verantwoorde zorg, goed hulpverlenerschap, goed vertegenwoordigerschap en wilsonbekwaamheid nader worden ingevuld door het veld. Het verleden leert dat dit geen eenvoudige opgave is. Mocht nu blijken dat het veld onder de alternatieve regeling onvoldoende initiatieven neemt dan blijft voor de overheid de mogelijkheid bestaan om door middel van AMvB's in te grijpen en enkele begrippen alsnog nader te omschrijven.

\subsection{Kanttekeningen alternatieve regeling}

In deze paragraaf wordt stilgestaan bij een aantal kanttekeningen die kunnen worden geplaatst bij de alternatieve regeling. In de regeling wordt een aantal nieuwe begrippen geïntroduceerd, komt het onderscheid tussen vrijwillig en onvrijwillig te vervallen en is de reikwijdte van de regeling ruimer dan die van de huidige Wet Bopz. Om te voorkomen dat deze aanpassingen in de praktijk aanleiding geven tot nieuwe problemen is het van belang dat in ieder geval aansluiting wordt gezocht bij de kwaliteitseisen die de wetgever in de nota 'Zicht op wetgeving' heeft geformuleerd. ${ }^{12}$ Volgens een van deze eisen moet de wetgever streven naar duidelijkheid en eenvoud van regelingen. Daarnaast dient wetgeving te voldoen aan de eis van uitvoerbaarheid en handhaafbaarheid. Achtereenvolgens worden de knelpunten, die zich bij de verschillende onderdelen van de alternatieve regeling kunnen voordoen, besproken.

122 In de nota 'Zicht op wetgeving' zijn zes kwaliteitseisen voor wetgeving geformuleerd. Het betreft de volgende eisen: rechtmatigheid en gerichtheid op verwerkelijking van rechtsbeginselen; doeltreffendheid en doelmatigheid; subsidiariteit en evenredigheid; uitvoerbaarheid en handhaafbaarheid; onderlinge afstemming met andere regelingen; eenvoud, duidelijkheid en toegankelijkheid (Kamerstukken II 2000-01, 22 008, nrs. 1-2). 


\subsubsection{Een aparte regeling voor de sector verstandelijk gehandicaptenzorg}

In de alternatieve regeling wordt rekening gehouden met de specifieke eigenschappen van cliënten met een verstandelijke handicap. Het gaat doorgaans om cliënten die vrijwel hun gehele leven aangewezen zijn op enige vorm van ondersteuning. Een verstandelijke handicap is, in tegenstelling tot in de psychiatrie, een stoornis die permanent aanwezig is. Van belang is dat een cliënt niet alleen leert omgaan met zijn beperkingen maar dat ook zijn mogelijkheden tot ontwikkeling worden gebracht. Meer dan 53.000 cliënten maken gebruik van ondersteund wonen. Daarvan verblijven rond 37.000 cliẻnten in een instituut, waarvan bij één op de zes cliënten sprake is van vrijheidsbeperking. Gezien deze specifieke kenmerken is een aparte regeling voor de toepassing van vrijheidsbeperking gerechtvaardigd. De sectoren psychiatrie en verstandelijk gehandicaptenzorg blijken op een aantal punten wezenlijk van elkaar te verschillen. Ook de terminologie van de Wet Bopz past niet bij de sector verstandelijk gehandicaptenzorg.

Recente ontwikkelingen doen de vraag rijzen of een aparte regeling voor de sector verstandelijk gehandicaptenzorg wel de voorkeur geniet. De grenzen tussen de verschillende sectoren zijn steeds meer aan het vervagen waardoor het afbakenen van een sector steeds minder van deze tijd is. Door de modernisering van de AWBZ zullen niet alleen de schotten tussen intramurale, semi-murale en extramurale zorg gaan verdwijnen maar kunnen cliënten met een verstandelijke handicap ook buiten hun eigen sector aanspraak maken op ondersteuning. . $^{23}$ Een cliënt met een verstandelijke handicap krijgt in het vervolg van het RIO een AWBZ-indicatie voor één van de zeven functies. ${ }^{124}$ Ook de term community care overstijgt het denken in sectoren. Door deze ontwikkeling als perspectief voorop te stellen, trachten beleidsmakers en belangenorganisaties om de kunstmatige scheiding tussen doelgroepen te overbruggen. Community care heeft immers tot doel om mensen met beperkingen volwaardig aan de samenleving te laten deelnemen, ongeacht het type beperking waarmee zij leven. ${ }^{125}$

Al deze recente ontwikkelingen maken duidelijk dat in de gezondheidszorg niet meer gedacht wordt in voorzieningen, maar in functies van zorg. Deze ontwik-

123 Met de gemoderniseerde AWBZ kunnen voorzieningen voor verstandelijk gehandicaptenzorg meerdere functies leveren aan meerdere doelgroepen (Besluit zorgaanspraken AWBZ van 25 oktober 2002, Stb. 527, p. 23).

124 De indicatiestelling voor deze functies is geregeld in het zorgindicatiebesluit (Besluit van 2 oktober 1997, Stb. 447). Dit besluit is door de modernisering van de AWBZ op een aantal punten gewijzigd. Deze wijzigingen staan aangegeven in het Besluit zorgaanspraken AWBZ (Besluit van 25 oktober 2002, Stb. 527).

125 RMO 2002, p. 13. 
kelingen staan haaks op de alternatieve regeling, die specifiek voor de sector verstandelijk gehandicaptenzorg is geschreven. Een voordeel van deze regeling is dat wordt uitgegaan van een persoonsgerichte benadering: ongeacht de status en de plaats waar de cliënt verblijft is vrijheidsbeperking mogelijk. Door uit te gaan van deze denkwijze wordt het ook mogelijk om cliënten met een verstandelijke handicap, die in een verpleeghuis of in een substitutieproject van een verzorgingshuis verblijven, te beperken in hun vrijheid. Een voorziening zal op dat moment moeten aangeven dat hij over voldoende deskundigheid beschikt om cliënten met een dergelijke problematiek aan te nemen.

\subsubsection{Criteria voor de toepassing van vrijheidsbeperking: gevaar wordt vervangen door noodzaak}

In de alternatieve regeling wordt een aantal randvoorwaarden vastgelegd. Elke toepassing van vrijheidsbeperking dient te voldoen aan de eisen van kwaliteit en transparantie. De beslissing wanneer moet worden overgegaan tot de toepassing van vrijheidsbeperking blijft echter voorbehouden aan de hulpverlener. De alternatieve regeling introduceert het begrip noodzaak: 'Een vrijheidsbeperking vindt niet plaats, dan nadat de noodzaak van de toepassing ervan is vastgesteld'. Noodzaak kan worden beschouwd als een operationalisering van goede zorg. Critici zullen het begrip noodzaak niet met open armen ontvangen. $\mathrm{Zij}$ zullen erop wijzen dat de deuren wagenwijd open worden gezet voor de toepassing van vrijheidsbeperking. Deze kritiek is echter niet terecht. Het begrip noodzaak is niet nieuw in deze sector. In artikel 60 Wet Bopz wordt gesproken over de noodzaak van opneming. 'De (...) noodzaak is aanwezig, indien de betrokkene zich ten gevolge van de stoornis van de geestvermogens niet buiten de inrichting kan handhaven' (artikel 60 lid $4 \mathrm{Bopz}$ ). Als het daarentegen gaat om de toepassing van vrijheidsbeperking gedurende het verblijf wordt in de Wet Bopz noodzaak vervangen door gevaar.

In de alternatieve regeling wordt het begrip gevaar niet genoemd: de gevaarssituaties worden door het noodzaakcriterium gedekt. Hoofdstuk 5 en 6 illustreren dat dit criterium beter past bij de sector verstandelijk gehandicaptenzorg. Het biedt meer mogelijkheden voor hulpverleners om de vrijheid van cliënten (tijdig) te beperken. ${ }^{126}$ Het is echter niet de bedoeling dat het aantal toepassingen

$126 \mathrm{Al}$ eerder in dit hoofdstuk is opgemerkt dat het onvermijdelijk is dat vrijheidsbeperking op bepaalde momenten wordt toegepast. Dit geldt ook als sprake is van gevaar voor andere cliënten of hulpverleners. Het begrip noodzaak wordt in dit geval opgerekt: vrijheidsbeperking wordt niet direct uit noodzaak voor de ontwikkeling van een cliënt toegepast. Het belang van een andere cliënt prevaleert in dit geval. Als in deze situatie vrijheidsbeperking onvermijdelijk is moet worden gezocht naar een manier die het minst ingrijpend is 
onder de alternatieve regeling explosief gaat toenemen. De essentie van de alternatieve regeling is dat vrijheidsbeperking een ultimum remedium blijft. Een hulpverlener moet kunnen aantonen dat de vrijheidsbeperkende maatregel doelmatig is, in verhouding staat tot het doel dat wordt beoogd en dat een alternatief met een minder ingrijpend karakter ontbreekt. Daarnaast moet hij ook rekening houden met de andere zorgvuldigheidseisen op grond waarvan de regionale toetsingscommissies vrijheidsbeperking beoordelen of sprake is van zorgvuldig handelen. Naast het voldoen aan het noodzakelijkheidcriterium geldt nog een aantal andere zorgvuldigheidseisen.

Hoewel de alternatieve regeling een ruimer criterium kent voor de toepassing van vrijheidsbeperking, bevat de regeling meer waarborgen dan onder de huidige Wet Bopz het geval is. Nieuwe elementen zijn een cliëntenvertrouwenspersoon, een interne toetsingscommissie vrijheidsbeperking en een regionale toetsingscommissie vrijheidsbeperking. Ook kunnen cliënten, ${ }^{12}$ vertegenwoordigers en cliëntenvertrouwenspersonen, naast het indienen van een klacht bij de klachtencommissie, zich wenden tot de rechter, als zij zich niet kunnen vinden in het oordeel van de regionale toetsingscommissie vrijheidsbeperking.

De mogelijkheid voor cliënten om naar de rechter toe te stappen ondervangt een ander kritiekpunt. Op grond van artikel 5 lid 4 Evrm dient elke vorm van vrijheidsbeneming door een rechter te worden getoetst. De Wet Bopz biedt deze mogelijkheid alleen aan cliënten die zich verzetten tegen opneming en niet aan cliënten die met een artikel 60 indicatie worden opgenomen. ${ }^{128} \mathrm{Bij}$ de totstandkoming van de Wet Bopz is veel kritiek geuit op deze wijze van handelen. In het Winterwerp-arrest is echter bepaald dat bij de procedure niet altijd een rechter betrokken hoeft te zijn, het mag ook een administratief orgaan zijn. ${ }^{129}$ Vereist is dat de toetsing plaatsvindt overeenkomstig een wettelijk voorgeschreven proce-

voor betrokken cliënt. Een hulpverlener zou zich in een dergelijke situatie ook kunnen beroepen op een conflict van plichten: het belang van een ander prevaleert in dit geval boven het belang van de cliënt (artikel $40 \mathrm{WvSr}$ ).

127 Een cliẻnt kan in dat geval worden bijgestaan door een clièntenvertrouwenspersoon.

128 Tijdens het verblijf van beide groepen cliënten is de situatie gelijk: op grond van artikel 41 Bopz kan een onvrijwillig opgenomen cliënt, waartoe ook een cliënt met een artikel $60 \mathrm{Bopz}$-indicatie gerekend wordt, een klacht indienen over de toepassing van dwangbehandeling of middelen of maatregelen. Indien deze klacht ongegrond wordt verklaard door de klachtencommissie, kan de cliënt zelf (artikel 41 lid 11) of de inspecteur vragen (artikel 41 lid 7) een verzoekschrift in te dienen ter verkrijging van de beslissing van de beslissing van de rechter over de klacht.

129 EHRM 24 oktober 1979, NJ 1980, 114 
dure (artikel 5 lid 1 aanhef en lid 1* Evrm) alsmede dat de vrijheidsbeneming achteraf door de cliënt of vertegenwoordiger kan worden voorgelegd aan een rechterlijke instantie. De artikel 60 procedure voldoet aan beide vereisten: zodra sprake is van verzet staat de toegang tot de rechter open. In de literatuur bestaat nog wel enige discussie over de mate van onafhankelijkheid van het indicatieorgaan en in hoeverre dit zich verdraagt met de strekking van artikel 5 Evrm. ${ }^{130}$ Rechters zullen, op grond van hun opleiding, hun status en ervaring doorgaans een andere toetsing verrichten dan indicatiecommissies.

\subsubsection{De reikwijdte van de regeling: toename van het aantal toepassingen van vrij- heidsbeperking}

De Wet Bopz heeft een beperkte reikwijdte. Alleen cliënten die onvrijwillig zijn opgenomen en verblijven in een instituut met een Bopz-aanmerking mogen worden beperkt in hun vrijheid. De alternatieve regeling laat het onderscheid tussen vrijwillig en onvrijwillig opgenomen cliënten vervallen en beperkt haar reikwijdte niet alleen tot instituten. Door deze wijzigingen krijgen hulpverleners meer speelruimte om vrijheidsbeperking toe te passen bij cliënten. Het gevaar bestaat dat hulpverleners ook meer vriiheidsbeperkende maatregelen gaan toepassen. $\mathrm{Zij}$ hoeven geen rekening meer te houden met de locatie waar een cliënt verblijft en ook niet te verifiëren of een cliënt onvrijwillig is opgenomen. De verwachting is echter dat er geen toename van vrijheidsbeperking zal plaatsvinden. Onder de Wet Bopz worden veel vrijheidsbeperkende maatregelen gedoogd. Deze studie heeft laten zien dat ook bij vrijwillig opgenomen cliënten vrijheidsbeperking op ruime schaal plaatsvindt. Daarnaast wordt vrijheidsbeperking ook buiten een instituut toegepast. Het huidige gedoogbeleid leidt tot ongelijkheden in de rechtspositie van cliënten. Een cliënt die verblijft in een gvt en te maken krijgt met vrijheidsbeperking geniet op dit moment niet dezelfde rechtspositie als een onvrijwillig opgenomen cliënt in een instituut. Vrijwillig opgenomen cliẻnten vallen onder de Wgbo, die minder bescherming biedt dan de Wet Bopz.

\subsubsection{De locaties van vrijheidsbeperking: onvoldoende toezicht op bepaalde locaties}

Een hulpverlener mag onder de alternatieve regeling in beginsel ook vrijheidsbeperkende maatregelen bij cliënten in de thuissituatie toepassen. De opdracht tot het toepassen van vrijheidsbeperking moet worden gegeven door een arts of een gedragsdeskundige. De feitelijke toepassing kan worden verricht door hulpverleners of personen die hiertoe bekwaam zijn. Dit hoeft niet in alle gevallen

130 Frijlink en Te Braake 1990, p. 955-961. 
een verzorgende of een verpleegkundige te zijn, maar mag ook een familielid zijn. De enige voorwaarde die de alternatieve regeling stelt is dat het familielid bekwaam moet zijn om de vrijheidsbeperkende maatregel toe te passen. De arts of gedragsdeskundige blijft eindverantwoordelijk voor de toepassing van vrijheidsbeperking. Een probleem in de thuissituatie is het doorlopende toezicht op bepaalde maatregelen en de uitvoerbaarheid van deze maatregelen. Separatie, fixatie en afzondering zijn maatregelen die vanwege de risico's, voortdurend toezicht vereisen. Een ander probleem vormt de bekwaamheid van familieleden. Niet alle vormen van vrijheidsbeperking kunnen door familieleden worden uitgevoerd. ${ }^{\text {in }}$ Fixatie en separatie zijn maatregelen die met grote zorgvuldigheid moeten worden toegepast. Deze problemen komen overigens ook voor in andere woonvormen. Steeds meer cliënten gaan kleinschaliger wonen. In deze woonvormen is niet sprake van doorlopend toezicht. Ook zullen deze woonvormen niet beschikken over een afzonderings- of een separeerruimte, wat betekent dat deze maatregelen niet langer mogen worden toegepast.

De alternatieve regeling biedt de mogelijkheid om bij $\mathrm{AMvB}$ nadere regels te stellen omtrent de veiligheid van toepassingen van vrijheidsbeperking. Denkbaar is dat ingrijpende vormen van vrijheidsbeperking niet door familieleden mogen worden toegepast. Daarnaast moet voor bepaalde vormen van vrijheidsbeperking, die door hulpverleners en/of familieleden worden uitgevoerd, voldoende zijn gewaarborgd dat voldaan is aan het vereiste van doorlopend toezicht. Een andere optie is om separatie, afzondering en fixatie niet toe te laten in bepaalde woonvormen, waaronder de thuissituatie. ${ }^{132}$ In paragraaf 7.4 is ook aan de orde gekomen dat voorzieningen de mogelijkheid moeten hebben om aan te geven waar voor hen de grenzen van ondersteuning liggen. Een voorziening kan vanwege de bouw van een voorziening, de locatie of een tekort aan deskundig personeel besluiten om een risicovolle handeling als separatie niet toe te passen. Dergelijke beslissingen maken onderdeel uit van het kwaliteitsbeleid in een

131 Naast voorbehouden handelingen die in de Wet big zijn vastgelegd, spreekt het veld ook wel over risicovolle handelingen. Deze handelingen zijn alleen voorbehouden aan bepaalde personen en zijn vastgelegd in wetgeving, waaronder de Wet Bopz. In deze wet is bepaald dat middelen of maatregelen alleen door een arts mogen worden toegepast (Nota van Toelichting bij het Besluit van 3 november 1993 , Stb. 563 , p. 3-4).

132 Sinds 1 april 2000 bestaat echter al voor ouders de mogelijkheid om op grond van de Wet Voorzieningen Gehandicaptenzorg subsidie aan te vragen voor het bouwen van een uitraaskamer. Artikel 1, lid 1c Wvg bepaalt dat 'tot de woonvoorziening wordt ook een uitraaskamer gerekend, waaronder wordt verstaan een verbliffsruimte waarin een gehandicapte, die vanwege een gedragsstoornis ernstig ontremd gedrag vertoont, zich kan afzonderen of tot rust kan komen'. 
voorziening en worden vastgelegd in het zorgplan van een cliënt. Van belang is dat een voorziening binnen de mogelijkheden die zij ter beschikking heeft goede zorg biedt aan cliënten. De keuze voor een dergelijk beleid heeft als consequentie dat niet alle functies, die in de AWBZ staan omschreven, worden geboden door een voorziening of een bepaalde locatie van een voorziening.

Hulpverleners komen op verschillende manieren in aanraking met vrijheidsbeperking in de thuissituatie. $\mathrm{Zij}$ kunnen op verzoek van de cliënt of familieleden van de cliënt worden betrokken bij de ondersteuning die thuis aan een cliënt wordt geboden. Denkbaar is echter ook dat hulpverleners indirect op de hoogte worden gebracht van vrijheidsbeperkende maatregelen bij cliënten die thuis wonen. Van een hulpverlener wordt verwacht dat hij zich afzijdig opstelt als het gaat om de thuissituatie van een cliënt. Dit gebied behoort tot de privé-sfeer van cliënten waarover hulpverleners weinig tot niets in te brengen hebben. Deze situatie verandert als een hulpverlener het vermoeden heeft dat binnen de thuissituatie sprake is van ondeskundig gebruik van vrijheidsbeperkende maatregelen waardoor gevaarlijke situaties (kunnen) ontstaan voor de cliënt. Een hulpverlener mag echter niet zonder gegronde redenen ingrijpen in de thuissituatie van een cliënt. Een meldcode voor hulpverleners in de zorg voor mensen met een verstandelijke handicap, analoog aan de meldcode kindermishandeling, ${ }^{13}$ kan in dit geval uitkomst bieden. Een melding van een hulpverlener kan aanleiding geven tot een nader onderzoek.

Om de rol en de mogelijkheden van hulpverleners aangaande de toepassing van vrijheidsbeperking in de thuissituatie nader te omschrijven is evenwel meer onderzoek nodig. In een dergelijk onderzoek dient aandacht te worden besteed aan het aspect toezicht, het afbakenen van grenzen (welke vormen van vrijheidsbeperking mogen in de thuissituatie worden toegepast) en de deskundigheid van mantelzorgers betreffende de toepassing van vrijheidsbeperking. Een gevolg van de alternatieve regeling is dat een hulpverlener (een verpleegkundige, een verzorgende of een huisarts) in de thuissituatie rekening dient te houden met de eisen van transparantie en kwaliteit waaronder het registreren van vrijheidsbeperking en een regelmatige toetsing en evaluatie van de vrijheidsbeperkende maatregelen. Ook de thuiszorgorganisatie heeft de verplichting om een interne toetsingscommissie vrijheidsbeperking in te stellen.

\subsubsection{Het begrip vrijheidsbeperking: gradaties aanbrengen}

De alternatieve regeling gooit alle vormen van vrijheidsbeperking op één hoop: alle mogelijke vormen van vrijheidsbeperking worden onder de regeling ge-

133 KNMG, Meldcode voor medici inzake kindermishandeling, Utrecht: 2002. 
plaatst. ${ }^{19}$ Deze dienen allen te voldoen aan dezelfde eisen van kwaliteit en transparantie. Deze ruime benadering heeft als voordeel dat inzichtelijk wordt gemaakt op welke verschillende manieren een cliënt in zijn vrijheid wordt beperkt. De nadruk komt niet alleen te liggen op de bekende, veel genoemde vormen van vrijheidsbeperking zoals separatie en fixatie, maar ook op minder ingrijpende vormen waaronder het begrenzen van het aantal consumpties alcohol, niet alleen op de weg mogen fietsen of niet op bezoek mogen gaan bij andere cliënten. Deze laatste drie voorbeelden worden door de buitenwereld doorgaans als minder ingrijpend ervaren. De cliënt kan de maatregel evenwel op cen hele andere manier ervaren omdat hij veel waarde hecht aan het alleen op stap gaan of het nuttigen van alcohol.

Een mogelijke tegenwerping is de tijd die hulpverleners kwijt zijn aan het registreren en evalueren van vrijheidsbeperking. Het gevaar bestaat dat deze vermeerdering van de administratieve werklast ten koste gaat van het verlenen van goede zorg. Er moet een redelijke verhouding bestaan tussen enerzijds het bieden van rechtsbescherming en anderzijds het bieden van goede zorg aan cliènten. Het lijkt daarom aantrekkelijk gradaties in vrijheidsbeperking aan te brengen. Een optie is dat alleen ernstige vormen van vrijheidsbeperking dienen te voldoen aan de zorgvuldigheideisen die neergelegd zijn in de alternatieve regeling. ${ }^{135}{ }^{136}$ Een voorbeeld van een ernstige vorm van vrijheidsbeperking is een van de middelen of maatregelen uit de Wet Bopz. Het is echter niet eenvoudig om enkel en alleen aan de hand van de inhoud van de maatregel vast te stellen welke vormen van vrijheidsbeperking ernstig zijn en welke niet. Elke cliënt ervaart vrijheidsbeperking op zijn eigen manier. Voor een cliënt kan een alcoholrestrictie ingrijpender zijn dan dat hij een half uur in een afzonderingsruimte moet doorbrengen. Een andere cliënt kan precies het tegenovergestelde ondervinden. Vooralsnog moeten alle vrijheidsbeperkende maatregelen daarom voldoen aan dezelfde eisen. Blankman koppelt in zijn preadvies de ernst van vrijheidsbeperking aan de mate van wilsonbekwaamheid: ernstige vrijheidsbeneming veron-

134 Het vrijheidsbeperkende karakter van een maatregel wordt ook niet ontnomen als een cliënt of zijn vertegenwoordiger toestemming verleent voor de toepassing van vrijheidsbeperking.

135 Dit betekent ook dat niet elke toepassing van vrijheidsbeperking even frequent hoeft te worden geregistreerd: de intensiteit van de registratie staat in verhouding tot de intensiteit van vrijheidsbeperking.

136 De Wbp bevat zorgvuldigheidseisen voor het verwerken van persoonsgegevens. Binnen persoonsgegevens onderscheidt deze wet de categorie 'bijzondere persoonsgegevens' (paragraaf 2 Wbp). De verwerking van persoonsgegevens betreffende iemands gezondheid mag alleen geschieden als aan een aantal aanvullende voorwaarden is voldaan (artikel $21 \mathrm{Wbp}$ ). 
derstelt wilsonbekwaamheid:'Aan de hand van de door het Europees Hof ontwikkelde criteria en met gebruikmaking van praktisch toepasbare richtlijnen inzake verzet en vaststelling van wilsonbekwaamheid dient een weging plaats te vinden.' ${ }^{137}$ Onduidelijk blijft op welke wijze deze weging plaats moet vinden. De uitspraak van Blankman, dat ernstige vrijheidsbeneming wilsonbekwaamheid veronderstelt, wringt met de jurisprudentie van het Europese Hof. ${ }^{138}$ Positief aan het voorstel van Blankman is dat hij ernstige vormen van vrijheidsbeperking meer waarborgen toebedeelt, in dit geval de betrokkenheid van de rechter. Om dergelijke discussies, die bovendien leiden tot waardeoordelen, te voorkomen wordt in de alternatieve regeling geen gewogen oordeel gegeven. Elke vorm van vrijheidsbeperking wordt in beginsel op dezelfde wijze benaderd. ${ }^{139}$

Om een geheel andere reden, namelijk het bieden van meer rechtsbescherming, is in de alternatieve regeling toch enige gradatie in vrijheidsbeperking aangebracht. Dit betekent allerminst dat minder ernstige vormen van vrijheidsbeperking worden uitgesloten van de eerder genoemde eisen van kwaliteit en transparantie. Het gaat in dit geval om extra waarborgen voor ernstige vormen van vrijheidsbeperking. Het onderscheid tussen ernstig en minder ernstig wordt niet bepaald door de aard van de maatregel, maar door de duur van de maatregel. Elke maatregel die langer dan een jaar voortduurt wordt door de interne toetsingscommissie vrijheidsbeperking gemeld aan de regionale toetsingscommissie vrijheidsbeperking. Positief aan deze werkwijze is dat hulpverleners worden gedwongen om een inventarisatie te maken van alle voorkomende vrijheidsbeperkingen. Veel van deze maatregelen zullen als vanzelfsprekend worden ervaren. De verwachting is dat, als eenmaal inzichtelijk is gemaakt welke vormen van vrijheidsbeperking bij een cliënt worden toegepast en over welke periode, het steeds minder tijd zal gaan kosten om te voldoen aan de zorgvuldigheidseisen die worden genoemd in de alternatieve regeling.

Een ander argument om gradaties aan te brengen in vrijheidsbeperking hangt samen met de bevoegdheid van hulpverleners om vrijheidsbeperking toe te passen. De Wet big noemt dertien (groepen van) voorbehouden handelingen (artikel 36 Wet Big), waartoe vrijheidsbeperking niet wordt gerekend. Deze afwezigheid in de Wet big betekent niet dat vrijheidsbeperking door iedereen mag wor-

137 Blankman 2003, p, 96-97.

138 Europees Hof voor de Rechten van de Mens, 26 januari 2002, BJ 2002, 20, m.nt. W. Dijkers.

139 Er geldt overigens wel de volgende uitzondering: niet elke vrijheidsbeperkende maatregel die langer dan een jaar duurt wordt voorgelegd aan de regionale toetsingscommissie vrijheidsbeperking. Het moet gaan om een 'fysieke' beperking in de vrijheid of medicatie. Hierdoor vallen alcoholrestricties buiten de definitie. 
den toegepast. Naast voorbehouden handelingen wordt in het veld en ook door de Inspectie gesproken over risicovolle handelingen. Het fixeren van een cliënt mag door een persoonlijk begeleider worden uitgevoerd, mits voldaan is aan aanvullende voorwaarden: de fixatie vindt plaats in opdracht van een arts en de persoonlijk begeleider heeft scholing gevolgd op het gebied van fixatie. In de alternatieve regeling krijgt naast de arts ook de gedragsdeskundige een bevoegdheid in deze. Het is evenwel nog maar de vraag of het alleenrecht van beiden stand kan houden. Onder de alternatieve regeling wordt het begrip vrijheidsbeperking opgerekt, waardoor een arts en een gedragsdeskundige over veel toepassingen moeten beslissen. Niet ondenkbaar is dat persoonlijk begeleiders in de praktijk degene zijn die over (eenvoudige vormen van) vrijheidsbeperking een besluit nemen. Beslissingen aangaande het aantal boterhammen dat een cliënt mag eten, de hoeveelheid bier die hij mag drinken, de vraag of hij twee of drie keer per week naar huis mag bellen vereisen niet voortdurend de betrokkenheid van een arts of een gedragsdeskundige. Voorlopig wordt het strikte regime van de alternatieve regeling aangehouden en dient de betrokkenheid van een arts en een gedragsdeskundige zoveel mogelijk te worden gehandhaafd. Een belangrijke reden hiervoor is dat hulpverleners zich eerst moeten realiseren welke verschillende vormen van vrijheidsbeperkende maatregelen zij aanwenden, alvorens de bevoegdheid tot het nemen van deze beslissingen wordt uitbesteed aan lager opgeleiden.

\subsubsection{Toestemming van de cliënt}

Nadat de arts of de gedragsdeskundige'bij een cliënt heeft vastgesteld dat vrijheidsbeperking noodzakelijk is, dient hij toestemming te vragen aan de cliënt of bij wilsonbekwaamheid van een cliënt aan diens vertegenwoordiger. Indien de betrokken cliënt wilsbekwaam is en geen toestemming verleent voor de toepassing van vrijheidsbeperking, dient een hulpverlener het standpunt van de cliënt te respecteren. ${ }^{140}$ Deze wijze van handelen komt tegemoet aan de eisen die in artikel 3 en artikel 8 Evrm zijn vastgelegd. De strekking van artikel 3 Evrm is dat niemand tegen zijn wil mag worden onderworpen aan een onmenselijke behandeling. Alleen een medische noodzaak of het beschermen van de rechten van

140 De Wgbo hanteert hetzelfde uitgangspunt. De mening van een wilsbekwame cliënt dient te allen tijde te worden gerespecteerd. Dit geldt in beginsel ook voor de mening van een wilsonbekwame cliënt. Alleen als voldaan is aan een drietal criteria - ingrijpende verrichting, vertegenwoordiger heeft toestemming verleend, verrichting is nodig om ernstig nadeel voor de cliënt te voorkomen mag een behandeling tegen de wil van een wilsonbekwame cliënt worden doorgezet (artikel 7:465 lid 6 BW). 
anderen vormen een rechtvaardiging voor het ingrijpen in de vrijheid van eer cliënt. In het eerste geval dient het wel te gaan om een wilsonbekwame cliënt. ${ }^{4}$ Uit het oogpunt van goede zorg is het van belang dat een hulpverlener, die te maken krijgt met een weigering van een cliënt, zeer nauwgezet te werk gaat. ${ }^{14}$ Het vragen van een second opinion is in dit geval zeker geen overbodige luxe Een cliënt die een noodzakelijke somatische handeling weigert, is ook niet pel definitie wilsonbekwaam. Hij kan gegronde redenen hebben voor deze weige ring. Als een cliënt toch onterecht wilsonbekwaam wordt verklaard, heeft hij dt mogelijkheid om zich, eventueel bijgestaan door een cliëntenvertrouwensper soon, te wenden tot een regionale toetsingscommissie vrijheidsbeperking dit vervolgens uitspraak kan doen over de toepassing van vrijheidsbeperking Daarmee wordt ook indirect een oordeel gegeven over de wilsonbekwaam heidsbeoordeling.

De Wet Bopz kent ook waarde toe aan verzet van een wilsonbekwame cliënt Alleen als sprake is van gevaar mag een hulpverlener tegen diens wil ingrijper in de vrijheid van een wilsonbekwame cliënt. De alternatieve regeling gaat an ders om met verzet van een wilsonbekwame cliënt. Deze regeling kent een an dere ingang voor de toepassing van vrijheidsbeperking. Allereerst wordt be paaid of een client wilsonbekwaam is. Als dit het geval is, wordt de vertegenwoordiger om toestemming gevraagd. Het verzet van een wilsonbekwame cliënt is op dat moment minder relevant. Een belangrijke reden voor deze wijziging is dat het niet mogelijk is om goede zorg te bieden aan cliënten als elk verzet als verzet wordt geïnterpreteerd. De empirische analyse laat zien dat onder de huidige wetgeving ook al veel verzet wordt genegeerd. Dit alles betekent niet dat verzet van een wilsonbekwame cliënt in de alternatieve regeling geen rol meer speelt. De alternatieve regeling biedt een aantal waarborgen waardoor zorgvuldiger kan worden omgegaan met de interpretatie van verzet. Het betreft de introductie van een cliëntenvertrouwenspersoon die op de hoogte wordt gebracht van de toepassing van vrijheidsbeperking. Ook moet een hulpverlener een second opinion vragen aan een onafhankelijke hulpverlener als de vertegenwoordiger ontbreekt of geen toestemming geeft. Naast deze waarborgen kan een wilsonbekwame cliënt, die het niet eens is met de verklaring dat hij wilsonbekwaam ter zake is, zich wenden tot een regionale toetsingscommissie vrijheidsbeperking. Hij kan worden bijgestaan door de cliëntenvertrouwenspersoon. Wilsonbekwaamheid en verzet zijn dusdanig met elkaar verbonden dat indirect ook een oordeel wordt gevraagd over het verzet van de cliënt. Als de

141 EHRM 24 september 1992, NJ 1993, 523.

142 Het uitgangspunt bij elke cliënt is dat hij zijn wil kan bepalen, tenzij het tegendeel blijkt. Daarbij moeten aan de bekwaamheid van cliënten geen hogere eisen worden gesteld dan in het algemeen bij mensen (Leenen 2000, p. 216). 
commissie van mening is dat de cliënt toch wilsbekwaam is, wordt daarmee ook het eventuele verzet van deze cliënt tegen de toepassing van vrijheidsbeperking gerespecteerd. Naast de cliënt heeft ook de cliëntenvertrouwenspersoon de mogelijkheid om een individuele melding te doen bij de regionale toetsingscommissie. Deze melding kan betrekking hebben op de toepassing van vrijheidsbeperking, die plaatsvindt bij een zich verzettende wilsonbekwame cliënt.

\subsection{Slot}

De alternatieve regeling zou op diverse punten een verbetering betekenen voor de rechtspositie van cliënten die te maken krijgen met vrijheidsbeperking. Elke cliënt die in zijn vrijheid wordt beperkt kan aanspraak maken op dezelfde waarborgen. Positief is ook de introductie van een cliëntenvertrouwenspersoon, een interne toetsingscommissie vrijheidsbeperking en een regionale toetsingscommissie vrijheidsbeperking. Daarnaast vervalt het onderscheid tussen vrijwillig en onvrijwillig opgenomen cliënten en wordt in de regeling rekening gehouden met de ontwikkelingen die gaande zijn in deze sector. Dit laatste aspect vergroot de kans op succes in de praktijk. Hulpverleners zullen zich meer schikken naar de inhoud van de alternatieve regeling, naarmate meer aansluiting is gezocht bij de praktijk.

De Wet Bopz heeft ertoe geleid dat hulpverleners bewuster omgaan met de toepassing van vrijheidsbeperking. In de nabije toekomst zal deze bewustwording moeten worden vergroot, wil de rechtspositie van cliënten op een redelijk niveau komen. Heldere en duidelijke wetgeving kan hiertoe bijdragen. Kastelein wijst in haar inaugurale rede op een aahtal algemene toetsingscriteria die voor wetgeving van belang zijn. ${ }^{143}$ Naast de aanwijzingen voor regelgeving wijst zij erop dat in het gezondheidsrecht niet meer moet worden geregeld dan noodzakelijk is, er meer onderlinge afstemming vereist is en de handhaafbaarheid en het toezicht adequaat moeten worden geregeld en ook op elkaar moeten worden afgestemd. Tot slot verdient het aanbeveling als zaken concreet worden geregeld. Met dit laatste wordt bedoeld dat de wetgever zoveel mogelijk aansluiting moet zoeken bij de praktijk, dat juridische normen niet te abstract moeten worden vormgegeven en dat zelfregulering alleen een optie is als consensus in het veld aanwezig is.

In de alternatieve regeling wordt op een aantal punten de mogelijkheid geboden om bij AMvB nadere regels te stellen ter verdere invulling van een aantal onduidelijke begrippen. Als medewerking van het veld daadwerkelijk uitblijft, zal de

143 W.R. Kastelein, Patiëntenwetgeving: bureaucratie of bescherming? Toetsing van (evaluatie van) patiëntenwetgeving (inaugurale rede Nijmegen), Lelystad: Koninklijke Vermande 2002, p. 27-28. 
wetgever zelf actie moeten ondernemen. Vooruitlopend op een alternatieve regeling zou het wenselijk zijn, als het veld alvast aan de slag zou gaan. Op het gebied van vrijheidsbeperking doen zich genoeg mogelijkheden voor: het ontwikkelen van kwaliteitscriteria voor de toepassing van vrijheidsbeperking, het verder vormgeven van de professionele standaarden en het ontwikkelen van (procedurele) criteria voor verantwoorde zorg en wilsonbekwaamheid. De taak van de wetgever is om een alternatieve regeling te ontwerpen waarin geen onduidelijke normen zijn opgenomen, de relatie met andere wetgeving (de Wgbo, de Wet big en de Kwaliteitswet zorginstellingen) duidelijk is en de handhaafbaarheid en toezicht op het handelen van hulpverleners adequaat is geregeld. 


\section{Conclusies en aanbevelingen}

In deze studie stond de volgende probleemstelling centraal: 'Wat is de (interne) rechtspositie van cliënten in de zorg voor mensen met een verstandelijke handicap in relatie tot de toepassing van vrijheidsbeperking, hoe krijgt deze in de praktijk gestalte en welke aanbevelingen kunnen terzake worden gedaan?' Deze probleemstelling is uitgewerkt in een aantal vraagstellingen die hier aan de hand van de belangrijkste bevindingen worden behandeld. Bij elke vraagstelling wordt ook een aantal aanbevelingen gedaan.

Wat is het gezondheidsrechtelijke kader voor de (interne) rechtspositie van cliënten in de zorg voor mensen met een verstandelijke handicap?

Het gezondheidsrechtelijke kader inzake de (interne) rechtspositie van cliënten in de zorg voor mensen met een verstandelijke handicap is gebaseerd op vier rechtsbeginselen, die invulling geven aan de relatie tussen de chiënt en de hulp. verlener. Naast het recht op bescherming en het recht op zelfbeschikking, nemen het recht op goede zorg en het recht op ontplooiing een centrale plaats in. De toevoeging van deze twee laatste rechtsbeginselen is gebaseerd op de gedachte dat zelfbeschikking en bescherming op zichzelf niet toereikend zijn om de rechtspositie van cliënten voldoende te waarborgen. Teveel aandacht voor het zelfbeschikkingsrecht heeft als gevolg dat cliënten onvoldoende aanspraak kunnen maken op de zorg waar zij recht op hebben. Hulpverleners zullen zich uit respect voor het zelfbeschikkingsrecht van cliënten terughoudend opstellen, wat niet ten goede komt aan de ontwikkeling van ciënten. Teveel nadruk op bescherming ontneemt cliënten de mogelijkheid om, al dan niet met ondersteuning van anderen, keuzes te maken en te leren van de consequenties die deze keuzes hebben.

Beide elementen, zelfbeschikking en bescherming, zijn onmisbaar voor de ontwikkeling van cliënten. Voorwaarde is wel dat beiden worden toegepast in de juiste verhouding. Het rechtsbeginsel goede zorg biedt deze ruimte. Een kenmerk van goede zorg is dat een hulpverlener zich actief opstelt en inspeelt op de behoeften van een cliënt. Afhankelijk van de situatie waarin een cliënt zich bevindt, bepaalt een hulpverlener of een cliënt in bescherming moet worden genomen dan wel de ruimte moet worden geboden om zijn eigen gang te gaan. In veel gevallen is niet sprake van óf bescherming óf het respecteren van het zelfbeschikkingsrecht. Belangrijk is dat de ondersteuning bijdraagt aan de ontplooiing van cliënten. Een kenmerk van de verstandelijk gehandicaptenzorg is dat cliënten gedurende een lange periode verblijven in een voorziening. Afhankelijk van de ontwikkeling die zij doormaken kunnen cliënten na verloop van tijd doorschuiven naar meer zelfstandige woonvormen. Deze ontwikkeling wordt mede bepaald door de (goede) zorg, die zich kenmerkt door een gepaste combinatie van bescherming en ruimte voor zelfbeschikking. Goede zorg vereist ook be- 
paalde kwaliteiten van hulpverleners. Vereist is dat hulpverleners de verantwoordelijkheid durven nemen om in te grijpen. Uit de motivering van een hulpverlener kan worden afgeleid op welke manier de zorg (in dit geval de toepassing van vrijheidsbeperking) heeft bijgedragen aan de ontplooiing van cliënten. Daarbij spelen ook de criteria subsidiariteit, proportionaliteit en effectiviteit een rol. Het zal overigens niet haalbaar zijn om steeds een bijdrage te leveren aan de ontplooiing van cliënten. In bepaalde situaties is het onvermijdelijk dat de vrijheid van cliënten wordt beperkt om gevaar voor anderen te voorkomen. Van een hulpverlener wordt op dat moment verwacht dat hij bij de uitvoering van de vrijheidsbeperkende maatregel alsnog, waar mogelijk is, een bijdrage probeert te leveren aan de ontplooiing van cliënten.

Naast het ingrijpen in de vrijheid van een cliënt kan een hulpverlener, mede uit het oogpunt van ontplooiing, ook besluiten om een cliënt zijn eigen gang te laten gaan. Aan deze beslissing kan een lang traject (van bescherming) vooraf zijn gegaan. Wederom moet uit de motivering van een hulpverlener blijken of het handelen voldoet aan de uitgangspunten van goede zorg. Het vierde rechtsbeginsel, het recht op ontplooiing, maakt het normatief kader voor de rechtspositie van cliënten met een verstandelijke handicap sluitend. In dit beginsel zijn elementen van de andere drie beginselen terug te vinden. Het recht op ontplooiing heeft tot doel om elke cliënt, ondanks zijn handicap, de mogelijkheid te bieden zich verder te ontwikkelen. De nadruk ligt daarbij op persoonlijke groei, waaronder wordt verstaan dat cliënten in staat moeten worden gesteld om bepaalde vaardigheden, kennis en attitudes te leren waardoor ze meer aansluiting kunnen vinden bij de maatschappij.

\section{Aanbeveling 1}

Het recht op ontplooiing is, in tegenstelling tot de andere drie rechtsbeginselen, nog onvoldoende uitgewerkt in wetgeving. In artikel 22 lid $3 \mathrm{Gw}$ wordt een te beperkte omschrijving gegeven van dit recht. Ook is in het Verdrag inzake de rechten van het kind (VRK) een bepaling over ontplooiing opgenomen (artikel 23). Deze heeft alleen betrekking op minderjarige cliënten met een verstandelijke handicap. Het bereiken van de leeftijdsgrens van 18 jaar betekent in de zorg voor mensen met een verstandelijke handicap echter niet dat cliënten geen ondersteuning meer nodig hebben om zich verder te ontplooien. Het verdient aanbeveling dat ook voor volwassen cliënten met een verstandelijke handicap het recht op ontplooiing wordt vastgelegd in een verdragsbepaling, die rechtstreekse werking heeft en derhalve kan worden ingeroepen door een cliënt met een verstandelijke handicap en/of zijn vertegenwoordiger. Daarnaast vereist het aanbeveling dat de inhoud van artikel 22 lid $3 \mathrm{Gw}$ wordt uitgebreid; het recht op ontplooiing van mensen met een verstandelijke handicap gaat verder dan de maatschappelijke en culturele ontplooiing. Volwaardig burgerschap veronder- 
stelt het benutten van de ontplooiingsmogelijkheden van cliënten op alle gebieden in de samenleving.

\section{Aanbeveling 2}

In het normatief kader wordt benadrukt dat hulpverleners dienen te beschikken over bepaalde kwaliteiten. Hiertoe behoort ook dat zij de verantwoordelijkheid nemen om op bepaalde momenten wel of niet in te grijpen in de vrijheid van cliēnten met als doel om de ontwikkeling van cliënten te bevorderen. Deze wijze van handelen moet nader worden uitgewerkt in de professionele standaard van persoonlijk begeleiders. Een belangrijke norm is in hoeverre een beslissing heeft bijgedragen aan de ontwikkeling van een cliënt.

Hoe verhoudt dit algemene kader zich tot de regelgeving die betrekking heeft op de toepassing van vrijheidsbeperking in de zorg voor mensen met een verstandelijke handicap? De Wet Bopz vormt het juridische kader voor de toepassing van vrijheidsbeperking in de zorg voor mensen met een verstandelijke handicap. Twee waarden staan centraal in deze wet: zelfbeschikking en bescherming. Een cliënt mag alleen worden beperkt in zijn vrijheid als voldaan is aan de (strikte) criteria die in de wet worden genoemd. Daarnaast beoogt de Wet Bopz de rechtspositie van onvrijwillig opgenomen cliënten te beschermen. De wetgever heeft bewust gekozen voor een nauw juridisch kader. Inbreuken op de vrijheid van cliënten moeten zoveel mogelijk worden voorkomen: vrijheidsbeperking vormt een laatste redmiddel. Dit laatste uitgangspunt is ook terug te vinden in het normatief kader dat in deze studie centraal staat. Toch is de inhoud van de Wet Bopz niet eenvoudig in te passen in dit kader. De twee rechtsbeginselen, recht op goede zorg en recht op ontplooiing, worden noch in de Wet Bopz, noch in de bijbehorende parlementaire stukken met zoveel woorden genoemd. Vrijheidsbeperking is uitsluitend gericht op het voorkomen van gevaar voor de cliënt zelf of voor anderen. Aan andere motieven biedt de Wet Bopz weinig tot geen ruimte.

Het gevolg van de huidige regelgeving is dat ook de 'vrijheid' van hulpverleners wordt beperkt. De Wet Bopz heeft de drempel verhoogd om in de verstandelijk gehandicaptenzorg in te grijpen op die momenten dat de noodzaak van vrijheidsbeperking aan de orde is. Dit betekent ook dat cliënten niet altijd de ondersteuning ontvangen waar zij recht op hebben. De actieve houding van een hulpverlener, die vereist is in de verstandelijk gehandicaptenzorg, is veranderd in een terughoudende opstelling: pas als sprake is van gevaar mag de vrijheid van een cliënt worden beperkt. De kern van het normatief kader is dat ondersteuning in de zorg voor mensen met een verstandelijke handicap meer omvat dan alleen ingrijpen bij gevaar. 


\section{Aanbeveling 3}

De Wet Bopz is van toepassing in de sectoren psychiatrie, psychogeriatrie en verstandelijk gehandicaptenzorg. De verstandelijk gehandicaptenzorg onderscheidt zich echter op een dusdanige manier van de andere sectoren, dat speciale aandacht van de wetgever gerechtvaardigd is. Een regeling voor de toepassing van vrijheidsbeperking, waarin de nadruk wordt gelegd op goede zorg en rechtsbescherming, is noodzakelijk om de rechtspositie van deze cliënten te kunnen waarborgen. Dit dient bij voorkeur een aparte regeling te zijn.

Welke problemen doen zich voor in de praktijk van de zorg voor mensen met een verstandelijke handicap ten aanzien van hun (interne) rechtspositie als het gaat om de toepassing van vrijheidsbeperking?

In de praktijk van de zorg voor mensen met een verstandelijke handicap doen zich diverse problemen voor als het gaat om de toepassing van vrijheidsbeperking. Eén van deze problemen is dat het huidige juridische kader (de Wet Bopz) niet de beoogde interne rechtsbescherming biedt aan cliënten die onvrijwillig zijn opgenomen in een instituut met een Bopz-aanmerking. Veel toepassingen van vrijheidsbeperking worden niet als zodanig herkend, waardoor cliënten een deel van hun bescherming mislopen. Een voorbeeld is de situatie dat een cliẻnt zich verzet tegen (een deel van) het zorgplan. Onder hulpverleners bestaat onduidelijkheid over de interpretatie van verzet. Regelmatig wordt verzet van een cliënt genegeerd. Het gevolg is dat dwangbehandeling niet als zodanig wordt geïnterpreteerd. Een ander probleem is de beperkte betekenis die in de praktijk wordt gegeven aan het begrip vrijheidsbeperking. Naast gevaar vormen ook andere motieven (bescherming, opvoeding en straffen en belonen) een reden om vrijheidsbeperking toe te passen. In de praktijk worden deze toepassingen doorgaans niet beschouwd als vrijheidsbeperking in de zin van de Wet Bopz. Dit betekent dat hulpverleners de vrijheid van cliënten beperken zonder dat zij de waarborgen van de Wet Bopz in acht nemen.

Een derde probleem is de toepassing van middelen of maatregelen in het kader van het zorgplan. Op grond van de Wet Bopz is het doel van de toepassing van middelen of maatregelen het afwenden van een tijdelijke noodsituatie (artikel 39 Bopz). De wetgever heeft bepaald dat deze vorm van vrijheidsbeperking niet langer dan zeven dagen mag worden toegepast. Deze termijn kan worden verlengd door de maatregel met toestemming van de cliënt en/of vertegenwoordiger op te nemen in het zorgplan. Naast de vraag of de cliënt en zijn vertegenwoordiger ook daadwerkelijk vrijwillig toestemming hebben gegeven voor de toepassing ervan, is relevant in hoeverre middelen of maatregelen ook een therapeutisch doel kunnen hebben. Bevindingen uit de praktijk laten zien dat deze toepassingen in het zorgplan maanden of zelfs jaren kunnen voortduren, zonder dat de Inspectie geïnformeerd wordt. 
Niet alleen de interne rechtspositie van onvrijwillig opgenomen cliènten wordt bedreigd. Het enge juridische kader voor de toepassing van vrijheidsbeperking leidt ook tot andere problemen in deze sector. De wetgever heeft bepaald dat vrijheidsbeperking alleen is toegestaan bij cliënten die onvrijwillig zijn opgenomen in een instituut met een Bopz-aanmerking. Vrijheidsbeperking wordt echter ook buiten dit kader toegepast. In instituten met een Bopz-aanmerking wordt nauwelijks onderscheid gemaakt tussen onvrijwillig en vrijwillig opgenomen cliënten. Beiden krijgen te maken met vrijheidsbeperking. Daarnaast is de rechtspositie van cliënten, die in andere woonvormen dan een instituut met een Bopz-aanmerking verblijven, onvoldoende gewaarborgd. Ook deze cliënten krijgen te maken met vrijheidsbeperkende maatregelen. Als gevolg van de veranderingen die zich in de zorg voor mensen met een verstandelijke handicap voordoen, zoals de modernisering van de $\mathrm{AWBZ}$ en het deconcentratiebeleid, gaan ook steeds meer cliënten waarbij vrijheidsbeperking aan de orde is buiten een instituut wonen. Daarnaast fuseren instituten met extramurale en semi-murale voorzieningen waardoor niet meer gesproken kan worden over instituten in engere zin.

Het gevolg van deze ontwikkelingen is dat in de zorg voor mensen met een verstandelijke handicap sprake is van een gedoogbeleid als het gaat om de toepassing van vrijheidsbeperking. Slechts een klein deel van alle vrijheidsbeperkende maatregelen is wettelijk toegestaan en wordt intern geregistreerd en gemeld aan de Inspectie. Cliënten die vrijwillig zijn opgenomen of verblijven in voorzieningen zonder een Bopz-aanmerking en te maken krijgen met vrijheidsbeperking worden niet op dezelfde wijze beschermd als onvrijwillig opgenomen cliënten. In de jurisprudentie is de problematiek aan de orde gekomen van cliënten die bereid zijn om hun verblijf in een instituut te continueren maar zich verzetten tegen de toepassing van vrijheidsbeperking. Diverse uitspraken laten zien dat instituten op dat moment niet verplicht zijn om de juridisch status van een cliënt te wijzigen, indien het verzet niet gericht is tegen het verblijf in het instituut. Het gevolg is dat deze (vrijwillig opgenomen) cliënten niet op dezelfde wijze worden beschermd als onvrijwillig opgenomen cliënten. Een arrest van de Hoge Raad uit 2001 lijkt een einde te maken aan deze jurisprudentie. Dwangbehandeling in een Bopz-locatie is in beginsel alleen nog mogelijk als een cliënt onvrijwillig is opgenomen. Deze uitspraak kan ertoe leiden dat in de praktijk veel cliënten de benodigde ondersteuning zullen mislopen. Een rechter zal niet snel een rechterlijke machtiging afgeven bij cliënten die zich niet verzetten tegen het verblijf in een instituut. Tot op heden bestaat er nog geen jurisprudentie over vrijheidsbeperking die wordt toegepast in voorzieningen zonder een Bopz-aanmerking. Duidelijk mag zijn dat als hulpverleners strikt handelen volgens de normen van de Wet Bopz veel cliënten de benodigde ondersteuning mislopen. De huidige situatie is onbevredigend. Hulpverleners hebben de intentie om, los van het huidige 
juridische kader, goede zorg te bieden aan cliënten. Deze wijze van handelen is echter niet met voldoende waarborgen omgeven.

\section{Aanbeveling 4}

Elke maatregel die tot vrijheidsbeperking leidt moet, ongeacht de intentie van de maatregel, de plaats van toepassing en de juridische status van de cliënt, inzichtelijk worden gemaakt en regelmatig worden geëvalueerd.

\section{Aanbeveling 5}

Elke voorziening, met of zonder Bopz-aanmerking, dient een visie op vrijheidsbeperking te hebben. Deze kan vervolgens worden vertaald in een kwaliteitsbeleid waarin het accent wordt gelegd op het regelmatig verantwoorden en evalueren van toepassingen van vrijheidsbeperking.

\section{Aanbeveling 6}

De reikwijdte van het huidige juridische kader voor de toepassing van vrijheidsbeperking moet niet beperkt blijven tot instituten met een Bopz-aanmerking. De resultaten van deze studie laten zien dat vrijheidsbeperkende maatregelen ook in andere voorzieningen voorkomen. De cliënten die in deze voorzieningen verblijven kunnen nu geen aanspraak maken op de waarborgen die in de Wet Bopz zijn vastgelegd.

\section{Welke juridische mogelijkheden zijn er om de gevonden knelpunten op te lossen?}

De gevonden knelpunten kunnen op verschillende manieren worden opgelost. Gezien de bevindingen van deze studie ligt het niet voor de hand om slechts een aantal bepalingen van de Wet Bopz te wijzigen: er zijn fundamentele wijzigingen vereist om de beoogde rechtsbescherming alsnog te kunnen bieden aan cliënten. In deze studie wordt de voorkeur uitgesproken voor een alternatieve regeling voor de toepassing van vrijheidsbeperking in de zorg voor mensen met een verstandelijke handicap. Deze regeling maakt het mogelijk om in te spelen op de knelpunten die zich in de praktijk voordoen.

De alternatieve regeling gaat van de gedachte uit dat een wettelijke regeling, die de toepassing van vrijheidsbeperking in de verstandelijk gehandicaptenzorg reguleert, niet alleen het accent dient te leggen op het zelfbeschikkingsrecht van cliënten maar ook op goede zorg en rechtsbescherming. Deze laatste twee elementen zijn onvoldoende terug te vinden in de huidige juridische kader voor de toepassing van vriipheidsbeperking. Goede zorg betekent dat cliënten aanspraak kunnen maken op de ondersteuning die zij nodig hebben om zich verder te kunnen ontplooien. Hulpverleners kunnen er niet mee volstaan dat zij zich, uit respect voor het zelfbeschikkingsrecht van cliënten, terughoudend opstellen. Van belang is dat zij hun verantwoordelijkheid nemen om de benodigde ondersteuning te bieden aan cliënten. Hiertoe behoort ook het beperken van de vrij- 
heid van cliënten. Onder de alternatieve regeling wordt het begrip gevaar vervangen door noodzaak. Dit begrip biedt hulpverleners meer mogelijkheden om de vrijheid van cliënten te beperken. $\mathrm{Om}$ te waarborgen dat hulpverleners op de juiste wijze omgaan met deze ruimte wordt in de alternatieve regeling, naast goede zorg, ook het accent gelegd op de rechtsbescherming van cliënten. Vereist is dat hulpverleners hun handelen achteraf zorgvuldig verantwoorden. Deze werkwijze vloeit ook voort uit het principe van goed hulpverlenerschap. In dat kader is het van belang dat situaties, waarin vrijheidsbeperking aan de orde is, zichtbaar en toetsbaar zijn.

Om tegemoet te kunnen komen aan de kritiek die wordt geuit op het huidige juridische kader is een belangrijk aspect de reikwijdte van de alternatieve regeling. Deze is van toepassing op de gehele verstandelijk gehandicaptenzorg. Allereerst gaat de regeling uit van een persoonsgerichte benadering. De toepassing van vrijheidsbeperking is niet meer afhankelijk van de soort voorziening waar een cliënt verblijft. Ook gvt'en en de thuissituatie vallen onder de reikwijdte van de regeling. De voorwaarde is echter wel dat sprake is van een hulpverleningsrelatie: een hulpverlener is betrokken bij de toepassing van vrijheidsbeperking. Daarnaast vervalt het onderscheid tussen vrijwillig en onvrijwillig opgenomen cliënten. Opneming wordt beschouwd als een bijzondere vorm van vrijheidsbeperking. Dit betekent overigens niet dat verzet van een cliënt in het vervolg mag worden genegeerd. Indien een cliënt en/of zijn vertegenwoordiger zich verzet tegen opneming, geldt een aantal extra voorwaarden waaraan voldaan moet zijn alvorens een cliënt kan worden beperkt in zijn vrijheid. Zodra cliënten zijn opgenomen worden degenen die ingestemd hebben met opneming en degenen die zich hebben verzet op dezelfde wijze benaderd. Het gevolg is ook dat het onderscheid tussen de interne en externe rechtspositie komt te vervallen. Er wordt niet langer onderscheid gemaakt tussen cliënten met een RM, een IBS, een Bopz-indicatie en vrijwillig opgenomen cliënten. Opneming maakt onderdeel uit van de ondersteuning die wordt geboden aan cliënten. De reikwijdte van de regeling wordt tot slot ook verruimd door de invulling die wordt gegeven aan het begrip vrijheidsbeperking. Alle maatregelen die de vrijheid van cliënten beperken, ongeacht de intentie ervan, vallen onder de regeling. Op deze manier vallen ook pedagogische en beschermende maatregelen onder de regeling.

Deze wijzigingen ten opzichte van de Wet Bopz dragen ertoe bij dat de rechtspositie van cliënten in de toekomst kan worden verbeterd. Het gevaar is wel dat door de ruimte die voor hulpverleners ontstaat meer vrijheidsbeperking wordt toegepast. Dit is echter een voorbarige gedachte. Ondanks de voorwaarden die in de Wet Bopz worden genoemd, worden bij onvrijwillig opgenomen cliënten ook niet-wettelijke maatregelen toegepast. Een deel van deze maatregelen is vanuit het oogpunt van goede zorg noodzakelijk. Ook bij vrijwillig opgenomen cliënten en cliënten die buiten instituten in een Bopz-aanmerking verblijven komt vrijheidsbeperking voor. Op al deze maatregelen vindt nauwelijks intern 
en extern toezicht plaats en zijn de waarborgen van de Wet Bopz niet van toepassing. De alternatieve regeling maakt een einde aan het huidige gedoogbeleid. De toepassingen van vrijheidsbeperking, die nu ook al plaatsvinden, komen onder een wettelijke regeling te vallen. Ook deze maatregelen dienen inzichtelijk te worden gemaakt en achteraf te worden verantwoord.

\section{Aanbeveling 7}

Het verdient aanbeveling dat de Wet Bopz wordt vervangen door een alternatieve regeling voor de toepassing van vrijheidsbeperking in de zorg voor mensen met een verstandelijke handicap. In deze regeling wordt rekening gehouden met de uitgangspunten die in deze sector centraal behoren te staan.

\section{Aanbeveling 8}

De wetgeving met betrekking tot de toepassing van vrijheidsbeperking moet persoonsgericht in plaats van instituutsgericht zijn. In de alternatieve regeling vervalt het locatiegebonden karakter: vrijheidsbeperking kan in beginsel overal plaatsvinden.

\section{Aanbeveling 9}

Om de rechtsbescherming in de alternatieve regeling nader invulling te geven verdient het aanbeveling dat een aantal waarborgen wordt geïntroduceerd zoals een regionale toetsingscommissie vrijheidsbeperking, een interne toetsingscommissie vrijheidsbeperking, een cliëntenvertrouwenspersoon, een second opininon en toezicht op langdurige toepassingen van vrijheidsbeperking.

\section{Aanbeveling 10}

Het verdient aanbeveling dat een cliëntenvertrouwenspersoon een actieve rol gaat vervullen in de verstandelijk gehandicaptenzorg. Deze behartigt alleen de belangen van de cliënt.

\section{Aanbeveling 11}

Tot het kwaliteitsbeleid van een voorziening behoort ook een omschrijving van de voorwaarden waaraan voldoen moet zijn om op een verantwoorde wijze vrijheidsbeperking te kunnen toepassen. Onvoldoende (deskundig) personeel of onvoldoende mogelijkheden om toezicht te houden op vrijheidsbeperkende maatregelen kunnen redenen zijn om bepaalde vormen van ondersteuning (vri)heidsbeperking) niet aan te bieden.

Wat betekent één en ander voor zowel wetgeving en zelfregulering als de praktijk?

De Wet Bopz vormt sinds 1994 het juridische kader voor de toepassing van vrijheidsbeperking in de verstandelijk gehandicaptenzorg. Deze wet heeft de intentie om bij te dragen aan een verbetering van de rechtspositie van (onvrijwillig 
opgenomen) cliënten. Bevindingen uit de praktijk laten zien dat het niet eenvoudig is om deze doelstelling te realiseren. De alternatieve regeling beoogt deze rechtsbescherming wel te bieden. Enerzijds door aan te sluiten bij de uitgangspunten die in de praktijk van de zorg voor mensen met een verstandelijke handicap centraal staan (goede zorg) en anderzijds door hulpverleners meer aan te spreken op hun verantwoordelijkheden. De introductie van een alternatieve regeling is echter niet toereikend om de rechtspositie van cliënten te verbeteren. Het is ook van belang dat hulpverleners een omslag in denken maken. In verschillende hoofdstukken is aan de orde gekomen dat het juridische perspectief nog te weinig aandacht krijgt in de verstandelijk gehandicaptenzorg. In deze sector is nog altijd een tegenbeweging aanwezig, die gericht is op het behoud van het bestaande.

Deze tegenbeweging blijft vasthouden aan het vertrouwde inzicht van, in de woorden van Van Gennep, het klinisch-medische defect paradigma. Het gaat ervan uit dat mensen met een verstandelijke handicap vanwege hun organische defecten aangewezen zijn op zorg in de beschermende omgeving van het instituut. Hierdoor worden zij niet beschouwd als individuen met mogelijkheden maar als afhankelijke individuen die aangewezen zijn op de sympathie van anderen. Deze tegenbeweging verhindert dat nieuwe inzichten de ruimte krijgen. Binnen het burgerschapsparadigma past ook het juridische perspectief. Dit perspectief leidt ook tot een andere denkwijze in de zorg voor mensen met een verstandelijke handicap. Cliënten moeten worden beschouwd als 'individuen met eigen rechten' die de mogelijkheid hebben om zelf invulling te geven aan hun leven. Daar waar zij niet in staat zijn om zelf de regie te voeren over hun rechten, behoort het tot de taken van hulpverleners (en ook van vertegenwoordigers) om deze rechten door middel van de juiste ondersteuning tastbaar te maken voor cliënten. De kunst is om cliënten met een verstandelijke handicap geen rechten te onthouden. In de verstandelijk gehandicaptenzorg zijn veel cliënten niet in staat om zelfstandig keuzes te maken: zij zijn afhankelijk van anderen. Zonder de juiste ondersteuning zullen zij altijd deze status behouden en niet of nauwelijks in staat zijn om zich te ontplooien. Deze afhankelijke positie, waarbij ook regelmatig sprake is van vrijheidsbeperking, vereist een passende rechtsbescherming. In het kader van het juridische perspectief wordt ook van hulpverleners verwacht dat zij kennis hebben van en inzicht hebben in de rechten van cliënten en deze ook respecteren. Dit betekent concreet dat een hulpverlener moet kunnen rechtvaardigen waarom hij heeft gekozen voor de toepassing van vrijheidsbeperking. Zijn handelen moet inzichtelijk en toetsbaar zijn. Deze elementen kunnen ertoe bijdragen dat hulpverleners zich (meer) gaan realiseren welke gevolgen hun handelen heeft voor de rechtspositie van cliënten.

De alternatieve regeling zal nadrukkelijk onder de aandacht van de hulpverleners moeten worden gebracht. $\mathrm{Zij}$ zijn uiteindelijk degene die beslissen of de vrijheid van een cliënt moet worden beperkt. De alternatieve regeling geeft het 
kader aan, waarbinnen en op grond waarvan hulpverleners vrijheidsbeperkende maatregelen mogen toepassen. Binnen dit kader wordt echter nog voldoende ruimte opengelaten voor zelfregulering. Diverse begrippen uit de regeling lenen zich om nader te worden uitgewerkt in de praktijk. De evaluatie van de Kwaliteitswet zorginstellingen laat echter zien dat op dit gebied in het veld nog onvoldoende initiatieven worden ontwikkeld. De sector verstandelijk gehandicaptenzorg dient actiever aan de slag te gaan met het thema vrijheidsbeperking. De professionele standaard van de verschillende beroepsgroepen kan op dit gebied nog meer duidelijkheid creëren. De brancheorganisatie Vereniging Gehandicaptenzorg Nederland (VGN) zou het initiatief moeten nemen om, in samenspraak met de verschillende beroepsgroepen, te werken aan één professionele standaard voor de gehele sector, waarin beschreven staat op welke wijze hulpverleners in deze sector om moeten gaan met vrijheidsbeperking. Het behoort echter tot de verantwoordelijkheid van de overheid om in de opleidingen van de verschillende beroepsgroepen de kennis te vergroten over het thema vrijheidsbeperking. Dit geldt niet alleen voor de opleidingen van persoonlijk begeleiders. Ook in de opleiding van de arts voor verstandelijk gehandicapten (AVG) moet meer aandacht worden besteed aan dit thema. Dit geldt met name voor de verantwoordelijkheden die AVG's hebben in relatie tot andere disciplines. Tevens wordt het, mede in het kader van de modernisering van de AWBZ, steeds belangrijker dat voorzieningen aan de buitenwereld (toekomstige cliënten, vertegenwoordigers, zorgkantoren) kunnen laten zien op welke wijze zij invulling geven aan hun kwaliteitsbeleid. Een belangrijk onderdeel van dit beleid vormt de visie op vrijheidsbeperking. Al deze ontwikkelingen, inclusief de alternatieve regeling, hebben maar één doel: de discussie over het thema vrijheidsbeperking gaande houden in de zorg voor mensen met een verstandelijke handicap. Op deze manier wordt een (voortdurende) bijdrage geleverd aan de verbetering van de rechtspositie van mensen met een verstandelijke handicap.

\section{Aanbeveling 12}

Wetgeving dient meer aan te sluiten bij de ontwikkelingen en de uitgangspunten die in de praktijk van de zorg voor mensen met een verstandelijke handicap centraal staan.

\section{Aanbeveling 13}

Het ontwerpen van nieuwe wetgeving is niet voldoende om de rechtspositie van cliënten te verbeteren. Het verdient aanbeveling dat het veld ook voortdurend aandacht blijft besteden aan het onderwerp vrijheidsbeperking. De brancheorganisatie VGN kan samen met de beroepsverenigingen het voortouw nemen in het ontwikkelen van professionele standaarden als het gaat om de toepassing van vrijheidsbeperking. Het ontwikkelen van richtlijnen en het stimuleren van onderzoek kunnen daartoe bijdragen. 


\section{Aanbeveling 14}

Het verdient aanbeveling dat in de opleidingen van hulpverleners meer aandacht wordt besteed aan het thema vrijheidsbeperking: in de eindtermen van de opleidingen van artsen, gedragsdeskundigen en persoonlijk begeleiders moet dit thema terugkeren.

\section{Aanbeveling 15}

Het behoort tot de verantwoordelijkheid van de voorzieningen om, als het gaat om de toepassing van vrijheidsbeperking, de deskundigheid van het personeel te bewaken en zonodig (bij)scholing aan te bieden.

\section{Tot slot}

De lezer die dit boek openslaat wordt op de eerste pagina geconfronteerd met een tekening over vrijheidsbeperking, gemaakt door een cliënt met een verstandelijke handicap. Deze tekening en de bijbehorende toelichting illustreren dat vrijheidsbeperking doorgaans een negatieve betekenis heeft voor cliënten. Paul, die deze tekening heeft gemaakt, heeft een cliënt getekend die letterlijk met zijn rug tegen de muur staat. Op het moment dat de deur van de kamer op slot gaat is de desbetreffende cliënt overgeleverd aan de goede bedoelingen van de hulpverlener, die uiteindelijk bepaalt wanneer hij weer van zijn kamer af mag komen.

In deze studie staat de rechtspositie van cliënten met een verstandelijke handicap centraal. De studie concentreert zich op het thema vrijheidsbeperking. Het recht op vrijheid is een essentieel recht en blijkt in de praktijk, ondanks een juridisch kader voor de toepassing van vrijheidsbeperking, toch regelmatig in het geding te zijn. De doelstelling van deze studie was om inzichtelijk te maken hoe de (interne) rechtspositie van cliënten met een verstandelijke handicap zowel in wet- en regelgeving is vastgelegd als in de praktijk wordt vormgegeven, in het bijzonder met betrekking tot de toepassing van vrijheidsbeperking.

In het gezondheidsrecht neemt het zelfbeschikkingsrecht een belangrijke plaats in. Deze studie heeft laten zien dat het zelfbeschikkingsrecht ook centraal staat in het huidige juridische kader voor de toepassing van vrijheidsbeperking: alleen als sprake is van gevaar voor een cliënt of anderen mag worden ingegrepen in zijn vrijheid. Ook wordt een enge definitie van vrijheidsbeperking gehanteerd. Dit uitgangspunt draagt in de verstandelijk gehandicaptenzorg niet bij aan (een verbetering van) de rechtspositie van cliënten; deze is verre van optimaal geregeld. Niet zelfbeschikking, maar ontplooiing dient het uitgangspunt te zijn van de zorg (ondersteuning) die wordt geboden aan cliënten. Dit betekent ook dat van hulpverleners een actievere houding wordt verwacht. Al het mogelijke moet worden gedaan om cliënten verder op weg te helpen. Ook vrijheidsbeperking behoort tot deze mogelijkheden. 
In deze studie wordt een aanzet gegeven voor een alternatieve regeling die ge tuige de resultaten van de tweede evaluatie Wet Bopz en twee invitationals con ferences wordt gesteund door het veld. Deze regeling biedt meer waarborger voor de rechtspositie van cliënten door het recht op goede zorg en rechtsbe scherming centraal te stellen. Daarnaast neemt het recht op ontplooiing een be langrijke plaats in.

Het uiteindelijke doel van deze studie is dat de praktijk aan de slag gaat met d bevindingen teneinde de rechtspositie van cliënten, die zich in een vergelijkban situatie bevinden als de cliënt die Paul heeft getekend, te waarborgen en waa nodig ook te verbeteren. Belangrijk is dat dergelijke maatregelen door hulpver leners inzichtelijk worden gemaakt en worden verantwoord. Ook dient de maat regel zoveel mogelijk bij te dragen aan de ontwikkeling van een cliënt. Het fei dat de cliënt die Paul heeft getekend achter een gesloten deur zit, dient in he leven van deze cliënt een bepaalde functie te dienen. Toch, wordt de wens uitge sproken dat de deur, die nu nog dicht is op de tekening, niet al te lang op slo hoeft te blijven. 


\section{Samenvatting}

In de laatste decennia van de vorige eeuw is het besef gegroeid dat mensen met een verstandelijke handicap ook de kans moeten krijgen om hun leven zoveel mogelijk naar eigen inzicht in te richten. Deze gedachte is terug te voeren op het burgerschapsparadigma waaronder wordt verstaan dat mensen met een verstandelijke handicap gelijkwaardig zijn aan mensen zonder een verstandelijke handicap en dezelfde rechten en plichten behoren te hebben als ieder andere burger in deze samenleving. De enkele gelijkstelling van rechten is niet genoeg om de rechtspositie van cliënten met een verstandelijke handicap te waarborgen. Cliënten moeten doorgaans geattendeerd worden op hun rechten en hebben (extra) hulp nodig bij het verwezenlijken van deze rechten. In het kader van het burgerschapsparadigma wordt gesproken over ondersteuning. Een cliënt heeft, afhankelijk van de beperkingen die hij ondervindt van zijn verstandelijke handicap, behoefte aan een bepaalde vorm van ondersteuning. Zonder ondersteuning van een persoonlijk begeleider of een vertegenwoordiger zal het voor veel cliënten niet eenvoudig zijn om zelfstandig keuzes te maken.

Het burgerschapsparadigma bouwt voort op het idee dat het zelfbeschikkingsrecht niet toereikend is voor mensen met een verstandelijke handicap. Dit recht(sbeginsel) gaat uit van de gedachte dat ieder individu, ongeacht zijn mogelijkheden om dit recht uit te oefenen, de vrijheid heeft om zelf richting te geven aan zijn leven. Het zelfbeschikkingsrecht neemt in onze samenleving een belangrijke plaats in: het vormt het kadér voor het patiëntenrecht dat sinds de jaren negentig van de vorige eeuw een explosieve groei heeft doorgemaakt. Zo wordt in de Wet Bopz benadrukt dat cliënten zo min mogelijk in hun vrijheid mogen worden beperkt. Alleen als sprake is van gevaar voor de cliënt zelf of anderen mag een vrijheidsbeperkende maatregel worden opgelegd. Ook in de verstandelijk gehandicaptenzorg dienen de uitgangspunten van het recht op zelfbeschikking te worden gerespecteerd. Cliënten met een verstandelijke handicap zijn mensen met eigen mogelijkheden en wensen. Het zelfbeschikkingsrecht veronderstelt echter ook dat hulpverleners zich zoveel mogelijk afzijdig moeten opstellen. Dit uitgangspunt is niet altijd in het voordeel van cliënten met een verstandelijke handicap, die doorgaans niet beschikken over voldoende handvatten om hun eigen leven zelfstandig vorm te geven. De intentie van het recht dient zodanig te zijn dat ook het zelfbeschikkingsrecht van deze personen tot ontwikkeling wordt gebracht. Het recht op goede zorg vormt in dit kader een belangrijk recht. Een cliënt met een verstandelijke handicap heeft recht op goede zorg in de zin van betrokkenheid, ondersteuning en bescherming waar nodig. Goede zorg stelt eisen aan de kwaliteiten van hulpverleners. Van hulpverleners wordt verwacht dat hun handelen niet beperkt blijft tot niet-ingrijpen en geen 
bemoeienis hebben met cliënten. Een goede hulpverlener komt op de juiste momenten in actie teneinde de mogelijkheden van cliënten verder tot ontwikkeling te brengen. Deze wijze van handelen vereist een omslag in denken. Enerzijds moet worden voorkomen dat hulpverleners zich (te) paternalistisch gaan opstellen en anderzijds wordt van hulpverleners verwacht dat zij cliënten niet (teveel) links laten liggen uit respect voor hun zelfbeschikkingsrecht.

De volgende vraag staat in deze studie centraal: Wat is de (interne) rechtspositie van cliënten in de zorg voor mensen met een verstandelijke handicap in relatie tot de toepassing van vrijheidsbeperking, hoe krijgt deze in de praktijk gestalte en welke aanbevelingen kunnen terzake worden gedaan?' Deze vraag is nader toegespitst op de toepassing van vrijheidsbeperking in relatie tot het recht op goede zorg en goed hulpverlenerschap. Vrijheidsbeperking is een veel besproken thema binnen de zorg voor mensen met een verstandelijke handicap. Nog al te vaak wordt de problematiek rondom dit thema weergegeven in de vorm van een tegenstelling: het bieden van bescherming of het bevorderen van zelfbeschikking van cliënten. In deze studie wordt afstand genomen van deze tegenstelling. In de zorg voor mensen met een verstandelijke handicap zijn beide elementen essentieel voor de rechtspositie van cliënten met een verstandelijke handicap. Met het oogmerk om een bijdrage te leveren aan de ontplooiing van cliënten is het aanvaardbaar om cliënten op bepaalde momenten te beschermen. Dit leidt in veel gevallen tot een beperking van hun vrijheid. Van belang is dat een hulpverlener kan aantonen dat deze beperking, althans voor zover mogelijk is, wordt gemotiveerd door de ontwikkeling van de cliënt.

In hoofdstuk 1 wordt de aanleiding van deze studie toegelicht. Ook wordt stilgestaan bij zowel het juridische kader als de functie van het recht in de zorg voor mensen met een verstandelijke handicap. Daarnaast wordt het begrip verstandelijke handicap uiteengezet en wordt een beschrijving gegeven van de sector verstandelijk gehandicaptenzorg en de ontwikkelingen die in deze sector gaande zijn.

De wijze waarop de empirische gegevens voor deze studie zijn verzameld en geanalyseerd wordt toegelicht in hoofdstuk 2 . Het empirische onderzoek is te kenmerken als kwalitatief onderzoek. Het omvat gegevens van twee onderzoeken. Allereerst zijn kwalitatieve gegevens verzameld in drie verschillende voorzieningen voor verstandelijk gehandicaptenzorg. In deze voorzieningen zijn, naast interviews met cliënten, vertegenwoordigers en hulpverleners, ook participerende observaties verricht en dossiers van cliënten bestudeerd. Daarnaast zijn de meest relevante uitkomsten van de tweede evaluatie Wet Bopz interne rechtspositie in de verstandelijk gehandicaptensector' meegenomen. De gegevens van beide onderzoeken zijn verwerkt in hoofdstuk 6 van dit boek.

Het normatief kader, dat in hoofistuk 3 wordt beschreven, gaat in op de rechtsbeginselen die in de zorg voor mensen met een verstandelijke handicap een rol van betekenis spelen. Naast het recht op bescherming en zelfbeschikking, wor- 
den twee andere beginselen geïntroduceerd: het recht op goede zorg en het recht op ontplooiing. Alvorens wordt ingegaan op de inhoud van en het verband tussen deze vier beginselen, wordt de betekenis van het recht binnen de sector verstandelijk gehandicaptenzorg onderbouwd. In deze sector wordt nog te weinig aandacht besteed aan de betekenis van het recht. In deze studie wordt het standpunt verdedigd dat een bepaalde vorm van juridisering onvermijdelijk is in deze sector. Daarvoor is een aantal redenen te noemen. De belangrijkste is dat de relatie tussen een cliënt met een verstandelijke handicap en zijn hulpverlener niet gelijkwaardig is. Cliënten bevinden zich doorgaans in een kwetsbare positie. Zij zijn minder in staat om op te komen voor hun eigen belangen. Daarnaast wordt hun relatie gekenmerkt door een zekere mate van afhankelijkheid. De hulpverlener bepaalt of vrijheidsbeperkende maatregelen worden toegepast. Daarnaast heeft hij ook zeggenschap over de duur ervan. Deze kwetsbare en afhankelijke positie van een cliënt vraagt om bescherming door het recht. Het recht heeft als taak om de rechtspositie van cliënten te waarborgen. Het is evenwel niet de enige functie van het recht in deze sector. Elke cliënt dient, binnen het kader van zijn mogelijkheden, de gelegenheid te krijgen om zijn leven naar eigen inzicht in te vullen. Dit betekent dat het recht ook als functie heeft om het zelfbeschikkingsrecht van cliënten te respecteren en, waar mogelijk, te bevorderen.

Hulpverleners hebben andere ideeën over juridisering in de zorg voor mensen met een verstandelijke handicap. Nog al te vaak overheerst het idee dat zij door het recht worden beperkt in hun handelen. Ethici voegen hieraan toe dat juridisering in deze sector leidt tot een verschraling van de zorg. Het eigen karakter van de zorgrelatie - afhankelijkheid van de cliënt - zou teniet worden gedaan door de introductie van het recht. Dit is een verkeerde veronderstelling. De afhankelijke positie van een cliënt wordt in het recht ook erkend, maar neemt een minder centrale positie in. Het recht benadrukt andere kenmerken van een zorgrelatie. Het recht beoogt de ongelijke relatie tussen de hulpverlener en de cliënt te herstellen. Gelijkwaardigheid en respect voor elkaar vormen essentiële elementen van een zorgrelatie en dragen bij aan een verdere ontwikkeling van cliënten. Verdedigd wordt dat het recht niet alleen is gericht op individualiteit en afstandelijkheid van cliënten. In de verstandelijk gehandicaptenzorg dient van een ruimere visie te worden uitgegaan: goede zorg en ontplooiing zijn begrippen die in het recht een belangrijke positie innemen.

Hulpverleners merken terecht op dat het recht bepaalde grenzen stelt en verlangt dat zij hun handelen verantwoorden. Deze kenmerken van het recht moeten niet als negatieve juridisering worden beschouwd, maar maken onderdeel uit van de (beschermende) functie die het recht vervult in de zorg voor mensen met een verstandelijke handicap. Binnen de grenzen van het recht wordt hulpverleners voldoende vrijheid geboden. Dit alles neemt niet weg dat in deze studie de stelling wordt verdedigd dat de Wet Bopz in de verstandelijk gehandi- 


\section{Samenvatting}

captenzorg als een vorm van negatieve juridisering kan worden beschouwd. De uitgangspunten van deze wet worden onderschreven, maar dat geldt niet voor de inhoud ervan. In de Wet Bopz wordt vooralsnog te weinig rekening gehouden met de specifieke kenmerken van de sector, waardoor de doelstellingen van de wet niet worden bereikt. Bovendien wordt teveel nadruk gelegd op het zelfbeschikkingsrecht van cliënten. In hoofdstuk 5, 6 en 7 wordt nader ingegaan op deze problematiek.

Vanwege de specifieke positie van mensen met een verstandelijke handicap wordt in deze studie de nadruk gelegd op het recht op ontplooiing. Cliënten verblijven, in tegenstelling tot psychogeriatrische patiënten of patiënten in een ziekenhuis, gedurende een lange periode in een voorziening voor verstandelijk gehandicaptenzorg. Het is van belang dat cliënten tijdens hun verblijf niet stil blijven staan in hun ontwikkeling. Het rechtsbeginsel recht op ontplooiing is in de jeugdzorg al langer ingeburgerd. Bescherming heeft in deze sector gaandeweg plaatsgemaakt voor ontplooiing. Een vergelijkbare ontwikkeling is aan de gang in de zorg voor mensen met een verstandelijke handicap. In het kader van het burgerschapsparadigma behoren cliënten de mogelijkheid te hebben om ervaringen op te doen teneinde zich verder te kunnen ontwikkelen. In het Verdrag inzake de rechten van het kind is in artikel 23 opgenomen dat elk kind met een verstandelijke handicap de ruimte moet hebben om zijn zelfstandigheid te bevorderen. De strekking van dit artikel is ook relevant voor volwassen cliënten met een verstandelijke handicap.

Het recht op ontplooiing kan worden verwezenlijkt door de juiste combinatie van bescherming en zelfbeschikking aan te bieden aan cliënten. Dit samenspel is terug te vinden in het rechtsbeginsel goede zorg. Uit dit beginsel vloeit voort dat zorg individueel is gericht en wordt verleend door hulpverleners met bepaalde kwaliteiten. Een hulpverlener moet zijn handelen inzichtelijk maken, verantwoording afleggen aan derden en zich kunnen inleven in de situatie waarin een cliënt zich bevindt teneinde een bijdrage te kunnen leveren aan de ontplooiing van cliënten. Zorg kan in dat kader ook worden beschouwd als het bieden van ondersteuning aan cliënten. De moderne invulling van zorg vertoont veel overeenkomsten met ondersteuning. De nadruk wordt niet meer gelegd op wat een cliënt niet kan, maar op het bevorderen van de empowerment van cliënten. Het recht op goede zorg is niet alleen terug te vinden in artikel 22 lid 1 van de Grondwet, maar is ook verankerd in diverse patiëntenwetten waaronder artikel 2 Kwaliteitswet zorginstellingen, artikel 40 lid 1 Wet big en artikel 7:453 BW (goed hulpverlenerschap). Een belangrijk verschil met het recht op gezondheidszorg (artikel 22 lid $1 \mathrm{Gw}$ ) is dat het recht op goede zorg niet bedoeld is als een sociaal grondrecht, maar eerder verwantschap toont met een individueel grondrecht.

Het bijzondere aan goede zorg is dat in dit rechtsbeginsel zowel ruimte bestaat voor zelfbeschikking als voor bescherming, waardoor een cliënt op het ene mo- 
ment in zijn vrijheid kan worden beperkt en op een ander moment de ruimte wordt geboden om zijn eigen gang te gaan. De reden om cliënten in bescherming te nemen is om hen te beschermen tegen zichzelf. Deze nauwe omschrijving van het beschermingsbeginsel illustreert dat bescherming in het teken moet staan van het welzijn van een cliënt. Redenen om tot bescherming over te gaan mogen in principe niet buiten de cliënt zelf liggen. Een tekort aan personeel, ongekwalificeerd personeel, de wijze waarop een voorziening is gebouwd of te grote groepen cliënten vormen geen redenen om een cliënt tegen zichzelf in bescherming te nemen. De vrijheid van een cliënt wordt op dat moment onterecht beperkt. Uiteraard moet wel rekening worden gehouden met de grenzen van het zelfbeschikkingsrecht. Het betreft in dit geval bescherming van het algemeen belang en bescherming van derden. Deze grenzen gelden voor elke burger in onze samenleving. Een inbreuk op het zelfbeschikkingsrecht is echter pas aan de orde als alternatieven geen uitkomst bieden, er een redelijke verhouding bestaat tussen het doel van de inbreuk en het gevolg ervan en de inbreuk wordt beëindigd zodra de noodzaak daartoe niet meer aanwezig is.

Het thema goed hulpverlenerschap vormt het onderwerp van hoofdstuk 4. Dit thema loopt door in de hoofdstukken 5 tot en met 7 , die alle drie betrekking hebben op de toepassing van vrijheidsbeperking. De kern van hoofdstuk 4 is dat in het kader van goede zorg, hulpverleners over bepaalde kwaliteiten moeten beschikken om deze zorg ook daadwerkelijk te kunnen bieden. De grote lijn die in het normatief kader wordt gepresenteerd leidt ertoe dat hulpverleners vanuit een ander perspectief aan de slag moeten gaan in de zorg voor mensen met een verstandelijke handicap. Zij zullen bewuster om moeten gaan met de rechten van mensen met verstandelijke handicap. Elke vrijheidsbeperking, hoe klein deze ook is, leidt tot een inbreuk op de vrijheid van een cliënt. Van belang is dat deze inbreuken tot een minimum worden beperkt. Goed hulpverlenerschap betekent niet dat een hulpverlener vrijwel nooit mag ingrijpen in het leven van een cliënt. Het omvat meer dan niet-ingrijpen en geen bemoeienis vertonen met een cliënt. Van de hulpverlener wordt verwacht dat hij zich actief opstelt. Zijn handelen dient gericht te zijn op het vergroten van de mogelijkheden van een cliënt. In plaats van niet mogen kan beter worden gesproken over ondersteunen waar mogelijk en noodzakelijk. Om te voorkomen dat deze wijze van handelen de kant opgaat van paternalisme, is het belangrijk dat een hulpverlener zijn handelen inzichtelijk maakt en kan verantwoorden naar derden toe.

Goed hulpverlenerschap veronderstelt ook een professionele standaard. Elke hulpverlener, waaronder ook een persoonlijk begeleider, kan terugvallen op zijn professionele standaard. In tegenstelling tot de professionele standaard van een arts voor verstandelijk gehandicapten (AVG) kan de inhoud van de professionele standaard van een persoonlijk begeleider voornamelijk niet-medisch worden genoemd. Alleen cliënten met een ernstige (meervoudige) handicap doen een beroep op de medische vaardigheden van persoonlijk begeleiders. Deze 
groep vormt echter slechts een deel van de populatie cliënten met een verstandelijke handicap. Mede ten gevolge van de ontwikkelingen in de sector verstandelijk gehandicaptenzorg, waaronder de nadruk die wordt gelegd op het bevorderen van de ontwikkelingsmogelijkheden van cliënten, zullen persoonlijk begeleiders op zoek moeten gaan naar nieuwe vormen van professionaliteit. Een goede hulpverlener onderscheidt zich van andere hulpverleners omdat hij het dilemma tussen bescherming en zelfbeschikking weet te voorkomen door de juiste vorm van ondersteuning aan te bieden aan een cliënt. Ten aanzien van het ondersteunen en begeleiden van cliënten bestaan evenwel nog weinig richtliinen. Een persoonlijk begeleider zal zich deze andere wijze van handelen voor een deel zelf eigen moeten maken. Daarnaast is het van belang dat het management en de beroepsgroep zich richten op het nader vormgeven van een eigen professionele standaard teneinde de positie van de persoonlijk begeleider te verstevigen. Een aantal aspecten dient hiertoe te worden uitgewerkt waaronder de reikwijdte van de verantwoordelijkheden van een persoonlijk begeleider en het ontwikkelen van kwaliteitsnormen voor de functie van een persoonlijk begeleider. Ook kunnen richtlijnen over de toepassing van vrijheidsbeperking meer invulling geven aan de professionele standaard. Een nader omschreven nrofessionele standaard is met name van belang om sterker te staan tegenover andere beroepsgroepen die werkzaam zijn in de verstandelijk gehandicaptenzorg. Persoonlijk begeleiders kunnen zich op grond van hun professionele standaard een eigen positie verwerven in deze sector. Ook zou meer inzicht ontstaan in de onderlinge verhouding tussen de verschillende beroepsgroepen.

Hoofdstuk 5 en 6 illustreren dat het huidige juridische kader voor de toepassing van vrijheidsbeperking in de sector verstandelijk gehandicaptenzorg niet toereikend is. De beoogde interne rechtsbescherming in de Wet Bopz wordt niet geboden aan cliënten en kan op een aantal punten worden verbeterd. In hoofdstuk 5 wordt het juridische kader van vrijheidsbeperking uiteengezet. In de verstandelijk gehandicaptenzorg vindt een breed scala aan vrijheidsbeperkende maatregelen plaats. Door in deze studie uit te gaan van een ruime definitie van vrijheidsbeperking wordt getracht een bredere rechtsbescherming te bieden aan cliënten met een verstandelijke handicap dan nu onder de Wet Bopz het geval is. De Wet Bopz beperkt de toepassing van vrijheidsbeperking tot middelen of maatregelen, dwangbehandeling en beperkingen ex artikel 40 Wet Bopz bij onvrijwillig opgenomen cliënten. De wetgever geeft hiermee aan dat vrijheidsbeperking tot een minimum beperkt moet blijven, mede gezien de gevolgen die de toepassing ervan heeft voor de individuele grondrechten van cliënten. De juridische analyse laat evenwel zien dat in de zorg voor mensen met een verstandelijke handicap ook sprake is van niet-wettelijke maatregelen. Naast het gevaarsmotief uit de Wet Bopz wordt in de literatuur een aantal andere motieven genoemd voor de toepassing van vrijheidsbeperking: beschermingsmotief, behandelingsmotief, handhaven van de orde, opvoedingsmotief en straffen en belo- 
nen. Ook komt vrijheidsbeperking voor bij vrijwillig opgenomen cliënten. Op grond van de Wet Bopz is toepassing van vrijheidsbeperking bij deze groep cliënten verboden. De jurisprudentie laat evenwel een ander beeld zien. Diverse uitspraken illustreren dat vrijheidsbeperking bij vrijwillig opgenomen cliënten is toegestaan, voor zover het verzet van een cliënt zich niet richt op het verblijf in een instituut. De Rechtbank Alkmaar is het niet eens met dit standpunt, maar vindt tegelijkertijd ook dat de leemte die is ontstaan niet moet worden opgevuld door het verlenen van een voorlopige machtiging. De Hoge Raad lijkt een paar jaar later deze uitspraak tegen te spreken. De benodigde zorg en ondersteuning kunnen pas worden geboden aan een cliënt als deze in het bezit is van de juiste juridische status. Dit alles betekent dat het huidige systeem van de Wet Bopz dusdanig in elkaar zit, dat alvorens dwangbehandeling of middelen of maatregelen mogen worden toegepast, eerst de juridische status moet worden aangepast. In de discussie wordt ook de Wgbo betrokken. Behalve de Wet Bopz biedt de Wgbo ook enige ruimte voor de toepassing van vrijheidsbeperking. Het gaat echter om somatische handelingen die, ondanks verzet van een wilsonbekwame cliënt, moeten worden uitgevoerd om ernstig nadeel voor de cliënt te voorkomen. De Wet Bopz gaat uit van een ruimer criterium: gevaar voor de cliënt zelf of anderen. De Wgbo is gezien de aard van de overeenkomst niet bedoeld voor een ingrijpende maatregel als vrijheidsbeperking in de zin van de Wet Bopz. De Wgbo heeft als doel om in overleg met de cliënt vrijwillig afspraken te maken over de begeleiding en ondersteuning die nodig is voor een cliënt. Daarnaast biedt de Wet Bopz meer waarborgen: interne registratie, melding aan de Inspectie, toetsing van de rechter en een Bopz-klachtrecht. Naast een ruimere interpretatie van de motieven voor vrijheidsbeperking en de toepassing van vrijheidsbeperking bij vrijwillig opgenomen cliënten laten eerdere onderzoeken zien dat ook buiten instituten vrijheidsbeperking voorkomt. De Wet Bopz geldt vooralsnog alleen in instituten.

Hoofdstuk 6 besteedt aandacht aan de toepassing van vrijheidsbeperking in de praktijk. Wat allereerst opvalt is dat het veld zich niet houdt aan de enge betekenis van vrijheidsbeperking die in de Wet Bopz wordt gehanteerd. In de sector verstandelijk gehandicaptenzorg worden veel toepassingen van vrijheidsbeperking gedoogd. De casus die in dit hoofdstuk worden gepresenteerd illustreren dat vrijheidsbeperking ook buiten het juridische kader plaatsvindt. Veel van deze toepassingen vinden overigens plaats met toestemming van cliënt en/of vertegenwoordiger (de zogenaamde middelen of maatregelen akkoord). De vraag is hierbij of beide partijen ook daadwerkelijk vrijwillig hebben ingestemd met de toepassing of dat toch niet sprake is van enig verzet. Het grootste probleem vormt evenwel de toepassingen van vrijheidsbeperking bij vrijwillig opgenomen cliënten. Het empirische onderzoek laat zien dat op de werkvloer nauwelijks onderscheid wordt gemaakt tussen vrijwillig en onvrijwillig opgenomen cliënten. Instituten vinden het belangrijker om, ongeacht de juridische 
status, aan elke cliënt kwalitatief goede zorg te bieden. De vraag is echter of vrijheidsbeperking bij elke cliënt op een verantwoorde wijze plaatsvindt, aangezien een deel van de waarborgen die de Wet Bopz biedt, niet van toepassing is op vrijwillig opgenomen cliënten.

De empirische analyse onderschrijft dat de Wet Bopz geen geschikt kader vormt voor de sector verstandelijk gehandicaptenzorg. Hulpverleners kunnen onvoldoende uit de voeten met het huidige juridische kader voor vrijheidsbeperking. Pas als sprake is van gevaar mag een hulpverlener ingrijpen in de vrijheid van een cliënt. Deze wijze van handelen strookt niet met het bieden van goede zorg aan cliënten. Persoonlijk begeleiders spreken in termen van beschermen, opvoeden en pedagogisch handelen. Deze terminologie komt niet voor in de Wet Bopz. Het gevolg is dat hulpverleners met hun handelen buiten de juridische kaders treden teneinde goede zorg te bieden aan cliënten.

De sector verstandelijk gehandicaptenzorg staat echter wel achter de uitgangspunten van de Wet Bopz. Hulpverleners onderschrijven dat bewuster moet worden omgegaan met toepassingen van vrijheidsbeperking. Enige vorm van verantwoording en toezicht is noodzakelijk om de rechtspositie van cliënten met een verstandelijke handicap te waarborgen.

In hoofdstuk 7 wordt, naar aanleiding van de bevindingen in hoofdstuk 5 en 6 , een aanzet gegeven voor een alternatieve regeling voor de toepassing van vrijheidsbeperking. De reikwijdte van dit alternatief beperkt zich vooralsnog tot de sector verstandelijk gehandicaptenzorg en de psychogeriatrie. ${ }^{1}$ Het voorstel gaat uit van de gedachte dat een wettelijke regeling die de toepassing van vrijheidsbeperking reguleert aandacht moet hebben voor goede zorg en rechtsbescherming. Beide uitgangspunten komen onvoldoende naar voren in de huidige Wet Bopz. Cliënten krijgen enerzijds niet de zorg waar ze recht op hebben en anderzijds worden zij onvoldoende beschermd tegen wettelijke en (met name) nietwettelijke vormen van vrijheidsbeperking.

Een kenmerk van de alternatieve regeling is dat het onderscheid tussen vrijwillig en onvrijwillig opgenomen cliënten komt te vervallen. Elke cliënt die is opgenomen in een voorziening kan te maken krijgen met vrijheidsbeperking. Het gevolg is ook dat het onderscheid tussen de externe en interne rechtspositie komt te vervallen. Een belangrijke reden is dat de Wet Bopz nog teveel wordt gekarakteriseerd als een opnamewet. Een groot deel van de bepalingen in deze wet heeft betrekking op de opneming van een cliënt. In de verstandelijk gehandicaptenzorg is het onderscheid tussen de externe en interne rechtspositie veel

1 Hoewel de alternatieve regeling ook is geschreven voor de sector psychogeriatrie, wordt de toepasbaarheid voor deze sector in dit boek buiten beschouwing gelaten. L. Arends, die een proefschrift over de rechtspositie van de psychogeriatrische patiènt voorbereidt, werkt dit aspect in zijn proefschrift uit. 
minder relevant. Een opneming in een voorziening wordt gezien als het startpunt voor de ondersteuning en begeleiding die nog gaat volgen. In de alternatieve regeling wordt opneming dan ook beschouwd als een bijzondere vorm van vrijheidsbeperking. Daarnaast wordt het begrip vrijheidsbeperking verruimd, waardoor ook pedagogische maatregelen en beschermende maatregelen tot dit begrip worden gerekend. De intentie van de maatregel is niet langer maatgevend: het gaat om de gevolgen van de maatregel. Een ander aspect van de alternatieve regeling is dat het locatiegebonden karakter van de Wet Bopz komt te vervallen. Vrijheidsbeperking kan in beginsel overal plaatsvinden. Deze verruiming van de reikwijdte van de regeling, komt tegemoet aan de werkwijze in de praktijk. Ook cliënten in een gvt krijgen te maken met vrijheidsbeperking. Een belangrijk verschil met de Wet Bopz is dat elke cliënt waarbij vrijheidsbeperking wordt toegepast aanspraak kan maken op een adequate rechtsbescherming. In de alternatieve regeling wordt de nadruk gelegd op kwaliteit en transparantie. Elke voorziening dient te beschikken over een intern registratiesysteem. De informatie uit dit systeem kan worden gebruikt voor het ontwikkelen van een beleid dat gericht is op het terugdringen van vrijheidsbeperking. Daarnaast wordt de functie van cliëntenvertrouwenspersoon (cvp) geïntroduceerd. Cliënten zijn minder in staat om op te komen voor hun eigen rechten waardoor zij ook niet snel zullen besluiten om een klacht in te dienen. Een cvp kan een cliënt wijzen op zijn rechten en waar nodig ook ondersteuning bieden.

Naast een cvp wordt een aantal regionale toetsingscommissies vrijheidsbeperking ingesteld. Deze commissies zijn multidisciplinair samengesteld en bestaan uit een arts (bij voorkeur een arts voor verstandelijk gehandicapten), een gedragsdeskundige, een ethicus en een jurist (tevens voorzitter van de commissie). Deze commissies toetsen of hulpverleners op een zorgvuldige wijze omgaan met de toepassing van vrijheidsbeperking. In elke voorziening is een interne toetsingscommissie vrijheidsbeperking aanwezig waarbij alle meldingen van vrijheidsbeperking worden geregistreerd. Alleen de ernstige vormen van vrijheidsbeperking worden twee keer per jaar doorgestuurd naar de regionale toetsingscommissie vrijheidsbeperking die vervolgens beoordeelt of zorgvuldig is gehandeld. Tevens wordt de regionale toetsingscommissie betrokken bij de opneming van cliënten (in de alternatieve regeling een bijzondere vorm van vrijheidsbeperking genoemd). Indien de vertegenwoordiger van een wilsonbekwame cliënt geen toestemming verleent of afwezig is richt het Regionaal Indicatieorgaan zich tot de regionale toetsingscommissie met het verzoek om de procedure voor opneming extern te toetsen. De regionale toetsingscommissie kan ook worden ingeroepen door een wilsonbekwame cliënt en/of de cliëntenvertrouwenspersoon als de desbetreffende cliënt het niet eens is met het oordeel van het Regionaal Indicatieorgaan. Daarnaast bestaat de mogelijkheid om op verzoek van een cliënt, een vertegenwoordiger, een cliëntenvertrouwenspersoon of een hulpverlener ook niet-ernstige vormen van vrijheidsbeperking te beoor- 
delen. De regionale toetsingscommissies vrijheidsbeperking toetsen, in de eerder genoemde situaties, aan de hand van een aantal zorgvuldigheidseisen of sprake is van een zorgvuldige toepassing van vrijheidsbeperking. Het voordeel van deze vorm van toetsing is dat enerzijds meer openheid ontstaat over vrijheidsbeperking en anderzijds ook meer controle mogelijk is. Bovendien biedt de samenstelling van de commissie de mogelijkheid om vanuit verschillende perspectieven, waaronder de praktijk, de ethiek en het recht, naar de problematiek te kijken.

Ofschoon de reikwijdte van de alternatieve regeling veel ruimer is dan die van de Wet Bopz, blijft de toepassing van vrijheidsbeperking ook nu een ultimum remedium. Om vrijheidsbeperking te mogen toepassen moet voldaan zijn aan het noodzakelijkheidscriterium. Noodzaak wordt in dit kader uitgelegd als noodzakelijk voor de cliënt zelf. Factoren die buiten de cliënt liggen worden in eerste instantie niet tot dit criterium gerekend. Noodzaak dient echter wel ruimte open te laten voor 'gevaar voor derden'. In deze betekenis draagt vrijheidsbeperking weliswaar niet direct bij aan het welzijn en de ontwikkeling van de cliënt, maar worden derden in bescherming genomen. Van belang is dat in aanmerking wordt genomen of de maatregel effectief is, in verhouding staat tot het doel dat wordt beoogd en er geen redelijk alternatief is met een minder ingrijpend karakter. In de uitvoering van de maatregel kan in een dergelijke situatie op diverse manieren een bijdrage worden geleverd aan de ontplooiing van cliënten (voortdurend in contact blijven met de cliënt, op zoek gaan naar alternatieven en de maatregel niet te lang laten voortduren).

In de alternatieve regeling wordt aansluiting gezocht bij de specifieke kenmerken van de sector verstandelijk gehandicaptenzorg. Dit voorkomt echter niet dat ook een aantal kanttekeningen kunnen worden geplaatst bij de inhoud ervan. Critici zullen erop wijzen dat de mogelijkheden om vrijheidsbeperking toe te passen zijn verruimd. De alternatieve regeling heeft een veel bredere reikwijdte dan de Wet Bopz. De verwachting is echter niet dat, mede vanwege het ruime gedoogbeleid dat nu al onder de Wet Bopz plaatsvindt, de toepassing van vrijheidsbeperking gaat toenemen. Ook de kritiek dat het criterium noodzaak de deur openzet voor de toepassing van vrijheidsbeperking is onterecht. Het begrip noodzaak sluit beter aan bij de visie die wordt gehanteerd in de sector verstandelijk gehandicaptenzorg: het bieden van goede zorg die gericht is op de ontplooiing van cliënten. Een belangrijke voorwaarde is dat hulpverleners hun handelen inzichtelijk maken en verantwoorden. Andere kanttekeningen die nader bekeken moeten worden zijn de mogelijkheden en beperkingen van toezicht op vrijheidsbeperking die buiten instituten plaatsvindt, het aanbrengen van gradaties in vrijheidsbeperking zodat niet elke vorm van vrijheidsbeperking hoeft te voldoen aan de strikte eisen van kwaliteit en transparantie en tot slot het geven van toestemming voor vrijheidsbeperking. Het begrip verzet blijft een lastig punt. De aanwezigheid van een crp, een interne toetsingscommissie vrijheids- 
beperking en de regionale toetsingscommissies vrijheidsbeperking bieden evenwel meer waarborgen om zorgvuldig om te gaan met de interpretatie van verzet van een cliënt. Het is de vraag of een aparte regeling voor de toepassing van vrijheidsbeperking in de sector verstandelijk gehandicaptenzorg wenselijk is. Aparte regelingen dragen niet bij aan de integratie van mensen met een verstandelijke handicap. In deze sector zijn echter dusdanige belangen in het geding, dat een aparte regeling om meerdere redenen gerechtvaardigd is. Cliënten in deze sector zijn doorgaans minder wilsbekwaam en worden, in tegenstelling tot in de psychiatrie en de verpleeghuissector, gedurende vrijwel hun hele leven geconfronteerd met (ingrijpende) vormen van vrijheidsbeperking.

Deze studie wordt afgesloten met een aantal conclusies en aanbevelingen (hoofdstuk 8). Benadrukt wordt dat de zorg aan mensen met een verstandelijke handicap vanuit een ander perspectief dient plaats te vinden. Onder ander perspectief wordt verstaan het juridische perspectief en de betekenis die dit perspectief voor cliënten met een verstandelijke handicap kan hebben. Van belang is echter wel dat in het recht voldoende aansluiting wordt gezocht bij de kenmerken van de sector verstandelijk gehandicaptenzorg. In het huidige juridische kader gebeurt dit nog onvoldoende waardoor hulpverleners de regels gaan ontwijken. De Wet Bopz is daar een goed voorbeeld van. Hulpverleners kunnen niet de benodigde ondersteuning bieden aan cliënten waardoor niet altijd sprake kan zijn van goede zorg. In hoofdstuk 8 wordt ook een aantal aanbevelingen gedaan teneinde de taken en bevoegdheden van de verschillende actoren in de sector verstandelijk gehandicaptenzorg te verduidelijken. Uiteindelijk dient het boek een bijdrage te leveren aan het verduidelijken van de rechtspositie van cliënten met een verstandelijke handicap. Hoewel het onderzoek slechts in een klein aantal voorzieningen heeft plaatsgevonden zijn de uitkomsten van het onderzoek wel degelijk van betekenis voor de sector verstandelijk gehandicaptenzorg. Een onderzoek, waarin de nadruk wordt gelegd op de rechten van cliënten, is in deze sector geen overbodige luxe. Meer aandacht voor rechten moet overigens niet leiden tot meer bureaucratisering in de zorg. Van hulpverleners wordt verwacht dat zij hun handelen inzichtelijk kunnen maken waarbij van belang is dat zij kunnen aangeven om welke reden een cliënt in zijn vrijheid wordt beperkt. De enige legitieme reden zou moeten zijn het stimuleren van de ontplooiing van cliënten. 



\section{Summary}

In the last decades of the previous century, the awareness has been growing that individuals with an intellectual disability too should have the chance to live their life as much as possible according to their own views. This notion can be traced back to the citizenship paradigm, which declares that "individuals with an intellectual disability are equal to individuals without this disability and ought to have the same rights and duties as any other member of society.' According equal rights in itself is not enough to guarantee the legal position of clients with an intellectual disability. Usually, clients need to be made aware of their rights, and need (extra) help to realize these rights. In the context of the citizenship paradigm the word 'support' is used. Depending on the limitations he experiences as a result of his intellectual disability, a client is in need of a certain measure of support. Without support from a personal coach or a representative, many clients will find it hard to make their choices by themselves.

The citizenship paradigm pursues the idea that the principle of self-determination is inadequate when it comes to individuals with an intellectual disability. This principle of law is based on the notion that any individual, irrespective of his ability to exercise this right, has the freedom to give direction to his life. The right to self-determination has an important place in our society: it forms the framework of the law on patients' rights, which have been growing explosively since the nineties of the previous century. The Dutch Psychiatric Hospitals (Compulsory Admissions) Act (from nôw on: Psychiatric Hospitals Act) emphasizes that clients are to be restricted as little as possible in their freedom. It is only in case of danger of the client to himself or to others that a freedom restricting measure can be applied. The principles of the right of self-determination should also be respected in the care for the intellectually disabled. Clients with an intellectual disability have their own abilities and wishes. The right to self-determination (in general) implies an attitude of the care provider of aloofness, of non-intervention. This is not always to the advantage of the legal position of clients with an intellectual disability, who usually lack the wherewithal to shape their lives independently. The intention of the law should encourage the development of the right of self-determination of these individuals. The right to good care is an important right in this context. A client with an intellectual disability has a right to good care in the sense that it is committed, supportive and protective where needed. Good care requires certain qualities of health care providers. Health care providers are expected to do more than to remain aloof from clients and to try not to interfere. The good health care provider knows when to act in order to give the client's abilities a chance to develop. This way of acting requires a new way of thinking. On the one hand, it is to be prevented that 
health care providers become (too) paternalistic; on the other hand health care providers are expected not to leave clients too much to themselves out of respect for their right to self-determination.

In this study, the central question is the following: 'What is the (internal) legal position of clients with an intellectual disability, in care, when it comes to the application of freedom restrictions; what form does the internal legal position take in practice and which relevant recommendations can be made?'

This question has been narrowed down to the application of freedom restrictions in relationship to the client's right to good care and the health care provider's right to good care providership. Freedom restriction in the care for clients with an intellectual disability is a much debated subject. All too often, the issue of freedom restriction is viewed either from the perspective of providing protection for the client or from the perspective of stimulating self-determination of clients. In this study, this opposition of views is abandoned. Both perspectives are considered as essential for the legal position of clients with an intellectual disability. At certain times, protecting clients when this is done with the intent to further the development of the client is acceptable. In many instances, this protection consists of a restriction of the client's freedom. It is important that the health care provider is able to explain this restriction in terms of the development of the client.

In chapter 1 the origin of this study is explained. The legal framework and the function of the law in the care for persons with an intellectual disability are described. Also, the concept of intellectual disability is explored and a description is given of the sector of care for the intellectually disabled and the ongoing developments in this sector.

The way, in which the empirical data for this study have been gathered and analyzed, is explained in chapter 2 . The empirical research can be characterized as a qualitative nature, and comprises of two investigations. In the first place, qualitative data have been gathered in three different types of institutions for the care of the intellectually disabled. In these institutions, interviews have been done with clients, client's representatives and health care providers, participating observation has been practiced and clients' files have been studied. Also, conclusions from the second evaluation of the Psychiatric Hospitals Act, relevant to the internal legal position of clients with an intellectual disability in care, have been taken into account. The results of both investigations are to be found in chapter 6.

The normative framework, described in chapter 3, explores the principles of law that are of importance to the care for individuals with an intellectual disability. Next to the right of protection and the right of self-determination, two other principles are introduced: the right to good care and the right to development. Before discussing the content of and the relation between these four principles, the import of law for the sector of care for individuals with an intellectual dis- 
ability is given a foundation. So far, too little attention has been given to the law in this sector. In this study, the stance is taken that a certain measure of juridisation is unavoidable in this sector. A number of reasons can be mentioned. Most importantly, the relationship of a client with an intellectual disability and his health care provider is not a relationship of equals. Mostly, clients are in a very vulnerable position. They are less able to be assertive when it comes to their interests. Apart from this, the relationship is characterized by a certain measure of dependency. It is up to the health care provider to decide whether he will apply freedom-restricting measures to a client. And is also the health care provider who decides on the duration of these measures. The client's vulnerable and dependent position asks for legal protection. It is the responsibility of the law to safeguard the legal position of clients. This, however, is not the only function of law in this sector. Every client ought to have, within the scope of his abilities, the chance to live life according to his own views. This means that it is also up to the law to respect, and if possible, to promote, the right to self-determination of clients.

Health care providers take a different view on juridisation in the care for individuals with an intellectual disability. All too often, the predominant idea is that the law restricts their freedom to act. Ethicists add to this that juridisation in this sector leads to a diminishing level of care. The inherent character of the care relationship - dependency of the client - would be affected by an increased impact of the law. This supposition is unfounded. The dependent position of the client is indeed acknowledged in law, but it is no longer the central issue. The law stresses other characteristics of the care relationship. The law proposes to amend the unequal positions of the relationship of health care provider and client. Equality and respect for each other are the essential elements of the care relationship and contribute to the further development of clients. It is defended that the law is not directed only at individuality and the health care provider's aloofness from clients. In the care for the intellectually disabled a broader view is necessary: good care and development are concepts that play an important part in law.

Health care providers rightly state that the law sets certain boundaries and demands their accountability for their actions. These characteristics of the law are not to be seen as negative juridisation, but form a part of the (protecting) role the law plays in the care for individuals with an intellectual disability. Within the boundaries of the law the health care providers have sufficient freedom. However, in this study the proposition is defended that the Psychiatric Hospitals Act can be seen as a form of negative juridisation in the sector of care for the intellectually disabled. The principles of this act are endorsed, but this is not the case when it comes to the contents of the act. As it is, the Psychiatric Hospitals Act takes little account of the specific characteristics of the sector, and as a result the goals of the act are not reached. Besides, there is too much stress on the right to 
self-determination of clients. In the chapters 5, 6 and 7 these problems are investigated further.

In this study, due to the specific position of individuals with an intellectual disability, the emphasis will be on the right to development. Unlike psycho-geriatric patients or patients in a hospital, clients in instutions for the care of the intellectually disabled stay there for long periods of time. It is of importance that during their stay, the clients' development does not stagnate. The right to development has already been established for some time as a principle of law in care for the young. By and by, the emphasis in this sector has shifted from protection to development. A similar change of perspective is ongoing in the care for those with an intellectual disability. In the context of the citizenship paradigm, clients should have the opportunity to gain experiences in order to be able to further their development. Article 23 of the Convention on the rights of the Child states that every mentally disabled child, whenever possible, should have the appropriate assistance in order to further his self-reliance. This article is also relevant for adult clients with an intellectual disability.

The right to development can be realized by offering clients the right combination of protection and self-determination. This mix can be deduced from the principle of law 'good care.' It follows from this principle that care has to be directed individually at each client, and that this care is given by care providers with certain qualities. A care provider has to be able to give care in a transparent way and to be accountable for his actions to third parties. Also, he has to be able to empathize with the situation the client is in, in order to be able to contribute to the development of clients. From this point of view, care can be seen as the offering of support to clients. In the modern interpretation, care is in many ways similar to support. The emphasis is no longer on what the client is unable to do, but on encouraging the 'empowerment' of clients. The right to good care is based on article 22 (1) of the Dutch Constitution, but is also laid down in a number of patients' rights acts, among them article $2 \mathrm{Kwz}$ (Care Institutions (Quality) Act), article 40 (1) Wet big (Individual Health Care Professions Act), and article 7:453 BW (the Civil Code) on good care providership. An important difference with the right to health care of article 22(1) is that the right to good care is not meant to be a socially defined civil right, as it shows more characteristics of an individual civil right.

The right to good care is special in this respect that there is room for self-determination as well as protection in this principle of law, which allows for the client's freedom to be restricted at one time and at another time gives more scope for the client's activities. The object of clients' protection is absolutely limited to protecting the client against himself. This narrow description of the principle of protection illustrates that protection is only allowed in the interest of the client. In principle, reasons for taking measures for protecting a client are not to be found outside the client. Staff shortages, unqualified staff, the way the insti- 
tution is built, or overcrowding of clients: none of these is a valid reason to protect client against himself. Restricting a client's freedom on any of these grounds is unjustified. Of course, the boundaries of the right to self-determination have to be taken into account. In this case, this concerns the protection of the common good and of third parties. These boundaries apply for all citizens in our society. However, there is only room for infringing the right to self-determination when there is no adequate alternative, and when there is a reasonable proportion between the object of the infringement and the consequences of it, and the infringement is stopped the very moment the necessity for it is no longer there.

The good health care providership is the central subject of chapter 4 . This theme is followed up in the chapters 5-7, which are all dealing with the application of freedom restrictions. The key issue in chapter 4 is that, in the context of good care, health care providers should possess certain qualities in order to be able to actually deliver good care. From the broad outline presented in the normative framework follows that there is a different perspective for health care professionals in the care for persons with an intellectual disability. They will have to become more aware of the rights of clients with an intellectual disability. Any restriction of freedom, however minor, constitutes a breach of the freedom of the client. It is essential that these breaches are limited to the minimum. Good health care providership does not mean that the care provider is almost never allowed to intervene in the life of a client. It consists of more than non-intervention and an attitude of aloofness towards the client. The role expected of care provider is an active one. His actions are to be directed at stimulating of the abilities of a client. Instead of talking about 'non-intervention,' it is preferable to talk of 'support where possible and necessary.' To prevent a development of this way of acting in the direction of paternalism, it is important that the care provider is transparent in his actions and is accountable to third parties.

Good health care providership presupposes a professional standard. Any care provider, including the personal coach, has a professional standard to fall back on. Unlike the professional standard of the medical specialist for the intellectually disabled, the content of the professional standard of a personal coach can be described as mainly non-medical. Only clients with serious (multiple) disabilities need a personal coach with some medical skills. This group is just one part of the population of clients with an intellectual disability. Partly as a result of developments in the sector of care for the intellectually disabled, among those the emphasis put on the developmental possibilities of clients, personal coaches will have to find new forms of professionalism. A good care provider distinguishes himself from others by solving the dilemma between protection and self-determination by finding a way to offer the right form of support to the client. As yet, however, there are few guidelines concerning the support and the coaching of clients. Personal coaches will have to find their way by themselves to the new way of coaching. It is also important that management and personal coaches 


\section{Summary}

work towards developing a professional standard in order to strengthen the position of the personal coach. Thereto a number of aspects will have to be outlined, including the scope of the responsibilities of the personal coach and the development of quality standards for the function of personal coach. Guidelines on the application of freedom restriction can help shape the professional standard. A better-defined professional standard is important especially to strengthen the position of the professional in relation to other professions in the field of care for the intellectually disabled. Personal coaches, with the help of their professional standard, can acquire their own position in the sector. In this way, the various relationships of the several professions are clarified.

Chapter 5 and 6 illustrate the shortcomings of the current legal framework for the application of freedom restriction in the sector of care for the intellectually disabled. The Psychiatric Hospitals Act proposes to safeguard the internal legal position of clients but it fails to deliver, and it can be improved on a number of points. In chapter 5 the legal framework concerning freedom restriction is set out. In the care for the intellectually disabled, a whole range of freedom restricting measures is applied. In this study, by giving a broad definition to freedom restriction, it is intended to offer a broader legal protection to clients with an intellectual disability than is the case under the regime of the current Psychiatric Hospitals Act. The Psychiatric Hospitals Act limits the application of freedom restriction to 'means' or 'measures,' forced treatment and restrictions on the basis of article 40 of the Act, to clients staying with a compulsory admission in the institution. In this way, the legislator indicates that the application of freedom restrictions has to be restricted to the minimum, in part because of the consequences of application for the clients' individual civil rights. However, legal analysis shows that in the care for individuals with an intellectual disability nonlegal measures also occur. Apart from the danger criterion in the Psychiatric Hospitals Act a number of other criteria has been proposed, in literature, for the application of freedom restriction: a protection criterion, a treatment criterion, a maintaining order criterion, an education criterion and a punishment-and-reward criterion. Freedom restriction is also applied to clients staying in the institution voluntarily. The Psychiatric Hospitals Act does not allow the application of freedom restriction for this group of clients. However, jurisprudence shows another picture. Several court decisions indicate that freedom restriction is allowed for voluntarily staying clients, as long as the client's resistance is not directed at his stay in the institution. The Court of Alkmaar disagrees with this opinion, but at the same time expresses the view that the existing hiatus is not to be remedied by issuing an interim authorization. A few years later, the Supreme Court disagrees with this judgement. The necessary care and support can only be offered to a client when the client possesses the correct legal status. According to the current system of the Psychiatric Hospitals Act, this means that the legal status of the client will have to be adjusted before enforced treatment or means 
or measures can be lawfully applied. The provisions on the medical treatment contract in the Civil Code also enter into this discussion. Besides the Psychiatric Hospitals Act, the Civil Code provisions on the medical treatment contract offer some room for the application of freedom restriction. This concerns somatic treatment only, which has to be carried out even though an incompetent client resists, when this is necessary to prevent serious harm to the client. The criterion in the Psychiatric Hospitals Act is broader: danger of the client to himself or to others. The Civil Code provisions on the medical treatment contract are by their very nature not intended to provide for far-reaching measures like the freedom restricting measures of the Psychiatric Hospitals Act. The Civil Code provisions propose to stimulate consultation and freely reached agreement between health care provider and the client on the treatment and support necessary to the client. In comparison, the Psychiatric Hospitals Act offers more safeguards: internal registration, informing the health care inspector, checks by the courts, and the right to complain as set out in the Psychiatric Hospitals Act.

Besides a broader interpretation of the criteria for freedom restriction and the application of freedom restriction with voluntarily residing clients, previous research has shown that freedom restriction is applied outside institutions as well. As yet, the Psychiatric Hospitals Act is only applicable within institutions.

Chapter 6 focuses on the application of freedom restriction in practice. The first thing that attracts notice is that the field does not adhere to the 'narrow' sense of freedom restriction according to the Psychiatric Hospitals Act. In the sector of care for the intellectually disabled, many applications of freedom restriction are 'tolerated.' The cases presented in this chapter illustrate that freedom restriction does occur in situations outside the legal framework. Many of these freedom restrictions are applied with the consent of the client and/or his representative (the so-called means and measures agreement). The question remains whether this consent has really been given freely for the application and whether there really is no resistance. However, the biggest problem is the application of freedom restriction with voluntarily residing clients. The empirical research shows that in practice hardly ever a distinction is made between voluntarily and involuntarily residing clients. Institutions are more interested in providing good quality care to all clients, irrespective of their legal status. The question then is whether freedom restriction is applied in a responsible way with all clients concerned, considering that some of the safeguards offered by the Psychiatric Hospitals Act do not apply to voluntarily resident clients.

The empirical analysis confirms the view that the Psychiatric Hospitals Act is not a suitable framework for the sector of care for the intellectually disabled. Care providers are hampered by the current legal framework concerning freedom restriction. Only in case of (serious) danger the care provider is allowed to restrict a client's freedom. This way of acting does not tally with delivering good care to clients. Personal coaches see their work in terms of protecting, educating 
and proceeding in an educational way. These terms are absent in the Psychiatric Hospitals Act. As a result, care providers act outside the legal framework in order to offer good care to clients.

The sector of care for the intellectually disabled does subscribe to the principles of the Psychiatric Hospitals Act. Care providers agree that it is necessary to become more aware when it comes to the application of freedom restriction. Some form of accountability and surveillance is needed to safeguard the legal position of clients with an intellectual disability.

With reference to the findings in chapters 5 and 6 , in chapter 7 an initial impetus is given for an alternative regulation for the application of freedom restriction. For now, the scope of this alternative is limited to the sector of care for the intellectually disabled and psychogeriatrics.' The proposal's starting point is that regulation by law of the application of freedom restriction should emphasize the rights to good care and legal protection. The latter two principles receive too little attention in the current Psychiatric Hospitals Act. On the one hand, clients do not receive the care they are entitled to, and on the other hand they are insufficiently protected against legal and (especially) illegal forms of freedom restriction.

The hallmark of the alternative regulation is that there is no longer a distinction between clients who are in the institution on a voluntary basis and those who were compulsorily admitted. Any client staying in an institution is liable to experience freedom restriction. In the alternative regulation the distinction between the external legal position and the internal legal position disappears. This is because the Psychiatric Hospitals Act is still too much a regulation about admission. Many of the articles of the Psychiatric Hospitals Act deal with the admission of a client to an institution. In the care for the intellectually disabled the distinction between external and internal legal position is much less relevant. The admission to an institution is seen as the starting-point for the support and coaching that is to follow. In the alternative regulation therefore, the admission is treated as a special form of freedom restriction. The concept of freedom restriction is also broadened in such a way that educational measures and protective measures become part of the concept. The intention of a measure is no longer the criterion: the consequences of a measure are. Another aspect of the alternative regulation is the letting go of the location bound character of the Psychiatric Hospitals Act. In principle, freedom restriction can happen anywhere. This widening of the scope of the regulation goes some way to meet the method

Although the alternative regulation has been written for the sector of psychogeriatric as well, the application of this regulation for this sector is not discussed in this book. L. Arends, who is working on a thesis on the legal position of the psychogeriatric patient, will develop this aspect in his thesis. 
of working in practice. Clients in a surrogate family unit can also encounter freedom restriction. An important difference (of the alternative regulation) compared with the Psychiatric Hospitals Act is that any client who experiences the application of freedom restriction is entitled to adequate legal protection. The alternative regulation emphasizes quality and transparence. Each institution will have to have an internal registration system. The information gathered by this system can be used to develop a policy directed at pushing back freedom restriction. Also, the function of client's advocate is introduced. Clients are less able to stand up for their rights, which also mean that they do not easily decide to file a complaint. The client's advocate can advise the client as to his rights and offer support where necessary.

In addition to a client's advocate, a number of regional assessment committees on freedom restriction will be provided. These committees are multidisciplinary in composition and consist of a physician (preferably a physician for the intellectually disabled), a specialist on behaviour, an ethicist and a lawyer (who is also presiding the committee). These committees assess whether care providers are duly careful in applying freedom restrictions. Each institution has its own internal assessment committee on freedom restriction, where all reports of freedom restriction are registered. Only the more serious forms of freedom restriction are sent on, twice a year, to the regional assessment committee, which then assesses whether the treatment was sufficiently careful. The regional assessment committee will also be involved in the admittance of clients (in the alternative regulation this is seen as a special form of freedom restriction). In case of absence or a refusal of the representative of an íncompetent client, the regional indication organ turns to the regional assessment committee with the request to assess the followed procedure of admittance externally. An incompetent client and/or the client's advocate can also approach the regional assessment committee when the client disagrees with the judgment of the regional indication organ. In addition the client, the representative, the client's advocate or a care worker can request the assessment of the less serious forms of freedom restriction. The regional assessment committees on freedom restriction determine whether the application of freedom restriction has been careful in the above named situations on the basis of requirements of carefulness. The advantage of this form of assessment is that freedom restriction will become more transparent and at the same time, an improved control is possible. Moreover, the composition of the committee makes it possible to view the issue from different perspectives, including practice, ethics and the law.

Although the scope of the alternative regulation is much broader than that of the Psychiatric Hospitals Act, the application of freedom restriction still remains an ultimum remedium. The application of freedom restriction is acceptable only when the criterion of necessity is met. Necessity in this context is viewed as a necessary for the client himself. In principle, factors outside the client are not 
considered part of the criterion. Necessity, however, does have to leave room for 'danger to others.' In this sense the freedom restriction does not directly contribute to the well-being and the development of the client, but third parties are being protected. It is important to assess whether the measure is effective, in proportion to the intended goal and there is no reasonable alternative that is less intrusive in character. Still, during the execution of the measure there are several ways in which a contribution is possible to the development of the client (keeping in contact with the client at all times, looking for alternatives, ending the measure as soon as possible).

In the alternative regulation reference is made to specific characteristics of the sector of care for the intellectually disabled. This will not prevent a number of critical comments to be voiced about the contents of the regulation. Critics will point out that the opportunities for the application of freedom restrictions have increased. The scope of the alternative regulation is much wider than that of the Psychiatric Hospitals Act. It is however the expectation, due to the actual wide practice of toleration under the Psychiatric Hospitals Act, that the application of freedom restriction will not increase. Critical voices, which state that the necessity criterion will throw the door to freedom restriction wide open, are wrong. The necessity criterion is better suited to the views held in the sector of care for the intellectually disabled: offering good care, directed at the development of clients. An important condition is that care providers are transparent in their actions and are accountable. Other comments that need closer attention relate to possibilities and limitations of surveillance of freedom restriction outside the instutions; the classification of freedom restriction in order to label some forms of freedom restriction as not needing to meet the strict demands of quality and transparence; and finally the giving of consent for freedom restriction. The concept of resistance remains a difficult issue. The availability of a client's advocate, an internal assessment committee and a regional assessment committee on freedom restriction offer extra safeguards for the careful interpretation of resistance of a client. In general, it is doubtful whether a separate regulation on the application of freedom restriction in the sector of care for the intellectually disabled is desirable. Separate regulations do not contribute to the integration of persons with an intellectual disability. However, the interests at issue in this sector are such, that they do justify a separate regulation for a number of reasons. Clients in this sector are usually less competent and, unlike clients in psychiatric and psychogeriatric institutions, they are often confronted with (serious) forms of freedom restriction for a large part of their life.

This study will be completed with a number of conclusions and recommendations (chapter 8). It is emphasized that the care for persons with an intellectual disability should be given from another perspective. With 'another perspective' is meant the legal perspective and the significance that this perspective can have for clients with an intellectual disability. It is however of importance that the law 
pays adequate attention to the characteristics of the sector of care for the intellectually disabled. In the current legal framework this is insufficiently the case, which leads to care providers evading the rules. The Psychiatric Hospitals Act is a case in point. Care providers are unable to offer clients the appropriate support and are therefore at times unable to deliver good care. In chapter 8 a number of recommendations is made in order to clarify the duties and responsibilities of the several actors in the sector of care for the intellectually disabled. In the end, this book should contribute to the clarification of the legal position of clients with a intellectual disability. Although the research has taken place in a small number of institutions, the outcomes of the research are relevant for the sector as a whole. Research with emphasis on the legal rights of clients is not a superfluous luxury in this sector. More attention to rights does not have to lead to more bureaucracy in care. Care providers are expected to be transparent in their actions, and it is important that they can indicate the reason why a client's freedom is being restricted. The only legitimate reason ought to be stimulation of the client's development. 



\section{Literatuur}

\section{Adriaans en Duker 1973}

Adriaans, P. en P. Duker, Behandeling van probleemgedrag bij zwakzimnigen, Rotterdam: Lemniscaat 1973.

\section{Arends, Blankman en Frederiks 2002}

Arends, L.A.P., Blankman K. en B.J.M. Frederiks, Evaluatie Wet Bopz, Deelonderzoek 10-3: Interne rechtspositie in de psychogeriatrie en de verstandelijk gehandicaptensector, Den Haag: ZonMw 2002.

\section{Arends en Frederiks 2003}

Arends, L.A.P. en B.J.M. Frederiks, "Hersenschimmen? Een beschouwing over de noodzaak van nieuwe wetgeving naar aanleiding van de tweede Wet Bopzevaluatie interne rechtspositie van psychogeriatrische patiënten en verstandelijk gehandicapten', Tijdschrift voor gezondheidsrecht (27) 2003-2, p. 80-92.

\section{Arends 2003}

Arends, L.A.P., "De interne rechtspositie van psychogeriatrische patiënten in verpleeg- en verzorgingshuizen", Tijdschrift voor Gerontologie en Geriatrie (34) 2003-2, p. 65-73.

\section{Arends en Dursun 2004}

Arends, L.A.P. en R. Dursun, Vrijheidsbeperkende maatregelen bij psychogeriatrische patiënten en verstandelijk gehandicapten op niet-Bopz-plaatsen, Rotterdam: Instituut Beleid en Management Gezondheidszorg Erasmus Medisch Centrum/Erasmus Universiteit Rotterdam (in opdracht van het Ministerie van VWS) 2004 (nog niet gepubliceerd).

\section{AVVV 2004}

AVVV, Beroepscompetentieprofiel basisverpleegkundige verstandelijk gehandicaptenzorg, Utrecht: 2004.

\section{Baarda e.a. 1996}

Baarda, D.B., Goede, de M.P.M. en A.G.E. van der Meer-Middelburg, Basisboek. Open interviewen, Houten: Educatieve Partners Nederland BV 1996, p. 26.

\section{Bakker e.a. 2002}

Bakker, R.H., L.J. Tiesinga, P. Gassman en Th. W.N. Dassen, "Vrijheidsbeperkende maatregelen in niet Bopz aangemerkte instellingen. Gelegaliseerde dwang 


\section{Literatuur}

of gedwongen legalisering?", Tijdschrift voor sociale Geneeskunde (80) 2002-7, p. 455-462.

\section{Bartels 2002}

Bartels, L.P., Instellingen van intramurale gezondheidszorg, Basisgegevens per 1-12002, Utrecht: Prismant 2002.

\section{Begeleidingscommissie evaluatie Wet Bopz 2002}

Begeleidingscommissie evaluatie Wet Bopz, Evaluatie Wet Bopz, Deelonderzoek 1010: Conclusies en aanbevelingen van de begeleidingscommissie, Den Haag: ZonMw 2002.

\section{Berghmans 1992}

Berghmans, R.L.P., Om bestwil: paternalisme in de psychiatrie. Een gezondheidsethische studie, Amsterdam: Thesis publishers 1992.

\section{Berghmans 2001}

Berghmans, R.L.P. e.a., Kwaliteit van dwang en drang in de psychiatrie, Utrecht/Maastricht: Instituut voor Gezondheidsethiek, Universiteit Maastricht en GGZ Nederland, 2001.

\section{Berlin 1996}

Berlin, I., Twee opvattingen van vrijheid, Amsterdam/Meppel: Boom 1996.

\section{Biesaart en Hubben 1997}

Biesaart, M.C.I.H. en J.H. Hubben, Beoordeling van wilsonbekwaamheid bij mensen met een verstandelijke handicap, Nijmegen: KU Nijmegen, Faculteit der Rechtsgeleerdheid 1997.

\section{Biesaart en Hubben 2000}

Biesaart, M.C.I.H. en J.H. Hubben, Methodiek voor de vaststelling van wilsonbekwaamheid bij mensen met een verstandelijke handicap, Nunspeet: Bestuurscentrum Stichting Philadelphia Zorg en Utrecht: Vereniging Gehandicaptenzorg Nederland 2000

\section{Blankman 1992}

Blankman, K., "Recht en gezondheid: menswaardigheid en rechtsbescherming van geestelijk gehandicapten", in: K. Blankman en J.E. Doek (red.), Recht en gezondheid: liber amicorum Mr. Oscar P.F. Oldenburg, Amsterdam: VU Uitgeverij 1992, p. 39-50. 


\section{Blankman 2003}

Blankman, K., Psychiatrie en recht. Rechtsbescherming bij vrijheidsbenteming in de sectoren verstandelijk gehandicaptenzorg en psychogeriatrie, Preadvies Vereniging voor Gezondheidsrecht, Utrecht 2003.

\section{Van den Brink 1999}

Brink, van den G.F.M., Een schaars goed: de betekenis van zorg in de hedendaagse levensloop, Utrecht: NIZW 1999.

\section{Buntinx 2002}

Buntinx, W.H.E., "De 'International Classification of Functionining Disability and Health' (ICF) en de nieuwe definitie van verstandelijke handicap van de American Assocaiation on Mental Retardation", in: G.H.M.M. ten Horn, W.H.E. Buntinx, R. Habekothé, E.Th. Klapwijk, W.A.L. van Leeuwen \& B. van Zijderveld (red.), Handboek mogelijkheden, Vraaggerichte zorg voor mensen met een verstandelijke handicap (L.10.2.2: 1-26), Maarssen: Elsevier 2002.

\section{Buntinx 2003}

Buntinx, W.H.E., "Wat is een verstandelijke handicap? Definitie, assessment en ondersteuning volgens het AAMR-model", Nederlands Tijdschrift voor de Zorg aan verstandelijk gehandicapten (29) 2003-1, p. 4-24.

\section{Carbo 2003}

Carbo, C., "Professionalisering van beroepsbeoefenaren: de knop is nog niet overal om", Markant (8) 2003-9, p. 26-28.

\section{College Bouw Ziekenhuisvoorzieningen 1999a}

College Bouw Ziekenhuisvoorzieningen, Bouwkundige-functionele maatstaven ten behoeve van nieuwbouwplannen voor afzonderingsvoorzieningen in de verstandelijk gehandicaptenzorg, Rapportnummer 075, Utrecht: 1999.

\section{College Bouw Ziekenhuisvoorzieningen 1999b}

College Bouw Ziekenhuisvoorzieningen, Bouwkundige-functionele maatstaven ten behoeve van nieuwbouwplannen voor separeervoorzieningen in de geestelijke gezondheidszorg, Rapportnummer 074, Utrecht: 1999.

\section{College Bouw Ziekenhuisvoorzieningen 2003}

College Bouw Ziekenhuisvoorzieningen, Separeer-en afzonderingsruimtes, Bouwmaatstaven voor nieuwbouw, Utrecht: 2003. 
Commissie Keuzen in de zorg 1991

Commissie Keuzen in de zorg, Kiezen en delen: een rapport van de commissie Keuzen in de zorg, Den Haag: Albani 1991.

\section{Duker 1975}

Duker, P.C.C., Zelfoerwondend gedrag bij zwakzinnigen, Gedragsanalyse en -therapie (diss. KU Nijmegen), Nijmegen: Stichting Studentenpers 1975.

\section{Dute 2000a}

Dute, J.C.J., "Hoofdlijnen van de regulering van de gezondheidszorg", in: J.C.J. Dute en H.E.G.M. Hermans (red.), Regulering van de gezondheidszorg, Maarssen: Elsevier Gezondheidszorg 2000, p. 15-38.

\section{Dute 2000b}

Dute, J.C.J., "De juridische context van de geestelijke gezondheidszorg", in: J. Graste en D.Baudien (red.), Waardenvol werk: ethiek in de geestelijke gezondheidszorg, Assen: Van Gorcum 2000, p. 149-172.

\section{Dworkin 1988}

Dworkin, G., The theory and practice of autonomy, Cambridge: Cambridge University Press 1988.

\section{Dijkers 2002}

Dijkers, W., "Wijzigingen van de Wet Bopz: de stand van zaken begin 2002", Trema (24) 2002-4, p. 167.

\section{Dijkers en T.P.J.C. Widdershoven 2002}

Dijkers, W., en T.P.J.C. Widdershoven, De Wet Bopz, artikelsgewijs commentaar (losbladig), Den Haag: Koninklijke Vermande 2002, p. C1-992-998.

\section{Dijkers 2003}

Dijkers, W, Doen en laten in de Bopz-machtigingsprocedure. Een onderzoek naar juridische posities (diss. Groningen), Den Haag: SDU Uitgevers BV 2003.

\section{Emans 1990}

Emans, B., Interviewen, Theorie, techniek en training, Groningen: Wolters-Noordhoff 1990.

\section{Frederiks en Dute 2003}

Frederiks, B.J.M en J.C.J. Dute, "Evaluatie Wet Bopz: Interne rechtspositie verstandelijk gehandicapten", Nederlands Tijdschrift voor de Zorg aan verstandelijk gehandicapten (28) 2003-3, p. 139-155. 
Frijlink en Te Braake 1990

Frijlink, A. en Th.A.M. te Braake, "Opneming in een zwakzinnigen- of verpleeginrichting, Bopz-novelle", Nederlands Juristenblad (65) 1990-24, p. 955-961.

\section{Frijlink 1991}

Frijlink, A., In vrijheid beperkt: een gezondheidsrechtelijk onderzoek naar vrijheidsbeperkende maatregelen in psychiatrische ziekenhuizen, zwakzinnigeninrichtingen en psychogeriatrische verpleeghuizen, Maastricht: Rijksuniversiteit Limburg 1991.

\section{De Geest 2004}

Geest, de G., "Hoe maken we van de rechtswetenschap een volwaardige wetenschap?', Nederlands Juristenblad (79) 2004-2, p. 58-66.

\section{Van Gennep 1997a}

Gennep, van A.Th.G., Paradigma-verschuiving in de visie op zorg voor mensen met een verstandelijke handicap (inaugurele rede Maastricht), Maastricht: 1997.

\section{Van Gennep 1997b}

Gennep, A.Th.G. van en C. Steman, Beperkte burgers, Over volwaardig burgerschap voor mensen met verstandelijke beperking, Utrecht: NIZW 1997.

\section{Van Gennep 2000}

Gennep, van A.Th.G., Emancipatie van de zwaksten in de samenleving: over paradigma's van verstandelijke handicap, Amsterdam: Boom 2000.

\section{Van Gennep en Van Hove 2000}

Gennep, van A.Th.G. en G. van Hove, "Zijn het burgerschapsparadigma en inclusie dan niet bruikbaar voor mensen met een ernstige verstandelijke handicap? Kanttekeningen bij een zorgelijke ontwikkeling", Nederlands Tijdschrift voor de Zorg aan verstandelijk gehandicapten (26) 2000-4, p. 245-255.

\section{Van Gennep 2002}

Gennep, A.Th.G. van, De Tweedeling (afscheidsrede Maastricht), Maastricht: 2002.

\section{Geneeskundige Inspectie voor de Geestelijke Volksgezondheid 1990}

Geneeskundige Inspectie voor de Geestelijke Volksgezondheid, Referentiekader algemene zwakzinnigeninrichtingen, Rijswijk: 1990.

\section{Gevers 1996}

Gevers J.K.M, "De toepassing van de WGBO in a-typische situaties", Tijdschrift voor Gezondheidsrecht (20), 1996-1, p. 8-15. 


\section{Literatuur}

\section{Gevers 2002}

Gevers, J.K.M., "Gezondheidsrecht - een plaatsbepaling opnieuw beschouwd", in: J.C.J. Dute, J.K.M. Gevers en G.R.J. de Groot (red.), Omzien naar de toekomst, Houten/Diegem: Bohn Stafleu Van Loghum 2002, p. 11-20.

\section{Gezondheidsraad 2002}

Gezondheidsraad, Anticonceptie voor mensen met een verstandelijke handicap, Den Haag: 2002, nr.14.

\section{GGZ Nederland}

GGZ Nederland, Modelhuisreglement, Utrecht: 1999.

\section{Van Ginneken 2002}

Ginneken, P. P. J. N. van, Evaluatie Wet Bopz, Deelonderzoek 10-2: Externe rechtspositie in de psychogeriatrie en de verstandelijk gehandicaptensector, Den Haag: ZonMw 2002.

\section{Gold 1958}

Gold, R., "Roles in sociological field observations", Social Forces, 1958-36, p. 217 223.

\section{De Groot en Donker 2002}

Groot, C. de en M. Donker, Evaluatie Wet Bopz, Deelonderzoek 10-6: De Wet Bopz in de kinder-en jeugdpsychiatrie, Den Haag: ZonMw 2002.

\section{Van Hooren e.a. 2002}

Hooren, R.H. van et al., "Autonomy and intellectual disability", Journal of Intellectual Disability Research (46) 2002-7, p. 560-568.

\section{Hubben 1993}

Hubben, J.H. "Professionele autonomie: grenzen en dynamiek". In: J.H. Hubben en H.D.C. Roscam Abbing (red.), Gezondheidsrecht in perspectief, 25 jaar Vereniging voor Gezondheidsrecht, Utrecht: De Tijdstroom 1993, p. 65-71.

\section{Huizing e.a. 2002}

Huizing, A.R., Maaskant, M.A., Hamers, J.P.H. en W. Groot, Een eigen invulling. Zorgbehoeften van mensen met een verstandelijke handicap, Maastricht: Universitaire Pers Maastricht 2002. 
Inspectie voor de Gezondheidszorg 1997

Inspectie voor de Gezondheidszorg, Zorg onder beperking: vrijheidsbeperkende matregelen in de zorg voor mensen met cen verstandelijke handicap in relatie tot de wet Bopz en Bopz-indicatiestelling in de verstandelijk gehandicaptenzorg, Rijswijk: 1997.

\section{Inspectie voor de Gezondheidszorg 1998}

Inspectie voor de Gezondheidszorg, Sterilisatie mensen met een verstandelijke handicap. Herzien advies van de Inspectie voor de Gezondheidszorg, Den Haag: 1998.

\section{Inspectie voor de Gezondheidszorg 2000a}

Inspectie voor de gezondheidszorg, Evaluatierapport 'Zorgen in de Zomer', Den Haag: 2000.

\section{Inspectie voor de Gezondheidszorg 2000b}

Inspectie voor de Gezondheidszorg, Criteria voor verantwoord handelen bij vrijheidsbeperkende maatregelen, Den Haag: 2000.

Inspectie voor de Gezondheidszorg 2001

Inspectie voor de Gezondheidszorg, Circulaire naar aanleiding van verbrandingen in de gehandicaptenzorg, Den Haag: 2001.

\section{Inspectie voor de Gezondheidszorg 2002a}

Inspectie voor de Gezondheidszorg, Risico's bij het gebruik van de Zweedse band in de gehandicaptenzorg, Den Haag: 2002.

\section{Inspectie voor de Gezondheidszorg 2002b}

Inspectie voor de Gezondheidszorg, Melden in het kader van de Wet Bopz aan de Inspectie voor de Gezondheidszorg, Den Haag: 2002.

\section{Inspectie voor de Gezondheidszorg 2002c}

Inspectie voor de Gezondheidszorg, Jaarrapport Inspectie voor de Gezondheidszorg 2001, Den Haag: 2002.

\section{Inspectie voor de Gezondheidszorg 2002d}

Inspectie voor de Gezondheidszorg, Staat van de gezondheidszorg 2002. Kwaliteitsborging in zorginstellingen: intentie, wet en praktijk, Den Haag: 2002.

\section{Inspectie voor de Gezondheidszorg 2003}

Inspectie voor de Gezondheidszorg, Jaarrapport Bopz 2002, Den Haag: 2003. 
Inspectie voor de Gezondheidszorg 2004

Inspectie voor de Gezondheidszorg, De uitvoering van de Wet Bopz vraagt meer aandacht. De resultaten van vier thematische onderzoeken op het terrein van de Wet bijzondere opnemingen in psychiatrische ziekenhuizen (Wet Bopz), Den Haag: 2004.

\section{Kastelein 2002}

Kastelein, W.R., Patiëntenwetgeving: bureaucratie of bescherming? Toetsing van (evaluatie van) patiëntenwetgeving (inaugurale rede Nijmegen), Lelystad: Koninklijke Vermande 2002.

\section{Kelk 1983}

Kelk, C., Recht voor geïnstitutionaliseerden: de functies van het recht in penitentiaire inrichtingen, psychiatrische ziekenhuizen en andere totale instituties (inaugurale reden Utrecht), Arnhem: Gouda Quint 1983.

\section{Kelk 1985}

Kelk, C., "Klagen of kwijnen: de rechten van verpleeghuispatiënten en de behandeling van hun klachten", Preadvies Vereniging voor Gezondheidsrecht, Utrecht: 1985.

\section{Kelk 1990}

Kelk, C., "Rechtsbeginselen en het Gezondheidsrecht", Tijdschrift voor Gezondheidsrecht (14) 1990-2, p. 109-120.

\section{Kersten 1999}

Kersten, M.C.O., "Het betrekken van mensen met een verstandelijke handicap bij dataverzameling voor wetenschappelijk onderzoek: methodologische consequenties", in: Flikweert, D.A. \& M.C.O. Kersten (Eds), Wetenschappelijk onderzoek ten behoeve van de zorg voor mensen met verstandelijke handicap, Plenaire lezingen van het congres gehouden op 29 en 30 oktober 1998, Utrecht: NGBZ en BBI 1999, p. 68-72.

\section{Kersten en Schuurman $\mathbf{2 0 0 0}$}

Kersten, M.C.O. en M.I.M. Schuurman, Ervaren mogelijkheden en beperkingen. Een instrument voor bevraging van mensen met een verstandelijke handicap, Utrecht: BBI 2000 ,

\section{Keurentjes 2003}

Keurentjes, R.B.M., De Wet Bopz: de betekenis van de wet voor de beroepsbeoefenaren in de geestelijke gezondheidszorg, vijfde herziene druk, Den Haag: Koninklijke Vermande 2003. 
Klanderman 1993

Klanderman, J.H.M., "Juridisering en dejuridisering", in: A.R.J. Groot en H.J.L.M. Van de Luytgaarden (red.), Zonder meer recht, Zwolle: W.E.J. Tjeenk Willink 1993, p. 293-337.

\section{Van de Klippe 1992}

Klippe, C.J. (Hanneke) van de, "De Bopz op het Binnenhof: bijna uitbehandeld", MGv Maandblad Geestelijke Volksgezondheid (47) 1992-3, p. 243-257.

\section{Van de Klippe 1994}

Klippe, C.J. (Hanneke) van de, "Behandeling en dwangtoepassing: de artikelen 38 en 39 Bopz", in: P.J.H. Laurs, Handboek opneming en verblijf, Arnhem: Gouda Quint 1994, B7-1-98.

\section{Van de Klippe 1997}

Klippe, C.J. (Hanneke) van de, Dwangtoepassing na onvrijwillige psychiatrische opname (diss. Amsterdam UvA), Nijmegen: Ars Aequi Libri 1997.

KNMG 2002

KNMG, Meldcode voor medici inzake kindermishandeling, Utrecht: 2002.

\section{De Koning 2001}

Koning, J. de, "Hoezo ongekwalificeerd?", Markant (6), 2001-8, p, 18-22.

\section{Krul-Steketee 1990}

Krul-Steketee, J., "De reikwijdte van de Bopz-novelle", Nederlands Juristenblad (65) 1990-29, p. 1160-1161.

\section{Krul-Steketee 1992}

Krul-Steketee, J., "De Bopz-novelle, mede bezien vanuit het Evrm", Tijdschrift voor Gezondheidsrecht (16) 1992-5, p. 268-277.

\section{Krul-Steketee 1993}

Krul-Steketee, J., "Waarborgt de Bopz rechtspositie demente bejaarden en zwakzinnigen?", Het Ziekenhuis (23) 1993-10, p. 458-463.

Kwaliteitsinstituut voor de gezondheidszorg CBO en Verpleegkundig Wetenschappelijke Raad 2001

Kwaliteitsinstituut voor de gezondheidszorg CBO en Verpleegkundig Wetenschappelijke Raad, Het gebruik van vrijheidsbeperkende interventies in de zorg. Een richtlijn voor verpleegkundigen en verzorgenden in een multidisciplinaire omgeving, Utrecht: 2001. 


\section{Literatuur}

\section{Landelijke Evaluatie Commissie EAT 1997}

Landelijke Evaluatie Commissie EAT, Protocol Electro Aversie Therapie, Rijswijk: 1997.

\section{De Langen 1973}

Langen, M. de, Recht voor jeugdigen: een onderzoek naar rechten en rechtsbeginselen in het jeugdrecht (diss. Utrecht), Alphen aan den Rijn: Samsom Uitgeverij 1973.

\section{Laurs 1988}

Laurs, P.J.H., Recht voor psychiatrische patiënten (diss. Utrecht), Arnhem: Gouda Quint 1988.

\section{Laurs 1992}

Laurs, P.J.H., "Wat de Bopz in petto heeft voor de psychogeriatrie en de gehandicaptenzorg", Het Ziekenhuis (22) 1992-12, p. 594-598.

\section{Leenen 1984}

Leenen, H.J.J., "Gelijkheid en ongelijkheid in de gezondheidszorg", Tijdschrift voor Gezondheidsrecht (8) 1984-2, p. 53-68,

\section{Leenen en Roscam Abbing 1986}

Leenen, H.J.J. en H.D.C. Roscam Abbing, Bestuurlijk gezondheidsrecht, Alphen aan den Rijn/Brussel: Samsom H.D. Tjeenk Willink 1986.

\section{Leenen 1990}

Leenen, H.J.J., Mensen, rechten, instituties en de staat in de gezondheidszorg (afscheidscollege Amsterdam UvA), Alphen aan den Rijn: Samson H.D. Tjeenk Willink 1990.

\section{Leenen 1993}

Leenen, H.J.J., "De verstandelijk gehandicapte in het gezondheidsrecht", in: W.A.L. van Leeuwen (red.), Vademecum Zorg voor Verstandelijk Gehandicapten, Houten/Diegem: Bohn Stafleu Van Loghum 1993, p. 1800-16.

\section{Leenen 2000}

Leenen, H.J.J., Handboek gezondheidsrecht, Deel 1 Rechten van mensen in de gezondheidszorg, vierde herziene druk bewerkt door H.J.J. Leenen en J.K.M. Gevers, Houten/Diegem: Bohn Stafleu Van Loghum 2000.

\section{Leenen 2002}

Leenen, H.J.J., Handboek gezondheidsrecht, Deel Il Gezondheidszorg en recht, vierde herziene druk, Houten/Diegem: Bohn Stafleu Van Loghum 2002. 


\section{Legemaate 1991}

Legemaate, J., De rechtspositie van vrijwillig opgenomen psychiatrische patiënten (diss. Amsterdam UvA), Arnhem: Gouda Quint 1991.

\section{Legemaate 1994a}

Legemaate, J., Recht en realiteit: juridische normering en het therapeutisch proces (inaugurale rede Rotterdam) Houten/Zaventum: Bohn Stafleu Van Loghum 1994.

\section{Legemaate 1994b}

Legemaate, J., "Goed recht: de betekenis en de gevolgen van het recht voor de praktijk van de hulpverlening", Preadvies Vereniging voor Gezondheidsrecht, Utrecht: 1994.

\section{Legemaate 1994c}

Legemaate, J., "De Bopz en de vrijwillige opneming: een voorbeeld van ongewenste juridisering", MGv Maandblad Geestelijke Volksgezondheid (49) 1994-6/7, p. 668-678.

\section{Legemaate 1996}

Legemaate, J., "Opneming en behandeling krachtens een behandelingsovereenkomst", in: P.J.H. Laurs, Handboek opneming en verbliif, Deventer: Gouda Quint 1996, p. B1-1-106.

\section{Legemaate 1998}

Legemaate, J., "De zorg van een goed hulpverlener, in relatie tot de professionele standaard", in: J. Legemaate (red.), De Wgbo: van tekst naar toepassing, derde druk, Houten/Diegem: Bohn Stafleu Van Loghum 1998, p. 14-25.

\section{Legemaate 1999}

Legemaate, J., "Evrm", in: B. Sluijters e.d. (red.), Gezondheidsrecht: tekst en commentaar, Deventer: Kluwer 1999.

\section{Legemaate, Arends en Van 't Riet 2002}

Legemaate, J., Arends, L.A.P. en A. van 't Riet, Evaluatie Wet Bopz, Deelonderzoek 10-5: Het klachtrecht en het toezicht door de Inspectie voor de gezondheidszorg, Den Haag: ZonMw 2002.

\section{Legemaate 2003a}

Legemaate, J., Professie, management en gezondheidsrecht (afscheidsrede Rotterdam), Den Haag: Koninklijke Vermande 2003. 


\section{Literatuur}

\section{Legemaate 2003b}

Legemaate, J., "Het klachtrecht van de Wet Bopz: geschiedenis en toekomst", in: P.J.P. Baart, P.W.H.M. Francissen, I.A. van Kleef-Deelen, S. Stulp en M. Zijp (red.), Handboek Cliëntenparticipatie, Houten/Diegem: Bohn Stafleu Van Loghum 2003.

\section{Lelie 1998}

Lelie, A., "Reflectie op wetenschappelijk handelen. Empirisch onderzoek in de medische ethiek", Tijdschrift voor geneeskunde en ethiek (8) 1998-1, p. 2-7.

\section{Luckasson e.a. 2002}

Luckasson, R., Brothwick-Duffy, S., Buntinx, W., Coulter, D., Craig, P., Schalock, R., Snell, M., Spitalnik, D., Spreat, S. en Tassé, M., Mental Retardation: Definition, Classification and Systems of Supports, Washington: American Association on Mental Retardation 2002.

\section{Maas e.a. 1998}

Maas, J.M.A.G. en Serail, S. en A.M.J. Janssen, Frequentieonderzoek geestelijk gehandicapten 1986, Tilburg: IVA 1998.

\section{Maso 1987}

Maso, I., Kwalitatief onderzoek, Meppel: Boom 1987.

\section{Maso en Smaling 1998}

Maso, I. en Smaling, A., Kwalitatief onderzoek: praktijk en theorie, Amsterdam: Boom 1998.

\section{Meininger 1992}

Meininger, H.P., "Ethische implicaties van elektro-aversie therapie. Overwegingen naar aanleiding van een casus", Nederlands Tijdschrift voor de zorg aan verstandelijk gehandicaptenzorg (25) 1992-4, p. 206-219.

\section{Ministerie van Justitie 1994}

Ministerie van Justitie, Handreiking voor de beoordeling van wilsbekwaamheid, Den Haag: 1994.

\section{Ministerie VWS en Geneeskundige Inspectie voor de geestelijke volksge- zondheid 1994}

Ministerie Volksgezondheid, Welzijn en Sport en Geneeskundige Inspectie voor de geestelijke volksgezondheid, 110 vragen over de Wet Bopz. Bijzondere opnemingen in psychiatrische ziekenhuizen, Rijswijk: 1994. 
Ministerie VWS en Minsterie van Justitie 1997

Ministerie Volksgezondheid, Welzijn en Sport en Ministerie van Justitie, Kabinetsstandpunt Evaluatie van de Wet Bopz, Rijswijk: 1997.

\section{Muller 2001}

Muller, E.R., "Conflictbeslechting: kruisbestuiving van rechtswetenschap en bestuurskunde", Meijers-reeks nr. 39, Deventer: Kluwer 2001.

\section{Van der Mijn 1983}

Mijn, W.B. van der, Wie stelt de dokter de wet?, Deventer: Kluwer 1983.

\section{NVAZ 1999}

NVAZ, "Gedragscode voor artsen bij beoordeling van verzet bij mensen met een verstandelijke handicap in het kader van de Wet Medisch-Wetenschappelijk Onderzoek met Mensen", Tijdschrift van de Vereniging van Artsen in de Zwakzinnigenzorg (17) 1999-3, p. 13-15.

\section{NVAVG 2002}

NVAVG, Model taakomschrijving Bopz-arts in de zorg voor mensen met een verstandelijke handicap, 2002.

\section{NVAVG 2003}

NVAVG, De eerste geneeskundige taken en verantwoordelijkheden in de zorg voor mensen met een verstandelijke handicap, 2003.

\section{Noordelijk Centrum voor Gezondheidsvraagstukken 1997}

Noordelijk Centrum voor Gezondheidsvraagstukken, Onderzoeksrapport vrijheidsbeperkende maatregelen, Groningen: Noordelijk Centrum voor Gezondheidsvraagstukken 1997.

\section{Van Ooyen-Houben e.a. 1999}

Ooyen-Houben, M. van e.a., Richtlijn Wet Bopz en pedagogische maatregelen in de kinder-en jeugdpsychiatrie, Utrecht: GGZ Nederland i.s.m. het Trimbosinstituut 1999.

\section{Overkamp 2000}

Overkamp, E.H., Instellingen nemen de wijk: een analyse van het beleid inzake de deconcentratie van instellingen voor mensen met een verstandelijke handicap en zijn empirische effecten (diss. Twente), Assen: Van Gorcum 2000. 


\section{Prosser en Bromley 1998}

Prosser, H. en J. Bromley, "Interviewing people with intellectual disabilities", in: E. Emerson, C. Hatton, J. Bromley and A. Caine (eds), Clinical Psychology and People with Intellectual Disabilities, Chichester: John Wiley and Sons 1998, p. 99-113.

\section{Raad voor Maatschappelijke Ontwikkeling 2002}

Raad voor Maatschappelijke Ontwikkeling, De handicap van de samenleving: over mogelijkheden en beperkingen van community care, Den Haag 2002.

\section{Raad voor de Volksgezondheid en Zorg 2002}

Raad voor de Volksgezondheid en Zorg, Samen leven in de samenleving, community care en community living, Zoetermeer 2002.

\section{Regionale toetsingscommissie euthanasie 2003}

Regionale toetsingscommissie euthanasie, Jaarverslag 2002, 2003.

\section{Van Reijsen 1999}

Reijsen, P.P.M. van, Medisch-professionele autonomie en gezondheidsrecht (diss. Nijmegen), Lelystad: Koninklijke Vermande 1999.

\section{Reinders 1994}

Reinders, J.S. (Hans), "Grenzen van het rechtendiscours", in: H.A.M. Manschot en M.A. Verkerk, Ethiek van de zorg: een discussie, Amsterdam/Meppel: Boom 1994.

\section{De Roode 2003}

Roode, R.P. de, De interne rechtspositie in de psychiatrie. Praktijkreeks Bopz, deel 2. Den Haag: Koninklijke Vermande 2003.

\section{Roscam Abbing 1983}

Roscam Abbing, H.D.C., In de beperking toont zich de meester: gezondheidsrecht tussen geneeskunde en recht (inaugurale rede Maastricht), Alphen aan den Rijn: Samsom Uitgeverij 1983.

\section{Schermer 2003}

Schermer, M.H.N., "Drang en informele dwang in de zorg", in: Centrum voor ethiek en gezondheid, Signalering Ethiek en Gezondheid. Raad voor de Volksgezondheid en Zorg, Zoetermeer 2003, p. 32-46. 
Schrojenstein Lantman-de Valk e.a. 2002

Schrojenstein Lantman-de Valk, H.M.J., Heurn-Nijsten, E.W.A. van en M. Wullink, Prevalentie-onderzoek mensen met een verstandelijke beperking in Nederland, Maastricht: Universiteit Maastricht, Capaciteitsgroep huisartsgeneeskunde 2002.

\section{Schuyt 1993}

Schuyt, C.J.M., "Tussen witte jassen en zwarte toga's: de plaats van het gezondheidsrecht in de moderne samenleving", in: J.H. Hubben, H.D.C. Roscam Abbing (red.), Gezondheidsrecht in perspectief, Utrecht: De Tijdstroom 1993, p. 156168.

\section{Schuurman 2003}

Schuurman, M.I.M., "Zelfbeschikking en eigen verantwoordelijkheid van mensen met een verstandelijke handicap", in: Centrum voor ethiek en gezondheid, Signalering Ethiek en Gezondheid. Raad voor de Volksgezondheid en Zorg, Zoetermeer 2003, p. 64-85.

Stichting Patiëntenvertrouwenspersoon Geestelijke Gezondheidszorg 1982

Stichting Patiëntenvertrouwenspersoon Geestelijke Gezondheidszorg, Taakomschrijving patiëntenvertrouwenspersoon, Utrecht 1982.

Stichting Patiëntenvertrouwenspersoon Geestelijke Gezondheidszorg 1999

Stichting Patiëntenvertrouwenspersoon Geestelijke Gezondheidszorg, Gedragsregels patiëntenvertrouwenspersoon, Utrecht 1999.

Smits 2003

Smits, J., "Het recht op kwaliteit", Markant, (8) 2003-2, p. 13.

\section{Stolker 2003}

Stolker, C.J.J.M., "Ja, geleerd zijn jullie wel! Over de status van de rechtswetenschap", Nederlands Juristenblad (78) 2003-15, p. 766-778.

\section{Tonkens 1999}

Tonkens, E., Het zelfontplooiingsregime: de actualiteit van Dennendal en de jaren zestig, Amsterdam: Bert Bakker 1999.

\section{Tronto 1993}

Tronto, J.C., Moral boundaries: a political argument for an ethic of care, New York/London: Routledge 1993. 


\section{Van Veen 2002a}

Veen, E.-B. van, De Wgbo: de betekenis voor de hulpverleners in de gezondheidszorg, derde gewijzigde druk, Lelystad: Koninklijke Vermande 2002.

\section{Van Veen 2002b}

Veen, E.-B. van, "Beter gezondheidsrecht - enkele beschouwingen naar aanleiding van goed recht", in: J.C.J. Dute, J.C.J. Gevers, J.K.M. en G.R.J. de Groot (red.), Omzien naar de toekomst, Houten/Diegem: Bohn Stafleu van Loghum 2002, p. 21-43.

\section{Van der Velden 1993}

Velden, W.G. van der, "Onderzoek van juridisering als probleem", in: A.R.J. Groot en H.J.L.M. Van de Luytgaarden, Zonder meer recht, Zwolle: W.E.J. Tjeenk Willink 1993.

\section{Vereniging Gehandicaptenzorg Nederland 2002}

Vereniging Gehandicaptenzorg Nederland, Model Kwaliteitssysteem Gehandicaptenzorg, Utrecht: 2002.

\section{Verkerk 1999}

Verkerk, M.A., "A care perspective on coercion and autonomy", Bioetics (13) 1999-3/4, p. 358-368.

\section{Verkerk 2001}

Verkerk, M.A., "Over drang als goed zorgen - een zorgethische beschouwing", Tijdschrift voor geneeskunde en ethiek, (11) 2001-4, p. 101-106.

\section{Welie 2002}

Welie, S.P.K., "Wilsbekwaamheid in de gezondheidszorg", in: Koppen, P.J. van et al. (red.), Het recht van binnen: psychologie van het recht, Deventer: Kluwer 2002, p. 86-90.

\section{Wesseling 1996}

Wesseling, M.F., Evaluatie Wet Bopz, Deelonderzoek 7: interne rechtspositie verstandelijk gehandicapten: gevaarlijk zelfstandig?, Rijswijk: Ministerie Volksgezondheid Welzijn en Sport 1996.

\section{Wester 1995}

Wester, F., Strategieèn voor kwalitatief onderzoek, Brussum: Coutinho 1995, derde druk. 


\section{T.P.J.C. Widdershoven 1996}

Widdershoven, T.P.J.C., "Artikel 38" (supplement 2), in: P.J.H. Laurs, Handboek opneming en verblijf, Arnhem: Gouda Quint 1996, p. C1/ Art. 38-824-1154.

\section{T.P.J.C. Widdershoven 1996}

Widdershoven, T.P.J.C., "Artikel 38" (supplement 10), in: P.J.H. Laurs, Handboek opneming en verblijf, Arnhem: Gouda Quint 2000, p. C1/ Art. 38-3-823.

\section{T.P.J.C. Widdershoven 2000}

Widdershoven, T.P.J.C., "Artikel 39 Bopz" (supplement 10), in: P.J.H. Laurs, Handboek opneming en verblijf, Arnhem: Gouda Quint 2000, p. C1/ Art. 39-3-110.

\section{T.P.J.C. Widdershoven 2003}

Widdershoven, T.P.J.C., "Psychiatrie en recht: de Wet Bopz en psychiatrie. Kanttekeningen bij een regeling", Preadvies Vereniging voor Gezondheidsrecht, Utrecht: 2003.

\section{G. Widdershoven $\mathbf{2 0 0 0}$}

Widdershoven, G., Ethiek in de kliniek: hedendaagse benaderingen in de gezondheidsethiek, Amsterdam/Meppel: Boom 2000.

\section{G. Widdershoven en Berghmans 2000}

Widdershoven, G. en R.L.P. Berghmans, "Autonomie in de hulpverlening", in: J.M.G.A. Graste en D.M.J. Baudien, Waardenvol Werk: ethiek in de geestelijke gezondheidszorg, Assen: Van Gorcum 2000, p. 47-59.

\section{G. Widdershoven, Berghmans en Welie 2003}

Widdershoven, G., Berghmans, R.L.P. en S.P.K. Welie, "Zelfbeschikking of goede zorg? Ethische kanttekeningen bij juridisering in de hulpverlening", in: A.H. Schene e.a., Jaarboek voor psychiatrie en psychotherapie, Houten/Diegem: Bohn Stafleu Van Loghum 2003, p. 325-338.

\section{Willems 1999}

Willems, J.C.M., Wie zal de opvoeders opvoeden? Kindermishandeling en het recht van kinderen op persoonswording (diss. Maastricht), Den Haag: T.M.C. Asser Press 1999.

\section{Willems 2003}

Willems, J.C.M., "Opvoedingsondersteuning moet vroeger, massaler en massiever", in: Recht op zorg van het gehandicapte kind, Utrecht: William Schrikker Stichting 2003, p. 9-14. 


\section{World Health Organization 1993}

World Health Organization, International statistical classification of diseases and related health problems (10th ed.), Geneva: Author 1993.

\section{World Health Organization 2001}

World Health Organization, ICF, International Classification of Functioning, Disability and Health, Geneva: WHO 2001

\section{Van Wijmen en Te Braake 1989}

Wijmen, F.C.B. van en Th.A.M. te Braake, "Token economy en rechten van patiënten", Maandblad Geestelijke Volksgezondheid (44) 1989-10, p. 1079-1090.

\section{Van Wijmen 1998}

Wijmen, F.C.B. van, "Consistentie van kwaliteitsregulering: ook een kwestie van kwaliteit", in: J.C.J. Dute en F.C.B. van Wijmen, Consistentie van wetgeving in de gezondheidszorg, Antwerpen-Groningen: Intersentia 1998.

\section{Van Wijmen 2000a}

Wijmen, F.C.B. van en J.C.J. Dute, "Wet- en regelgeving als sturingsinstrumenten in de gezondheidszorg", in: J.C.J Dute en H.E.G.M. Hermans (red.), Regulering van de gezondheidszorg, Maarssen: Elsevier gezondheidszorg 2000, p. 39-57.

\section{Van Wijmen 2000b}

Wijmen, F.C.B. van, "Richtlijnen voor verantwoorde zorg. Over de betekenis van standaardisering voor patiënt, professional en patiëntenzorg", Preadvies Vereniging voor Gezondheidsrecht, Utrecht: 2000.

\section{Van Wijmen 2002}

Wijmen, F.C.B. van, "Klagen noch kwijnen - enige beschouwingen over ontwikkelingen in de rechtsbescherming van verpleeghuispatiënten", in: J.C.J. Dute, J.K.M. Gevers en G.R.J. de Groot (red.), Omzien naar de toekomst, Houten/Diegem: Bohn Stafleu Van Loghum 2002, p. 226-240.

\section{ZorgOnderzoek Nederland 2002}

ZorgOnderzoek Nederland, Evaluatie Wet geneeskundige behandelingsovereenkomst, Den Haag: 2000.

\section{Zijlstra 2003}

Zijlstra, R., Dansen met olifanten. Een onderzoek naar de implementatie van het opvoedingsprogramma in de zorg voor mensen met ernstige meervoudige beperkingen (diss. Groningen), Groningen: Stichting Kinderstudies 2003. 


\section{Curriculum Vitae}

Brenda-Jolanda Frederiks werd op 16 mei 1972 geboren te Amstelveen. In 1989 deed zij eindexamen HAVO aan het Petrus Canisius College te Alkmaar. Twee jaar later, in 1991, behaalde zij ook het VWO-B diploma. In hetzelfde jaar verhuisde zij naar Maastricht, waar zij in september startte met de studie Gezondheidswetenschappen aan de Universiteit Maastricht, met als afstudeerrichting Beleid en Beheer van de Gezondheidszorg. Tijdens de doctoraalfase werd, in opdracht van het Ministerie VWS, onderzoek verricht naar 'Kwaliteitszorg in verpleeghuizen, een taak van elke verplegende en verzorgende'. In juni 1996 behaalde zij haar doctoraalexamen. In 1993 begon zij ook met de studie Rechtsgeleerdheid aan de Universiteit Maastricht, met als afstudeerrichting Gezondheidsrecht. Deze studie werd in mei 1998 afgerond. Het onderwerp van de doctoraalscriptie was 'wachtlijstomzeilende initiatieven in de gezondheidszorg'.

Van september 1998 tot en met juni 2003 heeft zij als assistent-in-opleiding gewerkt bij de sectie Gezondheidsrecht van de Universiteit Maastricht onder begeleiding van prof.mr. F.C.B. van Wijmen en mr.dr. J.C.J. Dute. Tijdens deze aanstelling werd het onderzoek, zoals beschreven in dit proefschrift, uitgevoerd in drie voorzieningen voor verstandelijk gehandicaptenzorg in Limburg.

Van januari 2001 tot en met oktober 2001 heeft zij als onderzoeker meegewerkt aan de tweede evaluatie van de Wet Bopz, onderdeel interne rechtspositie in de psychogeriatrie en de verstandelijk gehandicaptensector. Het onderzoek werd in samenwerking met dr.mr. K. Blankman en mr. L.A.P. Arends uitgevoerd. Aansluitend aan dit project heeft zij samen met Arends een voorstel geschreven voor een alternatieve regeling voor de toepassing van vrijheidsbeperking in de psychogeriatrie en de verstandelijk gehandicaptenzorg. Daarnaast heeft zij diverse presentaties gegeven op nationale en internationale congressen (Seattle, Melbourne en Montpellier). Ook heeft zij verscheidene publicaties op haar naam staan, waaronder in het Nederlands Tijdschrift voor Zorg aan verstandelijk gehandicapten en het Tijdschrift voor Gezondheidsrecht. Tevens is zij freelance juriste bij Stichting Raad op Maat te Gouda en lid van de ethische commissie van de Stichting Amarant te Tilburg.

Van juli 2003 tot en met december 2003 was zij als universitair docent werkzaam bij de sectie Gezondheidsrecht. Vanaf januari 2004 is zij als onderzoeker verbonden aan het Gouverneur Kremers Centrum en de sectie Gezondheidsrecht in het kader van een twee jarig post-doc project 'Kwaliteitscriteria voor vrijheidsbeperking in de verstandelijk gehandicaptenzorg'. 


\section{Curriculum Vitae}

Brenda-Jolanda Frederiks werd op 16 mei 1972 geboren te Amstelveen. In 1989 deed zij eindexamen HAVO aan het Petrus Canisius College te Alkmaar. Twee jaar later, in 1991, behaalde zij ook het VWO-B diploma. In hetzelfde jaar verhuisde zij naar Maastricht, waar zij in september startte met de studie Gezondheidswetenschappen aan de Universiteit Maastricht, met als afstudeerrichting Beleid en Beheer van de Gezondheidszorg. Tijdens de doctoraalfase werd, in opdracht van het Ministerie VWS, onderzoek verricht naar 'Kwaliteitszorg in verpleeghuizen, een taak van elke verplegende en verzorgende'. In juni 1996 behaalde zij haar doctoraalexamen. In 1993 begon zij ook met de studie Rechtsgeleerdheid aan de Universiteit Maastricht, met als afstudeerrichting Gezondheidsrecht. Deze studie werd in mei 1998 afgerond. Het onderwerp van de doctoraalscriptie was 'wachtlijstomzeilende initiatieven in de gezondheidszorg'.

Van september 1998 tot en met juni 2003 heeft zij als assistent-in-opleiding gewerkt bij de sectie Gezondheidsrecht van de Universiteit Maastricht onder begeleiding van prof.mr. F.C.B. van Wijmen en mr.dr. J.C.J. Dute. Tijdens deze aanstelling werd het onderzoek, zoals beschreven in dit proefschrift, uitgevoerd in drie voorzieningen voor verstandelijk gehandicaptenzorg in Limburg.

Van januari 2001 tot en met oktober 2001 heeft zij als onderzoeker meegewerkt aan de tweede evaluatie van de Wet Bopz, onderdeel interne rechtspositie in de psychogeriatrie en de verstandelijk gehandicaptensector. Het onderzoek werd in samenwerking met dr.mr. K. Blankman en mr. L.A.P. Arends uitgevoerd. Aansluitend aan dit project heeft zij samen met Arends een voorstel geschreven voor een alternatieve regeling voor de toepassing van vrijheidsbeperking in de psychogeriatrie en de verstandelijk gehandicaptenzorg. Daarnaast heeft zij diverse presentaties gegeven op nationale en internationale congressen (Seattle, Melbourne en Montpellier). Ook heeft zij verscheidene publicaties op haar naam staan, waaronder in het Nederlands Tijdschrift voor Zorg aan verstandelijk gehandicapten en het Tijdschrift voor Gezondheidsrecht. Tevens is zij freelance juriste bij Stichting Raad op Maat te Gouda en lid van de ethische commissie van de Stichting Amarant te Tilburg.

Van juli 2003 tot en met december 2003 was zij als universitair docent werkzaam bij de sectie Gezondheidsrecht. Vanaf januari 2004 is zij als onderzoeker verbonden aan het Gouverneur Kremers Centrum en de sectie Gezondheidsrecht in het kader van een twee jarig post-doc project 'Kwaliteitscriteria voor vrijheidsbeperking in de verstandelijk gehandicaptenzorg'. 
